UNIVERSIDADE DE BRASÍLIA CENTRO DE DESENVOLVIMENTO SUSTENTÁVEL

À PROCURA DA INCLUSIVIDADE: ESTUDO SOBRE OS FATORES DE INCLUSÃO SOCIOECONÔMICA EM DESTINOS TURÍSTICOS BRASILEIROS

João Paulo Faria Tasso

Orientador: Dr. Elimar Pinheiro do Nascimento

Tese de Doutorado

Brasília-DF, outubro/2014 
Tasso, João Paulo Faria.

À procura da inclusividade: estudo sobre os fatores de inclusão socioeconômica em destinos turísticos brasileiros/João Paulo Faria Tasso.

Brasília, 2014.

310p. : II.

Tese de Doutorado. Centro de Desenvolvimento Sustentável, Universidade de Brasília, Brasília.

1. Turismo Sustentável. 2. Inclusão e Exclusão Social. 3. Sistema Produtivo de Turismo. 4. Desenvolvimento Local. 5. Fatores de Inclusão Socioeconômica. 6. Barreirinhas. 7. Jijoca de Jericoacoara. I. Universidade de Brasília. CDS.

É concedida à Universidade de Brasília permissão para reproduzir cópias desta tese e emprestar ou vender tais cópias, somente para propósitos acadêmicos e científicos. $O$ autor reserva outros direitos de publicação e nenhuma parte desta tese de doutorado pode ser reproduzida sem a autorização por escrito do autor. 
UNIVERSIDADE DE BRASÍLIA

CENTRO DE DESENVOLVIMENTO SUSTENTÁVEL

\title{
À PROCURA DA INCLUSIVIDADE: ESTUDO SOBRE OS FATORES DE INCLUSÃO SOCIOECONÔMICA EM DESTINOS TURÍSTICOS BRASILEIROS
}

\author{
João Paulo Faria Tasso
}

Tese de Doutorado submetida ao Centro de Desenvolvimento Sustentável da Universidade de Brasília, como parte dos requisitos necessários para a obtenção de grau de Doutor em Desenvolvimento Sustentável, área de concentração em Política e Gestão Ambiental, opção acadêmica.

Aprovado por:

Elimar Pinheiro do Nascimento, Dr. (Centro de Desenvolvimento Sustentável - CDS/UnB) (Orientador)

Thomas Ludewigs, Dr. (Centro de Desenvolvimento Sustentável - CDS/UnB) (Examinador Interno)

Maurício de Carvalho Amazonas, Dr. (Centro de Desenvolvimento Sustentável - CDS/UnB) (Examinador Interno)

Luiz Carlos Spiller Pena, Dr. (Centro de Excelência em Turismo - CET/UnB) (Examinador Externo)

Daniela Fantoni Alvares, Dra. (Instituto Federal de Educação, Ciência e Tecnologia de Brasília IFB)

(Examinadora Externa)

$\overline{\text { Noemí Wallingre, Dra. (Universidad Nacional de Quilmes) }}$

(Suplente)

Brasília, 24 de novembro de 2014. 
Dedico este trabalho às quatro pessoas que mantiveram minha cabeça erguida, minha alegria constantemente renovada, e meu sonho fortalecido. Meus pais, Terezinha Maria Faria Tasso e Paulo Sérgio Tasso. Meu orientador, Elimar Pinheiro do Nascimento. E minha grande amiga Helena Araújo Costa. 
"O rio atinge seus objetivos, porque aprendeu a contornar os obstáculos"

(Lao Tsé) 


\section{AGRADECIMENTOS}

Aos meus pais amados, Terezinha Maria Faria Tasso e Paulo Sérgio Tasso, pelo enorme carinho, paciência e fé, e por terem dedicado suas vidas com muito amor à formação profissional, social e humana de seu filho.

Ao meu grande orientador e amigo, Elimar Pinheiro do Nascimento, por sua imensa sabedoria transmitida por orientações acadêmicas e para a vida, pela serenidade, segurança, amizade, companheirismo e simpatia, por estimular minha inquietude e minha superação. Mas mais do que isso, pelo enorme sorriso no rosto a cada reunião.

A Helena Araújo Costa, amiga eterna, que com suas palavras de incentivo, seu brilhantismo e companheirismo demonstrados nos inúmeros momentos de contribuição, fez com que eu ampliasse (mesmo achando que não fosse mais possível) minha admiração e meu respeito por tudo que ela é.

A Eleusina Rodrigues, amiga e companheira fiel, a quem guardo uma grande e verdadeira gratidão, pelas muitas contribuições diárias, pelas conversas descontraídas, pelo amplo conhecimento, paciência e contribuição no trabalho de campo.

Aos Professores Maurício Amazonas, Thomas Ludewigs, Luiz Spiller, Noemí Wallingre, Marutschka Moesch e Daniela Fantoni pelas ricas contribuições e discussões primordiais para a construção e fortalecimento deste trabalho.

Ao Ministro do Turismo, Dr. Vinícius Nobre Lages, pelas palavras de incentivo e pelas ricas contribuições no debate do tema aqui abordado, desde o período do meu mestrado.

A Kathleen Andereck, Rebekka Goodman, Jeniece Morales, Jessica Aquino e Richard Knopf, pela abertura de uma oportunidade única de aprendizado, pelos desafios que tanto contribuíram com minha formação, e pela forma tão acolhedora que me receberam, no período de um ano, na Arizona State University (ASU), School of Community Resources and Development (SCRD).

Aos meus dois grandes irmãos cearenses, Flavinho Pereira e Manoel, que tão carinhosamente me acolheram em suas casas, e foram companheiros fiéis no momento de realização dos exaustivos trabalhos de campo, me estimulando, a todo momento, com palavras de determinação.

A Alberto Cabral, amigo do peito, verdadeiro, pela sensatez nas orientações, pelo carinho nas palavras, e pela força extra nos momentos de exaustão mental e física.

A Caroline, minha irmã, Onofre e Olívia, meu avô e minha avó (in memoriam), meus tios e tias, primos e primas, pelo amor fraterno.

Aos amigos da comunidade de Cajueirinho - Flávio, Edimilson, Erilene, Viviane e Ana Célia pela pronta ajuda, determinação e comprometimento na aplicação dos inúmeros questionários, além do enorme carinho e palavras de incentivo.

Aos meus grandes amigos do CDS e companheiros de luta acadêmica (Marla, Patrícia, Michelle, Jair, James, Dani Rocco, Dani, Antônio, Márcia, Ana Pimenta, e tantos outros).

Aos professores, funcionários e alunos do Centro de Excelência em Turismo (CET/UnB), pelo apoio diário e vivência tão harmoniosa. Em especial aos grandes amigos Lívia Barros, Mozart 
Fazito, lara Brasileiro, Ana Rosa Santos, Karina Dias, Marutschka Moesch, Luiz Spiller, Neio Campos, Andrea Theorga, Everaldo Costa, Elenita Nascimento, Mario Carlos Beni, Barbara Rodrigues, Fernanda Hummel, Lana Pires e Neuza Farias.

Aos meus amigos brasilienses (Thiago, Flávio, Eric, Rui, Fabrício, Bergmann, Evie, Beto e Milton) por ouvirem minhas angústias, transformando-as poucos segundos depois em gargalhadas e determinação.

A todos os integrantes do LETS/UnB (Laboratório de Estudos em Turismo e Sustentabilidade) pelas tantas contribuições, ricas discussões, pela amizade e companheirismo sempre apresentados.

A todos os Professores do CDS/UnB, em especial a Jose Augusto Drummond, Saulo Rodrigues, Donald Sawyer, Thomas Ludewigs, Maurício Amazonas, Doris Sayago e Vanessa Castro, por instigarem à busca pelo conhecimento por meio do aprendizado coletivo e compartilhado.

A Cristina Carvalheira (e família), pelo tratamento sempre tão atencioso e carinhoso em todos meus momentos vivendo em Brasília, e pela torcida e energia positiva constante.

Ao CNPq e CAPES, pelo apoio financeiro na realização da pesquisa e na moradia em Brasília, além do suporte à realização do doutorado sanduíche nos EUA.

A André Luis Vizzaccaro Amaral, grande amigo e orientador, por ter sido o responsável por ampliar meus horizontes de percepção, resultando em minha forte identificação pessoal com a temática do Turismo e Inclusão social.

A todos os meus irmãos e irmãs da turma do Léhdz (em especial ao Tom, Rodz, Lehdão, Catatau, Guiga e Gabi, Magro, Marina e Mariana Tosi, Zézão, Ferdz, Família Canesin, Steban e Bel), por me fazerem sentir que a amizade é a base para cada conquista.

Ao pessoal do pensionato, em especial ao Sr. Jordete e Dona Guilhermina, pelas muitas preces, orações e o carinho fraterno durante esses mais de seis anos em Brasília.

Aos meus irmãos de vida (Gustavim, Branquim, Ricardo, e toda a turma) e suas famílias por tantas alegrias em nossas vitórias conjuntas e, mesmo que distantes, sabemos de nossa cumplicidade.

A todos os funcionários da Secretaria do CDS/UnB, em especial ao Antônio pelo grande apoio em todos os muitos momentos de necessidade.

A Adriana (Pousada do Rio) e Vânia (Restaurante Barlavento), pelo acolhimento e suporte, sempre tão carinhosas. Pela valorização deste trabalho e, principalmente, pelo pensamento sempre direcionado ao apoio e à melhoria da qualidade de vida das comunidades locais.

E aos demais que, porventura, acabaram não sendo citados, contudo, tiveram importante papel na concretização deste sonho. 


\section{RESUMO}

O presente trabalho concentrou-se no estudo sobre os fatores que influenciam os processos de inclusão socioeconômica de habitantes de regiões turísticas, de parques nacionais brasileiros, no sistema produtivo local do turismo. A justificativa é que a inclusão socioeconômica - seja ela pelo emprego formal, ou por práticas de inserção produtiva - é um dos aspectos essenciais do turismo sustentável. Os municípios estudados comparativamente são Barreirinhas (MA) e Jijoca de Jericoacoara (CE), localizados em regiões caracterizadas por suas potencialidades naturais protegidas por unidades de conservação - amplamente exploradas pelo setor turístico. Tais localidades se veem marcadas pela baixa participação de seus habitantes nos benefícios econômicos advindos da atividade turística. O cenário que se encontra é de alta incidência de pobreza e de baixos rendimentos econômicos de seus moradores. O objetivo final da tese é o de identificar e analisar os fatores que contribuem para, ou impedem, a inclusão socioeconômica da população local no sistema turístico. A literatura tem sinalizado no sentido de que o turismo, ainda que seja o principal motor da economia dessas localidades, não tem sido equânime na distribuição dos benefícios resultantes de suas atividades entre os diversos grupos de atores locais. Pergunta-se em que medida a dinâmica do turismo nesses locais permite ou não a inclusão socioeconômica dos habitantes no sistema produtivo local do turismo, e como ela ocorre. Por que alguns conseguem se inserir e outros não? Quais os fatores que contribuem para a inclusão socioeconômica? Espera-se que este estudo contribua para a discussão na construção de políticas públicas de inclusão social de maior efetividade. Foram testados 11 fatores de inclusão direta (pelo emprego formal): gênero; idade; religião; rede de relações sociais; conhecimento da área; local de nascimento; escolaridade; experiência anterior; capacitação profissional; proximidade física do local onde a atividade turística se desenvolve; e participação em cooperativas e/ou associações. Também foram testados nove fatores de inclusão indireta (pela venda de produtos): emissão de nota fiscal; regularidade no fornecimento; capital de giro e estrutura de suporte à produção; condições de pagamento; suficiência produtiva; disponibilidade logística; capacitação técnica e gerencial; participação efetiva em organizações coletivas de trabalho; e registros de inspeção sanitária (SIF, SIE e SIM). O trabalho permitiu concluir que os fatores de maior contribuição para inserção socioeconômica no sistema produtivo local de turismo, são: capacitação profissional, rede de relações sociais, experiência anterior, grau de escolaridade, e conhecimento da área/região (direta); regularidade no fornecimento; suficiência produtiva, disponibilidade logística, capacitação técnica e gerencial, e registros de inspeção sanitária (indireta).

Palavras-chave: Turismo Sustentável. Inclusão e Exclusão Social. Sistema Produtivo de Turismo. Desenvolvimento Local. Fatores de Inclusão Socioeconômica. Barreirinhas. Jijoca de Jericoacoara. 


\section{ABSTRACT}

The present dissertation focused on the study about the influence of factors on the socioeconomic inclusion processes of local population from touristic regions, close to Brazilian national parks, in the tourism productive system. The socio-economic inclusion - whether by formal employment, or productive insertion practices - is a key aspect of sustainable tourism. The study highlights two national tourism destinations, Barreirinhas (Maranhão State) and Jijoca de Jericoacoara (Ceará State), located in regions marked by their unique natural potential protected by Environmental Protection Areas - widely exploited by tourism activities. Such localities are marked by low participation of the local populations in the tourism economic benefits. The scenario is marked by high poverty rates and low economic incomes of its residents. The main objective is to identify and analyze the factors that contribute to, or hinder, the socioeconomic inclusion of local population in tourism system. The literature has signaled that tourism activity, which still the main economy driver in these localities, has not been equitable on the real economic benefits distribution resulting from its activities among diverse groups of local actors. One wonders to what extent the tourism dynamics of tourism at these sites allows or not the socioeconomic inclusion of local population in the tourism productive system, and how it occurs. Why some are able to be included and others not? What factors contribute to the socio-economic inclusion? It is hoped that this study contributes for the discussion on the construction of public policies for social inclusion of greater effectiveness. Eleven factors of direct inclusion (by formal employment) were tested: gender; age; religion; social relations networks; area/region knowledge; birth place; education; previous experience; professional training; physical proximity of the location where tourism is developed; and participation in cooperatives and/or associations. Nine factors of indirect inclusion were also tested (for selling products): problems regarding proper tax invoice; problems regarding the quality and diversity of production to meet with tourism seasonality (regular supply); lack of working capital, product processing facility and of storage location; impediments regarding payment conditions; insufficient production to meet demand; lack of logistics to support production flow; lack of professional training, technical and managerial; weakness in the collective work organization; and difficulties obtaining records of federal, state and municipal inspection services. The study revealed that the factors of greatest contribution to socio-economic inclusion in the tourism productive system are: professional training, social relations networks, previous experience, education, and area/region knowledge (direct); regular supply; sufficient production, logistics to support production flow, technical and managerial training, and records of inspection services (indirect).

Keywords: Sustainable Tourism. Social Inclusion and Exclusion. Tourism Production System. Local Development. Socioeconomic inclusion factors. Barreirinhas. Jijoca de Jericoacoara. 


\section{RESUMEN}

El presente trabajo se centró en el estudio de los factores que influyen en los procesos de inclusión socio-económica de las personas en el turismo de parques nacionales de Brasil, el sistema productivo local de turismo. La justificación es que la inclusión socio-económica - ya sea por el empleo formal, o las prácticas de inserción productiva - es un aspecto clave del turismo sostenible. Los municipios se estudian comparativamente Barreirinhas (MA) y Jijoca Jericoacoara (EC), situadas en regiones que se caracterizan por su potencial natural - para áreas de conservación protegidas - ampliamente explotados por la industria del turismo. Estas localidades se encuentran marcadas por la baja participación de los habitantes en la obtención de beneficios económicos del turismo. El escenario que se está elevada incidencia de la pobreza y los bajos ingresos económicos de sus habitantes. El objetivo final de la tesis es identificar y analizar los factores que contribuyen a, o dificultar, la inclusión socioeconómica de la población local en el sistema turístico. La literatura se ha señalado en el sentido de que el turismo, que sigue siendo el principal motor de la economía en estas localidades, no ha sido la distribución equitativa de los beneficios resultantes de sus actividades entre los diversos grupos de actores locales. Uno se pregunta en qué medida la dinámica del turismo en estos sitios permite o no la inclusión social y económica de las personas en el sistema productivo local del turismo y cómo se produce. ¿Por qué algunos son capaces de entrar y otros no? ¿Qué factores contribuyen a la inclusión social y económica? Se espera que este estudio contribuye al debate sobre la construcción de políticas públicas para la inclusión social de una mayor eficacia. Se probaron 11 factores a la inclusión (por el empleo formal) Directo: género; edad; religión; la red de relaciones sociales; conocimiento de la zona; Lugar de nacimiento; la educación; La experiencia previa; formación profesional; proximidad física de la ubicación donde se desarrolla el turismo; y la participación en las cooperativas y / o asociaciones. Inclusión indirecta de nueve factores también fueron probados (por la venta de productos): emisión de la factura; suministro regular; estructura de capital de trabajo y apoyo a la producción; condiciones de pago; suficiencia productiva; Disponibilidad de logística; técnica y capacitación gerencial; participación efectiva en las organizaciones colectivas de trabajo; y los registros de inspección sanitaria (SIF, SIE y SIM). EI estudio reveló que los factores de mayor contribución a las condiciones socioeconómicas en el sistema productivo local del turismo son: la formación profesional, la red de relaciones sociales, la experiencia previa, nivel de educación, y conocimiento de la zona / región (directa); suministro regular; suficiencia productiva, la disponibilidad, la logística, la capacitación técnica y de gestión, y los registros de inspección sanitaria (indirecta).

Palabras clave: Turismo Sostenible. Inclusión y Exclusión Social. Sistema Productivo de Turismo. Desarrollo Local. Factores Socioeconómicos Inclusión. Barreras. Jijoca Jericoacoara. 


\section{RÉSUMÉ}

Le présent travail a porté sur l'étude sur les facteurs qui influent sur les processus d'inclusion socio-économique des personnes dans le tourisme parcs nationaux brésiliens, le système productif local du tourisme. La justification est que l'inclusion socio-économique - que ce soit par l'emploi formel, ou des pratiques d'insertion productive - est un aspect clé du tourisme durable. Les municipalités sont relativement étudiés Barreirinhas (MA) et Jijoca Jericoacoara (CE), situés dans des régions caractérisées par leur potentiel naturel - pour les zones de conservation protégées - largement exploitées par l'industrie du tourisme. Ces localités se trouvent marqué par une faible participation des habitants en tirer des avantages économiques du tourisme. Le scénario qui est est la forte incidence de la pauvreté et du faible revenu économique de ses habitants. Le but ultime de la thèse est d'identifier et d'analyser les facteurs qui contribuent à, ou d'entraver l'intégration socio-économique des populations locales dans le système du tourisme. La littérature a signalé dans le sens que le tourisme, qui est toujours le principal moteur de l'économie dans ces localités, n'a pas été une répartition équitable des avantages qui découlent de ses activités entre les divers groupes d'acteurs locaux. On peut se demander dans quelle mesure la dynamique du tourisme sur ces sites permet ou non l'inclusion sociale et économique des personnes dans le système productif local du tourisme et de la façon dont elle se produit. Pourquoi certains sont capables de saisir et d'autres pas? Quels facteurs contribuent à l'inclusion sociale et économique? II est à espérer que cette étude contribue au débat sur la construction des politiques publiques pour l'inclusion sociale de plus grande efficacité. 11 facteurs à l'inclusion (par l'emploi formel) diriger ont été testés: le sexe; âge; religion; réseau de relations sociales; connaissance de la région; lieu de naissance; l'éducation; L'expérience antérieure; la formation professionnelle; proximité physique de l'endroit où le tourisme se développe; et la participation dans les coopératives et / ou associations. Inclusion indirecte de neuf facteurs ont également été testés (pour la vente de produits): émission de la facture; approvisionnement régulier; travailler la structure du capital et le soutien de la production; modalités de paiement; suffisance productive; Disponibilité logistique; technique et la formation des cadres; participation effective dans les organisations collectives de travail; et les dossiers de l'inspection sanitaire (FIS, SIE et SIM). L'étude a révélé que les facteurs de la plus grande contribution à des conditions socioéconomiques dans le système productif local du tourisme sont: la formation professionnelle, réseau de relations sociales, de l'expérience précédente, le niveau d'éducation, et de la connaissance de la zone / région (direct); approvisionnement régulier; suffisance productive, la disponibilité, la logistique, la formation technique et de gestion, et les dossiers d'inspection sanitaire (indirecte).

Mots-clés: Tourisme durable. L'inclusion et l'exclusion sociale. Système Productif du Tourisme. Développement local. Facteurs socio-économiques inclusion. Obstacles. Jijoca Jericoacoara. 


\section{LISTA DE FIGURAS}

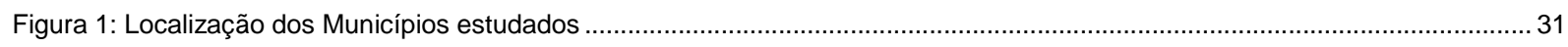

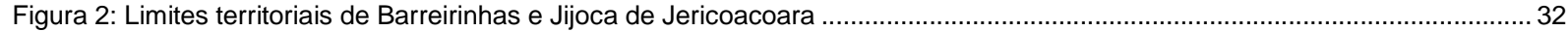

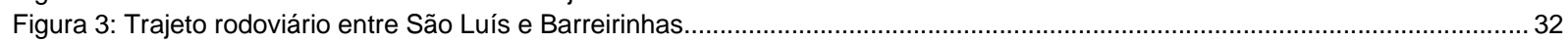

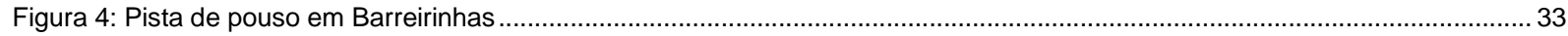

Figura 5: Trajeto rodoviário entre Fortaleza e Jijoca de Jericoacoara .............................................................................................34

Figura 6: Histórico-evolutivo dos municípios de Barreirinhas e Jijjoca de Jericoacoara................................................................. 36

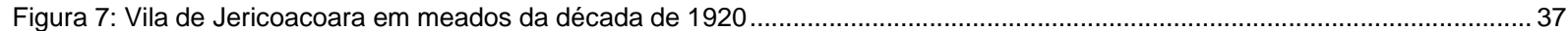

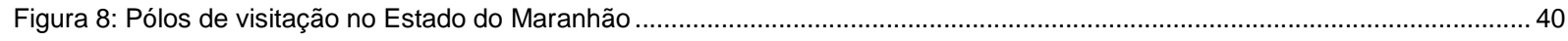

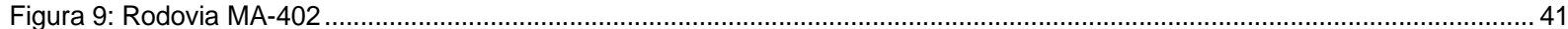

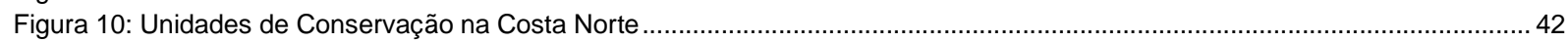

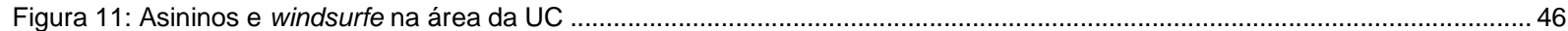

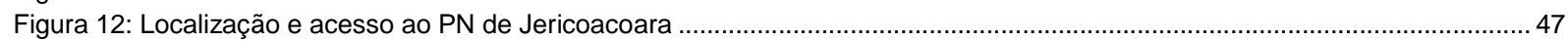

Figura 13: Localização e acesso ao PNLM.

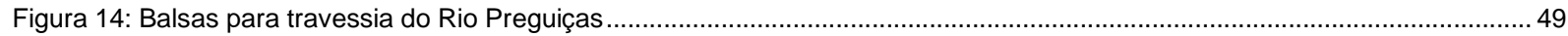

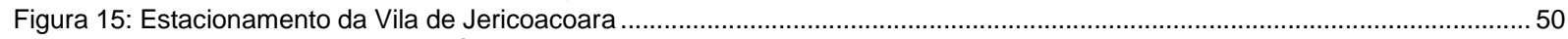

Figura 16: Zona de Amortecimento e Área de Influência do PN Lençóis Maranhenses ...............................................................52

Figura 17: Zona de Amortecimento e Área de Influência do PN Jericoacoara .......................................................................53

Figura 18: Campos de dunas dos PN dos Lençóis Maranhenses e de Jericoacoara....................................................................5

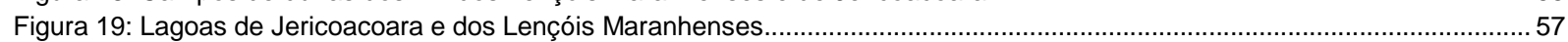

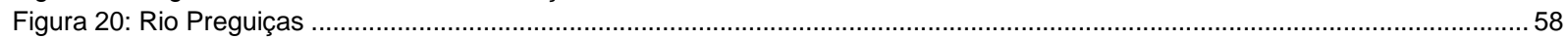

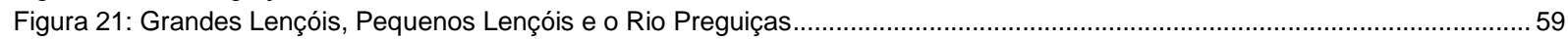

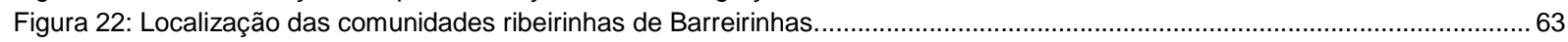

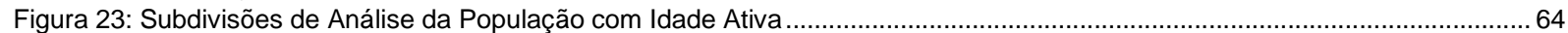

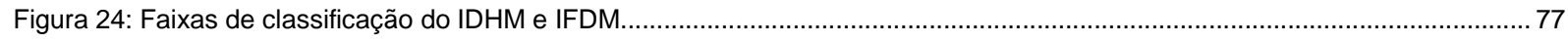

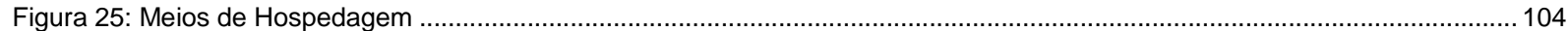

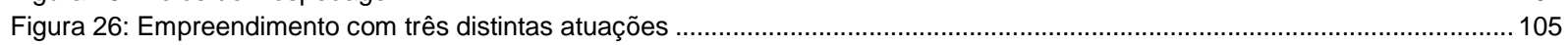

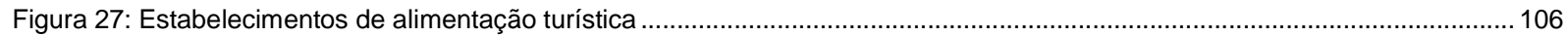

Figura 28: Transporte utilizado por trabalhadores para acesso à Vila de Jericoacoara ............................................................. 107

Figura 29: Estrutura de acomodação em jardineiras de Jericoacoara ....................................................................................... 107

Figura 30: Estrutura de acomodação em jardineiras dos Lençóis Maranhenses.............................................................................108

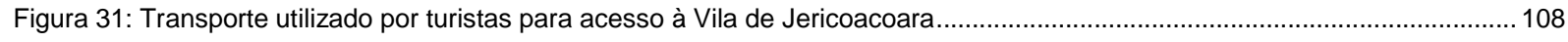

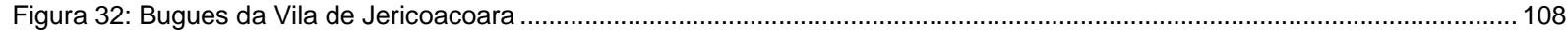

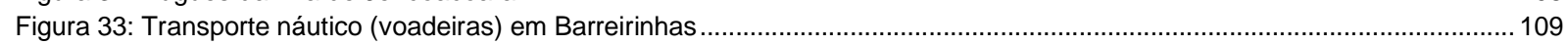

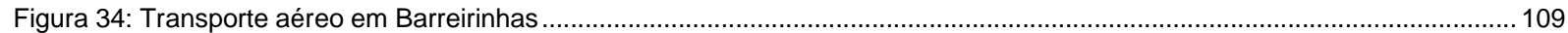

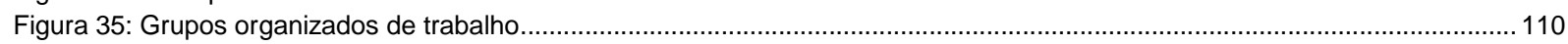

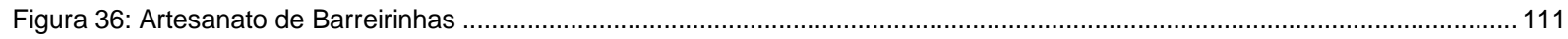

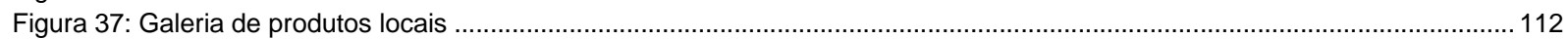

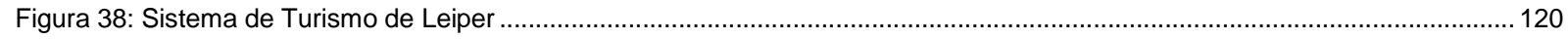

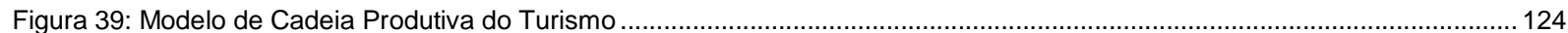

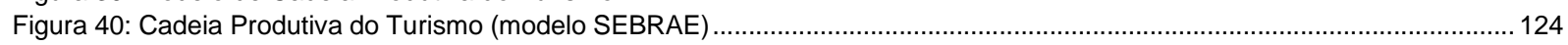

Figura 41: Cadeia Produtiva do Turismo

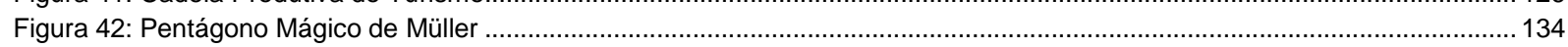

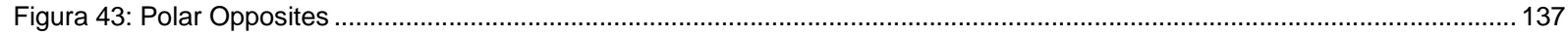

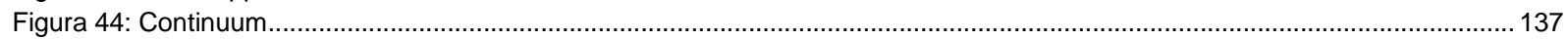

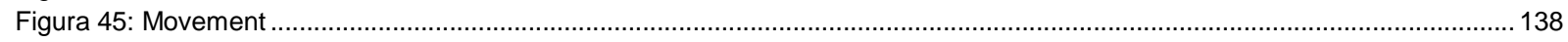

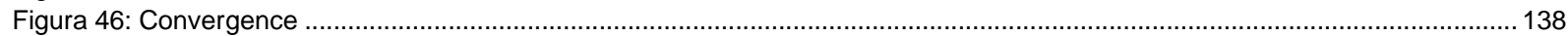

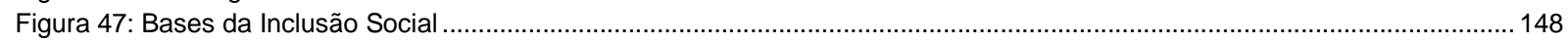

Figura 48: Figura do Atravessador pela ótica de pescadores de Barreirinhas..........................................................................156

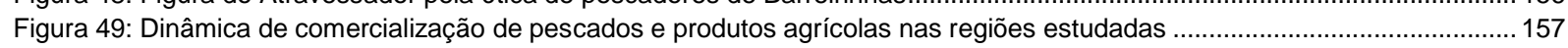

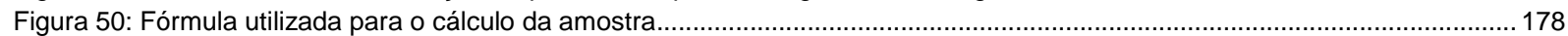

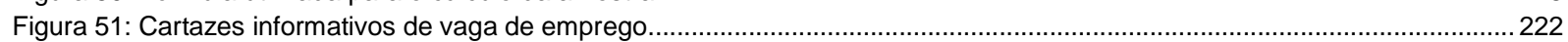

Figura 52: Frutas importadas de outras regiões vendidas nos mercados de Jericoacoara .......................................................223 


\section{LISTA DE TABELAS}

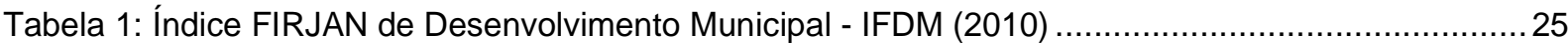

Tabela 2: População total e taxa média de crescimento anual (1991-2000 / 2000-2010) ........................60

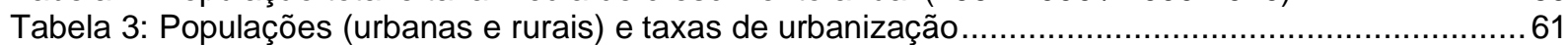

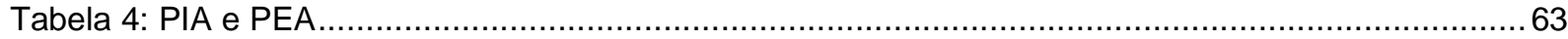

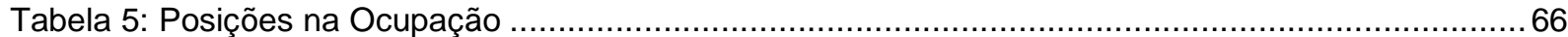

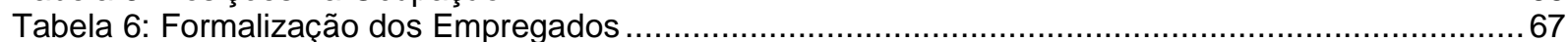

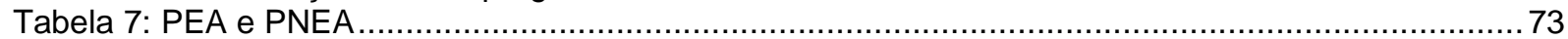

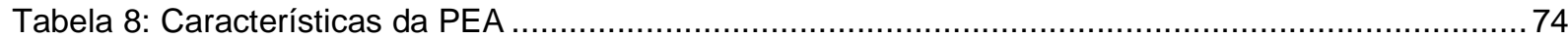

Tabela 9: Classes de Rendimentos Nominais Mensais da PIA e da PEA …..................................... 75

Tabela 10: Características da PEA em detrimento de sua renda ...................................................... 76

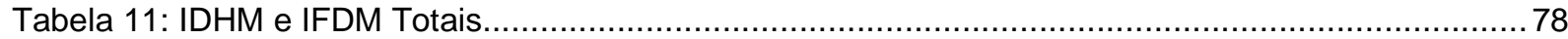

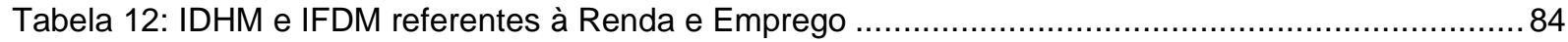

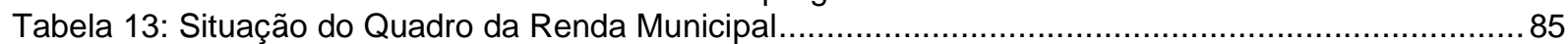

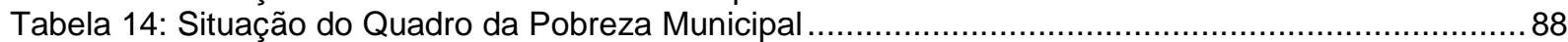

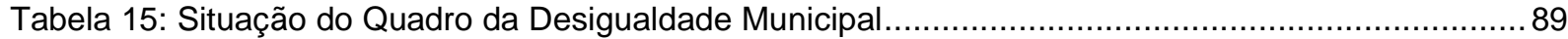

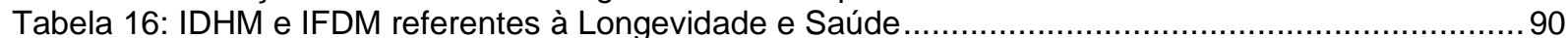

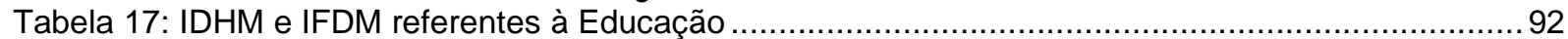

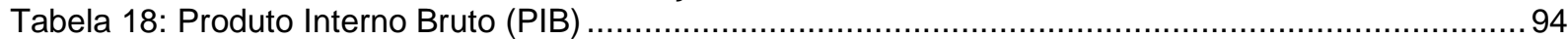

Tabela 19: Estabelecimentos Agrícolas com Área e Tipo de Ocupação ............................................97

Tabela 20: Custos e Benefícios resultantes da atividade turística........................................................ 142

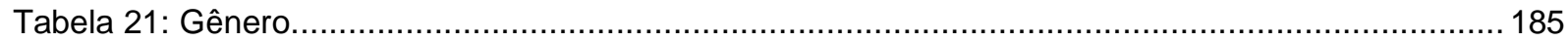

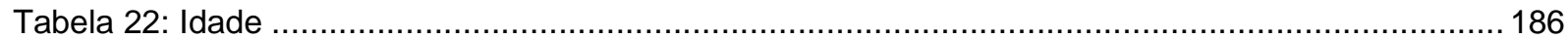

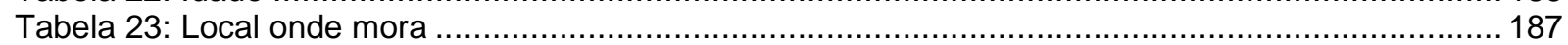

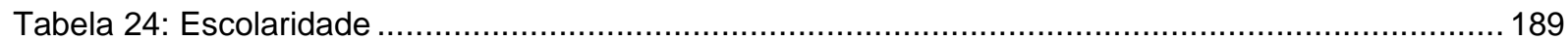

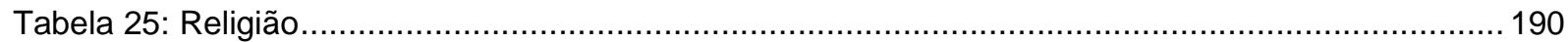

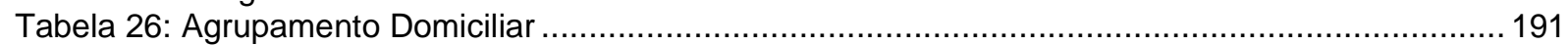

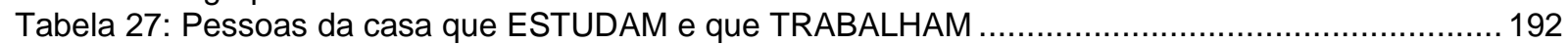

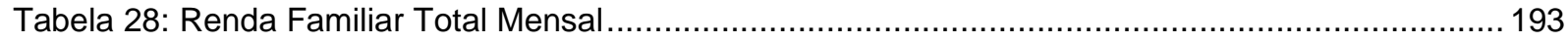

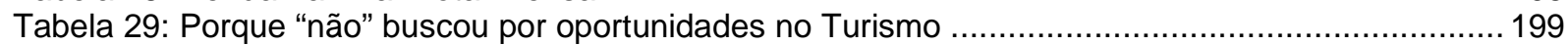

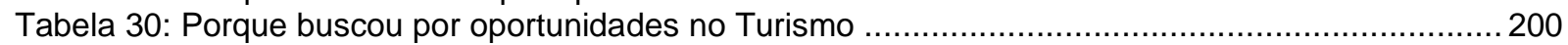

Tabela 31: Fatores de inclusão direta na visão dos incluídos e da população .......................................203

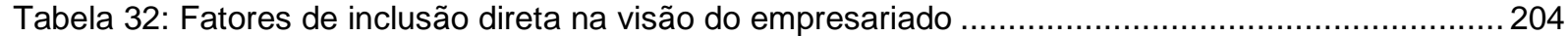

Tabela 33: Fatores avaliados por função na visão do empresariado (A) ...........................................2207

Tabela 34: Fatores avaliados por função na visão do empresariado (B) ........................................... 209

Tabela 35: Fatores avaliados por função na visão do empresariado (C) ...........................................210

Tabela 36: Fatores avaliados por função na visão do empresariado (D)............................................2. 212

Tabela 37: Fatores avaliados por função na visão do empresariado (E) ..........................................213

Tabela 38: Fatores avaliados por função na visão do empresariado (F) .........................................2 214

Tabela 39: Origem dos funcionários por função (Barreirinhas) .....................................................2219

Tabela 40: Origem dos funcionários por função (Jijoca de Jericoacoara) .........................................220

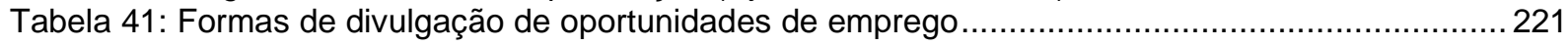

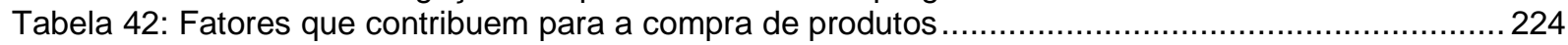




\section{LISTA DE QUADROS}

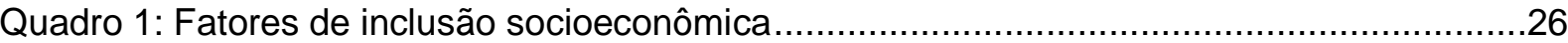

Quadro 2: Limites territoriais de Barreirinhas e de Jijoca de Jericoacoara ..............................31

Quadro 3: Características das Unidades de Conservação estudadas.....................................44

Quadro 4: Características ambientais da região dos Parques Nacionais estudados .................54

Quadro 5: Principais lagoas de Jericoacoara e dos Lençóis Maranhenses .............................57

Quadro 6: Marcos históricos das reflexões sobre sustentabilidade ....................................116

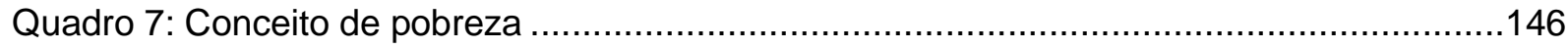

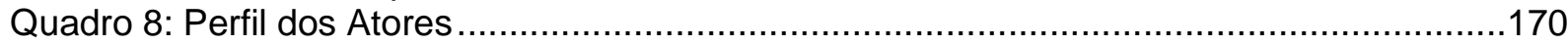

Quadro 9: Fatores de Inclusão Socioeconômica "Direta" ...................................................173

Quadro 10: Fatores de Inclusão Socioeconômica "Indireta" ..................................................177

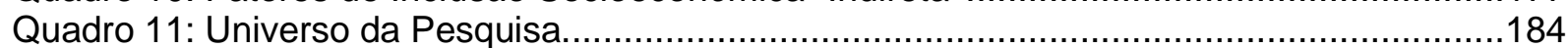

Quadro 12: Fatores de maior contribuição para a inclusão socioeconômica direta .................243

Quadro 13: Fatores de maior contribuição por função......................................................244

Quadro 14: Fatores de maior contribuição para a inclusão socioeconômica indireta ..............247 


\section{LISTA DE GRÁFICOS}

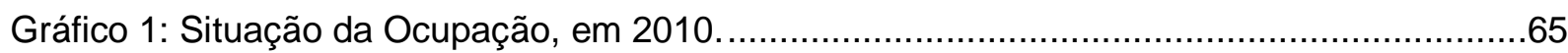

Gráfico 2: Empregos Formais por Segmentos de Abrangência............................................69

Gráfico 3: Situação relativa de Barreirinhas - MA (IDHM e IFDM) ..........................................79

Gráfico 4: Situação relativa de Jijoca de Jericoacoara - CE (IDHM e IFDM) ..........................79

Gráfico 5: Evolução dos Componentes do IDHM (Barreirinhas) ............................................80

Gráfico 6: Evolução dos Componentes do IDHM (Jijoca de Jericoacoara) ..............................81

Gráfico 7: Evolução dos Componentes do IFDM (Barreirinhas) ...........................................82

Gráfico 8: Evolução dos Componentes do IFDM (Jijoca de Jericoacoara) .............................82

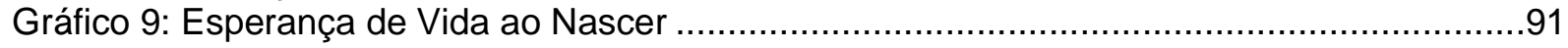

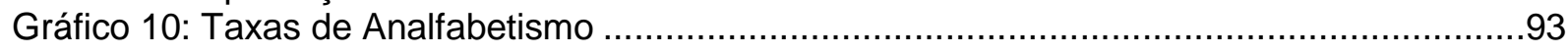

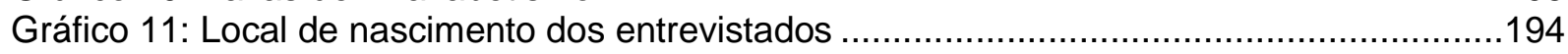

Gráfico 12: Tempo morando nos municípios estudados...................................................195

Gráfico 13: Participação dos entrevistados em cooperativas ou associações .........................196

Gráfico 14: Tipos de Associações e Cooperativas que os entrevistados participam ...............196

Gráfico 15: Segmentos Sociais dos entrevistados .........................................................197

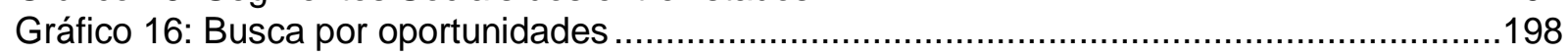

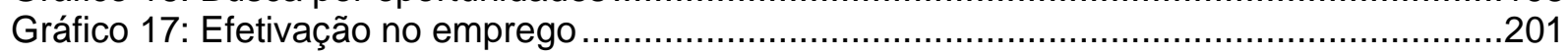

Gráfico 18: Fatores de maior e menor contribuição na visão do empresariado (DIRETA) ........206

Gráfico 19: Fatores que prejudicaram a inclusão direta ...................................................215

Gráfico 20: Funções dos entrevistados do trade turístico ..................................................216

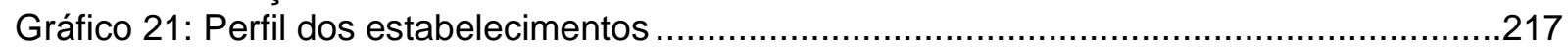

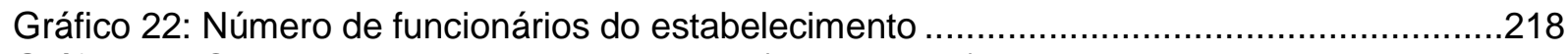

Gráfico 23: Origem dos produtos consumidos (Barreirinhas) ...........................................222

Gráfico 24: Origem dos produtos consumidos (Jijoca de Jericoacoara) ..............................223

Gráfico 25: Fatores de maior e menor contribuição na visão do empresariado (INDIRETA) ...225 


\section{LISTA DE BOXES}

Box 1: Definição de "População Economicamente Ativa" (PEA) …..........................................72

Box 2: Definição de "População Não Economicamente Ativa" (PNEA) ....................................72

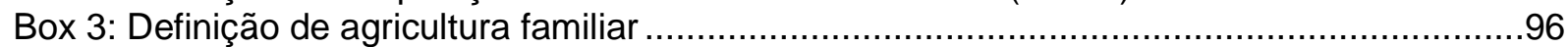

Box 4: Definição de destino turístico (grifo do autor) ......................................................102

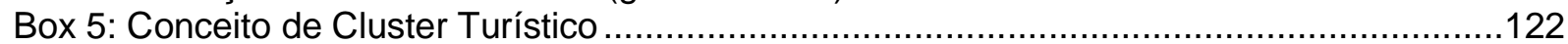

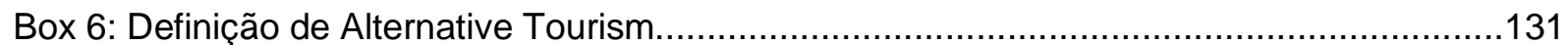

Box 7: Definição de Responsible Tourism......................................................................139 


\section{LISTA DE ABREVIATURAS E SIGLAS}

ACT - Atividades Características do Turismo

AECID - Agência Espanhola de Cooperação Internacional para o Desenvolvimento

Al - Área de Influência

Aprece - Associação dos Prefeitos do Estado do Ceará

BNDES - Banco Nacional de Desenvolvimento Econômico e Social

CAEMA - Companhia de Água e Esgoto do Maranhão

CAGED - Cadastro Geral de Empregados e Desempregados

CBC - Capital Brasileira da Cultura

CCP - Classificação Central de Produtos

CDS - Centro de Desenvolvimento Sustentável

CEAPE - Centro de Apoio dos Pequenos Empreendimentos

CMMAD - Comissão Mundial sobre Meio Ambiente e Desenvolvimento

CNI - Confederação Nacional das Indústrias

CNM - Confederação Nacional de Municípios

CNUMAH - Conferência das Nações Unidas sobre Meio Ambiente Humano

Cnumad - Conferência das Nações Unidas para o Meio Ambiente e o Desenvolvimento

COPPE - Instituto Alberto Luiz Coimbra de Pós-graduação e Pesquisa de Engenharia

CPT - Cadeia Produtiva do Turismo

DS - Desenvolvimento Sustentável

EEP - Empregado em empresa privada

Embratur - Instituto Brasileiro de Turismo

ENEM - Exame Nacional do Ensino Médio

FAPEC - Fundação de Apoio à Pesquisa, ao Ensino e à Cultura

FIPE - Fundação Instituto de Pesquisas Econômicas

FNDE - Fundo Nacional de Desenvolvimento da Educação

IABS - Instituto Ambiental Brasil Sustentável

IBAMA - Instituto Brasileiro do Meio Ambiente e dos Recursos Naturais Renováveis

IBGE - Instituto Brasileiro de Geografia e Estatística

ICMBio - Instituto Chico Mendes de Conservação da Biodiversidade

IDH - Índice de Desenvolvimento Humano

IFDM - Índice Firjan de Desenvolvimento Municipal

INEP - Instituto Nacional de Estudos e Pesquisas Educacionais Anísio Teixeira

INSS - Instituto Nacional do Seguro Social

Ipea - Instituto de Pesquisa Econômica Aplicada

ISPN - Instituto Sociedade, População e Natureza

ITCP - Incubadora Tecnológica de Cooperativas Populares

LETS - Laboratório de Estudos em Turismo e Sustentabilidade

MEC - Ministério da Educação

MDS - Ministério do Desenvolvimento Social e Combate a Fome

MS - Ministério da Saúde

MTE - Ministério do Trabalho e Emprego

MTur - Ministério do Turismo

UC - Unidade de Conservação

UNESCO - United Nations Educational, Scientific and Cultural Organization

UNWTO - World Tourism Organization

OCDE - Organização de Cooperação e de Desenvolvimento Econômico

OIT - Organização Internacional do Trabalho

OMT - Organização Mundial do Turismo

ONG - Organização Não Governamental

PAA - Programa de Aquisição de Alimentos

PBF - Programa Bolsa Família

PEA - População Economicamente Ativa

PETROBRAS - Petróleo Brasileiro S. A.

PIA - População em Idade Ativa

PIB - Produto Interno Bruto

PNAD - Pesquisa Nacional por Amostra de Domicílios

PNAE - Programa Nacional de Alimentação Escolar

PNEA - População Não Economicamente Ativa 
PNLM - Parque Nacional dos Lençóis Maranhenses

PNMT - Programa Nacional de Municipalização do Turismo

PNT - Política Nacional de Turismo

PNUD - Programa das Nações Unidas para o Desenvolvimento

Pronatec - Programa Nacional de Acesso ao Ensino Técnico e Emprego

RAIS - Relação Anual de Informações Sociais

SEBRAE - Serviço Brasileiro de Apoio às Micro e Pequenas Empresas

SETUR - Secretaria de Turismo

SIE - Serviço de Inspeção Estadual

SIF - Serviço de Inspeção Federal

SIM - Serviço de Inspeção Municipal

SNUC - Sistema Nacional de Unidades de Conservação da Natureza

SPLT - Sistema Produtivo Local de Turismo

SPSS - Statistical Package for the Social Sciences

ST-EP - Sustainable Tourism Eliminating Poverty

SUS - Sistema Único de Saúde

UFMA - Universidade Federal do Maranhão

UnB - Universidade de Brasília

UFRJ - Universidade Federal do Rio de Janeiro

WTTC - World Travel Tourism Council

WWF - World Wildlife Fund

ZA - Zona de Amortecimento 
SUMÁRIO

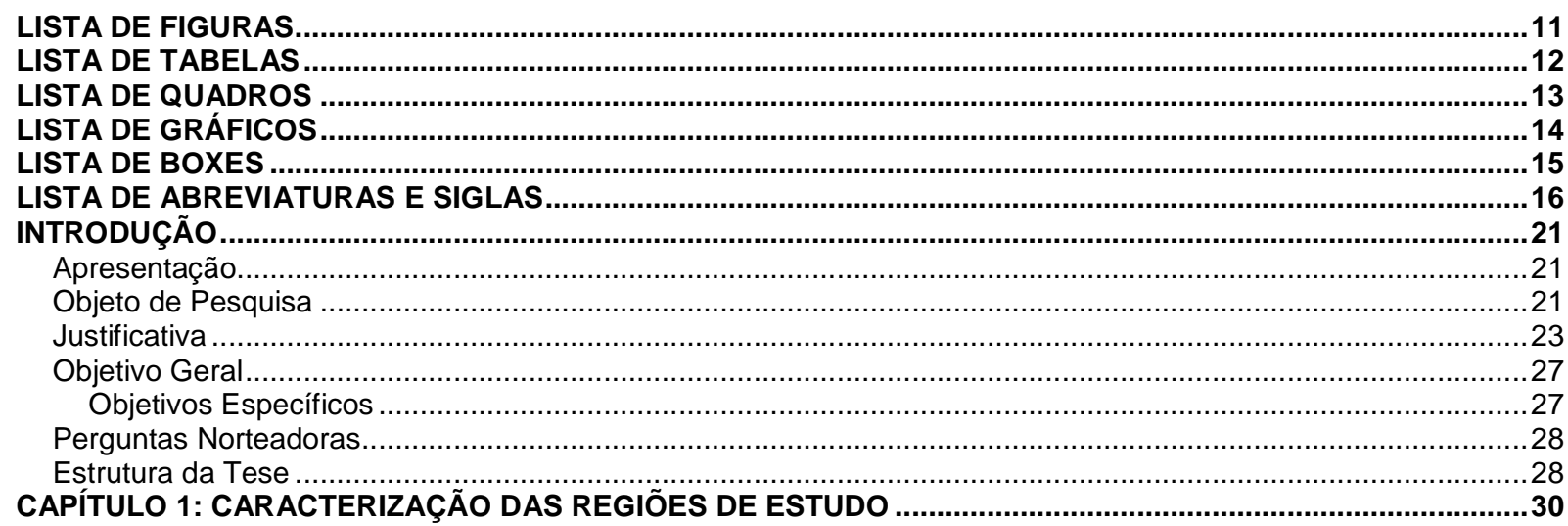

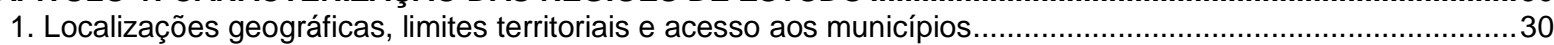

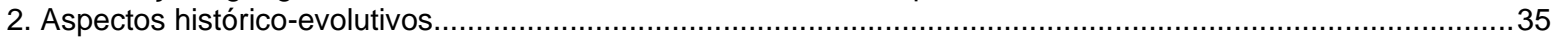

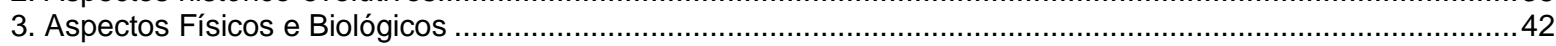

3.1. Parque Nacional dos Lençóis Maranhenses e Parque Nacional de Jericoacoara ................................42

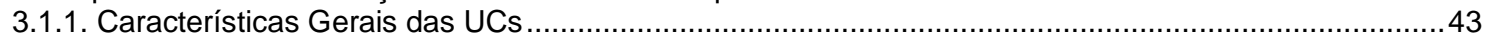

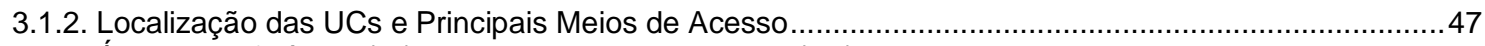

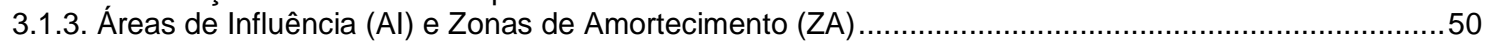

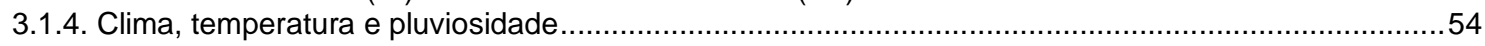

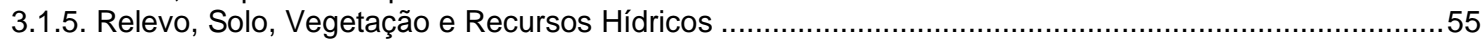

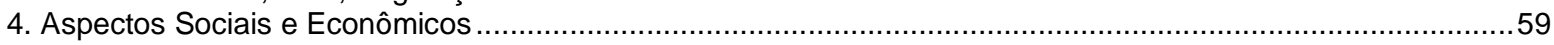

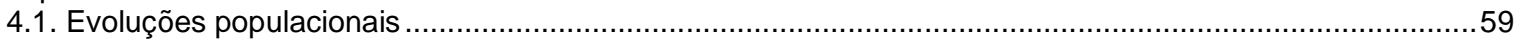

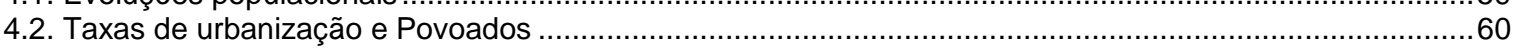

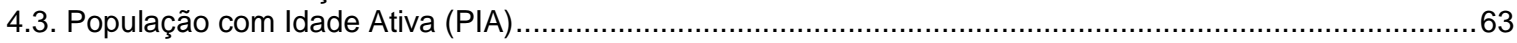

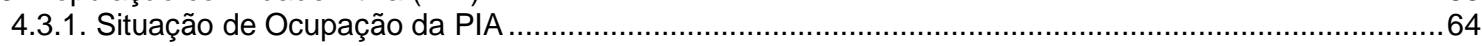

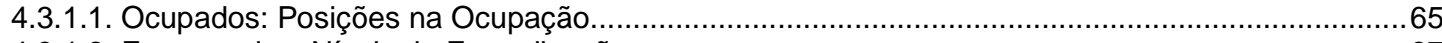

4.3.1.2. Empregados: Níveis de Formalização .............................................................................67

4.3.1.3. Empregados: Segmentos de Abrangência e Remuneração Média ...........................................68

4.3.1.4. Empregados: Gênero e Idade nos Principais Segmentos ....................................................69

4.3.1.5. Empregados: Ocupações com Maiores Estoques ............................................................. 70

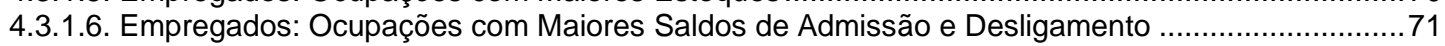

4.3.2. Condição de Atividade da PIA ...........................................................................................72

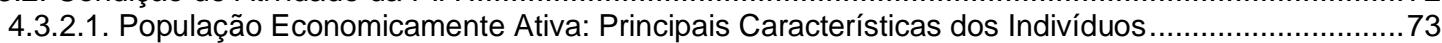

4.3.2.2. População Economicamente Ativa: Classes de Rendimento Nominais Mensais ...............................74

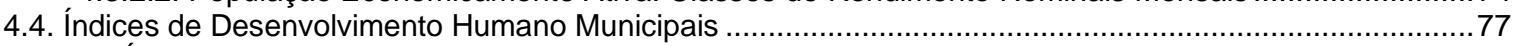

4.4.1. Índices Consolidados e Classificações nos Rankings Nacional e Estadual .......................................78

4.4.2. Evolução dos Componentes (Saúde/Longevidade, Educação, Emprego e Renda) .............................8 80

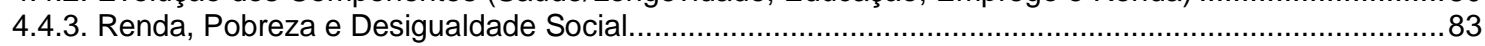

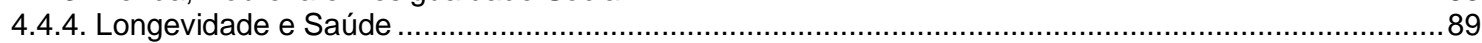

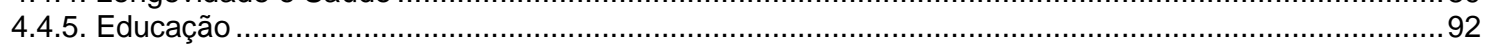

4.5. Produto Interno Bruto (PIB) e Principais Atividades Econômicas........................................................94

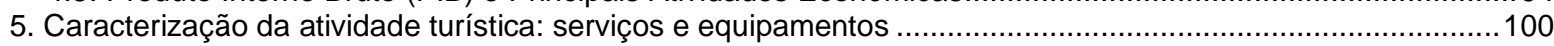

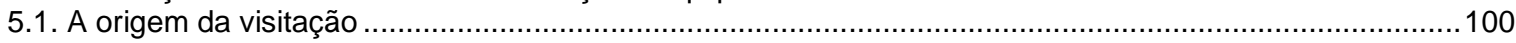

5.2. O advento dos serviços de suporte da atividade turística ...........................................................101

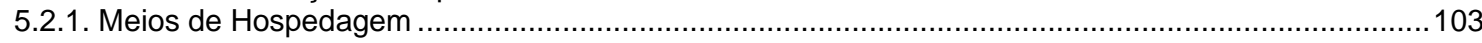

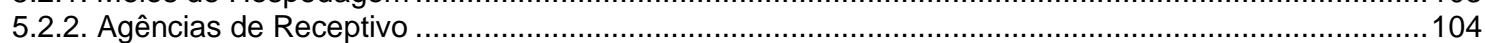

5.2.3. Estabelecimentos de alimentação turística ...................................................................... 105

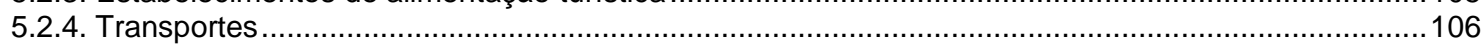

5.3. Os grupos organizados de produção e de prestação de serviços ....................................................110

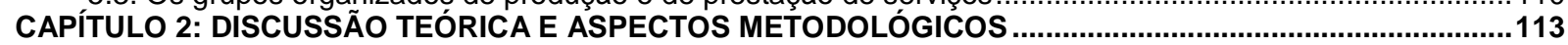

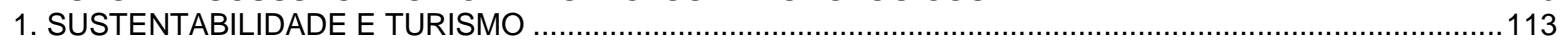

1.1. Sustentabilidade: a ascensão do debate ..............................................................................113

1.2. Turismo: concepções epistemológicas de um sistema complexo ......................................................117

1.3. Turismo Sustentável: o nascimento de uma nova perspectiva .......................................................128

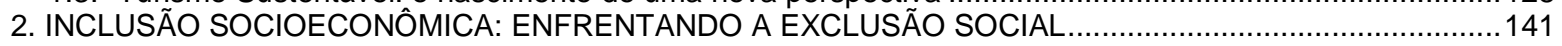


2.1. Inclusão Socioeconômica Direta: o pleno emprego e o trabalho decente ............................................. 149

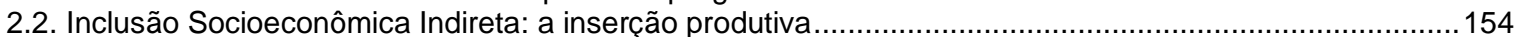

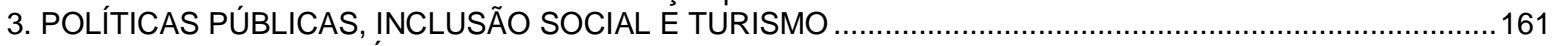

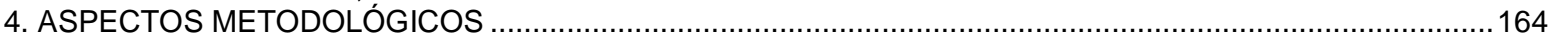

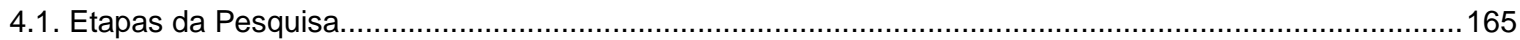

4.1.1. Etapa 01: Caracterização das Regiões Estudadas ...............................................................165

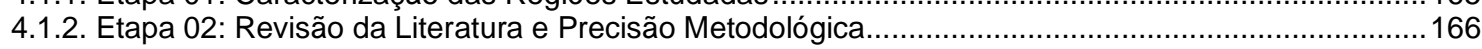

4.1.3. Etapa 03: Planejamento do Trabalho de Campo ................................................................. 166

4.1.4. Etapa 04: Realização do Trabalho de Campo ............................................................................ 167

4.1.5. Etapa 05: Sistematização e Análise do Dados Obtidos ............................................................168

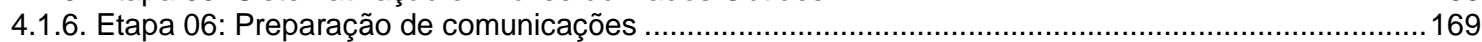

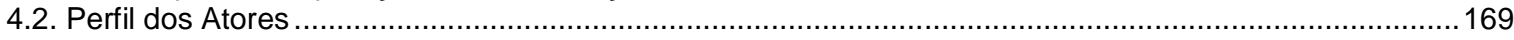

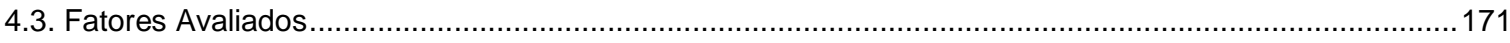

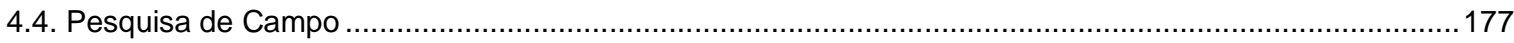

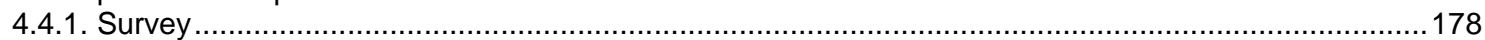

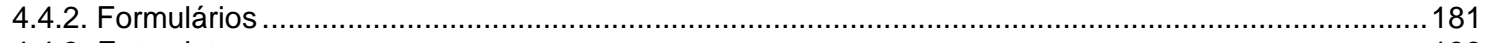

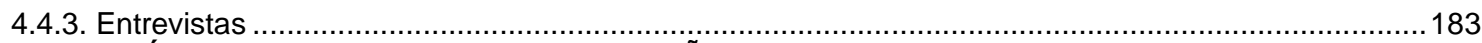

CAPÍTULO 3: ANÁLISE DOS RESULTADOS E REFLEXÃO............................................................................184

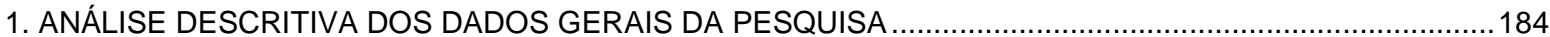

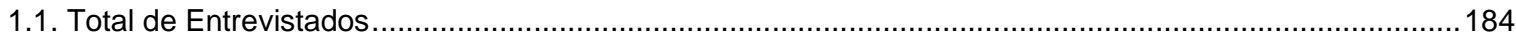

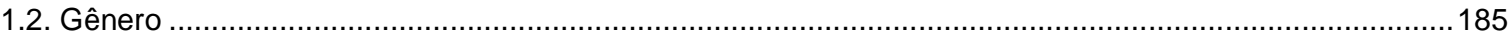

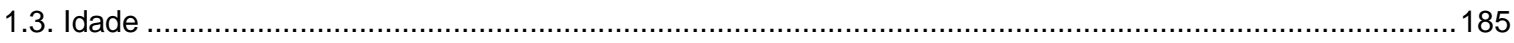

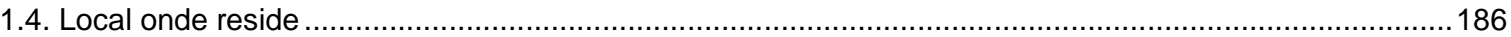

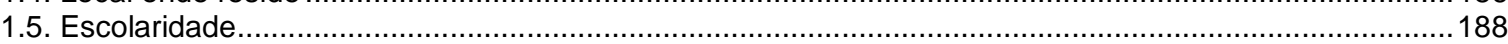

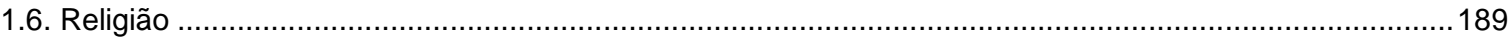

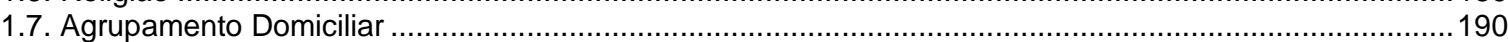

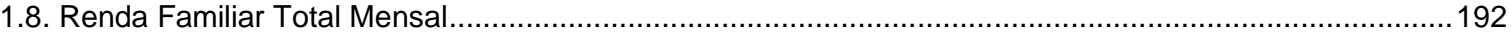

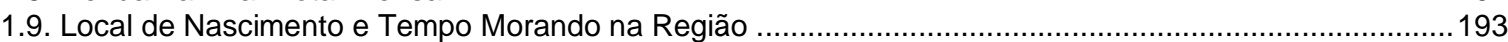

1.10. Participação em grupos organizados (cooperativas e associações) ................................................ 195

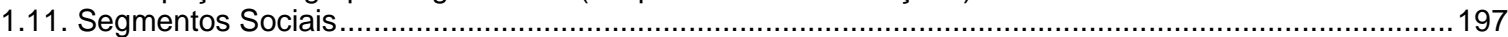

1.12. Busca por Oportunidades de Emprego no Turismo ...............................................................198

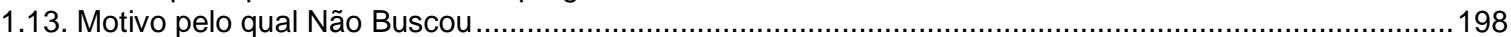

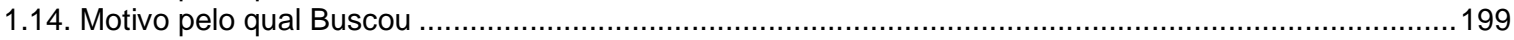

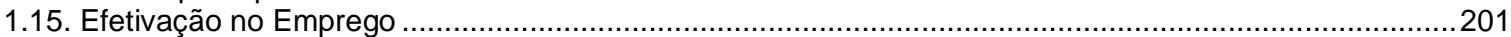

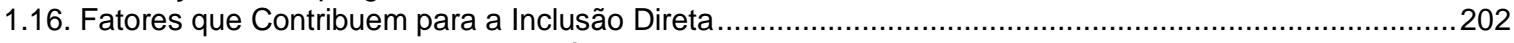

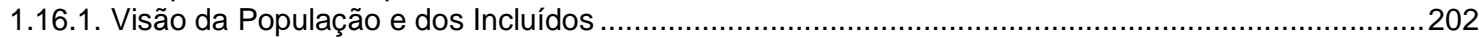

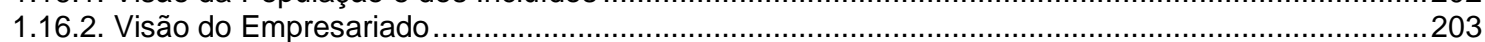

(A) Fatores diversos: apresentados pelos empresários..................................................................203

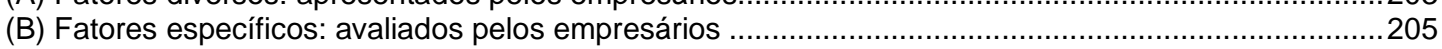

(C) Fatores específicos por função: avaliados pelos empresários ...............................................206

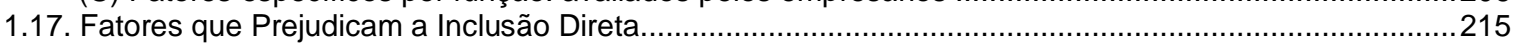

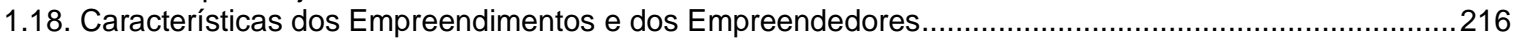

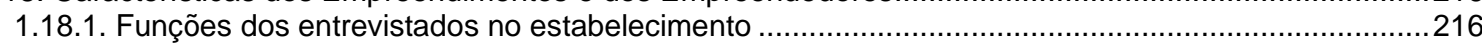

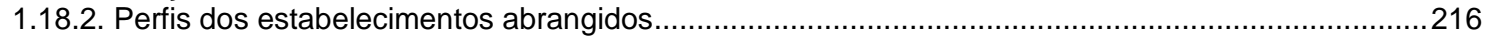

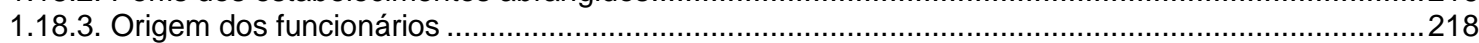

1.18.4. Formas de divulgação de oportunidades de emprego .......................................................220

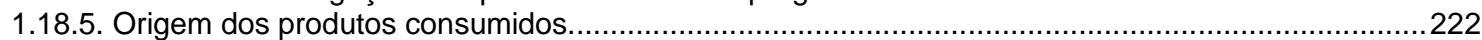

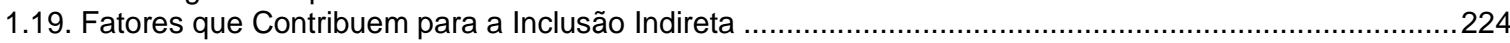

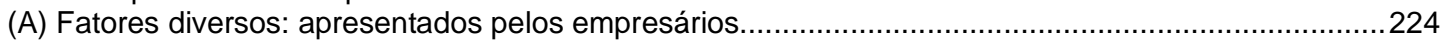

(B) Fatores específicos: avaliados pelos empresários ..............................................................22

(C) Fatores diversos: apresentados pelos grupos organizados locais .............................................226

(D) Fatores específicos: avaliados pelos grupos organizados locais .................................................229

2. ANÁLISE ESTATÍSTICA PELA MODELAGEM DA REGRESSÃO LOGÍSTICA.......................................231

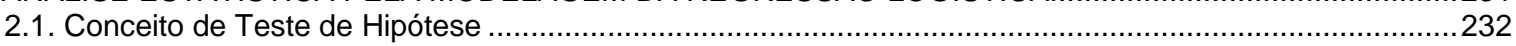

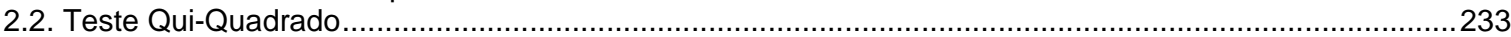

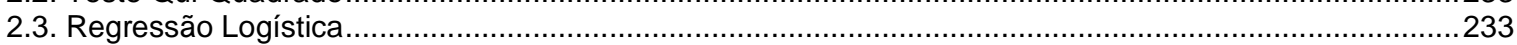

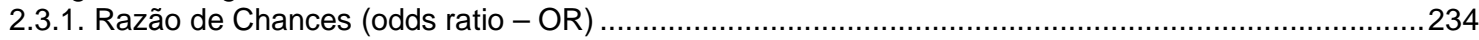

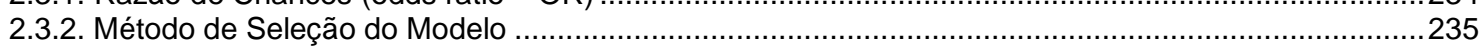

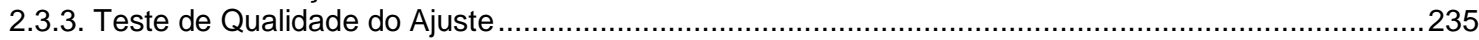

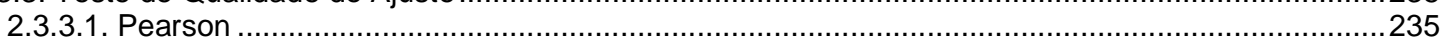

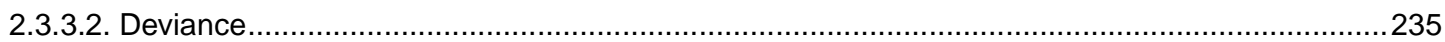




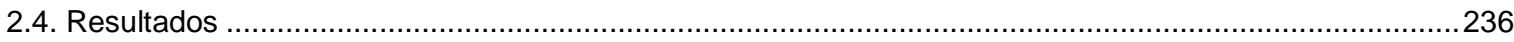

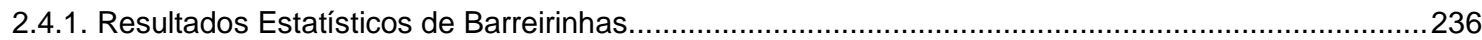

2.4.2. Resultados Estatísticos de Jijoca de Jericoacoara ...................................................................239

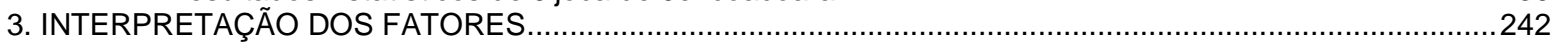

3.1. Interpretação dos fatores de inclusão socioeconômica direta ..........................................................242

3.2. Interpretação dos fatores de inclusão socioeconômica indireta .........................................................245

3.3. Classificação dos fatores conforme o grau de contribuição ..........................................................250

3.3.1. Classificação dos fatores de inclusão socioeconômica direta.....................................................251

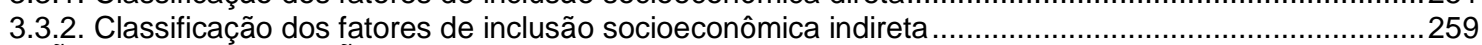

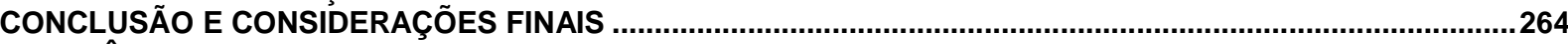

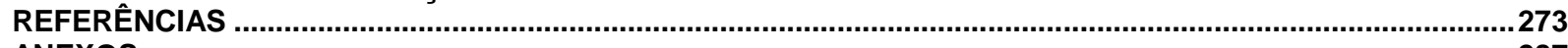

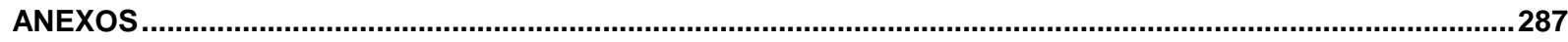

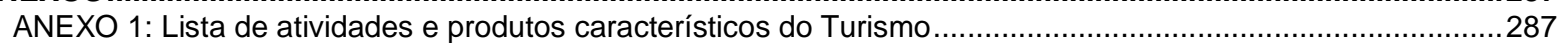

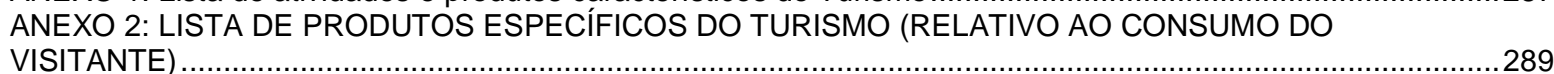

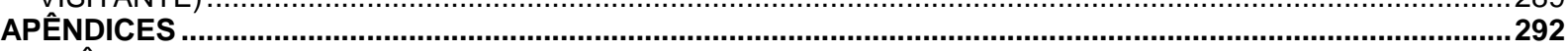

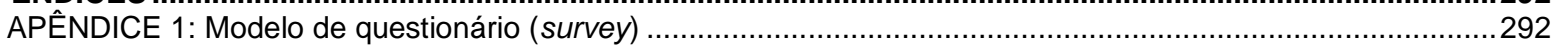

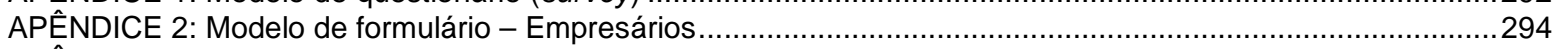

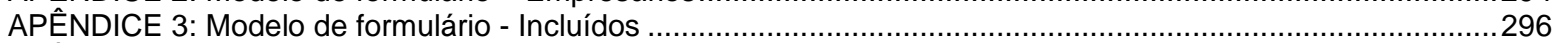

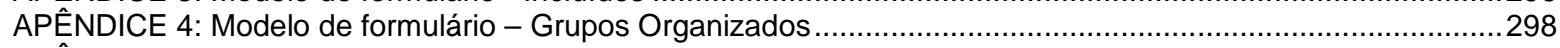

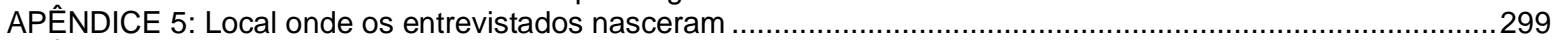

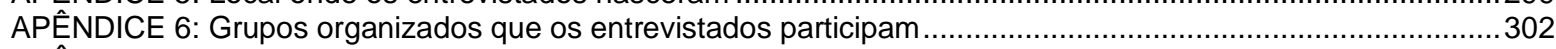

APÊNDICE 7: Avaliação dos fatores de inclusão direta (empresários) ........................................................304

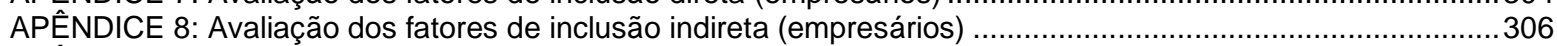

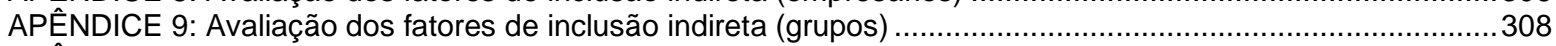

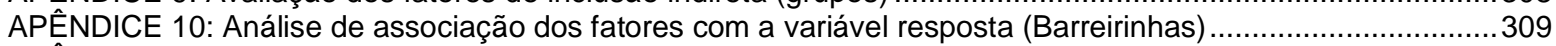

APÊNDICE 11: Análise de associação dos fatores com a variável resposta (Jijoca de Jericoacoara)..................310 


\section{INTRODUÇÃO}

\section{Apresentação}

O interesse pela temática de pesquisa da presente Tese de Doutorado emergiu de três momentos distintos. Num primeiro momento, da experiência adquirida pelo autor com o desenvolvimento de trabalhos técnicos no âmbito do "Projeto de Desenvolvimento do Turismo Sustentável". Este Projeto foi fruto de um acordo de cooperação entre o Ministério do Turismo (MTur) e a Agência Espanhola de Cooperação Internacional para o Desenvolvimento (Aecid), no qual teve o Instituto Ambiental Brasil Sustentável (IABS) como parceiro executor. As regiões abrangidas pelo Projeto foram: Lençóis Maranhenses, no Estado do maranhão; Delta do Parnaíba, e Serra da Capivara, no Estado do Piauí; e Jericoacoara, no Estado do Ceará.

O segundo momento se deu a partir da base de reflexão junto ao Laboratório de Estudos de Turismo e Sustentabilidade (LETS), vinculado ao Centro de Desenvolvimento Sustentável da Universidade de Brasília (CDS/UnB). Formado por docentes (de graduação e de pós-graduação) e discentes (de mestrado, doutorado e pós-doutorado) o grupo se apresentou como peça fundamental nos processos de construção da ideia central da Tese, por meio de discussões sobre as múltiplas abordagens teóricas, conceituais e metodológicas, e de significativas contribuições a partir da vivência de alguns integrantes nas áreas definidas para este estudo.

O terceiro e último momento, talvez de maior produtividade e direcionamento, partiu do trabalho de dissertação de mestrado do próprio autor, tratando da mesma temática - "inclusão socioeconômica" - porém, com um escopo menos abrangente. A partir dessa oportunidade, criouse o interesse pela ampliação da discussão, trazendo uma nova vertente de estudo (inclusão socioeconômica "indireta"), e um novo destino turístico (Jericoacoara), a fim de realizar uma análise comparativa, e o retorno às importantes questões suscitadas no trabalho anterior.

\section{Objeto de Pesquisa}

A Tese de Doutorado, ora apresentada, aborda a relação entre o alto nível de incidência da pobreza e baixos índices de emprego e renda nos municípios de Barreirinhas (MA) e de Jijoca de Jericoacoara (CE), e as potencialidades turísticas dessas regiões.

O seu objeto de pesquisa concentrou-se no estudo sobre os fatores que influem, de maneira positiva ou negativa, sobre a inclusão socioeconômica, direta e indireta, de habitantes 
de destinos turísticos no sistema produtivo local do turismo (SPLT), seja pelo emprego, seja pela geração de renda (comercialização).

Foram selecionados dois municípios, ambos da região Nordeste brasileira, para a realização da pesquisa e futura análise comparativa: Barreirinhas, no Estado do Maranhão, e Jijoca de Jericoacoara, no Estado do Ceará.

Definiu-se pelo estudo dessas localidades a partir de alguns aspectos - positivos e negativos - comuns às mesmas. Dentre os aspectos positivos, destaca-se a presença de unidades de conservação em suas áreas territoriais, representadas pelos Parques Nacionais ${ }^{1}$ dos Lençóis Maranhenses e de Jericoacoara, cenários naturais singulares. É notória a atratividade turística gerada por essas potencialidades desses destinos.

Jericoacoara, por exemplo, foi classificado como o $8^{\circ}$ destino turístico mais procurado do Brasil em 2013, pela Travelers' Choice Destinations (O POVO, 2013). Anteriormente, no ano de 1987, havia sido citada como uma das melhores praias do mundo, pelo artigo publicado no Post Travel Magazine, do Jornal norte-americano "The Washington Post" (THE WASHINGTON POST, 1987). Os Lençóis Maranhenses, por sua vez, têm se destacado, dentre outras coisas, por integrar a "Rota das Emoções" - roteiro formado por Jericoacoara (CE), Delta do Parnaíba (PI), e Lençóis Maranhenses (MA) -, premiada em $1^{\circ}$ lugar, em 2009, pelo Ministério do Turismo, como o melhor roteiro de viagens do Brasil (TERRA, 2009).

Por outro lado, no que se refere aos aspectos negativos, as amplas taxas de incidência da pobreza são características também comuns aos dois destinos. Essas taxas ultrapassam os $50 \%$ das populações, em cada localidade. Da mesma forma, os indicadores de emprego e renda atestam um cenário de reais problemas socioeconômicos nos dois municípios. Dentre os indicadores avaliados pelo índice de desenvolvimento municipal - saúde, educação, e emprego e renda - estes últimos são os de pior desempenho, considerados de baixo desenvolvimento.

Diante da contradição entre a grande disponibilidade de recursos naturais para aproveitamento sustentável e para o desenvolvimento includente das localidades, e o quadro de ampla pobreza e de baixo rendimento socioeconômico de grande parte dos habitantes dos destinos, pergunta-se: em que medida a dinâmica do turismo em tais localidades permite ou não a inclusão socioeconômica dos habitantes no SPLT. Por que alguns conseguem se inserir e

\footnotetext{
${ }^{1}$ Serão utilizadas no texto as abreviações "Parna" ou "PN" para referir-se à nomenclatura "Parque Nacional".
} 
outros não? Quais os fatores que contribuem para essa inclusão socioeconômica? E como ela ocorre?

\section{Justificativa}

Fatores de inclusão socioeconômica no SPLT são aqui entendidos como todo elemento que, contribuindo ou impedindo, acaba por criar forte influência sobre a participação efetiva de atores locais nos benefícios econômicos decorrentes da atividade turística. No caso, atores são considerados todos os indivíduos, grupos ou organizações que têm identidade própria, que são reconhecidos por outros, e que têm capacidade de agir e influenciar o seu contexto (NASCIMENTO, 1989).

A discussão sobre os fatores de inclusão socioeconômica no turismo tem notória relevância para a formulação de políticas públicas voltadas ao combate à exclusão social, sobretudo quando existe uma preocupação quanto à sua efetividade. Não havendo um conhecimento preciso dos fatores que influem sobre a inserção de habitantes de destinos turísticos no sistema produtivo do setor, as medidas governamentais acabam por não edificar estratégias e, consequentemente, produzem resultados ineficazes quanto à inclusão socioeconômica.

Dessa constatação decorre a relevância do objeto de estudo. E isso se fortalece se notarmos que o turismo no Brasil, segundo dados do Ministério do Turismo (BRASIL, 2013c):

(a) representou, em 2013, 3,7\% do Produto Interno Bruto (PIB) da economia brasileira;

(b) teve um crescimento de 32,4\%, entre 2003 e 2009, superior aos $24,6 \%$ da expansão da economia brasileira;

(c) gerou, até o final de 2012, 8,04 milhões de empregos diretos e indiretos, o que representa $8,3 \%$ do total de empregos no país;

(d) garantiu, em 2012, $R \$ 11,2$ bilhões em financiamentos concedidos por instituições financeiras oficiais ${ }^{2}$, representando um crescimento de $923,60 \%$ no volume de crédito destinado ao setor, em relação à 2003;

(e) ganhou destaque internacional pela realização de grandes eventos esportivos, como a Copa das Confederações em 2013, e a Copa do Mundo FIFA 2014;

\footnotetext{
2 Banco Nacional do Desenvolvimento Econômico e Social (BNDES), Banco do Brasil S/A (BB), Caixa Econômica Federal (CAIXA), Banco da Amazônia (BASA), e Banco do Nordeste (BNB).
} 
(f) é beneficiado por uma ampla biodiversidade e pelos 67 parques nacionais abertos à visitação, que fazem com que o Brasil seja reconhecido pelo Fórum Econômico Mundial como a maior potência do planeta em recursos naturais.

Em contrapartida, grande parte das populações residentes em destinos turísticos brasileiros (dentre eles, Jericoacoara e Lençóis Maranhenses) parece não ter tido participação, efetiva, nos reais benefícios econômicos decorrentes da dinamização desse setor.

Tal fato vai ao encontro do que é sinalizado pela literatura científica na qual se reforça que as atividades turísticas têm beneficiado de maneira desigual as populações locais (CORIOLANO, 2005, 2009; COSTA, 2009; IRVING, 2003, 2006; IRVING et al, 2005; KRIPPENDORF, 2001; CLARKE, 1997; SHARPLEY, 2000). Os destinos turísticos selecionados correspondem a essa assertiva na medida em que são caracterizados por uma ampla taxa de incidência da pobreza, baixos rendimentos econômicos de grande parte dos habitantes locais, e lacunas substanciais no que se refere aos indicadores de emprego e renda.

Em Barreirinhas e Jijoca de Jericoacoara, se considerada apenas a População Economicamente Ativa (PEA), do total da População em Idade Ativa (PIA), pode-se identificar que $77,4 \%$ e $71,5 \%$ desses indivíduos, respectivamente a cada município, possuem um rendimento inferior à um salário mínimo (IBGE, 2013).

Analisadas as taxas de incidência da pobreza, dos mesmos municípios, percebe-se que as mesmas ultrapassam os $50 \%$ do total das populações locais, perfazendo $53,46 \%$ em Jijoca de Jericoacoara, e 57,65\% em Barreirinhas (IBGE, 2013).

Os índices de desenvolvimento municipais, referentes ao ano de 2010, reforçam esse quadro negativo. Em ambos municípios, dentre todos os componentes analisados ("saúde", "educação" e "emprego e renda"), é justamente este último o indicador com pior rendimento, classificado, tanto em Barreirinhas como em Jijoca de Jericoacoara, como de baixo desenvolvimento, como mostra a Tabela 1 a seguir. 
Tabela 1: Índice FIRJAN de Desenvolvimento Municipal - IFDM (2010) ${ }^{3}$

\begin{tabular}{l|c|c|c|c}
\hline \multirow{2}{*}{ MUNICÍPIO } & IFDM & \multicolumn{3}{|c}{ ÁREAS DE DESENVOLVIMENTO } \\
\cline { 3 - 5 } & TOTAL & Educação & Saúde & Emprego e Renda \\
\hline Barreirinhas & 0.5466 & 0.5899 & 0.6583 & 0.3916 \\
\hline Jijoca de Jericoacoara & 0.6921 & 0.8174 & 0.8937 & 0.3652 \\
\hline
\end{tabular}

Fonte: Sistema FIRJAN (2013).

É importante destacar que o turismo não é tratado neste estudo como a atividade econômica responsável pela perpetuação destes baixos índices de desenvolvimento municipal, encontrados nos destinos estudados. Pelo contrário. Ele pode ser considerado, talvez, como o instrumento com maior capacidade de inverter esse quadro a partir da geração de trabalho, emprego e renda, de forma mais efetiva, para as comunidades locais.

Isso porque o setor de turismo é reconhecido como um segmento intensivo em mão de obra, que demanda um valor de produção para a geração de uma unidade de emprego notoriamente menor se comparado a outros setores econômicos, como a indústria têxtil, a construção civil e a siderurgia (FIPE, 2006). Mais do que isso. Tratam-se de destinos com significativa existência de equipamentos de acolhimento - como agências de recepção, hotéis, pousadas, resorts, restaurantes, lanchonetes e similares, entre outros - tanto para o aproveitamento responsável da mão de obra local, quanto para o estímulo às demais atividades produtivas locais, como a pesca artesanal, a agricultura familiar e $o$ artesanato.

Muitas são as discussões científicas sobre os impactos ambientais, sociais, econômicos e culturais, resultantes da dinamização do setor turístico em uma localidade. Entretanto, análises mais aprofundadas sobre os fatores que contribuem com tais impactos, dentre eles o de exclusão social, merecem o mesmo destaque.

Nesse sentido, reconhece-se a relevância de um estudo que não só amplie a discussão sobre os fatores que contribuem, ou que impedem, a inclusão socioeconômica de habitantes desses destinos no SPLT. Mas que, a partir de seus resultados, possa propor medidas alternativas, e mais eficazes, nos processos de implementação de políticas públicas locais de inclusão social que visem o combate às injustiças sociais junto aos grupos marginalizados. E não

\footnotetext{
${ }^{3}$ O IFDM é um estudo realizado anualmente pelo Sistema FIRJAN, tendo como base estatísticas públicas oficiais, disponibilizadas pelos Ministérios do Trabalho, da Educação e da Saúde. Varia de "0" a "1", sendo que quanto mais próximo de "1", mais desenvolvido é o município. Os componentes com níveis superiores à 0,8 pontos são considerados de "alto desenvolvimento". Entre 0,6 e 0,8 são classificados como de "desenvolvimento moderado". Entre 0,4 e 0,6, como de "desenvolvimento regular'. E abaixo de 0,4, como de "baixo desenvolvimento" (SISTEMA FIRJAN, 2013).
} 
apenas no setor de turismo, como em outros setores de serviços que careçam de melhor compreensão.

Os fatores de inclusão socioeconômica definidos para o estudo foram subdivididos em dois grupos: "diretos" e "indiretos" (ver Quadro 1). No primeiro grupo, destacam-se os fatores que possuem potencial para contribuir com, ou impedir, a inclusão dos habitantes locais, de forma direta, no mercado de trabalho do turismo. Ou seja, são características "do indivíduo" para a realização de funções com vínculo empregatício, como camareira, garçom/garçonete, recepcionista, serviços gerais, segurança, auxiliar de cozinha, dentre outros.

\section{Inclusão Socioeconômica "DIRETA"}

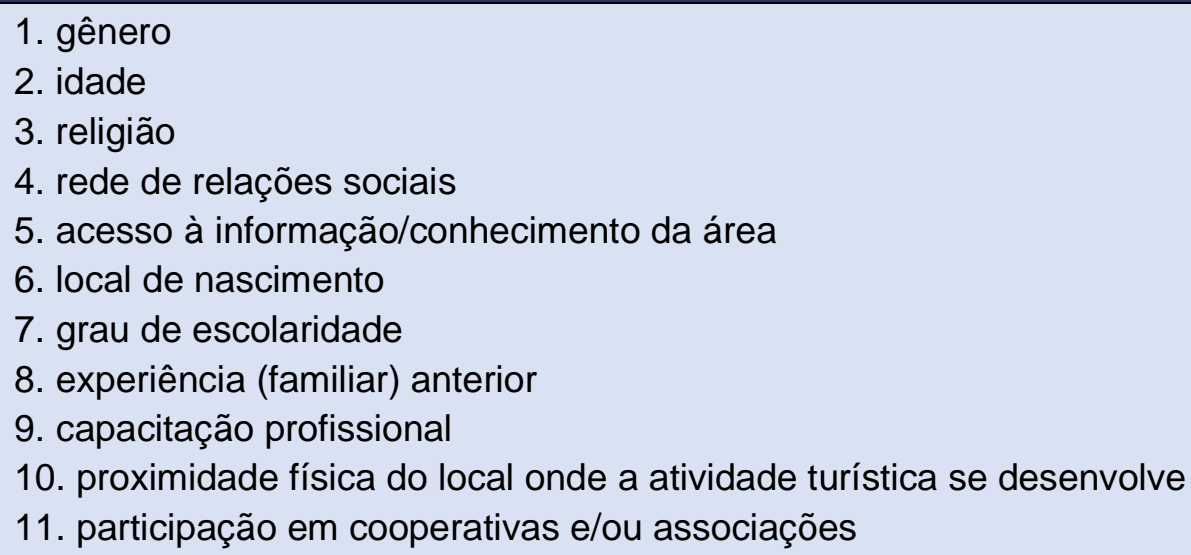

\section{Inclusão Socioeconômica "INDIRETA"}

1. problemas quanto à emissão de nota fiscal

2. problemas quanto à adequação da produção à sazonalidade do turismo

3. falta de capital de giro, de estrutura de beneficiamento e de local de estocagem

4. empecilhos quanto às condições de pagamento

5. insuficiência na produção para atendimento da demanda

6. indisponibilidade logística para o escoamento da produção

7. falta de capacitação profissional técnica e gerencial

8. fragilidade na organização coletiva do trabalho

9. dificuldades na obtenção de registros de serviços de inspeção sanitária (SIF / SIE / SIM)

\section{Quadro 1: Fatores de inclusão socioeconômica}

Fonte: próprio autor.

No segundo grupo, definiu-se por fatores com o mesmo potencial para contribuição ou impedimento, porém, para a inclusão indireta dos habitantes locais no SPLT, caracterizada pela prestação de serviços sem vínculo empregatício, divididos por duas ramificações: (a) pela 
comercialização de produtos locais, dentre alimentícios e artesanato; (b) pelo oferecimento de serviços específicos, como de motoristas de carros tracionados, guias turísticos, pilotos de embarcações, dentre outros. Ou seja, são características que se remetem, principalmente, aos "grupos (organizados) de trabalho".

É digno de nota que, no caso específico da venda de pescados, de produtos agrícolas e de artesanatos, buscou-se trabalhar os fatores que limitam ou contribuem para a comercialização "direta" entre a oferta (indivíduo e/ou grupos locais organizados) e a demanda (trade turístico).

Sabe-se que atravessadores possuem um papel de destaque - positivo e negativo - na cadeia produtiva como um todo, porém, que acabam por viabilizar rendimentos insuficientes aos pequenos produtores rurais. Dessa forma, não sendo entendido, nesta Tese, como uma estrutura de inclusão socioeconômica.

Ressalta-se que a terminologia central ("inclusão socioeconômica"), utilizada neste estudo, compreende o tratamento dos aspectos amplos da inclusão social, como a oferta acessível de equipamentos e serviços públicos (educação, saúde, habitação, cultura, etc.), porém, como pano de fundo. O âmago dos questionamentos e da análise está concentrado na vertente do avanço da renda individual, seja ela pelo pleno emprego, ou pela ocupação em atividades informais, como pela venda de produtos e/ou pelo oferecimento de serviços.

Espera-se que, a partir do estudo desses fatores, tais discussões possam contribuir com os processos de desenvolvimento turístico, acarretando melhorias nas condições de vida das comunidades locais por meio da geração de trabalho, emprego e renda e da distribuição mais equitativa dos benefícios econômicos decorrentes desse setor.

\section{Objetivo Geral}

O presente estudo teve como objetivo geral avaliar os fatores de inclusão socioeconômica (direta e indireta) de habitantes de dois destinos turísticos (Barreirinhas e Jijoca de Jericoacoara) no SPLT, e produzir insumos que contribuam para a formulação de políticas públicas mais eficazes.

\section{Objetivos Específicos}

Para a organização da estrutura de trabalho, e o direcionamento do arranjo metodológico, foram traçados cinco objetivos específicos: 
(1) Caracterizar o sistema produtivo local de turismo (SPLT) das regiões priorizadas, definindo a sua dinâmica e especificidades;

(2) Identificar quais, dentre os habitantes locais, estão incluídos ou não estão incluídos economicamente no SPLT, e a razão, forma e temporalidade de sua inclusão;

(3) Avaliar os fatores que mais influenciam os processos de inclusão socioeconômica no SPLT, considerando os aspectos econômicos, culturais, sociais, ambientais e políticos;

(4) Comparar as localidades investigadas em busca de fatores recorrentes e relevantes;

(5) Refletir sobre os fatores que as políticas públicas de inclusão social deveriam considerar para obter resultados mais satisfatórios.

\section{Perguntas Norteadoras}

O delineamento dos caminhos adotados neste trabalho segue as seguintes indagações, listadas abaixo:

1) Qual a atual situação socioeconômica dos municípios de suporte da atividade turística, dos destinos priorizados neste estudo, frente aos processos de desenvolvimento locais pautados no setor de turismo?

2) Como as comunidades locais visualizam a situação atual e como elas reagem às possíveis alternativas de inserção nos processos produtivos relativos ao turismo?

3) Quais são os fatores que contribuem (e como contribuem) para a inclusão socioeconômica de habitantes de destinos turísticos no sistema produtivo local do turismo?

4) A partir da identificação desses fatores, quais as contribuições do estudo para formulação de políticas públicas mais efetivas no sentido de assegurar a inclusão social e o turismo sustentável?

\section{Estrutura da Tese}

Pensando na melhor e mais clara apresentação dos dados e das informações gerais do estudo, a presente Tese foi estruturada em três capítulos, afora esta Introdução e a Conclusão.

O Capítulo I volta-se à caracterização multidimensional dos municípios em tela: Barreirinhas - MA e Jijoca de Jericoacoara - CE. As informações apresentadas nesse capítulo 
percorrem por segmentos socioeconômicos, histórico-evolutivos, territoriais e de acesso, infraestruturais, culturais, turísticos e ecológicos, todos de amplo interesse para a análise crítica das regiões dos destinos selecionados. São retratados os problemas e as potencialidades de cada localidade, buscando-se, a partir desse capítulo, descrever os cenários abrangidos pela Tese, e gerar discussões sobre as lacunas potenciais na interface entre os âmbitos sociais, econômicos e turísticos.

No Capítulo II são apresentadas discussões de ordem teórica e epistemológica com respeito aos conceitos centrais trabalhados nesta Tese, sejam eles: turismo sustentável; desenvolvimento local e sustentável; inclusão e exclusão social; inclusão socioeconômica; e sistema produtivo local de turismo. O intuito desse capítulo é o de discutir as diversas abordagens conceituais encontradas na literatura científica, criando uma base teórica que oriente a coleta de dados, apoie a análise e a interpretação, e sustente os argumentos do estudo, contribuindo para uma melhor compreensão da questão e a elaboração de insumos para futuras políticas públicas.

Complementa este capítulo a apresentação dos aspectos metodológicos e materiais utilizados para a construção desta Tese. Pretende-se deixar claro como foram planejadas, organizadas e realizadas as pesquisas de campo nos dois municípios, assim como seus limites de execução.

Já o terceiro e último capítulo (Capítulo III) apresenta a análise crítica das informações levantadas por meio de fontes secundárias e dos dados coletados nos trabalhos de campo. $O$ objetivo é apresentar e discutir os resultados da pesquisa, avaliando os fatores estudados, e apontando para novas perspectivas de inclusão socioeconômica em destinos turísticos brasileiros.

Ao final são apresentadas as considerações finais e as conclusões sobre a análise dos dados obtidos, classificando cada um dos fatores de inclusão socioeconômica (direta e indireta) de acordo com seu nível de influência, dentre "de forte probabilidade", "duvidoso", e "descartado".

O presente estudo, no entanto, não teve como objetivo definir relações causais entre fatores analisados e a inclusão legítima e propriamente dita. O esforço maior se concentrou na busca pelo reconhecimento dos fatores que gerem indícios de notória influência sobre a inclusão socioeconômica no SPLT, seja pela sua contribuição, seja pelo impedimento gerado. 


\section{CAPÍTULO 1: CARACTERIZAÇÃO DAS REGIÕES DE ESTUDO}

Neste primeiro capítulo serão apresentadas, de forma integrada e multidimensional, as características gerais sobre os dois municípios estudados, assim como os destinos turísticos dos quais fazem parte. Dentre outros, serão tratados aspectos histórico-evolutivos, socioeconômicos, territoriais e de acesso, infraestruturais, turísticos, culturais e ecológicos. Cada qual com subitens independentes.

O levantamento das informações, apresentadas a seguir, se deu por meio de pesquisas documentais e bibliográficas de fontes diversas. Foram encontrados dados relevantes em artigos de revistas científicas, teses de doutorado, dissertações de mestrado, livros, produtos de consultorias técnicas especializadas, e demais publicações, cujas temáticas voltavam-se às regiões priorizadas.

Todavia, os dados mais recentes, em especial os socioeconômicos, foram encontrados em páginas eletrônicas de órgãos, nacionais e internacionais, de válido reconhecimento científico, tais como o Instituto Brasileiro de Geografia e Estatística (IBGE), Programa das Nações Unidas para o Desenvolvimento (PNUD), Confederação Nacional dos Municípios (CNM), Ministério da Saúde (MS), Ministério do Trabalho e Emprego (MTE), Instituto de Pesquisa Econômica Aplicada (Ipea), Ministério da Educação (MEC), World Travel and Tourism Council (WTTC), World Tourism Organization (UNWTO), dentre outros.

A busca por informações resultou num melhor conhecimento do terreno de pesquisa, na identificação de lacunas potenciais nas localidades, e no diálogo com outros pesquisadores com projetos nas regiões, zelando sempre pela agregação de conhecimentos e experiências.

\section{Localizações geográficas, limites territoriais e acesso aos municípios}

Os municípios de Barreirinhas e de Jijoca de Jericoacoara, situados na região Nordeste brasileira, distanciam-se em cerca de $537 \mathrm{Km}$, considerando trajetos rodoviários regulares (DISTANCIA CIDADES.COM, 2013). Também podem ser encontrados caminhos alternativos, exclusivos para veículos tracionados - 4X4, com distâncias que podem chegar a $360 \mathrm{Km}$ (MORAIS BRITO VIAGENS E TURISMO, 2010).

Barreirinhas está localizado na Microrregião dos Lençóis Maranhenses, abrangida pela Mesorregião Norte Maranhense. Jijoca de Jericoacoara, por sua vez, pertence à Microrregião do 
Litoral de Camocim e Acaraú, contida na Mesorregião Noroeste Cearense. (CNM, 2013) - ver Figura 1.

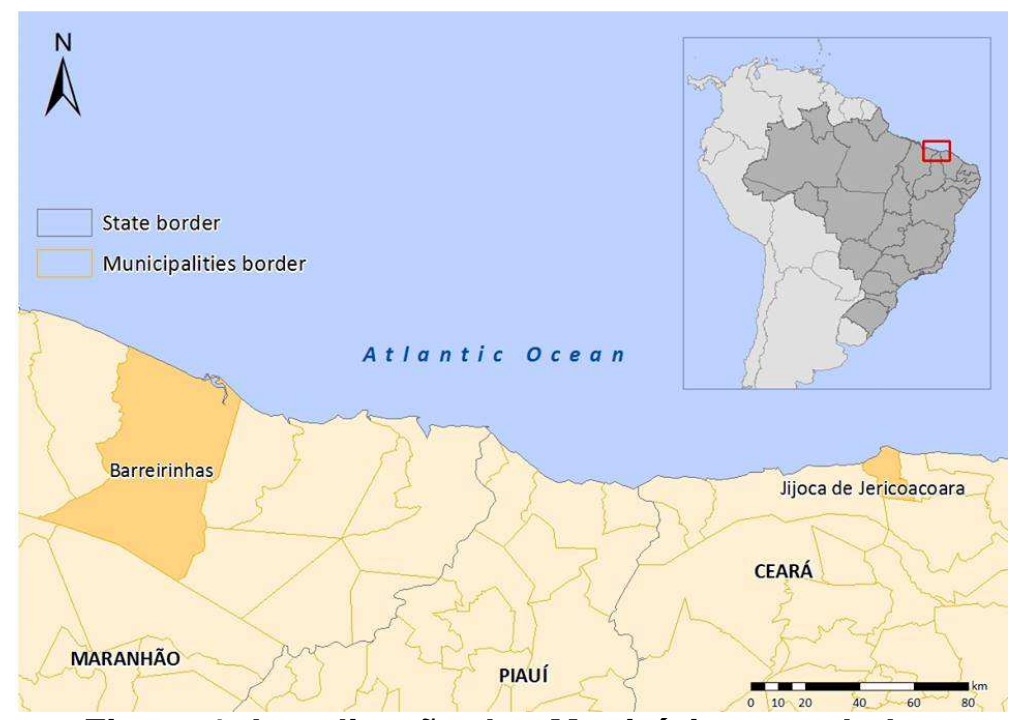

Figura 1: Localização dos Municípios estudados

Fonte: IBGE, 2010. Elaboração: Ana Pimenta Ribeiro.

As coordenadas geográficas de Barreirinhas e Jijoca de Jericoacoara são, respectivamente: $02^{\circ} 44^{\prime} 58^{\prime \prime}$ de Latitude Sul e $42^{\circ} 49^{\prime} 58^{\prime \prime}$ de Longitude Oeste / $02^{\circ} 48^{\prime} 2^{\prime \prime}$ de Latitude Sul e $40^{\circ} 30^{\prime} 36^{\prime \prime}$ de Longitude Oeste (DB CITY.COM).

Sobre as dimensões territoriais locais dos dois municípios, essas são claramente distintas. Barreirinhas possui uma área mais extensa, de $3.111,991 \mathrm{Km}^{2}$, enquanto que Jijoca de Jericoacoara conta com apenas $204,793 \mathrm{Km}^{2}$ (IBGE, 2013).

Ambos municípios possuem, ao Norte, o Oceano Atlântico como limite territorial. Os demais limites de cada município estão descritos, a seguir, no Quadro 2.

\begin{tabular}{|l|c|c|}
\cline { 2 - 3 } \multicolumn{1}{c|}{} & BARREIRINHAS & JIJOCA DE JERICOACOARA \\
\hline NORTE & Oceano Atlântico & Oceano Atlântico \\
\hline SUL & Município de Santa Quitéria do Maranhão & Município de Bela Cruz \\
\hline LESTE & $\begin{array}{c}\text { Município de Paulino Neves } \\
\text { Município de Santana do Maranhão }\end{array}$ & Município de Cruz \\
\hline OESTE & $\begin{array}{c}\text { Município de Santo Amaro do Maranhão } \\
\text { Município de Primeira Cruz }\end{array}$ & Município de Camocim \\
\hline
\end{tabular}

Quadro 2: Limites territoriais de Barreirinhas e de Jijoca de Jericoacoara

Fonte: Secretaria de Turismo de Barreirinhas, 2013; Aprece, 2013. 


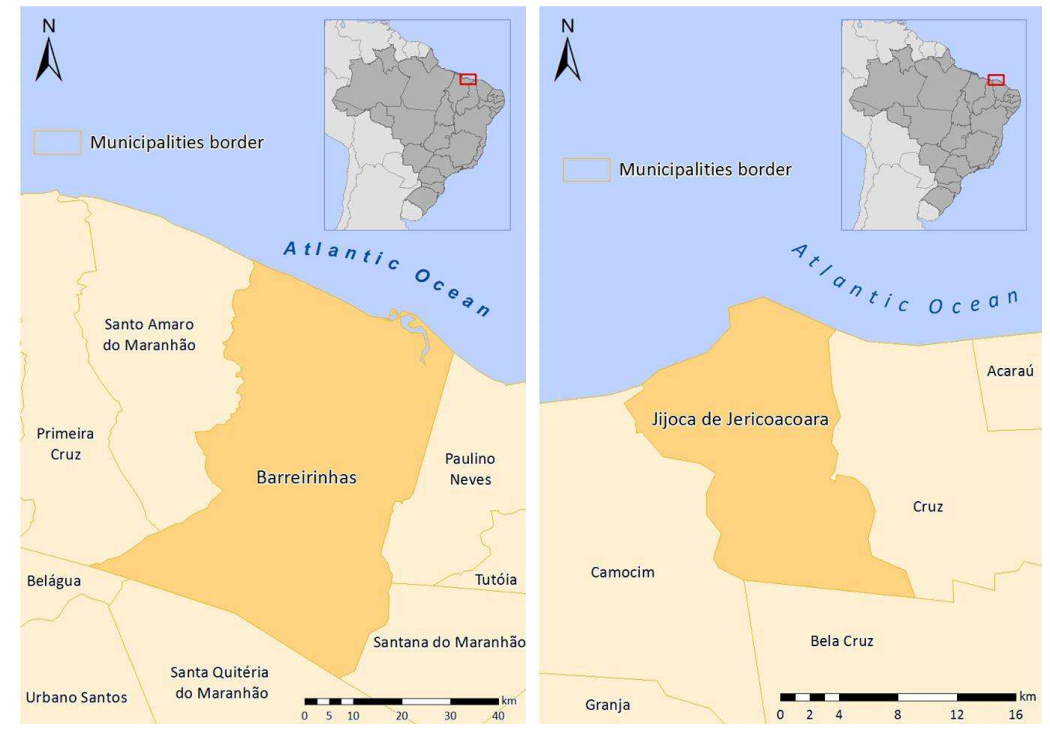

Figura 2: Limites territoriais de Barreirinhas e Jijoca de Jericoacoara Fonte: IBGE, 2010. Elaboração: Ana Pimenta Ribeiro.

A capital do Estado do Maranhão, São Luís, encontra-se a uma distância de $269 \mathrm{Km}$ do município de Barreirinhas. Enquanto que Fortaleza, capital do Estado do Ceará, dista $295 \mathrm{Km}$ do município de Jijoca de Jericoacoara.

As vias de acesso para Barreirinhas, partindo da capital do estado, são três: rodoviária, aérea, marítima-fluvial. O trajeto por via rodoviária (Figura 3) se dá pela BR-135, percorrendo, aproximadamente, $60 \mathrm{Km}$ até próximo ao município de Bacabeira, onde se pode ter acesso à rodovia BR-402 (também conhecida por "Translitorânea" ou "MA-402"), pela qual se percorre, passando pelo cruzamento com o trevo que leva ao município de Humberto de Campos, chegando ao destino final. A duração total do percurso é, em média, de três horas.

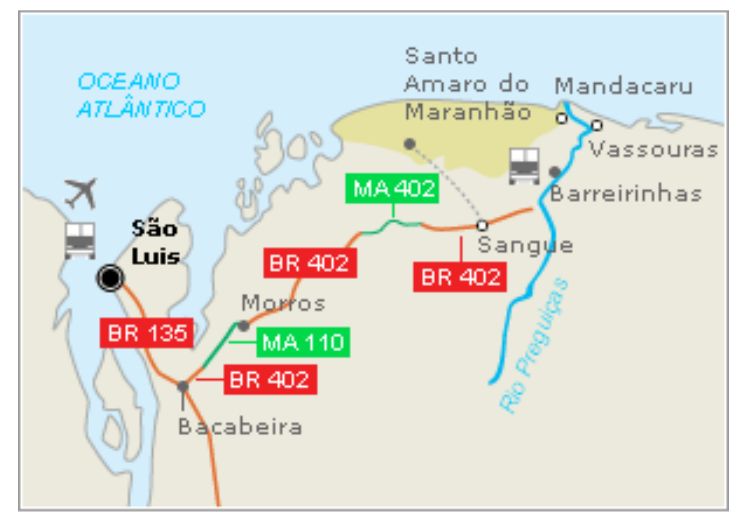

Figura 3: Trajeto rodoviário entre São Luís e Barreirinhas Fonte: UOL VIAGEM, 2009. 
Por via aérea o acesso se dá a partir do Aeroporto Internacional Marechal Cunha Machado, em São Luís, com a utilização de aeronaves de pequeno porte, bi ou monomotorizadas, de propriedade de empresas de táxi aéreo. Tratam-se de voos fretados até uma pista de pouso pavimentada (Figura 4), localizada no Bairro do Aeroporto, em Barreirinhas (ICMBIO, 2013). Uma segunda pista de pouso foi construída próxima à anterior, em um espaço no qual esperase, assim que disponibilizados os recursos necessários, ser edificado um terminal de passageiros, possibilitando, assim, o tráfego de aeronaves de grande porte para voos comerciais nacionais (SETUR-BARREIRINHAS, 2011). O tempo estimado do percurso é, em média, de cinquenta minutos.

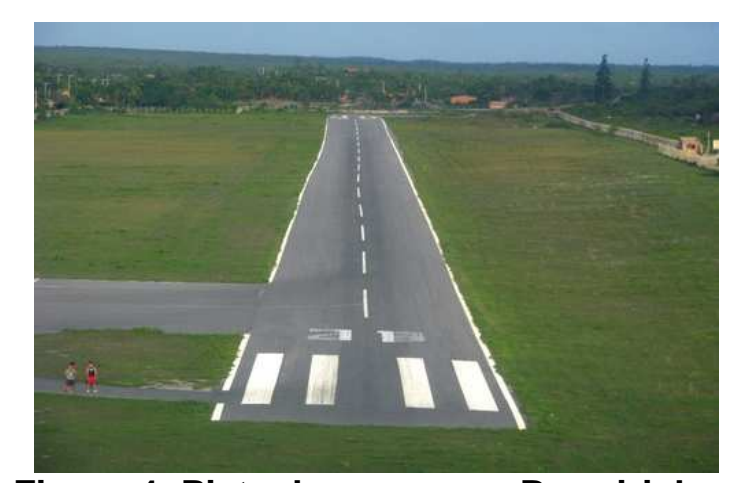

Figura 4: Pista de pouso em Barreirinhas

Fonte: Panoramio, por Marcos Comune.

Por fim, o acesso por via marítima-fluvial. O traçado se inicia em São José de Ribamar (Ilha de São Luís), até o canal do Rio Preguiças, no povoado de Atins. Outros pontos de acesso ao Parque Nacional dos Lençóis Maranhenses, e consequentemente ao município de Barreirinhas, podem ser identificados junto aos rios Alegre e Periá, pelos municípios de Humberto de Campos, Primeira Cruz e Santo Amaro do Maranhão.

Por sua vez, os meios de acesso à Jijoca de Jericoacoara são dois: rodoviário e aéreo. No primeiro, e mais convencional, segue-se pela rodovia CE 085 - também conhecida como "Estruturante Costa do Sol Poente", ou apenas "Estruturante" -, que liga a capital Fortaleza até o município (ver Figura 5). O trajeto de pouco menos de $300 \mathrm{~km}$ passa por vários entroncamentos circulares, não possui boa sinalização, acabando por demandar, em média, 06 horas de viagem. 


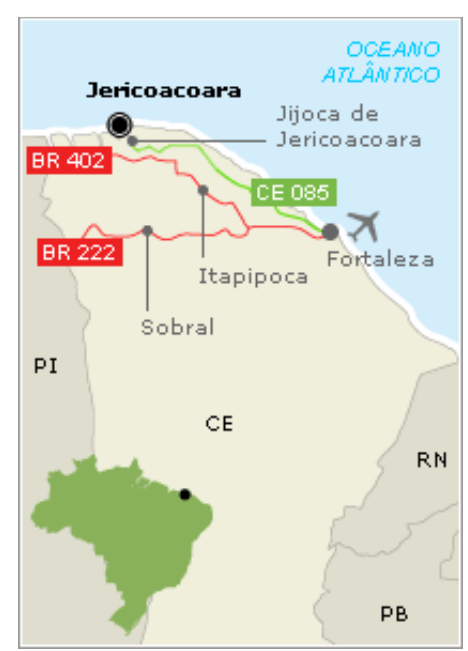

Figura 5: Trajeto rodoviário entre Fortaleza e Jijoca de Jericoacoara

Fonte: Jeri-Brazil, 2013.

O acesso por via aérea até Jijoca de Jericoacoara pode ser realizado de duas formas: aeronaves bimotores e helicóptero. Na primeira opção, o acesso pode se dar do Aeroporto Internacional "Pinto Martins" em Fortaleza, até o aeroporto mais próximo de Jijoca, a $50 \mathrm{Km}$, localizado no Município de Camocim. O tempo de duração do voo é de, aproximadamente, 60 minutos, e o restante do trajeto, realizado por terra, dura em torno de 90 minutos. Na segunda opção - helicóptero - adota-se, com maior frequência, o pouso na Vila de Jericoacoara, onde está a maior concentração de hotéis e pousadas. O percurso realizado num voo panorâmico a baixa altitude dura, em média, 50 minutos.

Até o momento de realização desta pesquisa pôde ser identificada a conclusão da pista de pousos e decolagens do recém projetado Aeroporto Internacional de Jericoacoara. A pista de 2,2 mil metros de extensão, por 45 metro de largura, considerada a segunda maior do Estado do Ceará, é fruto de um investimento de $\mathrm{R} \$ 47,4$ milhões por parte do Banco Nacional de Desenvolvimento Econômico e Social (BNDES) e do programa Proinvest. A partir dessa construção, será viabilizada uma nova via de acesso direto de Fortaleza à Jijoca de Jericoacoara, diminuindo em cinco horas o tempo de deslocamento, passando das atuais seis horas (por meio rodoviário) para apenas uma hora (por meio aéreo). (O POVO ONLINE, 2013)

O Aeroporto Internacional de Jericoacoara, ainda que como o próprio título destaca, vem sendo construído a $18 \mathrm{Km}$ do município de Jijoca de Jericoacoara, mais especificamente no Município de Cruz. Serão 10,5km de distância do limite mais próximo do Parque Nacional e $21 \mathrm{~km}$ da Vila de Jericoacoara (ICMBIO, 2011). A conclusão do terminal de passageiros está prevista para o segundo semestre de 2013 , com investimentos de $R \$ 11,4$ milhões. O intuito da 
construção do aeroporto é, além da dinamização do fluxo de turistas, servir como canal de escoamento da produção agrícola, em especial na exportação de flores e frutas para regiões europeias (O POVO ONLINE, 2013). O valor total do projeto é de $\mathrm{R} \$ 60,9$ milhões (ICMBIO, 2011).

\section{Aspectos histórico-evolutivos}

Os municípios de Jijoca de Jericoacoara e de Barreirinhas possuem algumas similaridades quanto ao quadro histórico-evolutivo de suas localidades. Ainda que as datas exatas de suas origens de povoamento não possam ser precisadas por meio de registros impressos, supõe-se que tais processos migratórios se deram pelo aparecimento de grupos indígenas que, atraídos pela fertilidade de áreas banhadas por extensos recursos hídricos, se fixaram nessas regiões.

A formação de grupos e de pequenos povoados foi determinada, principalmente, pela abundância de pescados ali encontrados, tanto no interior (lagoas e rios) quanto no litoral (mar ou foz dos rios). Mas também pelas áreas de campos e pastagens apropriadas para a criação de gado, e pela amenidade do clima. (IBGE, 2013; PREFEITURA MUNICIPAL DE JIJOCA DE JERICOACOARA, 2013; IBAMA/MMA, 2002)

Há indícios de que os primeiros grupos que habitaram a região, onde hoje se encontra o município de Barreirinhas, tenham sido os índios Caetés e Tapuios, em meados do século XVIII (BRASIL TURISMO, 2013). Em Jijoca de Jericoacoara, por sua vez, segundo historiadores, prevaleceram os índios de etnia Tremembé, que povoaram a área no século XVII, aproximadamente (SANTOS; FRANCO, 2012).

Os processos de colonização pelos portugueses que, em 1613, direcionaram suas rotas para o norte do Ceará buscando conquistar novas terras, dentre elas as hoje conhecidas como Maranhão, encontraram nas áreas costeiras de Jericoacoara um porto para se fixarem em busca de minérios preciosos e extração de sal (ICMBIO, 2011). A região serviu como base de apoio nas batalhas dos portugueses contra os franceses - que mantinham processos de ocupação das áreas maranhenses - por meio da instalação do forte, e também vilarejo, de Nossa Senhora do Rosário (ICMBIO, 2011).

Ainda no século XVII, a área de Barreirinhas, beneficiada por terras de grande fertilidade para a produção agrícola (na época, para exploração de cana de açúcar e produção de aguardente), e potenciais recursos hídricos para a atividade pesqueira (como o Rio Preguiças), 
foi alvo de constantes ataques de colonizadores ingleses, holandeses e franceses, contra os portugueses, buscando a conquista de espaços.

A partir daí, muitos são os relatos que tratam sobre os processos de migração populacional e de desenvolvimento nos dois municípios. Buscando uma melhor sistematização das informações levantadas, foi criada a Figura 6 a seguir.

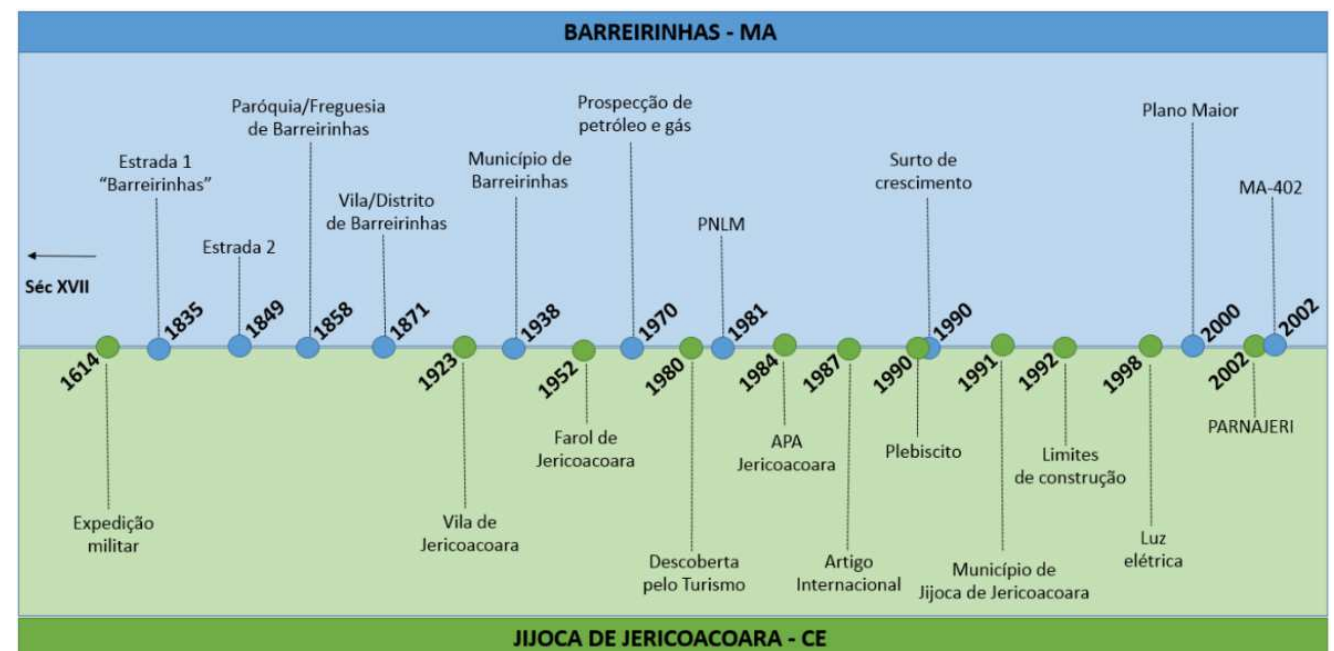

Figura 6: Histórico-evolutivo dos municípios de Barreirinhas e Jijjoca de Jericoacoara Fonte: próprio autor.

No ano de 1614 as praias de Jericoacoara foram alvo de colonizadores, que fixaram fortes e bases operacionais em suas áreas, por conta de sua localização estratégica entre Barra do Rio Ceará (atualmente bairro da cidade de Fortaleza), Camocim e São Luis do Maranhão. No mesmo ano, partindo das praias de Jericoacoara, uma expedição militar holandesa, capitaneada por Jacob Evers, inicia suas atividades de ocupação do Maranhão, tendo como comandante Gedeon Morris de Jonge, e como chefes Koin e Lichart. (APRECE, 2013)

Em 1835, foi construída a primeira estrada que propiciou a dinamização do processo inicial de migração em Barreirinhas, dadas as condições propícias encontradas para lavoura às margens dos rios Alegre, Periá, Negro, Preguiças e seus afluentes. Tal estrada teve sua extensão interligando os municípios de São Bernardo do Parnaíba (hoje, Município de São Bernardo) e Freguesia de Miritiba de São José do Periá (atual Humberto de Campos) (AECI, 2007). No mesmo ano, em 10 de outubro, a localidade recebe oficialmente o título de "Barreirinhas" (IBAMA/MMA, 2002). 
Já em 1849 o acesso à região de Barreirinhas foi facilitado pela construção da segunda estrada que, pela edificação de uma ponte sobre o rio Mocambo, permitiu a interligação entre a comarca de Campo Maior, no Estado do Piauí, e as comarcas de Brejo e de Icatú, no Estado do Maranhão. O resultado foi o aumento no desbravamento da área e a formação de novos povoados às margens do rio Preguiças - principal curso d'água do município (IBGE, 2013).

O ano de 1858 foi marcado como o período em que, ao se desmembrar dos municípios de Tutóia, Brejo, Miritiba de São José do Periá e São Bernardo, a localidade recebe a denominação de "Paróquia" (SILVA, 2008), ou por outros entendido como "Freguesia" (IBGE, 2013), pela Lei Provincial n` 841 (IBAMA/MMA, 2002). O título completo foi de "Freguesia de Nossa Senhora da Conceição das Barreirinhas".

Em 14 de junho de 1871 a localidade passa, então, a ser denominada como "Distrito de Barreirinhas" (ICMBIO, 2003), também tratado como "Vila de Barreirinhas" (IBGE, 2013), pela Lei $n^{\circ} 951$.

Anos mais tarde, em 1923, o pequeno povoado de pescadores (Figura 7) e de agricultores que se formou nas redondezas da praia de Jericoacoara - terras que até então pertenciam ao município de Acaraú - deu origem à "Vila de Jericoacoara", criada pela Lei municipal n` 94 de 29 de junho de 1923 (APRECE, 2013; PREFEITURA MUNICIPAL DE JIJOCA DE JERICOACOARA, 2013; JERI-BRAZIL, 2013).
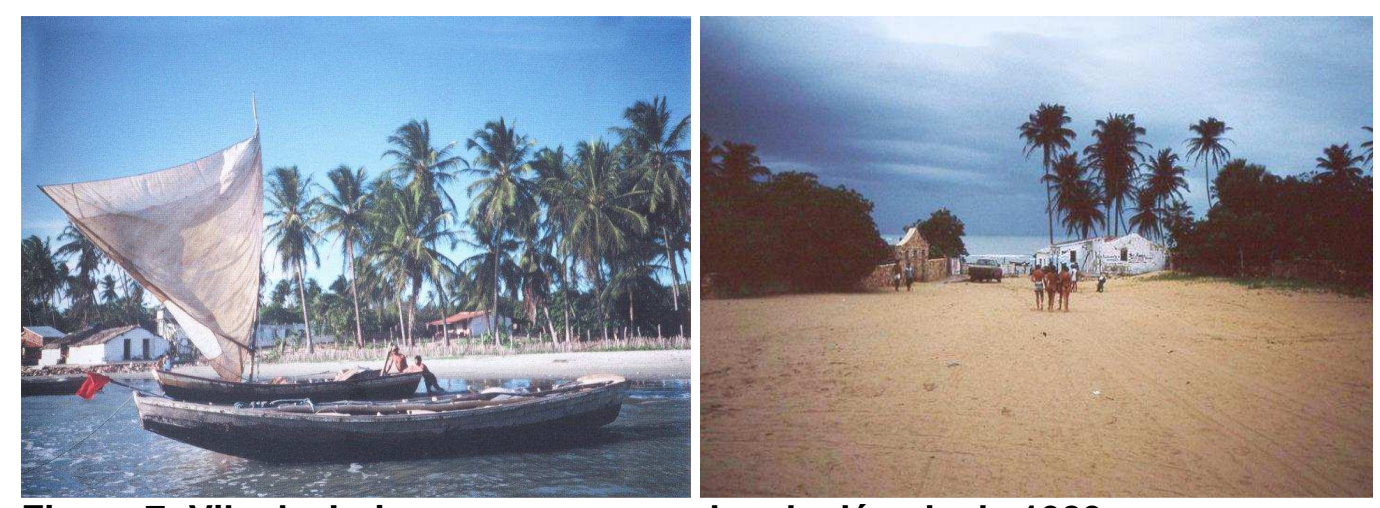

Figura 7: Vila de Jericoacoara em meados da década de 1920

Fonte: SETUR/Jijoca de Jericoacoara, sd.

A emancipação do município de Barreirinhas se dá em 29 de março do ano de 1938, a partir da Lei $n^{\circ} 45$ (PORTAL DE BARREIRINHAS, 2012; IBGE, 2013). Jericoacoara, ainda reconhecido como Vila, inaugura em 16 de novembro de 1952 o "Farol de Jericoacoara", construído no topo de um dos serrotes da costa, a 120 metros do nível do mar (ICMBIO, 2011). 
A década de 70 marca o início de um surto de mudanças socioeconômicas em Barreirinhas. A descoberta de potenciais petrolífero e de gás em sua bacia hidrográfica criou novas perspectivas de desenvolvimento para a região. Tubulações e gasodutos foram instalados, voltados à prospecção dos recursos, porém, que se constituem como uma ameaça contra a integridade de outros recursos naturais da região. O impacto ambiental, segundo a Plano do Manejo do Parque Nacional dos Lençóis Maranhenses, não tem assumido dimensões preocupantes dado que o combustível obtido é de baixa qualidade, o que inviabiliza sua exploração. (FUNDAÇÃO SOUSÂNDRADE DE APOIO E DESENVOLVIMENTO DA UNIVERSIDADE FEDERAL DO MARANHÃO, 2002)

Entre as décadas de 1970 e 1980, o cenário paradisíaco da região de Jericoacoara começa a ser reconhecido e descoberto pelo turismo nacional e internacional (ICMBIO, 2011; JERIBRAZIL, 2013). Ainda assim, a falta de infraestrutura básica - como luz elétrica - e de acesso aos potenciais naturais limitava a concentração massiva de interessados.

Logo depois, no início da década de 1980, as duas localidades avançaram notoriamente no que diz respeito à prudência com os recursos naturais disponíveis em suas áreas territoriais. Foram criadas, nesse período, duas unidades de conservação com o objetivo de conservar os ecossistemas e preservar a biodiversidade. Como primeiro grande passo, no ano de 1981, mais especificamente no dia 02 do mês de junho, foi criado o Parque Nacional dos Lençóis Maranhenses por meio do Decreto $n^{\circ} 86.060$ (ICMBIO, 2013; AECI, 2007). Em seguida, no ano de 1984, a vila de pescadores de Jericoacoara foi definida como uma Área de Proteção Ambiental (APA), por lei federal (ICMBIO, 2013; JERI-BRAZIL, 2013).

Na mesma época, entre 1980 e 1990, o surto de expansão no número de visitantes, tanto em Barreirinhas quanto na área de Jericoacoara, foi evidente. O crescimento da atividade turística em Barreirinhas ganha força por meio da ampla divulgação da região, mas, principalmente, do Parque Nacional dos Lençóis Maranhenses. O município, até então conhecido pela sua rotina pacata, se transforma, naquele momento, em um pólo turístico que atinge patamares nacionais e internacionais. Investidores externos e internos voltam-se à instalação de empreendimentos turísticos de pequeno, médio e grande porte (PORTAL DE BARREIRINHAS, 2012). As atividades tradicionais como a pesca e a extração de produtos primários - como milho, arroz, mandioca, caju, entre outros - vão, aos poucos, dando lugar à prestação de serviços em estabelecimentos hoteleiros e de alimentação, ou ainda nas obras de saneamento básico, urbanização e infraestrutura (SILVA, 2004). 
Assim como em Barreirinhas, a partir de 1980, os níveis de visitação na Vila de Jericoacoara - até então reconhecida como pequeno povoado de pescadores - aumentam consideravelmente, criando, aos poucos, o formato de destino turístico internacional (MOLINA, 2007). A descoberta das perfeitas condições naturais de vento e de maré por praticantes de windsurfe (esporte aquático com utilização de vela), fez com que a área se tornasse um ponto turístico de grande interesse por visitantes do mundo todo. Empreendimentos hoteleiros e gastronômicos surgem constantemente.

A abertura definitiva de Jericoacoara para o mundo se dá em 15 de março de 1987, quando a localidade é promovida internacionalmente pela publicação de um artigo na edição especial de viagens (Post Travel Magazine) do jornal norte-americano The Washington Post (THE WASHINGTON POST, 1987). Há quem diga que o artigo considerava Jericoacoara como uma das 10 mais belas praias do planeta (ICMBIO, 2011; JERI-BRAZIL, 2013; JERI.COM, 2013; ECOADVENTURE, 2013). Na verdade, não havia no artigo qualquer classificação de praias, e sim apenas um agrupamento aleatório com o título de "as melhores praias do mundo acenam", o que não diminui a importância do local e da publicação que atraiu olhares do mundo todo para a antiga vila de pescadores (THE GARDIAN, 2007). Vale ressaltar que anteriormente, em 1984, a Revista Geográfica Universal, enalteceu as belezas naturais da região e o modo de vida tradicional de seus moradores por meio da publicação do artigo: "Jericoacoara: um paraíso no Ceará" (FONTELES, 2004).

Anos mais tarde, mais precisamente em 07 de setembro de 1990, os moradores da Vila de Jericoacoara realizam um plebiscito no qual a vontade popular de emancipação política da área era expressada. A criação de um município autônomo, nomeado Jijoca de Jericoacoara, se deu seis meses mais tarde, em 06 de março de 1991, por meio da Lei $n^{\circ}$ 11.796. (PREFEITURA MUNICIPAL DE JIJOCA DE JERICOACOARA, 2013; APRECE, 2013)

O aparecimento de quantidades expressivas de unidades habitacionais, decorrentes do súbito aumento de empreendimentos turísticos edificados na Vila de Jericoacoara, fez com que os órgãos gestores do, então, "Município de Jijoca de Jericoacoara", proibissem, a partir de 1992, novas construções de mais alojamentos. O intuito seria o de limitar o número de turistas nessa região. (JERI-BRAZIL, 2013)

A partir de 1998 Jericoacoara é beneficiada por uma rede elétrica subterrânea que serviria, inicialmente, para suprir a demanda das casas dos moradores da vila. Anteriormente, só podiam ser encontradas lâmpadas alimentadas por geradores. (JERI-BRAZIL, 2013) 
No ano de 2000 dá-se início aos processos de planejamento, organização, operacionalização e desenvolvimento do setor de turismo no Estado do Maranhão, pensando nessa atividade como geradora de receitas, de trabalho e de melhorias nos índices de desenvolvimento local e regional (TASSO, 2011). O Governo do Estado do Maranhão implanta, no mesmo ano, o "Plano de Desenvolvimento Integral do Turismo do Maranhão", conhecido como Plano Maior. Constavam nesse Plano cinco pólos de visitação (), os quais seriam alvo das principais ações de desenvolvimento sustentável do turismo. Um deles é o Pólo dos Lençóis Maranhenses.

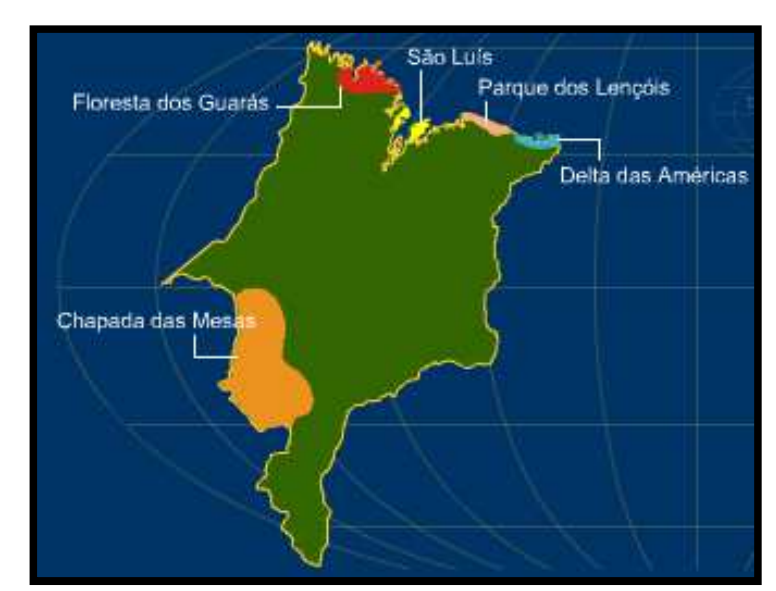

Figura 8: Pólos de visitação no Estado do Maranhão Fonte: MARANHÃO, 2010.

Finalmente, no ano de 2002, são deixadas duas importantes marcas nos quadros históricoevolutivos dos dois municípios em tela: a criação do Parque Nacional de Jericoacoara e a finalização da rodovia MA-402.

No primeiro caso, partindo da recategorização da APA criada em 1984, é criado em fevereiro de 2002 o Parque Nacional de Jericoacoara, estabelecendo seus limites, assegurando a preservação dos recursos naturais presentes, protegendo amostras dos ecossistemas costeiros, e proporcionando ações de educação ambiental, pesquisas científicas e turismo ecológico (ICMBIO, 2013).

No segundo, partindo de iniciativas governamentais do Estado do Maranhão, no ano de 2000, por meio do "Plano de Desenvolvimento Integral do Turismo do Maranhão" - também conhecido por "Plano Maior" -, foi construída a Rodovia MA-402 (ver Figura 9). Finalizada em 2002, a MA-402 (ou “Translitorânea") viabilizou a conexão rodoviária entre a capital, São Luís, e 
o município de Barreirinhas, facilitando o acesso aos turistas e dinamizando o setor. (MARANHÃO, 2000)

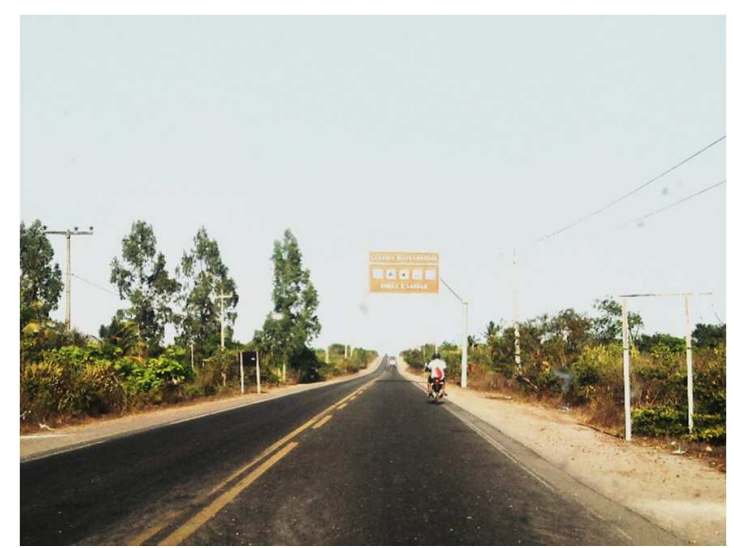

Figura 9: Rodovia MA-402

Fonte: próprio autor, 2013.

O termo "barreirinhas" já era comumente utilizado, ainda no século XVII, ao se referir às paredes de argila, de 10 a 20 metros de altura, formadas às margens do Rio Preguiças e envoltas por dunas de areia. Este termo deu origem ao nome do município. (PORTAL DE BARREIRINHAS, 2012; IBAMA/MMA, 2002)

Os cordões de imensas dunas, de coração esbranquiçada, e relevo plano, foram originalmente assemelhados a "lençóis jogados sobre a cama" por navegadores que, com suas embarcações, tangenciavam a costa da região, dando origem aos "lençóis maranhenses". (D'ANTONA, 2002).

Jijoca de Jericoacoara, por sua vez, faz alusão à combinação de três palavras da língua indígena tupi guarani: "jijoca" (casa das rãs), "Yuruco" (buraco) e "cuara" (tartaruga) (IPECE, 2006). O "buraco das tartarugas" justifica-se pela área de Jericoacoara ser um espaço utilizado por tartarugas marinhas para a desova (ICMBIO, 2011). Uma segunda ideia da origem do nome parte de antigos pescadores que, ao se referirem ao formato do "Serrote" (serra próxima à vila, onde foi construído o farol de Jericoacoara, em 1952), visto de alto mar, parece ter a imagem de um jacaré deitado, ou "quarando", ao sol, criando a antiga expressão "Jacarequara" (JERIBRAZIL, 2013).

Os dois municípios são atualmente conhecidos como os portões de entrada para seus respectivos parques nacionais, por suas localizações privilegiadas e estruturas de acesso à esses pólos de exploração turística de grande notoriedade em seus estados. 


\section{Aspectos Físicos e Biológicos}

\subsection{Parque Nacional dos Lençóis Maranhenses e Parque Nacional de Jericoacoara}

Unidades de Conservação caracterizadas por cenários paradisíacos singulares, de notória atratividade turística no Brasil e no mundo, os Parques Nacionais dos Lençóis Maranhenses e de Jericoacoara integram a "Rota das Emoções". Premiado pelo Ministério do Turismo, no ano de 2009, como o melhor roteiro turístico do Brasil, a Rota das Emoções é composta pelos Lençóis Maranhenses, Jericoacoara, e Delta do Parnaíba no Estado do Piauí (TERRA, 2009).

Os Parques fazem parte da região costeira interestadual denominada Costa Norte (CN), localizada nos Estados do Maranhão, Ceará e Piauí. Trata-se de uma zona cercada por áreas protegidas (Figura 10), cujo turismo tem sido um dos principais propulsores econômicos dos municípios que a integram, ao considerar como atrativos os recursos naturais existentes e as condições ambientais ainda preservadas (LIMA/COPPE/UFRJ, 2007).

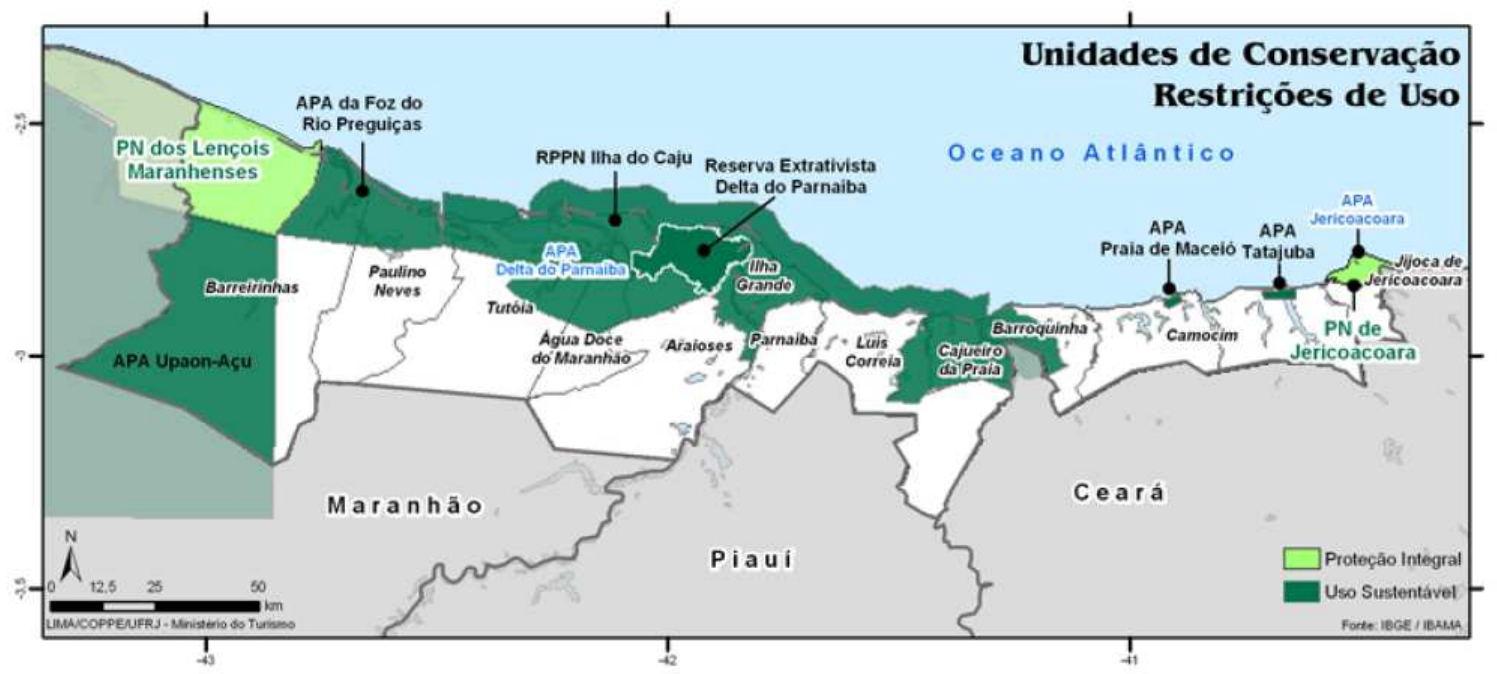

Figura 10: Unidades de Conservação na Costa Norte

Fonte: LIMA/COPPE/UFRJ, em base IBGE, 2006.

Além disso, os municípios reconhecidos como principais vias de acesso aos Parques Barreirinhas e Jijoca de Jericoacoara - estão entre os "65 Destinos Indutores de Desenvolvimento Turístico Regional", do Ministério do Turismo. Referem-se aqueles destinos com atrativos qualificados e infraestruturas básica e turística disponíveis, configurando-se em núcleos receptores e/ou distribuidores de fluxos turísticos. (BRASIL, 2013d) 
A potencialidade ambiental encontrada nesses destinos, somada a essas iniciativas de fortalecimento e de desenvolvimento integrado do setor de turismo nessas regiões, têm permitido acelerados processos, positivos e negativos, de exploração desses recursos naturais.

Os próximos tópicos buscam descrever não só as características centrais dessas unidades de conservação, ressaltadas por suas belas praias e lagoas interdunares, como também as atividades que se apresentam como conflitantes diante da proposta de sustentabilidade.

\subsubsection{Características Gerais das UCs}

Os Parques Nacionais dos Lençóis Maranhenses e de Jericoacoara são Unidades de Conservação (UC) de Proteção Integral que, segundo o Sistema Nacional de Unidades de Conservação da Natureza (SNUC), destinam-se à:

(...) proteção dos ecossistemas naturais de grande relevância e beleza cênica, onde podem ser realizadas atividades de recreação, educação e interpretação ambiental, e desenvolvidas pesquisas científicas. (SNUC, sd)

Algumas características das UCs estudadas estão descritas a seguir, no Quadro 3. Com datas de criação distanciadas por mais de 20 anos, os Parques Nacionais revelam potenciais problemas, comuns entre eles, e uma exuberância natural de grande atratividade turística.

O Parna dos Lençóis Maranhenses foi criado em 02 de junho de 1981, pelo Decreto $\mathrm{n}^{\circ}$ 86.060. Por outro lado, o Parna de Jericoacoara teve sua criação 21 anos mais tarde, apenas em 04 de fevereiro de 2002, por decreto sem numeração.

Tratam-se de áreas também distintas, no que tange a dimensão espacial. A UC maranhense possui 155.000 hectares de superfície, enquanto que a UC cearense 8.850 hectares. Os perímetros dos Parques, da mesma forma, possuem grande discrepância, sendo que nos Lençóis Maranhenses perfaz 270 km e em Jericoacoara pouco mais de $55 \mathrm{Km}$.

Barreirinhas é o município de maior abrangência pelo Parque Nacional dos Lençóis Maranhenses, compreendendo $44,86 \%$ de sua área. Em seguida está o município de Santo Amaro do Maranhão, com 42,15\% e, por fim, o município de Primeira Cruz, com 6,89\%. 


\begin{tabular}{|c|c|c|}
\hline $\begin{array}{l}\text { Nome da Unidade de } \\
\text { Conservação }\end{array}$ & $\begin{array}{c}\text { Parque Nacional } \\
\text { dos Lençóis Maranhenses }\end{array}$ & $\begin{array}{l}\text { Parque Nacional } \\
\text { de Jericoacoara }\end{array}$ \\
\hline $\begin{array}{l}\text { Número do Decreto e } \\
\text { Data de Criação }\end{array}$ & $\begin{array}{c}\text { Decreto } n^{\circ} 86.060 \\
02 \text { de junho de } 1981\end{array}$ & $\begin{array}{c}\text { Decreto Federal } \mathrm{S} / \mathrm{N}^{\circ} \\
04 \text { de fevereiro de } 2002\end{array}$ \\
\hline Superfície da UC (ha) & $155.000 \mathrm{ha}$ & 8.850 ha \\
\hline Perímetro da UC (km) & $270 \mathrm{~km}$ & $55,087 \mathrm{~km}$ \\
\hline $\begin{array}{l}\text { Municípios que } \\
\text { abrange e percentual } \\
\text { abrangido pela UC }\end{array}$ & $\begin{array}{l}\text { - Barreirinhas (44,86\%) } \\
\text { - Santo Amaro do Maranhão } \\
(42,15 \%) \\
\text { - Primeira Cruz }(6,89 \%)\end{array}$ & $\begin{array}{l}\text { - Jijoca de Jericoacoara }(60,22 \%) \\
\text { - Área da Marinha/União }(25,97 \%) \\
\text { - Cruz }(13,81 \%)\end{array}$ \\
\hline $\begin{array}{l}\text { Atividades } \\
\text { desenvolvidas }\end{array}$ & $\begin{array}{l}\text { - Atividades de uso público } \\
\text { - Fiscalização } \\
\text { - Pesquisa } \\
\text { - Educação Ambiental }\end{array}$ & $\begin{array}{l}\text { - Atividades de uso público } \\
\text { - Fiscalização } \\
\text { - Pesquisa } \\
\text { - Educação Ambiental }\end{array}$ \\
\hline Atividades conflitantes & $\begin{array}{l}\text { - Pesca artesanal } \\
\text { - Pesca industrial } \\
\text { - Degradação ambiental (corte de } \\
\text { mangue) } \\
\text { - Extrativismo } \\
\text { - Caça } \\
\text { - Rally } \\
\text { - Ocupação irregular (construção de } \\
\text { equipamentos urbanos e turísticos } \\
\text { desrespeitando o ambiente natural) } \\
\text { - Poluição dos atrativos naturais } \\
\text { - Exploração turística excessiva } \\
\text { concentrada em pontos atrativos }\end{array}$ & $\begin{array}{l}\text { - Retirada de areia e barro } \\
\text { - Acúmulo de lixo no interior da UC } \\
\text { (relacionado principalmente a atividade } \\
\text { turística) } \\
\text { - Esgotamento de fossas em locais } \\
\text { desapropriados } \\
\text { - Pastoreio de animais domésticos } \\
\text { (asininos) } \\
\text { - Pesca irregular (arrasto) dentro dos limites } \\
\text { da UC } \\
\text { - Trânsito desordenado de veículos, } \\
\text { pessoas e animais (acarretando em trilhas e } \\
\text { caminhos) } \\
\text { - Utilização da área marinha por esportes } \\
\text { náuticos } \\
\text { - Caça } \\
\text { - Linha de transmissão } \\
\text { - Vias de circulação no interior do Parque } \\
\text { (para o deslocamento até a Vila, povoados, } \\
\text { distritos e sedes próximas) } \\
\text { - Consumo de drogas ilícitas no interior do } \\
\text { Parque } \\
\text { - Visitação desordenada }\end{array}$ \\
\hline $\begin{array}{l}\text { Atividades de uso } \\
\text { público }\end{array}$ & $\begin{array}{l}\text { - Banho } \\
\text { - Camping } \\
\text { - Caminhada } \\
\text { - Passeios náuticos } \\
\text { - Surf } \\
\text { - Windsurf } \\
\text { - Educação ambiental } \\
\text { - Visitação científica }\end{array}$ & $\begin{array}{l}\text { - Banho (lagoas e mar) } \\
\text { - Caminhada } \\
\text { - Visitação científica } \\
\text { - Educação ambiental } \\
\text { - Surf } \\
\text { - Windsurf } \\
\text { - Kitesurf } \\
\text { - Observação de vida silvestre (cavalo } \\
\text { marinho) }\end{array}$ \\
\hline
\end{tabular}

Quadro 3: Características das Unidades de Conservação estudadas

Fonte: IBAMA/MMA, 2002; ICMBIO, 2011. 
Do lado cearense, o município com maior abrangência pelo Parna de Jericoacoara é Jijoca de Jericoacoara, com $60,22 \%$ do total da UC. A parte oceânica, que corresponde à $25,97 \%$ da UC, é uma área da Marinha/União. O município de Cruz, por sua vez, é abrangido por 13,81\% do Parque Nacional.

Como previsto pelo SNUC, as UCs estudadas realizam atividades de uso público, como visitação, recreação e turismo, além de ações de fiscalização, de pesquisa e de educação ambiental. Esta última vem sendo implementada há pouco pela nova gestão do ICMBio no PN dos Lençóis Maranhenses. Segundo o coordenador de Uso Público e Chefe substituto da Unidade, existe a previsão de estabelecimento de uma "Coordenação de Gestão", que desenvolverá atividades de gestão participativa da sociobiodiversidade e educação ambiental. No entanto, por ora, as ações de educação ambiental da UC são focadas na capacitação de condutores de visitantes e realização de palestras escolares e em alguns eventos.

Por outro lado, de acordo com os planos de manejo das duas UCs, e com planos de desenvolvimento turístico municipais, podem ser identificadas múltiplas atividades conflitantes com a sustentabilidade dos Parques. Algumas são comuns às duas áreas.

Uma delas é a atividade extrativista, de forma impactante, como a caça predatória e a pesca irregular. Nos Lençóis, a pesca irregular se dá de forma artesanal e industrial. Em Jericoacoara é comum a utilização da pesca de arrasto, visando a captura do camarão branco (Litopenaeus schmitti), de maior valor comercial. Porém, esse modelo de pesca impacta negativamente a fauna aquática pela captura conjunta de espécies de vertebrados e invertebrados marinhos, muitos deles abandonados nas praias. (ICMBIO, 2011)

Nos Lençóis Maranhenses são identificados cortes de mangue, e ocupações irregulares como construções de equipamentos urbanos e turísticos que desrespeitam o ambiente natural. A exploração turística excessiva, por vezes concentrada em pontos de maior atratividade, gera poluição dos recursos. Da mesma forma, em Jericoacoara percebe-se o grande acúmulo de lixo no interior da UC, decorrente da massificação da atividade turística e no desordenamento da visitação. O esgotamento de caminhões "limpa-fossa" em locais desapropriados, dentre eles lagoas no interior do Parque, potencializam a degradação na UC cearense. Há, ainda, retiradas ilegais de areia e barro das áreas do Parque, sobretudo para construção civil.

O trânsito desordenado de veículos também se configura em uma atividade conflitante nos dois parques nacionais. A criação de novos caminhos e a ampliação de trilhas, gera pisoteio, retirada da vegetação e atropelamento de pequenos animais. Isso se dá pela prática de Rallys 
(Lençóis Maranhenses) e pela circulação de veículos por vias que, passando pelo interior do parque, levam até povoados, distritos e sedes vizinhas, e também à Vila (Jericoacoara).

Há ainda um conflito com relação à situação fundiária dentro dos perímetros dos Parques. No interior de ambas UCs são encontradas habitações em áreas de domínio público, criando animais e cultivando a terra, o que contradiz com a categoria de proteção integral da área. (ICMBIO, 2011)

O consumo de drogas ilícitas no interior das UCs também é uma realidade atual de ambos destinos. Ainda, no Parna de Jericoacoara, podem ser identificadas outras atividades conflitantes específicas: pastoreio de animais domésticos e introduzidos, tais como caprinos, suínos, bovinos e equinos, mas principalmente de asininos (Figura 11); utilização da área marinha para a prática de esportes náuticos, como surf, kitesurfe windsurfe; e a instalação de uma linha de transmissão da companhia energética estadual na área do Parque.

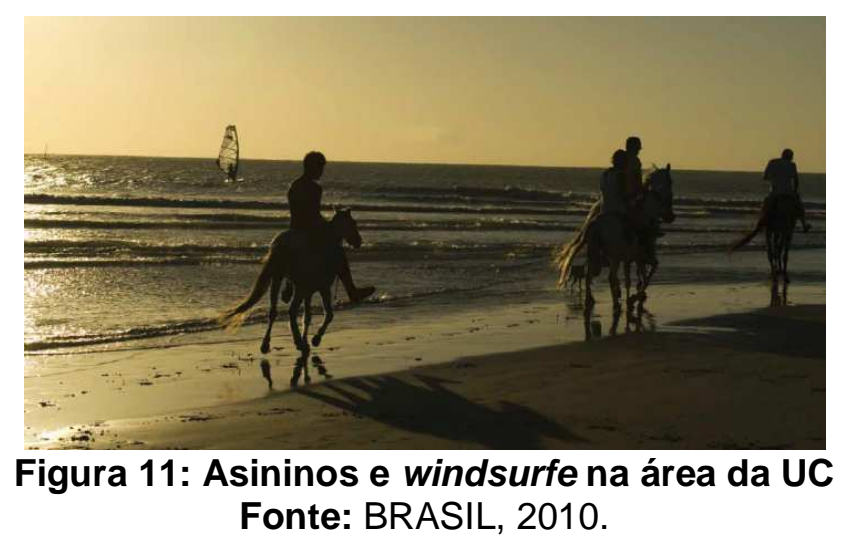

No que tange as atividades de uso público há similitudes entre algumas desenvolvidas nas áreas dos Parques Nacionais de Jericoacoara e dos Lençóis Maranhenses. A visitação turística, com a realização de caminhadas, de banhos nas lagoas e a prática de surfe windsurf são comuns às duas UCs. Ações de educação ambiental, ainda que não recorrentes, também vêm sendo, aos poucos, fortalecidas nas duas regiões, assim como visitações para realização de pesquisas científicas.

$\mathrm{Na}$ área do Parna dos Lençóis Maranhenses são realizados, ainda, passeios náuticos e camping. Em Jericoacoara, por sua vez, identifica-se a prática do kitesurf, e a observação do habitat de cavalos marinhos (Hippocampus reidi) em regiões de mangue. 


\subsubsection{Localização das UCs e Principais Meios de Acesso}

Os Parques Nacionais dos Lençóis Maranhenses e de Jericoacoara localizam-se em regiões litorâneas de seus respectivos estados. O PN de Jericoacoara encontra-se na porção oeste do litoral cearense, abrangida pelos municípios de Cruz e Jijoca de Jericoacoara, este último sendo a principal via de acesso à UC e à Vila de Jericoacoara por turistas procedentes de Fortaleza - ver Figura 12. (ICMBIO, 2011).

A Vila de Jericoacoara encontra-se distante, aproximadamente, $18 \mathrm{~km}$ da sede municipal. Trata-se de um vilarejo, tangenciado pela UC e moldado por uma consistente estrutura de acolhimento turístico, com hotéis, pousadas, bares, restaurantes, agências e operadoras, além de cooperativas e associações de bugueiros e guias de turismo.

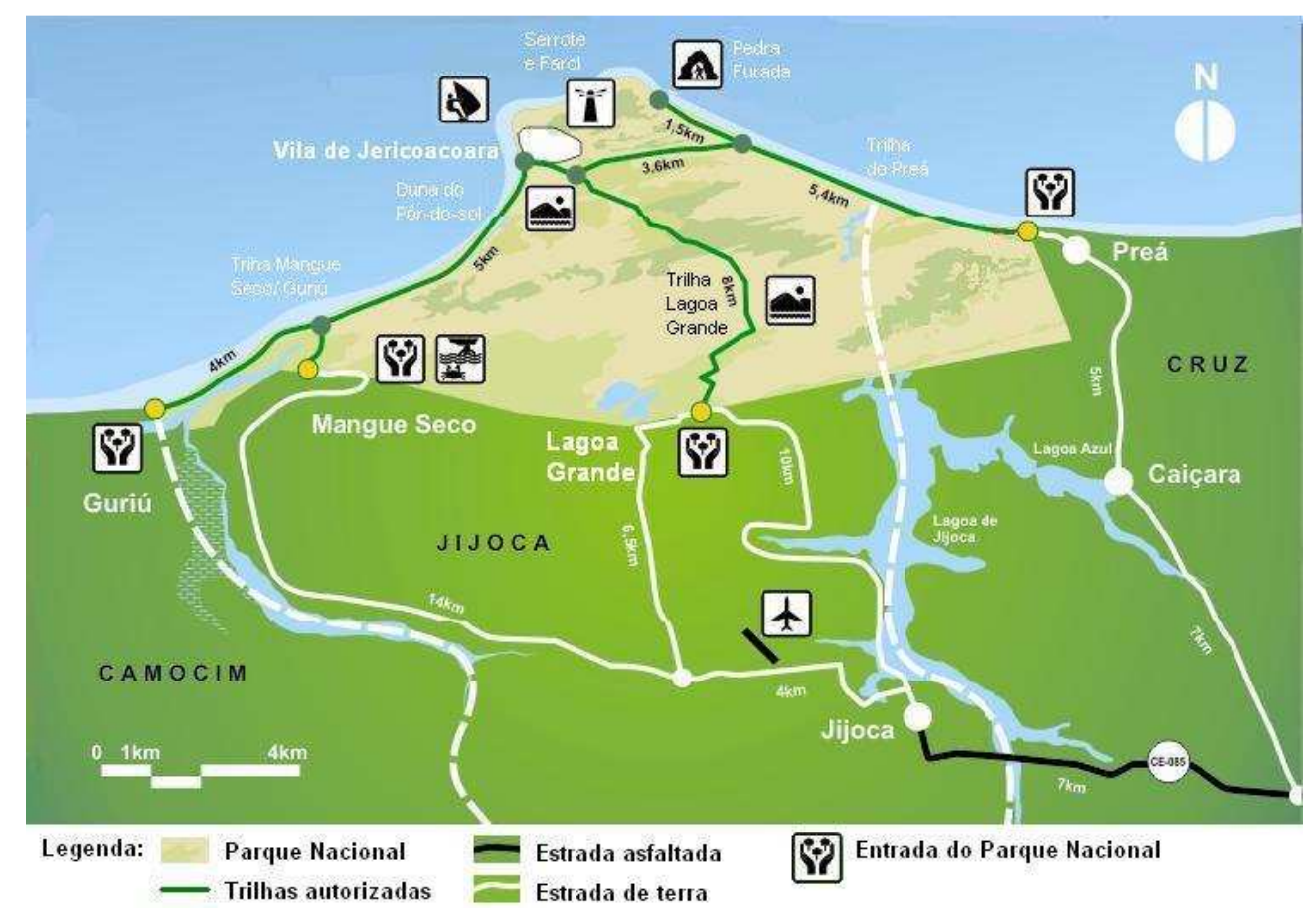

Figura 12: Localização e acesso ao PN de Jericoacoara Fonte: ICMBio, 2013.

O PN dos Lençóis Maranhenses, por sua vez, encontra-se na região do litoral oriental do Estado do Maranhão, alcançando os municípios de Primeira Cruz, Santo Amaro do Maranhão e Barreirinhas (FUNDAÇÃO SOUSÂNDRADE DE APOIO E DESENVOLVIMENTO DA UNIVERSIDADE FEDERAL DO MARANHÃO, 2002). Barreirinhas é considerada a principal via de acesso para a UC, dentre outros motivos, por sua estrutura de acolhimento turístico e sua 
proximidade aos principais pontos de interesse turístico, como as lagoas interdunares perenes "Esperança" e "Bonita" (identicadas na Figura 13).

Como principais meios de acesso a ambos Parques Nacionais, a partir de Jijoca de Jericoacoara e de Barreirinhas, são utilizados veículos tracionados (4X4), conhecidos mais popularmente como "jardineiras" ou "toyotas". A completa descrição desses está destacada no item 5.2.4 sobre "transportes turísticos".

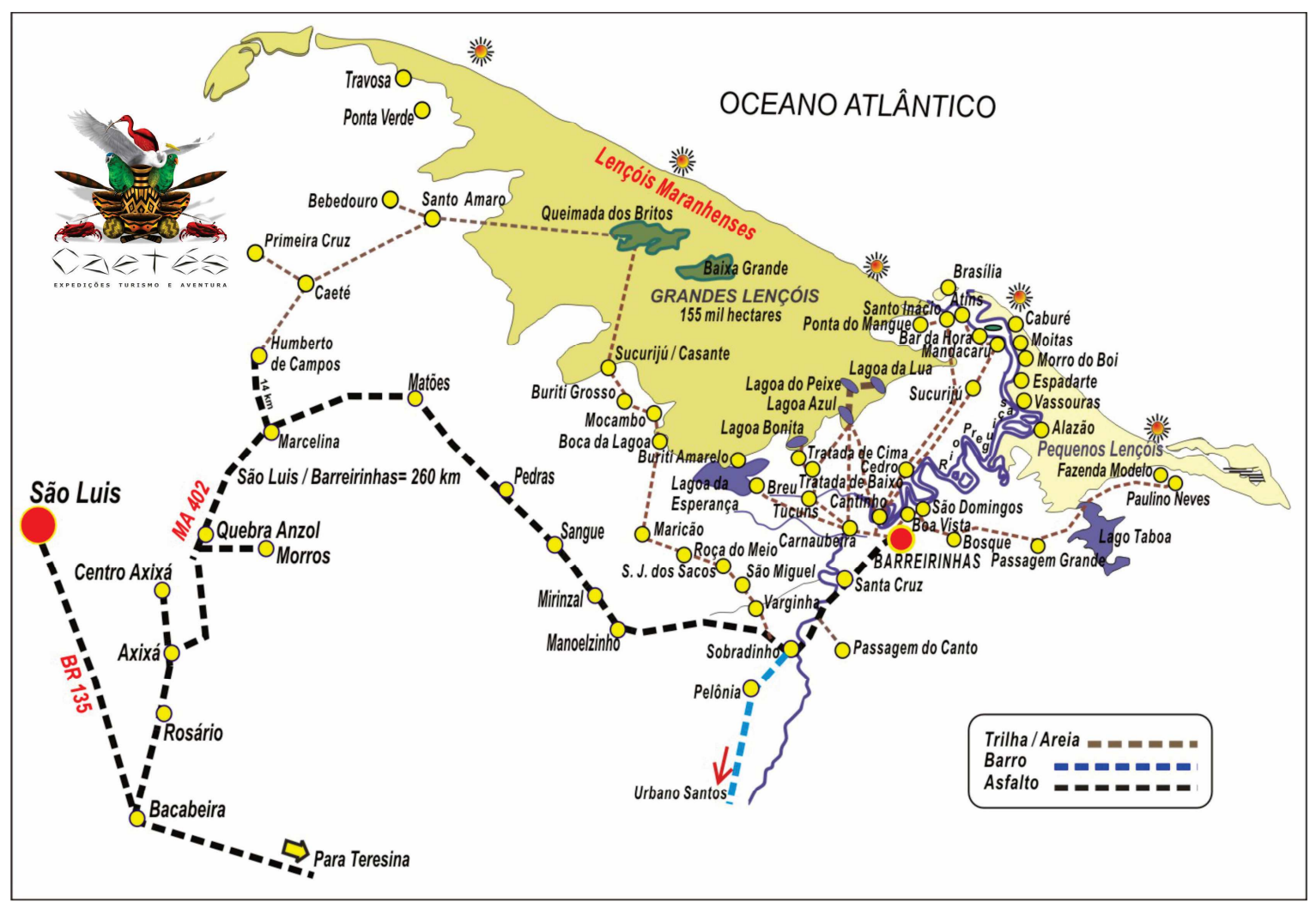

Figura 13: Localização e acesso ao PNLM

Fonte: Caetés Turismo, 2014.

Para se ter acesso ao interior do PNLM, partindo de Barreirinhas, as toyotas cruzam o Rio Preguiças realizando a travessia por meio de balsas (Figura 14). Em seguida, seguem por um trajeto de, aproximadamente, uma hora, composto por estradas de terra e de areia e, em períodos chuvosos, com áreas de alagamento, o que exige muito conhecimento e experiência por parte dos motoristas (SILVA, 2008). 


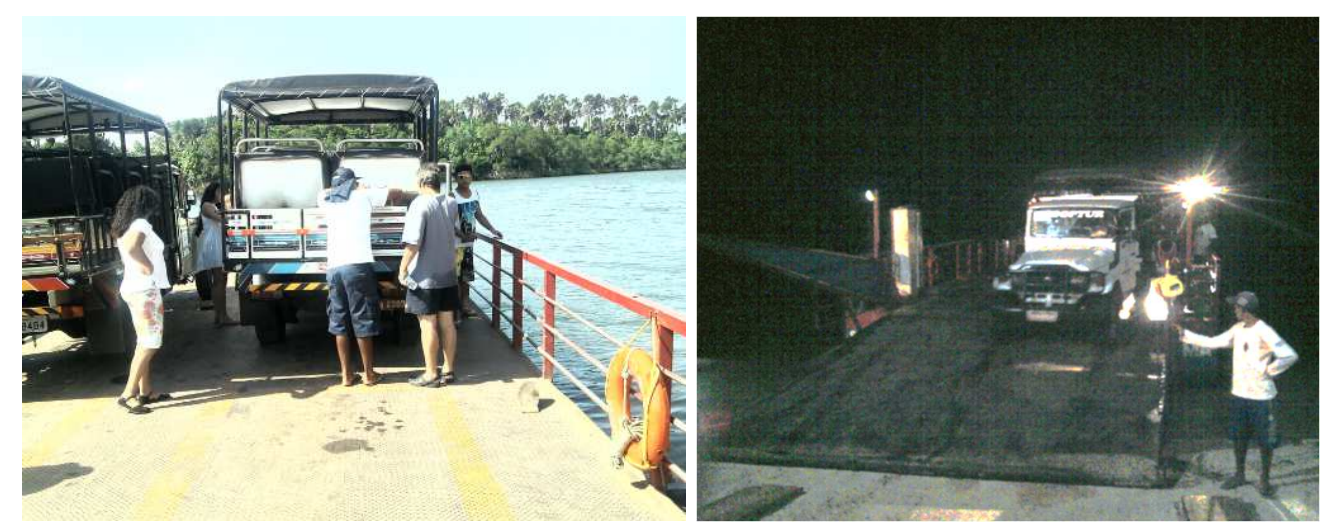

Figura 14: Balsas para travessia do Rio Preguiças

Fonte: próprio autor

Outros pontos também podem ser acessados para se adentrar na região da UC, como pelos municípios de Santo Amaro do Maranhão, Humberto de Campos, Primeira Cruz e Paulino Neves (para os Pequenos Lençóis).

Já o acesso à Vila de Jericoacoara, saindo da sede do município de Jijoca de Jericoacoara, é realizado por duas vias. A primeira delas é por estrada não-pavimentada ${ }^{4}$ que dá acesso à Vila do Preá, de onde se tem um dos quatro acessos à UC (pontos amarelos da Figura 12) por trilhas que cruzam o Parque Nacional.

O segundo trajeto, mais curto (18 km), é partindo da sede de Jijoca de Jericoacoara em direção ao povoado de Lagoa Grande, onde se encontra a rota para a Vila. Esse trajeto é bastante utilizado por turistas que deixam seus automóveis particulares na sede municipal e seguem por transfers realizados com jardineiras.

Assim como nos Lençóis, tratam-se de trechos de difícil acesso, arenosos, que demandam por veículos tracionados e conhecimento e destreza dos motoristas. Alguns visitantes optam por aventurar-se com carros próprios, realizando trajetos próximos à orla marítima.

É possível, ainda, acessar o Parque Nacional por dois outros trechos: a partir da Vila de Mangue Seco, utilizando uma ponte que passa sobre uma área de mangue; a partir da comunidade de Guriú, por meio da travessia por balsa. Ambos trechos dependem da dinâmica de marés. (ICMBIO, 2011)

\footnotetext{
${ }^{4}$ Até o momento de realização da primeira pesquisa de campo, no final de 2012.
} 
O aumento no trânsito de veículos na Vila de Jericoacoara resultou, desde a década de 1980, em vários impactos negativos, como rastros de combustível derramado na praia, e poluição sonora pela utilização de equipamentos de som.

Visando o ordenamento do trânsito de veículos na Vila de Jericoacoara, foi sancionada a Lei Municipal $n^{\circ} 289$, de 30 de dezembro de 2009, a qual criou um estacionamento (Figura 15), com capacidade para cerca de 1.500 carros, na entrada da vila. A lei determina que o visitante deixe o seu carro no estacionamento, e a administração municipal fica responsável pelo transporte do visitante até à pousada e o seu retorno até o estacionamento. Dessa forma, apenas veículos credenciados - dentre eles, jardineiras e bugues - poderão ter acesso para circular na vila. (PREFEITURA MUNICIPAL DE JIJOCA DE JERICOACOARA, 2011)
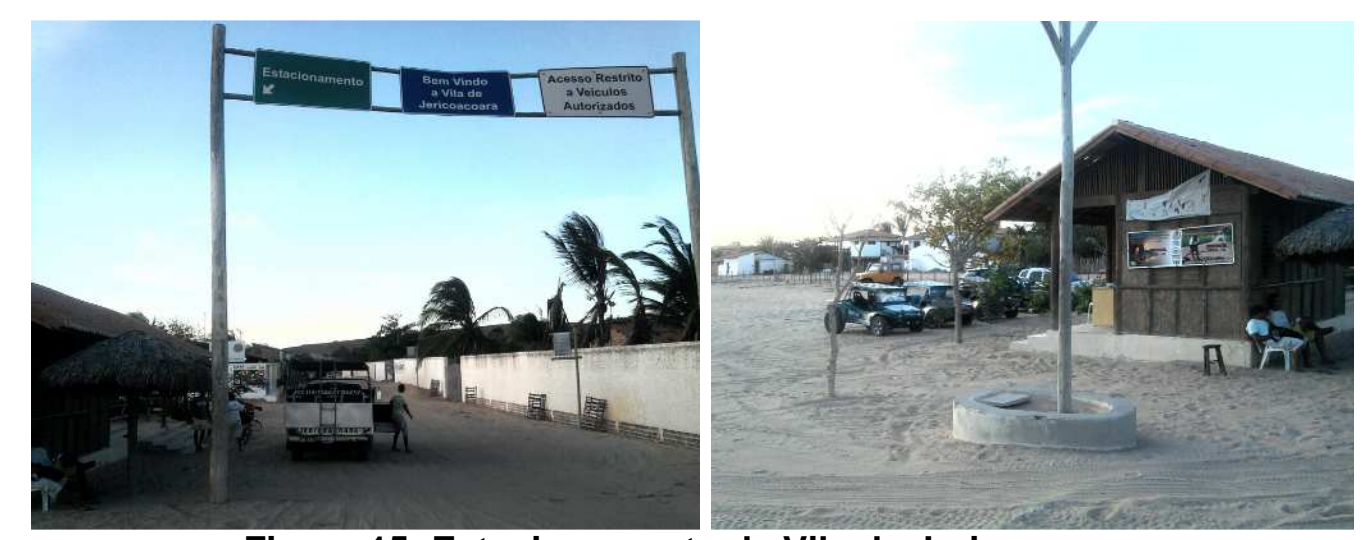

Figura 15: Estacionamento da Vila de Jericoacoara

Fonte: próprio autor

\subsection{3. Áreas de Influência (Al) e Zonas de Amortecimento (ZA)}

A Área de Influência $(\mathrm{Al})$ corresponde aos municípios da microrregião, às micro bacias onde estão inseridas a UC, e às demais áreas que exercem relações de interferência sobre o, ou pelo, Parque Nacional, por meio de fatores intrínsecos (IBAMA/MMA, 2002).

O Parna dos Lençóis Maranhenses engloba em sua Al (Figura 16) um total de 06 (seis) municípios do litoral oriental maranhense: Barreirinhas, Santo Amaro do Maranhão, Primeira Cruz, Humberto de Campos, Paulino Neves e Tutóia (IBAMA/MMA, 2002). Já o Parna de Jericoacoara possui 04 (quatro) municípios que compõem sua Al, por afetarem a socioeconomia da região da UC e de seu entorno: Jijoca de Jericoacoara, Cruz, Acaraú e Camocim (ICMBIO, 2011). 
Já a Zona de Amortecimento (ZA) refere-se, segundo a Lei $n^{\circ} 9.985$ que instituiu o SNUC, ao entorno da UC que, com o intuito de mitigar os impactos negativos sobre a unidade, apresenta normas e restrições específicas sobre qualquer atividade humana (BRASIL, 2000).

A ZA do Parque Nacional dos Lençóis Maranhenses (Figura 16) possui uma área de $4.232,31 \mathrm{Km}^{2}$. Seus limites são: a Oeste pelo Rio Negro; a Leste pelo Rio Preguiças; ao Sul pela nascente do riacho Mirinzal e pela Rodovia MA-402; e ao Norte pelo Oceano Atlântico e pelo limite do Parque Nacional. Na ZA exclui-se as sedes municipais de Barreirinhas, Primeira Cruz e Santo Amaro do Maranhão. Contudo, inclui duas Áreas de Proteção Ambiental (APA's), de Oeste para Leste: Upaon-Açu/Miritiba/Alto Preguiças e Foz do Rio Preguiças/Pequenos Lençóis/Região Lagunar Adjacente. No Oceano Atlântico a ZA equivale a $10 \mathrm{Km}$ a partir do limite da UC no mar, desde a foz do Rio Periá/Barra dos Veados, a Oeste, até parte da foz do Rio Preguiças, a Leste. (IBAMA/MMA, 2002)

A UC de Jericoacoara, por sua vez, possui uma ZA que abrange uma área terrestre total de $249,6 \mathrm{Km}^{2}$ (Figura 17). Perpassa à Oeste próxima à Vila de Tatajuba, no município de Camocim. Ao Sul estende-se até a extremidade da APA da Lagoa de Jijoca, divisa entre os municípios de Jijoca de Jericoacoara e Cruz. À Leste atinge a Lagoa Riacho da Prata, no município de Acaraú, seguindo em linha reta até atingir, ao Norte, o Oceano Atlântico. Sua extensão marinha adentra 4.635 metros (2,5 milhas náuticas), e percorre os limites costeiros dos municípios de Jijoca de Jericoacoara e de Cruz, e parte dos limites costeiros de Acaraú e Camocim. (ICMBIO, 2011). 

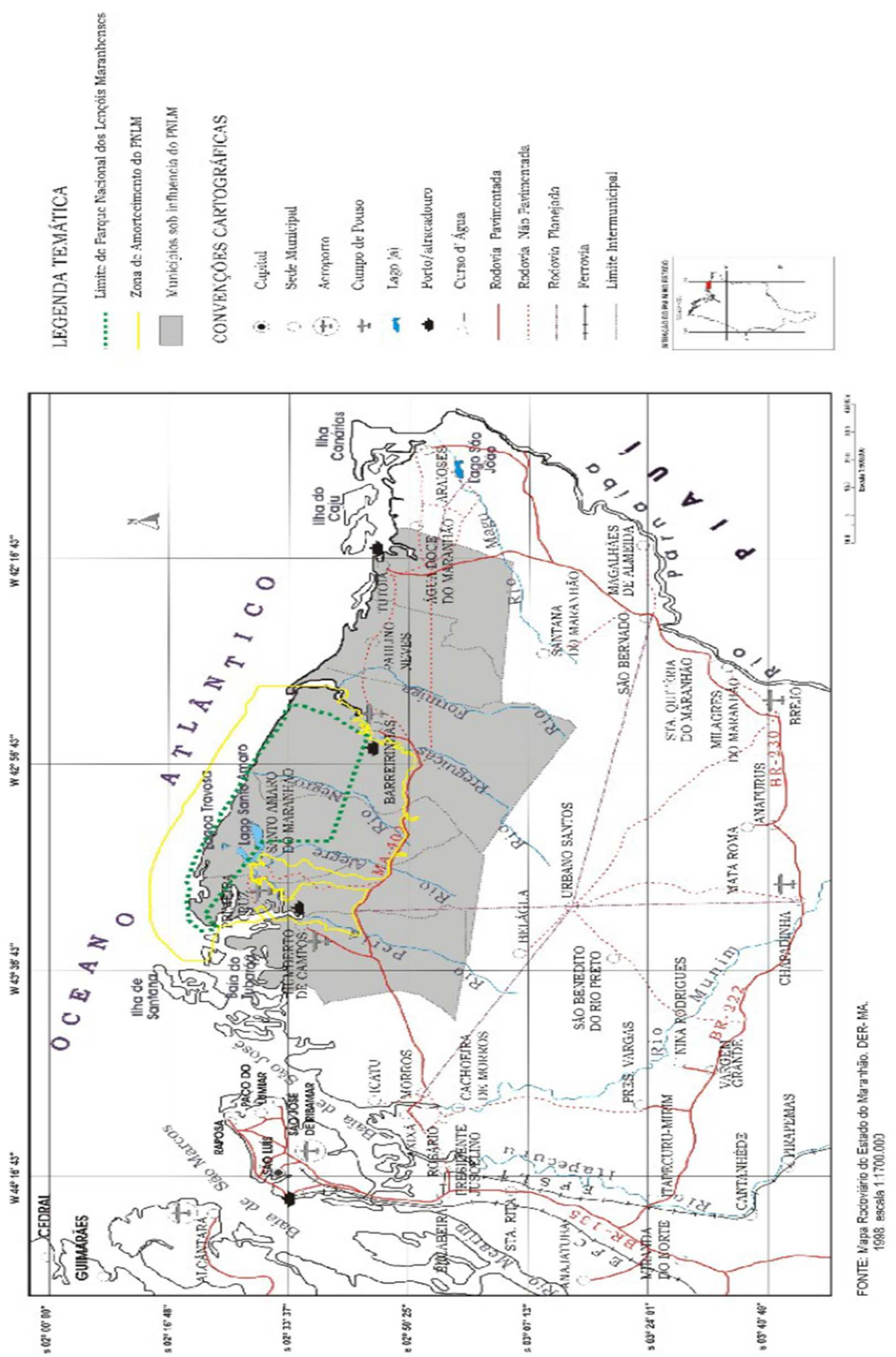

Figura 16: Zona de Amortecimento e Área de Influência do PN Lençóis Maranhenses Fonte: IBAMA/MMA, 2002. 


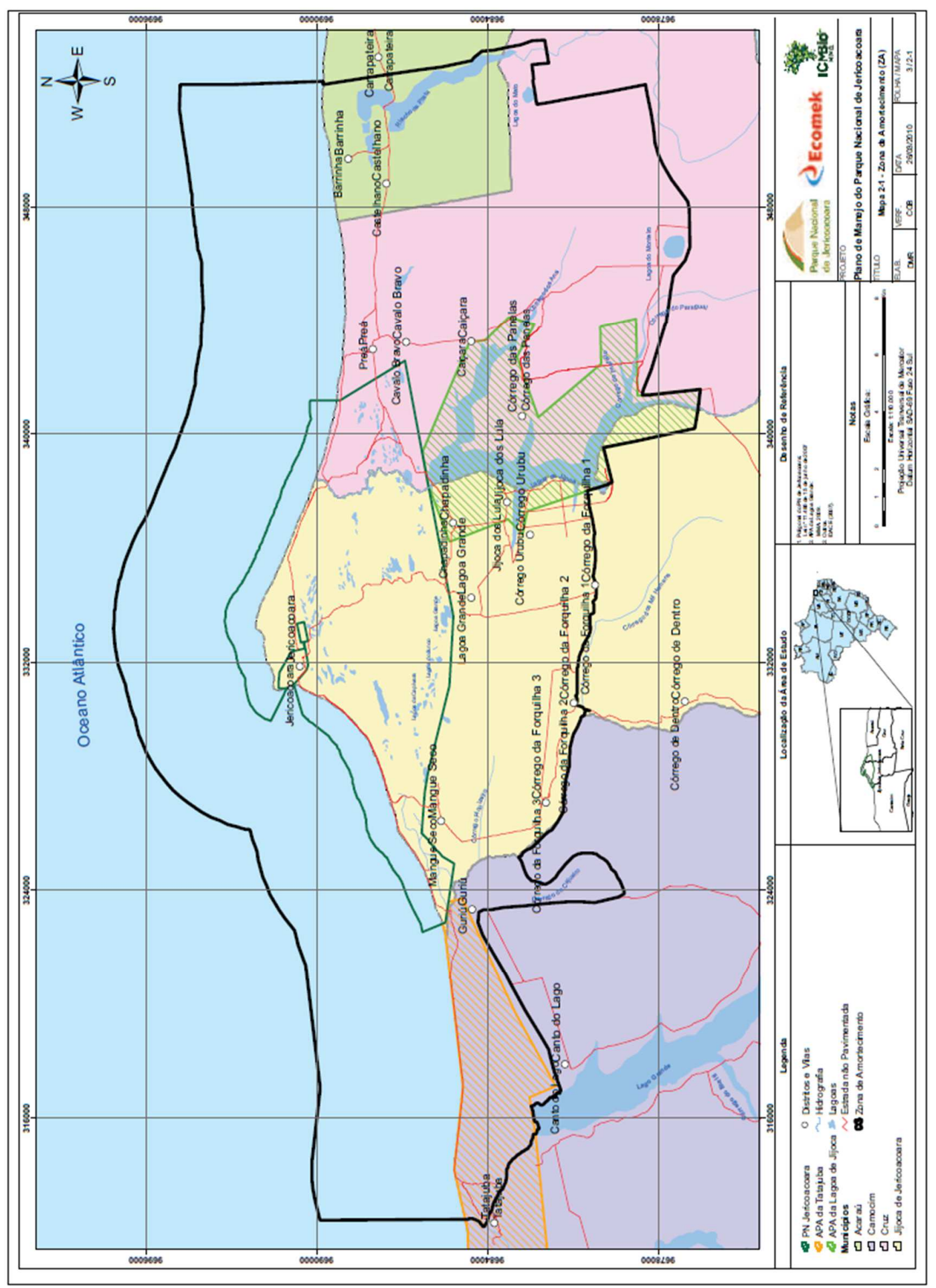

Figura 17: Zona de Amortecimento e Área de Influência do PN Jericoacoara Fonte: ICMBIO, 2011. 


\subsubsection{Clima, temperatura e pluviosidade}

A área onde se encontram os Lençóis Maranhenses pode ser caracterizada pela complexidade singular do clima ali identificado. São múltiplos fatores que agem diretamente sobre as condições climáticas e que interagem com os sistemas meteorológicos locais e regionais, tais como baixa latitude, energia solar irradiada (albedo), e grau de continentalidade ou maritimidade. (IBAMA/MMA, 2002; FUNDAÇÃO SOUSÂNDRADE DE APOIO E DESENVOLVIMENTO DA UNIVERSIDADE FEDERAL DO MARANHÃO, 2002)

Contudo, as regiões dos Parques Nacionais dos Lençóis Maranhenses e de Jericoacoara possuem similitudes quanto a algumas características climáticas. Tratam-se de climas quentes e úmidos - "Zona Equatorial" nos Lençóis Maranhenses, e "Tropical Quente Semiárido Brando" em Jericoacoara -, com temperaturas médias anuais acima de $26^{\circ} \mathrm{C}$ - ver Quadro 4. (IBAMA/MMA, 2002; ICMBIO, 2011)

\begin{tabular}{|l|c|c|}
\hline \multicolumn{1}{|c|}{ ASPECTOS } & BARREIRINHAS & JIJOCA DE JERICOACOARA \\
\hline Clima & Zona Equatorial & Tropical Quente Semiárido Brando \\
\hline Temperatura anual & $26^{\circ} \mathrm{a} 28,5^{\circ} \mathrm{C}$ & $26^{\circ} \mathrm{a} 28^{\circ} \mathrm{C}$ \\
\hline Pluviosidade anual & $1.600 \mathrm{~mm}$ & $1.034 \mathrm{~mm}$ \\
\hline Período chuvoso & janeiro a junho & dezembro a maio \\
\hline
\end{tabular}

Quadro 4: Características ambientais da região dos Parques Nacionais estudados Fonte: IBAMA/MMA, 2002; D'ANTONA, 2002; Governo do Estado do Ceará apud ICMBIO, 2011.

Diferenciam-se pelos níveis de precipitação. A média de pluviosidade na área dos Lençóis Maranhenses chega a $1.600 \mathrm{~mm}$ por ano, enquanto que em Jericoacoara a média não ultrapassa os $1.040 \mathrm{~mm} / \mathrm{ano}$.

Segundo a classificação climática de Köppen-Geiger (KOTTEK et al, 2006), a região do PNLM é do tipo " $A f$ ', com precipitações prolongadas e inexistência de estação seca definida, enquanto que a região do PN de Jericoacoara é do tipo " $A w$ ", com chuvas de verão.

A estação com maior incidência de chuvas na região do PNLM é percebida entre os meses de janeiro e junho, com elevados índices de precipitação nos meses de março e abril. Entre julho e dezembro nota-se um período de seca. A irregularidade pluviométrica em toda a zona costeira maranhense é gerada pela dinâmica da circulação atmosférica que, somada à proximidade da Linha do Equador, faz com que as estações na região dos Lençóis não sejam bem definidas, 
identificando, com maior propriedade, apenas duas: o verão e o inverno. (D’ANTONA, 2002; IBAMA/MMA, 2002)

Na região do PN de Jericoacoara o período de maior concentração de chuvas é similar à região maranhense, se estendendo entre os meses de dezembro e maio. Entre junho e novembro identifica-se um período baixa precipitação. (ICMBIO, 2011)

\subsubsection{Relevo, Solo, Vegetação e Recursos Hídricos}

As Unidades de Conservação em tela possuem algumas similaridades quanto aos aspectos geomorfológicos. Tratam-se de regiões destacadas por planícies litorâneas, de relevo suavemente ondulado, proporcionado por ações eólicas, marinhas e fluviais, que criam extensos campos de dunas livres (móveis) e fixas, do tipo barcanas. Possuem coloração cinza esbranquiçada, fina a média, com pequenas proporções de argila, e formadas por areias do tipo quartzosas marinhas.

Os Lençóis Maranhenses, em específico, apresentam um dos maiores registros de campo de dunas costeiras desenvolvido ao longo do quaternário (AB'SABBER, 2001). Suas extensões dunares são visivelmente superiores se comparado à Jericoacoara (Figura 18).

Os termos "campo de dunas", "morros" e "morraria" são utilizados frequentemente pelas comunidades locais que, por viverem em um relevo destacado por planícies, referem-se às dunas como morros, por representarem as maiores altitudes topográficas em relação ao nível do mar. São a partir desses "morros" que os guias turísticos locais, e a própria comunidade do interior, traçam suas rotas.

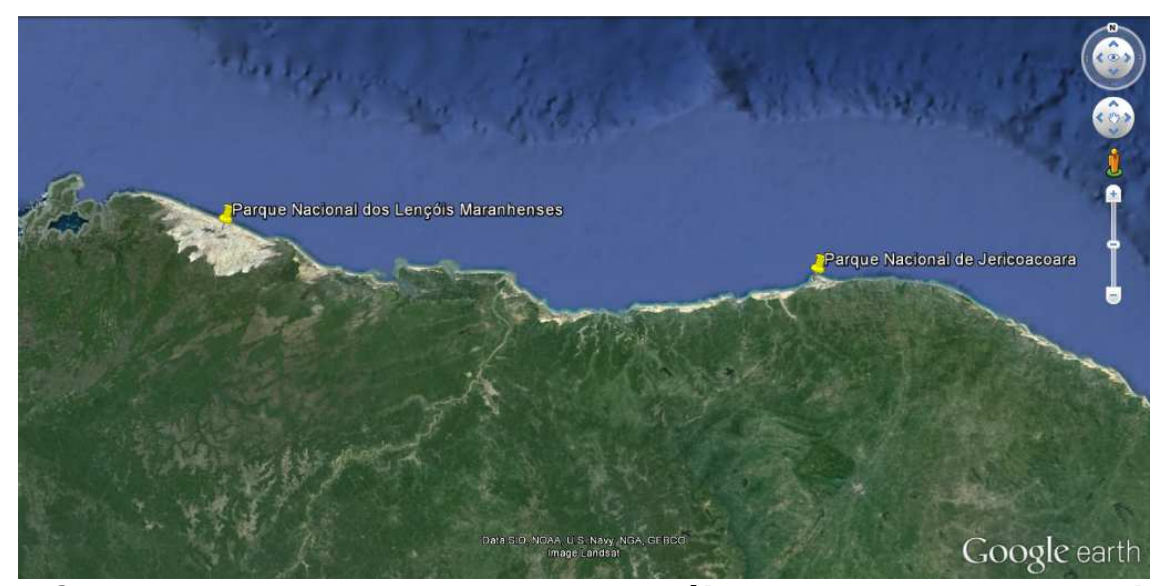

Figura 18: Campos de dunas dos PN dos Lençóis Maranhenses e de Jericoacoara Fonte: próprio autor, a partir do Google Earth (sem escala). 
Podem ser encontradas, nas duas regiões, áreas remanescentes de grandes campos de dunas fósseis, conhecidas por paleodunas. Tratam-se de representações de uma geração de dunas mais antigas que, dado aos processos pedogenéticos ${ }^{5}$, se estabilizaram.

Outras feições morfológicas também são características das áreas, como: faixas de praias, pós-praias, restingas, planícies de inundação e fluviomarinhas. Essas últimas dão origem a um ambiente complexo, formado pela deposição de sedimentos ricos em matéria orgânica, argila, e vegetação de mangue.

Os manguezais possuem fundamental importância para essas áreas, ao atuarem no fortalecimento da produtividade das águas costeiras próximas, bioestabilizando as planícies fluviomarinhas pelo provimento de alimentos em abundância e abrigo para a desova e repovoamento das mais diversas espécies de peixes, crustáceos (como camarão e caranguejo) e moluscos (como a ostra).

O aparecimento de lagoas interdunares de água doce é característico da região do PN dos Lençóis Maranhenses. São encontradas milhares delas, com formas, tamanhos e profundidades diversos. Algumas temporárias, outras perenes, mas com morfodinâmica própria. Formadas pela ação pluvial intensa, e pelo afloramento do lençol freático, as lagoas interdunares são os principais atrativos turísticos da UC.

Na região de Jericoacoara são mais comuns lagunas, de água salgada, caracterizadas por depressões que, pelo avanço das marés, geram algumas inundações. O mesmo ocorre na região costeira da UC maranhense.

Ainda na área do PN de Jericoacoara é encontrado outro domínio geomorfológico: tabuleiros pré-litorâneos. São terrenos mais estáveis, firmes e planos, com solos mais espessos, onde se encontram as sedes municipais.

Grosso modo, o complexo vegetacional encontrado no PN de Jericoacoara é similar ao do PN dos Lençóis Maranhenses, diretamente relacionados à sazonalidade climática dessas duas regiões. Nas áreas com influência marinha (restinga) - planícies litorâneas - aparecem vegetações rasteiras e arbustivas, gramíneo-herbácea e arbustiva-arbórea, típicas do Cerrado e Caatinga, servindo como instrumento de fixação de dunas. Em Jericoacoara, nas regiões subsequentes às faixas litorâneas, identifica-se espécies vegetais características de Mata de Tabuleiro. Nas regiões com influência fluvial são encontradas espécies de mata ciliar, compostas

\footnotetext{
${ }^{5}$ Processos de transformação do solo pela incidência de dois fatores climáticos e microrganismos.
} 
por babaçus e carnaúbas, e grande concentração de buritizais e coqueirais na região maranhense. Por fim, nas áreas de influência fluviomarinha, a vegetação típica são os manguezais, adaptados às condições de salinidade e aos baixos teores de oxigênio.

A riqueza de recursos hídricos das UC's estudadas, e de seus respectivos entornos, é representada por uma rede hidrográfica composta por lagoas, lagunas, córregos, riachos e rios. Na região do PN de Jericoacoara podem ser destacadas, como principais, 06 (seis) lagoas, e na região do PN dos Lençóis Maranhenses 04 (quatro). Tratam-se de lagoas perenes e temporárias, de grande atratividade turística - ver Quadro 5 e Figura 19.

\begin{tabular}{|c|c|}
\hline PN DOS LENÇÓIS MARANHENSES & PN DE JERICOACOARA \\
\hline $\begin{array}{c}\text { Lagoa do Peixe, Lagoa Azul, } \\
\text { Lagoa do Urubú, Lagoa Bonita }\end{array}$ & $\begin{array}{c}\text { Lagoa do Amâncio, Lagoa da Capivara, } \\
\text { Lagoa do Junco, Lagoa Grande, Lagoa do } \\
\text { Coração, Lagoa dos Homens }\end{array}$ \\
\hline
\end{tabular}

Quadro 5: Principais lagoas de Jericoacoara e dos Lençóis Maranhenses Fonte: IBAMA/MMA, 2002; ICMBIO, 2011.
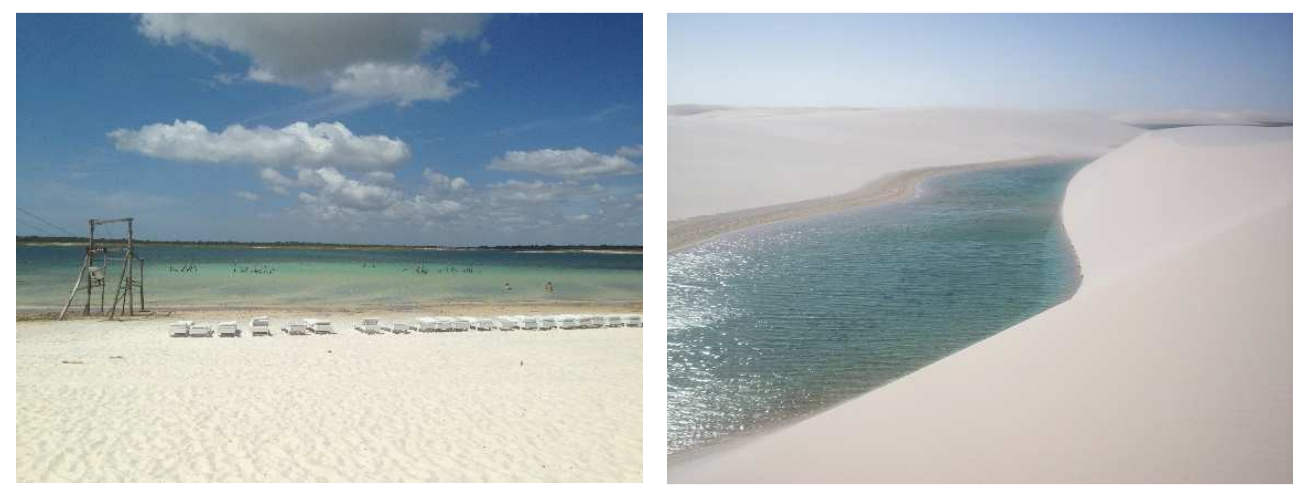

Figura 19: Lagoas de Jericoacoara e dos Lençóis Maranhenses

Fonte: próprio autor.

Os Parque Nacionais em foco estão inseridos, em maior proporção, em três bacias hidrográficas: bacia do Rio Coreaú (PN de Jericoacoara); e bacias do Rio Preguiças e do Rio Periá (PN dos Lençóis Maranhenses).

O Rio Preguiças - ver Figura 20 - é considerado o de maior importância na região dos Lençóis Maranhenses, por seus múltiplos benefícios como: fonte de alimento e de subsistência para populações do Município de Barreirinhas e do entorno; canal de acesso ao oceano; meio de comunicação entre vilas e povoados; instrumento de regulação biológica das áreas de mangue; recurso de lazer para a prática de esportes e banho; e atrativo para o turismo, por servir 
de curso fluvial navegável para passeios de "voadeiras"6 até pontos de visitação como Caburé, Mandacarú e Atins. É o maior rio da região, com uma extensão de $120 \mathrm{~km}$, e se configura como parte da história de ocupação e povoamento do município. (SETUR-BARREIRINHAS, 2011)

Muito da vida de Barreirinhas ocorre em função do rio Preguiças ou graças a ele: via de acesso para as comunidades e para o Parque Nacional; fonte de alimentos e recursos; área de lazer e de trabalho; enfim, o rio integra a vida cotidiana das pessoas que, sem hesitar, dizem: "o Preguiça é a nossa riqueza". (D'ANTONA, 2000, p.37)

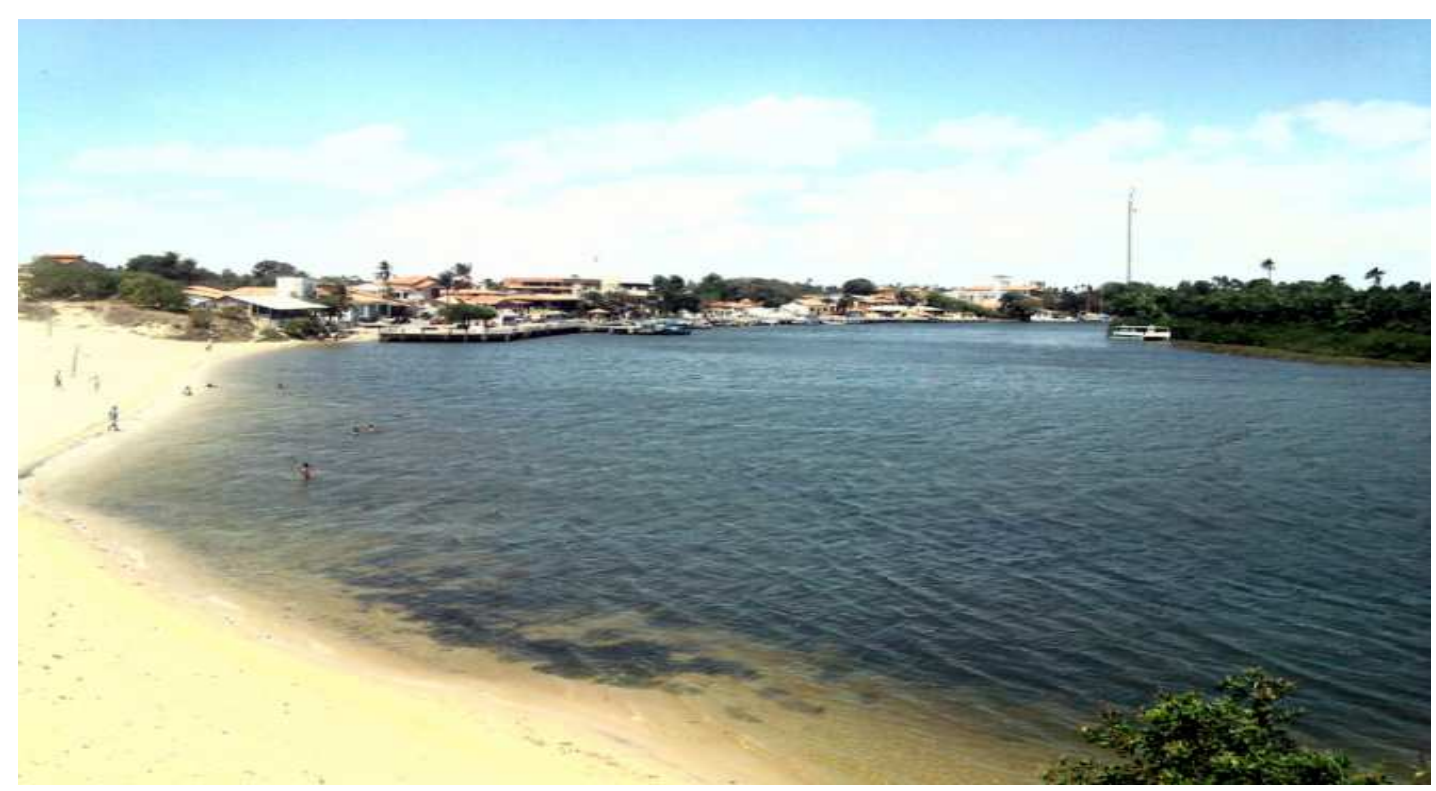

Figura 20: Rio Preguiças

Fonte: próprio autor.

O Rio Preguiças é o limite leste do Parque Nacional dos Lençóis Maranhenses. Por meio de sua travessia, a partir do Município de Barreirinhas (principal via), se tem acesso à UC. Contudo, o campo de dunas do Parque se estende até próximo ao Município de Tutóia, formando os popularmente conhecidos como "Pequenos Lençóis". Assim, como apresentado na Figura 21, o Rio Preguiças separa os "Grandes Lençóis" - localizados na área da UC, à sua margem esquerda - dos "Pequenos Lençóis", à sua margem direita.

\footnotetext{
${ }^{6}$ Pequenas embarcações de alumínio, geralmente cobertas e movidas a motor.
} 


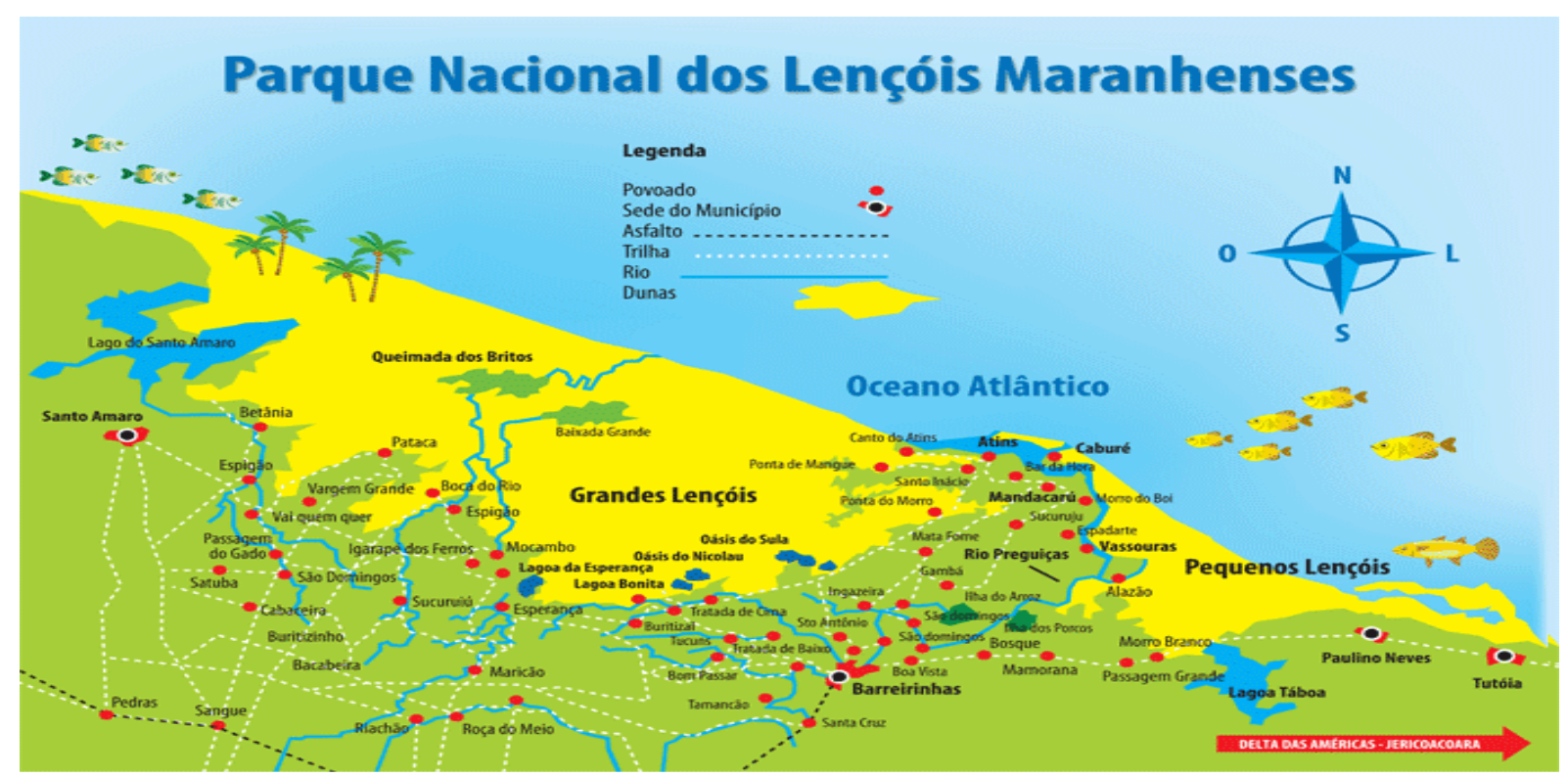

Figura 21: Grandes Lençóis, Pequenos Lençóis e o Rio Preguiças

Fonte: próprio autor, a partir de imagem disponibilizada na Pousada do Rio.

\section{Aspectos Sociais e Econômicos}

\subsection{Evoluções populacionais}

Entre os anos de 1991 e 2000 os municípios de Jijoca de Jericoacoara e de Barreirinhas presenciaram um aumento substancial em suas populações (Tabela 2). Se comparadas às taxas médias de crescimento anuais de seus estados (1,02\% em ambos) ou mesmo no Brasil (1,02\%), no mesmo período, percebe-se que nos dois municípios essas taxas foram superiores.

Em Barreirinhas a taxa média de crescimento anual chegou a 3,07\%, passando de 30.009 habitantes, para 39.498. Em Jijoca de Jericoacoara esse aumento foi ainda maior. A mesma taxa chegou a $8,28 \%$, passando de 5.908 para 12.089 habitantes.

Na década seguinte, entre 2000 e 2010, Barreirinhas continuou a aumentar sua taxa média de crescimento anual (Tabela 2), passando de 3,07\% para 3,35\%, superando novamente as taxas estadual e nacional, no mesmo período, respectivamente, de 1,02\% e 1,01\%. A população municipal atingiu 54.930 habitantes.

Jijoca de Jericoacoara, em contrapartida, sofreu uma notória redução de sua taxa média de crescimento anual (Tabela 2), de $8,28 \%$ para 3,47\%, porém, superando as taxas estadual e nacional, de 1,01\% cada. Sua população chegou a 17.002 . 
Tabela 2: População total e taxa média de crescimento anual (1991-2000 / 2000-2010)

\begin{tabular}{l|c|c|c|c|c}
\cline { 2 - 6 } & $\mathbf{1 9 9 1}$ & $\mathbf{2 0 0 0}$ & $\mathbf{2 0 1 0}$ & $\mathbf{T x}(\mathbf{9 1 - 0 0 )}$ & $\mathbf{T x}(\mathbf{0 0 - 1 0})$ \\
\hline BARREIRINHAS & 30.099 & 39.498 & 54.930 & $3,07 \%$ & $3,35 \%$ \\
\hline $\begin{array}{l}\text { JIJOCA DE } \\
\text { JERICOACOARA }\end{array}$ & 5.908 & 12.089 & 17.002 & $8,28 \%$ & $3,47 \%$ \\
\hline MARANHÃO & 4.930 .253 & 5.651 .475 & 6.574 .789 & $1,02 \%$ & $1,02 \%$ \\
\hline CEARÁ & 6.366 .647 & 7.430 .661 & 8.452 .381 & $1,02 \%$ & $1,01 \%$ \\
\hline BRASIL & 146.825 .475 & 169.798 .885 & 190.755 .799 & $1,02 \%$ & $1,01 \%$ \\
\hline
\end{tabular}

Fonte: próprio autor, a partir de dados do PNUD, 2013.

Muitos são os fatores que contribuíram para o crescimento populacional nesses dois municípios, porém, que leva como fio condutor a descoberta/valorização das áreas naturais aliada ao desenvolvimento da atividade turística nessas localidades.

A chegada de investidores externos, a multiplicação de empreendedores internos, as iniciativas estaduais e federais de estruturação do espaço urbano, a dinâmica acelerada de crescimento no número de visitantes, a promoção dos destinos e de seus cenários paradisíacos. Todos esses fatores, de alguma forma, fortaleceram a expansão populacional dessas localidades.

\subsection{Taxas de urbanização e Povoados}

Partindo de meados da década de 1980, os processos de desenvolvimento da atividade turística nos dois municípios em tela foram acompanhados por movimentos expressivos de urbanização de suas áreas.

O crescimento no número de visitantes e a dinamização do setor de serviços nas regiões circunvizinhas aos dois Parques Nacionais, até os dias atuais, tem refletido em um constante aumento nas taxas de urbanização municipais.

Barreirinhas apresentou taxas de urbanização mais elevadas que as de Jijoca de Jericoacoara, em todos os anos de análise (1991, 2000 e 2010), conforme Tabela 3. Foram, respectivamente, $24,73 \%$, 33,44\% e $40,15 \%$, contra taxas de $17,98 \%, 28,41 \%$ e $32,68 \%$, de Jijoca. Em contrapartida, nas últimas duas décadas, a taxa de urbanização de Jijoca de Jericoacoara teve um maior crescimento $(81,79 \%)$ em relação a de Barreirinhas, com $62,38 \%$. 
Tabela 3: Populações (urbanas e rurais) e taxas de urbanização

\begin{tabular}{|c|c|c|c|c|c|c|}
\hline & \multicolumn{3}{|c|}{ BARREIRINHAS } & \multicolumn{3}{|c|}{ JIJOCA DE JERICOACOARA } \\
\hline & 1991 & 2000 & 2010 & 1991 & 2000 & 2010 \\
\hline População Urbana & 7.442 & 13.209 & 22.053 & 1.062 & 3.434 & 5.556 \\
\hline População Rural & 22.657 & 26.289 & 32.877 & 4.846 & 8.655 & 11.446 \\
\hline Taxa de Urbanização & $24,73 \%$ & $33,44 \%$ & $40,15 \%$ & $17,98 \%$ & $28,41 \%$ & $32,68 \%$ \\
\hline $\begin{array}{l}\text { Crescimento da Taxa de } \\
\text { Urbanização (entre } 1991 \text { e } \\
\text { 2010) }\end{array}$ & \multicolumn{3}{|c|}{$62,38 \%$} & \multicolumn{3}{|c|}{$81,79 \%$} \\
\hline $\begin{array}{l}\text { Densidade Demográfica } \\
\left(\mathrm{hab} / \mathrm{km}^{2}\right)-2010\end{array}$ & \multicolumn{3}{|c|}{17,47} & \multicolumn{3}{|c|}{83,2} \\
\hline
\end{tabular}

Fonte: próprio autor, a partir de dados do PNUD, 2013.

Nota-se, portanto, um processo gradativo de urbanização nas duas regiões. Contudo, o ritmo desse processo nas localidades não foi tão intenso, se comparado aos seus respectivos estados e à federação. No ano de 2010, o Estado do Maranhão teve uma taxa de urbanização de $63 \%$. O Estado do Ceará apresentou uma taxa de $75 \%$. Enquanto que o Brasil, no mesmo período, teve uma taxa de urbanização de $84,3 \%$. (IBGE, 2011)

As zonas rurais continuam sendo as regiões com maiores concentrações populacionais. No último ano de referência (2010), 59,85\% da população barreirinhense, e 67,32\% da população jijoquense, se encontravam no campo, caracterizando-os como municípios essencialmente rurais.

As densidades demográficas das duas localidades, no entanto, são díspares. Jijoca apresenta uma concentração populacional de 83,2 habitantes por $\mathrm{km}^{2}$, notoriamente superior a Barreirinhas (com 17,47 hab/km²) e ao Estado do Ceará, com 56,76 hab/ $\mathrm{km}^{2}$. No caso do município maranhense, sua densidade demográfica é ainda menor do que o seu respectivo Estado, Maranhão, que atingiu 19,78 hab/km² (IBGE, 2010).

Os diversos grupamentos familiares que se formaram por toda a extensão territorial nas duas regiões, seja no espaço urbano ou rural, voltaram-se, principalmente, à atividade pesqueira artesanal e agrícola familiar, além da produção de artesanato (com o advento da atividade turística). O aproveitamento dos recursos naturais, ainda hoje para muitos como forma de subsistência, foi o principal fator de contribuição para fixação e formação de povoados nas áreas.

Segundo a Secretaria de Turismo e Meio Ambiente de Jijoca de Jericoacoara, atualmente são encontradas no município 21 comunidades: Córrego do Urubu I, Córrego do Urubu II, 
Mangue Seco, Lagoa Grande, Córrego de Dentro, Baixio I, Baixio II, Córrego do Mourão, Córrego da Forquilha I, Córrego da Forquilha II, Córrego da Forquilha III, Chapadinha, Borges, Jericoacoara (Vila), Lagoa das Pedras, Jijoca dos Lulas, Jijoca dos Bentos, Carro Quebrado, Córrego Perdido, Vila do Aeroporto, e a sede, Jijoca.

Em Barreirinhas, segundo o Sindicato dos Trabalhadores Rurais, são mais de 230 povoados (Figura 22), com destaque para: Laranjeiras, Tapuio, Cardosa (passeio de bóia), Caburé (pousadas), Atins, Vassouras, Morro do Boi, Mandacarú (farol), Tabocas, Braço, Morro Alto, Ponta do Mangue, Santo Inácio, Marcelino, Canto do Atins, São José dos Viúvos, Pacas, Varas (tentando se emancipar), Palmeiras dos Eduardo, Pequizeiro, Jabuti, Baixa D’Água, Fazendinha, Olho d'Água, Santa Maria, Engenho, Canoas, Manoelzinho, Croas, Baixão do Pomoaldo, Baixão dos Paulino, Anibal, Massangano I, Massangano II, Massangano III, Caboclo I, Caboclo II, Bom Passar, Paú, Carnaubeira, Móia, Sobradinho, Boa Vista, São Domingos, Cantinho, Santo Antônio.

No interior do Parque Nacional são 25 comunidades, tendo como principais: Achuí, Tratada dos Carlos, Tratada de Cima, Tucunes, Merizau, Bom Jardim, Buritizal, Buriti Amarelo, Janaúba, Vargem D’Água, Sedro, Mata Fome, Ponta do Mangue, Mucambo, Canto do Atins, Queimada dos Britos (Santo Amaro), Atins e Santo Inácio. 


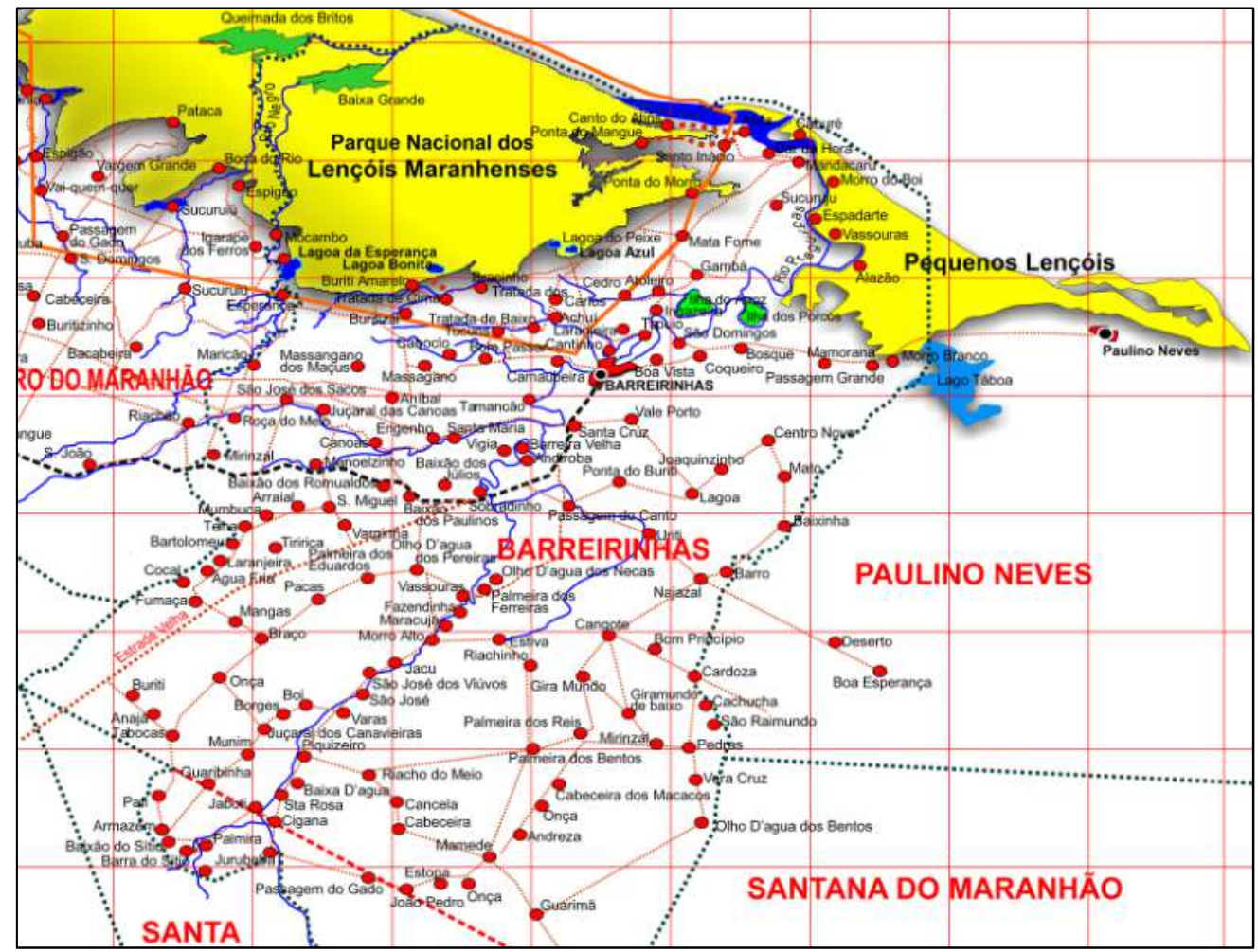

Figura 22: Localização das comunidades ribeirinhas de Barreirinhas. Fonte: SEBRAE, 2014.

\subsection{População com Idade Ativa (PIA)}

A proporção de indivíduos que, em 2010, compunha a População com Idade Ativa (PIA $)$ de Jijoca de Jericoacoara, foi de 82,1\% (13.969 indivíduos) da população total local, inferior à proporção de seu estado, que atingiu 84,1\% (7.111.302 indivíduos).

Comparando-se os dois municípios estudados, percebe-se que Barreirinhas apresentou uma menor proporção de indivíduos com idade ativa, chegando a 74,8\% (41.092 indivíduos), abaixo também da proporção de seu estado (80,0\% - 5.264.736) - ver Tabela 4.

Tabela 4: PIA e PEA

\begin{tabular}{c|c|c|c|c}
\cline { 2 - 5 } \multicolumn{1}{c|}{} & \multicolumn{4}{c}{2010} \\
\cline { 2 - 5 } & Barreirinhas & Jijoca de Jericoacoara & Maranhão & Ceará \\
\hline PIA & 41.092 & 13.969 & 5.264 .736 & 7.111 .302 \\
\hline
\end{tabular}

Fonte: próprio autor, com base no IBGE, Censo Demográfico 2010.

\footnotetext{
7 População com 10 anos ou mais de idade (IBGE, 2013).
} 
A partir desse agrupamento de indivíduos que compõe as PIAs das localidades estudadas, são ramificados dois outros segmentos de análise: quanto à "situação de ocupação" (ocupados e não ocupados); e quanto à "condição de atividade" (População Economicamente Ativa - PEA, e População Não Economicamente Ativa - PNEA). Tais subdivisões (Figura 23) são apresentadas a seguir, nos itens 4.3.1. e 4.3.2.

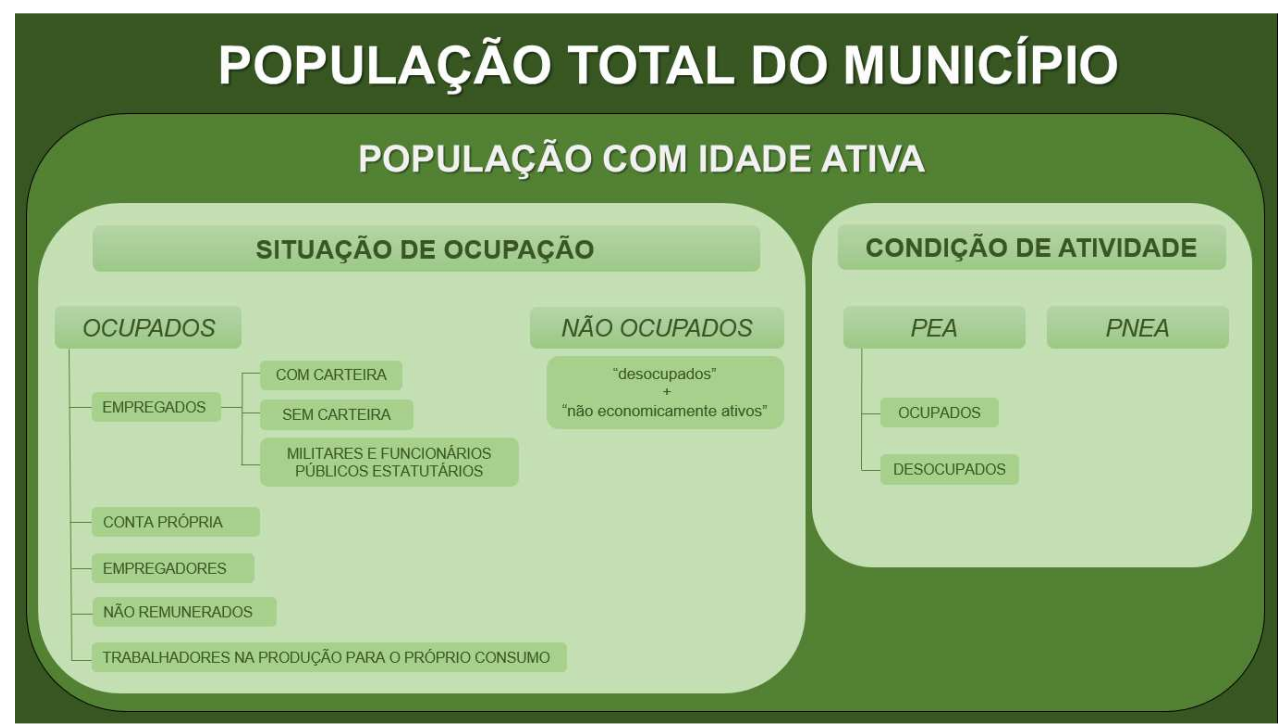

Figura 23: Subdivisões de Análise da População com Idade Ativa Fonte: próprio autor.

\subsubsection{Situação de Ocupação da PIA}

Dados do IBGE (2013) indicam que, no ano de 2010, a razão entre "ocupados"8 e "não ocupados"9 nos municípios estudados foi divergente. Em Barreirinhas havia uma maior porcentagem de não ocupados (54,9\% da PIA - 22.597 indivíduos), característica esta encontrada também no Estado do Maranhão (55,1\% da PIA - 2.903.348 indivíduos). Ver Gráfico 1.

Por outro lado, observou-se uma situação oposta em Jijoca de Jericoacoara (Gráfico 1), onde prevaleceu uma maior proporção de ocupados (53,7\% da PIA - 7.496 indivíduos), em contraposição ao Estado do Ceará que, assim como no Maranhão, apresentou uma maior porcentagem de não ocupados (52,7\% da PIA - 3.749.567).

\footnotetext{
${ }^{8}$ Pessoa que exerceu algum trabalho durante pelo menos uma hora completa na semana de referência, ou que tinha trabalho remunerado do qual estava temporariamente afastada nessa semana. (IBGE, 2010)

${ }^{9}$ Pessoa desocupada ou não economicamente ativa na semana de referência. (IBGE, 2010)
} 


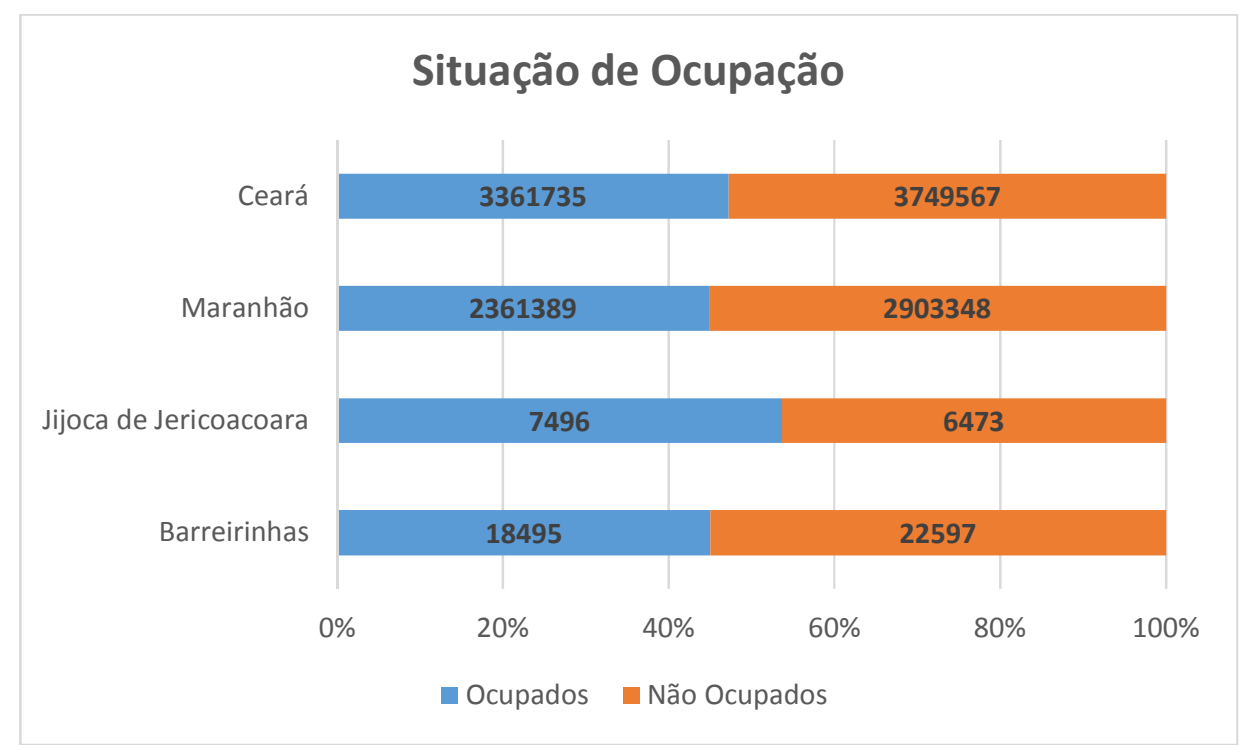

Gráfico 1: Situação da Ocupação, em 2010.

Fonte: IBGE, 2013.

Sendo assim, pôde-se perceber que, em 2010, o nível de ocupação de Jijoca de Jericoacoara $(53,7 \%)$ se sobressaiu ao nível do próprio estado $(47,3 \%)$ e ao do país $(53,3 \%)$. Por sua vez, o nível de ocupação de Barreirinhas $(45,1 \%)$ conseguiu ultrapassar o nível de ocupação de seu estado (44,9\%), ainda que distante do nível nacional.

\subsubsection{Ocupados: Posições na Ocupação}

Diante do quadro geral de posições na ocupação ${ }^{10}$ (ver Tabela 5) dos indivíduos ocupados, pode ser percebida uma similaridade entre os dois municípios estudados. Ambos atestaram uma maior proporção de "empregados" diante das demais posições na ocupação. Barreirinhas atingiu $42,1 \%$ (7.781 indivíduos) e Jijoca 55,8\% (4.186 indivíduos), ainda assim, taxas inferiores às de seus respectivos estados (56,0\% - 1.322.418 indivíduos; e 66,7\% - 2.240 .961 indivíduos).

\footnotetext{
${ }^{10}$ Considera-se posição na ocupação a "relação de trabalho existente entre a pessoa e o empreendimento em que trabalhava" (IBGE, 2010, p.38).
} 
Tabela 5: Posições na Ocupação

\begin{tabular}{l|c|c|c|c}
\cline { 2 - 5 } & \multicolumn{4}{|c}{2010} \\
\cline { 2 - 5 } & Barreirinhas & $\begin{array}{c}\text { Jijoca de } \\
\text { Jericoacoara }\end{array}$ & Maranhão & Ceará \\
\hline Empregados & $42,1 \%$ & $55,8 \%$ & $56,0 \%$ & $66,7 \%$ \\
\hline Conta Própria & $24,7 \%$ & $31,0 \%$ & $27,4 \%$ & $21,9 \%$ \\
\hline Empregadores & $0,8 \%$ & $0,4 \%$ & $0,9 \%$ & $1,2 \%$ \\
\hline Não remunerados & $7,6 \%$ & $3,3 \%$ & $3,3 \%$ & $2,3 \%$ \\
\hline $\begin{array}{l}\text { Trabalhadores na produção } \\
\text { para o próprio consumo }\end{array}$ & $24,8 \%$ & $9,5 \%$ & $12,4 \%$ & $7,9 \%$ \\
\hline
\end{tabular}

Fonte: próprio autor, com base no IBGE, Censo Demográfico 2010.

Em segundo plano, porém, tais municípios ressaltam divergências. Enquanto que em Jijoca a segunda maior proporção de ocupação está entre o grupo das pessoas que trabalham por "conta própria", atingindo 31,0\% (2.325 indivíduos), em Barreirinhas identifica-se os "trabalhadores na produção para o próprio consumo" com a segunda maior taxa $(24,8 \%-4.583$ indivíduos).

No caso de Jijoca, a proporção de trabalhadores por conta própria foi superior à do Estado do Ceará, que atingiu 21,9\% (737.061 indivíduos). Da mesma forma, a proporção de trabalhadores na produção para o próprio consumo em Barreirinhas superou à do Estado do Maranhão, com 12,4\% (291.711 indivíduos).

A margem de trabalhadores por conta própria em Barreirinhas (24,7\% - 4.567 indivíduos) esteve bem próxima da segunda colocação, contudo, abaixo da margem de 27,4\% (648.264 indivíduos) de seu estado.

Com menores porcentagens estiveram, em Jijoca: os "trabalhadores na produção para o próprio consumo" (9,5\% - 714 indivíduos), superando a margem estadual (7,9\% - 264.115 indivíduos); os "não remunerados" (3,3\% - 244 indivíduos), acima da taxa estadual (2,3\% - 78.838 indivíduos); e os "empregadores" (0,4\% - 27 indivíduos), abaixo da proporção estadual (1,2\% 40.760 indivíduos).

No caso de Barreirinhas, as menores porcentagens concentraram-se nos: "não remunerados" (7,6\% - 1.405 indivíduos), acima da taxa do Maranhão (3,3\% - 77,816 indivíduos); e "empregadores" (0,8\% - 158 indivíduos), abaixo da margem estadual (0,9\% - 21.180 indivíduos). 
Os dados supracitados conduzem à reflexão de que há, ainda, uma grande parcela dos moradores locais, nos dois municípios, ocupada com atividades informais, trabalhando na produção para o autoconsumo, ou em atividades por conta própria.

Se somadas as duas posições na ocupação, atinge-se 49,5\% do total de ocupações em Barreirinhas, e 40,5\% em Jijoca. Isso demonstra que os processos de inclusão socioeconômica das populações nos mercados de trabalho locais ainda têm enfrentado barreiras ao acesso ao emprego formal. O próximo subitem reforça tal análise ao apresentar a baixa porcentagem de empregados com carteira de trabalho assinada.

\subsubsection{Empregados: Níveis de Formalização}

A formalização dos empregados é obrigatória, por meio da assinatura da Carteira de Trabalho e Previdência Social, para a garantia ao acesso aos direitos trabalhistas como benefícios previdenciários, FGTS ${ }^{11}$ e seguro-desemprego (BRASIL, 2013k).

No entanto, o que se percebe nos municípios estudados é a ampla maioria dos empregados confinados à um cenário de informalidade e de privação de tais direitos trabalhistas.

A margem dos empregados sem carteira de trabalho assinada ultrapassa os $60 \%$ do total, em ambas localidades (ver Tabela 6). Em Barreirinhas chega a 65,9\% (5.129 indivíduos) e em Jijoca atinge 60,3\% (2.524 indivíduos). Tais margens chegam a ser superiores às margens dos Estados do Maranhão (50,8\% - 672.150 indivíduos) e do Ceará (45,7\% - 1.024 .959 indivíduos).

Tabela 6: Formalização dos Empregados

\begin{tabular}{l|c|c|c|c}
\cline { 2 - 5 } & Barreirinhas & $\begin{array}{c}\text { Jijoca de } \\
\text { Jericoacoara }\end{array}$ & Maranhão & Ceará \\
\cline { 2 - 5 } & $25,1 \%$ & $22,5 \%$ & $38,7 \%$ & $48,0 \%$ \\
\hline Com Carteira & $65,9 \%$ & $60,3 \%$ & $50,8 \%$ & $45,7 \%$ \\
\hline Sem Carteira & $9,0 \%$ & $17,2 \%$ & $10,5 \%$ & $6,3 \%$ \\
\hline $\begin{array}{l}\text { Militares e Funcionários } \\
\text { Públicos Estatutários }\end{array}$ & & &
\end{tabular}

Fonte: próprio autor, com base no IBGE, Censo Demográfico 2010.

A formalização dos empregados nessas regiões, por meio da assinatura da carteira de trabalho, parece ainda restrita a poucos. As taxas de Barreirinhas (25,1\% - 1.955 indivíduos) e

\footnotetext{
11 Fundo de Garantia do Tempo de Serviço.
} 
de Jijoca (22,5\% - 942 indivíduos) são inferiores às taxas de seus estados: Maranhão, com 38,7\% (510.996 indivíduos); e Ceará, com 48,0\% (1.075.391 indivíduos).

Quanto ao grupo composto por militares e funcionários públicos estatutários das duas localidades, as porcentagens são discrepantes, entre si e seus respectivos estados. No município maranhense, tal grupo atinge 9,0\% (697 indivíduos) do total de empregados, taxa inferior à de seu estado (10,5\% - 139.272 indivíduos).

Por outro lado, em Jijoca, o mesmo grupo atingiu 17,2\% (720 indivíduos) do total de empregados, taxa superior à do Estado do Ceará (6,3\% - 140.611 indivíduos).

\subsubsection{Empregados: Segmentos de Abrangência e Remuneração Média}

Dados mais recentes, referentes a 31 de dezembro de 2011, apresentados pelo Ministério do Trabalho e Emprego (MTE), por meio da "Relação Anual de Informações Sociais (RAIS)", demonstram que a formalização dos empregos com carteira assinada, nas duas localidades, encontra-se concentrada em trabalhos junto à Administração Pública.

Do total de 2.371 empregos formais encontrados em Barreirinhas, nos diversos segmentos de abrangência locais, 64,0\% (1.517 indivíduos) era referente a trabalhos no setor de Administração Pública. Enquanto que em Jijoca de Jericoacoara a taxa foi de 53,8\% (913 indivíduos) para o mesmo setor, diante do total de 1.697 empregos formais identificados - ver

\section{Gráfico 2.}

As semelhanças entre os dois municípios se extendem aos dois segmentos seguintes com maior abrangência entre os empregados formais (Gráfico 2). O setor de Serviços, provavelmente pela influência direta do turismo, esteve na segunda posição com 23,3\% (552 indivíduos) em Barreirinhas. Em Jijoca identificou-se uma proporção maior, chegando a 36,4\% (618 indivíduos).

O setor de Comércio também apresentou relativa expressão, chegando a 10,0\% (237 indivíduos) em Barreirinhas, e a 8,9\% (618 indivíduos) em Jijoca de Jericoacoara. Os demais segmentos de abrangência, como Construção Civil, Indústria de Transformação, e Serviços Industriais de Utilidade Pública (SIUP), refletiram taxas expressamente inferiores (ver Gráfico 2). 


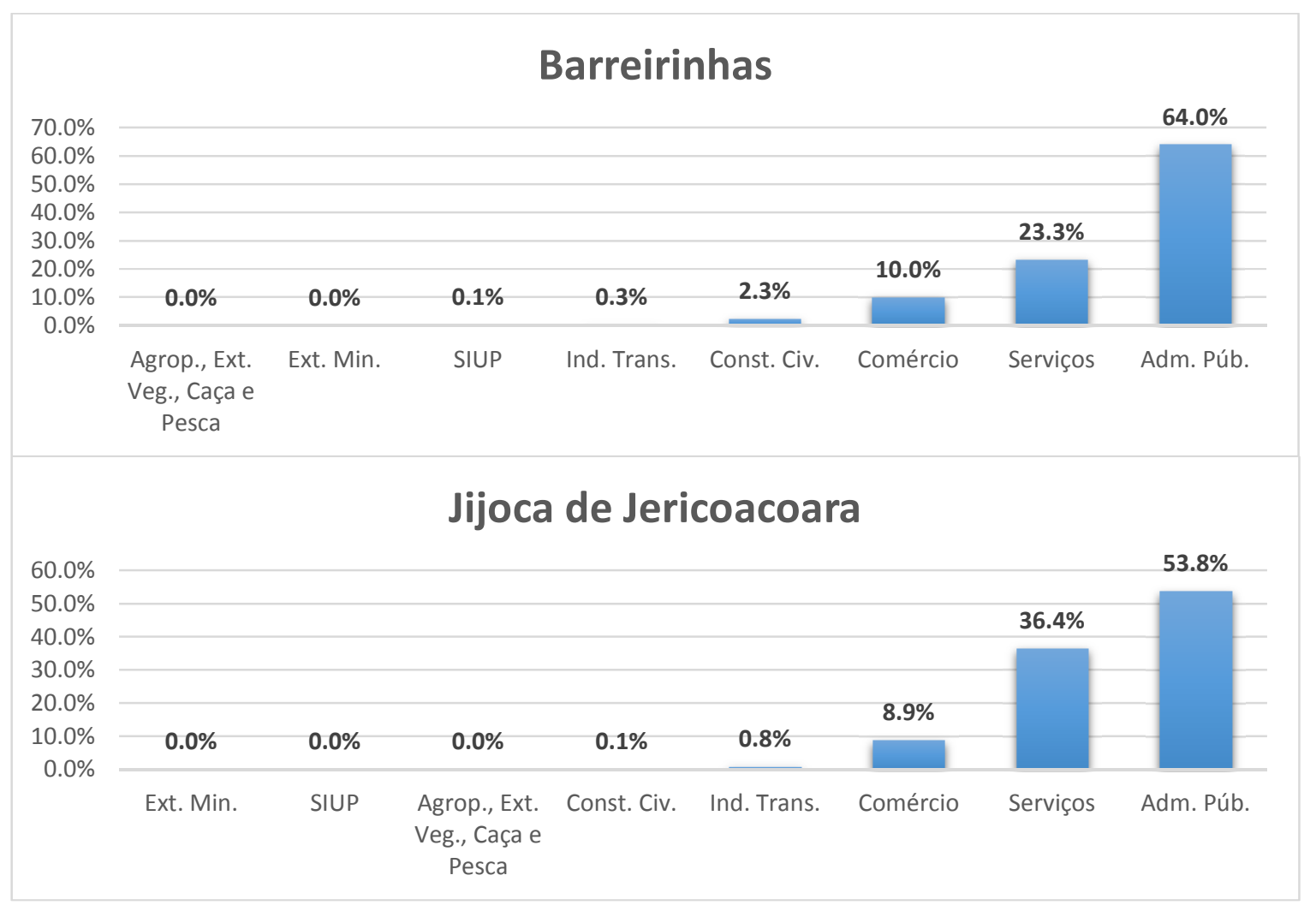

Gráfico 2: Empregos Formais por Segmentos de Abrangência

Fonte: próprio autor, com base nos dados de BRASIL, 2013j.

O segmento de Extração Mineral nas duas localidades foi nulo, assim como do setor de Agropecuária, Extração Vegetal, Caça e Pesca, o que demonstra a integral informalidade dentre os trabalhadores rurais.

Dentre os três segmentos com maior número de empregados formalizados, o setor de Administração Pública é aquele com a mais alta média de remuneração: $R \$ 1.245,06$ em Barreirinhas, e R $\$ 924,42$ em Jijoca.

Em relação ao setor de Serviços, a remuneração média no município maranhense é de $\mathrm{R} \$ 746,89$, e no município cearense de $\mathrm{R} \$ 724,15$. Por fim, no Comércio, identificou-se uma média de remuneração de $\mathrm{R} \$ 724,23$ em Barreirinhas, e $\mathrm{R} \$ 659,54$ em Jijoca.

\subsubsection{Empregados: Gênero e Idade nos Principais Segmentos}

Partindo do setor com maior composição de empregados formalizados nos dois municípios - Administração Pública - prevalece a ocupação por indivíduos do gênero feminino. Em 31 de 
dezembro de 2011, Barreirinhas contava com, aproximadamente, 70,0\% (1.058 indivíduos) de mulheres ocupando as vagas desse setor. Jijoca, por sua vez, atingiu 62,1\% (567 indivíduos). (BRASIL, 2013j)

No caso do setor de Serviços, a situação se inverte. Em ambas localidades nota-se uma maior margem de indivíduos do gênero masculino. As taxas foram de 57,6\% (318 indivíduos) em Barreirinhas, e 54,7\% (338 indivíduos) em Jijoca, no mesmo ano de análise. (BRASIL, 2013j)

Por fim, no segmento de Comércio, os indivíduos do gênero masculino são mais presentes em Jijoca, com 62,4\% (148 indivíduos) e, numa margem menor, também em Barreirinhas, com $51,6 \%$ (78 indivíduos). (BRASIL, 2013j)

Num panorama geral, levando-se em consideração todos os segmentos, predominam, nos dois municípios, empregados formais com faixa etária entre 30 e 39 anos. Tal faixa é identificada em, aproximadamente, 36,5\% (865 indivíduos) dos empregados formais de Barreirinhas, e em 33,2\% (563 indivíduos) dos mesmos em Jijoca. (BRASIL, 2013j)

A segunda maior concentração de empregados formais, nas duas localidades, está na faixa de indivíduos entre 25 e 29 anos. A taxa em Barreirinhas chegou a 20,6\% (490 indivíduos) e, em Jijoca, 25,1\% (426 indivíduos). (BRASIL, 2013j)

\subsubsection{Empregados: Ocupações com Maiores Estoques}

No que tange as ocupações com maiores estoques de empregados formais, identificou-se - em 31 de dezembro de 2011 - divergências entre os municípios.

Barreirinhas possui maior contingente (27,9\% - 661 indivíduos) de "Professores de Nível Superior na Educação Infantil para crianças de 04 a 06 anos", seguido por "Faxineiros" (17,6\% 417 indivíduos) e "Agentes Comunitários de Saúde" (7,6\% - 182 indivíduos). Tiveram destaque, ainda, "Auxiliar de Escritório e Geral" (3,3\% - 79 indivíduos) e "Vendedores de Comércio Varejista" (2,9\% - 69 indivíduos). (BRASIL, 2013j)

Já em Jijoca foi identificada, no mesmo período, uma maior proporção de "Faxineiros" (16,8\% - 286 indivíduos), de "Professores de Nível Superior na Educação Infantil para Crianças de 0 a 03 anos" (10,5\% - 178 indivíduos), e de "Vigias" (7,0\% - 120 indivíduos). Outras funções, como "Cozinheiro Geral" (5,9\% - 100 indivíduos) e "Camareiro(a) de Hotel” (5,7\% - 97 indivíduos) também ganharam destaque. (BRASIL, 2013j) 


\subsubsection{Empregados: Ocupações com Maiores Saldos de Admissão e Desligamento}

A análise ora apresentada é referente às admissões e aos desligamentos identificados no período compreendido entre janeiro de 2012 e setembro de $2013^{12}$, divulgadas pelo Cadastro Geral de Empregados e Desempregados (CAGED, 2013) do MTE.

O quadro geral de flutuação dos empregos formais reflete uma situação oposta entre Barreirinhas e Jijoca. No período de análise nota-se um saldo negativo de "-67" em Barreirinhas, representado pela admissão de 617 empregados, porém, com o desligamento de 684 indivíduos.

Em contraposição, Jijoca de Jericoacoara se viu num cenário de inclusão, com a admissão de 1.058 empregados formais, e o desligamento de 850 pessoas, resultando num saldo de “+208”.

Analisando-se os setores com maiores saldos de admissão e de desligamento nos dois municípios, novamente não se identifica similitudes. Enquanto que em Barreirinhas o setor de Comércio foi o de maior admissão, com saldo de 30 novas vagas de empregos formais preenchidas, em Jijoca o setor de Serviços foi o de maior destaque, com um saldo de 140 novos empregados formalizados.

Por outro lado, o setor de Construção Civil foi, em Barreirinhas, o de maior saldo negativo (desligamento), atingindo "-76" empregos. Em Jijoca não identificou-se nenhum saldo negativo para quaisquer setores de ocupação locais.

No que diz respeito às ocupações com maiores saldos de admissão, no período supracitado, tiveram maior destaque, em Jijoca, aquelas do setor de serviços com ligação direta com o segmento turístico: camareiro(a) de hotel (32) e cozinheiro geral (29). As ocupações de vendedor de comércio varejista (23), servente de obras (17), auxiliar nos serviços de alimentação (13), recepcionista de hotel (09) e agente de segurança (08) também compuseram a lista das ocupações de maior saldo.

Diferentemente de Jijoca, Barreirinhas não teve saldos expressivos em ocupações no setor turístico. A ocupação de camareiro(a) de hotel foi a única, com saldo de admissão de apenas 05 empregos formalizados no período. Em contrapartida, outras ocupações como operador de motosserra (30), operador de empilhadeira (22), servente de obras (19), professor de disciplinas

\footnotetext{
12 Último período com dados divulgados pelo IBGE em que a análise foi realizada pelo autor para a construção da tese.
} 
pedagógicas no ensino médio (13), varredor de rua (11), pedreiro (11) e coletor de lixo domiciliar (06), tiveram melhores saldos.

Dentre as ocupações com maiores saldos de desligamento, em Jijoca são destaque: servente de obras (-22); pedreiro de edificações (-10); pizzaiolo (-5); agente de segurança (-4); gerente financeiro (-4); assistente administrativo (-3); marceneiro (-3); forjador (-3); gerente de hotel (-2); e gerente comercial (-2).

Em Barreirinhas, os maiores saldos de desligamento estão entre as seguintes ocupações: trabalhador de extração florestal em geral (-70); operador de motosserra (-31); operador de empilhadeira (-26); pedreiro (-17); auxiliar de escritório em geral (-10); cozinheiro em geral (-8); recepcionista de hotel (-6); garçom (-5); porteiro de hotel (-5); e motorista de carro de passeio ($5)$.

\subsubsection{Condição de Atividade da PIA}

A análise sobre a condição de atividade da População com Idade Ativa (PIA) se subdivide entre os grupos de indivíduos que compõem a População Economicamente Ativa (PEA) - Box 1, e a População Não Economicamente Ativa (PNEA) - Box 2.

"Compreende o potencial de mão-de-obra com que pode contar o setor produtivo, isto é, a população ocupada e a população desocupada, assim definidas: população ocupada - aquelas pessoas que, num determinado período de referência, trabalharam ou tinham trabalho mas não trabalharam (por exemplo, pessoas em férias). População Desocupada - aquelas pessoas que não tinham trabalho, num determinado período de referência, mas estavam dispostas a trabalhar, e que, para isso, tomaram alguma providência efetiva (consultando pessoas, jornais, etc.)".

Box 1: Definição de "População Economicamente Ativa" (PEA)

Fonte: IBGE, 2013, grifo do próprio autor.

Também entendida como "População Economicamente Inativa (PEI)", a População Não Economicamente Ativa (PNEA) refere-se às pessoas não classificadas como "ocupadas" ou como "desocupadas". Inclui-se, aqui, idosos, crianças, estudantes, deficientes físicos, donas de casa (domésticas), desalentados (desempregados que há mais de um mês não buscam por trabalho) e outros que não estão diretamente envolvidos em atividades produtivas assalariadas.

\section{Box 2: Definição de "População Não Economicamente Ativa" (PNEA)}

Fonte: próprio autor, com base no IBGE, 2013.

Dados expressos na Tabela 7, a seguir, revelam que a PNEA (51,8\% - 21.290 indivíduos) do Município de Barreirinhas é maior do que a sua PEA (48,2\% - 19.802 indivíduos). A diferença 
atinge 3,6\% (1.488 indivíduos) entre os dois grupos. Tal característica é também reconhecida no Estado do Maranhão, contudo, com uma diferença inferior, atingindo 1,8\% (94.610 indivíduos).

Tabela 7: PEA e PNEA

\begin{tabular}{l|c|c|c|c}
\cline { 2 - 5 } & \multicolumn{4}{c}{2010} \\
\cline { 2 - 5 } & Barreirinhas & Jijoca de Jericoacoara & Maranhão & Ceará \\
\hline PEA & 19.802 & 7.924 & 2.585 .063 & 3.642 .506 \\
\hline PNEA & 21.290 & 6.045 & 2.679 .673 & 3.468 .796 \\
\hline
\end{tabular}

Fonte: próprio autor, com base no IBGE, Censo Demográfico 2010.

Divergentemente, em Jijoca de Jericoacoara foi reconhecido um maior número de indivíduos compondo a PEA (56,7\% - 7.924 indivíduos) do que a PNEA (43,3\% - 6.045 indivíduos), com uma diferença de 13,4\% (1.879 indivíduos). A similaridade se identifica em seu estado, onde a PEA é superior à PNEA, porém, atestando uma diferença também inferior: $2,4 \%$. Ver Tabela 7.

A partir daí pode-se refletir que, em relação à Barreirinhas, Jijoca possui maior contingente da população disponível para ser ocupado (ou já ocupado) nos setores produtivos locais.

\subsubsection{População Economicamente Ativa: Principais Características dos Indivíduos}

As características principais das PEAs dos dois municípios são equivalentes: em Barreirinhas e em Jijoca de Jericoacoara, respectivamente, predominam indivíduos do gênero masculino (58,7\% e 57,5\%), pardos (76,5\% e 65,5\%), sem instrução ou com ensino fundamental incompleto $(65,4 \%$ e $50,7 \%)$, entre 20 a 29 anos (31,0\% e $31,7 \%)$. A Tabela 8 apresenta os dados detalhados. 
Tabela 8: Características da PEA

\begin{tabular}{|c|c|c|}
\hline \multirow[t]{2}{*}{ 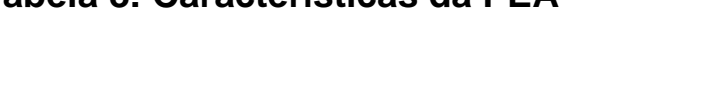 } & \multicolumn{2}{|c|}{2010} \\
\hline & Barreirinhas & Jijoca de Jericoacoara \\
\hline População Economicamente Ativa (PEA) & 19.802 & 7.924 \\
\hline \multicolumn{3}{|l|}{ Gênero } \\
\hline Masculino & 11.623 & 4.557 \\
\hline Feminino & 8.179 & 3.367 \\
\hline \multicolumn{3}{|l|}{ Cor ou Raça } \\
\hline Amarela & 171 & 14 \\
\hline Branca & 3.406 & 2.545 \\
\hline Indígena & - & - \\
\hline Parda & 15.158 & 5.195 \\
\hline Preta & 1.067 & 169 \\
\hline Sem declaração & - & - \\
\hline \multicolumn{3}{|l|}{ Nível de Instrução Formal } \\
\hline Sem instrução até fundamental incompleto & 12.957 & 4.022 \\
\hline Fundamental completo até médio incompleto & 3.147 & 1.725 \\
\hline Médio completo até superior incompleto & 2.960 & 1.668 \\
\hline Superior complete & 650 & 492 \\
\hline Não determinado & 88 & 17 \\
\hline \multicolumn{3}{|l|}{ Idade } \\
\hline 10 a 13 anos & 1.026 & 87 \\
\hline 14 anos & 310 & 52 \\
\hline 15 anos & 305 & 120 \\
\hline 16 ou 17 anos & 774 & 280 \\
\hline 18 ou 19 anos & 1.044 & 429 \\
\hline 20 a 24 anos & 3.163 & 1.259 \\
\hline 25 a 29 anos & 2.982 & 1.259 \\
\hline 30 a 34 anos & 2.524 & 1.110 \\
\hline 35 a 39 anos & 2.028 & 958 \\
\hline 40 a 44 anos & 1.722 & 765 \\
\hline 45 a 49 anos & 1.235 & 575 \\
\hline 50 a 54 anos & 874 & 395 \\
\hline 55 a 59 anos & 918 & 295 \\
\hline 60 a 69 anos & 600 & 240 \\
\hline 70 anos ou mais & 297 & 100 \\
\hline
\end{tabular}

Fonte: próprio autor, com base no IBGE, Censo Demográfico 2010.

\subsubsection{População Economicamente Ativa: Classes de Rendimento Nominais Mensais}

Ainda que os potenciais naturais encontrados nas duas regiões estimulem 0 desenvolvimento dos setores agropecuário e de serviços (por conta do turismo), o rendimento da classe trabalhadora permanece deficitário. As classes de rendimento nominais mensais dos municípios em tela, tanto da PIA como da PEA, enfatizam a grande maioria vivendo com rendimentos abaixo de um salário mínimo, como apresentado na Tabela 9. 
Tabela 9: Classes de Rendimentos Nominais Mensais da PIA e da PEA

\begin{tabular}{|c|c|c|c|c|}
\hline & \multicolumn{2}{|c|}{ Barreirinhas } & \multicolumn{2}{|c|}{$\begin{array}{c}\text { Jijoca de } \\
\text { Jericoacoara }\end{array}$} \\
\hline \multicolumn{5}{|c|}{ PIA - Classes de rendimento nominal mensal } \\
\hline Sem rendimento & 19.806 & \multirow{4}{*}{$\begin{array}{l}35.997 \\
(87,6 \%)\end{array}$} & 4.859 & \multirow{4}{*}{$\begin{array}{c}11.433 \\
(81,8 \%)\end{array}$} \\
\hline De até $1 / 4$ de salário mínimo & 5.340 & & 1.467 & \\
\hline De 1/4 a 1/2 salário mínimo & 3.789 & & 1.273 & \\
\hline De $1 / 2$ a 1 salário mínimo & 7.062 & & 3.834 & \\
\hline De 1 a 2 salários mínimos & 3.616 & & 1.424 & \\
\hline De 2 a 3 salários mínimos & 645 & & 442 & \\
\hline De 3 a 5 salários mínimos & 464 & & 358 & \\
\hline De 5 a 10 salários mínimos & 242 & & 245 & \\
\hline De 10 a 15 salários mínimos & 74 & & 50 & \\
\hline De 15 a 20 salários mínimos & 42 & & 13 & \\
\hline De 20 a 30 salários mínimos & 11 & & - & \\
\hline De mais de 30 salários mínimos & - & & 05 & \\
\hline \multicolumn{5}{|c|}{ PEA - Classes de rendimento nominal mensal } \\
\hline Sem rendimento & 5.515 & \multirow{4}{*}{$\begin{array}{l}15.334 \\
(77,4 \%)\end{array}$} & 970 & \multirow{4}{*}{$\begin{array}{c}5.665 \\
(71,5 \%)\end{array}$} \\
\hline De até $1 / 4$ de salário mínimo & 2.756 & & 899 & \\
\hline De $1 / 4$ a $1 / 2$ salário mínimo & 2.569 & & 1.064 & \\
\hline De 1/2 a 1 salário mínimo & 4.494 & & 2.732 & \\
\hline De 1 a 2 salários mínimos & 3.073 & & 1.215 & \\
\hline De 2 a 3 salários mínimos & 625 & & 421 & \\
\hline De 3 a 5 salários mínimos & 422 & & 330 & \\
\hline De 5 a 10 salários mínimos & 231 & & 229 & \\
\hline De 10 a 15 salários mínimos & 64 & & 47 & \\
\hline De 15 a 20 salários mínimos & 42 & & 13 & \\
\hline De 20 a 30 salários mínimos & 11 & & - & \\
\hline De mais de 30 salários mínimos & - & & 5 & \\
\hline
\end{tabular}

Fonte: próprio autor, com base no Censo Demográfico 2010 do IBGE, 2013.

Se considerados apenas indivíduos enquadrados no grupo da População Economicamente Ativa (PEA), nos dois municípios as classes de rendimento inferiores a um salário mínimo atingem margens superiores aos 70\%. Em Barreirinhas chega a 77,4\% desse grupo, e em Jijoca atinge $71,5 \%$ - ver Tabela 9.

Em uma análise mais abrangente, considerando classes de rendimentos nominais mensais da População com Idade Ativa (PIA), as margens de indivíduos com rendimentos menores que um salário mínimo são ainda maiores, ultrapassando os $80 \%$ desse grupo. Barreirinhas chegou a $87,6 \%$ do total, e Jijoca $81,8 \%$.

As características gerais da população que sobrevive com os menores rendimentos mensais são, exatamente, as mesmas características que predominam nos grupos das PEAs nos dois municípios: pardos e sem instrução ou com ensino fundamental incompleto (ver Tabela 10). 
No caso da idade, nota-se diferenças nos rendimentos do grupo de indivíduos entre 20 e 29 anos (faixa etária que predomina entre as PEAs), nas duas localidades. Em Barreirinhas, os indivíduos entre 20 e 24 anos contam com uma renda média de menos de um salário mínimo $(R \$ 463,39)$ enquanto que em Jijoca a renda na mesma faixa etária é de pouco mais de um salário mínimo ( $R$ \$520,53). Já entre os indivíduos de 25 a 29 anos de Barreirinhas, o rendimento nominal médio mensal atinge pouco mais de um salário mínimo $(\mathrm{R} \$ 523,25)$, bem abaixo da linha média de rendimento em Jijoca, que já se aproximava de $R \$ 700,00$ (Tabela 10).

Tabela 10: Características da PEA em detrimento de sua renda

\begin{tabular}{|c|c|c|}
\hline & Barreirinhas & $\begin{array}{c}\text { Jijoca de } \\
\text { Jericoacoara }\end{array}$ \\
\hline \multicolumn{3}{|c|}{ PEA (Ocupados) - Valor do rendimento nominal médio mensal (com rendimento de trabalho) } \\
\hline \multicolumn{3}{|c|}{ Pela Cor ou Raça } \\
\hline Amarela & $\mathrm{R} \$ 1.588,45$ & $\mathrm{R} \$ 1.166,78$ \\
\hline Branca & $\mathrm{R} \$ 766,63$ & $\mathrm{R} \$ 942,46$ \\
\hline Indígena & - & - \\
\hline Parda & $\mathrm{R} \$ 573,66$ & $\mathrm{R} \$ 604,09$ \\
\hline Preta & $\mathrm{R} \$ 658,50$ & $\mathrm{R} \$ 688,96$ \\
\hline Sem declaração & - & - \\
\hline \multicolumn{3}{|l|}{ Pelo Nível de Instrução Formal } \\
\hline Sem instrução e fundamental incompleto & $\mathrm{R} \$ 439,55$ & $\mathrm{R} \$ 454,57$ \\
\hline Fundamental completo e médio incompleto & $\mathrm{R} \$ 549,05$ & $\mathrm{R} \$ 564,63$ \\
\hline Médio completo e superior incompleto & $\mathrm{R} \$ 881,87$ & $\mathrm{R} \$ 967,23$ \\
\hline Superior complete & $\mathrm{R} \$ 1.680,11$ & $\mathrm{R} \$ 2.014,42$ \\
\hline Não determinado & $R \$ 353,44$ & $\mathrm{R} \$ 50,00$ \\
\hline \multicolumn{3}{|l|}{ Pela Idade } \\
\hline 10 a 13 anos & $\mathrm{R} \$ 278,18$ & $\mathrm{R} \$ 131,72$ \\
\hline 14 anos & $\mathrm{R} \$ 247,19$ & $\mathrm{R} \$ 113,40$ \\
\hline 15 anos & $\mathrm{R} \$ 238,51$ & $\mathrm{R} \$ 192,88$ \\
\hline 16 ou 17 anos & $\mathrm{R} \$ 239,12$ & $\mathrm{R} \$ 302,90$ \\
\hline 18 ou 19 anos & $\mathrm{R} \$ 316,35$ & $\mathrm{R} \$ 409,81$ \\
\hline 20 a 24 anos & $\mathrm{R} \$ 463,39$ & $\mathrm{R} \$ 520,53$ \\
\hline 25 a 29 anos & $\mathrm{R} \$ 523,25$ & $\mathrm{R} \$ 678,21$ \\
\hline 30 a 34 anos & $\mathrm{R} \$ 639,38$ & $\mathrm{R} \$ 899,16$ \\
\hline 35 a 39 anos & $\mathrm{R} \$ 710,53$ & $\mathrm{R} \$ 720,09$ \\
\hline 40 a 44 anos & $\mathrm{R} \$ 968,47$ & $\mathrm{R} \$ 854,65$ \\
\hline 45 a 49 anos & $\mathrm{R} \$ 997,81$ & $\mathrm{R} \$ 1.052,16$ \\
\hline 50 a 54 anos & $\mathrm{R} \$ 838,65$ & $\mathrm{R} \$ 837,47$ \\
\hline 55 a 59 anos & $\mathrm{R} \$ 527,90$ & $\mathrm{R} \$ 903,59$ \\
\hline 60 a 69 anos & $\mathrm{R} \$ 646,15$ & $\mathrm{R} \$ 720,35$ \\
\hline 70 anos ou mais & $\mathrm{R} \$ 401,64$ & $\mathrm{R} \$ 484,82$ \\
\hline
\end{tabular}

Fonte: próprio autor, com base no Censo Demográfico 2010 do IBGE, 2013. 


\section{4. Índices de Desenvolvimento Humano Municipais}

Para se ter uma clara ideia da atual situação dos municípios estudados, diante dos demais municípios brasileiros, serão analisados dois índices: (a) Índice de Desenvolvimento Humano Municipal (IDHM); (b) Índice Firjan de Desenvolvimento Municipal (IFDM).

Ainda que possuam similitudes entre eles - como a análise das variáveis de "saúde/longevidade" (vida longa e saudável), "renda" (padrão de vida digno) e "educação" (acesso ao conhecimento) - muitas são as especificidades metodológicas e limitações de cada um.

O IDHM leva em consideração, como fonte de informações, os Censos Demográficos e as Pesquisas Nacionais por Amostras de Município (PNAD), realizados pelo IBGE. Seu período de atualização é de 10 em 10 anos.

Por sua vez, o IFDM se aprofunda por dados administrativos oficiais e de declaração obrigatória disponibilizados pelos municípios, e pelos Ministérios da Educação, da Saúde, e do Trabalho. Avalia outros aspectos importantes para serem analisados nesta pesquisa, como o número de empregos com carteira assinada e direitos trabalhistas garantidos. $E$ tem seus dados atualizados anualmente, porém, somente com referência a partir do ano 2000.

As pontuações dos dois índices variam entre 0 e 1, diferenciando-se as escalas de classificação e casas decimais ${ }^{13}$, como mostra a Figura 24. No IDHM são cinco faixas e no IFDM apenas quatro.

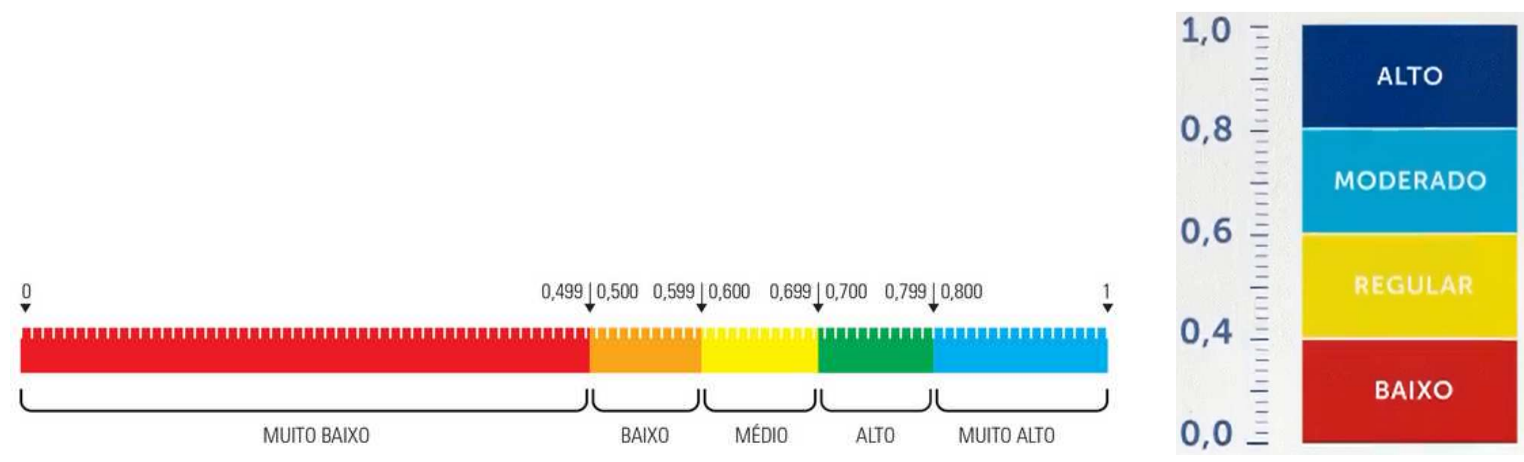

Figura 24: Faixas de classificação do IDHM e IFDM

Fonte: PNUD, 2013; Sistema FIRJAN, 2013.

\footnotetext{
${ }^{13}$ São utilizadas três casas decimais no IDHM e quatro casas decimais no IFDM.
} 


\subsection{1. Índices Consolidados e Classificações nos Rankings Nacional e Estadual}

Em um panorama geral, os dois municípios se diferenciam pelas faixas de desenvolvimento na qual foram classificados, de acordo com seus índices totais (Tabela 11). No ano de 2010, Barreirinhas atingiu uma faixa entre 0,5 e 0,6. Foram atestados 0,570 (IDHM) e 0.5466 (IFDM), pontuações que o situa em faixas de "desenvolvimento baixo" (IDHM) ou de "desenvolvimento regular" (IFDM).

Jijoca de Jericoacoara, por sua vez, atingiu uma faixa superior, entre 0,6 e 0,7. Atestou índices de 0,652 (IDHM) e 0.6921 (IFDM), no mesmo ano, o que lhe posiciona nas faixas de "desenvolvimento médio" ou de "desenvolvimento moderado".

\section{Tabela 11: IDHM e IFDM Totais}

\begin{tabular}{l|c|c|c|c}
\cline { 2 - 5 } & \multicolumn{2}{c|}{ BARREIRINHAS } & \multicolumn{2}{c}{ JIJOCA DE JERICOACOARA } \\
\cline { 2 - 5 } & 2000 & 2010 & 2000 & 2010 \\
\hline IDHM & 0,361 & 0,570 & 0,422 & 0,652 \\
\hline IFDM & 0.3698 & 0.5466 & 0.3805 & 0.6921 \\
\hline
\end{tabular}

Fonte: próprio autor, a partir de dados do PNUD, 2013 e do Sistema FIRJAN, 2013.

No ranking geral de classificação dos 5.565 municípios brasileiros, Jijoca de Jericoacoara se sobressai à Barreirinhas, tanto pelo IDHM quanto pelo IFDM. Pelo IDHM, o município ocupa a $3070^{a}$ posição, o que demonstra que, aproximadamente, $55,1 \%$ dos municípios brasileiros encontram-se em melhor situação. Por outro lado, pelo IFDM, possui uma melhor classificação 1874ª posição - estando abaixo de, aproximadamente, 33,6\% dos demais municípios do Brasil.

Barreirinhas possui um pior desempenho, com classificações não tão distintas entre os dois índices. A partir do IDHM, ocupa a $4841^{\text {a }}$ posição, tendo, aproximadamente, $86,9 \%$ dos municípios nacionais em melhor situação. Já pelo IFDM Barreirinhas ocupa a $4647^{a}$ posição, classificando-se abaixo de $83,4 \%$ dos demais.

No ranking estadual do IDHM, Barreirinhas ocupa a 111 a posição, dentre os 217 municípios do Maranhão, estando à frente de, aproximadamente, 47,4\% dos mesmos. Jijoca encontra-se na $22^{a}$ posição dos 184 municípios do Ceará, estando em melhor situação do que, aproximadamente, $87,5 \%$ dos municípios do Estado.

Já no ranking estadual do IFDM, Barreirinhas está melhor classificado - na 79ª posição atestando um nível de desenvolvimento humano maior do que, aproximadamente, $63,6 \%$ do 
demais municípios maranhenses. Jijoca, por sua vez, classifica-se na $18^{\underline{a}}$ posição, à frente de, aproximadamente, 90,2\% dos municípios cearenses.

É possível notar, a partir dos gráficos a seguir (Gráfico 3 e Gráfico 4), que os dois municípios estão abaixo da média de seus respectivos estados, tanto pelo IDHM quanto pelo IFDM.
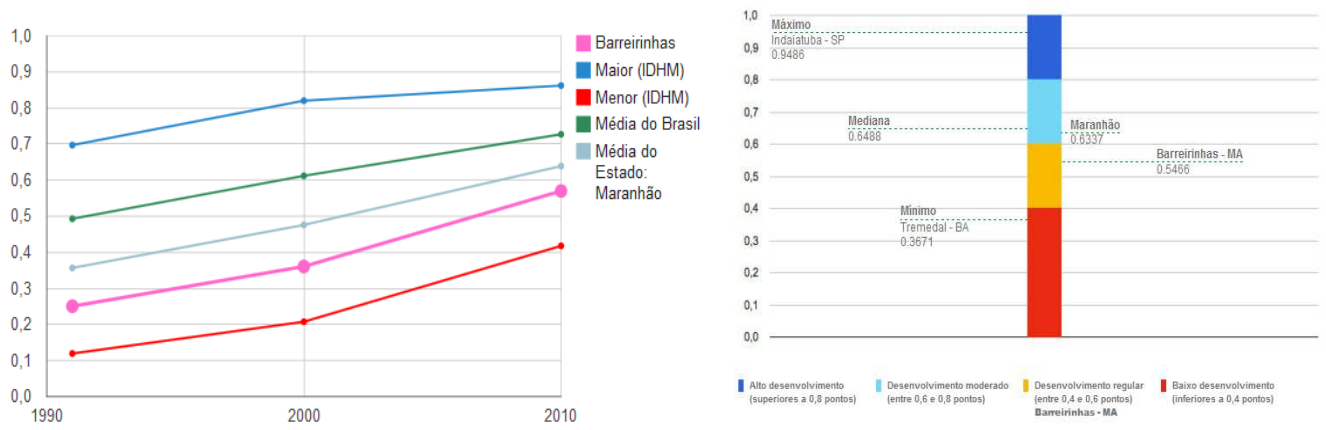

Gráfico 3: Situação relativa de Barreirinhas - MA (IDHM e IFDM)

Fonte: PNUD, 2013; Sistema FIRJAN, 2013.
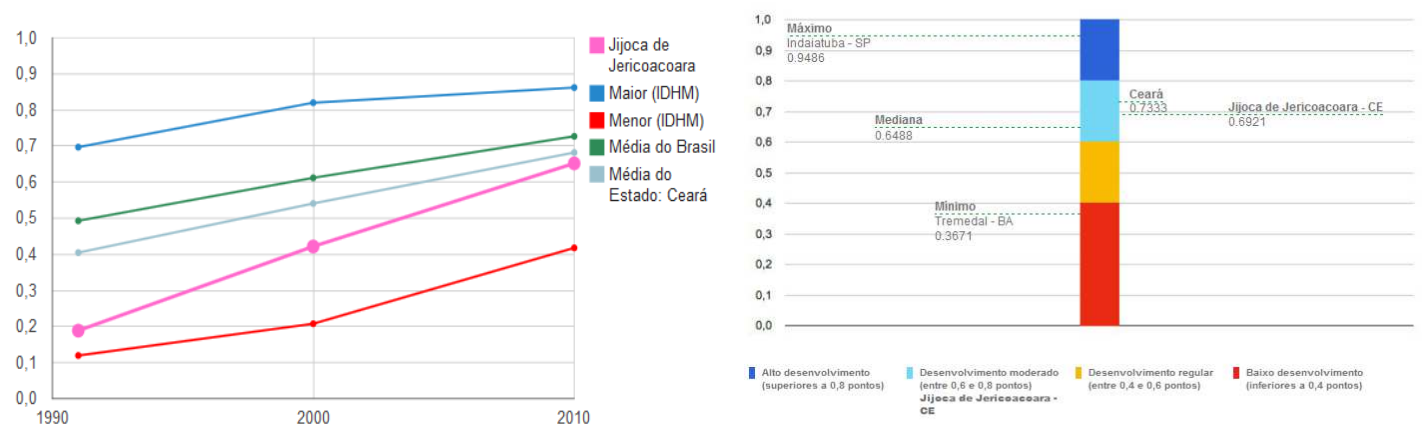

Gráfico 4: Situação relativa de Jijoca de Jericoacoara - CE (IDHM e IFDM) Fonte: PNUD, 2013; Sistema FIRJAN, 2013.

Porém, em um aspecto mais amplo (nacional) - ver Gráfico 3 e Gráfico 4 - os dois índices revelam classificações difusas. Pelo IDHM, ambos municípios encontram-se abaixo da média brasileira, enquanto que pelo IFDM, Jijoca de Jericoacoara encontra-se acima da média nacional.

A seguir, serão apresentadas a evolução e as características específicas das ramificações consideradas pelos índices gerais de cada município em tela, buscando identificar lacunas específicas que mereçam maior atenção para se atingir um melhor nível de desenvolvimento. 


\subsubsection{Evolução dos Componentes (Saúde/Longevidade, Educação, Emprego e Renda)}

Analisando o quadro histórico-evolutivo dos indicadores avaliados pelo IDHM, nota-se, nos dois municípios em tela, entre os anos de 1991 e 2010, um gradual crescimento de seus componentes.

Tanto em Barreirinhas quanto em Jijoca de Jericoacoara atingiu-se, nesse período, incrementos acima da média nacional (47,46\%) e das médias de seus respectivos estados (78,99\% no Maranhão e 68,40\% no Ceará). O incremento do IDHM de Barreirinhas foi, nas últimas duas décadas, de 127,09\%. O incremento do IDHM de Jijoca foi ainda maior, de $244,97 \%$ no mesmo período.

Entretanto, o avanço de maior notoriedade em cada município se deu em décadas distintas. Em Barreirinhas, a década entre 2000 e 2010 teve maior expressão no aumento do IDHM, chegando ao incremento de $57,89 \%$, em comparação aos $43,82 \%$ de crescimento na década anterior - ver Gráfico 5.

Jijoca de Jericoacoara teve uma proporção de incremento contrária. A década entre 2000 e 2010 teve menor expressão no aumento do IDHM, atingindo $54,50 \%$, contra os $123,28 \%$ na década anterior - ver Gráfico 6.

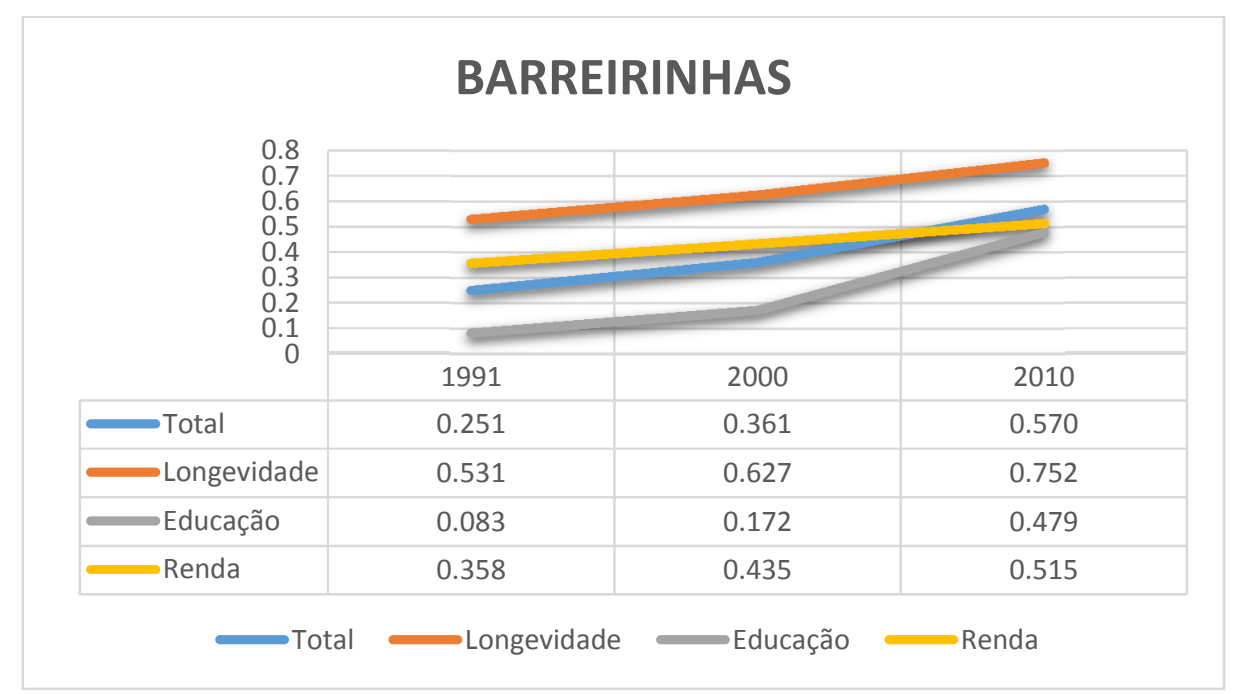

Gráfico 5: Evolução dos Componentes do IDHM (Barreirinhas)

Fonte: próprio autor, com base nos dados do PNUD, 2013. 


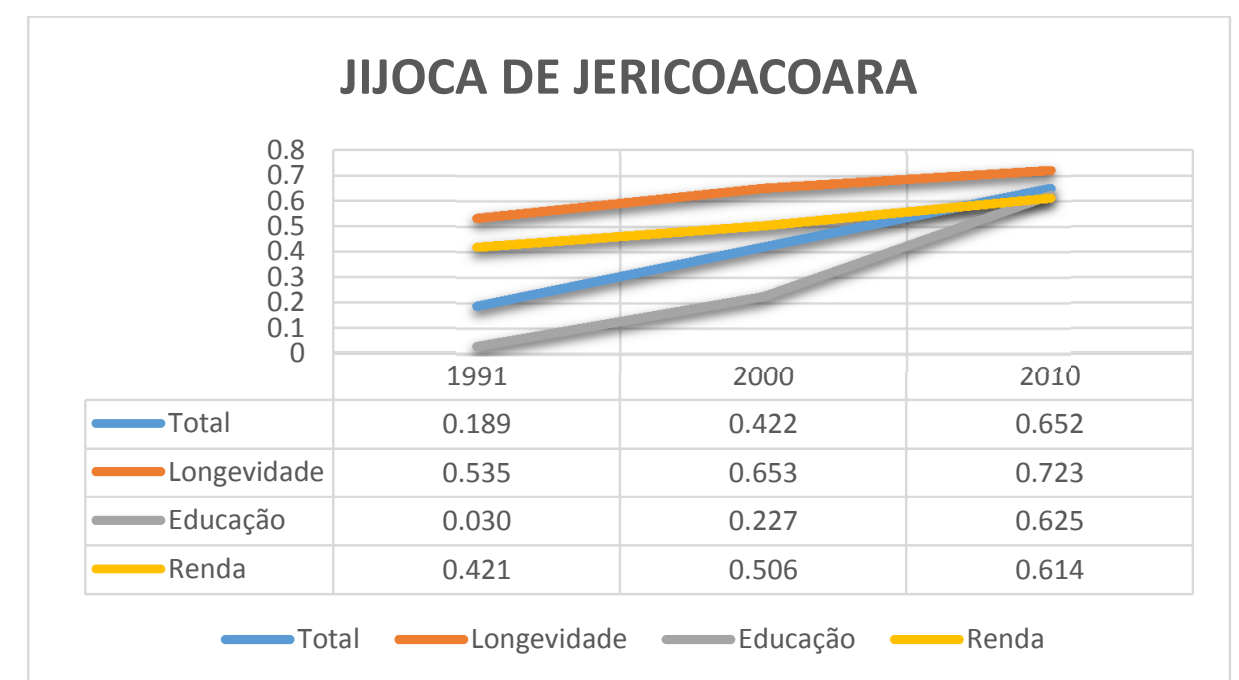

\section{Gráfico 6: Evolução dos Componentes do IDHM (Jijoca de Jericoacoara)}

Fonte: próprio autor, com base nos dados do PNUD, 2013.

Em termos de crescimento, o indicador "Educação" foi o de maior crescimento entre os anos de 1991 e 2010, nos dois municípios, segundo o IDHM. Em Barreirinhas, tal indicador teve um crescimento de 0,396 (82,6\%) e em Jijoca de 0,595 (95,2\%). Ainda assim, mesmo com o aumento, o índice da "Educação" não superou, em Barreirinhas, os índices de "Longevidade" e de "Renda". Em Jijoca o mesmo ultrapassou o índice de "Renda".

No que tange os indicadores com menor crescimento, no mesmo período, as localidades continuam mantendo similaridades. O componente "Longevidade" foi, nos dois municípios, o que teve menor crescimento. Em Barreirinhas apresentou um incremento de 0,221 (29\%) e em Jijoca de 0,188 (26\%). Contudo, tal componente permanece como o de maior contribuição para o IDHM total das localidades, sendo o indicador com maior índice dentre os demais.

Numa análise por um outro recorte temporal ${ }^{14}$ (2000 a 2010), avaliando-se a evolução dos indicadores específicos do IFDM, pode-se perceber que, nos dois municípios estudados, há oscilações de avanço e retrocesso entre os componentes.

Dentre os três componentes analisados, o de "emprego e renda" é o de pior contribuição para o índice total dos dois municípios, conforme Gráfico 7 e Gráfico 8. As suas pontuações absolutas são visivelmente inferiores, não ultrapassando, em nenhum dos casos, a margem dos 0.4 , mantendo-se nas escalas de "baixo desenvolvimento".

\footnotetext{
${ }^{14}$ O Sistema FIRJAN não apresenta pesquisas realizadas referentes aos anos de 2001, 2002, 2003 e 2004.
} 


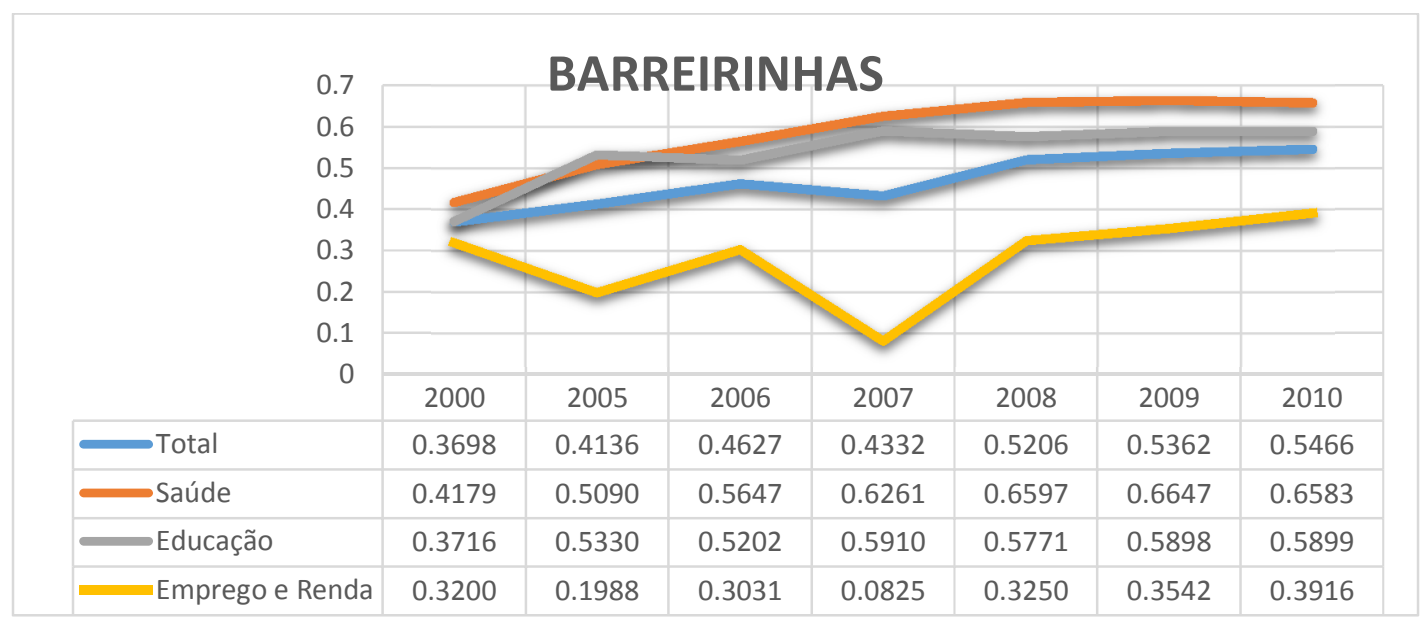

Gráfico 7: Evolução dos Componentes do IFDM (Barreirinhas)

Fonte: próprio autor, com base nos dados do Sistema FIRJAN, 2013.

Em todos os anos analisados, esse componente esteve nitidamente abaixo da linha de desenvolvimento dos demais. Isso reflete uma lacuna por maiores e mais efetivas políticas públicas para esse segmento. Tal fato só vem a fortalecer a relevância desta pesquisa.

Contudo, há que se analisar o quadro de crescimento de todos os componentes, assim como no IDHM. Mesmo se tratando do indicador com menor índice, o componente "Emprego e Renda" foi, em Jijoca de Jericoacoara, no espaço de dez anos, o de maior crescimento, com incremento de 0.2009 (55\%). Contraditoriamente, em Barreirinhas, tal componente foi o de menor crescimento, atingindo um incremento de apenas $0.0716(18,3 \%)$.

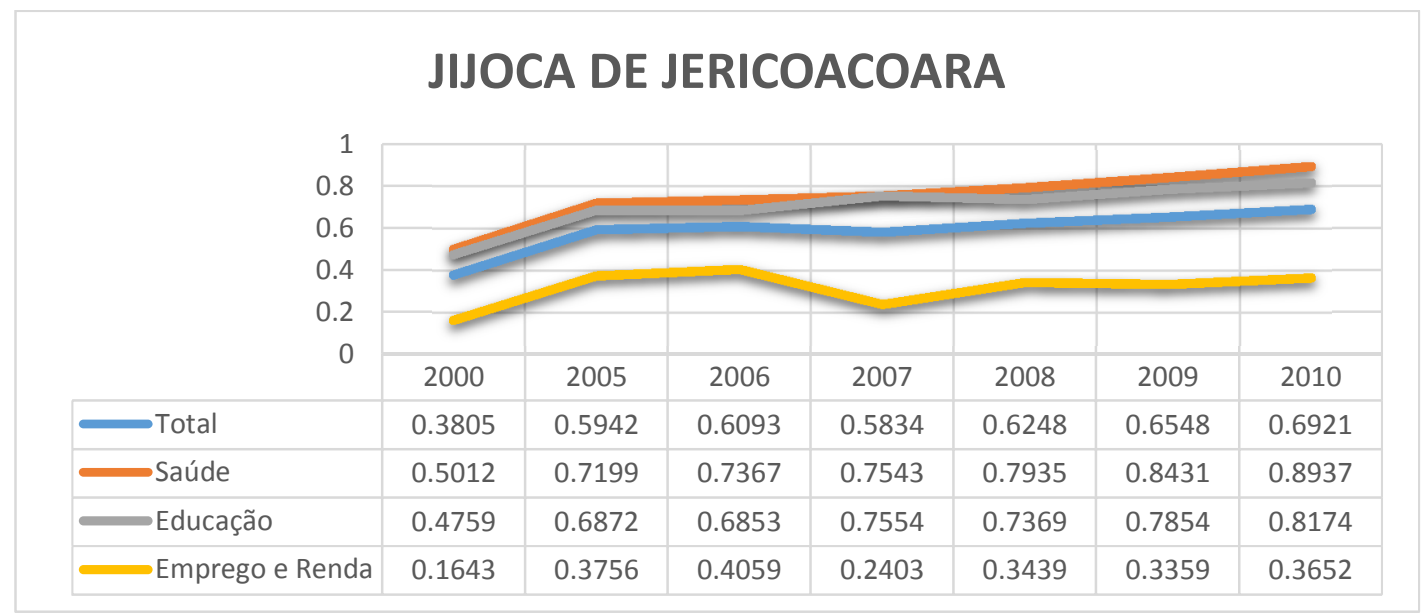

Gráfico 8: Evolução dos Componentes do IFDM (Jijoca de Jericoacoara) Fonte: próprio autor, com base nos dados do Sistema FIRJAN, 2013. 
A situação de contradição se repete ao analisar-se o indicador "Educação" dos dois municípios. Mesmo se configurando como o que mais contribuiu nessa década, para ambas as localidades, seu crescimento em Jijoca foi o de menor expressão dentre os demais índices, atingindo um incremento de 0.3415 (41,7\%). Em Barreirinhas, ao contrário, foi o de maior crescimento, com 0.2183 (37\%).

Todas as informações apresentadas neste tópico refletem as graduais melhorias identificadas nos índices totais e dos componentes que integram os índices de desenvolvimento humano de Barreirinhas e de Jijoca nas últimas décadas. Nota-se, porém, que as contribuições mais substanciais decorreram das esferas da "saúde/longevidade" e da "educação", não demonstrando a mesma capacidade para a de "emprego e renda".

\subsubsection{Renda, Pobreza e Desigualdade Social}

Pela análise específica do componente "renda" do IDHM (ver Tabela 12), nota-se que Barreirinhas encontra-se classificado na categoria de Baixo Desenvolvimento, atingindo um índice de 0.515. Tal classificação Ihe posiciona abaixo do nível estadual (0.612 - Médio Desenvolvimento) e nacional (0.739 - Alto Desenvolvimento).

O componente "emprego e renda" do IFDM do município corrobora com o baixo desenvolvimento do município nessa esfera. Sua margem chegou a 0.3916 (Desenvolvimento Baixo), inferior ao nível estadual (0.5563 - Desenvolvimento Regular) e do Brasil (0.7914 Desenvolvimento Moderado).

Ainda assim, se comparado aos municípios com maior proximidade, Barreirinhas possui melhor "IDHM-Renda" que os demais, estando abaixo apenas do índice do município de Tutóia (0.543) - Tabela 12. No caso do "IFDM-Emprego e Renda" a situação se repete, porém, ficando abaixo apenas do índice do município de Santa Quitéria do Maranhão (0.4172).

Por sua vez, o componente "IDHM-Renda" do município de Jijoca de Jericoacoara atingiu 0.614, classificando-o na categoria de Médio Desenvolvimento e, assim como Barreirinhas, abaixo do índice do seu estado (0.651 - Médio Desenvolvimento) e do Brasil (Tabela 12).

Situação distinta ocorre na análise do "IFDM-Emprego e Renda" que classifica Jijoca na categoria de Baixo Desenvolvimento, pelo índice de 0.3652 atingido. De toda forma, permanecendo abaixo do índice de seu estado (0.6645 - Desenvolvimento Moderado) e nacional. 
Tabela 12: IDHM e IFDM referentes à Renda e Emprego

\begin{tabular}{c|c|c}
\cline { 2 - 3 } & \multicolumn{2}{c}{ INDICES (2010) } \\
\cline { 2 - 3 } & $\begin{array}{c}\text { IDHM } \\
\text { Renda }\end{array}$ & $\begin{array}{c}\text { IFDM } \\
\text { Emprego e Renda }\end{array}$ \\
\hline BRASIL & 0.739 & 0.7914 \\
\hline MARANHÃO & 0.612 & 0.5563 \\
\hline Barreirinhas & 0.515 & 0.3916 \\
\hline Santa Quitéria do Maranhão & 0.490 & 0.4172 \\
\hline Santana do Maranhão & 0.445 & 0.0762 \\
\hline Santo Amaro do Maranhão & 0.454 & 0.2149 \\
\hline Primeira Cruz & 0.448 & 0.0000 \\
\hline Humberto de Campos & 0.443 & 0.3131 \\
\hline Paulino Neves & 0.481 & 0.2253 \\
\hline Tutóia & 0.543 & 0.2309 \\
\hline CEARÁ & 0.651 & 0.6645 \\
\hline Jijoca de Jericoacoara & 0.614 & 0.3652 \\
\hline Bela Cruz & 0.533 & 0.2554 \\
\hline Cruz & 0.573 & 0.2545 \\
\hline Camocim & 0.565 & 0.3679 \\
\hline Acaraú & 0.554 & 0.3341 \\
\hline Granja & 0.495 & 0.2682 \\
\hline
\end{tabular}

Fonte: próprio autor, com base nos dados do Sistema FIRJAN, 2013 e PNUD, 2013.

Assim como Barreirinhas, Jijoca possui índices superiores aos índices dos municípios vizinhos, atestando o "IDHM-Renda" acima de todas as localidades e o "IFDM-Emprego e Renda" abaixo apenas do município de Camocim (0.3679 - Desenvolvimento Baixo). Dados descritos na Tabela 12.

O nível de renda per capita dos dois municípios em tela estiveram, nas últimas duas décadas, em relevante distanciamento dos níveis nacional e de seus respectivos estados.

No ano de 1991, a renda per capita média do Brasil encontrava-se próxima aos $R \$ 450,00$. Do Maranhão e do Ceará próximas a $R \$ 157,00$ e $R \$ 220,00$, respectivamente. Enquanto que em Barreirinhas não ultrapassava os $\mathrm{R} \$ 75,00$ e, em Jijoca, não mais do que $R \$ 110,00$.

Vinte anos mais tarde pôde-se perceber taxas de crescimentos substanciais na renda per capita nas duas localidades, superiores, inclusive, às taxas de crescimento nacional $(77,4 \%)$, do Maranhão (130,3\%) e do Ceará (109,5\%).

Jijoca de Jericoacoara teve aumento superior ao de Barreirinhas, atestando 232,9\%, passando de $\mathrm{R} \$ 109,78$ em 1991 para $\mathrm{R} \$ 365,46$ em 2010. Na localidade maranhense atestouse um crescimento de 164,7\%, passando de $\mathrm{R} \$ 74,44$ em 1991 para $R \$ 197,08$ em 2010. Ressalta-se, porém, que a renda per capita média nas suas regiões permanecem, ainda em 
2010, muito distantes do nível nacional, que é de $R \$ 793,87$. Os dados estão disponíveis na Tabela 13.

Tabela 13: Situação do Quadro da Renda Municipal ${ }^{15}$

\begin{tabular}{l|c|c|c|c|c|c|c|c|c}
\hline \multirow{2}{*}{ Renda } & \multicolumn{3}{c}{ Barreirinhas } & \multicolumn{3}{c|}{ Jijoca de Jericoacoara } & \multicolumn{3}{c}{ BRASIL } \\
\cline { 2 - 10 } & 1991 & 2000 & 2010 & 1991 & 2000 & 2010 & 1991 & 2000 & 2010 \\
\hline $\begin{array}{l}\text { Renda per } \\
\text { capita média }\end{array}$ & 74,44 & 119,52 & 197,08 & 109,78 & 187,01 & 365,46 & 447,56 & 592,46 & 793,87 \\
\hline $\begin{array}{l}\text { Renda per } \\
\text { capita média } \\
\text { dos } \\
\text { extremamente } \\
\text { pobres }\end{array}$ & 35,61 & 31,94 & 24,15 & 45,86 & 30,29 & 35,40 & 40,91 & 35,64 & 31,66 \\
\hline $\begin{array}{l}\text { Renda per } \\
\text { capita média } \\
\text { dos pobres }\end{array}$ & 50,77 & 49,99 & 49,83 & 61,56 & 56,89 & 68,95 & 71,86 & 72,75 & 75,19 \\
\hline $\begin{array}{l}\text { Renda per } \\
\text { capita média } \\
\text { dos vulneráveis } \\
\text { à pobreza }\end{array}$ & 57,93 & 67,02 & 92,89 & 82,41 & 81,06 & 120,88 & 113,41 & 123,07 & 142,72 \\
\hline $\begin{array}{l}\text { \% da renda } \\
\text { proveniente de } \\
\text { rendimentos do } \\
\text { trabalho }\end{array}$ & 88,94 & 76,50 & 66,51 & 74,85 & 79,99 & 71,14 & 84,26 & 76,55 & 74,32 \\
\hline $\begin{array}{l}\text { Rendimento } \\
\text { médio dos } \\
\text { ocupados - 18 } \\
\text { anos ou mais }\end{array}$ & - & - & 426,43 & - & - & 646,37 & - & - & $1.296,19$ \\
\hline
\end{tabular}

Fonte: próprio autor, com base nos dados do Pnud, 2013.

Nos dois municípios, e também no Brasil, as maiores taxas de crescimento da renda se deram no segundo período (2000-2010). Barreirinhas teve uma taxa de crescimento de 64,9\% no segundo período, contra $60,5 \%$ no primeiro período. Jijoca contou com taxas maiores, sendo $95,4 \%$ no segundo período, contra $70,3 \%$ no primeiro. No Brasil foram $32,4 \%$ no primeiro, e 34,0\% no segundo. Ver Tabela 13.

No que diz respeito à renda per capita média do grupo dos indivíduos classificados como extremamente pobres, referente ao ano de 2010 (ver Tabela 13), nota-se que diante da média nacional $(R \$ 31,66)$ e a do Estado do Maranhão $(R \$ 28,61)$, Barreirinhas possui um índice menor

\footnotetext{
15 Dados dos Estados do Maranhão e do Ceará foram descritos fora da Tabela.
} 
$(\mathrm{R} \$ 24,15)$. Jijoca, no entanto, atingiu um índice de $\mathrm{R} \$ 35,40$, superior ao do Estado do Ceará $(\mathrm{R} \$ 34,39)$ e ao do Brasil.

Entretanto, considerando-se a renda per capita média apenas dos indivíduos que compõem o grupo dos pobres, tanto Barreirinhas quanto Jijoca apresentaram médias abaixo das médias nacional $(R \$ 75,19)$ e de seus respectivos estados: Maranhão $(R \$ 62,13)$ e Ceará $(R \$ 72,00)$. No último ano de referência (2010), Barreirinhas atingiu $R \$ 49,83$ e Jijoca $R \$ 68,95$, como apresentado na Tabela 13.

Da mesma forma, quanto aos indivíduos que integram o grupo dos vulneráveis à pobreza, os dois municípios tiveram rendas per capitas médias inferiores à renda nacional, e à renda de seus respectivos estados.

Enquanto no Brasil, no ano de 2010 , a renda era de $\mathrm{R} \$ 142,72$ para tal grupo, e no Maranhão chegou a $R \$ 113,11$, em Barreirinhas atingiu $R \$ 92,89$. Jijoca também esteve com uma média inferior à do Ceará $(R \$ 128,56)$ e à do Brasil, chegando a $R \$ 120,88$. (Tabela 13)

Analisando a porcentagem da renda proveniente de rendimentos do trabalho (Tabela 13), percebe-se que, nas últimas duas décadas, houve uma redução brusca de $25,0 \%$ em Barreirinhas, superando a redução nacional, no mesmo período, que foi de $11,8 \%$, e a redução no Maranhão, que atingiu 18,0\%. Jijoca de Jericoacoara apresentou uma redução bem menos significativa, de apenas 4,95\%, inferior a redução no Ceará (14,6\%) e do Brasil.

Há indícios de que tal redução possa ter sido fortalecida, a partir do ano de 2000, pela implementação de projetos governamentais de transferência de renda em todo o território nacional.

Dentre outros, ganha destaque o Programa de Garantia de Renda Mínima, implantado pelo Governo Federal no ano de 1998, posteriormente intitulado como Bolsa-Escola (em 2001) e como Bolsa Família (em 2003). Tal projeto integrou, inicialmente, um programa maior conhecido por Fome Zero. Atualmente faz parte do Plano Brasil Sem Miséria, que visa ações de garantia de renda, inclusão produtiva e acesso aos serviços públicos para 16 milhões de brasileiros com renda familiar per capita inferior a $\mathrm{R} \$ 70,00$ mensais (BRASIL, 2013g).

O intuito do Programa Bolsa Família (PBF), Lei $n^{\circ} 10.836$ de janeiro de 2004, é: 
(...) articular os diversos agentes políticos em torno da promoção e inclusão social das famílias que vivem em situação de pobreza e extrema pobreza. Nesse sentido, estabeleceu um modelo de gestão compartilhada, em que a União, os estados e os municípios atuam como co-responsáveis pela sua implementação, gestão e fiscalização. (BRASIL, 2013f)

No período entre 2004 e $2013^{16}$ identifica-se um aumento de $218,3 \%$ no recurso total destinado ao município de Barreirinhas, passando de $\mathrm{R} \$ 5.271 .240,00$ para $\mathrm{R} \$ 16.778 .152,00$. Em Jijoca o aumento foi ainda maior, chegando a $321,4 \%$ no mesmo período, passando de $\mathrm{R} \$ 986.688,00$ para $\mathrm{R} \$ 4.157 .806,00$. (BRASIL, 2013g)

Por essa perspectiva nota-se que o contínuo aumento dos repasses governamentais tem influído diretamente na diminuição dos índices de renda provenientes de rendimento do trabalho nas duas regiões.

É digno de nota que, assim como destaca Pochmann (2003, p.35), "a oferta de uma ação governamental isolada não é suficiente para a ruptura do ciclo estrutural de pobreza no Brasil".

E como resultado dessa diminuição, a porcentagem da renda proveniente de trabalhos está, nas duas localidades, abaixo da porcentagem nacional. Em 2010, Barreirinhas atingiu $66,51 \%$, Jijoca $71,14 \%$, e no Brasil $74,32 \%$. Vale ressaltar que, pela análise sob a perspectiva estadual, Barreirinhas ficou abaixo da média do Maranhão (71,74\%), e Jijoca acima da média do Ceará $(70,33 \%)$.

Como apresentado anteriormente, margens superiores a $70 \%$ das PEAs e a $80 \%$ das PIAs, das duas localidades, encontram-se sujeitas a classes de rendimentos inferiores a 01 salário mínimo.

Considerando-se o rendimento médio do grupo dos ocupados em Barreirinhas e em Jijoca, com idade de 18 anos ou mais, no ano de 2010, tais médias estiveram notoriamente abaixo do rendimento nacional e de seus respectivos estados (Tabela 13).

Enquanto que no Brasil tal rendimento médio desse grupo atingiu $R \$ 1.296,19$, e no Ceará chegou a $R \$ 821,34$, em Jijoca não ultrapassou os $R \$ 647,00$. No Maranhão a média foi de $\mathrm{R} \$ 735,96$, enquanto que em Barreirinhas não superou $\mathrm{R} \$ 427,00$.

O quadro de pobreza dos dois municípios vem sendo diminuído ao longo das duas últimas décadas, porém, abaixo do ritmo do país e de seus respectivos estados. Entre 1991 e 2010 a

\footnotetext{
${ }^{16}$ Período disponibilizado para acesso no site "Portal da Transparência" do Governo Federal. Acesso realizado em novembro de 2013.
} 
redução nacional da porcentagem total de pobres ${ }^{17}$ atingiu $60,1 \%$. No Maranhão chegou a uma redução de 46,0\%, contra 38,3\% em Barreirinhas. No Ceará atingiu-se uma redução da pobreza em $54,3 \%$, enquanto que em Jijoca chegou-se a redução de $53,3 \%$.

A situação se repete quanto à redução do quadro da extrema pobreza. No mesmo período, Barreirinhas e Jijoca apresentaram uma redução abaixo das médias nacional e de seus estados.

A redução nacional da porcentagem dos extremamente pobres ${ }^{18}$ chegou a $64,5 \%$. No Maranhão $50,7 \%$ e no Ceará $68,0 \%$. Abaixo estiveram Jijoca, com redução de $63,17 \%$, e Barreirinhas com $43,69 \%$.

A redução da porcentagem dos vulneráveis à pobreza ${ }^{19}$ nas duas localidades também foi menos expressiva que a redução em seus respectivos estados e no Brasil. Foram: 33,5\% em Jijoca; 33,6\% no Ceará; 15,6\% em Barreirinhas; 27,8\% no Maranhão; e 44,37\% no Brasil. Ver

\section{Tabela 14.}

Pode-se perceber que as porcentagens de indivíduos pobres, de extremamente pobres e de vulneráveis à pobreza, nos dois municípios, estiveram acima das porcentagens estaduais e brasileiras (Tabela 14).

No ano de 2010 foram classificados como pobres: 55,6\% da população de Barreirinhas; $39,5 \%$ do Maranhão; 36,4\% de Jijoca; 30,32\% do Ceará; e 15,20\% da população nacional.

Tabela 14: Situação do Quadro da Pobreza Municipal 20

\begin{tabular}{l|c|c|c|c|c|c|c|c|c}
\hline \multirow{2}{*}{ Pobreza } & \multicolumn{3}{|c|}{ Barreirinhas } & \multicolumn{3}{c|}{ Jijoca de Jericoacoara } & \multicolumn{3}{c}{ BRASIL } \\
\cline { 2 - 11 } & 1991 & 2000 & 2010 & 1991 & 2000 & 2010 & 1991 & 2000 & 2010 \\
\hline \% de pobres & 90,25 & 79,42 & 55,65 & 77,95 & 67,27 & 36,40 & 38,16 & 27,90 & 15,20 \\
\hline $\begin{array}{l}\text { \% de } \\
\begin{array}{l}\text { extremamente } \\
\text { pobres }\end{array}\end{array}$ & 66,71 & 57,57 & 37,56 & 50,81 & 42,47 & 18,71 & 18,64 & 12,48 & 6,62 \\
\hline $\begin{array}{l}\text { \% de } \\
\text { vulneráveis à } \\
\text { pobreza }\end{array}$ & 96,04 & 91,69 & 79,37 & 92,43 & 82,99 & 61,49 & 58,53 & 48,39 & 32,56 \\
\hline
\end{tabular}

Fonte: próprio autor, com base nos dados do Pnud, 2013.

\footnotetext{
17 Proporção dos indivíduos com renda domiciliar per capita igual ou inferior a $R \$ 140,00$ mensais, referente a agosto de 2010 (PNUD, 2010)

18 Proporção dos indivíduos com renda domiciliar per capita igual ou inferior a $\mathrm{R} \$ 70,00$ mensais, referente a agosto de 2010 (PNUD, 2010).

19 Proporção dos indivíduos com renda domiciliar per capita igual ou inferior a $\mathrm{R} \$ 255,00$ mensais, equivalente a $1 / 2$ salário mínimo, referente a agosto de 2010 (PNUD, 2010).

20 Dados dos Estados do Maranhão e do Ceará foram descritos fora da Tabela.
} 
No mesmo período, quanto ao grupo de extremamente pobres, contabilizou-se: $37,5 \%$ em Barreirinhas; 22,5\% no Maranhão; 18,7\% em Jijoca; 14,7\% no Ceará; e 6,62\% no Brasil. Com respeito aos vulneráveis à pobreza, foram: $79,4 \%$ em Barreirinhas; $63,6 \%$ no Maranhão; $61,5 \%$ em Jijoca; $54,8 \%$ no Ceará; e 32,5\% em todo território nacional.

Ainda que nas últimas duas décadas as porcentagens de pobreza tenham diminuído nas duas localidades, a desigualdade social - resultante da concentração de renda díspar aumentou, também em ambas (Tabela 15). O aumento foi muito próximo nos dois municípios, predominando maior desigualdade na cidade maranhense.

\section{Tabela 15: Situação do Quadro da Desigualdade Municipal}

\begin{tabular}{l|c|c|c|c|c|c|c|c|c}
\hline \multirow{2}{*}{ Desigualdade } & \multicolumn{4}{|c|}{ Barreirinhas } & \multicolumn{3}{c|}{ Jijoca de Jericoacoara } & \multicolumn{3}{c}{ BRASIL } \\
\cline { 2 - 10 } & 1991 & 2000 & 2010 & 1991 & 2000 & 2010 & 1991 & 2000 & 2010 \\
\hline Índice de Gini & 0,49 & 0,63 & 0,61 & 0,46 & 0,65 & 0,59 & 0,63 & 0,64 & 0,60 \\
\hline
\end{tabular}

Fonte: próprio autor, com base nos dados do Pnud, 2013.

Entre 1991 e 2010, Barreirinhas teve seu Índice de Gini aumentado em 0,12, passando de 0,49 para 0,61 , enquanto que no Maranhão o aumento foi de 0,02 , passando de 0,60 para 0,62.

Jijoca, por sua vez, teve seu índice aumentado em 0,13, passando de 0,46 para 0,59, enquanto que no Ceará o mesmo índice sofreu redução de 0,05, passando de 0,66 para 0,61. No âmbito nacional, a desigualdade diminuiu, pela redução de 0,03, atingindo 0,60 em 2010.

\subsubsection{Longevidade e Saúde}

Diferentemente dos índices de renda e emprego, anteriormente descritos e enquadrados como "Baixo e Médio Desenvolvimento", os índices de longevidade e de saúde de Barreirinhas e Jijoca encontram-se numa classificação entre "Moderado e Alto Desenvolvimento".

O "IDHM-Longevidade" de Barreirinhas atingiu 0.752 (Alto Desenvolvimento) e o "IFDMSaúde" chegou a 0.6583 (Desenvolvimento Moderado) - ver Tabela 16. Tais índices estiveram abaixo dos respectivos índices do Maranhão, com 0.757 (Alto Desenvolvimento) e 0.6839 (Desenvolvimento Moderado), e do Brasil, com 0.816 (Muito Alto Desenvolvimento) e 0.8091 (Desenvolvimento Alto).

Em Jijoca de Jericoacoara o "IDHM-Longevidade" chegou a 0.723 (Alto Desenvolvimento) e o "IFDM-Saúde" atingiu 0.8937 (Desenvolvimento Alto). No primeiro caso, o índice foi inferior 
às médias do Ceará, com 0.793 (Alto Desenvolvimento), e do Brasil. Porém, no segundo caso, Jijoca superou a média de seu estado, que atestou 0.7951 (Desenvolvimento Moderado), e do próprio país. Dados descritos na Tabela 16.

Tabela 16: IDHM e IFDM referentes à Longevidade e Saúde

\begin{tabular}{c|c|c}
\multirow{2}{*}{} & \multicolumn{2}{c}{ ÍNDICES (2010) } \\
\cline { 2 - 3 } & $\begin{array}{c}\text { IDHM } \\
\text { Longevidade }\end{array}$ & $\begin{array}{c}\text { IFDM } \\
\text { Saúde }\end{array}$ \\
\hline BRASIL & 0.816 & 0.8091 \\
\hline MARANHÃO & 0.757 & 0.6839 \\
\hline Barreirinhas & 0.752 & 0.6583 \\
\hline Santa Quitéria do Maranhão & 0.760 & 0.6759 \\
\hline Santana do Maranhão & 0.758 & 0.6899 \\
\hline Santo Amaro do Maranhão & 0.738 & 0.5792 \\
\hline Primeira Cruz & 0.722 & 0.6628 \\
\hline Humberto de Campos & 0.759 & 0.5783 \\
\hline Paulino Neves & 0.720 & 0.5774 \\
\hline Tutóia & 0.722 & 0.7217 \\
\hline CEARÁ & 0.793 & 0.7951 \\
\hline Jijoca de Jericoacoara & 0.723 & 0.8937 \\
\hline Bela Cruz & 0.760 & 0.8484 \\
\hline Cruz & 0.752 & 0.8803 \\
\hline Camocim & 0.729 & 0.7749 \\
\hline Acaraú & 0.758 & 0.7910 \\
\hline Granja & 0.778 & 0.6579 \\
\hline
\end{tabular}

Fonte: próprio autor, com base nos dados do Sistema FIRJAN, 2013 e PNUD, 2013.

Em comparação aos municípios próximos, o "IDHM-Longevidade" de Barreirinhas não superou os índices de Santa Quitéria do Maranhão (0.760), de Santana do Maranhão (0.758) e de Humberto de Campos (0.759). Já quanto ao "IFDM-Saúde", Barreirinhas teve seu índice superado por Santa Quitéria do Maranhão (0.6759), Santana do Maranhão (0.6899), Primeira Cruz (0.6628) e Tutóia (0.7217).

No caso de Jijoca, os dois índices apresentam resultados diametralmente opostos entre si. O "IDHM-Longevidade" do município cearense é inferior ao mesmo índice de todos os demais municípios vizinhos, enquanto que o "IFDM-Saúde" é superior aos mesmos.

Analisando-se, ainda, o quadro da esperança de vida ao nascer dos dois municípios estudados, percebe-se que, em 1991, Barreirinhas apresentava uma expectativa média de vida de 56,85 anos, inferior à de Jijoca, de 57,07 anos. Dados disponíveis no Gráfico 9.

Duas décadas mais tarde, a esperança média de vida de Barreirinhas havia aumentado 13,26 anos, atingindo uma média de 70,11 anos, e ultrapassando a média de 68,35 anos de Jijoca (que reconheceu um aumento de 11,28 anos). 
Todavia, a partir do último ano de análise (2010), os dois municípios permanecem com expectativas médias de vida ao nascer inferiores às médias do Estado do Maranhão $(70,40$ anos), do Ceará (72,60 anos), e do Brasil (73,94 anos). Ver Gráfico 9.

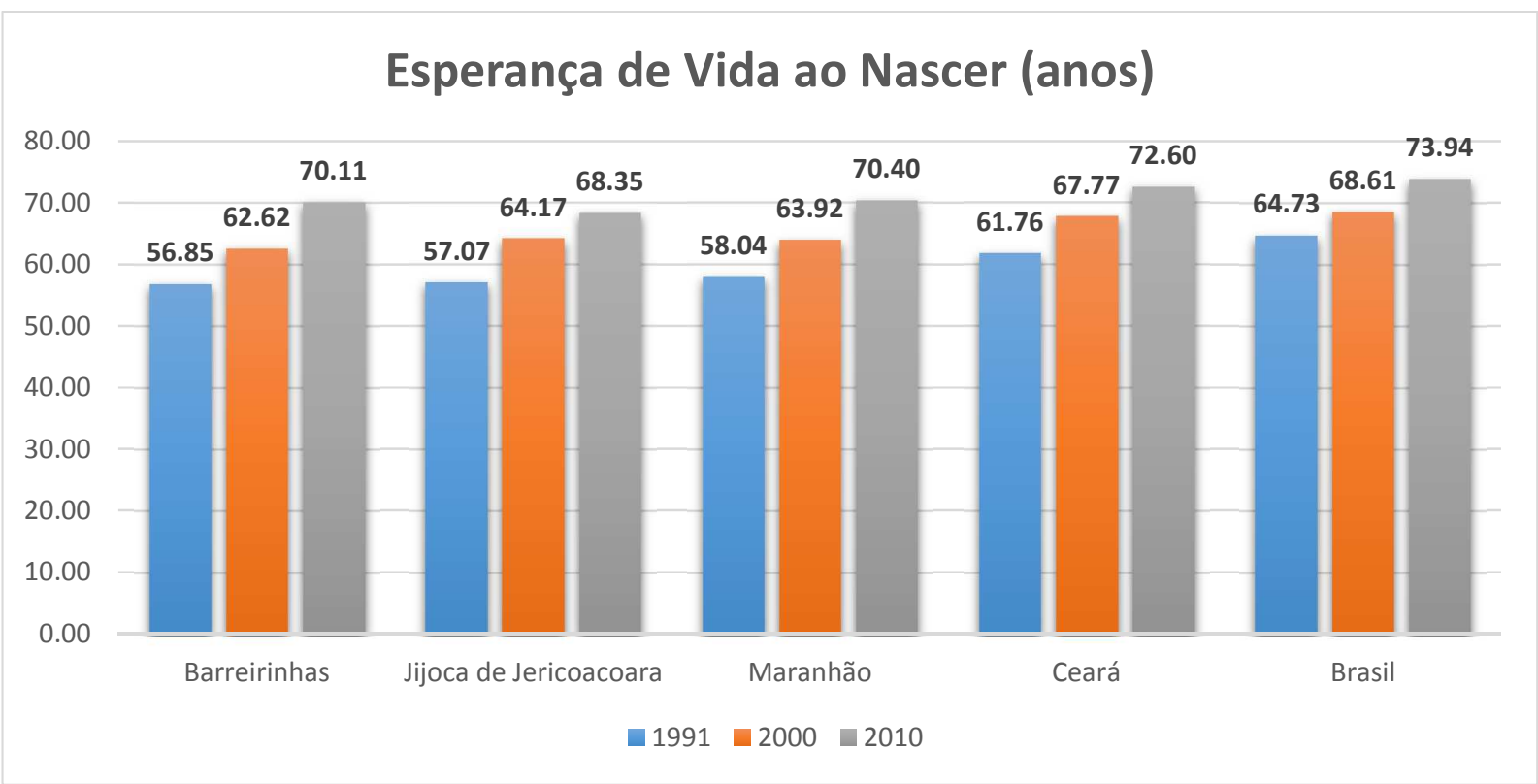

Gráfico 9: Esperança de Vida ao Nascer

Fonte: próprio autor, com base no Pnud, 2013.

Segundo o último estudo sobre Assistência Médica Sanitária, realizado pelo IBGE (2009), foram identificados em Jijoca de Jericoacoara o total de 10 estabelecimentos de saúde no município, todos públicos municipais, e com atendimento pelo Sistema Único de Saúde (SUS). Nesses não são disponibilizados serviços de internação, não havendo nenhum leito para tal finalidade.

Barreirinhas, do contrário, possui uma melhor estrutura de atendimento público de saúde. São, no total, 25 estabelecimentos de saúde no município, dos quais 22 são públicos municipais e 03 são privados. São 23 estabelecimentos ${ }^{21}$ com atendimento pelo SUS, dentre os quais 21 não possuem serviços de internação e, dos que possuem, apenas 01 é público.

Identificou-se o total de 66 leitos para internação pública pelo SUS. Há que se ressaltar que, no ano de 2005, dos 59 leitos disponíveis para internação, nenhum era disponibilizado pela

\footnotetext{
2122 públicos e 01 privado.
} 
rede de saúde pública municipal. Essa notória mudança pode ser vista como um indicativo de contribuição para o aumento substancial da esperança de vida no município maranhense.

\subsubsection{Educação}

Os índices do componente "Educação" de Jijoca de Jericoacoara estiveram, em 2010, melhor classificados dos que os mesmos índices de Barreirinhas. Atingindo 0.625 (IDHMEducação) e 0.8174 (IFDM-Educação), Jijoca se enquadrou nas classificações de "Médio Desenvolvimento" e "Desenvolvimento Alto", respectivamente.

Numa perspectiva oposta, Barreirinhas apresentou índices de apenas 0.479 (IDHMEducação) e 0,5899 (IFDM-Educação), o que acabou por classificar tal componente como de "Muito Baixo Desenvolvimento" e "Desenvolvimento Regular", respectivamente. Tais dados encontram-se descritos na Tabela 17.

Em comparação aos índices do Estado do Ceará (0.615 e 0.7403), Jijoca se sobressaiu novamente. Quanto às médias nacionais (0.637 e 0.7692), Jijoca esteve abaixo no IDHM e acima no IFDM. Por fim, quanto aos municípios vizinhos, superou todas as médias apresentadas nos dois índices.

\section{Tabela 17: IDHM e IFDM referentes à Educação}

\begin{tabular}{c|c|c}
\cline { 2 - 3 } & \multicolumn{2}{c}{ ÍNDICES (2010) } \\
\cline { 2 - 3 } BRASIL & $\begin{array}{c}\text { IDHM } \\
\text { Educação }\end{array}$ & $\begin{array}{c}\text { IFDM } \\
\text { Educação }\end{array}$ \\
\hline MARANHÃO & 0.637 & 0.7692 \\
\hline Barreirinhas & 0.562 & 0.6608 \\
\hline Santa Quitéria do Maranhão & 0.479 & 0.5899 \\
\hline Santana do Maranhão & 0.458 & 0.6226 \\
\hline Santo Amaro do Maranhão & 0.394 & 0.5887 \\
\hline Primeira Cruz & 0.416 & 0.5727 \\
\hline Humberto de Campos & 0.414 & 0.5379 \\
\hline Paulino Neves & 0.455 & 0.6131 \\
\hline Tutóia & 0.511 & 0.6243 \\
\hline CEARÁ & 0.451 & 0.5778 \\
\hline Jijoca de Jericoacoara & 0.615 & 0.7403 \\
\hline Bela Cruz & 0.625 & 0.8174 \\
\hline Cruz & 0.598 & 0.7313 \\
\hline Camocim & 0.586 & 0.7954 \\
\hline Acaraú & 0.578 & 0.7507 \\
\hline Granja & 0.517 & 0.7193 \\
\hline prôn & 0.453 & 0.6920
\end{tabular}

Fonte: próprio autor, com base nos dados do Sistema FIRJAN, 2013 e PNUD, 2013. 
Barreirinhas, ao contrário, esteve abaixo das médias do Estado do Maranhão (0.562 e 0.6608) e do Brasil. No entanto, no IDHM, mesmo com seu baixo índice, se sobressaiu aos demais municípios próximos, só ficando abaixo de Paulino Neves. No IFDM, foi superado por Santa Quitéria do Maranhão, Humberto de Campos e, novamente, Paulino Neves.

A lacuna que se reconhece no campo educacional, em ambos municípios, é também refletida pelas amplas taxas de analfabetismo dos indivíduos com 15 anos ou mais de idade nessas localidades.

Superiores às taxas dos Estados do Maranhão (20,9\%) e do Ceará (18,7\%), as taxas de analfabetismo de Barreirinhas $(25,4 \%)$ e de Jijoca de Jericoacoara $(23,5 \%)$ encontravam-se, até 2010, muito distantes da média nacional (9,6\%). Ver Gráfico 10.

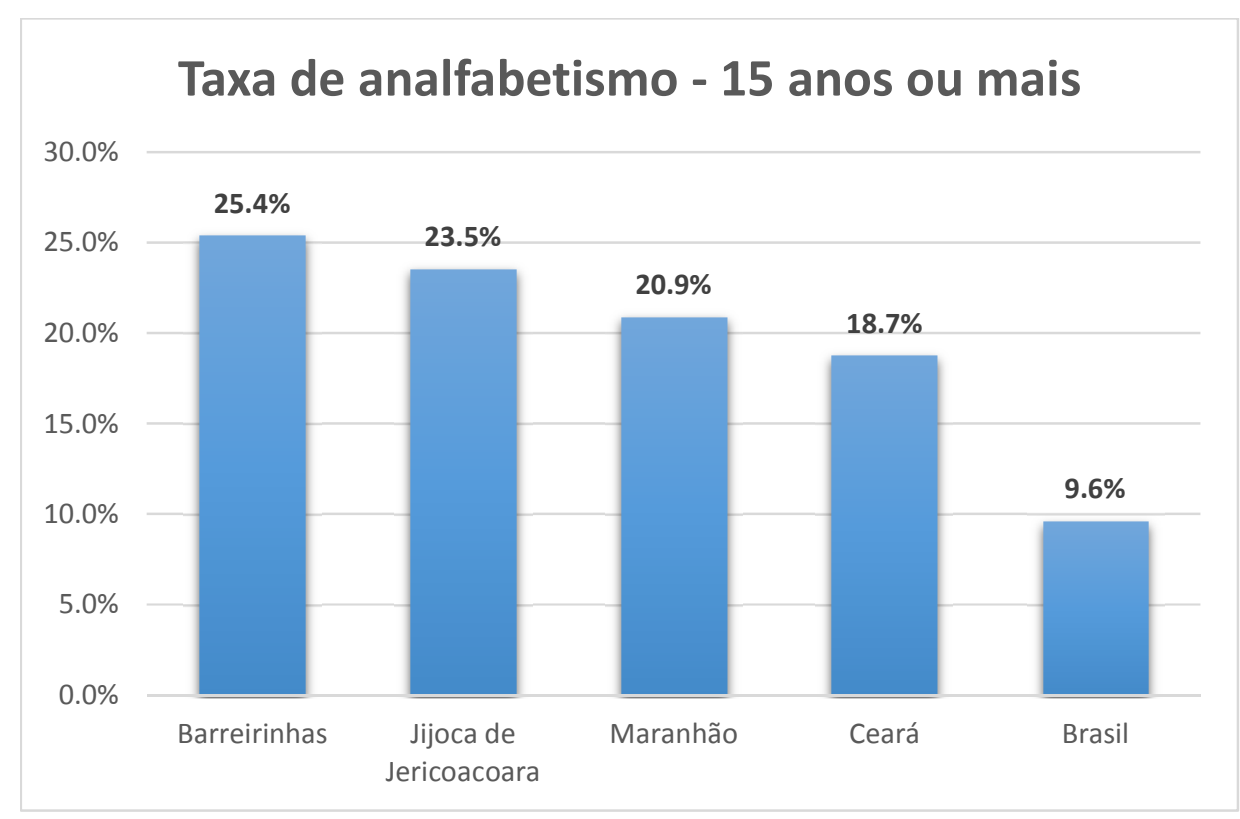

Gráfico 10: Taxas de Analfabetismo

Fonte: próprio autor, a partir dos dados do Pnud, 2013.

No quadro geral, de acordo com o último Censo Demográfico do IBGE, Barreirinhas conta com 63\% (34.599 indivíduos) de sua população residente alfabetizada, diante de 72\% (12.247 indivíduos) de Jijoca de Jericoacoara. 


\subsection{Produto Interno Bruto (PIB) e Principais Atividades Econômicas}

Pela análise do Produto Interno Bruto (PIB) dos municípios estudados é possível avaliar as atividades econômicas de maior expressão desenvolvidas nas localidades, por meio de estimativas do valor adicionado da agropecuária, indústria e serviços, a preços correntes.

Seguindo pelo valor do PIB total a preços correntes, Barreirinhas se destaca como a localidade com maior valor agregado dentre seus respectivos municípios vizinhos. O município maranhense atingiu, em 2010, o total de $\mathrm{R} \$ 175.409,00$.

Em contrapartida, no mesmo ano, pôde ser reconhecido um cenário oposto com relação à Jijoca. Atingindo um total de $\mathrm{R} \$ 79.039,00$, Jijoca de Jericoacoara foi o município com o menor PIB dentre as localidades vizinhas. Os dados estão apresentados na Tabela 18.

Tabela 18: Produto Interno Bruto (PIB)

\begin{tabular}{l|c|c|c|c}
\cline { 2 - 5 } & \multicolumn{4}{c}{$\mathbf{2 0 1 0}$} \\
\cline { 2 - 5 } & $\begin{array}{c}\text { PIB } \\
\text { Total (R\$) }\end{array}$ & $\begin{array}{c}\text { PIB } \\
\text { Agropecuária (R\$) }\end{array}$ & $\begin{array}{c}\text { PIB } \\
\text { Indústria (R\$) }\end{array}$ & $\begin{array}{c}\text { PIB } \\
\text { Serviços (R\$) }\end{array}$ \\
\hline MARANHÃO & 175.409 & 46.561 & 18.865 & 105.595 \\
\hline$\quad$ Barreirinhas & 100.479 & 28.777 & 9.886 & 58.895 \\
\hline $\begin{array}{l}\text { Santa Quitéria do } \\
\text { Maranhão }\end{array}$ & 39.875 & 14.669 & 3.170 & 21.540 \\
\hline Santana do Maranhão & 39.393 & 6.730 & 3.854 & 28.203 \\
\hline Santo Amaro do Maranhão & 39.533 & 9.421 & 3.785 & 25.791 \\
\hline Primeira Cruz & 86.635 & 23.539 & 7.542 & 53.715 \\
\hline Humberto de Campos & 54.737 & 19.842 & 4.015 & 30.113 \\
\hline Paulino Neves & 146.465 & 36.855 & 15.480 & 90.536 \\
\hline Tutóia & \multicolumn{5}{|l}{} \\
\hline CEARÁ & 79.039 & 5.742 & 10.168 & 58.825 \\
\hline Jijoca de Jericoacoara & 120.465 & 17.498 & 12.155 & 87.124 \\
\hline Bela Cruz & 94.030 & 12.392 & 10.130 & 67.695 \\
\hline Cruz & 318.396 & 38.811 & 46.362 & 210.839 \\
\hline Camocim & 309.490 & 33.652 & 68.554 & 187.789 \\
\hline Acaraú & 191.681 & 21.563 & 19.402 & 144.826 \\
\hline Granja
\end{tabular}

Fonte: próprio autor, com base no Censo Demográfico 2010 (IBGE, 2013).

A situação se inverte ao analisar-se o crescimento histórico do PIB total (a preços correntes) das duas localidades. Em Jijoca foi identificado um aumento de 380,1\% no período compreendido entre os anos de 2000 e 2010, considerado o maior aumento dentre os municípios vizinhos. (IBGE, 2013)

Em Barreirinhas, pode sua vez, identificou-se um aumento de $306,8 \%$. Contudo, tal aumento não foi o de maior expressão. Acima dele estiveram o aumento em Tutóia $(335,5 \%)$, 
Santana do Maranhão (352,6\%), Santa Quitéria do Maranhão (363,6\%), Paulino Neves (369,1\%) e Santo Amaro do Maranhão (375,5\%). (IBGE, 2013)

A partir da Tabela 18 pode-se reconhecer, também, a supremacia do setor de serviços nos dois municípios estudados. No ano de 2010, em Barreirinhas, o valor adicionado bruto a esse setor chegou a $60,2 \%(R \$ 105.595,00)$. Em Jijoca, no mesmo ano, a porcentagem foi ainda maior, atingindo $74,4 \%(\mathrm{R} \$ 58.825,00)$.

Por conta da notória potencialidade ambiental encontrada nas duas regiões, o setor de serviços tem no turismo sua principal fonte de recursos. Os atrativos naturais somados às manifestações culturais, apresentadas principalmente pelo artesanato, dinamizam a atividade turística, atraindo a demanda nacional e internacional.

Diante dos municípios vizinhos, Barreirinhas possui maior PIB no setor de serviços que as demais localidades, dentre outras coisas, por sua localização privilegiada próxima ao Parque Nacional. O mesmo ocorre nos segmentos agropecuário, cujo valor agregado atingiu $R \$ 46.561,00$, e industrial, com valor de $R \$ 18.865,00$, superiores aos valores dos demais municípios próximos.

Jericoacoara, no entanto, possui um valor agregado ao setor de serviços inferior aos dos municípios de Camocim ( $R \$ 210.839,00)$, Acaraú $(R \$ 187.789,00)$ e Granja ( $R \$ 144.826,00)$ ) No setor agropecuário possui o menor valor agregado $(\mathrm{R} \$ 5.542,00)$ dentre os municípios vizinhos. Por fim, no ramo industrial, atingiu um valor agregado de $R \$ 10.168,00$, superando apenas o município de Cruz.

No contexto geral, Barreirinhas e Jijoca de Jericoacoara possuem similitudes quanto às principais atividades econômicas desenvolvidas. Os dois municípios são capitaneados pelo turismo (agências de receptivo, cooperativas de transportes e passeios, etc.) e pelas diversas subatividades dele ramificadas, como: comércio de produtos locais (castanha de caju, artesanato, lojas de confecções e moda praia) e industrializados (pequenos mercados); meios de hospedagem (resorts, hotéis, pousadas, hostels, etc.); e estabelecimentos gastronômicos (restaurantes, lanchonetes e bares). (ICMBIO, 2011; IBAMA/MMA, 2002)

Outras atividades subsequentes e, em sua maioria, praticadas informalmente, também são características das duas localidades, como a agricultura familiar (Box 3), a pesca artesanal e o artesanato. 
"A agricultura familiar é uma forma de produção onde predomina a interação entre gestão e trabalho; são os agricultores familiares que dirigem o processo produtivo, dando ênfase na diversificação e utilizando o trabalho familiar, eventualmente complementado pelo trabalho assalariado".

\section{Box 3: Definição de agricultura familiar}

Fonte: BRASIL, 2013h.

$\mathrm{Na}$ agricultura, afora a abundância de cultivo do caju e do aproveitamento de sua castanha para o comércio local e para exportação, também se destacam as produções de carnaúba (cera e fibra) e madeira (carvão vegetal e lenha).

Os dois municípios são também caracterizados por cultivos de lavouras temporárias e permanentes, as quais são destinadas, em maior proporção, para subsistência. Quanto às temporárias, ambos se destacam pelas produções de milho, de mandioca (e seus derivados, como farinha, tiquira ${ }^{22}$ e goma) e de feijão. Ganha espaço em Barreirinhas, ainda, a produção de melancia, arroz e acerola. Em Jijoca destaca-se também o cultivo de batata doce.

Quanto às lavouras permanentes, o cultivo de banana, castanha de caju e coco-da-baía, são comuns nas duas localidades. Em Barreirinhas há, ainda, o cultivo de açaí, buriti, carambola, bacuri e de laranja, enquanto que em Jijoca identifica-se o cultivo de manga. São comuns mecanismos de troca - "escambos" - principalmente nas áreas rurais.

Segundo dados fornecidos pelo Censo Agropecuário (IBGE, 2006), Barreirinhas contava com 1.119 estabelecimentos agrícolas até 2006, os quais ocupavam uma área de 12.312ha. Jijoca, no entanto, contava com um maior número de estabelecimentos agrícolas, totalizando 1.389, porém, que ocupavam uma área menor, de 9.986ha. Dados apresentados na Tabela 19.

Do total de estabelecimentos dos dois municípios, a maioria estava, em ambos, com os proprietários: 37,6\% em Barreirinhas, e 89,7\% em Jijoca de Jericoacoara. Da mesma forma, as maiores áreas também estavam em posse dos proprietários: 85,3\% em Barreirinhas, e 95,9\% em Jijoca.

No entanto, no caso de Barreirinhas, se somados os produtores sem área, os ocupantes e os assentados, a porcentagem atinge $47,8 \%$ do total de estabelecimentos agrícolas do município, ultrapassando os proprietários. Ainda assim, só ocupando $8,5 \%$ da área total.

\footnotetext{
${ }^{22}$ Bebida com forte teor alcoólico, produzida artesanalmente a partir da mandioca, geralmente de cor azulada.
} 
Tabela 19: Estabelecimentos Agrícolas com Área e Tipo de Ocupação

\begin{tabular}{l|c|c|c|c}
\hline \multirow{2}{*}{ Tipo de Ocupação } & \multicolumn{2}{c|}{ Área (ha) } & \multicolumn{2}{c}{ N $^{\circ}$ de estabelecimentos } \\
\cline { 2 - 5 } & Barreirinhas & Jijoca & Barreirinhas & Jijoca \\
\hline Arrendatários & 544 & 152 & 84 & 45 \\
\hline Assentados & 65 & 25 & 14 & 25 \\
\hline Ocupantes & 985 & 204 & 402 & 44 \\
\hline Parceiros & 215 & 25 & 79 & 22 \\
\hline Produtores Sem Área & - & - & 119 & 6 \\
\hline Proprietários & 10.503 & 9.580 & 421 & 1.247 \\
\hline TOTAL & $\mathbf{1 2 . 3 1 2}$ & $\mathbf{9 . 9 8 6}$ & $\mathbf{1 . 1 1 9}$ & $\mathbf{1 . 3 8 9}$ \\
\hline
\end{tabular}

Fonte: IBGE, 2006.

Como ressaltado no Plano de Manejo do PNLM, a dificuldade de acesso à terra, somada ao solo pobre e a falta de tecnologia dos grupos de produtores sem terra e dos ocupantes, acaba por criar um cenário de miséria característico de regiões atrasadas, confinando tais indivíduos à um padrão de luta pela sobrevivência (IBAMA/MMA,2002)

A atividade pesqueira é, assim como a agrícola, realizada, com maior proporção, como meio de subsistência para comunidades ribeirinhas ao longo das margens do Rio Preguiças (Barreirinhas) ou áreas próximas ao oceano. São utilizadas técnicas rústicas, com aspectos artesanais, voltadas para o próprio consumo.

Segundo o Ministério da Pesca e Aquicultura (BRASIL, 2011b):

O pescador (a) artesanal é o profissional que, devidamente licenciado pelo Ministério da Pesca e Aquicultura, exerce a pesca com fins comerciais, de forma autônoma ou em regime de economia familiar, com meios de produção próprios ou mediante contrato de parcerias, desembarcada ou com embarcações de pequeno porte. Para a maior parte deles o conhecimento é passado de pai para filho ou pelas pessoas mais velhas e experientes de suas comunidades. Os pescadores conhecem bem o ambiente onde trabalham como o mar, as marés, os manguezais, os rios, lagoas e os peixes.

A riqueza de pescados destacada pelos mananciais encontrados, principalmente pelo Rio Preguiças em Barreirinhas, assim como pelo Oceano Atlântico que limita os dois municípios, foi, historicamente, a potencialidade que fomentou a formação dos primeiros grupamentos populacionais nas duas regiões.

Em virtude dessa potencialidade são reconhecidas, atualmente, práticas de pesca comerciais realizadas por empresas externas aos dois municípios, advindas de Belém (PA), Camocim (CE), Luíz Correia (PI), São Luís (MA), Fortaleza (CE), dentre outras. 
Segundo informações fornecidas, por entrevista, pela Colônia de Pescadores Z-18 (Barreirinhas), até 2005 foram contabilizadas mais de 80 embarcações oriundas de outros estados brasileiros, que utilizam a pesca de arrasto como técnica mais frequente.

As capitais Fortaleza e São Luís são os principais pólos de comercialização dos pescados produzidos nas regiões de Jijoca de Jericoacoara e de Barreirinhas, respectivamente. No entanto, a maior quantidade ainda é utilizada para o consumo interno.

No município de Barreirinhas, em específico, tanto a atividade pesqueira quanto a agrícola, remetem-se a um processo de determinismo geográfico (D'ANTONA, 1997). Fatores naturais combinados influenciam diretamente no manejo produtivo das comunidades locais, principalmente no que tange ao deslocamento "interior-litoral".

A chuva que se intensifica no período de inverno, vem acompanhada de ventos brandos na região. Nesse sentido, o cultivo da mandioca no interior é prejudicado, enquanto que a pesca no litoral se viabiliza, ao ponto em que são utilizadas pequenas embarcações como canoas para a atividade pesqueira. O deslocamento “interior-litoral” é evidente. (D’ANTONA, 1997)

Em contrapartida, no verão, reconhece-se um período seco, acompanhado de fortes ventos. A atividade pesqueira acaba se reduzindo, sendo praticada em menor escala por alguns moradores do litoral. O deslocamento "litoral-interior" é mais frequente para o aproveitamento da agricultura. (D'ANTONA, 1997)

Tanto em Barreirinhas quanto em Jijoca, somadas às atividades de lavoura, pesca e extrativismo vegetal, está a criação de pequenos rebanhos, dentre eles: asinos, bovinos, caprinos, equinos, galináceos, muares, ovinos e suínos. Em Barreirinhas encontra-se, ainda, a produção de bubalinos. (IBGE, 2012)

De toda forma, o dinamismo e o fortalecimento do setor de turismo, restringidos às ações de estruturação e expansão da rede de equipamentos e serviços turísticos (em especial meios de hospedagem e restaurantes), acarretaram em influentes alterações nessas práticas cotidianas das populações locais (CARVALHO, 2007).

Atualmente pode-se reconhecer um processo de contínuo desenraizamento cultural dos modos tradicionais de produção dos grupos locais. Paulatinamente, tais grupos têm voltado suas atenções à busca por trabalho, emprego e renda junto aos setores de comércio e de prestação de serviços. 
(...) antigas comunidades pesqueiras marítimas [...] transformaram-se em povoados litorâneos - caracterizados pelo baixo percentual de moradores envolvidos com a pesca; pelo aumento de moradores que se dedicam ao comércio (bodegas, mercadinhos e padarias), "envolvidos" em atividades de prestação de serviços domésticos para proprietários de segundaresidência (caseiros, cozinheiras, faxineiras) e para turistas (hospedagem, alimentação, entretenimento); pela tendência ao distanciamento entre os que são o lugar e o permanente convívio com "estranhos" à comunidade (uns chegam e ficam, outros apenas passam horas e/ou dias e vão embora). (LIMA, 2002, p.92-93)

O crescimento das taxas de urbanização nas duas localidades, em decorrência do aumento do êxodo rural, vem sendo induzido pelo estereótipo de melhores oportunidades e condições de trabalho no meio urbano/turístico ${ }^{23}$. A falta de valorização e de incentivo, pelo setor turístico, às atividades rurais e à produção familiar, desenvolvidas por grupos de pequenos produtores, potencializa tal processo.

D’Antona já alertava, ainda em 1997 (p.25), para a necessidade de novos estudos sobre as comunidades locais da região dos Lençóis Maranhenses e os dinâmicos processos de transformação:

Modificações como a urbanização, o turismo, a degradação ambiental, (...) e a falta de informações sobre o modo de vida nos Lençóis Maranhenses indicam a necessidade de registro, de acompanhamento. Pouco foi escrito sobre as comunidades e elas estão em franca transformação. Parece-me que o trabalho etnográfico, neste momento, adquire relevância para o presente trabalho e como memória para futuros.

Os resultados desses processos de transformação, ainda hoje aparentes, são: o desregrado processo de urbanização e formação de favelas; a exploração massiva da mão-deobra desqualificada; a pesca predatória e outras ações de degradação ambiental; o amadorismo nas atividades turísticas desenvolvidas; a ausência de fomento e fortalecimento da produção tradicional e familiar no meio rural.

\footnotetext{
${ }^{23}$ A Vila de Jericoacoara, ainda que estabelecida em zona rural, tem refletido aspectos essencialmente urbanos, dada a grande concentração de estabelecimentos turísticos em sua área.
} 


\section{Caracterização da atividade turística: serviços e equipamentos}

\subsection{A origem da visitação}

A origem da visitação aos atrativos naturais encontrados nas regiões das localidades estudadas se dá entre 1970 e 1980. Por conta das dificuldades de acesso e da falta de estrutura de acolhimento, apenas aventureiros se motivavam.

O aspecto paradisíaco dos Lençóis Maranhenses e das praias de Jericoacoara foram, aos poucos, sendo difundidos de forma interpessoal. No primeiro caso, interessados partiam de São Luís e percorriam, aproximadamente, quinhentos quilômetros dos quais mais de trezentos eram compostos por estradas sem qualquer pavimentação, totalizando oito horas de viagem ( $\mathrm{AECl}$, 2007).

A visitação, inicialmente, se dava por curtos passeios pelo Rio Preguiças, com a utilização de pequenas embarcações improvisadas de pescadores. Posteriormente, buscavam pela Praia do Caburé, aproveitando o ciclo migratório dos pescadores que se deslocavam até tal região em períodos de chuva. (AECI, 2007)

Para pernoites, os visitantes - aventureiros, jovens e pesquisadores - se hospedavam em "casas de pouso" (ranchos de pescadores), dormiam em redes, e eram guiados pelos próprios moradores. (AECI, 2007)

A partir daí, deu-se início à visitação dos campos de dunas (historicamente conhecidos por "morrarias") por meio da utilização de veículos com carrocerias improvisadas com tábuas para o transporte de passageiros, denominados "pau-de-arara" (AECI, 2007).

As difíceis condições de acesso à Vila de Jericoacoara não eram diferentes. O trajeto, realizado com a utilização de animais (como cavalos e jegues), ou mesmo a pé, se dava pelo amplo campo de dunas.

Não havia qualquer meio de transporte motorizado. No período noturno, a iluminação se dava apenas pela luz de lampiões, e as casas de pescadores eram, assim como na região de Barreirinhas, as principais estruturas de acolhimento aos viajantes. (MOLINA, 2007b) 


\subsection{O advento dos serviços de suporte da atividade turística}

A atividade turística nas duas regiões foi, aos poucos, ganhando forma, sendo acompanhada por melhorias na infraestrutura básica dos espaços, como o sistema de luz elétrica, e a consequente abertura à demanda nacional e internacional, tanto de turistas quanto de investidores.

O cenário característico de uma vida pacata e tranquila, vivenciada por grupos de pequenos produtores rurais (pescadores e agricultores), dá espaço a uma paisagem de fluxos migratórios constantes, e transformações evidentes.

De um lado, a limitação da exploração massiva de visitantes, antes imposta pela falta de estrutura de suporte ao setor turístico, dá lugar à um modelo de crescimento acelerado da atividade. Potencializam-se os processos de edificação de empreendimentos de acolhimento de grande, médio e pequeno porte. Ampliam-se, consideravelmente, os investimentos governamentais, federais e estaduais, em ações que corroborem com o desenvolvimento do setor (principalmente no que tange os meios de acesso aos destinos, como pavimentação de estradas). Novos mercados se abrem e, com eles, novas oportunidades de trabalho e emprego.

Por outro lado, a massificação da atividade gerou uma série de impactos negativos, de ordem ambiental, social, cultural e econômica, dentre outros: degradação natural pela construção de equipamentos turísticos e urbanos em locais inapropriados; poluição dos atrativos e do destino como um todo; favelização, excesso de lixo, ausência de saneamento básico, dentre outras deficiências na infraestrutura urbana; desenraizamento das atividades produtivas familiares tradicionais e descaracterização de manifestações culturais, como o artesanato; baixa qualificação do capital humano utilizado nos setores que envolvem a atividade; e exclusão social, principalmente dos pequenos produtores rurais.

O dinamismo econômico fomentado pelo fortalecimento da atividade turística nas duas localidades estimulou o comércio mas, principalmente, o setor de serviços de suporte à visitação, tais como: meios de hospedagem (hotéis, pousadas, resorts, albergues, etc.); serviços de alimentação (restaurantes, bares, lanchonetes, sorveterias, etc.); serviços de transporte e transfer (bugues, toyotas, táxis, mototáxis, voadeiras, etc.); e serviços de receptivo (agências de viagem e operadoras). 
Durante a realização da pesquisa de campo buscou-se identificar, em sua totalidade, o número exato de estabelecimentos formalizados e de grupos organizados que prestam tais serviços de suporte ao turismo.

Porém, ainda que estabelecidos contatos diretos com os Secretários de Turismo das duas localidades e, portanto, tendo acesso às bases de informações atualizadas, o número exato de empreendimentos não pode ser precisado.

Novos estabelecimentos surgem com a mesma frequência e dinamismo que outros encerram suas atividades. Há, ainda, a questão da sazonalidade, na qual alguns estabelecimentos só retomam suas atividades em períodos de alta temporada.

Tomando como base a pesquisa de campo, somada à relação dos prestadores de serviços de suporte ao turismo, formalizados, concedida pela Secretaria Municipal de Turismo (SECTUR) ${ }^{24}$, haviam no Município de Barreirinhas, até o ano de 2012: 42 agências de viagens/operadoras de turismo; 07 transportadoras de turismo; 31 estabelecimentos de alimentação; e 52 meios de hospedagem.

Com respeito à Jijoca de Jericoacoara, para o mesmo período, os dados foram levantados por meio de acesso ao Sistema de Inventariação da Oferta Turística (BRASIL, 2013i) e somados àqueles obtidos com a pesquisa de campo. Os prestadores de serviços turísticos formais contabilizados no município foram: 07 agências de viagens/operadoras de turismo; 12 transportadoras de turismo; 99 estabelecimentos de alimentação; e 120 meios de hospedagem.

Toda essa estrutura de acolhimento, atualmente encontrada nas duas localidades, concretizou um processo histórico de mudanças territoriais, no qual os espaços de povoados de pequenos produtores rurais se apresentam, agora, ao cenário turístico, como destinos turísticos indutores. O conceito de destino turístico é destacado no Box 4.

destino turístico (...) refere-se ao lugar onde os turistas pretendem passar o seu tempo quando estão longe de casa. Esta unidade geográfica visitada pelos turistas pode ser uma vila ou vilarejo, uma cidade, uma região ou uma ilha ou, mesmo, um país inteiro. Ademais, um destino pode ser uma única localidade, um conjunto de múltiplos destinos, como parte de um tour, ou, mesmo, um destino móvel, como no caso dos cruzeiros marítimos".

Box 4: Definição de destino turístico (grifo do autor)

Fonte: LOHMANN; PANOSSO NETTO, 2008, p. 347.

${ }^{24}$ Entrevista realizada com a Ex-Secretária de Turismo do município. 
Classificados pelo Ministério do Turismo (MTur) como dois dos 65 destinos indutores do desenvolvimento turístico regional, Barreirinhas e Jijoca de Jericoacoara "possuem infraestrutura básica e turística e atrativos qualificados, que se caracterizam como núcleo receptor (...) de fluxos turísticos" (BRASIL, 2013d).

Além disso, tais destinos turísticos estão inseridos no roteiro de turismo integrado denominado "Rota das Emoções" 25. Englobando quatorze municípios dos Estados do Ceará, Maranhão e Piauí, a Rota das Emoções tem como principais atrativos os Lençóis Maranhenses (MA), Delta do Parnaíba (PI) e Jericoacoara (CE).

Em junho de 2009 tal roteiro foi vencedor do concurso "Troféu Roteiros do Brasil", realizado pelo Programa de Regionalização do Turismo, do Ministério do Turismo. Nessa oportunidade, a Rota das Emoções foi eleito o roteiro turístico do ano, prêmio este disputado por mais de 90 roteiros brasileiros. (ICMBIO, 2011)

\subsubsection{Meios de Hospedagem}

Atualmente os destinos turísticos estudados possuem estruturas de acolhimento diversificadas, com empreendimentos hoteleiros de micro, pequeno, médio e grande porte, capazes de atenderem a distintos perfis de turistas. Tratam-se de pousadas, hotéis, resorts, albergues, hospedarias familiares e outros (Figura 25).

Em Barreirinhas encontram-se concentrados na sede municipal. Há, porém, algumas pousadas de pequeno e médio porte instaladas nas regiões das praias, no povoado de Atins e em Caburé.

Em Jijoca, por sua vez, a concentração de meios de hospedagem está no espaço interno da Vila de Jericoacoara. Contudo, podem ser encontradas pequenas pousadas na sede do município.

\footnotetext{
${ }^{25}$ Execução pelo SEBRAE nos três estados, contando com a parceria das prefeituras locais, governos estaduais, e do próprio Ministério do Turismo.
} 

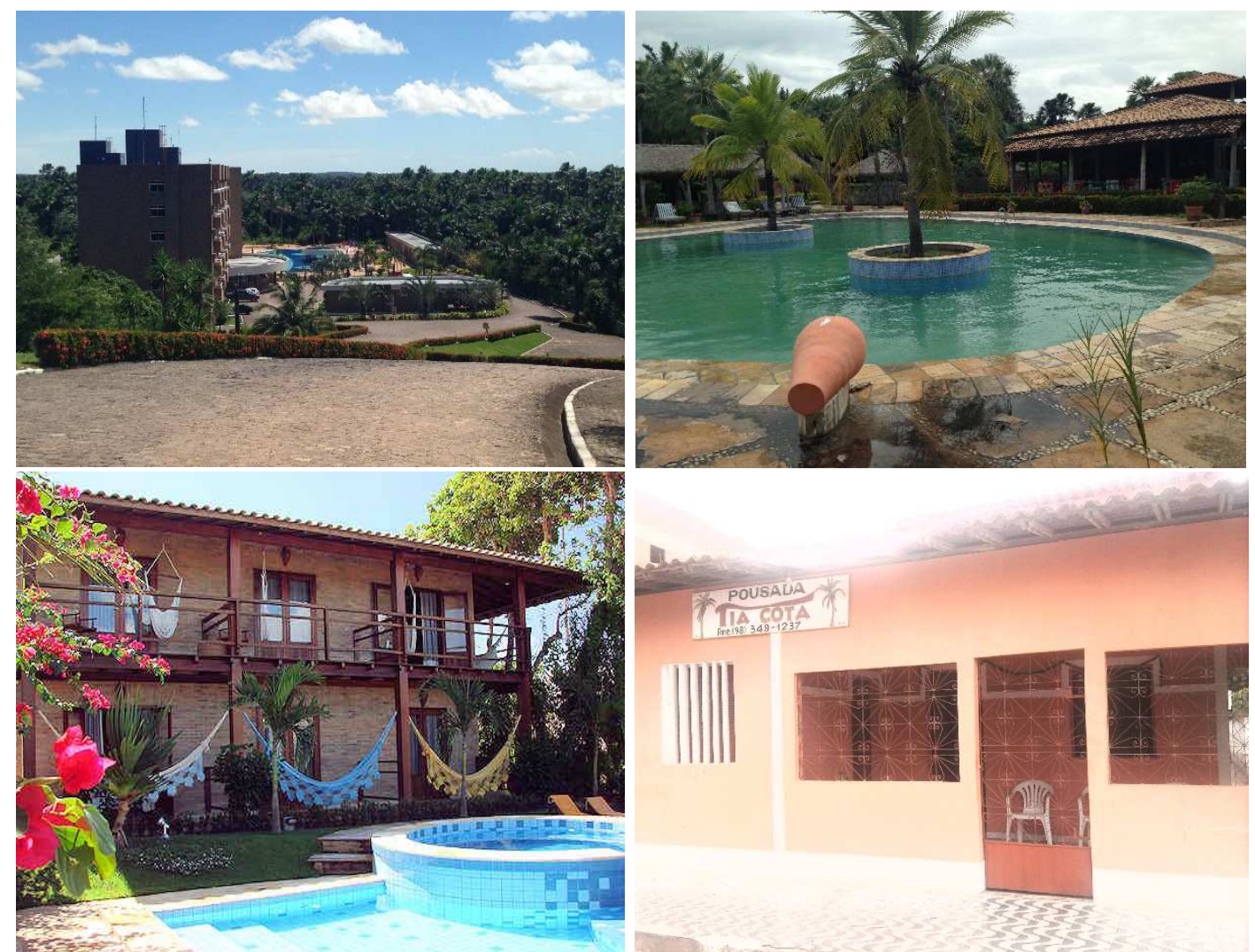

Figura 25: Meios de Hospedagem

Fonte: próprio autor.

\subsubsection{Agências de Receptivo}

Em sua maioria, as agências de receptivo, de ambos destinos, dedicam-se não só à criação de roteiros e à venda dos mesmos. Suas atividades perpassam pela administração e operacionalização dos serviços de suporte à visitação turística, tais como organização de meios de transporte para o acesso aos pontos de visitação, aluguel de equipamentos, transfer para as capitais dos estados, dentre outros.

Algumas delas foram implantadas nos destinos como filiais de agências com sede nas capitais, Fortaleza e São Luís, pensando-se na otimização dos serviços. Em Barreirinhas, concentram-se na sede municipal, e em Jijoca, na Vila de Jericoacoara.

É importante destacar que tem sido comum empreendimentos turísticos, nos dois destinos, que se apresentam com mais de uma tipologia de atuação turística. São agências que, além dos 
serviços que lhe são próprios, realizam outros serviços, como de hospedagem e de alimentação (Figura 26). Este fato tem sido encarado como um problema presente e recorrente nos destinos.

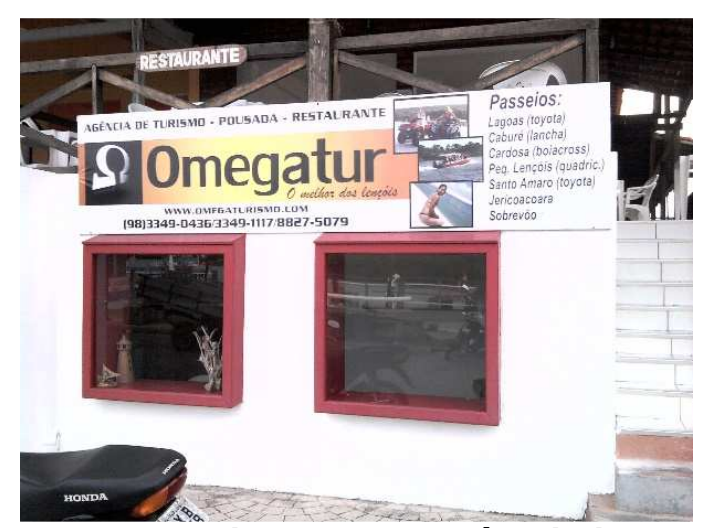

Figura 26: Empreendimento com três distintas atuações Fonte: próprio autor.

\subsubsection{Estabelecimentos de alimentação turística}

Em Barreirinhas pode-se encontrar uma grande quantidade de estabelecimentos de alimentação turística concentrados na sede municipal, próximos ao Rio Preguiças, na Avenida "Beira Rio". Em menor número estão empreendimentos distantes do centro, como na praia de Caburé.

Já os estabelecimentos de alimentação de Jijoca, como os demais segmentos, concentram-se na Vila de Jericoacoara. Outros, em menor número, também são encontrados na sede.

Assim como os meios de hospedagem, são identificados empreendimentos de micro, pequeno, médio e grande porte, em ambos destinos (Figura 27). É comum que alguns apresentem-se como ramificações dos empreendimentos hoteleiros.

Com maior frequência, oferecem pescados, frutos do mar e sucos de polpa, vistos como os produtos mais procurados pelos turistas. De toda forma, também são oferecidas carnes variadas, frutas típicas regionais, lanches de rápido preparo, pizzas e comidas orientais. 


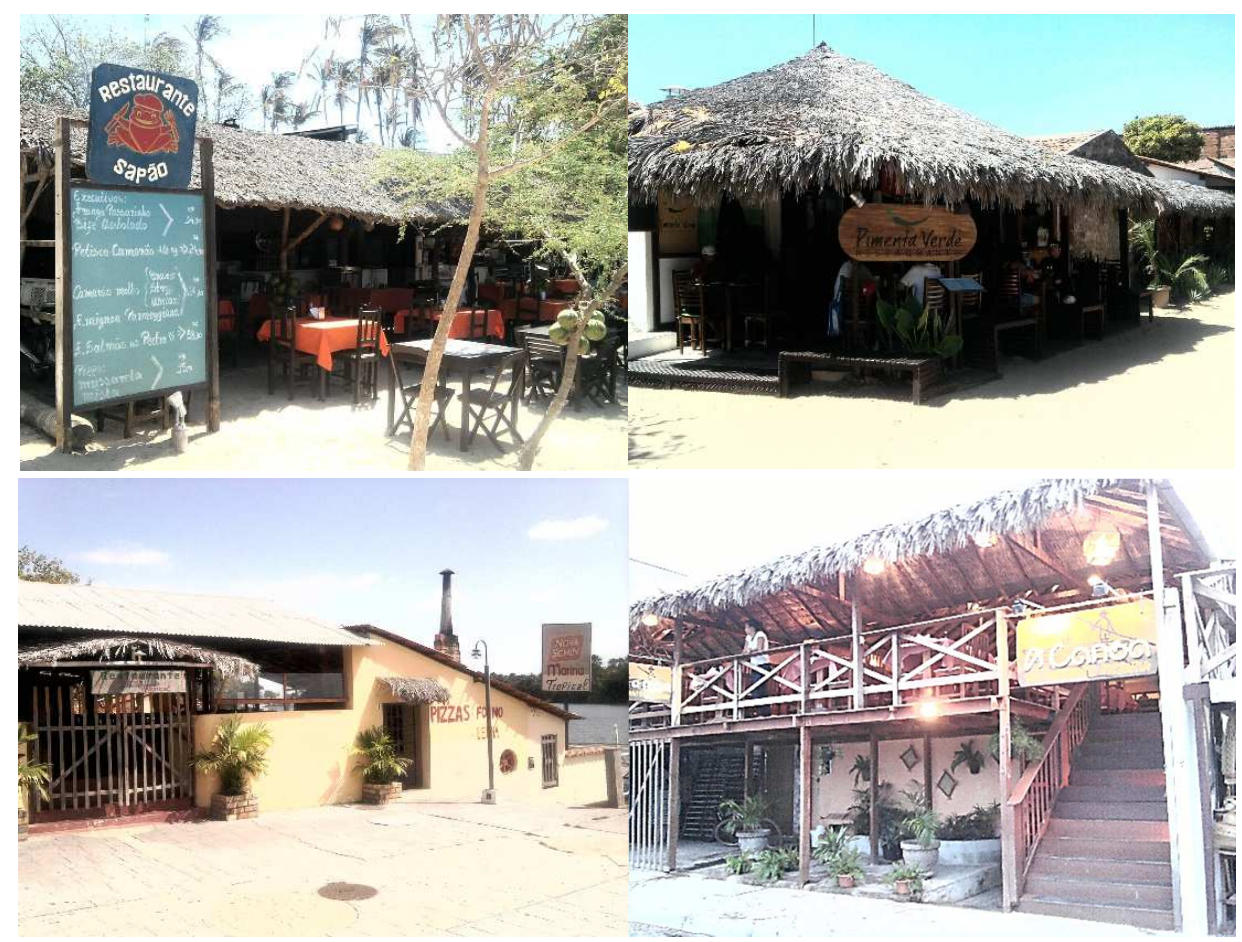

Figura 27: Estabelecimentos de alimentação turística

Fonte: próprio autor.

\subsubsection{Transportes}

Conhecidos por "toyotas" ou "jardineiras", a função primária desses veículos tracionados é distinta no contexto turístico dos dois destinos estudados. Na região dos Lençóis Maranhenses são utilizados, com maior frequência, como meio de transporte para o acesso direto aos pontos de visitação, como as lagoas, por meio de roteiros turísticos previamente definidos.

Já na região de Jericoacoara as jardineiras são mais comumente utilizadas como meio de deslocamento de visitantes, moradores locais e trabalhadores (Figura 28), entre a sede municipal e a Vila de Jericoacoara. Também realizam o mesmo itinerário transportando cargas. 

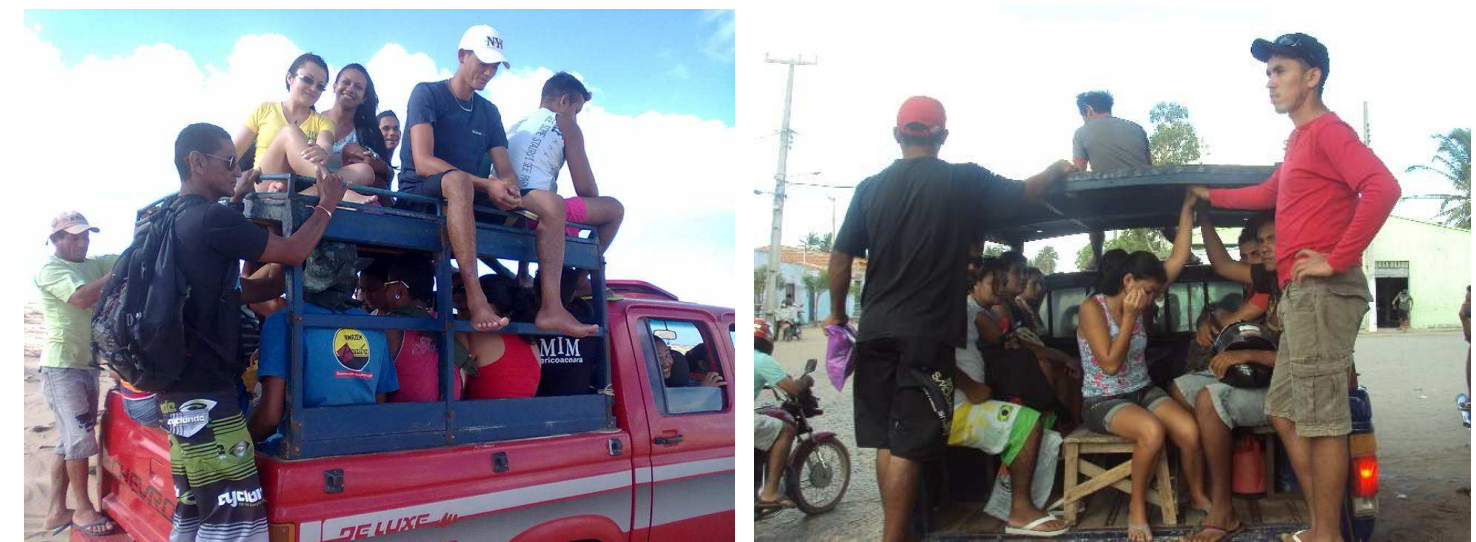

Figura 28: Transporte utilizado por trabalhadores para acesso à Vila de Jericoacoara

Fonte: próprio autor.

Nesse sentido, nota-se a diferença nas estruturas-padrão de acomodação dos passageiros em veículos das regiões de Jericoacoara e dos Lençóis Maranhenses, como apresentado na Figura 29 e na Figura 30. Observa-se que, no primeiro caso, os veículos foram adaptados para o transfer de bagagens e passageiros, diferentemente do segundo modelo de veículo, dos Lençóis, que foi adapatado unicamente para passeios.

Destaca-se, porém, que em Barreirinhas também são encontrados modelos de toyotas para transporte de cargas e de moradores locais das zonas rurais para a sede municipal. Ainda assim, pouco vinculados ao contexto turístico.

Em Jijoca há, ainda, um modelo diferenciado de jardineira, utilizado pela Empresa de Transportes Fretcar para o transporte de maior número de passageiros, frequentemente, turistas. Ver Figura 31.
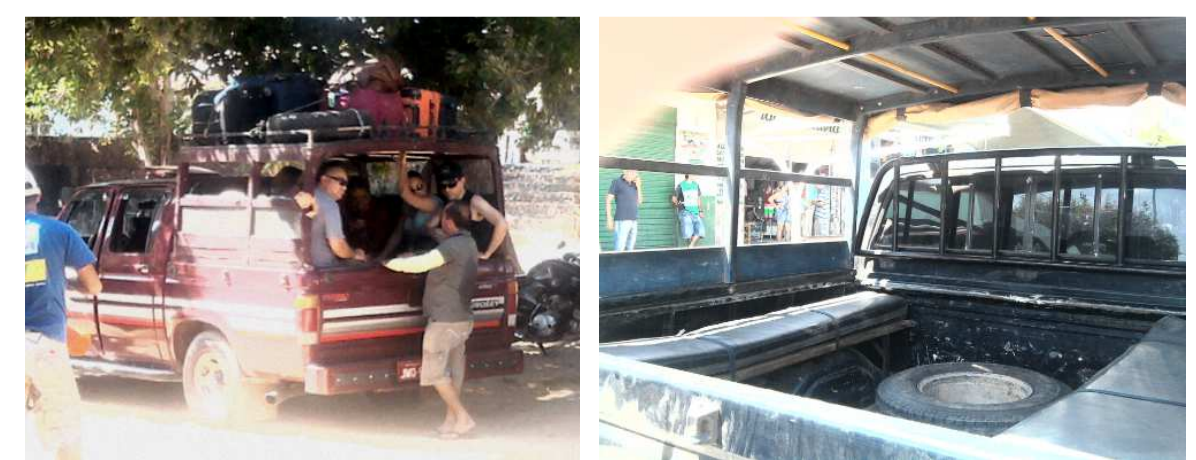

Figura 29: Estrutura de acomodação em jardineiras de Jericoacoara

Fonte: próprio autor 

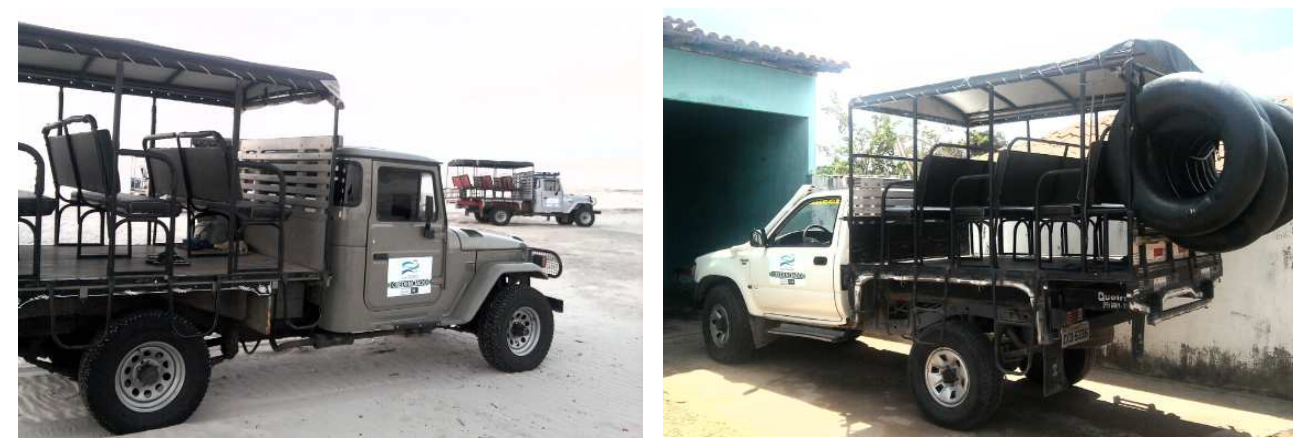

Figura 30: Estrutura de acomodação em jardineiras dos Lençóis Maranhenses Fonte: próprio autor.

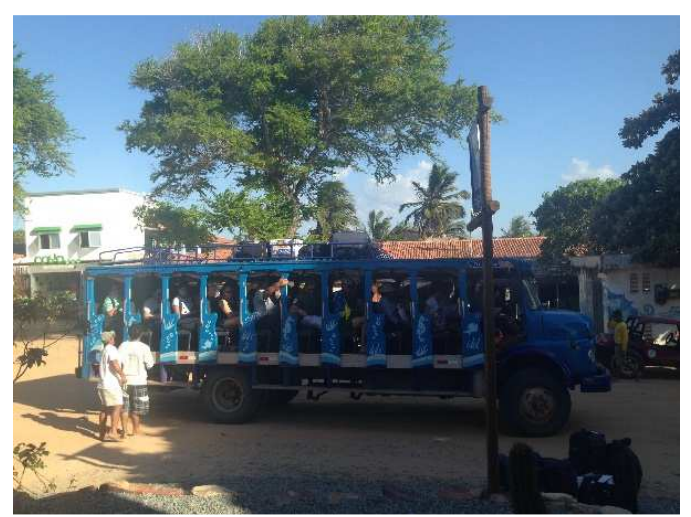

Figura 31: Transporte utilizado por turistas para acesso à Vila de Jericoacoara Fonte: próprio autor.

O acesso aos pontos de visitação de Jericoacoara, diferentemente dos Lençóis, se dá, em maior proporção, pela utilização de veículos menores, conhecidos por "bugues" (Figura 32). Vale ressaltar que os bugues também realizam o transporte de turistas entre a Vila de Jericoacoara e a sede municipal, porém, por se tratarem de veículos de pequeno porte, não são optados com frequência por visitantes com bagagens.
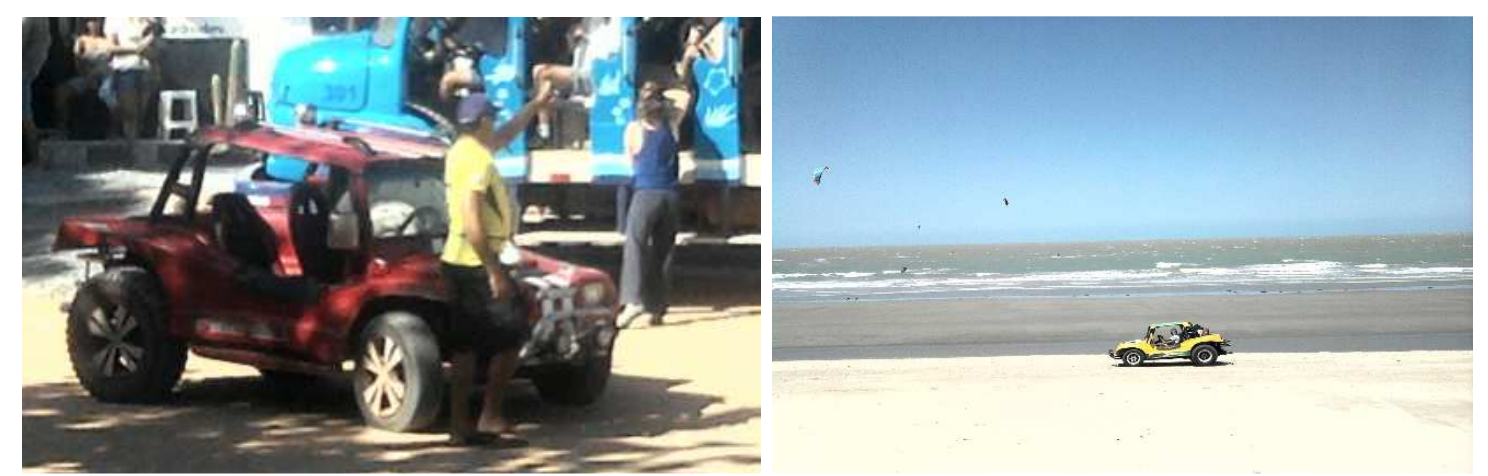

Figura 32: Bugues da Vila de Jericoacoara

Fonte: próprio autor. 
Outros pontos de visitação do destino maranhense também são acessados por via fluvial, pelo Rio Preguiças, por meio da utilização de pequenas embarcações de alumínio, à motor, conhecidas como "voadeiras" (Figura 33). Essas embarcações servem tanto para o acesso a pontos turísticos - como Mandacaru, Atins e Caburé - como para circulação de moradores de comunidades ribeirinhas.
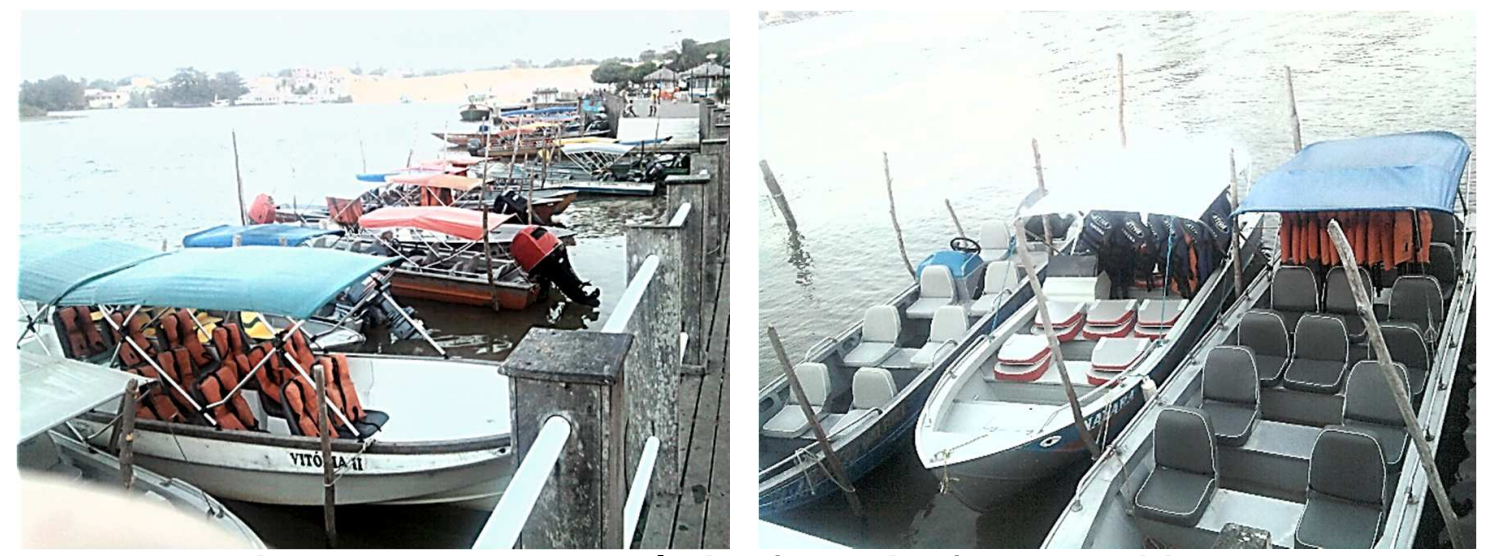

Figura 33: Transporte náutico (voadeiras) em Barreirinhas

Fonte: próprio autor.

A utilização de voos fretados para a realização de roteiros turísticos alternativos - como o de sobrevôo ao Parque Nacional dos Lençóis Maranhenses - também são disponíveis. São utilizadas aeronaves de pequeno porte (monomotores e bimotores), a partir de uma pista de pouso pavimentada (Figura 34), no município (ICMBIO, 2013).
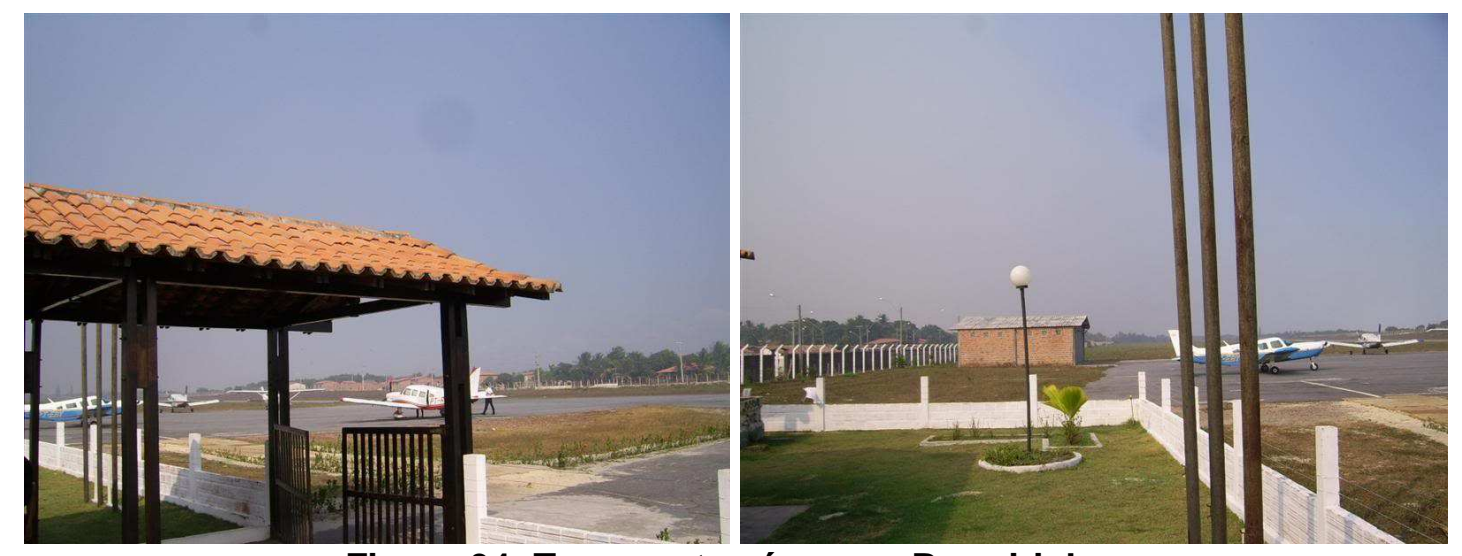

Figura 34: Transporte aéreo em Barreirinhas

Fonte: SETUR, 2013. 


\subsection{Os grupos organizados de produção e de prestação de serviços}

Atores locais perceberam no Turismo uma oportunidade de geração de trabalho e renda e, por meio da criação de organizações coletivas de trabalho (sejam elas cooperativas, associações, colônias ou sindicatos), a sua inserção direta e competitiva nesse mercado.

Apoiados pelas agências do SEBRAE locais, pela Incubadora Tecnológica de Cooperativas Populares (ITCP-COPPE/UFRJ) e pelo Centro de Apoio dos Pequenos Empreendimentos doo Estado do Maranhão (CEAPE-MA) - dentre outros - os interessados puderam melhor se estruturar como grupo de trabalho formal.

Muitos são os grupos que desenvolvem, atualmente, de forma coletiva e organizada, atividades voltadas ao sistema turístico dos dois destinos estudados. São grupos organizados de motoristas de carros tracionados (toyoteiros/caminhoneteiros) e de bugues (bugueiros), pilotos de embarcações náuticas (voadeiras), guias e condutores de turismo, artesãos, pequenos produtores rurais (pescadores artesanais e agricultores familiares), taxistas e mototaxistas. Alguns desses grupos estão representados na Figura 35, a seguir.

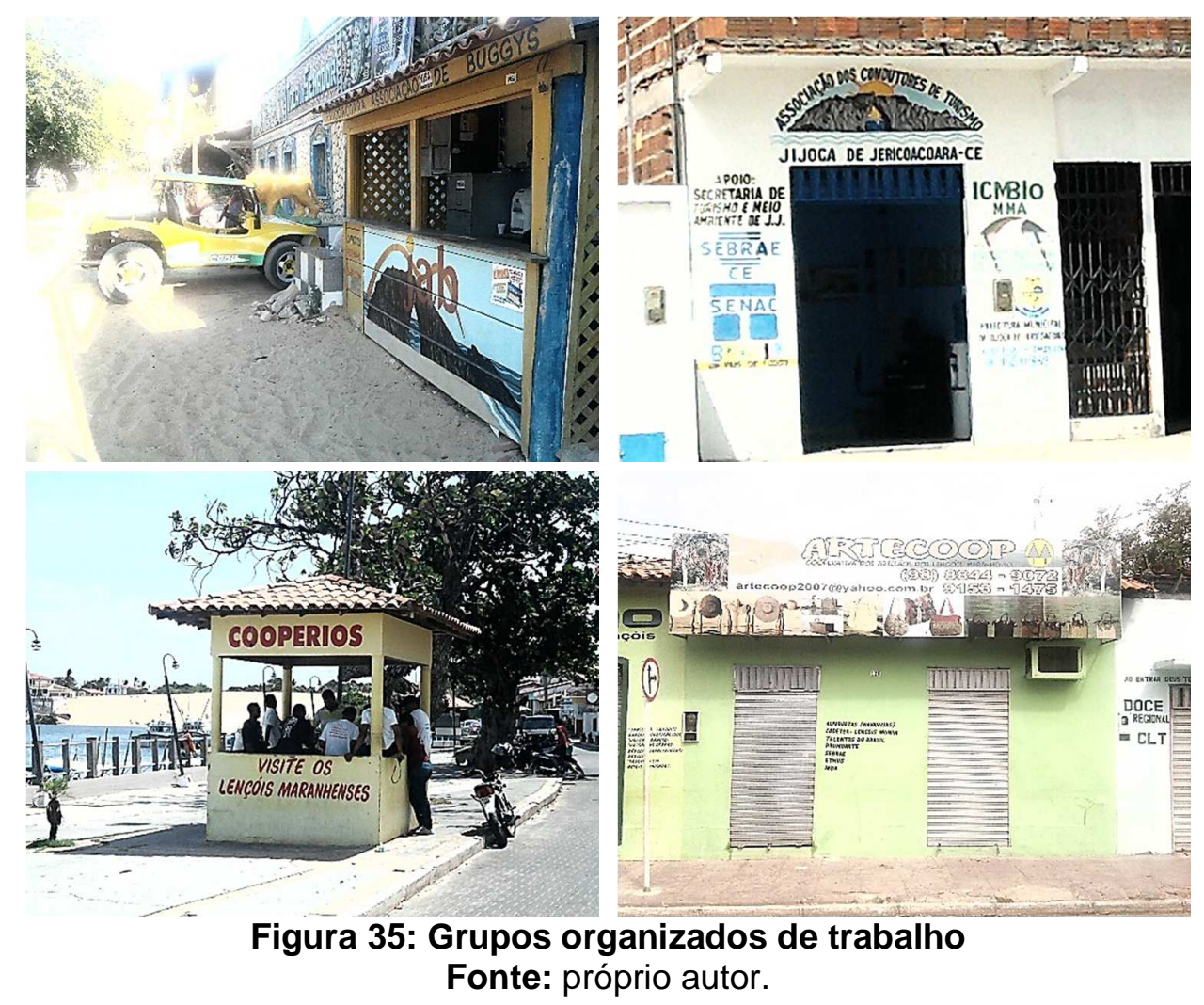


Entretanto, a formalização dos serviços turísticos nem sempre é primada pelos atores locais. Trabalhos informais, desenvolvidos sem o devido comprometimento com a qualidade dos serviços, também ocupam um notório espaço na cadeia do turismo.

Nesse grupo podem ser identificados motoristas descredenciados, equipamentos impróprios para a realização das atividades, guias e condutores turísticos despreparados, pilotos sem capacitação quanto às medidas de segurança, dentre outros. São os chamados "piratas", comuns em Jericoacoara e em Barreirinhas, cujo tipo de atividade gera conflitos diretos com os grupos organizados.

O artesanato típico, amplamente promovido e comercializado nos dois municípios, pode ser encontrado sob as mais diversas formas, como: bolsas, chapéus, artigos de decoração, toalhas de mesa, redes, vestuário feminino, brinquedos, dentre outros.

Em Barreirinhas, grande parte do artesanato é confeccionado utilizando-se como matériaprima a fibra da palmeira de buriti (Figura 36). São peças muito apreciadas pelos visitantes, e uma representação da identidade cultural local.
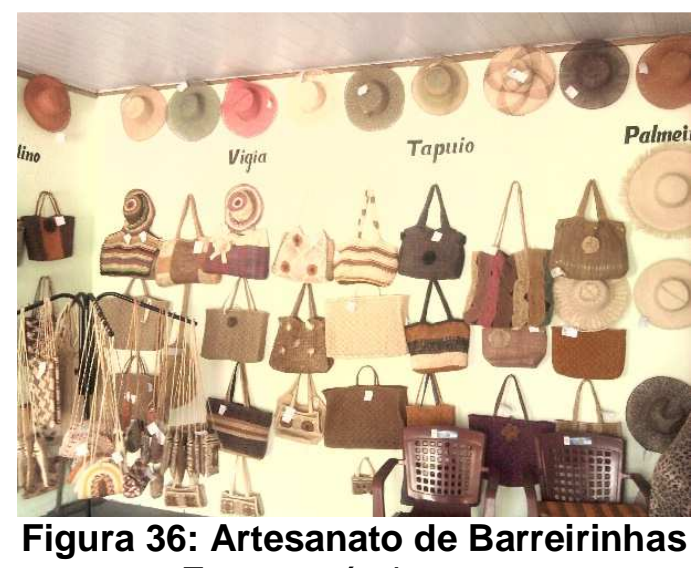

Fonte: próprio autor.

São vendidas no centro da sede municipal, expostas em lojas, centro de artesanato e galeria de produtos típicos da região. Nessa galeria ("Arte da Terra" - Figura 37) são encontrados, além do artesanato, produtos de pequenos produtores rurais (agricultores familiares) como o mel, licores, refrescos, doces e castanhas. 


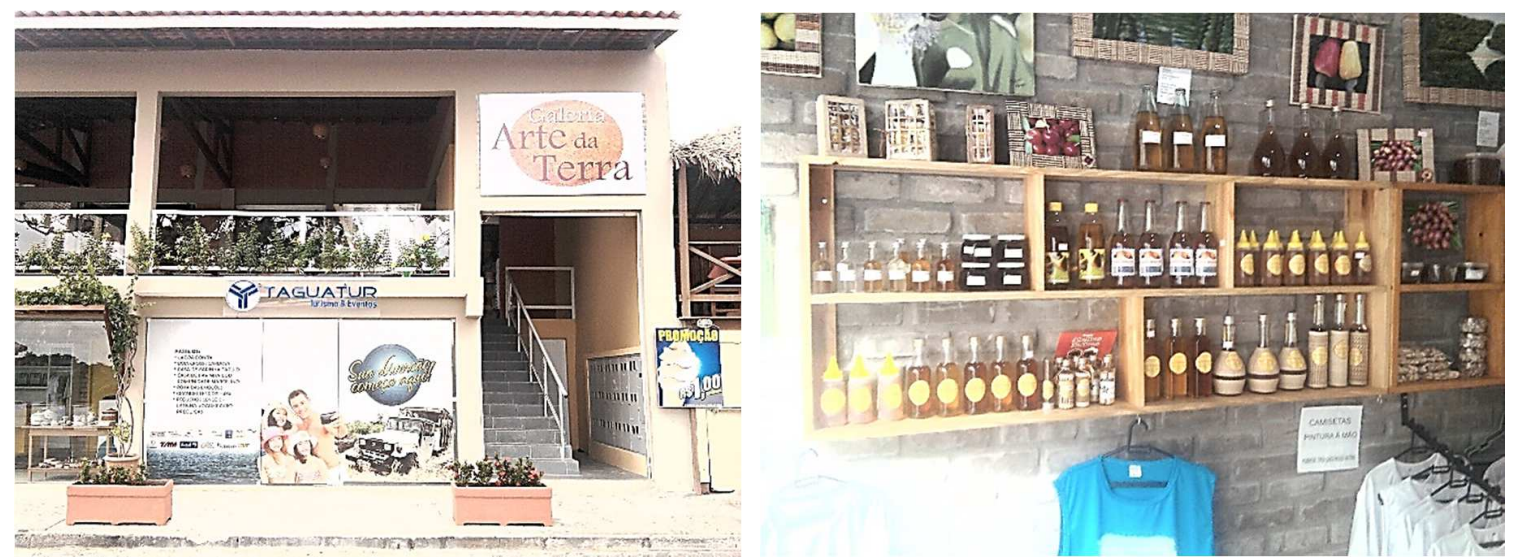

Figura 37: Galeria de produtos locais

Fonte: próprio autor.

O artesanato da região de Jericoacoara tem maior destaque para indumentárias confeccionadas em pontos de crochê, vendidas pelas próprias artesãs na praia da Vila, em lojas de artesanato espalhadas pelo município, ou no Centro de Artesanato. Tal centro foi estruturado pela Prefeitura Municipal e pelo Governo do Estado do Ceará, e abriga a Associação das Crocheteiras, que receberam apoio da agência do SEBRAE local. 


\section{CAPÍTULO 2: DISCUSSÃO TEÓRICA E ASPECTOS METODOLÓGICOS}

O primeiro objetivo do Capítulo 2 é o de fundamentar as reflexões resultantes da análise empírica realizada, por meio da construção de um espaço de discussão teórica. Ainda que apresentado por subdivisões temáticas, buscou-se, neste capítulo, criar um fio condutor (sustentabilidade e turismo) o qual perpassasse por todas as subsessões de discussão e, da mesma forma, as integrasse.

Já o segundo objetivo deste capítulo é o de apresentar a metodologia definida e utilizada para a realização da pesquisa. São descritos os aspectos que compuseram o arranjo metodológico, os materiais empregados para a coleta de dados, as técnicas de análises, o planejamento e a organização das atividades, a realização dos trabalhos de campo, assim como os limites de execução.

Nesse sentido, o segundo Capítulo foi estruturado a partir de quatro seções: (a) "Sustentabilidade e Turismo": fundamentos do campo de reflexão; (b) "Inclusão Socioeconômica": fundamentos da discussão do problema de pesquisa; (c) "Políticas Públicas, Inclusão Social e Turismo": fundamentos da finalidade última da pesquisa; e (d) "Aspectos Metodológicos": fundamentos do planejamento, da organização e da execução da pesquisa.

\section{SUSTENTABILIDADE E TURISMO}

Compreender a complexidade dos debates que envolvem conceitos e abordagens sobre sustentabilidade e turismo pressupõe, ao menos, três esferas complementares de conhecimento, discutidas nos tópicos a seguir.

\subsection{Sustentabilidade: a ascensão do debate}

A primeira esfera de conhecimento volta-se à origem dual da noção de sustentabilidade, pela biologia e pela economia. No primeiro caso, por meio da ecologia, a ideia de sustentabilidade está agregada ao entendimento de resiliência dos ecossistemas diante de distúrbios antrópicos ou naturais (NASCIMENTO, 2012).

No segundo caso, pela economia, toma-se o termo "sustentabilidade" como um adjetivo para a noção de desenvolvimento, face à percepção crescente, ao longo do século $X X$, da 
impossibilidade de se perdurar um padrão de produção e consumo em expansão, dado à finitude dos recursos naturais (NASCIMENTO, 2012).

A utilização do termo, neste último caso, perpassou por um novo entendimento de desenvolvimento que, até nos anos 70 , restringia-se ao sinônimo de enriquecimento, progresso material, ou qualquer outra conotação de mero crescimento econômico (VEIGA, 2005).

Dessa forma, ultrapassou a noção puramente economicista de fundamentalistas de mercado, que voltavam-se ao "efeito cascata" ao considerarem que o desenvolvimento - por eles tratado como conceito redundante - viria naturalmente, como resultado do progresso econômico (SACHS, 2008).

Mais do que isso. Configurou-se em um modelo ideológico fundamentado por um processo histórico-evolutivo de importantes reflexões e marcos nos campos da socioeconomia e do meio ambiente. Dentre outros, estão destacados no Quadro 6:

\begin{tabular}{|c|c|}
\hline 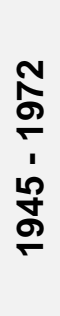 & $\begin{array}{l}\text { A emersão das discussões sobre a problemática ambiental (EHRLICH, 1968; CARSON, } \\
\text { 1962; HARDIN, 1968; BOULDING, 1966; GEORGESCU-ROEGEN, 1971; NELISSEN et } \\
\text { al., 1997;) no período marcado pela expansão da economia capitalista global e a } \\
\text { industrialização das economias periféricas, compreendido entre o pós-guerra e } 1972 \\
\text { (MACHADO, 2005). }\end{array}$ \\
\hline \multirow{2}{*}{$\begin{array}{l}\text { N } \\
\text { న }\end{array}$} & $\begin{array}{l}\text { O debate central da publicação Limits to Growth (Limites do Crescimento), patrocinado } \\
\text { pelo Clube de Roma (MEADOWS et al., 1972), no qual se popularizou a questão } \\
\text { ambiental, ao tempo em que foram apresentadas as problemáticas da exploração de } \\
\text { recursos naturais finitos e da poluição como elementos determinantes nos processos } \\
\text { social e econômico (NOBRE \& AMAZONAS, 2002). }\end{array}$ \\
\hline & $\begin{array}{l}\text { A Conferência das Nações Unidas sobre Meio Ambiente Humano (CNUMAH), em } \\
\text { Estocolmo, que trouxe à tona a necessidade de se repensar o processo produtivo } \\
\text { dominante, insatisfatório, e a adesão da perspectiva ambientalista ao discurso do } \\
\text { desenvolvimento (MACHADO, 2005), com forma de erradicação da pobreza. }\end{array}$ \\
\hline
\end{tabular}




\begin{tabular}{|c|c|}
\hline $\begin{array}{l}\stackrel{\Re}{\mathscr{\Omega}} \\
\stackrel{\sigma}{\sigma}\end{array}$ & $\begin{array}{l}\text { A formulação do conceito de "ecodesenvolvimento", por Maurice Strong, primeiro diretor- } \\
\text { executivo da United Nations Environment Programme (UNEP) e integrante da Comissão } \\
\text { Brundtland (NOBRE \& AMAZONAS, 2002). Os princípios básicos dessa nova perspectiva } \\
\text { de desenvolvimento, formulados por Ignacy Sachs, foram: solidariedade com as futuras } \\
\text { gerações; atendimento das necessidades básicas; preservação dos recursos naturais e } \\
\text { do meio ambiente como um todo; elaboração de um sistema social que garanta respeito } \\
\text { cultural, segurança social e emprego; programas de educação; e participação da } \\
\text { população envolvida (BRÜSEKE in CAVALCANTI, 1995). }\end{array}$ \\
\hline $\begin{array}{l}\text { ホ̦ } \\
\stackrel{2}{\sigma}\end{array}$ & $\begin{array}{l}\text { As contribuições de Celso Furtado sobre a necessidade de se instaurar um padrão de } \\
\text { desenvolvimento mais igualitário, pelo ajuste de padrões de consumo específicos de } \\
\text { grupos privilegiados, com foco na redução do desperdício, na extinção da dependência e } \\
\text { do mimetismo cultural, na diminuição da concentração de renda, e na simetria das } \\
\text { relações norte-sul (FURTADO, 1974). }\end{array}$ \\
\hline $\begin{array}{l}\widehat{\text { o̊ }} \\
\stackrel{1}{+}\end{array}$ & $\begin{array}{l}\text { O relatório Our Common Future (Nosso Futuro Comum), também conhecido por "Relatório } \\
\text { Brundtland", apresentado pela Comissão Mundial sobre Meio Ambiente e } \\
\text { Desenvolvimento (CMMAD). Nesse momento tratou-se com maior profundidade a } \\
\text { perspectiva da responsabilidade intergeracional e, como maior contribuição, a definição } \\
\text { do conceito de "desenvolvimento sustentável" (CMMAD, 1991; VEIGA, 2005). }\end{array}$ \\
\hline ুㅗ & $\begin{array}{l}\text { A Conferência das Nações Unidas sobre Meio Ambiente e Desenvolvimento (CNUMAD), } \\
\text { realizada no Rio de Janeiro. Suas discussões, assim como em 1972, fortaleceram a } \\
\text { aproximação da dimensão social - além da ambiental - à noção de desenvolvimento. } \\
\text { Implicou na necessidade de se englobar aspectos como a equidade social, a solidariedade } \\
\text { e a ética à sustentabilidade (NASCIMENTO, 2012). O foco esteve na busca por modos } \\
\text { eficientes no uso dos recursos naturais pensando no desenvolvimento sustentável de } \\
\text { populações carentes. Nessa oportunidade foi apresentada a "Agenda 21", primeiro } \\
\text { documento condensado em princípios de sustentabilidade ambiental, lançado como } \\
\text { compromisso internacional (BURSZTYN \& BURSZTYN, 2010). }\end{array}$ \\
\hline 욤 & $\begin{array}{l}\text { A assinatura do Protocolo de Kyoto, quando foi estabelecido um compromisso de redução, } \\
\text { em } 5 \% \text {, das emissões de gases de efeito estufa, relativas aos valores do ano de 1990, } \\
\text { pelos países industrializados com maiores taxas de emissão (BURSZTYN, 2004). }\end{array}$ \\
\hline
\end{tabular}




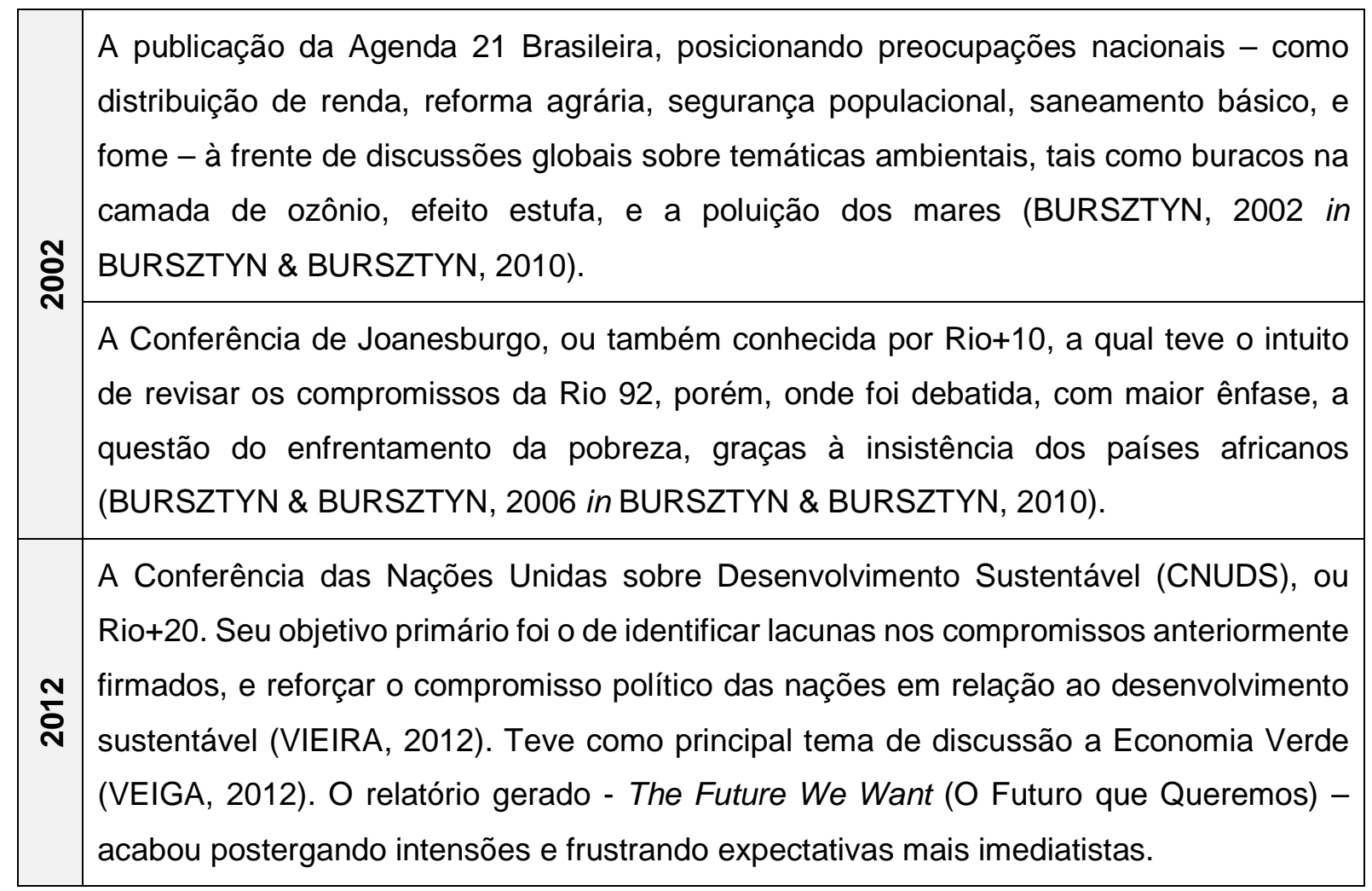

\section{Quadro 6: Marcos históricos das reflexões sobre sustentabilidade}

Fonte: Próprio autor.

Estes e muitos outros debates sobre sustentabilidade e desenvolvimento, tratados historicamente nos campos político, acadêmico e ideológico, têm se tornado, na verdade, um campo de disputa (NASCIMENTO \& COSTA, 2010; NOBRE \& AMAZONAS, 2002) - sentido utilizado por Bourdieu - no qual podem ser notados momentos de oposição nos discursos e, em outros momentos, de complementação (NASCIMENTO, 2012).

Naturalmente, os processos de complementação se deram pela complexificação tanto do substantivo "desenvolvimento", quanto do adjetivo "sustentável". No primeiro, pela adição de novos subjetivos como econômico, político, cultural, local, social, territorial, ambiental (SACHS, 2008). Já no segundo, pela expansão das perspectivas antes restritas ao social e ao ambiental, e que passam a fazer menção, também, à universalização de direitos sociais, como moradia, saúde, trabalho e educação (BELLEN, 2006), assim como à ética e à liberdade individual (SEN, 2000).

Todo esse processo de criação e de recriação dos discursos e da teoria do desenvolvimento sustentável como um novo paradigma, ou mesmo como uma ideia contida num 
processo de transição paradigmática, pressupõe não apenas a ampliação das teorias precedentes, mas a reavaliação e a reconstrução das mesmas:

\begin{abstract}
É por isso que uma nova teoria, por mais particular que seja seu âmbito de aplicação, nunca ou quase nunca é um mero incremento ao que já é conhecido. Sua assimilação requer a reconstrução da teoria precedente e a reavaliação dos fatos anteriores. (KUHN, 2012, p.07, tradução livre pelo próprio autor)
\end{abstract}

Seja ele visto como uma ideia poderosa (REDCLIFT, 1987), uma ambiguidade de conceitos (O'RIORDAN, 1993; DRYZEH 1997; WORSTER, 1993), uma nova ideologia (BAUDIN, 2009), um discurso (MACHADO, 2005), um novo valor (VEIGA, 2010), um conceito político-normativo (NOBRE \& AMAZONAS, 2002), um conceito transitório (ALLEMAND, 2007), um oximoro (LATOUCHE, 2011; FRIEND, 1992), ou mesmo uma fraude (RICHARDSON, 1997), o Desenvolvimento Sustentável e seus pressupostos têm sido fortemente incorporados aos estudos e às discussões sobre Turismo.

\title{
1.2. Turismo: concepções epistemológicas de um sistema complexo
}

A segunda esfera de conhecimento trata da complexidade do fenômeno turístico, por meio dos múltiplos olhares e concepções epistemológicas, e da pluralidade de um sistema estruturado por componentes tangíveis e intangíveis.

Como ponto de partida, refletimos sobre a limitação em se reconhecer uma concepção teórica de Turismo que, como afirma Moesch (2002; 2004), supere paradigmas fossilizados, e preocupe-se em contribuir epistemologicamente a partir de uma abordagem complexa do fenômeno (KRIPPENDORF, 2001; MOLINA, 1998; URRY, 1998; HEALTH \& WALL, 1992; PRZECLAWSKI, 1993), para além do isolamento disciplinar cartesiano.

Historicamente, mesmo as diversas definições holísticas sobre Turismo, apresentadas pós segunda guerra mundial, foram incapazes de superar: (a) o reducionismo em seu tratamento epistemológico, marcado pela produção do conhecimento pautada na trilogia pesquisatecnologia-progresso (MOESCH, 2013); (b) o pragmatismo do entendimento da atividade como um fenômeno compartimentado, categorizado, mensurável e linear, traduzindo-o como uma "indústria" (SINCLAIR, STABLER, 1991; SESSA, 1993; KOTLER, 1995; GLAESSER, 2003; MOORE, DOHERTY, 2011; ARDAHAEY, 2011).

A compreensão do fenômeno turístico demanda mais do que isso. Não apenas o entendimento da multisetorialidade e da dinamicidade de sua estrutura material. Mas também da 
complexidade, da transversalidade, da multidimensionalidade e da interdisciplinaridade de um sistema formado por elementos também subjetivos e imateriais.

Faz-se necessário a substituição de "um pensamento que isola e separa por um pensamento que distingue e une, (...) substituir um pensamento disjuntivo e redutor por um pensamento complexo" (MORIN, 2003, p.89).

Julga-se importante adotar ideias que se oponham às abordagens reducionistas de que "o todo é apenas a soma das partes", a partir da quebra de tal paradigma a favor de um pensamento sistêmico, não-linear, integrativo, cooperativo, ecológico e holístico (CAPRA, 1982).

O enfoque no entendimento complexo do Turismo como um "sistema" tem sido amplamente utilizado em estudos turísticos globais. O pensamento sistêmico, em sua origem, ganha notoriedade a partir da obra Teoria geral dos sistemas, de 1968, apresentada pelo biólogo alemão Ludwing von Bertalanffy (LOHMANN, PANOSSO NETTO, 2011).

De acordo com Bertalanffy (1973 apud VASCONCELLOS, 2002, p. 199-200), um sistema pode ser entendido como o "todo integrado cujas propriedades não podem ser reduzidas às propriedades das partes, e as propriedades sistêmicas são destruídas quando o sistema é dissecado". Ou seja, trata-se de uma unidade complexa, em que o todo é mais do que a soma de suas partes. E por conta disso, as múltiplas interligações entre os vários elementos e variáveis que compõem o sistema produzem causas e efeitos complexos, que demandam por olhares também complexos (PANOSSO NETTO, 2005).

A teoria geral de sistemas, difundida por modelos experimentais fechados e abertos, acabou tornando-se constante em análises críticas e estudos no contexto turístico (sistema social aberto). O olhar sistêmico torna-se um modelo de referência para o melhor entendimento da multiplicidade e da complexidade do setor de Turismo, inclusive para a proposição de ações voltadas à sustentabilidade do setor:

(...) o turismo é um complexo sistema de subsetores, e olhando para ele como uma indústria só será oferecida uma visão limitada das questões em jogo. Neste contexto, uma abordagem sistemática é a mais adequada para a análise e estudo de estratégias, ações e políticas para o desenvolvimento do turismo sustentável. (BUDEANU, 2004, p. 74, tradução livre pelo próprio autor)

Alguns autores de referência - tais como Salah-Eldin Abdel Wahab, Raymundo Cuervo, Neil Leiper, Alberto Sessa, Pierre Lané, Sergio Molina, Renzo Bernardi, Mario Carlos Beni e 
Roberto C. Boullón - capitanearam os estudos e as análises do Turismo pela vertente da teoria geral de sistemas.

A compreensão e análise sistêmica no turismo contribui para a melhor e mais clara compreensão do contexto o qual é estudado, e para retratar as interações e relacionamentos entre as partes constituintes (HALL, 2001). Contudo, os modelos sistêmicos, por mais esclarecedores que possam parecer, possuem suas limitações:

(...) modelos sistêmicos do Turismo, (...) são considerados modelos formais, capazes de dar uma noção geral do que é o fenômeno, mas não são capazes de explicar as especificidades de cada sistema, uma vez que os conceitos de entrada, saída e realimentação (input, output, feedback, respectivamente) falham na concepção e análise, por exemplo, da influência da cultura e das motivações subjetivas dos turistas. (PANOSSO NETTO, 2005, p. 81)

No Brasil, o mais conhecido modelo analítico de Turismo, sob o enfoque da Teoria dos Sistemas, é o de Mario Carlos Beni, denominado de Sistur - Sistema de Turismo (BENI, 2003). O Sistur possui notória contribuição na tentativa de minimizar a complexidade dos movimentos e das inter-relações das funções turísticas com os elementos e variáveis que compõem esse sistema (BENI, 2003).

Grosso modo, o Sistur pode ser entendido pela ramificação do sistema em três conjuntos: (a) conjunto das Relações Ambientais - RA, compreendendo os subsistemas ecológico, econômico, social e cultural; (b) conjunto da Organização Estrutural - OE, compreendendo a superestrutura (entidades públicas, ordenação jurídico-administrativa e ações normativas e executivas da Política Nacional de Turismo) e a infraestrutura (sistemas de transporte, segurança, acesso, comunicações e serviços de apoio à comunidade); e (c) conjunto das Ações Operacionais - AO, compreendendo o subsistema de produção, distribuição e consumo. (BENI, 2003)

De acordo com abordagens sobre o tema (STEAR, 2003a; 2003b; LEIPER, 2003), analisando-se o contexto geral, todo Sistema de Turismo é composto por, ao menos, cinco elementos primários:

1. Humano: trata-se do turista propriamente dito, fator imprescindível para que toda e qualquer atividade do sistema se desenvolva;

2. Origem: elemento geográfico onde dá-se o início e o fim da viagem turística;

3. Rotas Turísticas: caminhos traçados e percorridos para se chegar ao destino turístico; 
4. Destino Turístico: espaço físico (móvel ou não) onde se concentram os potenciais turísticos buscados pelo visitante;

5. Cadeia Produtiva do Turismo: "conjunto complexo de atividades e serviços ligados ao deslocamento, visitas, transportes, alojamentos, lazer, alimentação e circulação de produtos típicos" (PROVINCIALI, 2002, p. 11-12).

Todos estes elementos se configuram em um sistema aberto que sofre influência direta e indireta de ambientes sociais, políticos, econômicos, tecnológicos, legais, culturais, dentre outros. A estrutura do sistema (modelo de Leiper) está destacada a seguir na Figura 38.

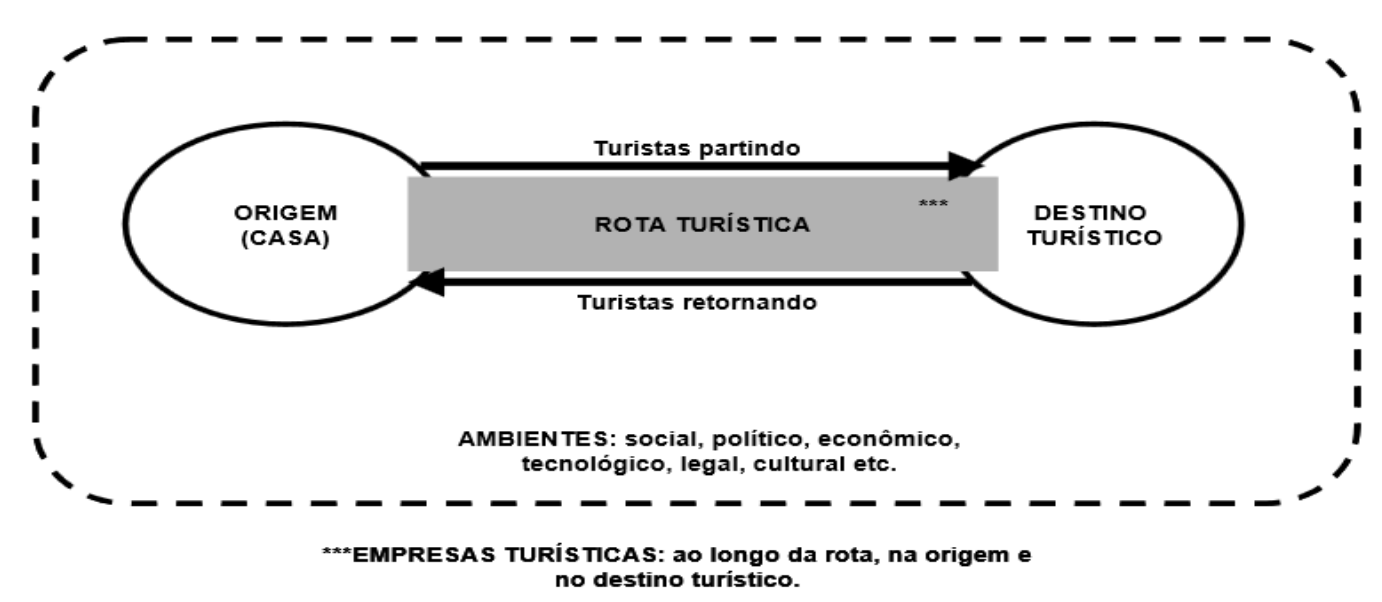

Figura 38: Sistema de Turismo de Leiper

Fonte: LEIPER, 2003 adaptado por COSTA, 2009.

O Sistema de Turismo possui, em sua estrutura complexa, interações e interdependências entre as múltiplas empresas de subsetores específicos que se complementam para resultar em um produto turístico final. Esse encadeamento entre empresas compreende o quinto elemento, anteriormente destacado: a "Cadeia Produtiva do Turismo" - СРТ².

$\mathrm{Na}$ literatura internacional é possível encontrar alguns estudos publicados sobre o tema "Tourism Supply Chain - TSC"27 (ver UNWTO, 1994; BUHALIS, LAWS, 2001; SINCLAIR, STABLER, 1997; PAGE, 2003, LUSTOSA, SCAVARDA, 2001; YILMAZ, BITITCI, 2006; TAPPER, FONT, 2004), contudo, ainda limitados.

\footnotetext{
${ }^{26}$ Será utilizada a sigla "CPT", no corpo do texto, para facilitar a leitura.

${ }^{27}$ Cadeia de Oferta Turística.
} 
Outros conceitos equivalentes também são utilizados no contexto internacional, tais como "Tourism Value Chain"28 (KAUKAL et al., 2000; YILMAZ, BITITCI, 2006; POON, 1993), "Tourism Industry Chain"29 (ALFORD, 2005), "Tourism Clusters"30/"Clusters Turísticos"/“Agrupamiento Turístico" (NOVELLI, SCHMITZ, SPENCER, 2006; FLOWERS, EASTERLING, 2006; TOLEDO, ÁlVAREZ-VALDÉS, POLLERO, 2003; PORTER, 1998; YUZBASIOGLU, OTAMIS, DEMIR, 2011; CARNER, 2001; MONFORT MIR, 2000; GUTIÉRREZ, BORDAS, 1993; GOLLUB, HOSIER, WOO, 2002; NORDIN, 2003; ESTEVE SECALL, 2002), "Microcluster Turístico" (RODRíGUEZ DOMÍNGUEZ, 2001), "Tourism Networks31” (BAGGIO, COOPER, 2010; BAGGIO, SCOTT, COOPER, 2008; CROSS, BORGATTI, PARKER, 2002; DALE, 2002) e "Cadena Turística"32 (TINARD, 1996).

Todavia, grande parte desses conceitos são abstratos, não estabelecendo um entendimento homogêneo e consensual, refletindo, assim, numa lacuna analítica, conceitual e descritiva.

\footnotetext{
(...) o consenso ainda não foi alcançado sobre a melhor forma de caracterizar a Cadeia Produtiva do Turismo (TSC) e a limitada literatura não fornece orientações para pesquisadores e gestores de turismo e hotelaria. A definição clara de TSC e uma estrutura conceitual para Gestão da Cadeia Produtiva do Turismo (TSCM) são necessários para se avançar nesse campo. (ZHANG, SONG, HUANG, 2009, p. 346 - Tradução livre pelo próprio autor)
}

A mesma escassez e heterogeneidade nas definições e descrições de Cadeia Produtiva do Turismo pôde ser identificada no quadro de pesquisas e publicações de âmbito nacional.

São tratamentos por meio de sua concepção original (BRASIL, 2011a; SEBRAE, 2006, 2008; PROVINCIALI, 2002; SOUZA, 2003; CNI, 1998; BALANZÁ, NADAL, 2003; MASSARI, 2005; CNI, SENAI, IEL, 1998), ou ainda por "Cadeia Turística" (SOUZA, 1998), "Sistema Produtivo de Turismo" (COSTA, SOUTO-MAIOR, 2008), "Pólo Produtivo de Turismo", "Arranjo Produtivo Local de Turismo - APTur" (BARRETO, OLIVEIRA, SICSÚ, 2007; MAMBERTI, BRAGA, 2004; ALBAGLI, BRITTO, 2003), "Cadeia de Valor" (ALMEIDA, 2002; GARRIDO, 2001), "Pólo Turístico" (BANCO DO NORDESTE, 2000), "Cluster Turístico" - Box 5 (ZACARELLI, 2004; BARBOSA, ZAMBONI, 2000; LINS, 2000; DA CUNHA \& DA CUNHA, 2005; BENI, 2003;

\footnotetext{
${ }^{28}$ Cadeia de Valor do Turismo.

${ }^{29}$ Cadeia da Indústria do Turismo.

${ }^{30}$ Agrupamentos de Turismo.

${ }^{31}$ Redes de Turismo.

${ }^{32}$ Cadeia Turística.
} 
RODRIGUES, 2001;), "Distrito Industrial de Turismo", ou "Rede Turística" (BERNARDES et al, 2006; CHON, 2003). Tratamentos diferenciados que acabam mais por confundir do que esclarecer sobre o que está sendo tratado (SILVA, 2004b)

Entende-se cluster turístico como "o conjunto complexo de diferentes elementos, entre os quais se
encontram os serviços prestados por empresas ou negócios turísticos (alojamento, restauração,
agência de viagens, parques - aquáticos, temáticos, etc.); a riqueza que proporciona a experiência
das férias de um turista; o encontro multidimensional entre empresas e indústrias relacionadas; as
infra-estruturas de comunicação e transporte; as atividades complementares (dotação comercial,
tradição em feiras, etc.); os serviços de apoio (formação e informação, etc.); e os recursos naturais e
as políticas institucionais" [tradução livre de SILVA, 2004].
as políticas institucionais" [tradução livre de SILVA, 2004]

\section{Box 5: Conceito de Cluster Turístico}

Fonte: MONFORT MIR, 2000, p. 46.

Entretanto nota-se a mesma imprecisão quanto à descrição de quais são os subsetores específicos que compõem essa rede de mercado. A começar pela Pesquisa Nacional por Amostra de Domicílios (PNAD) do IBGE, na qual se reconhece a limitação em se mensurar os níveis de ocupação no turismo dada à indefinição de quais seriam as reais "Atividades Características do Turismo (ACT)":

Uma das principais limitações das medições da ocupação no turismo, formal ou informal, decorre da definição de quais são as atividades características do turismo e do grau de detalhamento dos Códigos de Atividade Econômica com que cada fonte trabalha. (PNAD, 2010, p.10)

Características intrínsecas ao setor de serviços - tais como inseparabilidade, variabilidade, perecibilidade e intangibilidade (KOTLER, 2000) - dificultam a aplicação convencional da ideia de CPT. O desenho comumente aplicado aos sistemas de produção industrial, como o setor de agronegócios, compartimentados, com sucessões de operações de transformação dissociáveis (BATALHA, 1997), pouco se encaixam no complexo e multifacetado cenário turístico. Talvez apenas no subsetor da Hotelaria:

(...) verifica-se [que] em alguns sub-setores do turismo [onde] existem características assemelhadas à indústria, como, por exemplo, a hotelaria, [a] utilização desse modelo pode ser apropriada. [...] conclui-se que o modelo da cadeia produtiva é parcialmente representativo para o "setor" do turismo, ficando circunscrito a alguns sub-setores e/ou arranjos de integração horizontal de empresas, em segmentos específicos. (GARRIDO, 2001, p.61-62).

O que se nota é que Turismo possui cinco características (GARRIDO, 2001, p. 60) que lhe atribuem maior complexidade: (a) Heterogeneidade: "conjunto de produtos e serviços bastante diversificados e de difícil padronização"; (b) Fragmentação: "cada produto ou serviço, 
geralmente, fica a cargo de um fornecedor"; (c) Dispersão Espacial: "cada fornecedor presta seu serviço ou vende seu produto em seu próprio espaço"; (d) Interdependência: "os diversos componentes precisam estar interconectados de forma precisa"; (e) Instantaneidade: "produto é consumido no local e no momento em que é produzido".

A imaterialidade - como exemplo das manifestações culturais - também está presente no conjunto complexo de elementos que formam a CPT, o que a diferencia dos demais modelos de cadeia por possuir elementos também abstratos (SOUZA, 1998).

Há, entretanto, tentativas que se propõem a pontuar todos os múltiplos subsetores que interagem nessa cadeia para a formação de um mercado turístico e que, consequentemente, estão englobados em um sistema maior.

Uma primeira abordagem destaca doze subsetores (MOLLO, TAKASAGO, 2008), como sendo aqueles representativos da CPT. Dividem-se em:

$\checkmark$ Transportes: rodoviário regular de passageiros; rodoviário não regular de passageiros; aéreo regular; aéreo não regular; regular próprio para exploração de pontos turísticos;

$\checkmark$ Atividades Auxiliares: ao transporte terrestre; ao transporte aéreo;

$\checkmark$ Estabelecimentos: de serviços de alimentação; hoteleiros e de alojamento temporário;

$\checkmark$ Viagens: agências e organizadores;

$\checkmark$ Serviços: recreativos, culturais e esportivos; aluguel de automóveis e outros meios de transporte.

Seguindo a descrição da Confederação Nacional das Indústrias (CNI/SENAI/IEL, 1998), outros subsetores deveriam também ser adicionados àqueles supracitados, por terem uma interação muito próxima ao Turismo. São eles (ver Figura 39): marketing; organizadores de eventos e conferências; setores de infraestrutura básica e serviços públicos (saúde, saneamento, telecomunicações, segurança, e abastecimento de água e energia); e comércio em geral. Notase que nesse modelo, o turista é o elemento central, e os subsetores parecem se formatar para 0 atendimento de suas necessidades.

Uma outra concepção de cadeia turística, ainda mais detalhada, subdivide a mesma em três esferas: cadeia principal, cadeia a montante e cadeia a jusante (SEBRAE, 2008 - ver Figura 40). 
$\mathrm{Na}$ cadeia principal estão contemplados os restaurantes, bares e atividades hoteleiras, assim como as agências receptivas, operadoras de viagens, e organizadores de eventos. Já na cadeia a montante englobam-se atividades de patrimônio natural, cultural e histórico, além de transporte, construção civil, indústria moveleira e de confecções, equipamentos de hotelaria, produção e fornecimento de alimentos e bebidas, e indústria de toucador. Por fim, na cadeia a jusante, estão alguns produtos turísticos e a prestação de serviços aos turistas, como comércio em geral, o artesanato e a cultura, os serviços terceirizados, as empresas de entretenimento e a publicidade.

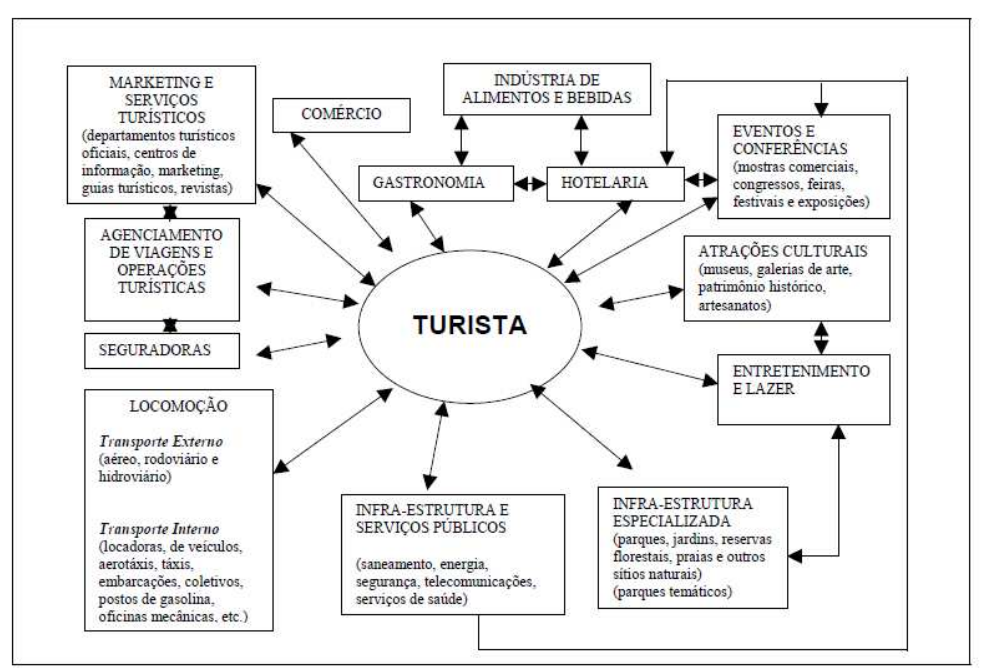

Figura 39: Modelo de Cadeia Produtiva do Turismo

Fonte: CNI/SENAI/IEL, 1998 apud GARRIDO, 2001, p. 62.

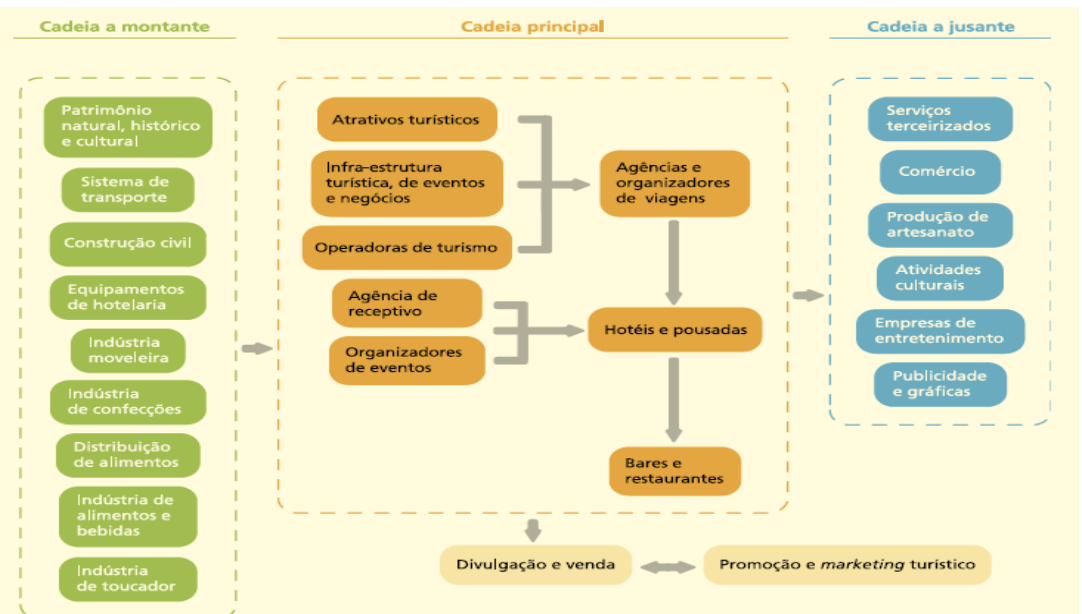

Figura 40: Cadeia Produtiva do Turismo (modelo SEBRAE)

Fonte: SEBRAE, 2008, p. 13. 
Diferentemente do modelo da CNI, o modelo de CPT do SEBRAE se estrutura num arranjo em que os subsetores que a compõem se formatam não apenas para o atendimento das necessidades diretas do turista, como também para o suporte de outros subsetores.

O último modelo a ser aqui destacado (BRASIL, 2011c) - Figura 41 - é ainda mais abrangente, subdividindo-se em três componentes principais:

- Setores Líderes: meios de hospedagem, empresas de alimentação turística, promoção de eventos, agências de viagem, operadoras turísticas, e empresas de entretenimento;

- Indústrias e Serviços Relacionados: construção civil, fabricação de móveis, alimentos e bebidas, confecções, calçados, higiene e limpeza, editorial e gráfica, transportes (aéreo, terrestre e marítimo), locadoras de veículos, publicidade, lavanderias, dentre outros;

- Infraestrutura de Apoio: escolas de turismo, serviços de elaboração de projetos, assistência técnica, infraestrutura física, instituições governamentais, telecomunicações, sistema de segurança, sistema de seguros, convênio com universidades, representações diplomáticas, casas de câmbio e bancos, equipamento médico e hospitalar, serviços de recuperação do patrimônio público, delegacias de polícia, elaboração de projetos, dentre outros. 


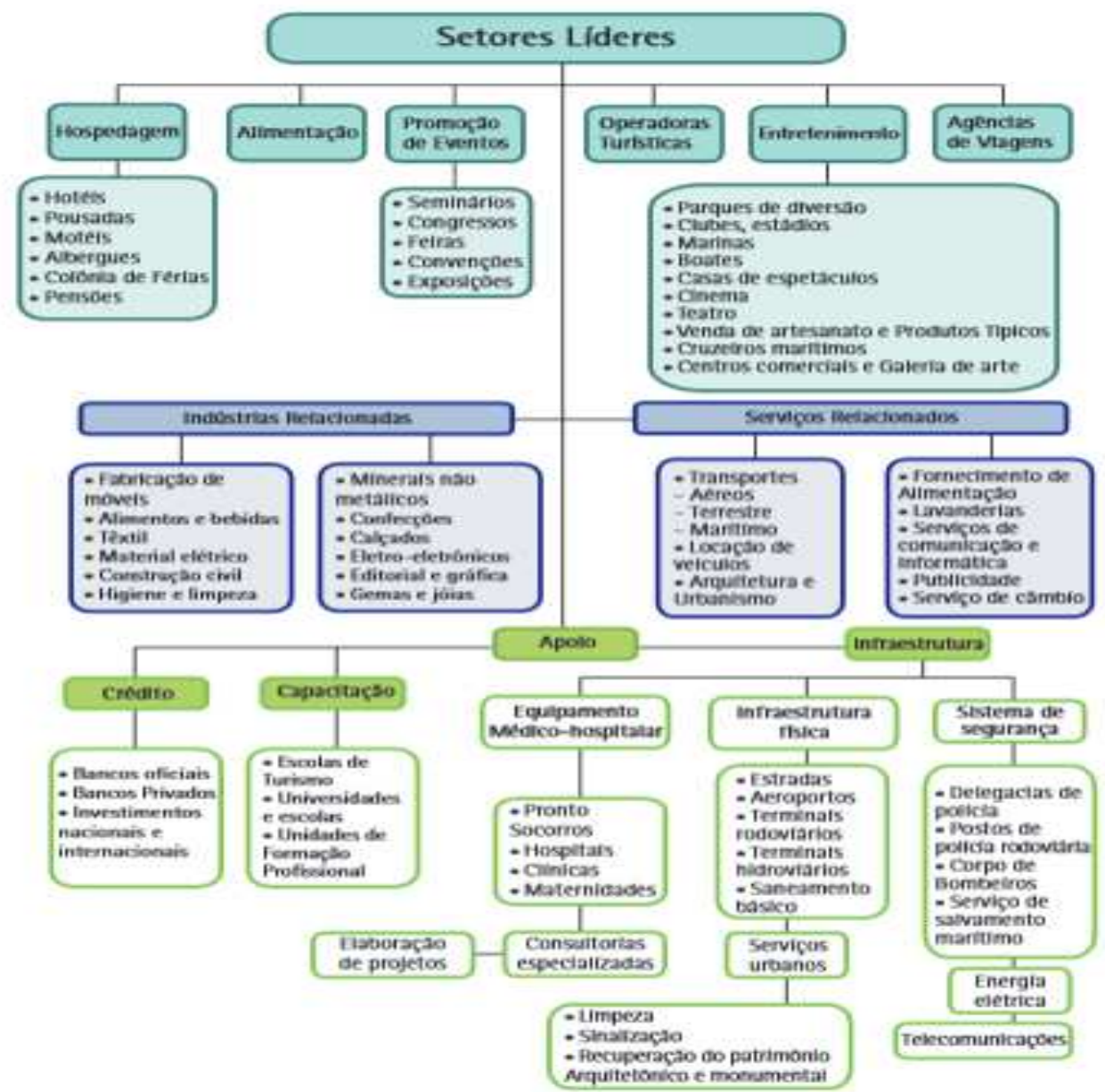

Figura 41: Cadeia Produtiva do Turismo

Fonte: BRASIL, 2011c.

Talvez, estes sejam apenas alguns dos mais perceptíveis subsetores da Cadeia Turística. Outros muitos podem se inserir, variando com as especificidades de cada destino. Prova disso está na "Classificação Central de Produtos - CCP" (Central Product Classification) ${ }^{33}$, apresentada pela Organização Mundial do Turismo (OMT, 2001), representada por três ramificações:

(a) Produtos Característicos do Turismo: que, em caso de ausência de visitantes, teriam suas atividades visivelmente prejudicadas, ou mesmo deixariam de existir. São divididos em sete atividades, 19 subatividades e 96 produtos (ANEXO 1);

\footnotetext{
${ }^{33}$ Elaborada pelas Nações Unidas.
} 
(b) Produtos Conexos ao Turismo: considerados específicos do Turismo em alguns países, e não específicos em outros;

(c) Produtos Específicos do Turismo: as duas categorias anteriores grupadas. Ao todo são 170 produtos (ANEXO 2).

Outras duas ramificações podem ser acrescentadas à esta classificação: atividades "potenciadas pelo Turismo" (que não são nomeadamente turísticas, mas que sofrem influência direta) e "outras atividades" (paralelas ao Turismo, que influenciam o desenvolvimento da atividade). (GOUVEIA E DUARTE, 2001)

Nota-se, portanto, a multiplicidade de elementos que compõem uma mesma atividade econômica. Isso sem contar setores tangentes que impactam, ou são impactos, pelo Turismo, podendo chegar a 52 setores da economia (OMT apud FAPEC, 2006).

Diante disso, o mais correto seria tratar o Turismo por meio de não apenas "uma" cadeia produtiva, mas sim "diversas" cadeias produtivas relacionadas (SILVA, 2004b). A necessidade de se pensar em múltiplas cadeias produtivas para o Turismo decorre, principalmente, de antigas questões ainda pouco esclarecidas:

1. No caso de municípios assentados em modelos de desenvolvimento local pautados no setor turístico, cujas dimensões urbanísticas (infraestruturais) se deram pela elaboração e aplicação de Planos de Desenvolvimento Turísticos - como é o caso de Barreirinhas e de Jijoca de Jericoacoara -, como seria possível agrupar, numa única cadeia produtiva, um leque tão variado de subsetores, com características e especificidades tão heterogêneas? Ou mesmo, por outra perspectiva, como desagregar subsetores - como o de comércio, de saúde ou de construção civil - da estrutura complexa que compõe a CPT, sendo que muitos desses foram criados a partir da incidência de demanda, turística e local, por seus serviços? (TASSO, 2011);

2. Como planejar políticas públicas efetivas para a inclusão socioeconômica de residentes de destinos turísticos, sem se ter clara a contribuição exata do consumo turístico em alguns subsetores da cadeia, assim como das atividades produtivas à eles encadeadas para trás e para frente? Como exemplo estão os restaurantes, estabelecimentos onde se alimentam turistas e residentes, que realizam o mesmo tipo de consumo e pagam o mesmo preço por isso. Tal fato dificulta a mensuração da produção e da renda do setor. (SILVA, 2004b) 
Tais questões refletiram como limitações para se conseguir definir quais os subsetores da CPT deveriam ser abrangidos por esta pesquisa. Quais seriam os mais representativos? Quais os de maior evidência nas regiões de estudo?

Definiu-se, então, pela busca de documentos que apresentassem relações de prestadores de serviços locais, considerados estritamente turísticos. Para tanto foram estabelecidos contatos junto às Secretarias Municipais de Turismo dos dois municípios estudados.

A partir daí, pode-se notar similitudes quanto aos elementos centrais das CPT dos dois destinos. A maior concentração de prestadores de serviços turísticos está nos seguintes segmentos: (a) Meios de Hospedagem; (b) Serviços e Equipamentos de Gastronomia; (c) Serviços e Equipamentos de Agenciamento; (d) Serviços e Equipamentos de Transporte; (e) Outros específicos (guias/condutores de turismo, artesãos, pequenos produtores rurais ${ }^{34}$ ).

Sendo assim, o presente trabalho está concentrado no estudo sobre fatores que influem sobre a inclusão socioeconômica no Sistema Produtivo Local de Turismo dos dois destinos estudados, mais precisamente nas ramificações da Cadeia Produtiva do Turismo composta pelos cinco segmentos específicos destacados.

\subsection{Turismo Sustentável: o nascimento de uma nova perspectiva}

A terceira esfera de conhecimento corresponde à reflexão sobre a proeminência do Turismo, como atividade econômica de notório destaque no cenário global, e o contexto da sustentabilidade permeando os seus diversos modelos de desenvolvimento.

O Turismo corresponde à soma de serviços e de relações resultantes de uma mudança voluntária e temporária de residência, por motivos outros que não profissionais ou de negócios (OMT, 1994).

No ano de 2013, os setores de Viagens e Turismo contribuíram, diretamente, US $\$ 2,2$ trilhões para o PIB mundial, fruto de seu crescimento econômico que atingiu, no mesmo ano, $3,0 \%$. Pelo terceiro ano consecutivo, o acelerado ritmo de crescimento dessas atividades ultrapassou as taxas de crescimento da economia global, superando setores da economia como distribuição e varejo, manufaturas, serviços financeiros e empresariais, e serviços públicos. (WTTC, 2014)

\footnotetext{
34 Tanto pela produção de insumos para o mercado turístico, quanto pelo oferecimento de atividades de turismo de base comunitária.
} 
Indiretamente, ainda em 2013, os setores de Viagens e Turismo representaram US $\$ 7$ trilhões (9,5\% do PIB da economia mundial), US\$754 bilhões em investimentos $(4,4 \%$ do total global de investimentos), e US $\$ 1.3$ trilhões em exportações (5,4\% das exportações mundiais). (WTTC, 2014)

No cenário brasileiro a pujança do setor de Turismo também é evidente. Entre os anos de 2003 e 2009 o setor apresentou um crescimento de $32,4 \%$, superando a expansão de $24,6 \%$ da economia brasileira (BRASIL, 2013c). Já entre 2007 e 2011 a atividade atingiu um nível de crescimento de 18,5\%, chegando a representação de 3,7\% do PIB nacional (BRASIL, 2012c). Em 2012, a participação do Turismo na economia brasileira era de US $\$ 76,9$ bilhões (WTTC, 2013).

Contudo, novos olhares têm sido repousados sob o turismo, entendendo-o como um instrumento dicotômico de desenvolvimento, capaz de contribuir tanto para o equilíbrio (ambiental, social, econômico, cultural, etc.), quanto para o desequilíbrio.

Diante de complexos embates históricos que trouxeram à tona discussões massivas sobre a interação homem-natureza, sobre a impossibilidade de se perdurar um padrão de produção e de consumo que se expandia, sobre as mazelas sociais de um mundo em desordem, e sobre a importância da responsabilidade intergeracional, o Turismo acaba se inserindo na pauta de discussões sobre sustentabilidade.

Nada espantoso se lembrarmos que, assim como em outros segmentos da economia, o Turismo teve um desenvolvimento acelerado pela utilização intensiva - predatória e imprudente - dos recursos naturais que formam seus atrativos e a base de sustentação de suas atividades (DIAS, 2008). E, portanto, abrindo espaço para discussões aprofundadas com respeito aos seus impactos sobre o meio ambiente (meio físico), sobre as comunidades locais, e a busca pelo desenvolvimento sustentável.

No contexto histórico, o desenvolvimento de práticas turísticas ganha notoriedade a partir do século XIX. Contudo, é na década de 1950 que o Turismo se configura como uma atividade de massa, com significância socioeconômica e cultural. A atividade nasce e se desenvolve com o sistema capitalista, quando em 1960 se apresenta como potencial fonte de lucros (BUTLER, 1998), de investimentos e de lazer para milhões de pessoas. (MOESCH, 2000)

Tratada pela ótica de lazer, a prática do Turismo não é mais atribuída como "uma prerrogativa de alguns cidadãos privilegiados; sua existência é aceita e constitui parte integrante 
do estilo de vida para um número crescente de pessoas em todo o mundo" (RUSCHMANN, 2006, p. 13).

O início da atenção voltada às consequências negativas do crescimento desenfreado do Turismo de Massa ${ }^{35}$ - modelo largamente associado e responsabilizado por tais impactos (COOPER, OZDIL, 1992; SWARBROOKE, 2000) - se deu paralelamente à eclosão das discussões sobre os limites naturais globais, na década de 1970 (SHARPLEY, 2000).

Em meados de 1972 nasce uma primeira proposta concreta de avaliação dos impactos do setor turístico, fomentada pelo Banco Mundial, na qual fossem considerados seis aspectos: vinculações entre o meio ambiente e os recursos; design e construção do projeto; operações; fatores socioculturais; repercussões na saúde; e considerações a longo prazo (DIAS, 2008).

Mas é na década de 1980 que os debates sobre Turismo e Sustentabilidade ganharam dimensões mais abrangentes. Acompanhado pela ascensão do movimento ambientalista e das implicações do Relatório Brundtland, o Turismo se alocou num quadro de discussões que levava como pano de fundo os pressupostos do Desenvolvimento Sustentável.

Fato este decorrente da percepção dos impactos negativos no sistema natural (destacados a seguir - DIAS, 2008, p. 24-5) resultantes da exploração massiva pelo setor, somada aos regulamentos legislativos, nacionais e internacionais, cada vez mais rigorosos.

- Grande urbanização de áreas rurais, sem planejamento e infraestrutura sanitária adequadas. Particularmente importante são as áreas próximas a represas, a santuários paisagísticos, praias de rara beleza etc.;

- Aumento de resíduos de todo tipo, particularmente os sólidos, que modificam a paisagem e o meio ambiente. São particularmente significativos os sacos de lixo e os vasilhames de bebidas em lugares públicos;

- Com o aumento de pessoas nas zonas naturais, há uma fuga da fauna silvestre e a diminuição de sua capacidade de reprodução. As espécies vegetais, por sua vez, são recolhidas de forma irresponsável, quando não destruídas pelo volume de trânsito no local;

- Modificações significativas e irreversíveis na paisagem, pela proliferação de infraestruturas e construções. Aqui se incluem a abertura de novas vias de comunicação, instalações turísticas de todo tipo etc.

Em consequência, o Turismo, de início, começou a ganhar novas concepções que o redirecionaram para perspectivas diametralmente opostas as do modelo de Turismo de Massa. Partiu de um conceito genérico intitulado "Alternative Tourism" (Turismo Alternativo - Box 6),

\footnotetext{
35 Segundo Ruschmann (1997, p. 110) o turismo de massa é "caracterizado pelo grande volume de pessoas que viajam em grupos ou individualmente para os mesmos lugares, geralmente nas mesmas épocas do ano".
} 
formulado por membros da International Academy for the Study of Tourism ${ }^{36}$, considerado um modelo de Turismo que contribui com o desenvolvimento sustentável de uma sociedade. Da mesma forma, no encontro realizado pela OMT em Tamanrasset, na Argelia, tratou-se o conceito de Turismo Alternativo como um caminho para assegurar o desenvolvimento sustentável da própria atividade turística. (LANFANT \& GRABURN, 1992 in HARRIS, GRIFFIN, WILLIAMS, 2002)

"Turismo Alternativo é definido como turismo de pequena escala, desenvolvido pela população local e com base na preocupação pelo meio ambiente local e capacidade de carga" - traduzido pelo próprio autor.

Box 6: Definição de Alternative Tourism Fonte: KILIPIRIS, ZARDAVA, 2012, p. 47.

A partir daí desencadeou-se uma série de tipologias que, sinonimamente, primavam pela melhoria dos benefícios ambientais, tais como: "eco", "apropriado", "soff" (suave), "de baixa escala", "green" (verde), "responsável", dentre outras (MELER \& HAM, 2012).

A prudência quanto aos aspectos ambientais se justifica ao pensarmos que esses são a matéria-prima essencial para o desenvolvimento de atividades turísticas. $E$ que por apresentarem, por vezes, propriedades extremamente sensíveis, merecem formas adequadas e planejadas de consumo e gerenciamento dos recursos, para além da mera obtenção de renda (DIAS, 2008). Lickorish e Jenkins compartilham desta ideia ao ressaltar que:

O relacionamento entre o meio ambiente e o turismo é muito próximo. Muitos
recursos do meio ambiente são atrações para os turistas. As instalações e a
infra-estrutura do turismo compreendem um aspecto do meio ambiente
construído. O desenvolvimento do turismo e o uso de uma área geram impactos
ambientais. É essencial que esses relacionamentos sejam compreendidos a fim
de se planejarem, desenvolverem e gerenciarem os recursos adequadamente.
(LICKORISH; JENKINS, 2001, p. 117)

Contudo, mesmo com propulsão das "questões verdes" e a alusão à consciência ambiental junto às novas tipologias de Turismo, pode-se dizer que essas estavam, visivelmente, mais preocupadas com a redução dos custos (SWARBROOKE, 2000).

Em sua sexta Assembleia Geral (no ano de 1985), em Sófia na Bulgária, a OMT apresentou dois documentos: Tourism Bill of Rights e o Tourist Code. Neles ressaltava-se, dentre outras

${ }^{36}$ Academia Internacional para o Estudo do Turismo, Zakopane, Polônia. 
coisas, a importância da proteção do meio ambiente turístico - humano, natural, cultural, social - por se constituir como um legado de toda a humanidade, gerações presentes e futuras (UNWTO, 1985).

A partir de 1990, o quadro de debates sobre Turismo, que envolviam questões ambientais como um aspecto central de suas discussões, deram espaço ao fortalecimento de abordagens de cunho social. Comunidades locais de destinos turísticos passam a ganhar maior atenção. Não só pela sua importância nos processos participativos de desenvolvimento da atividade, como também pela necessidade de se distribuir, de forma mais equânime, os benefícios econômicos decorrentes do Turismo. (SWARBROOKE, 2000)

Passa-se, então, a vislumbrar um novo modelo de desenvolvimento econômico do Turismo, no qual deve ser concebido para "melhorar a qualidade de vida da comunidade visada; oferecer ao visitante uma elevada qualidade de experiências; manter a qualidade do ambiente de que tanto a comunidade anfitriã como os visitantes dependem". (OMT, 1996, p. 12)

Pouco a pouco, a emersão do discurso do "Turismo Sustentável" foi se configurando numa ideia forte (SAARINEN, 2006), frequente nas discussões relativas ao tema em diversos eventos internacionais. Dentre outros, destaca-se, no período, a Conferência Mundial de Turismo Sustentável Globo ' $90^{37}$, realizada em Vancouver. Nela, o tratamento do conceito, que até então voltava-se com maior propriedade aos aspectos sociais e ambientais, ganhou novos e importantes elementos em sua descrição. A OMT apresentou novas vertentes ao incluir, com maior propriedade, aspectos "culturais", "estéticos" e "de futuro" ao seu entendimento:

(...) o desenvolvimento do turismo sustentável pode satisfazer as necessidades econômicas, sociais e estéticas, simultaneamente as integridades cultural e ecológica. Pode ser benéfico aos anfitriões e para os visitantes enquanto protege e melhora a mesma oportunidade para o futuro. (OMT, 1993, p. 51)

Vale ressaltar que durante a Conferência Rio-92, mesmo com a notória visibilidade das discussões sobre sustentabilidade, o setor de Turismo foi mencionado ainda de forma muito pontual. Não foram aberto espaços de discussões sobre o tema. Apenas superficialmente lembrado no principal documento da Conferência, a Agenda 21, em sessões temáticas voltadas à "Conservação e gestão dos Recursos", "Desenvolvimento Sustentável das Zonas de

${ }^{37}$ Globe 90 Conference, Tourism Stream, Action Strategy Sustainable Tourism Development, Vancouver, BC, Canadá, 1990. 
Montanha", "Agricultura e Desenvolvimento Rural Sustentáveis" e "Luta contra o desflorestamento". (DIAS, 2008)

Todavia, duas importantes ações foram tomadas para se tentar compensar o baixo protagonismo das discussões sobre Turismo durante a Rio-92. A primeira se deu no mesmo ano da Conferência, pela união de esforços entre a OMT, o Conselho Mundial da Indústria de Viagens e Turismo (WTTC ${ }^{38}$ ) e o Conselho da Terra. O resultado desses esforços culminou no documento “Agenda 21 para a Indústria de Viagens e Turismo", publicado em 1994, estruturado como um plano de ação para o Turismo, no qual os pressupostos do Desenvolvimento Sustentável passam a ser tomados como indispensáveis para o sucesso da atividade. (DIAS, 2008)

A segunda ação se deu no ano de 1997, com a realização da 19ํㅗㄹ sessão da Assembleia Geral da ONU, quando a temática do Turismo Sustentável se fez presente em vários parágrafos do documento final do evento (DIAS, 2008).

No ano de 1999 foi divulgado um informe sobre Turismo e Desenvolvimento Sustentável, pela Comissão para o Desenvolvimento Sustentável (CDS), o qual estabeleceu um programa de trabalho internacional sobre o tema (DIAS, 2008).

Ainda em 1999, foi apresentado o documento intitulado "Código Mundial de Ética do Turismo", por meio da Assembleia Geral da OMT, realizada em Santiago do Chile. Dentre outras passagens de grande relevância para os debates da época, relatou-se, em seu Artigo 5 - "O turismo, atividade benéfica para os países e as comunidades de destino" -, a importância da geração de empregos e da distribuição de benefícios entre todos os envolvidos:

As populações e comunidades locais se associarão às atividades turísticas e terão uma participação equitativa nos benefícios econômicos, sociais, e culturais, especialmente se beneficiando da criação direta e indireta de empregos. (BRASIL, 2007a, p. 119)

Três anos mais tarde, em 2002, o Turismo ganha atenção e reconhecimento como instrumento de contribuição para o Desenvolvimento Sustentável na Cúpula Mundial do Desenvolvimento Sustentável, em Johannesburgo, na África do Sul. O documento principal gerado do evento destacou, em parágrafo específico (número 41), medidas gerais sobre o tema. (DIAS, 2008)

38 World Travel and Tourism Council. 
Afora os eventos realizados, pesquisadores, nacionais e internacionais, já se fixavam na busca por uma descrição holística de Turismo Sustentável, visando atingir a abrangência de elementos indispensáveis à complexa caracterização do conceito.

Descrições menos complexas consideram um menor número de elementos participando dessa interação. Como exemplo, na representação de Lane (1994, apud SHARPLEY, 2000), o Turismo Sustentável é uma relação triangular e balanceada entre (a) os turistas, (b) a indústria do turismo, e (c) as áreas de acolhimento, população local e seus habitats, onde não há perturbação do equilíbrio de nenhuma das esferas.

Sob outra perspectiva, agora um pouco mais complexa, está a imagem do "Pentágono Mágico" (Figura 42) de Müller. Nela busca-se o equilíbrio entre cinco elementos que interagem entre si, contudo, não se sobrepondo uns aos outros. Os elementos são: saúde econômica; bem estar subjetivo (da comunidade receptora); otimização da satisfação das necessidades do cliente; natureza intacta e proteção dos recursos; e cultural saudável.

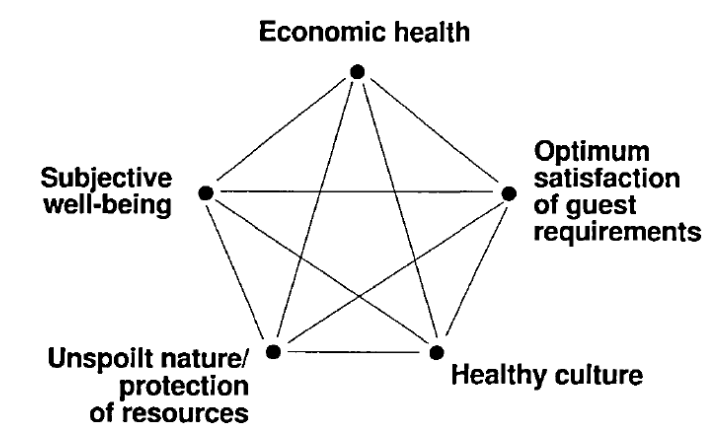

Figura 42: Pentágono Mágico de Müller Fonte: Müller, 1994, p.133.

Naturalmente, novos aspectos, elementos específicos e critérios não antes abordados foram, aos poucos, agregados àqueles considerados como razões fundamentais para o equilíbrio e sustentabilidade do setor. Um desses novos aspectos trata do respeito às aspirações e desejos (e, consequentemente, do consenso) das comunidades receptoras, assim como da participação dos mesmos nos benefícios econômicos decorrentes do Turismo. Tais elementos podem ser encontrados na definição de Turismo Sustentável elaborada em parceria entre o World Wildlife Fund (WWF) e o Tourism Concern, a qual entende que essa proposta: 
Opera dentro das capacidades naturais de regeneração e produtividade futura dos recursos naturais; reconhece a contribuição que as pessoas e comunidades, costumes e estilos de vida fazem à experiência do turismo; aceita que estas pessoas devam ter uma participação equitativa nos benefícios econômicos do turismo; e é guiado pelos desejos das pessoas e comunidades locais nas áreas visitadas. (EBER, 1992, apud DIAS, 2008, p. 59)

Somados às características supracitadas, outros aspectos mereceram destaque nos processos de construção de modelos que busquem solidificar práticas de Turismo Sustentável. Pontuados a seguir, nota-se novas percepções quanto à importância de articulação entre esferas de poderes locais, redução do desperdício, qualificação da mão de obra, responsabilidade na comercialização da atividade, e incentivo a pesquisa científica em destinos (GARROD \& FYALL, 1998):

1. Redução do desperdício e do consumo excessivo, aumentando a resiliência do ambiente degradado;

2. Articulação entre os poderes público e privado, visando a minimização de conflitos e problemas;

3. Qualificação múltipla da mão de obra dos residentes para que os mesmos possam atuar em todos os níveis do setor;

4. Responsabilidade nos procedimentos de comercialização do turismo, primando pela conscientização sobre o respeito aos ambientes sociais, culturais e naturais dos destinos;

5. Ampliação do quadro de pesquisas desenvolvidas em destinos turísticos que busquem pela análise situacional da atividade, como forma de identificar impactos e problemas, alternativas e a melhoria do setor.

Gradativamente, os processos de ampliação do entendimento do conceito de Turismo Sustentável sofreram avanços consideráveis. Para se atingir o desenvolvimento coeso da atividade, os quesitos perpassavam por esferas cada vez mais específicas (pontuados a seguir). A ética na implementação da atividade, o incentivo à participação e à cooperação de todos os atores envolvidos, o direcionamento do comportamento do visitante para uma postura responsável, a integração com a economia local, dentre tantos outros, são apenas alguns exemplos de novas abordagens. 
- Ser ecologicamente suportado e economicamente viável, simultaneamente;

- Distribuir equitativamente seus benefícios;

- Observar a ética e ser socialmente aceito pela comunidade receptora;

- Integrar-se com todos os aspectos do ambiente, de modo a respeitar áreas frágeis e a capacidade de suporte das áreas visitadas;

- Incentivar a participação de todos os atores envolvidos, pois a conservação da herança cultural e natural envolve cooperação, planejamento e manejo;

- Garantir a satisfação do turista e, concomitantemente, direcionar o seu comportamento no sentido da conservação dos ambientes e respeito à cultura local;

- Estar integrado à economia local e promover a melhoria da qualidade de vida das comunidades receptoras;

- Ser necessariamente planejado e aplicar os princípios de sustentabilidade a todos os componentes do produto turístico (desde os transportes utilizados, a harmonia das instalações construídas com o ambiente, a questão do saneamento, o uso eficiente de energia etc.);

- Realizar marketing responsável;

- Pesquisar e monitorar a atividade turística de modo a garantir que o desenvolvimento dessa atividade aconteça de acordo com os princípios e critérios da sustentabilidade, de maneira que os avanços sejam mantidos, evitando retrocessos. (FRANCE, 1998 apud BRASIL, 2007b, p. 44-5)

Tendo como pano de fundo o importante trabalho de Clarke (1997), estruturado por uma vasta e densa revisão de literatura, são apresentados a seguir quatro posicionamentos sobre Turismo Sustentável que, cronologicamente sequenciados, representam as diferentes visões e entendimentos históricos sobre o tema. Clarke os divide em: (a) pólos opostos; (b) continuidade, (c) movimento, e (d) convergência.

O primeiro e mais antigo posicionamento, tratado por Clarke como "pólos opostos" (Figura 43), se sustentou na dicotomia do Turismo reconhecida por esteriótipos concentrados em aspectos negativo (Turismo de Massa) e positivo (Turismo Sustentável ${ }^{39}$ ). Todo e qualquer "mau" impacto social ou ambiental decorrente da atividade era delegado ao modelo de massa, tendo-o como destrutivo e que, necessariamente, deveria ser substituído pelo "bom" modelo, sustentável. 


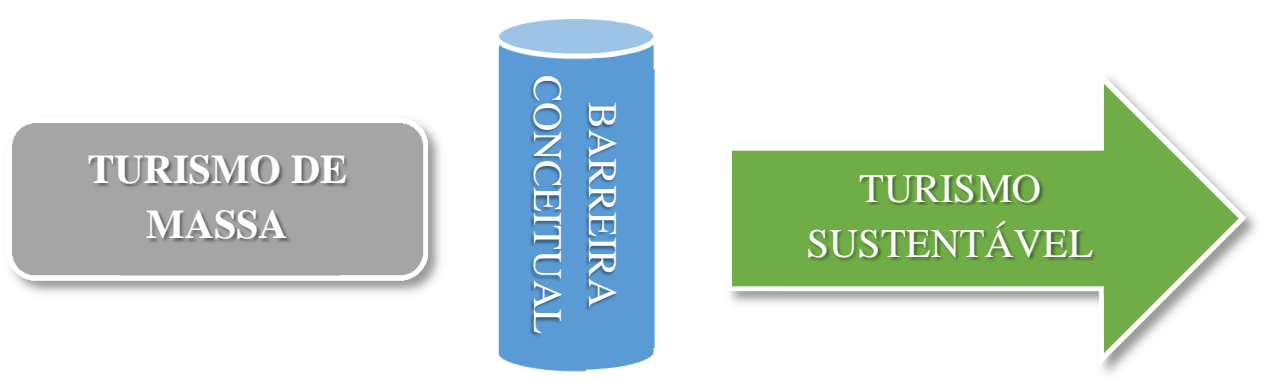

Figura 43: Polar Opposites

Fonte: Clarke, 1997, p.225 (elaborado pelo autor)

Com a chegada dos anos 1990 tal posicionamento ganha rejeição por ser improdutivo, abrindo espaço à um novo posicionamento, tratado como "continuidade" (Figura 44). Neste, reconhecia-se dois pontos importantes: (a) o Turismo Sustentável utilizou os sistemas de infraestrutura, de transporte e de reserva do Turismo de Massa para se desenvolver; (b) se mal gerido, o Turismo Sustentável pode abrir um novo caminho para a reestruturação do Turismo de Massa.
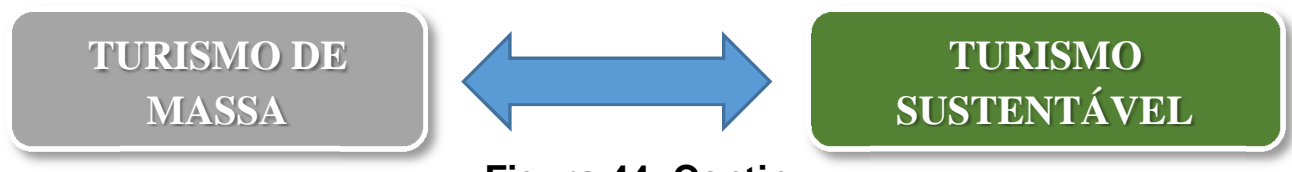

Figura 44: Continuum

Fonte: Clarke, 1997, p.226 (elaborado pelo autor)

Ambos posicionamentos sofreram críticas ao serem tomados como simplistas (por não reconhecerem a complexidade e dinamicidade do fenômeno turístico) e impraticáveis (por tratar de uma visão de Turismo Sustentável ainda limitada e insuficiente para oferecer soluções práticas aos problemas do setor). (CLARKE,1997)

Destas críticas resultou o terceiro posicionamento: "movimento" (Figura 45). Nesse novo posicionamento, o Turismo Sustentável já não é mais entendido de forma estática, mas sim sob um aspecto de constante movimento, como uma meta a ser atingida. Por sua vez, o Turismo de Massa passa a não ser mais visto como o vilão ridicularizado, mas como um objeto para transformação (reforma), gerando maior objetividade (e menos emotividade) às discussões sobre escala. (CLARKE, 1997) 
Ainda como parte deste posicionamento, buscou-se operacionalizar o conhecimento atual em direção ao alcance da meta maior, em contraponto ao massivo debate do "é ou não é Turismo Sustentável". (CLARKE, 1997)

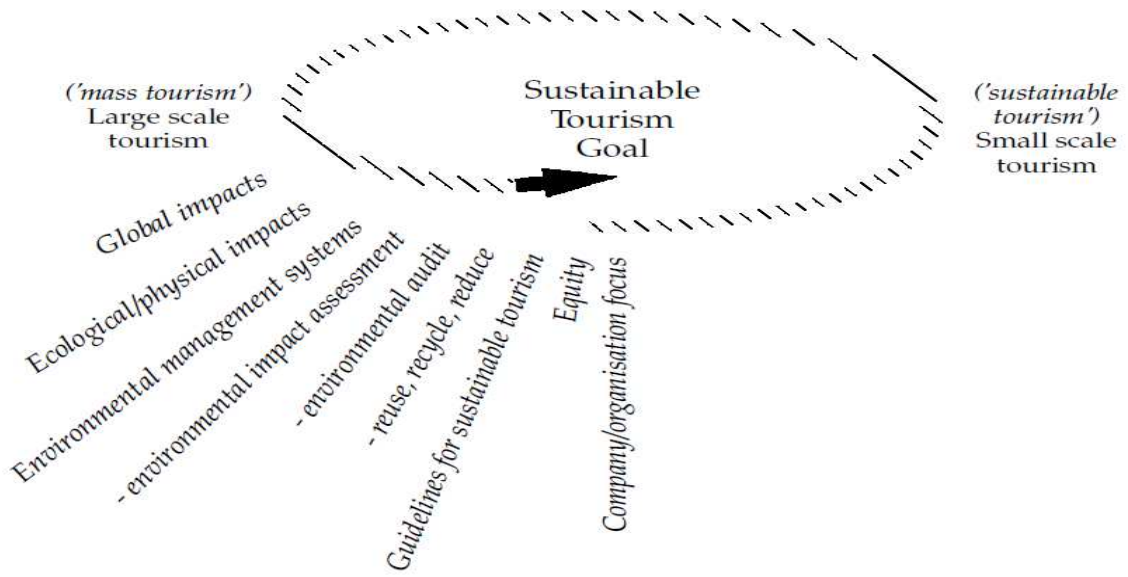

Figura 45: Movement

Fonte: Clarke, 1997, p.228

Por fim, o quarto e último posicionamento ("convergência" - Figura 46) é estruturado a partir do entendimento de que o Turismo Sustentável é uma meta que, independentemente da escala da estrutura da atividade, deve ser almejada.

Se em larga escala, buscando-se atingir objetivos dominantemente físicos e ecológicos. Se em baixa escala, oferecendo uma plataforma local de cunho social. O mais importante, nesse sentido, está na harmonia do movimento geral de todos os elementos, em uma mesma direção. (CLARKE, 1997)

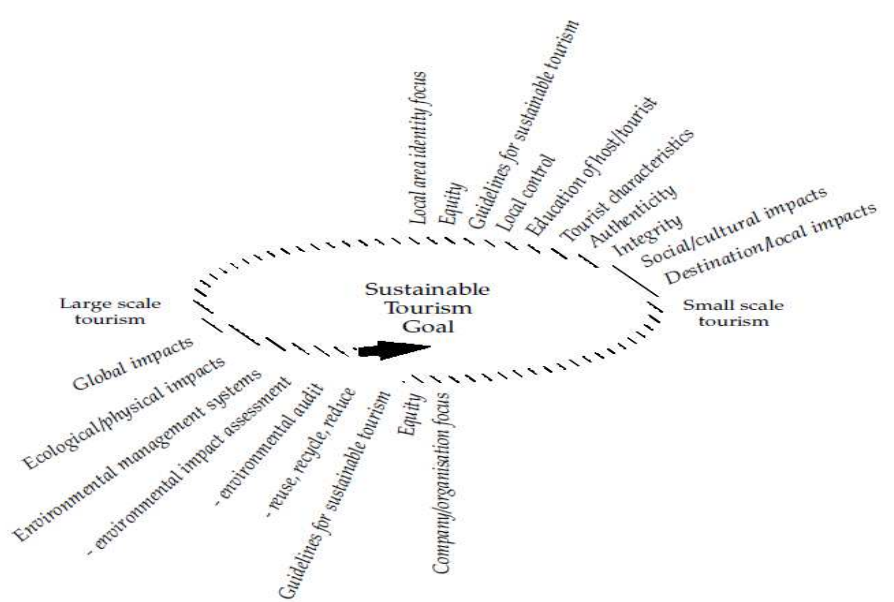

Figura 46: Convergence

Fonte: Clarke, 1997, p.228. 
As muitas concepções e posicionamentos que tanto contribuem para o melhor entendimento dos pressupostos do Turismo Sustentável, remeteram-se, ainda, à importância das transformações do próprio indivíduo e de seus valores sociais. A responsabilidade e o consumo consciente e responsável, por exemplo, passaram a integrar a vasta gama de elementos que formam tal modelo de desenvolvimento:

\begin{abstract}
O desenvolvimento do turismo sustentável exige, em geral, uma transformação nos valores sociais e estilos de vida e, em particular, na adoção do consumo 'responsável'. No entanto, apesar de estudos que sugerem uma maior consciência ambiental por parte dos turistas, há pouca evidência para sugerir que, na realidade, formas mais adequadas ou aceitáveis de consumo do turismo estão sendo adotadas. (SHARPLEY, 2009, p. 78 - tradução do autor)
\end{abstract}

A falta de "cultura turística" dos visitantes que, ao se comportarem de forma alienada em relação ao destino, não reconhecem qualquer noção de responsabilidade quanto à preservação dos aspectos originais do meio que se inserem, pode ser comumente identificada (RUSCHMANN, 1997, p. 110)

Essa nova ótica de responsabilidade individual no desenvolvimento de atividades turísticas tem suas raízes em 1980, com a Manila Conference on World Tourism ${ }^{40}$, quando considerou-se a responsabilidade dos estados no desenvolvimento e na melhoria do Turismo. No Código Global de Ética da OMT, de 2001, também pôde ser identificada a proposta de se promover uma ordem turística mundial equitativa, "responsável" e sustentável. Entretanto, foi a partir da publicação "The Holiday Makers", em 1984, de Jost Krippendorf, que a temática do Turismo Responsável foi tratada com maior propriedade. (GOODWIN, 2012 in GOODWIN \& FONT, 2012)

Grosso modo, a proposta do "Responsible Tourism" (Turismo Responsável - Box 7) é a de fazer "melhores lugares para as pessoas viverem, e melhores lugares para as pessoas visitarem" (ICRT, 2014 - tradução do próprio autor), pensando que a ordem das duas vertentes é essencial.

"Turismo Responsável não discute a questão de desenvolvimento de pequena escala ou proteção desnecessária, mas por modos de ação individual que reconheçam a necessidade de sentir e ser responsável pelo desenvolvimento e atividade de uma área turística de tal forma que os valores apropriados são mantidos por todos os envolvidos" - traduzido pelo próprio autor.

Box 7: Definição de Responsible Tourism

Fonte: GILBERT et al, 1994 apud KILIPIRIS, ZARDAVA, 2012, p. 47.

${ }^{40}$ Conferência de Manila sobre o Turismo Mundial, Filipinas. 
Com a apresentação da "Declaração de Cape Town"41, em 2002, resultado de trabalhos sul-africanos sobre o tema, e contando com a contribuição discursiva de mais de 20 países, as abordagens sobre Turismo Responsável ganharam notória repercussão, e se apresentando como uma ramificação do Turismo Sustentável (ICRT, 2014).

Diante de tantas descrições, discursos e abordagens, recheadas de atributos, de elementos indispensáveis e de orientações para se atingir o modelo ideal, devemos nos perguntar: esse modelo ideal, padrão, completo, complexo e sustentável, é possível ser atingido? Ou o mais factível é a adoção de medidas que classifiquem a prática da atividade entre mais ou menos sustentável?

Como destacado por Costa (2009), não há um instrumento que possa definir se destinos turísticos são ou não sustentáveis, como um padrão estático. Na verdade, a sustentabilidade a qual the é atribuída diz respeito a um padrão de desenvolvimento, um modelo a ser buscado, e não a uma tipologia ou segmento da atividade turística (CLARKE, 1997).

De modo geral, o conceito de Turismo Sustentável deveria ser considerado como um paradigma que se adapta e legitima uma ampla variedade de abordagens de acordo com circunstâncias específicas, e não, como muitas vezes é tratado, a partir de um quadro rígido (HUNTER, 1997).

Há que se lembrar que as aspirações por um modelo de Turismo que alcance objetivos complexos, de âmbitos tão distintos, "envolve tomada de medidas políticas vigorosas" (OMT, 1993, p. 51), que levem em consideração estratégias de desenvolvimento qualitativas.

Pôde-se perceber, nos últimos anos, que a proposta de estruturação de modelos de Turismo Sustentável vem sendo utilizada por órgãos governamentais, em várias partes do mundo, como uma ferramenta efetiva e eficaz em ações voltadas ao Desenvolvimento Sustentável, tais como: no fortalecimento de economias emergentes (Vietnã, Cambodja, Laos e Cuba); na base da economia rural e das sociedades rurais (Portugal, França, Espanha e Itália); na recuperação de antigas cidades industriais (Reino Unido e EUA); dentre outras. (SWARBROOKE, 2000)

Todavia, o aspecto da inclusão socioeconômica das comunidades residentes - objeto de estudo desta Tese -, assim como de outros elementos retoricamente destacados nas concepções

\footnotetext{
${ }^{41}$ A "Declaração da Cidade do Cabo" foi gerada a partir da realização da "Conferência de Cape Town sobre Turismo Responsável em Destinos", organizada pelo Responsible Tourism Partnership e Western Cape Tourism, em agosto de 2002, precedendo a Cúpula Mundial sobre Desenvolvimento Sustentável, em Joanesburgo, no mesmo ano.
} 
sobre Turismo Sustentável, merece profundos questionamentos quanto à sua realidade prática. Os modelos de Turismo Sustentável aplicados atualmente:

(...) Também desconsideram a inserção da população residente no processo produtivo e, com isso, não atentam até para o sistema de gestão, infraestrutura, equipamentos e serviços receptivos, e a competitividade local, regional e internacional dos preços praticados na comercialização do produto turístico final. Conforme por nós entendido, o conceito de turismo sustentável deve ser ampliado (...) e, portanto, definido como um processo preservacionista estratégico de desenvolvimento interativo e articulado, espacialmente delimitado e localizado. (BENI, 2003, p. 116, grifo do autor)

Muito ainda há de se fazer pelo aumento da atenção às populações residentes. Como, por exemplo, pelo fortalecimento da relação entre o Turismo e os diversos outros setores econômicos (HUNTER, 1995), tais como a pesca artesanal e a agricultura familiar, trabalhando de forma integrada. Articulações como essa serviriam de estímulo para criação de estratégias alternativas de desenvolvimento que tenham como meta a melhoria da qualidade de vida de grupos locais.

É importante que se tenha em mente que o Turismo não pode ser tratado como um instrumento que, isoladamente, promova a sustentabilidade de um local. Nenhuma cidade pode ser considerada sustentável com bases fundadas estritamente no turismo, necessitando de muitos outros componentes para chegar a esse status. (HUNTER, 2002).

Para que o local seja sustentável, é preciso articulação entre o turismo e os demais setores, com operação harmônica e diversificada, zelando por recursos naturais, pela inclusão social e pela viabilidade econômica em longo prazo (HUNTER, 2002).

Contudo, em casos extremos, "atividades de outros setores econômicos são vistas como um 'ataque' ao turismo" (JENNER \& SMITH, 1992 in WILLIAMS, 2004, p.315 - tradução do próprio autor), quando, na verdade, deveriam fazer parte de um processo de desenvolvimento endógeno, fomentado por políticas públicas que primem pela equidade, inclusão social, inclusão socioeconômica e socioprodutiva, no sistema produtivo de destinos turísticos. No tópico a seguir são discutidos tais conceitos.

\section{INCLUSÃO SOCIOECONÔMICA: ENFRENTANDO A EXCLUSÃO SOCIAL}

Toda e qualquer tentativa de ampliação de benefícios socioeconômicos para uma determinada região, por meio da atividade turística, pode ser acompanhada do surgimento de custos, também econômicos, para uma pequena parcela de sua população local. 
Nesse sentido é de extrema importância que tais custos estejam previstos e contabilizados em tomadas de decisões nos processos de implementação de projetos de desenvolvimento da atividade. Alguns custos e benefícios são destacados na Tabela 20, a seguir.

\section{Tabela 20: Custos e Benefícios resultantes da atividade turística}

\begin{tabular}{l|l}
\hline \multicolumn{1}{c|}{ BENEFícios } & \multicolumn{1}{c}{ CUSTOS } \\
\hline $\begin{array}{l}\text { - Criação de empregos } \\
\text { - Injeção de renda na economia local pelo } \\
\text { efeito multiplicador }\end{array}$ & $\begin{array}{l}\text { - Muitos empregos são mal remunerados } \\
\text { e/ou sazonais } \\
\text { - Custos de ocasião, ex: dinheiro investido } \\
\text { em turismo que não poderá ser usado } \\
\text { posteriormente para outras finalidades } \\
\text { Auxílio para a manutenção da viabilidade }\end{array}$ \\
$\begin{array}{l}\text { - Reforma e reestruturação da economia } \\
\text { em cidades e metrópoles onde outras } \\
\text { atividades industriais estão em declínio }\end{array}$ & $\begin{array}{l}\text { - A necessidade de investir em } \\
\text { infraestrutura dispendiosa que pode ser } \\
\text { usada apenas em parte do ano }\end{array}$ \\
$\begin{array}{c}\text { - Estímulo a investimentos internos e } \\
\text { industriais }\end{array}$ & $\begin{array}{l}\text { Excessiva dependência do turismo, } \\
\text { tornando a economia local vulnerável a } \\
\text { mudanças no mercado de turismo }\end{array}$ \\
\hline
\end{tabular}

Fonte: SWARBROOKE, 2000, p. 95 (adaptado pelo autor).

Entretanto, a sustentabilidade socioeconômica, vislumbrada com o desenvolvimento do setor turístico em dada região, não pode ser atingida, apenas, pela otimização dos benefícios econômicos e pela diminuição dos custos que os acompanham. Outros aspectos de grande relevância devem ser priorizados, como a distribuição equitativa desses benefícios, a concorrência justa entre empresas locais e de fora, dentre outros destacados a seguir (SWARBROOKE, 2000):

- Garantia de distribuição equitativa dos benefícios econômicos por toda a comunidade local, em especial os grupos economicamente mais carentes;

- Certificação de pagamento de preço justo por parte dos turistas;

- Ação de divisão imparcial dos custos entre a indústria do turismo e os órgãos governamentais locais; 
- Proteção de empresas locais quanto a concorrência desigual com empresas estrangeiras que não tenham compromissos notórios com o destino;

- Redução da fuga de capital da economia local.

Mais do que isso. Para se atingir a meta de construção de um cenário turístico que tenha, como pano de fundo, a sustentabilidade em seus âmbitos social e econômico, é necessário que se fomente o respeito aos quatro "E"s nos processos de desenvolvimento do setor (SWARBROOKE, 2000):

(a) Equidade: tratamento igual assegurado a todos os que, de forma justa, investem no Turismo;

(b) Equivalência de oportunidades: tanto para os que desejam ser turistas, quanto para a indústria do turismo;

(c) Ética: postura ética e honesta dos governos locais e da indústria do turismo para com sua população local, seus visitantes e seus fornecedores;

(d) Equivalência de parceria: respeito dos visitantes no tratamento aos prestadores de serviços, reconhecendo-os como parceiros e não como subalternos.

Todavia, nota-se que, atualmente, inúmeras são as experiências de desenvolvimento de sistemas turísticos locais que acabam por direcionar os seus esforços para a canalização dos benefícios econômicos, dos quais, normalmente, os moradores locais não usufruem devidamente (UNWTO, 2014; KRIPPENDORF, 2001; CORIOLANO, 2009; 2005; COSTA, 2009; IRVING, 2002, 2003; 2006; IRVING et al, 2005; CLARKE, 1997; SHARPLEY, 2000).

O aproveitamento das potencialidades ambiental e cultural, presentes em regiões economicamente desfavorecidas, para o desenvolvimento do sistema produtivo local de turismo, tem sido acompanhado, com raras exceções, de processos crescentes de exclusão social (ES $\left.{ }^{42}\right)$, como destacado a seguir.

A indústria turística tem se implantado em velocidade e magnitude crescentes, principalmente em regiões menos favorecidas sob a ótica socioeconômica, mas extremamente privilegiadas com relação ao seu patrimônio cultural e ambiental. O avanço turístico, no entanto, nem sempre ocorre a favor das populações locais e, frequentemente, é responsável por fenômenos significativos de exclusão social, descaracterização cultural e degradação ambiental. (IRVING, 2002, p. 19)

\footnotetext{
42 Será utilizada no corpo do texto para se referir ao termo "exclusão social".
} 
A partir de incursões preliminares e da realização da pesquisa de campo nas regiões de Jijoca de Jericoacoara e de Barreirinhas, puderam ser notadas características de ES no núcleo dos processos de desenvolvimento turístico locais.

Muito embora outros pensadores, como o filósofo grego Aristóteles, e o economista político escocês e filósofo Adam Smith, já explorassem outras vertentes tangentes à ideia da "exclusão social" - em especial a falta de escolha individual ou a liberdade de se fazer escolhas -, o conceito original teve sua origem no ano de 1974, com o filósofo francês Rene Lenoir ${ }^{43}$ (ROGERS et al, 2008).

Lenoir utilizou-se do termo para referir-se ao décimo da população de seu país composto por suicidas, delinquentes, pessoas marginalizadas, famílias monoparentais e disfuncionais, tóxico dependentes, deficientes mentais e físicos, idosos, crianças maltratadas, dentre outros, por ele tratado, "desajustes" sociais (SEN, 2000b).

Ao longo do tempo, o conceito de ES foi sendo reformulado, reentendido e expandido para além das características centrais originais, concentradas, inicialmente, em disfunções físicas e mentais humanas, e na invalidez socioeconômica.

Outras perspectivas, como a de Nascimento (1994, p. 61), ampliam o entendimento do conceito ao avaliar que "o excluído não é apenas aquele que se encontra em situação de carência material, mas aquele que não é reconhecido como sujeito, que é estigmatizado, considerado nefasto ou perigoso à sociedade".

Amartya Sen, por sua vez, em seu estudo "Social Exclusion: Concept, Application and Scrutiny in 200044", apresenta o conceito de ES subdividido em duas grandes categorias: exclusão social ativa e exclusão social passiva (SEN, 2000b). Podem ser assim descritas:

\footnotetext{
- Exclusão social ativa - algo promulgado por lei ou por pronunciamento, como não permitir que um grupo de pessoas, por conta de sua etnia ou qualquer outra razão que a define, possa participar de um processo político.

- Exclusão social passiva - algo que vem através de processos sociais (em oposição ao legal) tais como pobreza ou isolamento. Ninguém pode excluir uma pessoa de comprar comida ou de participar em alguma atividade social, mas por conta de uma economia estagnada ou uma crise financeira, ele ou ela pode não ser capaz de pagá-lo, portanto, ser excluído. (ROGERS et al, 2008, p. $246-$ tradução livre pelo autor)
}

\footnotetext{
${ }^{43}$ Ver LENOIR, René. Les Exclus: Un Français sur Dix. Paris: Editions du Seuil, 1974/1989.

${ }^{44}$ Exclusão Social: Conceito, Aplicação e Exame em 2000. Tradução livre pelo autor.
} 
Seja a ES apresentada por caráter passivo ou ativo, seu entendimento mais aprofundado demanda por uma primeira premissa básica: a exclusão é multidimensional (ROSSAVALON, 1995; DONZELOT, 1991; FRACASSI et al, 1985), com características que perpassam pelas dimensões "econômica", "política", "cultural" e "social" (NASCIMENTO, 1998).

Por se tratar de um campo teórico múltiplo (NASCIMENTO, 1998), que compreende uma rica variedade de situações (BOUGET, 1992), a ES pode ser apresentada sob concepções e abordagens diversas. Como uma ruptura de vínculos sociais, comunitários, familiares ou mesmo individuais (XIBERRAS, 1992). Como um conflito entre atores in e atores out do mercado na relação "capital versus trabalho", na sociedade pós-industrial, fruto do aumento da desigualdade social (TOURAINE, 1991). Ou ainda, como uma situação de desfiliação, em que os indivíduos se encontram, simultaneamente, desintegrados do mundo do trabalho e desinseridos do meio social (CASTELL, 1991).

No Brasil, a trajetória histórica das discussões sobre o tema inicia-se nos anos 1960 e 1970, pelas abordagens sobre desigualdade social e marginalidade. Em seguida, na década de 1980, centralizam-se estudos sobre pobreza, substituídos mais tarde, entre 1980 e 1990, pela questão específica de ES. (QUEIROZ, 2002)

[...] o país deixou para trás as discussões em torno das desigualdades regionais ou sociais, e mesmo o interesse pelo estudo dos pobres e seu modo de vida, para se concentrar no entendimento de um fenômeno que parecia novo: o da exclusão social. (NASCIMENTO, 2000, p. 76)

A ES no país pôde ser entendida, de um lado, como o resultado da crise econômica, aguda e prolongada, que se instaurou sobre uma estrutura social extremamente heterogênea (JAGUARIBE, 1989). Por outra ótica, retira-se a responsabilidade de tal crise, caracterizando-a como um processo que apenas acelerou e fortaleceu o que já era preexistente, transformando a ES em um processo de "apartação" (BUARQUE, 1993), ou seja, quando a exclusão atinge seu ponto extremo, quando o "outro" torna-se um "dessemelhante" (NASCIMENTO, 1993).

Nota-se que as duas abordagens anteriores pressupõem o aspecto econômico como o instrumento de maior influência na estruturação das formas de ES. Entretanto, outros autores (TELLES, 1992; NASCIMENTO, 1994; DEMO, 2002) assumem que o aspecto político merece a mesma atenção, pensando que a ES é fruto da falta de uma clara e igualitária abertura política, com a validação de direitos, que promovam a integração social. 
$\mathrm{Na}$ verdade, a exclusão social no Brasil deve ser entendida como um processo múltiplo, "simultaneamente econômico (expulsão do mundo do trabalho), cultural (representação específica de não reconhecimento ou negação de direitos) e social (ruptura de vínculos societários e, por vezes, comunitários)" (NASCIMENTO, 2000, p. 68).

Martins (1997) discorda com tais pontos anteriores, por acreditar que, na verdade, os aspectos econômico, político e social são apenas parte de processos excludentes. Nesse sentido, para o autor, não há exclusão, dado que os chamados "excluídos" estão contidos no sistema, sendo, então, vítimas de problemas criados no interior da sociedade (QUEIROZ, 2002).

No presente trabalho entende-se que duas características centrais fazem da ES um aspecto negativo: "atenta contra a justiça social, entendida como igualdade de oportunidades, e degrada a solidariedade social" (BARRY, 2001 apud PNUD, 2009, p. 48).

De acordo com dados apresentados no primeiro capítulo desta tese, os cenários de ES nos dois destinos turísticos estudados podem ser caracterizados por um processo de "mau desenvolvimento", no qual o Produto Interno Bruto é crescente, no entanto, acompanhado de baixos níveis de emprego e renda, além de amplos níveis de desigualdades sociais, e condições de extrema pobreza (Quadro 7) (SACHS, 2008).

A concepção ampla de pobreza pode ser descrita como uma lacuna de recursos/capacidades que permitem que a pessoa possa viver sua vida como ele ou ela valoriza, englobando domínios como renda, saúde, educação, empoderamento, e direitos humanos.

\section{Quadro 7: Conceito de pobreza}

Fonte: SEN, 1999 apud WRI et al, 2005 (tradução livre do autor / grifo do autor).

O combate à pobreza foi identificado como um dos maiores desafios globais e estabelecido como um dos Objetivos do Milênio $\left(M D G s^{45}\right)$ pela Organização das Nações Unidas, durante a Cúpula do Milênio, em 2000. Como resposta a este desafio, a OMT anunciou, em 2002, a iniciativa "ST-EP (Sustainable Tourism - Eliminating Poverty) ${ }^{46 ", ~ n a ~ C u ́ p u l a ~ M u n d i a l ~ s o b r e ~}$ Desenvolvimento Sustentável, em Joanesburgo. (UNWTO, 2014)

A iniciativa $S T$-EP foi criada pensando que o Turismo pode desempenhar um papel significativo no combate à extrema pobreza e à fome, contribuindo com a igualdade de gênero,

\footnotetext{
45 Millenium Development Goals.

46 Turismo Sustentável - Eliminando a Pobreza.
} 
com a sustentabilidade ambiental e no fortalecimento da parceria global (UNWTO, 2014). Tal iniciativa é descrita a seguir.

(...) promove a redução da pobreza por meio da prestação de assistência à projetos de desenvolvimento sustentável. A iniciativa se concentra em melhorar o trabalho de longo prazo das organizações para promover o turismo sustentável - social, econômico e ecológico - com atividades que, especificamente, aliviem a pobreza, garantam o desenvolvimento e criem empregos para pessoas vivendo com menos de um dólar por dia. (UNWTO, 2014, s/n)

Em consonância como a iniciativa anterior está a ideia conhecida por "pro-poor tourism" PPT (Turismo voltado aos pobres), aprovada na mesma oportunidade em Joanesburgo (BRICKER, BLACK, COTTRELL, 2013; MEYER, 2011). O foco deste conceito está na intervenção para o alivio da pobreza de comunidades marginalizadas, utilizando-se da atividade turística como uma ferramenta estratégica (APTDC, 2013; JAMIESON, GOODWIN, EDMUNDS, 2013) capaz de gerar reais benefícios aos mesmos. (PRO-POOR TOURISM PARTNERSHIP, 2014)

A ideia do PPT é a de criar uma rede de benefícios ("net benefits") para os economicamente pobres, pensando que muitos deles foram prejudicados com a implementação da prática turística em suas áreas, como a perda de espaço territorial, de acesso à prática pesqueira, de produção agrícola ou mesmo de acesso aos recursos naturais de parques nacionais. Nesse sentido, a ideia assegura que tais aspectos negativos não sejam ignorados e que os benefícios sejam contabilizados e demonstrados, por meio de ganhos claros e tangíveis para as comunidades locais. (PRO-POOR TOURISM PARTNERSHIP, 2014)

Iniciativas como estas são necessárias para se explorar as potencialidades do crescimento, criando oportunidades efetivas de participação e de benefício econômico para grupos residentes, puxando números crescentes de empregos decentes (sem deixar de lado a melhoria das atividades informais) e referenciando-se em um modelo de desenvolvimento includente. $O$ modelo alternativo tratado como "desenvolvimento includente", em oposição ao conhecido "crescimento excludente" (SACHS, 2008):

(...) requer, acima de tudo, a garantia do exercício dos direitos civis, cívicos e políticos. A democracia é um valor verdadeiramente fundamental e garante também a transparência e a responsabilização necessárias ao funcionamento dos processos de desenvolvimento. Todos os cidadãos devem ter acesso, em igualdade de condições, a programas de assistência (para deficientes, mães e filhos) voltados para a compensação das desigualdades naturais ou físicas, a oportunidade de acesso a serviços públicos, tais como educação, proteção à saúde e moradia. (SACHS, 2008, p. 81) 
Tratando-se de um componente notório do setor de serviços (o qual é a base sustentadora dos processos de desenvolvimento implantados nessas regiões), a atividade turística em Barreirinhas e em Jijoca de Jericoacoara deveria se apresentar como uma ferramenta de alta eficiência para a inclusão social. Principalmente no que tange as vertentes de emprego e renda, consideradas, nos dois municípios, como as de pior contribuição para os índices de desenvolvimento municipais.

A perspectiva no turismo como uma ferramenta norteadora de iniciativas de inclusão social em destinos brasileiros se justifica ao ponto em que essa atividade é considerada potencial para a geração de trabalho, emprego e renda, em seus subsetores, e um setor econômico capaz de combater a pobreza e a exclusão, construindo um turismo sustentável (LAGE e MILONE, 2001; CAVALCANTI, 1999; GOELDNER et al., 2002; OCDE, 2008; WORLD BANK, 2006; OMT, 2010).

A inclusão social a qual é aqui remetida está atrelada, com maior propriedade, ao objetivo de conquista da justiça social, mais especificamente na justiça participativa, na qual busca-se a garantia de um nível de vida digno para todos, igualdade de oportunidades, acesso à formação, disponibilidade de trabalho, participação cultural, e a minimização das diferenças sociais (BOMBASSARO; KRÜGGELER; SOUZA, 2009). Além disso, acompanhada do avanço da renda individual, e da acessível oferta de equipamentos e de serviços públicos, configuradas como as bases do conceito de inclusão social (ver Figura 47):

As bases da inclusão social podem ser identificadas sinteticamente na capacidade de um país fazer avançar tanto a renda individual de sua população como a oferta acessível de equipamentos e serviços públicos. [...] Como indicadores relativos à oferta de equipamentos e serviços públicos destacam-se os complexos da educação, saúde, habitação, cultura e informática. Já em relação à renda individual da população são fundamentais as variáveis referentes ao universo dos habitantes que vivem em condições de pobreza, de desemprego e sub-ocupação e, ainda, sem o precário acesso à proteção previdenciária. (POCHMANN, 2005, p. 13)

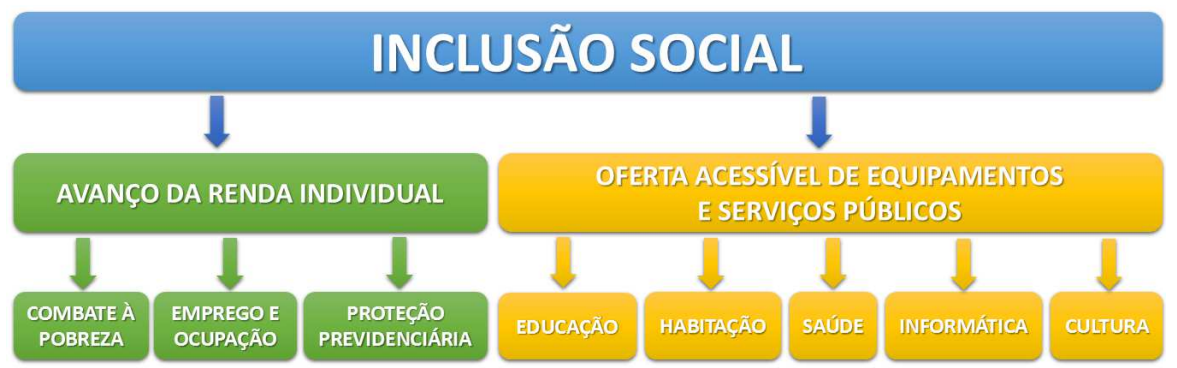

Figura 47: Bases da Inclusão Social

Fonte: elaboração própria, com base em Pochmann, 2005. 
Diante das ramificações apresentadas ressalta-se que o foco do presente trabalho está no estudo sobre os obstáculos para a inclusão socioeconômica, ou seja, no avanço da renda individual proporcionada pelo emprego no Turismo (inclusão direta) ou pela ocupação em alguma atividade econômica tangente ao setor (inclusão indireta). Ainda assim, para o perfeito entendimento do cenário, não se abandona, neste trabalho, as demais bases da inclusão social.

A discussão sobre inclusão socioeconômica no Turismo, nas áreas contempladas pela pesquisa, merece atenção pela precariedade ou ainda baixa eficiência nas medidas voltadas ao aprimoramento das oportunidades, diretas e indiretas, de avanço da renda individual das populações locais a partir desse setor.

Nos dois subitens a seguir serão tratadas as duas vertentes de inclusão socioeconômica estudadas: inclusão direta, por meio do pleno emprego; e inclusão indireta, por meio da inserção produtiva.

\subsection{Inclusão Socioeconômica Direta: o pleno emprego e o trabalho decente}

Um dos determinantes para a formatação da injustiça social e, consequentemente, da estruturação da ES, é o desemprego (PNUD, 2009; DEMO, 2002), que gera muito mais do que a perda de rendimentos. Ele acarreta, também, na perda de liberdades do indivíduo, de suas habilidades, e de seus vínculos sociais (SEN, 2000).

Pochmann concorda com tal afirmação ao destacar que, no caso do Brasil, a expansão do desemprego já tem ultrapassado formas anteriores de exclusão, como o analfabetismo:

No caso do Brasil, a exclusão social tem se mostrado um fenômeno essencialmente complexo. Isto porque os avanços no combate às velhas formas de exclusão social (analfabetismo e pobreza absoluta) nos últimos vinte anos, têm sido ultrapassados pela expansão do desemprego, da violência e pela ampliação da desigualdade sob novas formas (POCHMANN, 2004, p. 68).

Por outro lado, a partir de meados de 2010, o cenário do mercado de trabalho brasileiro tem ganhado conotações positivas diante dos surpreendentes dados, divulgados pelo IBGE, referentes aos indicadores de desemprego nacionais.

Influenciada pelos impactos da crise financeira internacional, a economia brasileira se encontrou, naquele período, numa fase de significativa recuperação das perdas de empregos reconhecidas em 2009 (KON, 2012). As taxas de desocupação apresentadas em 2010 atingiram 
uma média de 5,3\% da PEA, seguindo por consideráveis reduções que chegaram a registrar, em dezembro de 2013 , a marca de $4,3 \%$.

A divulgação de taxas tão reduzidas de desocupação no âmbito nacional tem conduzido economistas, especialistas e estudiosos à ampliação do debate sobre a proximidade do Brasil em atingir o chamado "pleno emprego", melhor entendido a seguir.

As conceituações teóricas sobre o pleno emprego implicam, no caso da oferta de mão de obra, o desenvolvimento das potencialidades da população ativa e, do lado da procura de trabalhadores, a capacidade de criação de emprego em números e nas qualificações suficientes e em condições adequadas à oferta, sem comprometer, contudo, a produtividade do trabalho. (KON, 2012 p. 20)

De acordo com a Organização Internacional do Trabalho (OIT, 2014), o pleno emprego é uma condição necessária para que os objetivos do desenvolvimento econômico das sociedades possam ser atingidos, alcançando o progresso social e melhores níveis de vida. Além disso, deve servir como um aporte para o desenvolvimento de capacidades e competências, visando a erradicação da pobreza e da fome, e a realização pessoal e o bem-estar coletivo (OIT, 2014).

No entanto, o pleno emprego não é o objetivo único. Junto à ele deve estar acompanhada a ideia de "trabalho decente". Aspecto introduzido pela OIT em 1999, o trabalho decente pode ser representado por um ponto de convergência de quatro objetivos estratégicos, os quais sintetizam as aspirações de todos os trabalhadores quanto às condições de segurança, dignidade, liberdade e igualdade (KON, 2012). São eles (OIT, 2014b):

(1) Liberdade sindical e reconhecimento efetivo do direito de negociação coletiva;

(2) Eliminação de todas as formas de trabalho forçado;

(3) Abolição efetiva do trabalho infantil;

(4) Eliminação de todas as formas de discriminação em matéria de emprego e ocupação, a promoção do emprego produtivo e de qualidade, a extensão da proteção social e o fortalecimento do diálogo social;

O espaço de discussão que se abre, no entanto, é se as características qualitativas dos empregos gerados no Brasil condizem com tais pressupostos destacados, ou apenas refletem, por meio de dados estatísticos, uma situação equivocada de conforto quanto à proximidade do pleno emprego e do trabalho decente. 
É imprescindível que, ao se interpretar alguns indicadores nacionais de emprego e de ocupação, tenha-se em mente que algumas características implícitas aos resultados, por vezes, acabam não sendo expostas com a mesma magnitude.

Um exemplo claro seria a "taxa de desocupação", da Pesquisa Mensal de Emprego (PME), que em fevereiro de 2014 correspondeu a 5,1\%, e foi fielmente divulgada pelo Ministério da Fazenda como sinônimo de "índice de desemprego" (BRASIL, 2014a; IBGE, 2014). Contudo, deve-se lembrar que, ao resultado da taxa de desocupação, não estão incorporados: trabalhadores sem vínculo legal com empregadores; condições de subemprego; trabalhadores por conta própria que podem desenvolver atividades tanto satisfatórias, quanto desprotegidas e precárias; baixos salários e rendimentos médios insuficientes; atividades com baixas cargas horárias, que podem chegar a apenas uma hora; e alto nível da informalidade (KON, 2012). Todas essas características são embutidas na "taxa de ocupação".

Além disso, vale ressaltar que a PME é realizada por meio de uma amostra probabilística que toma como espaço de abrangência as áreas urbanas das regiões metropolitanas de Recife, Belo Horizonte, São Paulo, Porto Alegre, Salvador e Rio de Janeiro (IBGE, 2007). Nesse sentido, as demais Unidades Federativas, onde são consideráveis as discrepantes estruturas ocupacionais em relação às metrópoles, não influem no resultado final apresentado (KON, 2012).

O quadro em que se encontra a economia brasileira é paradoxal, caracterizado pela "euforia no mercado financeiro e desespero no mercado de trabalho" (PASTORE, 2003, p. 29). Para se saldar a perversa e ampla dívida social, que se estende por mais de quarenta anos de rápido crescimento econômico sob a forma de desemprego e subemprego, o Brasil deve capitanear seus esforços para se reestruturar numa gigantesca fábrica de empregos (SACHS, 2004).

Diante disso, deve-se refletir sobre a notoriedade do setor de Turismo na criação de vagas de emprego em seu sistema e nas atividades à ele conectadas. Analisando-se o quadro de ocupação do ano de 2013, os setores de Viagens e Turismo contribuíram, só nesse ano, com a geração de 1,4 milhões de novos postos de trabalho diretos. No mesmo ano, 4,7 milhões de novos empregos foram criados como resultado específico da atividade turística. Ao todo são 266 milhões de empregos indiretos e 101 milhões de empregos diretos, o que representa um em cada 11 empregos no total mundial. A contribuição de tais setores para o emprego cresceu 1,8\%, também em 2013. (WTTC, 2014) 
Tratando-se do Brasil, foi identificado, entre os anos de 2003 e 2012, um total de quase três milhões de empregos diretos gerados em todo território nacional (WTTC, 2013). Estima-se que até o ano de 2022 o Turismo no Brasil seja promotor de 3,63 milhões de empregos (BRASIL, 2013c).

Considerando-se os empregos ${ }^{47}$ diretos e indiretos gerados em 2012, eleva-se para 8,04 milhões de postos de trabalho, o que representa $8,3 \%$ do total de empregos gerados no país (WTTC, 2013). Até 2023 são estimados 10,59 milhões de empregos diretos e indiretos, o que representaria, aproximadamente, 9,5\% do total de empregos do território nacional (BRASIL, 2013c).

Ainda que dados sobre os impactos positivos do Turismo, expressos e publicados, mereçam atenção e precaução em sua análise - ao ponto que muitas vezes esses acabam sendo superestimados (COOPER, 2007) -, torna-se inquestionável a notoriedade de sua capacidade de geração de trabalho, emprego e renda, e a potencialidade desse setor na dinamização da economia de um país, região e/ou localidade.

Mas quais são os fatores que influem sobre a inclusão socioeconômica direta no SPLT? Consensos e unanimidades de argumentos atestam a retórica de que os fatores com maior influência nos processos de inclusão socioeconômica pelo emprego sejam o nível de instrução formal (escolaridade) e a capacitação profissional.

Ramos (1997) apresenta alguns argumentos que fortalecem a necessidade de melhor reflexão sobre esses fatores consensuais, para que, a partir daí, possam surgir contribuições efetivas para as políticas de inclusão social e de emprego:

Parte-se do suposto de que a necessidade de elevar a escolaridade da mão-deobra, de formar e reciclar os trabalhadores empregados e desempregados, (...) e qualificação são pontos que gozam de unanimidade nacional. (RAMOS, 1997, p. 07)

Pode-se argumentar, com uma certa dose de razão, que não necessariamente essas tendências sirvam como referência para vislumbrar os atuais e futuros problemas do mercado de trabalho no Brasil. (RAMOS, 1997, p. 07-08)

(...) taxas de escolarização devem ser observadas com certo cuidado, dado que podem não estar representando uma estratégia de acumular maior capital humano e, sim, dificuldades de inserção no mercado de trabalho. (RAMOS, 1997, p. 16)

\footnotetext{
${ }^{47}$ Em "Atividades Características do Turismo", descritas no subitem 1.2.
} 
Essa associação tão estreita entre os problemas do desemprego e a formação tem como referência a já mencionada menor taxa de desemprego entre os que têm maior nível de escolaridade, uma correlação negativa que é generalizada na vida adulta. (RAMOS, 1997, p. 17)

Ou seja, não existem evidências sólidas que permitam afirmar que, sempre e em qualquer caso, os programas de formação são eficientes e eficazes para reduzir a vulnerabilidade ao desemprego e elevar os salários dos beneficiários. (RAMOS, 1997, p. 18)

Concordando com tais argumentos, Segnini (2000) destaca que a qualificação (escolaridade e formação profissional) se transformou num fetiche, que tem acarretado em vultosos gastos, em todo o mundo, para a requalificação de trabalhadores, porém, com pífios resultados gerados nos processos de inserção no mercado de trabalho.

O desemprego crescente de trabalhadores escolarizados, sobretudo nos setores
mais modernos da sociedade, é tomado como um dos argumentos para tornar
relativa essa perspectiva instrumental da educação que se expressa como se
fosse capaz de garantir o emprego ou, até mesmo, o trabalho. (SEGNINI, 2000,
p. 75)

Nota-se, portanto, que não há evidências sólidas de uma relação causal entre a qualificação (escolaridade e formação profissional), e a efetividade da inclusão no mercado de trabalho. Cabe, aqui, questionar tais consensos ao ponto em que tem-se reconhecido no mercado de trabalho brasileiro:

- O aumento do crescente desemprego de trabalhadores escolarizados (SEGNINI, 2000);

- A ampliação das desigualdades, tanto geracionais, quanto raciais e de gênero (SEGNINI, 2000);

- O descompasso entre a demanda de trabalho e o perfil da oferta, quando são notadas ocupações por assalariados que possuem uma sobrequaalificação relativa ao posto de trabalho que ocupam (RAMOS, 1997).

É digno de nota que o objetivo do presente trabalho não é o definir a relação causal entre variáveis dependentes (inclusão ou não inclusão) e variáveis independentes (nível de escolaridade, gênero, idade, etc.). Ao contrário. Busca-se aqui reconhecer os fatores que geram indícios de contribuição para a inclusão socioeconômica no SPLT.

Para tanto, são destacados onze fatores como possíveis variáveis com potenciais influências nos processos de inclusão socioeconômica de habitantes de destinos turísticos: gênero; idade; religião; rede de relações sociais; acesso à informação; local de nascimento; grau 
de escolaridade; experiência (familiar) anterior; capacitação profissional; proximidade física do local onde a atividade turística se desenvolve; participação em cooperativas e/ou associações.

Entende-se por fatores que contribuem para a inclusão socioeconômica no SPT os processos sociais nos quais os atores estão envolvidos, ou são por eles impactados em seus processos decisórios, e que contribuem para o sucesso de sua inserção (TASSO, 2011). No caso, atores são considerados todos os indivíduos, grupos ou organizações que têm identidade própria, são reconhecidos por outros, e têm capacidade de agir e influenciar o seu contexto (NASCIMENTO, 1989).

\subsection{Inclusão Socioeconômica Indireta: a inserção produtiva}

Ao se deparar com singularidades naturais, cenários paradisíacos, multiplicidades culturais, uma ampla potencialidade produtiva, e uma considerável estrutura de acolhimento, não passaria pela cabeça de um visitante outra imagem que não fosse de harmonia e autossuficiência do destino turístico.

Entretanto, os processos de desenvolvimento local de alguns destinos turísticos brasileiros pouco refletem modelos autossuficientes. Entende-se "desenvolvimento local" como o processo endógeno de promoção do dinamismo socioeconômico de uma unidade territorial, por meio da organização social em nível local, da preservação do patrimônio ambiental, e da exploração das capacidades e das potencialidades encontradas, buscando a autogestão pelos residentes e a melhoria da qualidade de vida de sua população (BUARQUE, 1999; IRVING, 2001).

Mesmo com todas as potencialidades - produtivas e naturais - encontradas nos dois destinos turísticos em tela, são evidentes os contrastes sociais, os traços de pobreza e de miséria, e a ausência de um sistema produtivo turístico mais integrador, que busque pelo desenvolvimento endógeno das localidades.

O quadro de desigualdade social e de exclusão está presente, principalmente, entre os pequenos produtores rurais desses destinos. Essa categoria de pequenos produtores "inclui todos aqueles envolvidos em atividades de pequena escala realizadas fora do universo das empresas modernas" (SACHS, 2008, p. 48-9).

Em sua maioria, encontram-se em zonas rurais afastadas dos centros de maior aglomeração turística. Com raras exceções, desenvolvem atividades informais e tradicionais, como a pesca, a agricultura e o artesanato, se mantendo confinados em um cenário de extrema pobreza. 
As restrições às oportunidades de acesso aos benefícios econômicos advindos da atividade turística, impostas a esses grupos de pequenos produtores rurais, se dão, dentre outras formas, pela dinâmica das cadeias produtivas do pescado e de produtos agrícolas, nessas regiões, que têm como peça estratégica a figura do, popularmente conhecido, "atravessador" (middlemen ou fish traders).

Os atravessadores são intermediários nos processos de comercialização entre a oferta (pequenos produtores rurais) e a demanda (dentre outras, o trade turístico). Possuem um papel determinante na dinamização da produção, por suprirem as necessidades primárias para o desenvolvimento das atividades produtivas, em especial da pesca artesanal, como destacado a seguir:

\footnotetext{
São atores comuns na atividade pesqueira. Frequentemente são o único elo entre pescadores e o mercado, ou a única fonte de crédito. O sistema de negociação dos atravessadores opera dentro de um amplo ambiente econômico e político, que pode ter implicações cruciais para a atividade pesqueira, em geral, e para o comércio pesqueiro, em particular. (PEDROZA, 2012, p. 02 - tradução pelo autor)
}

Por meio de relações informais, que se desenvolvem por laços de amizade ou vínculos familiares, os pequenos produtores rurais estabelecem um ciclo vicioso de dependência econômica com os atravessadores.

Estes últimos, ao fornecerem apoios providenciais - como gelo, isca, combustível, mantimentos para a família, equipamentos mecânicos e de pesca, alimento para a tripulação, ou mesmo recurso financeiro em espécie para reforma e aquisição de embarcações (CAPELLESSO \& CAZELLA, 2013; MERJIN, 1989; VINH, 2008) -, não determinam taxas de juros futuras, o que caracteriza uma intrincada rede de financiamento (BRASIL, 2011b).

Não há quaisquer procedimentos legais para o estabelecimento do empréstimo entre o concedente e o credor, o que permite que os atravessadores adquiram as safras de pesca e desfrutem de comissões (VINH, 2008). Dessa forma, a produção (em sua totalidade, na maioria dos casos) acaba sendo direcionada para uma venda, de baixo retorno financeiro, aos atravessadores, como um compromisso estabelecido e como uma forma de retribuição.

Reuniões participativas com pescadores artesanais e agricultores familiares de Barreirinhas elucidaram a figura do atravessador como um ator-chave na cadeia produtiva e no sistema turístico local. Sua posição na cadeia de distribuição, dos produtores até os 
estabelecimentos turísticos locais, pode ser identificada pelas setas vermelhas nas ilustrações criadas pelos próprios pescadores (Figura 48).
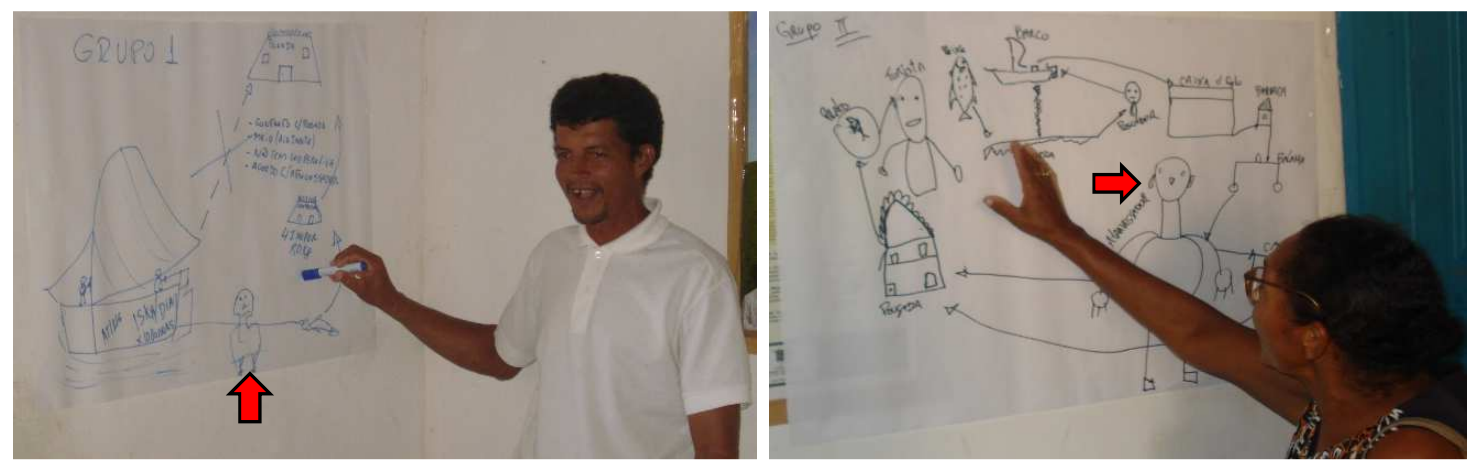

Figura 48: Figura do Atravessador pela ótica de pescadores de Barreirinhas Fonte: IABS, 2008a.

As semelhanças deste modelo de cadeia de distribuição de pescados e de produtos agrícolas, cuja figura do atravessador é um aspecto central, se estendem à região de Jijoca de Jericoacoara. A partir da entrevista realizada junto ao Sindicato de Trabalhadores Rurais desse município, pode-se identificar similitudes nos processos:

(...) a questão da agricultura precisa ser melhorada bastante, porque a agricultura é muito desvalorizada. Por quê? Somente porque tem a questão dos produtos, quando os agricultores colhem e vendem diretamente para o atravessador. Aí é que está o problema, porque eles passam o ano todo trabalhando, e quando vão vender seus produtos vendem por uma mixaria. É por isso que eles não querem mais trabalhar na agricultura. (SINDICATO DOS TRABALHADORES RURAIS DE JIJOCA DE JERICOACOARA, 2012)

O desenraizamento cultural, pelo afastamento dos pequenos produtores de suas atividades tradicionais, pode ser decorrente dos processos de desenvolvimento do Turismo no Brasil. Tais processos têm gerado uma baixa contribuição para a inclusão de comunidades locais, e tem acarretado em impactos socioambientais irreversíveis, e na considerável perda da identidade cultural local (BURSZTYN, 2005).

Grosso modo, a dinâmica de comercialização e de distribuição de pescados e de produtos agrícolas nas regiões de Barreirinhas e de Jijoca de Jericoacoara, a partir dos pequenos produtores rurais até os estabelecimentos do trade turístico, é estruturada da seguinte forma (Figura 49):

1. A maior parcela dos pequenos produtores rurais, tanto de Barreirinhas quanto de Jijoca de Jericoacoara, direcionam suas produções para o autoconsumo. Porém, seus 
excedentes são comercializados, em maior quantidade, com atravessadores locais. A venda para pequenos mercados, peixarias, diretamente para turistas e estabelecimentos do trade, ou mesmo porta a porta, pode também ser identificada, porém em menor quantidade. Outro canal de escoamento da produção artesanal e familiar se dá pela comercialização direta com as Prefeituras Municipais, a partir do Programa de Aquisição de Alimentos (PAA $)^{48}$ e do Programa Nacional de Alimentação Escolar (PNAE) ${ }^{49}$, ambos do Governo Federal.

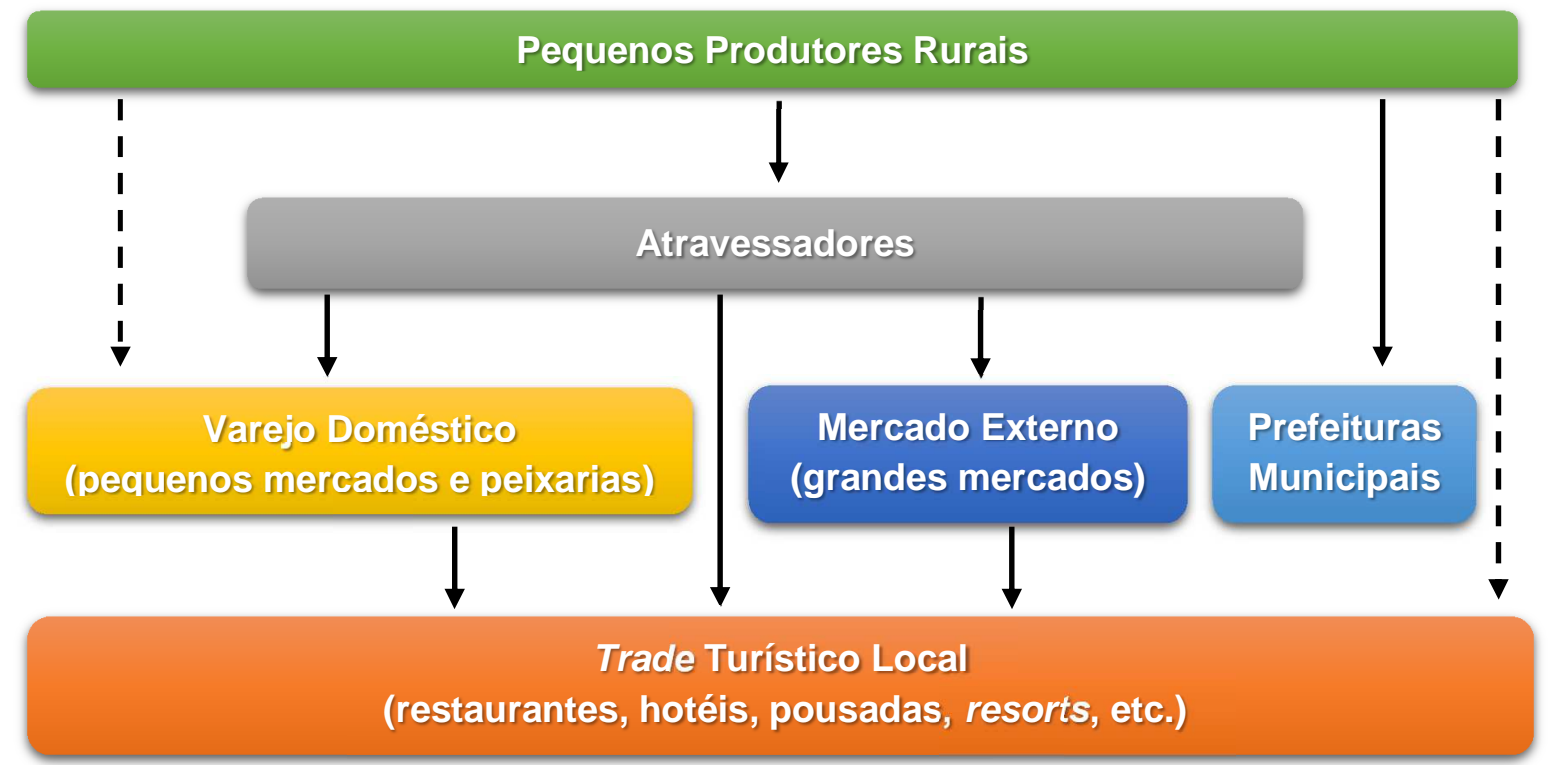

Figura 49: Dinâmica de comercialização de pescados e produtos agrícolas nas regiões estudadas

Fonte: próprio autor

2. Os atravessadores da agricultura, tanto em Jijoca quanto em Barreirinhas, revendem a castanha de caju - um dos principais insumos das duas regiões - diretamente para mercados externos. No caso de Jijoca, a venda se canaliza, dentre outras, para fábricas de Fortaleza, em especial a CIONE50. Em Barreirinhas, os grandes mercados de São Luís aparecem como notórios consumidores. No caso de produtos com produção em

\footnotetext{
${ }^{48}$ Criado em 2003 como forma de enfrentar a pobreza e a fome no Brasil e, concomitantemente, fortalecer a agricultura familiar. O Governo Federal adquire produtos alimentícios diretamente de agricultores familiares, assentados de reforma agrária, comunidades indígenas e demais povos e comunidades tradicionais, pensando na distribuição dos mesmos para a população com maior vulnerabilidade social e na formação de estoques estratégicos. (BRASIL, 2014g) ${ }^{49}$ Programa no qual é determinada a utilização de, no mínimo, 30\% dos recursos oriundos do Fundo Nacional de Desenvolvimento da Educação (FNDE) para aquisição de produtos da agricultura familiar para utilização na merenda de escolas públicas dos municípios. (BRASIL, 2014h)

${ }^{50}$ Companhia Industrial de Óleos do Nordeste. Mais informações: http://www.cione.com.br/
} 
menor escala (como a farinha, o feijão e o milho), os atravessadores da agricultura direcionam suas vendas para os pequenos mercados locais. Com relação aos atravessadores da pesca, os procedimentos de compra dos produtos in natura (por valores irrisórios) para revenda (a valores elevados) a mercados externos, peixarias e pequenos mercados locais, ou mesmo para a venda direta aos estabelecimentos do trade turístico, se dá, dentre outras coisas, em razão das espécies, dado que muitas delas não são utilizadas para oferecimento aos turistas.

3. O trade turístico local de Barreirinhas e de Jijoca de Jericoacoara, representado pelos hotéis, pousadas, restaurantes, resorts, lanchonetes, entre outros, possuem similaridades quanto aos padrões de comercialização. Estudos pretéritos realizados nas regiões (SAWYER; TASSO; ASSAD; 2010) indicaram que estabelecimentos de grande porte e parte dos de médio porte de Barreirinhas e de Jijoca buscam por maiores variedades e quantidades de produtos nas capitais (São Luís e Fortaleza) de seus respectivos estados, em grandes mercados, geralmente utilizando-se de veículos próprios dos proprietários (IABS, 2008b). Por outro lado, estabelecimentos de pequeno porte e a outra parte dos de médio porte privilegiam a compra de produtos localmente, por meio de atravessadores locais, peixarias, supermercados, vendas e varejões (IABS, 2008b). Segundo entrevista junto ao Sindicato dos Trabalhadores Rurais de Barreirinhas, muitos produtos agrícolas - como tomate, abacaxi, laranja, cebola, pimentão e banana - oferecidos por estabelecimentos turísticos do município são, também, advindos do pólo produtivo da Serra do Tianguá (Ceará). A cada 15 dias caminhões carregados de produtos chegam a Barreirinhas. Mercados e estabelecimentos turísticos locais também se deslocam até lá.

Este modelo de cadeia produtiva pesqueira e agrícola, comum em muitos destinos turísticos brasileiros, prejudica os estabelecimentos da demanda, que arcam com custos abusivos dos produtos, ou dão preferência para empresas externas. Da mesma forma, impede a inclusão socioprodutiva desses grupos de pequenos produtores rurais no mercado turístico.

A inclusão socioprodutiva, também tratada como "inclusão produtiva", "inserção produtiva" e "inserção socioprodutiva", pode ser entendida como o processo voltado à conquista de autonomia, pela formação de cidadãos que se integrem ao mundo pelo trabalho, conduzindo-os a uma vida digna, tendo seus direitos assegurados (BRASIL, 2012a; BRASIL, 2012b). 
Tratam-se de ações que contribuem para a geração de trabalho e renda para famílias usuárias da política de assistência social, por meio do fortalecimento de arranjos e de organizações produtivas comunitárias, da instrumentalização e da capacitação profissional, da valorização da identidade cultural local e do saber-fazer tradicional (SERGIPE, 2014; SEMCAS, 2013).

A inclusão produtiva é concebida como uma das vertentes de projetos de enfrentamento da pobreza, definida pelo Governo Federal Brasileiro a partir do "Plano Brasil Sem Miséria". Esta vertente, que prevê ações no campo e na cidade, busca, dentre outras coisas, fortalecer atividades de agricultores familiares de baixa renda, pelo aumento da capacidade produtiva e pela inserção dos produtos no mercado, por meio de acompanhamento técnico, oferecimento de insumos e de água (BRASIL, 2012b).

A estratégia da inclusão socioprodutiva apresenta-se como uma "condição necessária para o desenvolvimento humano" (SIMÕES, PEIXOTO, 2009, p.03), na qual a qualificação profissional é, talvez, a referência mais imediata, seguida pelas iniciativas de promoção do empreendedorismo individual, microcrédito produtivo orientado, fomento e apoio à economia solidária, ou ainda, inserção pelo trabalho assalariado ou associado (BRASIL, 2013b).

No entanto, em grande parte dos casos, as ações voltadas à inclusão socioprodutiva em destinos turísticos brasileiros limitam-se apenas ao primeiro passo, representado pela capacitação e qualificação profissional dos interessados, e pela concessão de ferramentas e equipamentos pontuais para os pequenos produtores rurais. A entrevista realizada junto ao Sindicato dos Pescadores de Barreirinhas ressaltou a grande necessidade de se discutir as reais demandas dos trabalhadores rurais:

Nós temos hoje projetos voltados ao pescador artesanal como coisas, assim, kits de pesca que é uma canoa com motorzinho de rabeta, uma caixa térmica, colete, essas coisas todas. Então, hoje, eles (Governo Federal) estão acordando, mas eles não sentam para discutir a necessidade real do trabalhador. Eis que essas questões que estamos pensando em trazer: discutir a real situação do trabalhador. Porque se ele permanecer assim, ele nunca vai melhorar, nunca vai condicionar melhores dias para a família, porque ele vai ficar sempre daquele jeito e acha que vai ter que morrer daquele jeito.

Há indicativos, portanto, de que projetos e políticas de inclusão socioprodutiva em regiões turísticas possam estar deixando lacunas substanciais para que a efetividade de seus processos seja atingida, merecendo novos debates e reflexões: 
Presente na LOAS (Lei Orgânica de Assistência Social) e na nova PNAS (Política Nacional de Assistência Social), as estratégias de inclusão produtiva carecem não só de diagnóstico, como também de um profundo debate teórico-politico, sobretudo nos municípios, de modo a rever os equívocos impostos a estas ações, recentemente, e que têm impresso, à noção e à proposta de inclusão produtiva, um sentido conservador, ingênuo e imediatista, na medida em que aparecem reduzidas às estratégias de capacitação e de inserção subordinada e precarizada ao mercado de trabalho (setor não-organizado). (ALMEIDA, 2009, p. 96)

Com a implementação de políticas e projetos de inclusão socioprodutiva sem a eficiência e a eficácia necessárias, acarreta-se o confinamento da grande parcela da maioria trabalhadora limitada às atividades informais, não direcionando benefícios e melhorias para as comunidades de baixa renda.

Essa estrutura de trabalho, caracterizada pelo confinamento de grupos populares a atividades informais, como uma forma de inserção inadequada, cujo modelo não provém o conjunto de benefícios legais e de direito aos seus atuantes, é apenas uma das representações das formas de ES encontradas:

(...) o critério de exclusão social capta de forma mais abrangente as várias formas de inserção precária ou de falta de acesso a um conjunto de bens sociais. Associa-se mais de perto ao que Amartya Sen chamou de restrição às liberdades instrumentais, tais como: liberdades políticas, facilidades econômicas, oportunidades sociais, garantias de transparência e segurança protetora (POCHMANN, 2004, p. 67-8).

A informalidade nas atividades econômicas tem, segundo Sachs (2008), uma distorção recorrente em suas idealizações, baseada em duas visões distintas: estratégias de sobrevivência e estratégias de desenvolvimento. É visto pelo autor que, mesmo tratando-se de propostas criativas, as primeiras só conseguem oferecer - às custas de sacrifícios e de muitas dificuldades - rendimentos insuficientes aos trabalhadores.

Entretanto, é comum a identificação de uma visão míope de muitos pequenos produtores que, mesmo desprovidos de direitos que lhes deveriam ser assegurados (como o acesso à previdência social, o direito à aposentadoria, ou qualquer outro meio de proteção individual por leis trabalhistas), se mantêm "apegados à sua informalidade" (SACHS, 2008, p. 51). 
Esta perspectiva se explica pelos pequenos produtores terem a necessidade de remuneração imediata após a produção, além de se encontrarem numa situação em que não arcam com encargos sociais ou impostos (SACHS, 2008).

Nesse sentido, como atingir a eficácia e a eficiência na implementação de projetos de inclusão socioprodutiva em regiões turísticas? Quais são os reais obstáculos a serem superados?

O presente estudo analisou nove fatores que, mesmo não estabelecendo uma relação causal, podem ser responsáveis pela contribuição para a inclusão socioeconômica indireta. Tais fatores são: problemas quanto à emissão de nota fiscal; problemas quanto à adequação da produção à sazonalidade do Turismo; falta de capital de giro, de estrutura de beneficiamento e de local de estocagem; empecilhos quanto às condições de pagamento; insuficiência na produção para atendimento da demanda; indisponibilidade logística para o escoamento da produção; falta de capacitação profissional técnica e gerencial; fragilidade na organização coletiva do trabalho; e dificuldades na obtenção de registros de serviços de inspeção sanitária (SIF / SIE / SIM).

\section{POLÍTICAS PÚBLICAS, INCLUSÃO SOCIAL E TURISMO}

Destinos turísticos brasileiros têm sido objeto de discussões (e de intervenções públicas) a respeito das dimensões da sustentabilidade, entre outros, os aspectos da equidade social. A vulnerabilidade social e econômica das populações locais desses destinos é o que, por vezes, sustenta e amplia essas discussões e intervenções.

Atualmente, a busca pela inclusão social se configura em uma das preocupações centrais do Governo e da sociedade brasileira. E o vigor, o dinamismo e a crescente expansão da atividade turística no país parecem ser características que fundamentam a ótica de que o Turismo pode capitanear mudanças sociais e econômicas, principalmente em benefício dos menos favorecidos.

No Plano Nacional de Turismo 2007-2010, intitulado “Uma Viagem de Inclusão”, essa visão fica bem evidente: 
O turismo, sobretudo, vai cumprir sua função social. Chegou a vez do turismo de inclusão. Uma inclusão na mais ampla acepção da palavra: inclusão de novos clientes para o turismo interno, inclusão de novos destinos, inclusão de novos segmentos de turistas, inclusão de mais turistas estrangeiros, inclusão de mais divisas para o Brasil, inclusão de novos investimentos, inclusão de novas oportunidades de qualificação profissional, inclusão de novos postos de trabalho para o brasileiro. Inclusão para reduzir as desigualdades regionais e para fazer do Brasil um país de todos (BRASIL, 2007a, p. 08).

Dados informativos que ilustram a pujança do Turismo - como o crescimento do setor em $18,5 \%$ somente entre 2007 e 2011 , e a geração de quase três milhões de postos de empregos diretos entre 2003 e 2012 (BRASIL, 2013c) - fortalecem a ideia dessa atividade como ferramenta de mudança socioeconômica para o Brasil.

Nessa perspectiva são adotadas Políticas Públicas de Turismo, modelos entedidos como "o direcionamento dado pelo governo federal, estadual, municipal ou regional para o desenvolvimento da atividade turística, após ter consultado os representantes do setor turístico e da sociedade" (LOHMANN, PANOSSO NETTO, 2008, p.121).

A construção desses modelos específicos deve perpassar por avaliações nos diferentes níveis de governo, sejam eles municipal, estadual ou federal, visando a criação de estruturas públicas de gestão apropriadas, e mesmo a edificação da política de turismo nacional (COOPER, 2007).

Dentre outras vertentes de atuação, as políticas públicas de turismo e as políticas de desenvolvimento local implementadas em regiões turísticas, têm sido direcionadas à inclusão social, por meio de projetos de enfrentamento da pobreza, seguindo a Lei Orgânica de Assistência Social - LOAS - nacional.

Tais projetos compreendem o subsídio, financeiro e técnico, de iniciativas de grupos populares, como forma de estimular a capacidade produtiva e de gestão e, consequentemente, gerar melhorias nas condições de subsistência, o fortalecimento da organização social, a prudência com o meio ambiente e a elevação do padrão da qualidade de vida desses grupos (PRESIDÊNCIA DA REPÚBLICA, 1993).

Nos processos de implantação de estratégias de inclusão social, o desafio está na busca para se encontrar caminhos que resgatem, recriem e amplifiquem a escala de práticas sociais e de governo, diferentemente daquelas pautadas no assistencialismo e na institucionalização da pobreza (POCHMANN, 2002). 
Historicamente, políticas de turismo tiveram como premissa, dentre outras coisas, a integração socioeconômica das populações residentes. A Política Nacional do Turismo (PNT), por exemplo, estabelecida pela Lei 8181/91 e Decreto 448/92, teve como finalidade promover e incrementar a atividade como fonte de renda, de geração de emprego, qualificando os recursos humanos envolvidos, diminuindo as desigualdades regionais, e incluindo os moradores como participantes nos benefícios econômicos do setor.

Da mesma forma, a Política Nacional do Ecoturismo - elaborada pelo, na época, Ministério da Indústria, do Comércio e do Turismo e pelo Ministério do Meio Ambiente, dos Recursos Hídricos e da Amazônia Legal (IBAMA) - entendia que o aproveitamento das potencialidades naturais deveria contribuir como estímulo à identificação do ecoturismo como atividade econômica viável para a participação efetiva das comunidades.

Em seguida, pela apresentação do Programa Nacional de Municipalização do Turismo (PNMT), buscou-se a capacitação e conscientização de agentes das comunidades locais de destinos turísticos. O intuito foi o de geração de divisas e de postos de trabalho nos municípios, mobilizando as comunidades para a gestão e participação efetiva nos processos decisórios locais.

Atualmente, o cenário político nacional tem apresentado uma série de propostas de rebatimento ao alarmante estado de pobreza, e de desigualdade social, que se instaura em regiões de muitos destinos turísticos do país.

Como exemplos aparecem os "Programas de Integração à Produção Associada ao Turismo" e as propostas de "Estruturação do Turismo em Áreas Priorizadas" e de "Fomento ao Turismo de Base Comunitária", desenvolvidos pelo Ministério do Turismo - MTur.

Os primeiros buscam agregar valor e competitividade aos destinos, voltando-se à melhoria da qualidade de atividades e de produtos, desenvolvidos por comunidades locais, tendo como objetivo a inserção desses na cadeia produtiva do turismo (BRASIL, 2014b).

O conceito de produção associada ao turismo pode ser assim entendido:

Qualquer produção artesanal, industrial ou agropecuária que detenha atributos naturais e/ou culturais de uma determinada localidade ou região, capazes de agregar valor ao produto turístico. São as riquezas, os valores e os sabores brasileiros. É o design, o estilismo, a tecnologia: o moderno e o tradicional. É ressaltar o diferencial do produto turístico para incrementar sua competitividade. (BRASIL, 2011c, p. 13) 
Os segundos apoiam a formulação e a implementação de projetos de desenvolvimento local e de geração de renda, por meio do turismo, em áreas com baixos índices de desenvolvimento humano. O foco é na promoção da inclusão social e nos pressupostos da economia solidária, primando pelo modelo de base comunitária, com incentivo ao associativismo, cooperativismo, empreendedorismo, melhoria da qualidade dos serviços, estabelecimento de padrões e normas de atendimento diferenciado (BRASIL, 2014d)

Outra ação potencial do governo federal é o "Programa Nacional de Acesso ao Ensino Técnico e Emprego - PRONATEC". Por meio de uma parceria firmada entre o Ministério da Educação e o Ministério do Turismo, o intitulado PRONATEC TURISMO tem como objetivo desenvolver ações de qualificação profissional para indivíduos que já se encontram inseridos no setor turístico (54 cursos) e para aqueles interessados em se inserir (21 cursos) (BRASIL, 2014c).

\section{ASPECTOS METODOLÓGICOS}

O estudo desenvolvido teve caráter comparativo, com abordagens simultaneamente quantitativas e qualitativas, e numa forma de apresentação analítico-descritiva dos dados. A definição pela realização da pesquisa por meio de uma análise comparativa de dois destinos turísticos segue o tratamento durkheimeano, o qual entende a pesquisa comparada como um "ponto intermediário entre a complexidade dos objetos em seu estado bruto e a possibilidade do conhecimento científico poder estabelecer explicações generalizáveis" (SCHNEIDER, SCHIMITT, 1998, p. 18).

Estudos comparativos permitem abordagens de diversos níveis de análise, seja pelo tratamento individualizado (do destino) ou simultâneo, podendo estabelecer relações entre as características das estruturas internas, dos processos inerentes e do seu ambiente (BRUYNE, HERMAN, SCHOUTHEETE, 1977).

Os dois municípios selecionados - Barreirinhas e Jijoca de Jericoacoara - foram escolhidos para serem comparados em razão dos seguintes critérios:

- Tratam-se de destinos com expressivo dinamismo turístico;

- Localizados em áreas de entorno de Unidades de Conservação de Proteção Integral (Parques Nacionais dos Lençóis Maranhenses e de Jericoacoara, respectivamente);

- Integrantes de um mesmo circuito turístico, a "Rota das Emoções"; 
- Caracterizados pelo aumento crescente do fluxo de turistas e da rede de equipamentos de acolhimento, tais como hotéis, pousadas, resorts, restaurantes, bares, agências e operadoras, dentre outros;

- Com baixos escores dos indicadores sociais de suas populações locais;

- Pela importância de tais destinos nos cenários turísticos estaduais - Maranhão e Ceará - e nacional.

O levantamento das informações gerais e a coleta dos dados específicos, analisados na pesquisa, foram possíveis mediante abordagens exploratórias, quantitativas e qualitativas: (a) Exploratória, pela observação in loco, estabelecimento de contatos com atores-chave, e análise de dados secundários; (b) Quantitativa, por meio da aplicação de survey junto a população local; (c) Qualitativa, pela aplicação de formulários e entrevistas, não-estruturadas e semiestruturadas, com empresários do trade turístico, empregados (incluídos) no setor de Turismo, e grupos organizados locais com ligação direta ao tema de pesquisa.

O desenvolvimento da pesquisa se deu com a realização de suas atividades distribuídas por seis etapas, descritas com maior detalhamento a seguir.

\subsection{Etapas da Pesquisa}

\subsubsection{Etapa 01: Caracterização das Regiões Estudadas}

A primeira etapa teve como foco a caracterização, integral e multidimensional, dos dois destinos turísticos definidos como objeto da presente pesquisa, tendo em vista o alcance do primeiro objetivo específico desta pesquisa. Para tanto, realizou-se pesquisas documentais e bibliográficas, a fontes diversas, escritas e orais, acerca dos cenários dos territórios estudados.

Foram analisados dados gerais atualizados apresentados por meio de teses, dissertações, livros, artigos em revistas científicas, clippings de notícias de sítios eletrônicos locais e nacionais, dentre outras publicações, que contextualizassem os processos histórico-evolutivos locais, a atividade turística e os efeitos e impactos decorrentes dela, os potenciais encontrados, a dinâmica do sistema produtivo local de turismo, e a imagem do setor pelos atores e grupos locais interessados.

Dados socioeconômicos e de desenvolvimento humano específicos, quantitativos e qualitativos, foram levantados junto aos diversos órgãos especializados, tais como IBGE, Ipea, 
PNUD, Confederação Nacional dos Municípios (CNM), Ministérios da Saúde (MS), do Trabalho e Emprego (MTE), da Educação (MEC), do Turismo (MTur), ICMBio, Ibama, FIPE e Sistema Firjan, com informações publicadas entre os anos de 1991 e 2013.

A partir da primeira etapa pode-se melhor reconhecer os terrenos de pesquisa, assim como estabelecer diálogos com pesquisados e projetos desenvolvidos nas regiões, zelando pela agregação de conhecimentos.

\subsubsection{Etapa 02: Revisão da Literatura e Precisão Metodológica}

$\mathrm{Na}$ segunda etapa foi realizada a revisão da literatura a partir da consulta, mais aprofundada e mais abrangente, da bibliografia básica utilizada no início do trabalho. A partir de tal revisão pôde-se edificar a base de discussões teóricas que serviriam para a reflexão empírica, contribuindo para uma melhor interpretação da realidade estudada e, também, para o melhor tratamento dos dados levantados nos trabalhos de campo.

Os principais conceitos abordados no trabalho foram: inclusão e exclusão social; turismo sustentável e responsável; desenvolvimento local e sustentável; sistemas e cadeias produtivas do turismo, e inclusão socioeconômica e socioprodutiva.

Foram buscados campos de discussão teórica sobre tais temas em diversas fontes, nacionais e internacionais, principalmente em portais de bases de dados como o Portal de Periódicos da CAPES e o portal de acesso às bases de dados internacionais da Universidade Estadual do Arizona ${ }^{51}$. Foram consultadas teses, dissertações, livros e artigos que trabalharam com tais conceitos centrais da pesquisa.

A bibliografia consultada permitiu, ainda, refinar a metodologia do estudo, conferindo maior detalhamento aos métodos e técnicas utilizados no estudo.

\subsubsection{Etapa 03: Planejamento do Trabalho de Campo}

A terceira etapa consistiu no planejamento e na preparação dos instrumentos para a coleta de dados em dois trabalhos de campo. As atividades realizadas foram:

\footnotetext{
51 Tal portal pôde ser acessado pelo autor por conta do período de um ano de realização do Doutorado Sanduíche, nos EUA, junto a essa universidade.
} 
1. Elaboração, discussão, refinamento e pré-teste de quatro diferentes modelos de survey e formulários ${ }^{52}$, que foram aplicados nas duas regiões com (a) população local, (b) empresários do trade turístico, (c) incluídos no sistema produtivo local de turismo, e (d) grupos organizados com trabalhos tangentes à atividade turística.

2. Desenho do plano amostral para os municípios de Barreirinhas e Jijoca de Jericoacoara;

3. Seleção e capacitação dos dois grupos de entrevistadores em cada um dos dois municípios;

4. Organização da estrutura logística (carro e voadeira ${ }^{53}$ ) para acesso às comunidades, urbanas e rurais, dos dois municípios estudados, e demais materiais a serem utilizados (gravador e materiais de escritório como blocos de notas, canetas, etc.);

O desenho amostral probabilístico e a estrutura do instrumento de survey foram preparados para que os dados gerados pudessem ser analisados com ferramental estatístico univariado e multivariado.

\subsubsection{Etapa 04: Realização do Trabalho de Campo}

A etapa seguinte, quarta etapa, foi destinada à realização de dois trabalhos de campo em cada uma das duas localidades foco da pesquisa. O primeiro trabalho de campo foi realizado entre os dias 12 e 27 de novembro de 2012, na região de Jijoca de Jericoacoara, e entre os dias 28 de novembro e 04 de dezembro de 2012, na região de Barreirinhas.

Nesse primeiro trabalho de campo foram coletados os dados com a aplicação do survey com as populações locais de cada município, e do formulário com indivíduos incluídos no SPLT, empresários do trade turístico, e grupos organizados com trabalhos tangentes ao setor. Ainda, nessa oportunidade, foram realizadas entrevistas não-estruturadas com indivíduos incluídos no SPLT e alguns atores com ligação direta ao tema de pesquisa, dentre eles, secretários municipais de turismo e presidentes de sindicados (trabalhadores rurais e pescadores).

O segundo trabalho de campo foi realizado entre os dias 28 de maio e 01 de junho de 2014 , na região de Barreirinhas, e entre os dias 02 e 06 de junho de 2014, na região de Jijoca de Jericoacoara.

\footnotetext{
52 Diferentemente do modelo de survey, aplicado com as populações locais e com os incluídos no SPLT, os modelos de formulários continham questões abertas, tratadas pelo autor, as quais puderam ser melhor discutidas no momento de aplicação junto aos empresários do trade turístico e grupos organizados locais.

53 Pequena embarcação náutica, muito utilizada em Barreirinhas para o transporte turístico.
} 
Buscou-se, em um primeiro momento, retrabalhar algumas questões que surgiram a partir de uma análise prévia dos resultados do primeiro campo. Para tanto, foram realizadas entrevistas semiestruturadas com empresários do trade turístico, as quais focaram na tentativa de melhor entendimento e aprofundamento sobre os fatores com maior frequência de respostas no primeiro campo.

Além disso, foi possível ampliar o número de formulários aplicados junto aos estabelecimentos de cada região, aumentando a abrangência da pesquisa, assim como o número de indivíduos incluídos no SPLT.

\subsubsection{Etapa 05: Sistematização e Análise do Dados Obtidos}

A quinta etapa concentrou-se na sistematização e análise de todos os dados obtidos nos dois trabalhos de campo. Inclui-se as seguintes atividades: digitação, codificação, tabulação, processamento e análise dos dados por meio da utilização dos softwares IBM SPSS Statistics 20.0 (Statical Package for Social Science) e Free $R$.

No contexto dos dados gerais da pesquisa, foram realizadas análises estatísticas descritivas por frequência. Em contrapartida, para o tratamento dos dados específicos (fatores de inclusão direta) e avaliação do efeito que tais fatores podem exercer sobre a probabilidade associada à ocorrência do evento (efetiva inclusão socioeconômica), foi utilizada a modelagem estatística não-paramétrica, ou seja, que "supõem que as variáveis sejam medidas em uma escala nominal ou ordinal” (MALHOTRA, 2001, p. 415) de Regressão Logística.

A técnica de Regressão Logística "foi desenvolvida por volta de 1960 em resposta ao desafio de realizar predições ou explicar a ocorrência de determinados fenômenos quando a variável dependente fosse de natureza binária" (FIPECAFI, 2011, p. 282).

Trata-se de uma regressão múltipla, cuja variável de saída/dependente é categórica dicotômica (no caso desta tese, "incluído ou não incluído"), e as duas ou mais variáveis previsoras/independentes podem ser contínuas, categóricas, ou mesmo uma mistura das duas num único modelo (ou seja, podendo ser "qualitativas") (PALLANT, 2007; FIELD, 2009; FIPECAFI, 2011).

Dessa forma, a modelagem estatística de Regressão Logística foi definida como a mais apropriada para esta pesquisa, dado que a variável dependente ("inclusão socioeconômica 
direta") e as demais variáveis independentes ("escolaridade", "capacitação profissional", "religião", etc.) possuem as exatas características exigidas para se aplicar o modelo.

É digno de nota que a análise estatística não foi realizada para a avaliação dos fatores de inclusão socioeconômica indireta, por se tratarem de números limitados de grupos organizados entrevistados. Nesse sentido, a contraposição entre os grupos que "conseguem vender produtos ou oferecer serviços" e aqueles que "não conseguem vender produtos ou oferecer serviços" não poderia aferir, estatisticamente, por uma amostra pequena, um resultado válido.

Para tanto definiu-se, como estratégia metodológica mais adequada, a utilização da análise descritiva, contrapondo os resultados obtidos na aplicação dos formulários referentes aos respondentes do empresariado, e os resultados obtidos referentes aos grupos organizados locais. Permitiu-se, a partir daí, classificar os fatores de inclusão indireta por sua relevância apresentada pela recorrência de respostas por aqueles que consomem (demanda) produtos e serviços, e por aqueles que os oferecem (oferta).

\subsubsection{Etapa 06: Preparação de comunicações}

Por fim, a sexta e última etapa voltou-se à elaboração do texto da presente tese. O intuito posterior é o de apresentar os resultados da pesquisa em congressos e seminários específicos da área de Turismo, ou tangentes à mesma, nacionais e internacionais, a fim de que se fomente novas discussões sobre os resultados, a partir do diálogo com demais especialistas. A publicação de artigos em revistas e periódicos científicos também será buscada após a avaliação final do trabalho realizado.

\subsection{Perfil dos Atores}

Visando o melhor entendimento sobre os fatores que contribuem para a inclusão socioeconômica no SPLT, buscou-se contemplar diferentes perfis de atores locais que pudessem ressaltar aspectos relevantes para a análise final. Os sete perfis contemplados estão destacados no Quadro 8, a seguir. 
INCLUÍDOS (diretos): indivíduos empregados - com ou sem carteira assinada - em empresas privadas do trade turístico, ou aposentados que trabalhavam nesse setor.

INCLUÍDOS (indiretos): indivíduos autônomos, que vendem seus produtos ou oferecem seus serviços diretamente para empresas privadas do trade turístico.

EMPRESÁRIOS: proprietários de estabelecimentos do trade turístico, dentre meios de hospedagem (hotéis, pousadas, resorts, hostels, etc.), equipamentos de gastronomia (restaurantes, bares e lanchonetes), e equipamentos de agenciamento (agências, operadoras e receptivo).

GRUPOS ORGANIZADOS: cooperativas, associações e sindicatos de meios de transporte (voadeiras, toyotas, bugues, táxis e mototáxis), condução de visitantes (guias) e venda de produtos (pequenos produtores rurais e artesãos), que fornecem - direta ou indiretamente - serviços de suporte e produtos para o trade turístico.

\begin{tabular}{|c|c|}
\hline के & $\begin{array}{l}\text { NÃO INCLUÍDOS (diretos): indivíduos empregados - com ou sem carteira assinada - } \\
\text { em outras empresas privadas. }\end{array}$ \\
\hline & $\begin{array}{l}\text { NÃO INCLUÍDOS (indiretos): indivíduos autônomos que não vendem seus produtos ou } \\
\text { não oferecem seus serviços diretamente para empresas privadas do trade turístico. }\end{array}$ \\
\hline & $\begin{array}{l}\text { DESEMPREGADOS E APOSENTADOS: indivíduos que não possuem trabalho ou } \\
\text { emprego, nem mesmo realizam algum tipo de atividade geradora de renda, e que estão } \\
\text { à procura de emprego. Aposentados que não trabalhavam no setor de turismo. }\end{array}$ \\
\hline
\end{tabular}

\section{Quadro 8: Perfil dos Atores}

Fonte: próprio autor.

A abrangência de diferentes perfis de atores contribuiu para o esclarecimento de dúvidas centrais sobre os fatores de inclusão socioeconômica no Turismo, tais como:

- Empresários: Quais fatores influem, com maior significância, no momento de contratar um indivíduo para determinada função? E quais fatores influem, com maior significância, no processo de compra de produtos ou contratação de serviços específicos?

- Incluídos: Quais fatores contribuíram, com maior significância, para que conseguissem o emprego, para que conseguissem vender seus produtos, ou oferecer seus serviços, diretamente aos estabelecimentos do trade turístico?

- Não Incluídos, Desempregados e Aposentados: Em algum momento buscaram por emprego no setor de Turismo? Ou mesmo, buscaram vender seus produtos ou oferecer 
seus serviços diretamente ao trade turístico? Por que buscaram? Por que não buscaram? Por que não conseguiram? Quais os fatores que influenciaram, com maior significância, para que não conseguissem o emprego, ou mesmo não conseguissem oferecer seus produtos e serviços?

- Grupos Organizados: Quais as maiores dificuldades enfrentadas pelo grupo para se inserir, competitivamente, no mercado turístico? Quais os fatores influem, com maior significância, para que consigam vender seus produtos ou oferecer seus serviços no SPLT?

\subsection{Fatores Avaliados}

Os fatores avaliados nesta pesquisa foram definidos pensando-se nas múltiplas caraterísticas que poderiam contribuir para que um indivíduo, ou um grupo de indivíduos, consiga um emprego ou mesmo consiga oferecer seus produtos ou serviços diretamente no mercado turístico.

Muitos desses fatores já haviam sido destacados, em estudos e trabalhos técnicos pretéritos, como empecilhos para a efetivação de empregos formais (RAMOS, 1997; SEGNINI, 2000; SAWYER; TASSO; ASSAD; 2010; COSTA, NASCIMENTO, 2009; TASSO, 2011; AGUIAR, 2013) ou para a efetivação de vendas diretas de produtos (ISPN, 2011; CAPELLESSO \& CAZELLA, 2013; MERJIN, 1989; VINH, 2008; BRASIL, 2011b, IABS, 2008a).

Como ressaltado no primeiro capítulo desta tese, os fatores de inclusão socioeconômica foram subdivididos em dois grupos: "diretos" (inclusão direta no mercado de trabalho turístico, por meio do emprego formal) e "indiretos" (inclusão direta de produtos e serviços, por meio da comercialização e realização de atividades de suporte). As justificativas para a escolha de cada um dos fatores definidos encontram-se no Quadro 9 e no Quadro 10, a seguir:

\section{FATORES DE INCLUSÃO SOCIOECONÔMICA "DIRETA"}

Gênero: pode influenciar, ou mesmo determinar, a escolha por um candidato à vaga em funções específicas, tais como camareira, segurança/vigia noturno ou cozinheira.

Idade: assim como o gênero, a idade também pode ser decisiva nos processos de seleção de um candidato a vagas em funções específicas, quando jovens poderiam ser favorecidos (em funções que exijam melhor aptidão física) e os mais velhos preteridos. 
Religião: o segmento religioso pode ser um obstáculo na busca por oportunidades de emprego e efetivação do candidato, dado que algumas religiões condenam a realização de trabalhos assalariados em determinados dias da semana, dentre outras imposições aos seus seguidores que podem ser contrárias àquelas identificadas no setor turístico.

Rede de relações sociais: a busca por pessoas próximas (tratadas pelos empresários como "de confiança") pode fazer com que a indicação por conhecidos, para compor o quadro de funcionários de estabelecimentos turísticos, seja um fator que contribua diretamente para a inclusão de habitantes locais no SPLT. A ausência de um contato interno, que indique o candidato interessado, pode resultar num impedimento ao acesso ao emprego.

Acesso à informação/conhecimento da área: o conhecimento sobre a dinâmica da atividade turística, os setores que o compõem, os atrativos turísticos locais, os atores envolvidos, pode contribuir para o acesso ao emprego no setor. Empreendedores do trade podem valorizar candidatos que, independente da função desempenhada, sejam bem informados sobre o contexto turístico local, e que estejam aptos a esclarecer dúvidas de visitantes. A carência de informações pode ter um efeito inverso.

Local de nascimento: a tendência natural de que um número crescente de habitantes locais venha a buscar por oportunidades de emprego no setor de turismo, e conseguir, dado ao aumento gradativo da atividade nas regiões, pode ter um movimento contrário com 0 surgimento de um estigma qualquer em relação aos nativos.

Grau de escolaridade: 0 alto índice de instrução formal dos candidatos à vaga de emprego no setor turístico pode ser um elemento favorável, ou mesmo determinante, para sua inclusão. Funções específicas podem exigir, como aspecto primordial, mais do que em outras funções, um alto grau de escolaridade daqueles que pretendem desenvolvê-la. Por outro lado, algumas funções podem não ter a mesma exigência quanto ao nível de instrução formal (ou mesmo desconsiderá-la), primando por outros aspectos.

Experiência (familiar) anterior: a experiência anterior em funções específicas do quadro de atividades do setor de turismo pode ser vista, pelos empresários, tanto como um aspecto positivo quanto negativo. Positivo: o funcionário contratado não precisará de um acompanhamento próximo, demandando menos tempo no detalhamento de sua função e em sua capacitação. Ele poderá, ainda, por meio de sua experiência anterior, preencher lacunas e corrigir problemas que possa já ter vivenciado com o mesmo trabalho em outros 
estabelecimentos. Negativo: o mesmo funcionário pode trazer consigo "vícios" na função, decorrente de orientações distintas aprendidas em outros estabelecimentos, o que demandaria tempo para sua correção.

É digno de nota que a experiência, muitas vezes obtida pelo aprendizado repassado entre pessoas da mesma família, ou mesmo pelo desenvolvimento da função em múltiplos estabelecimentos, pode ter outras interpretações pelos contratantes: muita experiência pode ser sinônimo de alta exigência salarial; rotatividade negativa pela falta de comprometimento com um único local de trabalho.

Capacitação profissional: a capacitação profissional obtida por meio de cursos técnicos especializados voltados ao desenvolvimento de funções no setor de turismo pode ser um fator que contribui, ou mesmo determina, a inclusão socioeconômica no SPLT. Por outra perspectiva, a mão de obra local agregada ao setor não necessariamente necessite de tal capacitação para a desempenho de atividades que mereçam pouca, ou nenhuma, qualificação.

Proximidade física do local onde a atividade turística se desenvolve: 0 amplo distanciamento físico entre o local de moradia dos habitantes e o espaço onde se encontram grande parte dos estabelecimentos do trade turístico pode: (a) desestimular a procura de empregos por interessados; (b) dificultar o deslocamento diário para a realização de sua função no estabelecimento; (c) prejudicar o estabelecimento em atividades matinais, pelas constantes faltas imprevistas de funcionários para o café da manhã, dado ao difícil meio de acesso ao local de trabalho. A maior proximidade pode ser estimulante.

Participação em cooperativas e/ou associações: em determinadas circunstâncias, a organização coletiva pode ser a única forma de habitantes locais se inserirem no SPLT, seja por meio de cooperativas, associações ou sindicatos. A organização formal de grupos de trabalho pode criar uma estrutura de atendimento e suporte ao desenvolvimento do setor como pelo trabalho de guias turísticos e transportes credenciados - que seja privilegiada pelo trade em razão de outros indivíduos que não participem de grupos organizados.

Quadro 9: Fatores de Inclusão Socioeconômica "Direta"

FONTE: próprio autor. 


\section{FATORES DE INCLUSÃO SOCIOECONÔMICA "INDIRETA"}

Problemas quanto à emissão de nota fiscal: dentre as muitas exigências de grande parte dos estabelecimentos de médio e grande porte - em especial os resorts - a apresentação de notas fiscais pelos fornecedores, para a efetivação das compras de produtos, pode ser um fator determinante que limita a comercialização direta com pequenos produtores rurais locais. A prática de emissão desse documento fiscal pode, por outro lado, contribuir direta e substancialmente com a venda de produtos pelos grupos de pequenos produtores.

Empecilhos quanto às condições de pagamento: os subsetores de grandes redes hoteleiras responsáveis pelos pedidos, controle de estoque, pagamentos e cobranças (financeiro), acabam por demandar não apenas a emissão da nota fiscal por seus fornecedores, como também prazos para a efetivação do pagamento. Tais prazos chegam a uma média de até 20 dias, o que prejudica os pescadores que necessitam do recurso financeiro de imediato com o ganho da pesca para suprimento de suas necessidades báscias. O prazo de pagamento pode ser, então, um obstáculo para a inclusão socioprodutiva no SPLT. Vale ressaltar, ainda, que alguns estabelecimentos realizam seus pagamentos apenas por transferência bancária, o que dificulta ainda mais o desenvolvimento da comercialização. Nesse sentido, a presença dos atravessadores se torna evidente, ao ponto em que eles realizam - ainda que por vezes de forma desonesta e com abusiva exploração dos produtores - o pagamento imediato do produto, e mesmo, em parte, antecipadamente.

Problemas quanto à adequação da produção à sazonalidade do turismo: o descompasso entre a sazonalidade do turismo, e a sazonalidade de algumas espécies de pescados e de frutas típicas das regiões estudadas, pode ser um segundo obstáculo para a inclusão socioprodutiva. Períodos de alta temporada, por vezes, coincidem com períodos de defeso de pescados ou de estiagem nas lavouras. Produtos muito procurados pelos estabelecimentos locais, para oferecimento aos turistas, como é o caso do camarão, acabam sendo encontrados apenas congelados nas capitais dos estados, vindos de outras regiões do país. Ou, em menor quantidade, nas peixarias municipais que estocam o produto. A sazonalidade do turismo também interfere diretamente na produção rural, dado que em períodos de baixa temporada, o consumo é drasticamente reduzido, e os produtores prejudicados. Dessa forma, por parte dos produtores, não há como se garantir a regularidade no fornecimento (por todo o ano) dos 
produtos exigidos. E por parte dos estabelecimentos, não há como se garantir a compra constante, dado aos períodos de baixa temporada.

Falta de capital de giro, de estrutura de beneficiamento e de local de estocagem: a ausência de um alicerce econômico que cubra os muitos custos nos processos produtivos é uma realidade comum a todos os grupos de pequenos produtores rurais, nas duas regiões. Pescadores, mesmo com embarcações próprias, não possuem renda suficiente para arcar com gastos como iscas, gelo para acondicionamento dos pescados, óleo diesel para o barco, comida ("rancho") para a tripulação, dentre outros. Os agricultores, em geral, não têm recurso para a compra de embalagens para os doces produzidos, caixas térmicas para manter a qualidade e frescor das frutas, gás de cozinha, ou mesmo recurso para o pagamento dos transportes.

Outra questão tangente, que pode somar-se como fator limitante de inclusão, é a preferência de alguns estabelecimentos do trade pela compra de produtos já beneficiados, como pescados eviscerados apresentados em filés e postas, ou frutas em forma de doces e polpas. Para tanto são necessárias estruturas físicas com equipamentos específicos e apropriados para sua correta produção. Mais do que isso. Para o acondicionamento do produto beneficiado, ou até mesmo para a conservação de produtos sazonais, necessita-se de locais adequados para estocagem, que mantenham a qualidade dos produtos.

Nesse aspecto, atravessadores ganham espaço e se sobressaem sobre os grupos de pequenos produtores rurais que, por não disporem dessa infraestrutura (ou por possuírem algo semelhante, em péssimas condições), mantêm-se distantes do mercado de turismo.

Insuficiência na produção para atendimento da demanda: alguns aspectos como a provisão da quantidade necessária e a manutenção do padrão de oferecimento dos produtos e dos serviços são outras exigências às quais grupos de pequenos produtores, por vezes, não conseguem cumprir. Períodos de alta temporada turística demandam uma produção em grande escala. Porém, a produção desses grupos, por ser ainda notoriamente limitada, pode acabar dando lugar à comercialização do trade diretamente com atravessadores, que possuem melhores estruturas de atendimento às necessidades dos mesmos e garantem, na maioria dos casos, o padrão e a quantidade demandados.

Indisponibilidade logística para o escoamento da produção: a falta de meios de transporte para escoamento dos produtos até os estabelecimentos turísticos também pode se configurar 
como um notório obstáculo. Os grupos não dispõem de carros tracionados com estrutura interna para acondicionamento e entrega dos produtos, como os atravessadores. A dificuldade no acesso a algumas áreas rurais, principalmente em períodos de chuva, é outro fator que limita o escoamento. O sistema de comunicação, em algumas áreas, também é falho, o que prejudica o contato com os compradores.

Falta de capacitação profissional técnica e gerencial: lacunas técnicas e gerenciais na organização dos grupos de produtores podem ser identificadas como barreiras que impedem a inclusão socioprodutiva. Necessidades básicas como cursos de beneficiamento de produtos, de boas práticas de fabricação e de higiene pessoal, somam-se aos problemas de má gerenciamento da produção, dos gastos, do estoque, das receitas. Todo o trabalho que pode ser identificado em arranjos produtivos locais, realizado sem o suporte de ferramentas técnicas e informatizadas, tendem a um sistema organizacional arcaico. Os processos de beneficiamento dos produtos, de modo a manter uma padronização para o mercado, são difíceis de serem assimilados. A ausência de acompanhamento técnico em todas as etapas, desde o manejo, passando pelo beneficiamento do produto, até a entrega, resulta em falhas na cadeia produtiva e, consequentemente, no desagrado dos compradores.

Fragilidade na organização coletiva do trabalho: este obstáculo ganha um caráter essencialmente cultural e, por vezes, político. Tomadas de decisões realizadas sem um número expressivo de cooperados; falta de participação efetiva em cursos técnicos oferecidos por organismos locais; falta de comprometimento e de sensibilização com projetos de desenvolvimento nas regiões estudadas; falta de consenso, entre membros dos grupos comunitários, sobre aspectos intrínsecos ao trabalho, como a necessidade de readequação dos hábitos produtivos, e das funções desempenhadas no grupo; posicionamentos contrários de integrantes de grupos de cooperados quanto à implantação de novos projetos de fortalecimento produtivo, por fazerem analogia às ações e campanhas políticas das Prefeituras Municipais, que apoiam essas ações. Essas são algumas das muitas características dessa fragilidade da autogestão.

Dificuldades na obtenção de registros de serviços de inspeção sanitária (SIF / SIE / SIM): o SIF é um sistema nacional de avaliação e controle da produção de alimentos, comestíveis ou não, de origem animal. Implantado pelo Ministério da Agricultura, Pecuária e Abastecimento do Brasil - MAPA (BRASIL, 2013a), o selo "S.I.F" atesta a qualidade sanitária e a conformidade do produto com a legislação brasileira. Suas classificações, exigências e critérios vão de 
acordo com a abrangência de comercialização do produto, podendo ser solicitada a inspeção pelos órgãos competentes ${ }^{54}$ para venda interestadual ou internacional (SIF), intermunicipal no próprio estado (SIE), ou apenas para o próprio município (SIM). O intuito desses serviços é o de reduzir a clandestinidade da produção e do comércio de produtos de origem animal sem as devidas precauções higiênico-sanitárias, podendo disseminar doenças como tuberculose, salmonelose, listeriose, brucelose e teniose. Contudo, as exigências para se atingir um padrão de qualidade que permita a obtenção do selo (mesmo o SIM), ainda estão distantes da realidade dos pequenos produtores rurais. São solicitadas, dentre outros: a vistoria do terreno onde se pretende construir o local de beneficiamento dos produtos; a apresentação de documentos como alvará de funcionamento, licença ambiental, plantas e memoriais; atendimento de regulamentos técnicos; análise laboratorial, fiscal e de controle de processo e de monitoramento da qualidade das matérias-primas, insumos e produtos; além da presença de um responsável técnico (BRASIL, 2013b). Por conta disso, muitos estabelecimentos do trade adquirem produtos nas capitais dos estados, em grandes frigoríficos, supermercados e peixarias, que atestam a qualidade por meio de selos de inspeção sanitária. Esse fator pode se configurar num obstáculo para a inclusão socioprodutiva.

\section{Quadro 10: Fatores de Inclusão Socioeconômica "Indireta"}

FONTE: próprio autor.

Por meio da análise e teste dos fatores supracitados foi possível considerar, ao final da pesquisa, a partir de uma reflexão crítica, quais os fatores de maior e menor contribuição e influência nos processos de inclusão socioeconômica direta e indireta no SPLT.

\subsection{Pesquisa de Campo}

A realização das pesquisas de campo visou o levantamento de dados primários por meio da: (a) aplicação de questionários (survey) com as populações locais dos dois municípios; (b) aplicação de formulários com atores do SPLT, dentre empresários, indivíduos incluídos e grupos organizados; (c) entrevistas não estruturadas e semi-estruturadas com atores do SPLT.

\footnotetext{
${ }^{54}$ Superintendência Federal de Agricultura (para "SIF”), Secretaria Estadual de Agricultura (para "SIE"), Secretaria Municipal de Agricultura (para "SIM").
} 


\subsubsection{Survey}

Para a aplicação do survey foi realizado o desenho de uma amostra probabilística para cada um dos destinos turísticos estudados, determinando o tamanho de cada amostra com base na estimativa da proporção populacional. A fórmula utilizada é apresentada na Figura $\mathbf{5 0 .}$

$$
n=\frac{N \cdot \hat{p} \cdot \hat{q} \cdot\left(Z_{\alpha / 2}\right)^{2}}{\hat{p} \cdot \hat{q} \cdot\left(Z_{\alpha / 2}\right)^{2}+(N-1) \cdot E^{2}}
$$

Figura 50: Fórmula utilizada para o cálculo da amostra FONTE: MALHOTRA, 2001.

Onde: "n" = número de indivíduos na amostra; "N" = tamanho da população; "Zळ/2" = valor crítico que corresponde ao grau de confiança desejado; "p" = proporção populacional de indivíduos que pertence a categoria estudada; "q" = proporção populacional de indivíduos que não pertence a categoria estudada; e "E" = margem de erro.

Após o cálculo, utilizando um grau de confiança de 95\% (valor crítico de 1,96), margem de erro de $5 \%(0,05)$, "p" = 0,5, "q" = 0,5, e com as populações de 54.930 (Barreirinhas) e 17.002 (Jijoca de Jericoacoara), as amostras finais ficaram em: 381 questionários para Barreirinhas e 375 questionários ${ }^{55}$ para Jijoca de Jericoacoara. A unidade escolhida para aplicação do survey foi a unidade "domiciliar".

Visando o auxílio na aplicação dos questionários, foram selecionados jovens estudantes do ensino médio em cada um dos municípios. Em Barreirinhas foram capacitados, aproximadamente, 20 jovens estudantes integrantes de um projeto social local conhecido como "Projeto Ação e Arte". Em Jijoca de Jericoacoara trabalhou-se com, aproximadamente, 14 jovens estudantes integrantes de um grupo organizado (cooperativa) de produtores rurais de cajuína, conhecido como "CoopCaju".

A capacitação dos grupos de entrevistadores se deu por meio oficinas, tendo como conteúdo programático os seguintes tópicos de discussão:

(a) O que é uma pesquisa?

(b) Sobre o que se trata esta pesquisa em específico?

55 O número real de questionários válidos em Jijoca de Jericoacoara superou a quantidade amostral definida, sendo então considerado o total de 395. 
(c) Qual é o objetivo da pesquisa e onde ela será desenvolvida?

(d) Como será realizada a pesquisa?

(e) O que é um questionário, como instrumento de coleta de informação, e para que ele serve? - Apresentação do questionário ao grupo de entrevistadores (modelo no Apêndice 1);

(f) Quais são as funções e obrigações do entrevistador na pesquisa?

(g) Quais são os erros comuns de um entrevistador?

(h) Quais serão os entrevistados e como se apresentar para realizar a entrevista?

(i) Leitura do questionário;

(j) Levantamento de dúvidas e esclarecimentos.

Como uma primeira atividade teste ("pré-teste"), os grupos de entrevistadores aplicaram, por entrevistador, um questionário com moradores próximos ao local de realização da oficina, e retornaram com o questionário preenchido para análise e esclarecimentos sobre eventuais erros cometidos. Os erros foram discutidos coletivamente, e os entrevistadores orientados como deveriam proceder para evita-los.

A partir do esclarecimento de todas as dúvidas, foram entregues crachás de identificação aos entrevistadores, nos quais constavam o nome do entrevistador e a instituição a qual o mesmo estava representando (no caso, o Centro de Desenvolvimento Sustentável da Universidade de Brasília - CDS/UnB).

Com o auxílio de mapas de ruas e de avenidas referentes aos dois municípios estudados, os entrevistadores, devidamente identificados, foram distribuídos por bairros/regiões, dentre áreas urbanas e rurais.

Buscou-se, com a pesquisa, abranger toda a extensão territorial dos dois municípios, em especial regiões que melhor representassem seus respectivos contingentes populacionais, ou seja, comunidades rurais e urbanas (além das áreas centrais de cada município) que possuíssem um número expressivo de residências. Foram atingidas comunidades ribeirinhas e essencialmente rurais afastadas das sedes (centro) das localidades.

Em Barreirinhas, além das áreas adjuntas ao centro, foram abrangidas comunidades mais distantes, dentre elas: Tapuio, Mandacaru, Atins, Laranjeiras, Tabocas, Gambá, Vassouras, Morro do Boi, Ponta do Mangue, Bar da Hora, Residencial Brasil, Carnaubal, Santa Cruz, Santa Rita, Rio Novo, Chapadinha, Santarém, Cardosa, Murici, Barreira Velha, Sicuruju, Mucambo, Ladeira, Mata Fome, Cangote, Faixo do Tangue, Morro Alto, Vila Anselmo, Riacho do Meio, 
Arraial, Estivo, Buriti, Palmeira dos Reis, Pedras, Marcelino, Tambuí, Poços, Carnaubeira, Sobradinho, Boa Vista, Aeroporto Novo, Jabuti, Varas, Santo Antônio, Caburé, Braço, Morro Alto, Santo Inácio, Canto do Atins, São José dos Viúvos, Pacas, Palmeiras dos Eduardo, Pequizeiro, Baixa D’Água, Fazendinha, Olho d'Água, Santa Maria, Engenho, Canoas, Manoelzinho, Croas, Baixão do Pomoaldo, Baixão dos Paulino, Anibal, Massangano I, Massangano II, Massangano III, Caboclo I, Caboclo II, Bom Passar, Paú, , Móia, São Domingos e Cantinho.

Da mesma forma se procedeu em Jijoca de Jericoacoara. As comunidades contempladas, além daquelas adjuntas à sede, foram: Córrego do Urubu I, Córrego do Urubu II, Mangue Seco, Lagoa Grande, Córrego de Dentro, Baixio I, Baixio II, Córrego do Mourão, Córrego da Forquilha I, Córrego da Forquilha II, Córrego da Forquilha III, Chapadinha, Borges, Jericoacoara (Vila), Carro Quebrado, Córrego Perdido e Vila do Aeroporto.

Os questionários foram aplicados todos os dias da semana, entre 09:00 e 21:00 horas, unicamente em domicílios. Foi determinado que deveriam ser entrevistados apenas indivíduos com idade igual ou superior a 16 (dezesseis) anos, presentes no domicílio no momento da entrevista. A escolha de cada um dos domicílios pelos pesquisadores seguiu um método específico, definido da seguinte forma:

a) o entrevistador se deslocava para o lado direito da rua em que havia sido previamente orientado a aplicar os questionários;

b) caminhava pela frente das três primeiras casas da rua;

c) tentava aplicar o questionário na quarta casa;

d) se conseguisse aplicar o questionário, o entrevistador deveria dar prosseguimento na atividade repetindo a ação até o final da rua, passando, em seguida, para o outro lado da rua;

e) se não conseguisse aplicar o questionário, o entrevistador deveria se deslocar à casa da esquerda e tentar aplicar nesse domicílio. Caso ainda não conseguisse, o entrevistador deveria se deslocar à casa da direita.

f) em casa de insucesso (casas vazias) deveria retomar o mesmo procedimento, passando por mais três casas e entrevistando as pessoas da quarta casa.

Tal método destacado não pôde ser reproduzido, com a mesma exatidão, em algumas pequenas comunidades ribeirinhas (de pescadores artesanais), ou ainda, em pequenas comunidades rurais (de agricultores familiares). Nessas regiões foram encontradas poucas residências, em sua maioria afastadas umas das outras. Em casos como esse, os 
entrevistadores buscaram abranger aqueles domicílios localizados em espaços próximos ao Rio Preguiças (em Barreirinhas) ou próximos às praças e vilas centrais, atingindo, por vezes, domicílios sequenciais.

Para o acesso às comunidades ribeirinhas de Barreirinhas, ao longo do Rio Preguiças, foram utilizados serviços de transporte aquaviário, embarcações de pequeno porte, a motor, conhecidas na região como "voadeiras".

Os questionários preenchidos foram analisados pelo pesquisador, com olhar crítico, buscando identificar possíveis problemas no preenchimento dos mesmos. Após, foram sorteados $10 \%$ do total de questionários aplicados em cada região para a certificação de correta realização da atividade, retornando até o domicílio selecionado.

As últimas atividades da etapa de aplicação do survey foram: (a) pagamento dos grupos de entrevistadores; (b) sistematização, tabulação e codificação dos dados obtidos; (c) criação das bases de dados no software SPSS 20.0 com os dados obtidos; (d) análise crítica dos resultados.

\subsubsection{Formulários}

A aplicação dos formulários (Apêndice 2, Apêndice 3 e Apêndice 4) teve como alvo de investigação os empresários do trade turístico, os indivíduos incluídos no SPLT, e os grupos organizados com trabalhos tangentes ao setor.

Quanto aos empresários, buscou-se abranger estabelecimentos de pequeno, médio e grande porte, localizados, em maior proporção, na sede de Barreirinhas e na Vila de Jericoacoara. De toda forma, foram contemplados alguns estabelecimentos fora dessas zonas de maior concentração do trade, como estabelecimentos na sede de Jijoca de Jericoacoara e afastados do centro de Barreirinhas.

O foco da aplicação dos formulários nos estabelecimentos do trade esteve em proprietários ou gerentes de hotéis, pousadas, resorts, restaurantes, bares, agências de turismo e operadoras. Ao todo foram abrangidos 58 (cinquenta e oito) estabelecimentos em Barreirinhas e 60 (sessenta) estabelecimentos em Jijoca de Jericoacoara, selecionados aleatoriamente.

Os formulários foram aplicados em períodos de alta e baixa estação (específicas de cada destino) para que estabelecimentos que mantenham suas atividades apenas em períodos de alta também fossem cobertos pela pesquisa. 
É importante destacar que, durante a realização da pesquisa, mesmo tendo como referência informações atualizadas da Secretaria de Turismo de Barreirinhas e do Inventário da Oferta Turística de Jijoca de Jericoacoara (pelo Sistema de Inventariação da Oferta Turística do Ministério do Turismo), é improvável que se consiga mensurar o número exato de estabelecimentos em cada destino. A dinâmica de encerramento de atividades, mudanças de proprietários, troca de nomes do estabelecimento, criação de novos empreendimentos, é constante.

Quanto aos indivíduos incluídos, selecionados também de forma aleatória ${ }^{56}$, buscou-se atingir as mais diversas funções desenvolvidas por eles nos estabelecimentos. Foram entrevistados incluídos nas funções mais frequentes encontradas nos destinos, como camareiras, chefs de cozinha, auxiliares de cozinha, secretárias/telefonistas, segurança/vigias noturnos, garçom/garçonete, receptivo (agentes de turismo), responsáveis por serviços gerais e recepcionistas.

O total de indivíduos incluídos no SPLT entrevistados foi de 74 (setenta e quatro) pessoas em Barreirinhas, e 95 (noventa e cinco) pessoas em Jijoca de Jericoacoara. O método se deu pela entrevista de até dois funcionários, em funções distintas, dos próprios estabelecimentos que haviam sido selecionados para a entrevista com os empresários.

$\mathrm{Na}$ vila de Jericoacoara as entrevistas puderam ser mais facilmente ampliadas, dado que muitos funcionários dos estabelecimentos do trade se deslocam até a praça central para descansarem, durante o período de almoço, o que permitia o acesso à uma maior concentração de atores.

Por fim, no caso dos grupos organizados, foram abrangidas associações e cooperativas de guias e condutores de turismo, bugueiros, artesãos, toyoteiros, agricultores familiares, pescadores artesanais, pilotos de voadeiras, mototaxistas e taxistas, das regiões dos dois municípios.

Por se encontrarem em menor número (grupos com características essencialmente de suporte turístico) buscou-se abranger todos os principais de cada região. Ao todo foram nove grupos em Barreirinhas e nove grupos em Jijoca de Jericoacoara.

\footnotetext{
${ }^{56}$ Ao final de cada entrevista realizada com proprietários ou gerentes, buscou-se aplicar alguns formulários com empregados (de diversas funções) do próprio estabelecimento abrangido, de acordo com a disponibilidade dos mesmos e com a autorização de seus superiores.
} 


\subsubsection{Entrevistas}

As entrevistas não estruturadas realizadas serviram para ressaltar alguns aspectos intrínsecos à pesquisa que, direta ou indiretamente, afetam os processos de inclusão socioeconômica nos dois destinos. Foram realizadas entrevistas não estruturadas com indivíduos incluídos que puderam apresentar informações até então pouco discutidas, como: a falta de segurança no transporte de trabalhadores no trajeto entre os locais de moradia e trabalho; a falta de auxílio financeiro para o pagamento do transporte; o não cumprimento dos encargos trabalhistas; dentre outros.

No caso das entrevistas semi-estruturadas, essas tiveram como objetivo central o aprofundamento, junto aos empresários, na discussão sobre os fatores destacados com maior frequência de respostas nos dois municípios. 


\section{CAPÍTULO 3: ANÁLISE DOS RESULTADOS E REFLEXÃO}

O Capítulo 3 tem como objetivo apresentar a análise dos dados obtidos nas duas pesquisas de campo, organizados e sistematizados para tratamento com o suporte operacional dos softwares SPSS 20.0 e Free R. Foram utilizadas expressões gráficas, tabelas, quadros e boxes informativos, organizados e apresentados por três tópicos:

1. Análise Estatítica Descritiva dos Dados Gerais da Pesquisa

2. Análise Estatística Inferencial pela Modelagem da Regressão Logística

3. Interpretação dos Fatores

A análise da frequência de respostas se deu por percentagens válidas, entendidas no presente estudo como a percentagem total de respostas subtraída a percentagem de respostas perdidas ou faltantes (provavelmente pelo não preenchimento de alguma lacuna no questionário/formulário no momento da aplicação).

\section{ANÁLISE DESCRITIVA DOS DADOS GERAIS DA PESQUISA}

Visando facilitar a identificação e análise das representações gráficas das informações, serão utilizadas as cores verde e azul para distinguir os dados de Barreirinhas e de Jijoca de Jericoacoara, respectivamente.

\subsection{Total de Entrevistados}

O universo da pesquisa, também entendido como "população-alvo" (BARBETTA, 1998), foi composto por quatro grupos de interesse, em cada município estudado: população local; indivíduos incluídos; empresários do trade turístico; e grupos organizados com atividades tangentes ao setor turístico. O total de entrevistados de cada grupo, em cada região, é apresentado a seguir, no Quadro 11.

\begin{tabular}{|l|c|c|}
\cline { 2 - 3 } \multicolumn{1}{c|}{} & BARREIRINHAS & JIJOCA DE JERICOACOARA \\
\hline População Local & 381 & 395 \\
\hline Incluídos & 74 & 95 \\
\hline Empresários & 58 & 60 \\
\hline Grupos Organizados & 09 & 09 \\
\hline
\end{tabular}

Quadro 11: Universo da Pesquisa

Fonte: pesquisa do autor. 


\subsection{Gênero}

No que tange a realização do survey com as populações locais de Barreirinhas e de Jijoca de Jericoacoara, houve uma maior frequência de entrevistas com indivíduos do sexo feminino em ambas localidades. No primeiro município atingiu-se 53,5\% (204 mulheres) do total e, no segundo município, 63,0\% (249 mulheres).

Com relação aos empresários entrevistados, a relação se inverte. Nos dois municípios, a frequência de proprietários, de gerentes e demais responsáveis presentes, do sexo masculino, foi superior. Em Barreirinhas chegou a 58,6\% (34 homens) e em Jijoca 53,3\% (32 homens).

A pesquisa junto aos incluídos foi bem equilibrada quanto ao gênero, nos dois municípios. Em Barreirinhas houve uma distribuição homogênea (50\% - 37 indivíduos para cada gênero) e, em Jijoca, com uma pequena margem superior para os indivíduos do gênero feminino $(51,6 \%$ 49 mulheres).

Dos representantes de grupos entrevistados, por sua vez, prevaleceram os homens, em ambas localidades. Em Barreirinhas foram oito (88,9\%) entrevistados do sexo masculino, e em Jijoca seis $(66,7 \%)$. As informações completas estão destacadas na Tabela 21, a seguir.

Tabela 21: Gênero

\begin{tabular}{|c|c|c|c|c|c|c|c|c|c|}
\hline & & \multicolumn{8}{|c|}{ BARREIRINHAS } \\
\hline & & \multicolumn{2}{|c|}{ População } & \multicolumn{2}{|c|}{ Empresários } & \multicolumn{2}{|c|}{ Incluídos } & \multicolumn{2}{|c|}{ Grupos } \\
\hline & & Frequency & Percent & Frequency & Percent & Frequency & Percent & Frequency & Percent \\
\hline \multirow{6}{*}{$\begin{array}{l}\frac{\overline{0}}{\pi} \\
>\end{array}$} & masculino & 177 & 46.5 & 34 & 58.6 & 37 & 50.0 & 8 & 88.9 \\
\hline & feminino & 204 & 53.5 & 24 & 41.4 & 37 & 50.0 & 1 & 11.1 \\
\hline & Total & 381 & 100.0 & 58 & 100.0 & 74 & 100.0 & 9 & 100.0 \\
\hline & & \multicolumn{8}{|c|}{ JIJOCA DE JERICOACOARA } \\
\hline & & \multicolumn{2}{|c|}{ População } & \multicolumn{2}{|c|}{ Empresários } & \multicolumn{2}{|c|}{ Incluídos } & \multicolumn{2}{|c|}{ Grupos } \\
\hline & & Frequency & Percent & Frequency & Percent & Frequency & Percent & Frequency & Percent \\
\hline \multirow{3}{*}{$\frac{\text { 음 }}{>}$} & masculino & 146 & 37.0 & 32 & 53.3 & 46 & 48.4 & 6 & 66.7 \\
\hline & feminino & 249 & 63.0 & 28 & 46.7 & 49 & 51.6 & 3 & 33.3 \\
\hline & Total & 395 & 100.0 & 60 & 100.0 & 95 & 100.0 & 9 & 100.0 \\
\hline
\end{tabular}

Fonte: pesquisa do autor.

\subsection{Idade}

A idade dos entrevistados (ver Tabela 22) variou entre 16 anos de idade (mínima) e 78 anos. A faixa etária com maior frequência entre os entrevistados das populações locais, em ambas localidades, foi entre 25 e 34 anos de idade $(31,8 \%$ - 121 pessoas em Barreirinhas, e $26,1 \%$ - 103 pessoas em Jijoca). 
Entre os empresários de Barreirinhas, a faixa etária com maior destaque foi também entre 25 e 34 anos de idade (27,6\% - 16 pessoas). Em Jijoca ficou dividida entre a faixa etária de 25 a 34 anos de idade (33,3\% - 20 pessoas) e a faixa de 45 a 54 anos de idade (33,3\% - 20 pessoas).

Com respeito às faixas etárias dos incluídos, Barreirinhas e Jijoca se diferenciam. A maioria dos entrevistados em Barreirinhas estavam na faixa de 16 a 24 anos (40,5\% - 30 indivíduos). Enquanto que em Jijoca, prevaleceram indivíduos com idades entre 25 e 34 anos (33,7\% - 32 indivíduos).

Entre os representantes dos grupos organizados, tanto em Barreirinhas (55,6\% - 05 indivíduos) quanto em Jijoca (44,4\% - 04 indivíduos), os entrevistados estavam na faixa de 35 a 44 anos de idade.

Tabela 22: Idade

\begin{tabular}{|c|c|c|c|c|c|c|c|c|c|}
\hline & \multicolumn{8}{|c|}{ BARREIRINHAS } \\
\hline & & \multicolumn{2}{|c|}{ População } & \multicolumn{2}{|c|}{ Empresários } & \multicolumn{2}{|c|}{ Incluídos } & \multicolumn{2}{|c|}{ Grupos } \\
\hline & & Frequency & Percent & Frequency & Percent & Frequency & Percent & Frequency & Percent \\
\hline \multirow{10}{*}{$\frac{\overline{0}}{\frac{\pi}{\pi}}$} & 16 a 24 & 109 & 28.6 & 5 & 8.6 & 30 & 40.5 & - & - \\
\hline & 25 a 34 & 121 & 31.8 & 16 & 27.6 & 26 & 35.1 & - & - \\
\hline & 35 a 44 & 74 & 19.4 & 14 & 24.1 & 14 & 18.9 & 5 & 55.6 \\
\hline & 45 a 54 & 47 & 12.3 & 15 & 25.9 & 3 & 4.1 & 2 & 22.2 \\
\hline & 55 ou + & 25 & 6.6 & 8 & 13.8 & - & - & 2 & 22.2 \\
\hline & NR & 5 & 1.3 & - & - & 1 & 1.4 & - & - \\
\hline & Total & 381 & 100.0 & 58 & 100.0 & 74 & 100.0 & 9 & 100.0 \\
\hline & & \multicolumn{8}{|c|}{ JIJOCA DE JERICOACOARA } \\
\hline & & \multicolumn{2}{|c|}{ População } & \multicolumn{2}{|c|}{ Empresários } & \multicolumn{2}{|c|}{ Incluídos } & \multicolumn{2}{|c|}{ Grupos } \\
\hline & & Frequency & Percent & Frequency & Percent & Frequency & Percent & Frequency & Percent \\
\hline \multirow{7}{*}{$\frac{\overline{0}}{\frac{0}{\pi}}$} & 16 a 24 & 66 & 16.7 & 4 & 6.7 & 28 & 29.5 & 1 & 11.1 \\
\hline & 25 a 34 & 103 & 26.1 & 20 & 33.3 & 32 & 33.7 & 2 & 22.2 \\
\hline & 35 a 44 & 80 & 20.3 & 13 & 21.7 & 25 & 26.3 & 4 & 44.4 \\
\hline & 45 a 54 & 58 & 14.7 & 20 & 33.3 & 6 & 6.3 & 2 & 22.2 \\
\hline & 55 ou + & 83 & 21.0 & 3 & 5.0 & 4 & 4.2 & - & - \\
\hline & NR & 5 & 1.3 & - & - & - & - & - & - \\
\hline & Total & 395 & 100.0 & 60 & 100.0 & 95 & 100.0 & 9 & 100.0 \\
\hline
\end{tabular}

Fonte: pesquisa do autor.

\subsection{Local onde reside}

Para a aplicação do survey com as populações locais buscou-se concentrar um maior número de questionários em regiões com maiores concentrações populacionais. Nos dois municípios, de acordo com informações obtidas junto aos Sindicatos de Trabalhadores Rurais das duas localidades, a maior concentração de habitantes está nas sedes (centros) de Barreirinhas e de Jijoca de Jericoacoara. 
Para tanto foram aplicados, aproximadamente, $50 \%$ dos questionários nas sedes municipais e, o restante, distribuído entre as diversas comunidades circunvizinhas. Em Barreirinhas foram entrevistadas 208 pessoas $(54,6 \%)$ em residências do centro municipal. Em Jijoca foram 192 pessoas (48,6\%) entrevistadas na sede de Jijoca. Ver Tabela 23.

Com relação aos dados levantados, referentes aos indivíduos "incluídos", pode-se notar, a partir da Tabela 23, que os entrevistados em Barreirinhas residem, em sua maioria $(81,1 \%$ - 60 pessoas) no centro da cidade, onde a concentração de estabelecimentos do trade é consideravelmente superior que nas outras áreas do município. Em contrapartida, em Jijoca de Jericoacoara, mais da metade $(52,6 \%$ - 50 pessoas) dos trabalhadores incluídos estão distribuídos entre as muitas comunidades circunvizinhas à Vila de Jericoacoara (onde se concentra a grande maioria dos equipamentos turísticos) - ver Tabela 23.

\section{Tabela 23: Local onde mora}

\begin{tabular}{|c|c|c|c|c|c|}
\hline & \multicolumn{4}{|c|}{ BARREIRINHAS } \\
\hline & & \multicolumn{2}{|c|}{ População } & \multicolumn{2}{|c|}{ Incluídos } \\
\hline & & Frequency & Percent & Frequency & Percent \\
\hline \multirow{6}{*}{ 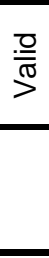 } & Barreirinhas (Centro) & 208 & 54.6 & 60 & 81.1 \\
\hline & Comunidades & 173 & 45.4 & 14 & 18.9 \\
\hline & Total & 381 & 100.0 & 74 & 100.0 \\
\hline & & \multicolumn{4}{|c|}{ JIJOCA DE JERICOACOARA } \\
\hline & & \multicolumn{2}{|c|}{ População } & \multicolumn{2}{|c|}{ Incluídos } \\
\hline & & Frequency & Percent & Frequency & Percent \\
\hline \multirow{4}{*}{$\frac{. \overline{0}}{\frac{.0}{\widetilde{J}}}$} & Jijoca (Centro) & 192 & 48.6 & 23 & 24.2 \\
\hline & Comunidades & 163 & 41.3 & 50 & 52.6 \\
\hline & Vila de Jeri & 40 & 10.1 & 22 & 23.2 \\
\hline & Total & 395 & 100.0 & 95 & 100.0 \\
\hline
\end{tabular}

Fonte: pesquisa do autor.

Além do centro de Barreirinhas, as comunidades circunvizinhas abrangidas foram: (a) Varas, Mata Come, Faixo do Tangue, Riacho do Meio, Arraial, Estivo, Palmeira dos Reis, Buriti, Santa Rita, Marcelino, Tambuí, Carnaubeira, Poços, Cardosa, Murici, Barreira Velha, Sicuruju, Santo Antônio, Jabuti, Carnaubal, Ponta do Mangue, Braço, Santo Inácio, Canto do Atins, São José dos Viúvos, Pacas, Palmeiras dos Eduardo, Pequizeiro, Baixa D’água, Fazendinha, Olho D’água, Santa Maria, Engenho, Canoas, Croas, Baixão do Pomoaldo, Baixão dos Paulino, Aníbal, Massangano I, Massangano II, Massangano III, Caboclo I, Caboclo II, Bom Passar, Paú, Móia, São Domingos e Cantinho (0,3\% - 01 indivíduo cada); (b) Ladeira, Residencial Brasil, Morro Alto, Vila Anselmo, Sobradinho, Mucambo e Santa Cruz (0,5\% - 02 indivíduos cada); (c) Pedras, Aeroporto Novo, Boa Vista, Morro do Boi e Manoelzinho (0,8\% - 03 indivíduos cada); (d) Cangote 
e Caburé (1,0\% - 04 indivíduos cada); (e) Vassouras (1,3\% - 05 indivíduos); (f) Mandacaru, Tabocas e Laranjeiras (1,6\% - 06 indivíduos cada); (g) Bar da Hora (1,8\% - 07 indivíduos); (h) Santarém/Atoleiro (2.4\% - 09 indivíduos); (i) Tapuio (2,9\% - 11 indivíduos); (j) Gambá (3,7\% - 14 indivíduos); (k) Atins (6,3\% - 24 indivíduos).

As comunidades abrangidas em Jijoca de Jericoacoara, por sua vez, foram: (a) Córrego do Urubu II (0,8\% - 03 indivíduos); (b) Córrego do Urubu I, Borges e Chapadinha (1,0\% - 04 indivíduos cada); (c) Carro Quebrado (1,3\% - 05 indivíduos); (d) Córrego Perdido (1,8\% - 07 indivíduos); (e) Córrego da Forquilha I, Baixio Il e Córrego do Mourão (2,5\% - 10 indivíduos cada); (f) Vila do Aeroporto (3,0\% - 12 indivíduos cada); (g) Córrego da Forquilha II (4,3\% - 17 indivíduos); (h) Baixio I (4,8\% - 19 indivíduos); (i) Córrego da Forquilha III (7,1\% - 28 indivíduos); (j) Mangue Seco (7,6\% - 30 indivíduos).

As comunidades específicas dos incluídos, e suas respectivas porcentagens, encontramse destacadas no Apêndice 5.

\subsection{Escolaridade}

Pode-se notar, a partir da Tabela 24, a similitude entre os níveis de instrução formal da maioria dos indivíduos das populações locais entrevistadas. Em ambos municípios, o nível de escolaridade mais frequente entre os entrevistados foi o ensino fundamental incompleto, em $50,4 \%$ (192 pessoas) da população de Barreirinhas, e em 30,9\% (122 pessoas) da população de Jijoca.

Entre os empresários/gerentes do trade, porém, essa similitude entre os destinos se encerra. Barreirinhas apresentou 43,1\% (25 entrevistados) dos empresários na faixa do ensino médio completo. Jijoca, no entanto, apresentou 56,7\% (34 entrevistados) dos empresários na faixa do ensino superior completo, atestando um melhor nível de instrução formal dos mesmos. Ver Tabela 24.

A situação se inverte ao analisar os dados obtidos referentes aos incluídos entrevistados em cada destino - ver Tabela 24. A maior frequência de entrevistados de Barreirinhas atestou possuir o ensino médio completo (41,9\% - 31 indivíduos). No caso de Jijoca, a maior frequência de respostas entre os incluídos foi de um nível de escolaridade notoriamente pior: ensino fundamental incompleto (33,7\% - 32 indivíduos). 
Se analisados apenas os entrevistados incluídos cujo nível educacional não ultrapassa o ensino fundamental completo, poderemos perceber que em Barreirinhas a margem chega a apenas $28,4 \%$ (21 pessoas) dos empregados. Em contrapartida, em Jijoca de Jericoacoara, a margem dos empregados nessas condições chega a, aproximadamente, $58 \%$ (55 pessoas).

No caso do nível de escolaridade dos representantes dos grupos organizados de cada região, há uma concordância entre os destinos (dados na Tabela 24). Tanto em Barreirinhas quanto em Jijoca os maiores índices se concentram no ensino médio completo, atingindo 55,6\% (05 indivíduos) e 33,3\% (03 indivíduos), respectivamente.

\section{Tabela 24: Escolaridade}

\begin{tabular}{|c|c|c|c|c|c|c|c|c|c|}
\hline & \multicolumn{8}{|c|}{ BARREIRINHAS } \\
\hline & & \multicolumn{2}{|c|}{ População } & \multicolumn{2}{|c|}{ Empresários } & \multicolumn{2}{|c|}{ Incluídos } & \multicolumn{2}{|c|}{ Grupos } \\
\hline & & Frequency & Percent & Frequency & Percent & Frequency & Percent & Frequency & Percent \\
\hline \multirow{13}{*}{$\frac{\text { 음 }}{>}$} & sem escolaridade & 24 & 6.3 & - & - & - & - & - & - \\
\hline & fundamental incomplete & 192 & 50.4 & 5 & 8.6 & 16 & 21.6 & 1 & 11.1 \\
\hline & fundamental complete & 26 & 6.8 & 5 & 8.6 & 5 & 6.8 & 1 & 11.1 \\
\hline & médio incomplete & 57 & 15.0 & 3 & 5.2 & 18 & 24.3 & 1 & 11.1 \\
\hline & médio complete & 63 & 16.5 & 25 & 43.1 & 31 & 41.9 & 5 & 55.6 \\
\hline & superior incompleto & 7 & 1.8 & 5 & 8.6 & 2 & 2.7 & 0 & 0.0 \\
\hline & superior completo & 9 & 2.4 & 13 & 22.4 & 2 & 2.7 & 1 & 11.1 \\
\hline & Pós-graduação & - & - & 2 & 3.4 & - & - & - & - \\
\hline & não respondeu & 3 & 0.8 & - & - & - & - & - & - \\
\hline & \multirow[t]{4}{*}{ Total } & 381 & 100.0 & 58 & 100.0 & 74 & 100.0 & 9 & 100.0 \\
\hline & & \multicolumn{8}{|c|}{ JIJOCA DE JERICOACOARA } \\
\hline & & \multicolumn{2}{|c|}{ População } & \multicolumn{2}{|c|}{ Empresários } & \multicolumn{2}{|c|}{ Incluídos } & \multicolumn{2}{|c|}{ Grupos } \\
\hline & & Frequency & Percent & Frequency & Percent & Frequency & Percent & Frequency & Percent \\
\hline \multirow{10}{*}{$\frac{.0}{\frac{\pi}{\pi}}$} & sem escolaridade & 105 & 26.6 & - & - & 7 & 7.4 & - & - \\
\hline & fundamental incompleto & 122 & 30.9 & 2 & 3.3 & 32 & 33.7 & 2 & 22.2 \\
\hline & fundamental completo & 54 & 13.7 & 2 & 3.3 & 16 & 16.8 & 1 & 11.1 \\
\hline & médio incompleto & 32 & 8.1 & 2 & 3.3 & 13 & 13.7 & 0 & 0.0 \\
\hline & médio complete & 62 & 15.7 & 14 & 23.3 & 22 & 23.2 & 3 & 33.3 \\
\hline & superior incompleto & 4 & 1.0 & 4 & 6.7 & 1 & 1.1 & 1 & 11.1 \\
\hline & superior completo & 6 & 1.5 & 34 & 56.7 & 3 & 3.2 & 2 & 22.2 \\
\hline & Pós-graduação & 7 & 1.8 & 2 & 3.3 & - & - & - & - \\
\hline & não respondeu & 3 & 0.8 & - & - & 1 & 1.1 & - & - \\
\hline & Total & 395 & 100.0 & 60 & 100.0 & 95 & 100.0 & 9 & 100.0 \\
\hline
\end{tabular}

Fonte: pesquisa do autor.

\subsection{Religião}

Quanto ao aspecto religioso pôde-se notar que, tanto em Barreirinhas quanto em Jijoca de Jericoacoara, prevaleceu a religião católica nas pesquisas com a população local e com os incluídos. 
Identificou-se, no entanto, uma margem superior de católicos entrevistados em Jijoca, com relação à Barreirinhas. Enquanto que as margens de católicos da população de Jijoca $(86,1 \%$ 340 pessoas) e dos incluídos ( $86,3 \%$ - 82 pessoas) ultrapassaram os $86 \%$, em Barreirinhas as mesmas margens ficaram em $72,2 \%$ (275 pessoas) e 68,9\% (51 pessoas), respectivamente, como apresentado na Tabela 25.

Tabela 25: Religião

\begin{tabular}{|c|c|c|c|c|c|c|c|c|}
\hline & \multicolumn{4}{|c|}{ BARREIRINHAS } & \multicolumn{4}{|c|}{ JIJOCA DE JERICOACOARA } \\
\hline & \multicolumn{2}{|c|}{ População } & \multicolumn{2}{|c|}{ Incluídos } & \multicolumn{2}{|c|}{ População } & \multicolumn{2}{|c|}{ Incluídos } \\
\hline & Frequency & Percent & Frequency & Percent & Frequency & Percent & Frequency & Percent \\
\hline Católica & 275 & 72.2 & 51 & 68.9 & 340 & 86.1 & 82 & 86.3 \\
\hline Espírita & 4 & 1.0 & - & - & 1 & 0.3 & 1 & 1.1 \\
\hline evangélica (de missão) & 3 & 0.8 & 6 & 8.1 & 19 & 4.8 & 1 & 1.1 \\
\hline evangélica (pentecostal) & 18 & 4.7 & 4 & 5.4 & 19 & 4.8 & 6 & 6.3 \\
\hline nenhuma (ateu/agnóst) & 24 & 6.3 & 5 & 6.8 & 5 & 1.3 & 3 & 3.2 \\
\hline ๑ testemunha de Jeová & - & - & - & - & 5 & 1.3 & - & - \\
\hline స్ congregação cristã & - & - & - & - & 1 & 0.3 & 1 & 1.1 \\
\hline$>$ candomblé & - & - & - & - & 1 & 0.3 & 1 & 1.1 \\
\hline não respondeu & 5 & 1.3 & 1 & 1.4 & 2 & 0.5 & - & - \\
\hline adventista & 1 & 0.3 & 2 & 2.7 & - & - & - & - \\
\hline protestante & 51 & 13.4 & 5 & 6.8 & - & - & - & \\
\hline evangélica bíblica & - & & - & - & 2 & 0.5 & - & \\
\hline Total & 381 & 100.0 & 74 & 100.0 & 395 & 100.0 & 95 & 100.0 \\
\hline
\end{tabular}

Fonte: pesquisa do autor.

\subsection{Agrupamento Domiciliar}

A unidade domiciliar da maioria dos entrevistados da população de Barreirinhas é formada por cinco pessoas ${ }^{57}$ (23,4\% - 89 indivíduos). Em Jijoca esse número de moradores numa mesma unidade domiciliar, pela maior frequência de respostas, foi menor, apenas quatro pessoas $(27,6 \%$ - 109 indivíduos). Ver Tabela 26.

Quanto ao grupo dos incluídos, entrevistados em Barreirinhas, a margem ficou entre três e quatro pessoas (20,3\% - 15 indivíduos, cada). No caso dos incluídos de Jijoca, a margem com maior frequência foi de quatro pessoas (29,5\% - 28 indivíduos). Dados na Tabela 26.

A maior parcela dos domicílios das populações locais entrevistadas, de Barreirinhas (35,4\% - 135 pessoas) e de Jijoca de Jericoacoara (37,2\% - 147 pessoas), não possui nenhum indivíduo estudando. Já entre os grupos de indivíduos incluídos constatou-se que, dentre as

\footnotetext{
57 Sendo que as respostas são de quantas pessoas moram na casa além do próprio entrevistado.
} 
pessoas que residem em suas residências, apenas uma, na maioria dos casos, está estudando (37,8\% em Barreirinhas e 30,5\% em Jijoca). Ver Tabela 27.

Tabela 26: Agrupamento Domiciliar

\begin{tabular}{|c|c|c|c|c|c|c|c|c|c|}
\hline & \multicolumn{4}{|c|}{ BARREIRINHAS } & \multicolumn{4}{|c|}{ JIJOCA DE JERICOACOARA } \\
\hline & & \multicolumn{2}{|c|}{ População } & \multicolumn{2}{|c|}{ Incluídos } & \multicolumn{2}{|c|}{ População } & \multicolumn{2}{|c|}{ Incluídos } \\
\hline & & Frequency & Percent & Frequency & Percent & Frequency & Percent & Frequency & Percent \\
\hline & 0.00 & 4 & 1.0 & - & - & 12 & 3.0 & 5 & 5.3 \\
\hline & 1.00 & 24 & 6.3 & 5 & 6.8 & 42 & 10.6 & 9 & 9.5 \\
\hline & 2.00 & 39 & 10.2 & 15 & 20.3 & - & - & 18 & 18.9 \\
\hline & 3.00 & 75 & 19.7 & 15 & 20.3 & 109 & 27.6 & 28 & 29.5 \\
\hline & 4.00 & 89 & 23.4 & 14 & 18.9 & 76 & 19.2 & 21 & 22.1 \\
\hline & 5.00 & 59 & 15.5 & 10 & 13.5 & 38 & 9.6 & 6 & 6.3 \\
\hline & 6.00 & 41 & 10.8 & 4 & 5.4 & 15 & 3.8 & 3 & 3.2 \\
\hline 음 & 7.00 & 22 & 5.8 & 6 & 8.1 & 11 & 2.8 & 2 & 2.1 \\
\hline$>^{\pi}$ & 8.00 & 13 & 3.4 & 2 & 2.7 & 6 & 1.5 & 2 & 2.1 \\
\hline & 9.00 & 5 & 1.3 & 2 & 2.7 & 1 & 0.3 & - & - \\
\hline & 10.00 & 7 & 1.8 & 1 & 1.4 & 2 & 0.5 & - & - \\
\hline & 11.00 & 2 & 0.5 & - & - & - & - & - & - \\
\hline & 12.00 & 1 & 0.3 & - & - & - & - & 1 & 1.1 \\
\hline & 15.00 & - & - & - & - & 1 & 0.3 & - & - \\
\hline & NR & - & - & - & - & 82 & 20.8 & - & - \\
\hline & Total & 381 & 100.0 & 74 & 100.0 & 395 & 100.0 & 95 & 100.0 \\
\hline
\end{tabular}

Fonte: pesquisa do autor.

Foi ressaltado pela maioria dos entrevistados das populações locais, e também pela maioria dos entrevistados dos grupos de incluídos que, nesses mesmos domicílios, apenas uma pessoa possui alguma atividade remunerada. Pela população as margens foram de 42,8\% (163 pessoas) em Barreirinhas, e de 41,0\% (162 pessoas) em Jijoca. Pelos indivíduos incluídos, as margens atingiram 42,1\% (40 pessoas) em Jijoca e 27,0\% (20 pessoas) em Barreirinhas. Vale ressaltar que em Jijoca, o número de duas pessoas do domicílio trabalhando $(41,1 \%$ - 39 pessoas) também foi expressivo, como indicado na Tabela 27. 
Tabela 27: Pessoas da casa que ESTUDAM e que TRABALHAM

\begin{tabular}{|c|c|c|c|c|c|c|c|c|c|}
\hline & \multicolumn{8}{|c|}{ BARREIRINHAS } \\
\hline & & \multicolumn{4}{|c|}{ ESTUDAM } & \multicolumn{4}{|c|}{ TRABALHAM } \\
\hline & & \multicolumn{2}{|c|}{ População } & \multicolumn{2}{|c|}{ Incluídos } & \multicolumn{2}{|c|}{ População } & \multicolumn{2}{|c|}{ Incluídos } \\
\hline & & Frequency & Percent & Frequency & Percent & Frequency & Percent & Frequency & \begin{tabular}{|l} 
Percent \\
\end{tabular} \\
\hline \multirow{15}{*}{$\frac{. \overline{0}}{\bar{\sigma}}$} & 0.00 & 135 & 35.4 & 7 & 9.5 & 116 & 30.4 & 16 & 21.6 \\
\hline & 1.00 & 74 & 19.4 & 28 & 37.8 & 163 & 42.8 & 20 & 27.0 \\
\hline & 2.00 & 78 & 20.5 & 19 & 25.7 & 70 & 18.4 & 15 & 20.3 \\
\hline & 3.00 & 50 & 13.1 & 8 & 10.8 & 16 & 4.2 & 10 & 13.5 \\
\hline & 4.00 & 28 & 7.3 & 4 & 5.4 & 12 & 3.1 & 6 & 8.1 \\
\hline & 5.00 & 8 & 2.1 & 3 & 4.1 & 3 & 0.8 & 1 & 1.4 \\
\hline & 6.00 & 7 & 1.8 & - & - & - & - & 1 & 1.4 \\
\hline & 7.00 & - & - & - & - & 1 & 0.3 & - & - \\
\hline & 8.00 & 1 & 0.3 & - & - & - & - & - & - \\
\hline & NR & - & - & 5 & 6.8 & - & - & 5 & 6.8 \\
\hline & Total & 381 & 100.0 & 74 & 100.0 & 381 & 100.0 & 74 & 100.0 \\
\hline & & \multicolumn{8}{|c|}{ JIJOCA DE JERICOACOARA } \\
\hline & & \multicolumn{4}{|c|}{ ESTUDAM } & \multicolumn{4}{|c|}{ TRABALHAM } \\
\hline & & \multicolumn{2}{|c|}{ População } & \multicolumn{2}{|c|}{ Incluídos } & \multicolumn{2}{|c|}{ População } & \multicolumn{2}{|c|}{ Incluídos } \\
\hline & & Frequency & Percent & Frequency & Percent & Frequency & Percent & Frequency & Percent \\
\hline \multirow{11}{*}{$\frac{\frac{0}{\pi}}{>}$} & 0.00 & 147 & 37.2 & 27 & 28.4 & 92 & 23.3 & 5 & 5.3 \\
\hline & 1.00 & 116 & 29.4 & 29 & 30.5 & 162 & 41.0 & 40 & 42.1 \\
\hline & 2.00 & 82 & 20.8 & 22 & 23.2 & - & - & 39 & 41.1 \\
\hline & 3.00 & 28 & 7.1 & 12 & 12.6 & 17 & 4.3 & 6 & 6.3 \\
\hline & 4.00 & 14 & 3.5 & 3 & 3.2 & 10 & 2.5 & 4 & 4.2 \\
\hline & 5.00 & 3 & 0.8 & 1 & 1.1 & 2 & .5 & 1 & 1.1 \\
\hline & 6.00 & 2 & 0.5 & - & - & 1 & .3 & - & - \\
\hline & 8.00 & 1 & 0.3 & - & - & - & - & - & - \\
\hline & 9.00 & 1 & 0.3 & 1 & 1.1 & 1 & .3 & - & - \\
\hline & NR & 1 & 0.3 & - & & 110 & 27.8 & - & - \\
\hline & Total & 395 & 100.0 & 95 & 100.0 & 395 & 100.0 & 95 & 100.0 \\
\hline
\end{tabular}

Fonte: pesquisa do autor.

\subsection{Renda Familiar Total Mensal}

Os indivíduos das populações locais entrevistadas ressaltaram, com maior frequência de respostas, que a renda total mensal familiar de seus domicílios está na faixa de $R \$ 545,01$ a $R \$$ $1.090,00$ (um e dois salários mínimos, respectivamente). No município maranhense a porcentagem de respostas nessa faixa de renda atingiu 31,5\% (120 entrevistados), e no município cearense 28,9\% (114 entrevistados). Ver Tabela 28.

Com relação aos indivíduos incluídos, entrevistados nas duas regiões, a situação é a mesma. A renda média mensal de seus domicílios se encontra, em maior proporção, entre um e dois salários mínimos. A porcentagem desta faixa de renda em Jijoca atingiu 42,1\% (40 respostas). 
Em Barreirinhas tal faixa de renda foi citada por $35,1 \%$ dos entrevistados (26 respostas), tendo também notória frequência de respostas para a faixa entre $R \$ 1.090,01$ e $R \$ 2.725,00$ (dois e cinco salários mínimos, respectivamente), chegando a 33,8\% (25 respostas). Informações na Tabela 28.

Tabela 28: Renda Familiar Total Mensal

\begin{tabular}{|c|c|c|c|c|c|c|c|c|c|}
\hline & \multicolumn{4}{|c|}{ BARREIRINHAS } & \multicolumn{4}{|c|}{ JIJOCA DE JERICOACOARA } \\
\hline & & \multicolumn{2}{|c|}{ População } & \multicolumn{2}{|c|}{ Incluídos } & \multicolumn{2}{|c|}{ População } & \multicolumn{2}{|c|}{ Incluídos } \\
\hline & & Freq & Percent & Freq & Percent & Freq & Percent & Freq & Percent \\
\hline \multirow{8}{*}{ 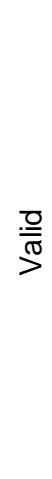 } & até $R \$ 136,25(0-1 / 4 \mathrm{SM})$ & 44 & 11.5 & 1 & 1.4 & 46 & 11.6 & 3 & 3.2 \\
\hline & de $R \$ 136,26$ a $R \$ 272,50$ (1/4 SM a 1/2 SM) & 53 & 13.9 & 4 & 5.4 & 49 & 12.4 & 4 & 4.2 \\
\hline & de $R \$ 272,51$ a $R \$ 545,00$ (1/2 SM a 1 SM) & 75 & 19.7 & 13 & 17.6 & 114 & 28.9 & 20 & 21.1 \\
\hline & de $R \$ 545,01$ a $R \$ 1.090,00$ (1 SM a 2 SM) & 120 & 31.5 & 26 & 35.1 & 111 & 28.1 & 40 & 42.1 \\
\hline & de $R \$ 1.090,01$ a $R \$ 2.725,00$ (2 SM a 5 SM) & 53 & 13.9 & 25 & 33.8 & 55 & 13.9 & 22 & 23.2 \\
\hline & $\mathrm{R} \$ 2.725,01$ ou mais (+ de $5 \mathrm{SM})$ & 15 & 3.9 & 4 & 5.4 & 5 & 1.3 & 6 & 6.3 \\
\hline & não respondeu/não sabe & 21 & 5.5 & 1 & 1.4 & 15 & 3.8 & 3 & 3.2 \\
\hline & Total & 381 & 100.0 & 74 & 100.0 & 395 & 100.0 & 95 & 100.0 \\
\hline
\end{tabular}

Fonte: pesquisa do autor.

\subsection{Local de Nascimento e Tempo Morando na Região}

Entre os entrevistados das populações locais prevaleceu indivíduos nativos das duas localidades. Em Barreirinhas chegou a 87,9\% (335 pessoas) dos entrevistados e, em Jijoca, 65,8\% (260 pessoas). Ver Gráfico 11.

Quanto ao grupo dos empresários entrevistados não se percebe a mesma similaridade entre os dois destinos. Enquanto que em Barreirinhas mais da metade dos indivíduos (51,7\% 30 pessoas) eram nascidos no próprio município, em Jijoca prevaleceram indivíduos de fora da localidade (71,7\% - 48 pessoas), que não das capitais de seus estados.

A grande parcela dos indivíduos incluídos entrevistados nasceu nos próprios municípios de estudo, porém, as margens de cada localidade foram bastantes distintas (Gráfico 11). Jijoca atestou 58,9\% (56 pessoas) de seus entrevistados, e Barreirinhas 86,5\% (64 pessoas).

Com respeito aos entrevistados representantes dos grupos organizados, há similitudes entre as duas regiões, contudo, para o destaque de indivíduos nascidos em outros municípios/localidades (que não das capitais dos estados). Em Barreirinhas foram cinco pessoas 
(55,6\%) e, em Jijoca, quatro pessoas de fora (44.4\%) e quatro pessoas do próprio município $(44,4 \%)$. Ver Gráfico 11, a seguir.

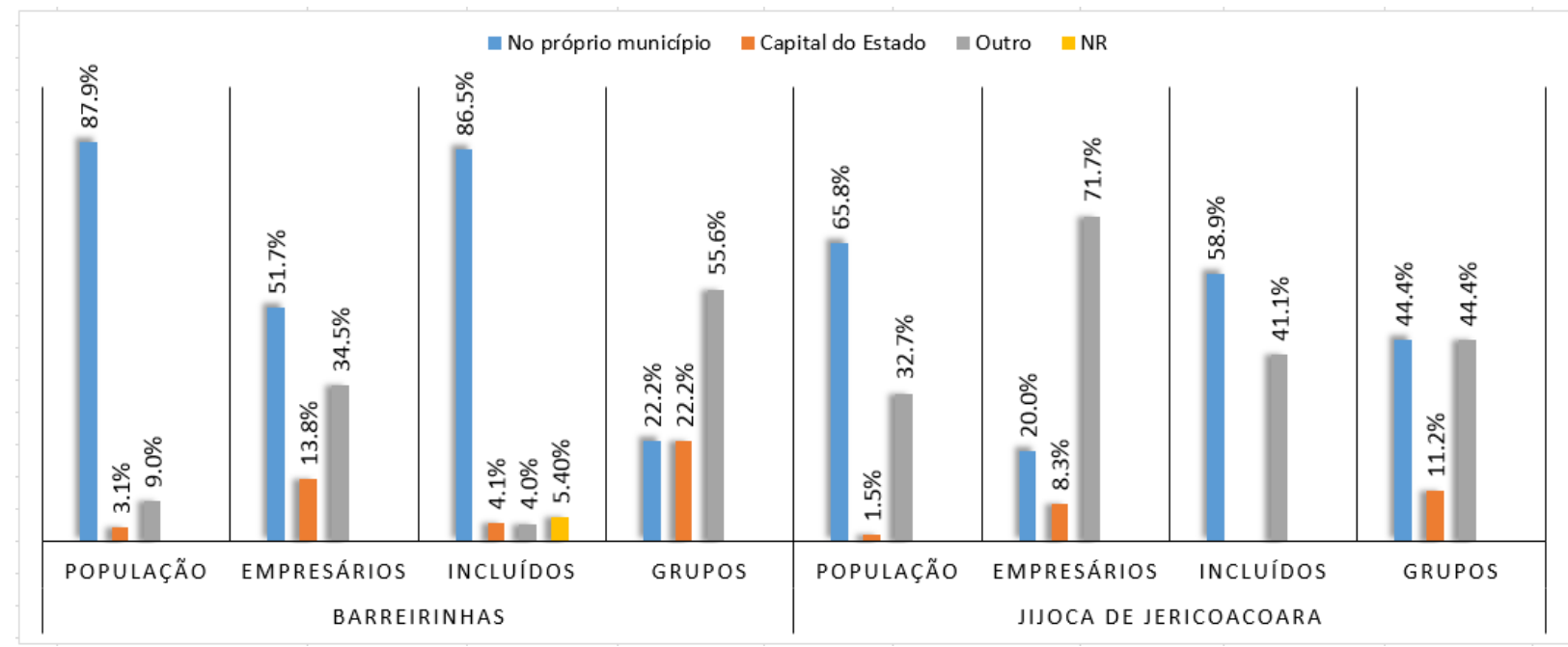

Gráfico 11: Local de nascimento dos entrevistados

Fonte: pesquisa do autor.

A descrição completa de quais municípios de fora foram citados pelos entrevistados, assim como suas respectivas porcentagens, são apresentadas no Apêndice 5.

Dos entrevistados que não nasceram nos municípios estudados pode-se perceber, a partir do Gráfico 12, que a maior porcentagem de respondentes já vive nessas localidades há 21 anos ou mais. Da população de Barreirinhas foram 28,3\% (13 indivíduos), e da população de Jijoca de Jericoacoara foram 28,9\% (39 indivíduos). Já dos incluídos de Barreirinhas foram 40,0\% (04 pessoas), e de Jijoca $33,3 \%$ (13 pessoas). 


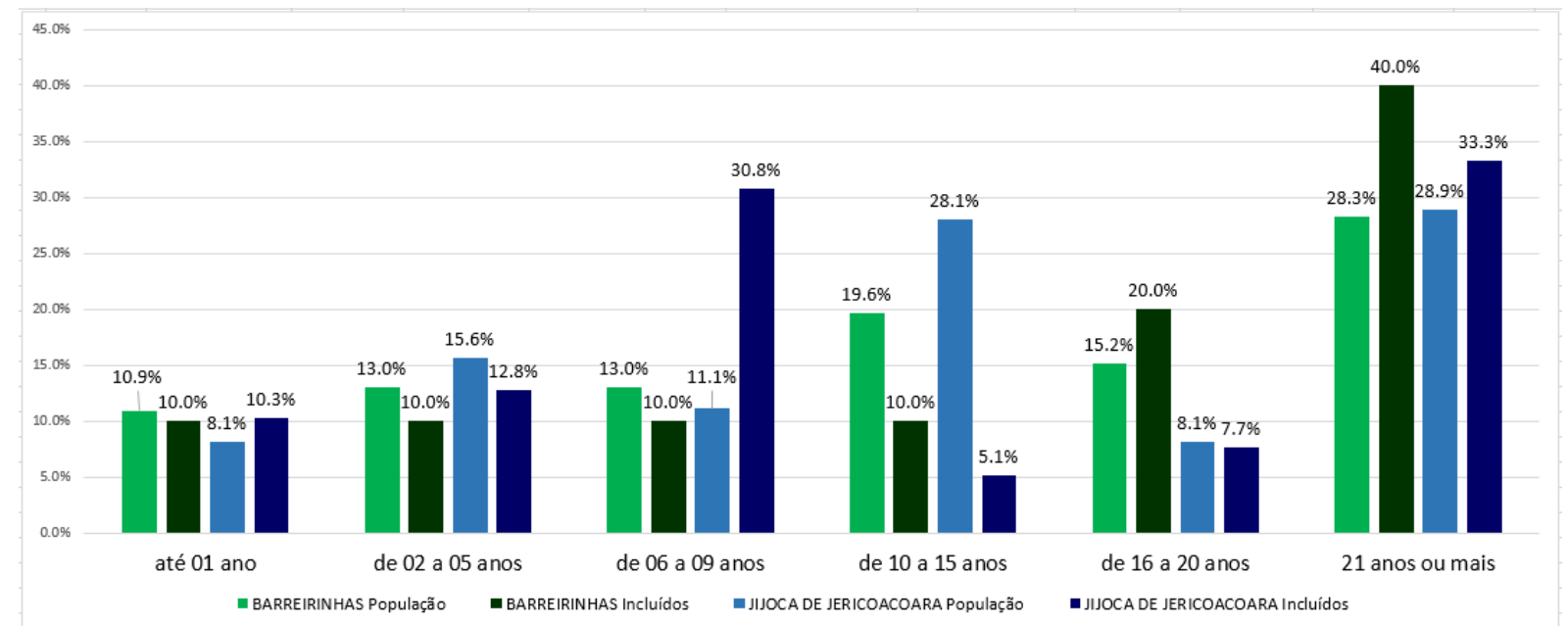

Gráfico 12: Tempo morando nos municípios estudados

Fonte: pesquisa do autor.

\subsection{Participação em grupos organizados (cooperativas e associações)}

De acordo com os dados levantados, a maior fração dos entrevistados das populações e dos grupos de incluídos dos dois municípios não participa de grupos organizados, como cooperativas e associações.

Entre os indivíduos da população de Barreirinhas, 35,7\% (136 pessoas) participam de algum grupo organizado, enquanto que em Jijoca apenas 5,8\% (23 pessoas) dos entrevistados de sua população integram tais grupos. Por sua vez, do grupo de incluídos de Barreirinhas, $28,4 \%$ (21 pessoas) dos entrevistados citaram que participam, contra 8,4\% (08 pessoas) de Jijoca. Dados completos apresentados no Gráfico 13.

Os grupos com maior frequência de respostas pelos indivíduos das populações locais e dos grupos de incluídos, dos dois destinos, foram as Associações Comunitárias (de Moradores). Foram citadas por 32,4\% (44 pessoas) dos entrevistados da população de Barreirinhas, 43,5\% (10 pessoas) da população de Jijoca de Jericoacoara, 23,8\% (05 pessoas) dos incluídos de Barreirinhas, e 37,5\% (03 pessoas) dos incluídos de Jijoca. Ver Gráfico 14. 


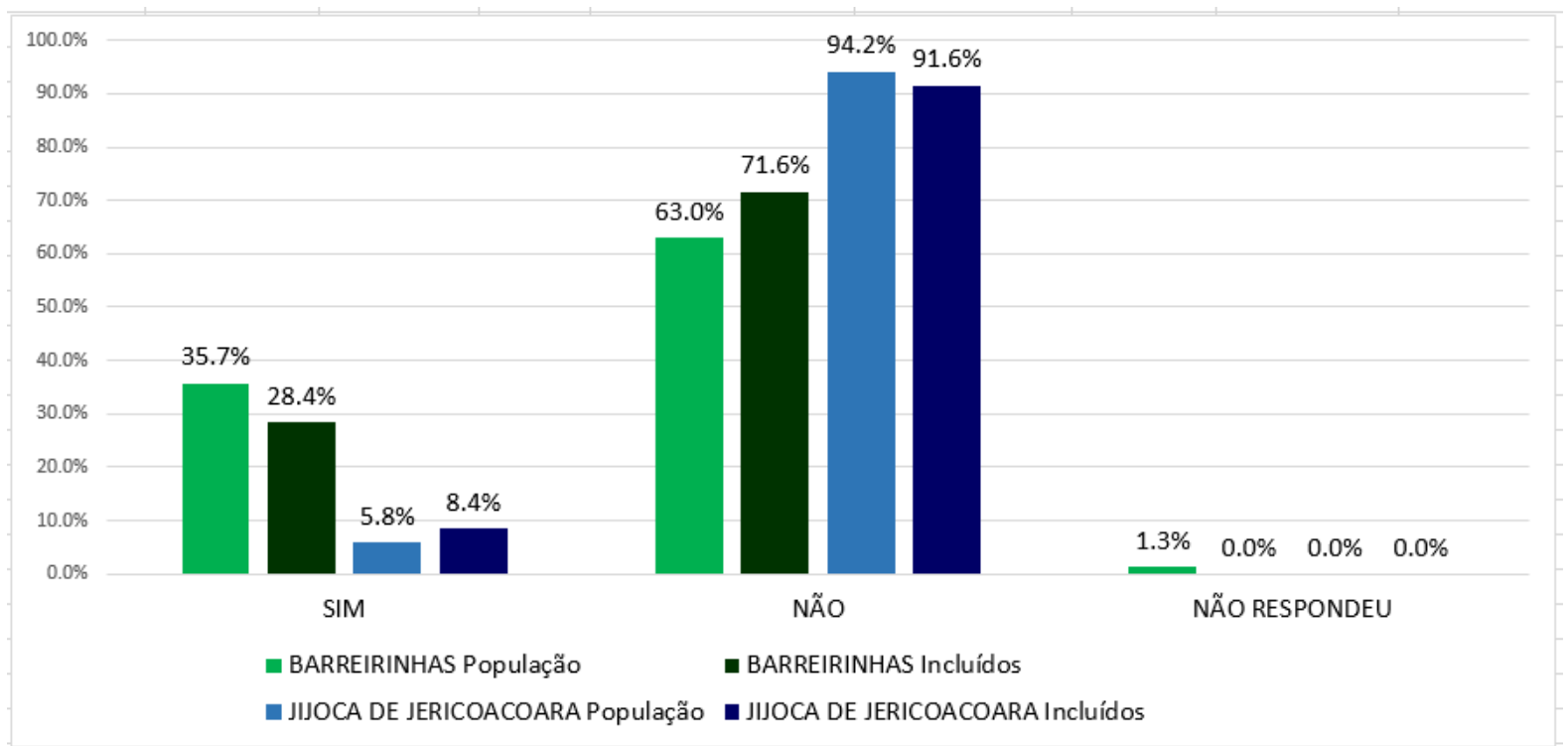

Gráfico 13: Participação dos entrevistados em cooperativas ou associações Fonte: pesquisa do autor.

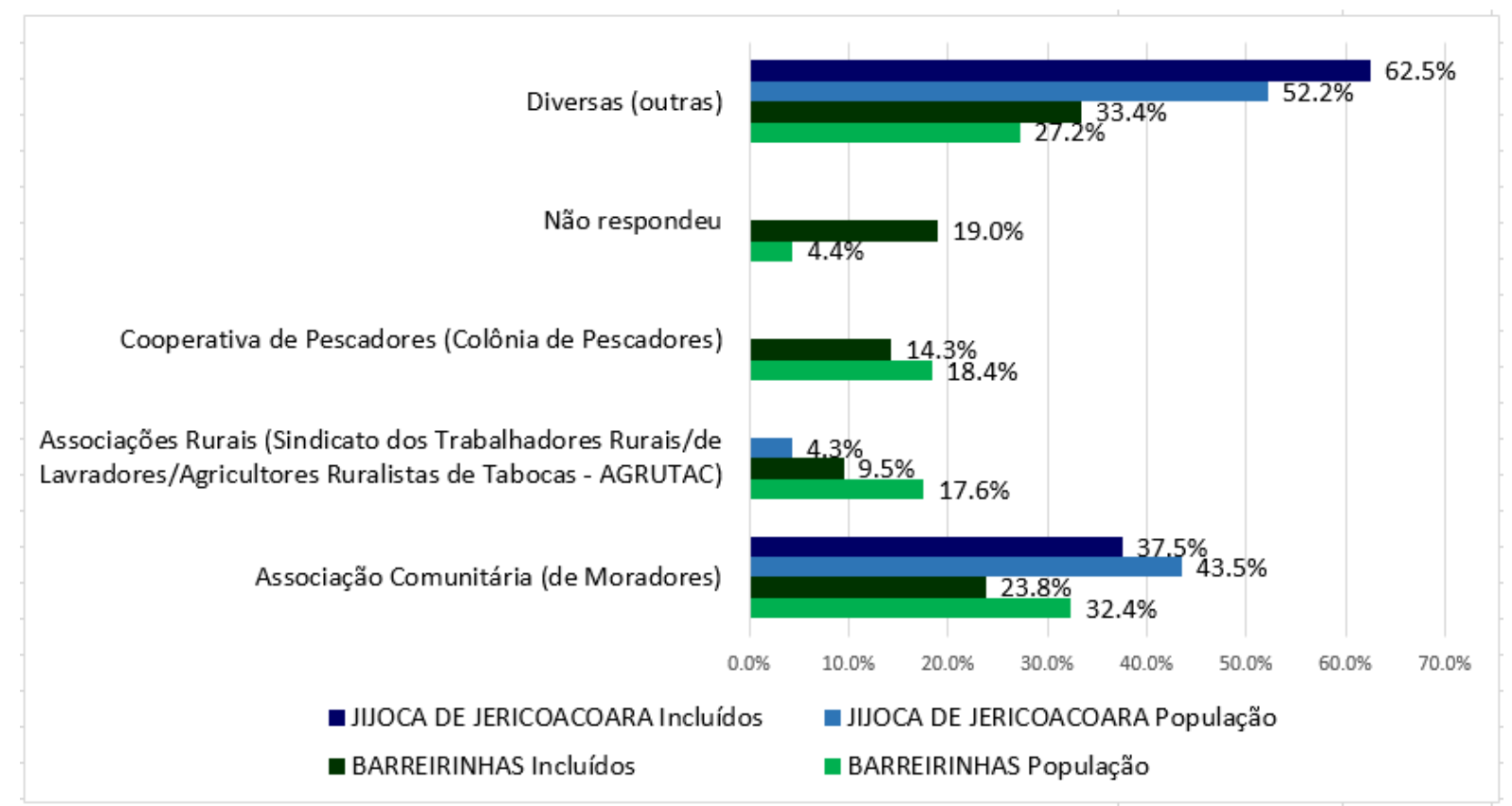

Gráfico 14: Tipos de Associações e Cooperativas que os entrevistados participam Fonte: pesquisa do autor.

Outros grupos também mereceram destaque, dentre eles: Cooperativas de Pescadores (Colônia de Pescadores), e Associações/Sindicatos de Trabalhadores Rurais. Os demais grupos, e suas respectivas porcentagens individuais, podem ser vislumbrados no Apêndice 6. 


\subsection{Segmentos Sociais}

A aplicação do survey com as populações locais mostrou que a notória maioria dos entrevistados (ver Gráfico 15), nos dois destinos, realizam atividades por conta própria, como autônomos. São 35,5\% (170 indivíduos) do total de respostas ${ }^{58}$ dos entrevistados de Jijoca de Jericoacoara, e 50,0\% (238 indivíduos) dos entrevistados de Barreirinhas.

Tal fato demonstra a ainda reduzida absorção de grande parte da mão de obra local em trabalhos formais com carteira assinada, seja no Turismo ou nos demais setores econômicos de Barreirinhas e de Jijoca de Jericoacoara.

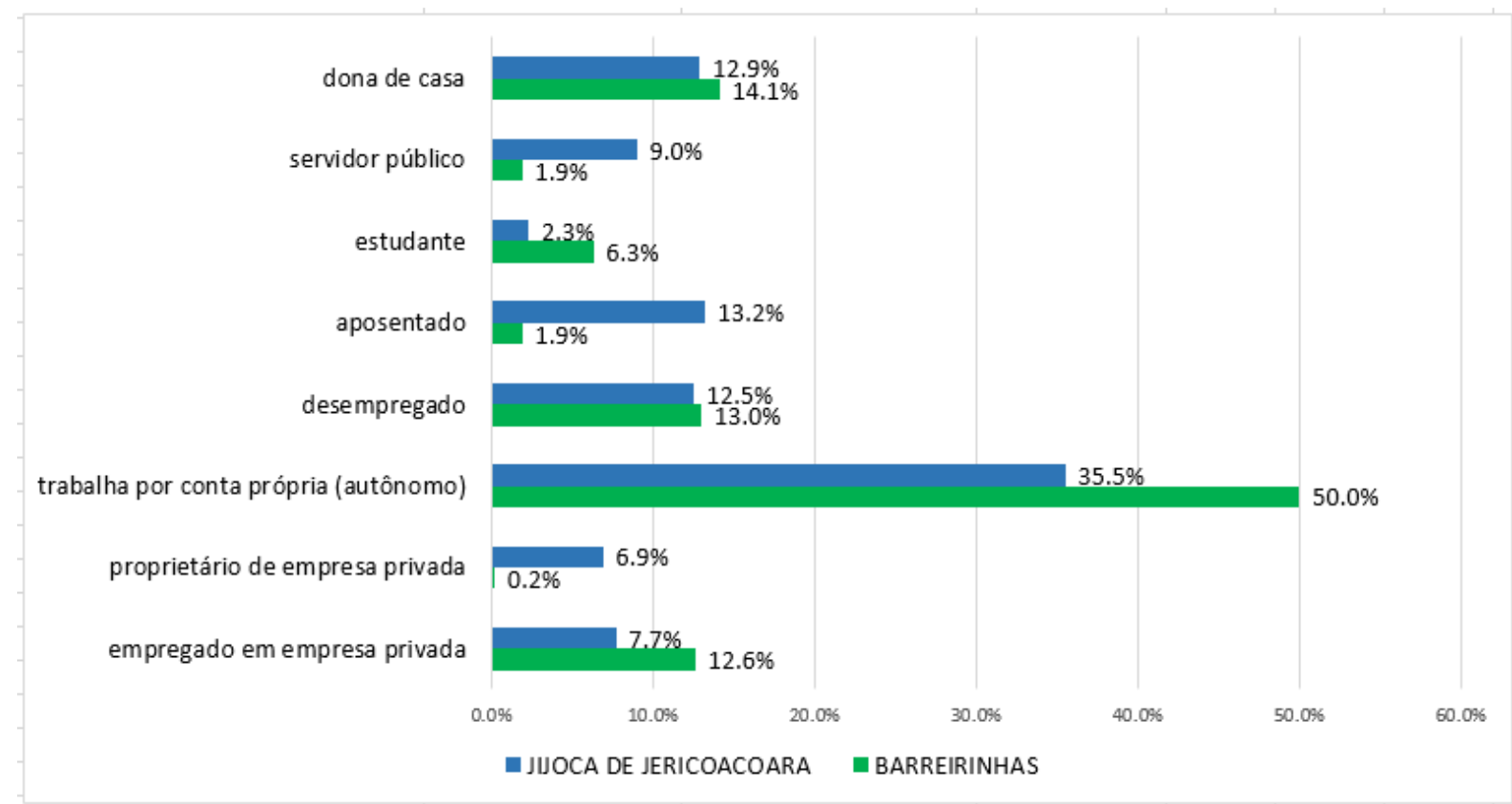

\section{Gráfico 15: Segmentos Sociais dos entrevistados}

Fonte: pesquisa do autor.

É digno de nota a ampla frequência de respostas indicando indivíduos desempregados (12,5\% em Jijoca e 13,0\% em Barreirinhas) superando o número de empregados (7,7\% em Jijoca e $12,6 \%$ em Barreirinhas).

\footnotetext{
${ }^{58}$ A questão sobre segmentos sociais admitia mais de uma resposta por parte dos entrevistados. O número total de respostas em Barreirinhas foi de 476 (ultrapassando os 381 questionários) e em Jijoca foi de 479 (ultrapassando os 395 questionários).
} 


\subsection{Busca por Oportunidades de Emprego no Turismo}

A ampla maioria dos entrevistados das populações locais dos dois destinos ressaltou, de acordo com o Gráfico 16, nunca terem buscado por oportunidades de trabalho no setor de Turismo. Em Jijoca de Jericoacoara a margem dessas respostas chegou a $82,5 \%$ dos entrevistados (326 pessoas), e em Barreirinhas, uma margem pouco menor, de 76,6\% (292 pessoas).

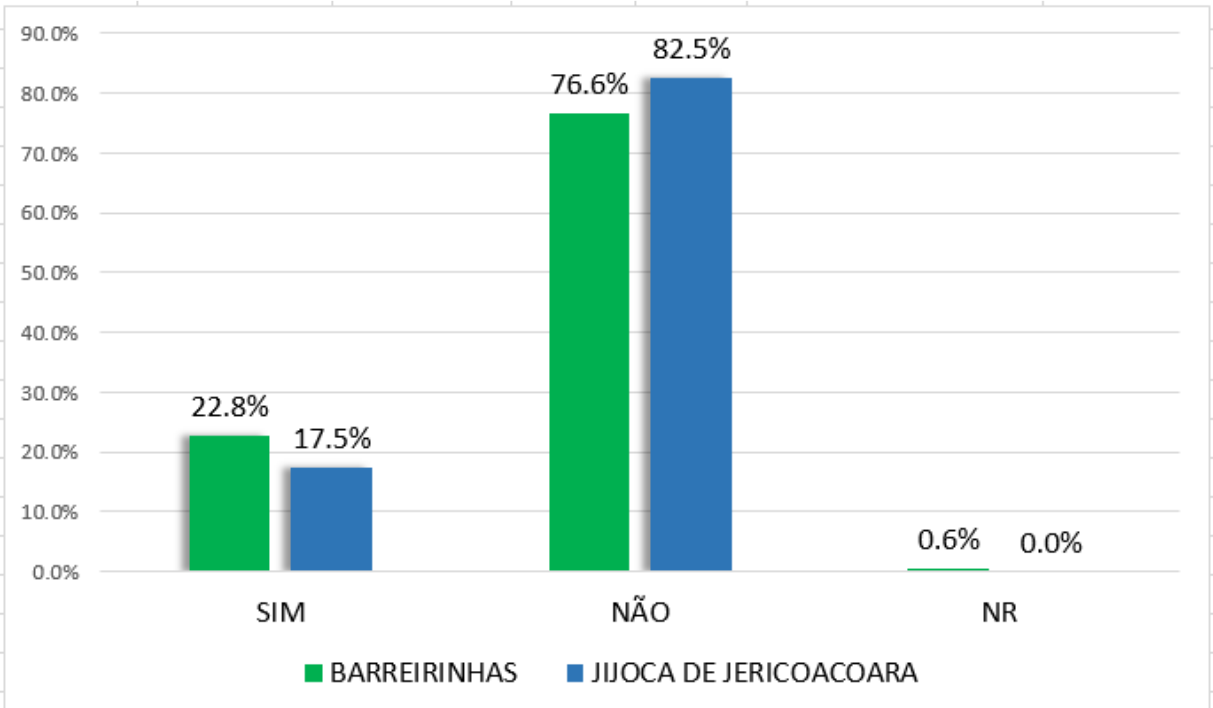

\section{Gráfico 16: Busca por oportunidades}

Fonte: pesquisa do autor.

\subsection{Motivo pelo qual Não Buscou}

Três foram os motivos citados, com maior frequência de respostas ${ }^{59}$ pelos entrevistados, que justificam o desinteresse dos mesmos em buscar por oportunidades de trabalho no mercado turístico (Tabela 29). São eles:

(a) não gostarem desse tipo de atividade: citado por 15,6\% (60 entrevistados) de Barreirinhas, e 9,5\% (31 entrevistados) de Jijoca;

\footnotetext{
${ }^{59}$ A questão sobre motivos pelos quais não buscou por oportunidades no setor de Turismo admitia mais de uma resposta por parte dos entrevistados. O número total de respostas em Barreirinhas foi de 384 (ultrapassando o total de 292 indivíduos que não buscaram) e em Jijoca foi de 326 (equivalente aos exatos 326 indivíduos que não buscaram).
} 
(b) não quererem abandonar suas atividades tradicionais: citado por 14,8\% (57 entrevistados) de Barreirinhas, e 30,7\% (100 entrevistados) de Jijoca;

(c) não possuírem estudo suficiente: citado por 12,8\% (49 entrevistados) de Barreirinhas, e $20,9 \%$ (68 entrevistados) de Jijoca.

Tabela 29: Porque "não" buscou por oportunidades no Turismo

\begin{tabular}{|c|c|c|c|c|c|}
\hline & \multicolumn{2}{|c|}{ BARREIRINHAS } & \multicolumn{2}{|c|}{$\begin{array}{l}\text { JIJOCA DE } \\
\text { JERICOACOARA }\end{array}$} \\
\hline & & Frequency & Percent & Frequency & Percent \\
\hline & não quero (queria) abandonar minha atividade tradicional & 57 & 14.8 & 100 & 30.7 \\
\hline & os salários são (eram) baixos & 21 & 5.5 & 8 & 2.5 \\
\hline & as condições de trabalho são (eram) ruins & 18 & 4.7 & 5 & 1.5 \\
\hline & os benefícios são (eram) poucos & - & - & 4 & 1.2 \\
\hline & não quero (queria) sair do campo (meio rural) & 1 & 0.3 & 6 & 1.8 \\
\hline & não gosto (gostava) desse tipo de atividade & 60 & 15.6 & 31 & 9.5 \\
\hline & não há vagas para pessoas sem qualificação/capacitação & 36 & 9.4 & 10 & 3.1 \\
\hline & não há vagas para pessoas sem experiência & 35 & 9.1 & 6 & 1.8 \\
\hline & não tenho (tinha) conhecidos que possam (podiam) me ajudar & - & - & 13 & 4.0 \\
\hline & $\begin{array}{l}\text { não tenho (tinha) estudo suficiente/não há vagas para pessoas } \\
\text { sem escolaridade }\end{array}$ & 49 & 12.8 & 68 & 20.9 \\
\hline & moro (morava) muito longe do trabalho & 38 & 9.9 & 18 & 5.5 \\
\hline & não respondeu/não sabe & 18 & 4.7 & 6 & 1.8 \\
\hline & na época não existia Turismo & - & - & 14 & 4.3 \\
\hline 므 & idade avançada/pouca idade & 1 & 0.3 & 6 & 1.8 \\
\hline$\stackrel{\bar{\pi}}{>}$ & $\begin{array}{l}\text { por ter que cuidar das crianças/dos pais/família/por não querer } \\
\text { ficar longe da família }\end{array}$ & 10 & 2.6 & 13 & 4.0 \\
\hline & por ter arrumado um trabalho em casa & - & - & 1 & 0.3 \\
\hline & por ainda ser estudante & - & - & 3 & 0.9 \\
\hline & por falta de estrutura & 1 & 0.3 & 1 & 0.3 \\
\hline & por não gostar de emprego fixo/gosto de trabalhar por conta & - & - & 2 & 0.6 \\
\hline & $\begin{array}{l}\text { buscava em outra área de interesse pessoal/não tenho } \\
\text { interesse nessa área }\end{array}$ & 1 & 0.3 & 2 & 0.6 \\
\hline & decidi abrir o próprio estabelecimento & - & - & 3 & 0.9 \\
\hline & não teve oportunidade & 4 & 1.0 & 1 & 0.3 \\
\hline & por já ter se aposentado & - & - & 1 & 0.3 \\
\hline & por problemas de saúde & - & - & 2 & 0.6 \\
\hline & por ser beneficiário do Bolsa Família & 1 & 0.3 & - & - \\
\hline & não tenho conhecimento sobre o setor & 28 & 7.3 & - & - \\
\hline & outro & 5 & 1.3 & - & - \\
\hline & Total & 384 & 100.0 & 326 & 100.0 \\
\hline
\end{tabular}

Fonte: pesquisa do autor.

\subsection{Motivo pelo qual Buscou}

Um aspecto recorrente, e comum a todos os entrevistados dos dois grupos (população e incluídos) dos dois destinos, foi o de ter buscado por oportunidades pelo fato de "gostar desse 
tipo de atividade". Tal aspecto mencionado (ver Tabela 30) em Barreirinhas por 25,3\% (22 pessoas) dos entrevistados da população, e por $23,1 \%$ (18 pessoas) dos incluídos. Também foi citado com frequência em Jijoca, por 15,5\% (11 pessoas) da população, e por 17,0\% (17 pessoas) dos incluídos.

Outro aspecto ressaltado com frequência (Tabela 30) foi o de "necessidade financeira". Na região cearense, tal aspecto foi o mais citado pela população, com 23,9\% (17 pessoas) das respostas, e pelos incluídos, com 25,0\% (25 pessoas) das respostas. Entre os incluídos de Barreirinhas, esse aspecto também ganha destaque, sendo ressaltado por 14,1\% (11 pessoas) dos entrevistados do grupo.

Tabela 30: Porque buscou por oportunidades no Turismo ${ }^{60}$

\begin{tabular}{|c|c|c|c|c|c|c|c|c|}
\hline & \multicolumn{4}{|c|}{ BARREIRINHAS } & \multicolumn{4}{|c|}{$\begin{array}{c}\text { JIJOCA DE } \\
\text { JERICOACOARA }\end{array}$} \\
\hline & \multicolumn{2}{|c|}{ População } & \multicolumn{2}{|c|}{ Incluídos } & \multicolumn{2}{|c|}{ População } & \multicolumn{2}{|c|}{ Incluídos } \\
\hline & Freq & Percent & Freq & Percent & Freq & Percent & Freq & Percent \\
\hline $\begin{array}{l}\text { não quero (queria) mais trabalhar em minha atividade } \\
\text { tradicional }\end{array}$ & 16 & 18.4 & 1 & 1.3 & 2 & 2.8 & 5 & 5.0 \\
\hline os salários são (eram) altos & 16 & 18.4 & - & - & 5 & 7.0 & 5 & 5.0 \\
\hline as condições de trabalho são (eram) boas & 11 & 12.6 & - & - & 6 & 8.5 & 5 & 5.0 \\
\hline os benefícios são (eram) muitos & 1 & 1.1 & 1 & 1.3 & 1 & 1.4 & 2 & 2.0 \\
\hline quero (queria) me capacitar nas áreas do setor & 4 & 4.6 & 1 & 1.3 & 2 & 2.8 & 3 & 3.0 \\
\hline por valorizar minha cultura/meus costumes & 2 & 2.3 & 2 & 2.6 & - & - & - & - \\
\hline quero (queria) sair do campo (meio rural) & 1 & 1.1 & - & - & 1 & 1.4 & 2 & 2.0 \\
\hline gosto (gostava) desse tipo de atividade & 22 & 25.3 & 18 & 23.1 & 11 & 15.5 & 17 & 17.0 \\
\hline um conhecido me convidou/me indicou & - & - & 11 & 14.1 & 10 & 14.1 & 20 & 20.0 \\
\hline tenho (tinha) bom estudo & - & - & - & & 1 & 1.4 & 1 & 1.0 \\
\hline 으 moro próximo do trabalho & - & - & - & - & 1 & 1.4 & 1 & 1.0 \\
\hline$\stackrel{\pi}{>}$ para melhorar as condições de vida (da família) & 1 & 1.1 & 1 & 1.3 & 1 & 1.4 & - & - \\
\hline por não ter outra opção de trabalho/é onde tem emprego & 1 & 1.1 & 27 & 34.6 & 6 & 8.5 & 9 & 9.0 \\
\hline procurava por outro trabalho com melhor remuneração & 1 & 1.1 & 1 & 1.3 & 3 & 4.2 & 2 & 2.0 \\
\hline necessidade financeira & 4 & 4.6 & 11 & 14.1 & 17 & 23.9 & 25 & 25.0 \\
\hline já trabalhava com turismo & 2 & 2.3 & - & - & - & - & & \\
\hline por pessoas da família já trabalharem com isso & - & - & - & - & 2 & 2.8 & 2 & 2.0 \\
\hline $\begin{array}{l}\text { queria me comunicar com estrangeiros/melhorar o idioma } \\
\text { estrangeiro }\end{array}$ & - & - & 1 & 1.3 & - & - & - & \\
\hline por ter uma formação na área de turismo/em área próxima & - & - & 3 & 3.8 & 1 & 1.4 & 1 & 1.0 \\
\hline outro & 2 & 2.3 & - & - & - & - & - & - \\
\hline não respondeu/não sabe & 3 & 3.4 & - & - & 1 & 1.4 & - & - \\
\hline Total & 87 & 100.0 & 78 & 100.0 & 71 & 100.0 & 100 & 100.0 \\
\hline
\end{tabular}

Fonte: pesquisa do autor.

${ }^{60}$ A questão sobre motivos pelos quais buscou por oportunidades no setor de Turismo admitia mais de uma resposta por parte dos entrevistados. O número total de respostas em Barreirinhas, pela população, foi de 87 (equivalente aos exatos 87 indivíduos que buscaram), e pelos incluídos, foi de 78 (ultrapassando o total de 74 indivíduos incluídos). 0 número total de respostas em Jijoca, pela população, foi de 71 (ultrapassando o total de 69 indivíduos que buscaram), e pelos incluídos, foi de 100 (ultrapassando o total de 95 incluídos). 
Ainda assim, outros aspectos parecem ter influências distintas nas duas regiões. $O$ aspecto mais citado entre os incluídos de Barreirinhas, por exemplo, foi o "por não ter outra opção de trabalho/é onde tem emprego" (34,6\% - 27 pessoas). No mesmo destino, outros dois aspectos são recorrentes entre as respostas da população: "não querer mais trabalhar em sua atividade tradicional" (18,4\% - 16 pessoas), e "os salários são altos" (18,4\% - 16 pessoas). Dados na Tabela 30.

Já em Jijoca há um outro aspecto, comum entre as respostas da população e dos incluídos: "indicação/convite por conhecidos" (14,1\% - 10 pessoas, e 20,0\% - 20 pessoas, respectivamente).

\subsection{Efetivação no Emprego}

O número de entrevistados da população de Jijoca de Jericoacoara que buscou, e que conseguiu se efetivar no emprego no setor turístico, é notoriamente superior ao número do mesmo grupo de entrevistados em Barreirinhas.

No destino cearense, do total de 69 indivíduos que buscaram, 63 deles (91,3\%) conseguiram se efetivar no emprego. Em contrapartida, no destino maranhense, dos 87 indivíduos que buscaram, apenas 46 deles (52,9\%) preencheram a vaga. Os dados são apresentados no Gráfico 17.

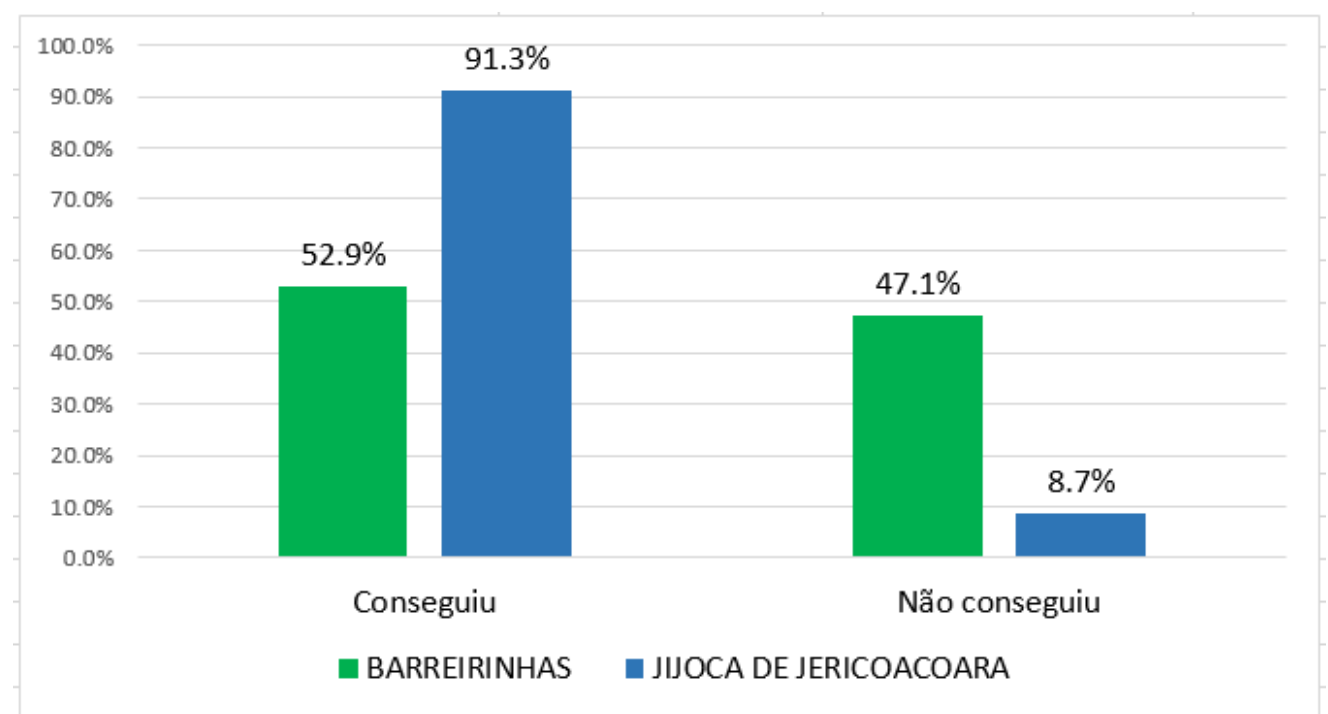

Gráfico 17: Efetivação no emprego

Fonte: pesquisa do autor. 


\subsection{Fatores que Contribuem para a Inclusão Direta}

\subsubsection{Visão da População e dos Incluídos}

Dentre todos os muitos fatores apresentados pelos entrevistados ${ }^{61}$, das populações e dos grupos dos incluídos, como aqueles que contribuíram para a efetivação no emprego buscado, há um, em específico, que ganhou destaque como o mais citado em três dos quatro grupos: "a indicação por conhecidos".

Esse fator foi o de maior frequência de respostas em Jijoca, tanto por sua população (38,5\% - 25 pessoas) quanto pelos incluídos (42,6\% - 43 pessoas). Também foi o mais ressaltado pelos incluídos de Barreirinhas (29,1\% - 23 pessoas), e o segundo mais citado pela população desse município (32,8\% - 20 pessoas). Ver Tabela 31.

O fator com maior destaque nas respostas da população maranhense foi o "bom conhecimento sobre a área (região)" (37,7\% - 23 pessoas), o qual também foi o segundo mais citado pelos incluídos dessa localidade (17,7\% - 14 pessoas).

Vale ressaltar a alta frequência de respostas para dois outros fatores: "capacitação técnica para o serviço" e "experiência anterior com o mesmo trabalho". O primeiro, esteve presente em $15,2 \%$ (12 pessoas) das respostas dos incluídos de Barreirinhas, e foi o segundo mais citado pela população de Jijoca (23,1\% - 15 pessoas) e pelos incluídos do município cearense $(20,8 \%$ - 21 pessoas). Dados descritos na Tabela 31.

No caso do segundo fator, foi lembrado por 13,9\% (11 pessoas) dos incluídos de Barreirinhas, e foi o terceiro mais frequente entre as respostas da população de Jijoca $(21,5 \%$ 14 pessoas) e do incluídos desse município (17,8\% - 18 pessoas). Dados na Tabela 31, a seguir.

\footnotetext{
${ }^{61}$ A questão sobre os fatores que contribuem para a inclusão direta no Turismo admitia mais de uma resposta por parte dos entrevistados. O número total de respostas em Barreirinhas, pela população, foi de 61 (acima dos 46 indivíduos que buscaram e conseguiram) e, pelos incluídos, foi de 79 (acima do total de 74 indivíduos desse grupo). O número total de respostas em Jijoca, pela população, foi de 65 (acima dos 63 indivíduos que buscaram e conseguiram) e, pelos incluídos, foi de 101 (acima do total de 95 indivíduos desse grupo).
} 
Tabela 31: Fatores de inclusão direta na visão dos incluídos e da população

\begin{tabular}{|c|c|c|c|c|c|c|c|c|c|}
\hline & \multicolumn{4}{|c|}{ BARREIRINHAS } & \multicolumn{4}{|c|}{$\begin{array}{l}\text { JIJOCA DE } \\
\text { JERICOACOARA }\end{array}$} \\
\hline & & \multicolumn{2}{|c|}{ População } & \multicolumn{2}{|c|}{ Incluídos } & \multicolumn{2}{|c|}{ População } & \multicolumn{2}{|c|}{ Incluídos } \\
\hline & & Freq & Percent & Freq & Percent & Freq & Percent & Freq & Percent \\
\hline \multirow{18}{*}{$\frac{\text { 음 }}{>}$} & meu nível de escolaridade & 2 & 3.3 & 2 & 2.5 & 1 & 1.5 & 1 & 1.0 \\
\hline & minha capacitação técnica para o serviço & 6 & 9.8 & 12 & 15.2 & 15 & 23.1 & 21 & 20.8 \\
\hline & minha idade & 1 & 1.6 & - & - & 1 & 1.5 & 1 & 1.0 \\
\hline & minha experiência anterior com o mesmo trabalho & 4 & 6.6 & 11 & 13.9 & 14 & 21.5 & 18 & 17.8 \\
\hline & por eu (não) ter nascido no município & - & - & - & & 1 & 1.5 & 1 & 1.0 \\
\hline & por eu ter sido indicado por conhecidos & 20 & 32.8 & 23 & 29.1 & 25 & 38.5 & 43 & 42.6 \\
\hline & a urgente necessidade de preenchimento da vaga & 1 & 1.6 & 2 & 2.5 & 4 & 6.2 & 7 & 6.9 \\
\hline & por eu conhecer bem a área (região) & 23 & 37.7 & 14 & 17.7 & 1 & 1.5 & 1 & 1.0 \\
\hline & por eu ser responsável/ser organizado & 1 & 1.6 & 4 & 5.1 & 1 & 1.5 & 1 & 1.0 \\
\hline & por eu ser bom no que faço & 1 & 1.6 & 1 & 1.3 & - & - & - & - \\
\hline & por eu ser uma pessoa boa/simpática & - & - & 2 & 2.5 & 2 & 3.1 & 2 & 2.0 \\
\hline & por eu ser honesto(a) & - & - & 2 & 2.5 & - & - & - & - \\
\hline & $\begin{array}{l}\text { o grande interesse em trabalhar/esforço } \\
\text { pessoal/dedicação }\end{array}$ & - & - & 2 & 2.5 & - & - & 4 & 4.0 \\
\hline & por eu falar inglês & - & - & 1 & 1.3 & - & - & - & - \\
\hline & por levar jeito para a atividade & - & - & - & - & - & - & 1 & 1.0 \\
\hline & outro & 1 & 1.6 & - & - & - & - & - & - \\
\hline & não respondeu/não sabe & 1 & 1.6 & 3 & 3.8 & - & - & - & - \\
\hline & Total & 61 & 100.0 & 79 & 100.0 & 65 & 100.0 & 101 & 100.0 \\
\hline
\end{tabular}

Fonte: pesquisa do autor.

\subsubsection{Visão do Empresariado}

\section{(A) Fatores diversos: apresentados pelos empresários}

Por parte do empresariado dos dois destinos, as visões sobre os fatores que influem nos processos decisórios de contratação, ou não contratação, de um candidato à vaga disponível, são heterogêneas.

Quando questionados, por meio de pergunta aberta, sobre os fatores que influem na decisão de contratar um candidato, independente da função, a maior frequência de respostas dos empresários do trade turístico de Barreirinhas voltou-se à "capacitação e qualificação profissional (cursos)" dos mesmos, com 17,1\% (12 pessoas). Em seguida apareceram a "experiência anterior" (12,9\% - 09 pessoas) e a "boa vontade/sem experiência/boa disposição para o trabalho" (11,4\% - 08 pessoas). Dados descritos na Tabela 32.

Pela visão dos empresários cearenses, entrevistados, a "boa vontade/sem experiência/boa disposição para o trabalho" aparece em primeiro lugar, como a mais frequente resposta, com 
16,6\% (26 pessoas). Logo após, são citadas a "boa aparência/higiene pessoal" (10,8\% - 17 pessoas) e a "indicação por conhecidos" (10,2\% - 16 pessoas). Ver Tabela 32.

Tabela 32: Fatores de inclusão direta na visão do empresariado ${ }^{62}$

\begin{tabular}{|c|c|c|c|c|}
\hline & \multicolumn{2}{|c|}{ BARREIRINHAS } & \multicolumn{2}{|c|}{$\begin{array}{l}\text { JIJOCA DE } \\
\text { JERICOACOARA }\end{array}$} \\
\hline & Freq & Percent & Freq & Percent \\
\hline currículo & 1 & 1.4 & 6 & 3.8 \\
\hline conhecimento da área/região & 5 & 7.1 & 1 & .6 \\
\hline indicação por conhecidos/ser alguém conhecido/de confiança & 5 & 7.1 & 16 & 10.2 \\
\hline experiência anterior & 9 & 12.9 & 10 & 6.4 \\
\hline honestidade & 1 & 1.4 & 4 & 2.5 \\
\hline nível de escolaridade & 1 & 1.4 & 10 & 6.4 \\
\hline capacitação/qualificação profissional/cursos realizados & 12 & 17.1 & 7 & 4.5 \\
\hline $\begin{array}{l}\text { responsabilidade/profissionalismo/pontualidade/competência/ postura } \\
\text { profissional/disciplina }\end{array}$ & 6 & 8.6 & 9 & 5.7 \\
\hline $\begin{array}{l}\text { qualidade no atendimento do turista/boa comunicação/simpatia/bom } \\
\text { humor/carisma/extrovertido/atencioso }\end{array}$ & 7 & 10.0 & 9 & 5.7 \\
\hline ser do local (nativo) & 3 & 4.3 & 5 & 3.2 \\
\hline ser dinâmico/esperto/com capacidade de resolver problemas/proativo & 2 & 2.9 & 1 & .6 \\
\hline ter boas referências/saber onde trabalhou & 2 & 2.9 & 3 & 1.9 \\
\hline idade & 1 & 1.4 & 1 & .6 \\
\hline boa aparência/higiene pessoal/vestir-se bem & 1 & 1.4 & 17 & 10.8 \\
\hline 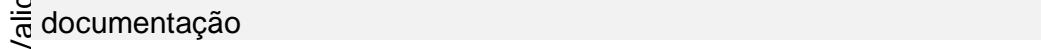 & - & - & 2 & 1.3 \\
\hline$>_{\text {fluência em outro idioma/falar inglês/ser bilíngue }}$ & 1 & 1.4 & 6 & 3.8 \\
\hline $\begin{array}{l}\text { sem experiência/boa vontade/vontade de aprender/boa disposição para o } \\
\text { trabalho }\end{array}$ & 8 & 11.4 & 26 & 16.6 \\
\hline participação em cooperativa & 1 & 1.4 & - & - \\
\hline sem vícios (fumo/drogas/bebidas) & - & - & 3 & 1.9 \\
\hline gostar do local (Jeri) que está trabalhando & - & - & 1 & .6 \\
\hline morar próximo do trabalho & - & - & 7 & 4.5 \\
\hline ter paciência/ser uma pessoa calma & - & - & 3 & 1.9 \\
\hline quem estiver disponível (pela alta rotatividade de funcionários) & - & - & 3 & 1.9 \\
\hline ser uma pessoa discreta & - & - & 1 & .6 \\
\hline ter flexibilidade quanto aos horários & - & - & 2 & 1.3 \\
\hline ter noções básicas da função & - & - & 1 & .6 \\
\hline capacidade de trabalhar em grupo & - & - & 1 & .6 \\
\hline saber usar o computador (recepcionista) & - & - & 1 & .6 \\
\hline não respondeu/não sabe & 4 & 5.7 & 1 & .6 \\
\hline Total & 70 & 100.0 & 157 & 100.0 \\
\hline
\end{tabular}

Fonte: pesquisa do autor.

\footnotetext{
62 A questão sobre os fatores de inclusão direta na visão do empresariado admitia mais de uma resposta por parte dos entrevistados. O número total de respostas em Barreirinhas foi de 70 (ultrapassando os 58 empresários entrevistados), e em Jijoca foi de 157 (ultrapassando os 60 empresários entrevistados).
} 


\section{(B) Fatores específicos: avaliados pelos empresários}

Logo em seguida, os empresários puderam avaliar os 11 (onze) fatores de inclusão direta, analisados neste trabalho, conferindo notas entre " 0 " e "9" para cada um deles. A forma de avaliação foi quanto ao nível de relevância do fator, de forma individual, sendo: "0" equivalente à nenhuma relevância para a inclusão; e "9" equivalente à relevância extrema para a inclusão.

Nota-se que houve similitudes entre os dois destinos tanto quanto aos três fatores citados como de maior contribuição, quanto aos dois fatores ressaltados como de menor contribuição (informações no Gráfico 18).

Do total de empresários entrevistados em Barreirinhas, 51,7\% (30 pessoas) destacou o fator "capacitação profissional" com a nota "9". Outros 48,3\% (28 pessoas) dos entrevistados deram destaque para o fator "conhecimento da área" conferindo nota "9". E, em terceiro lugar, com 41,4\% (24 pessoas), foi apresentado o fator "experiência anterior", também com a nota "9".

Quanto aos empresários de Jijoca de Jericoacoara, os mesmos fatores foram os mais frequentes nas respostas, apenas em ordem distinta da apresentada no município maranhense. O fator "conhecimento da área" foi lembrado por 56,7\% (34 pessoas) dos entrevistados, seguido do fator "capacitação profissional" por 50,0\% (30 pessoas), e do fator "experiência anterior" por $41,7 \%$ (25 pessoas).

Com respeito aos fatores com menor contribuição, novamente, houve homogeneidade entre os dois destinos. O fator "religião" recebeu nota "0" por 63,3\% (38 pessoas) dos empresários de Jijoca, e por 37,9\% (22 pessoas) dos empresários de Barreirinhas. Em seguida aparece o fator "gênero", classificado com a nota "0" por 41,7\% (25 pessoas) dos empresários de Jijoca, e por 24,1\% (14 pessoas) dos empresários de Barreirinhas.

A seguir, no Gráfico 18, é possível identificar as margens de avaliação - supracitadas dos fatores considerados de maior e de menor contribuição, na visão do empresariado. A avaliação total de todos os fatores pode ser encontrada no Apêndice 7. 


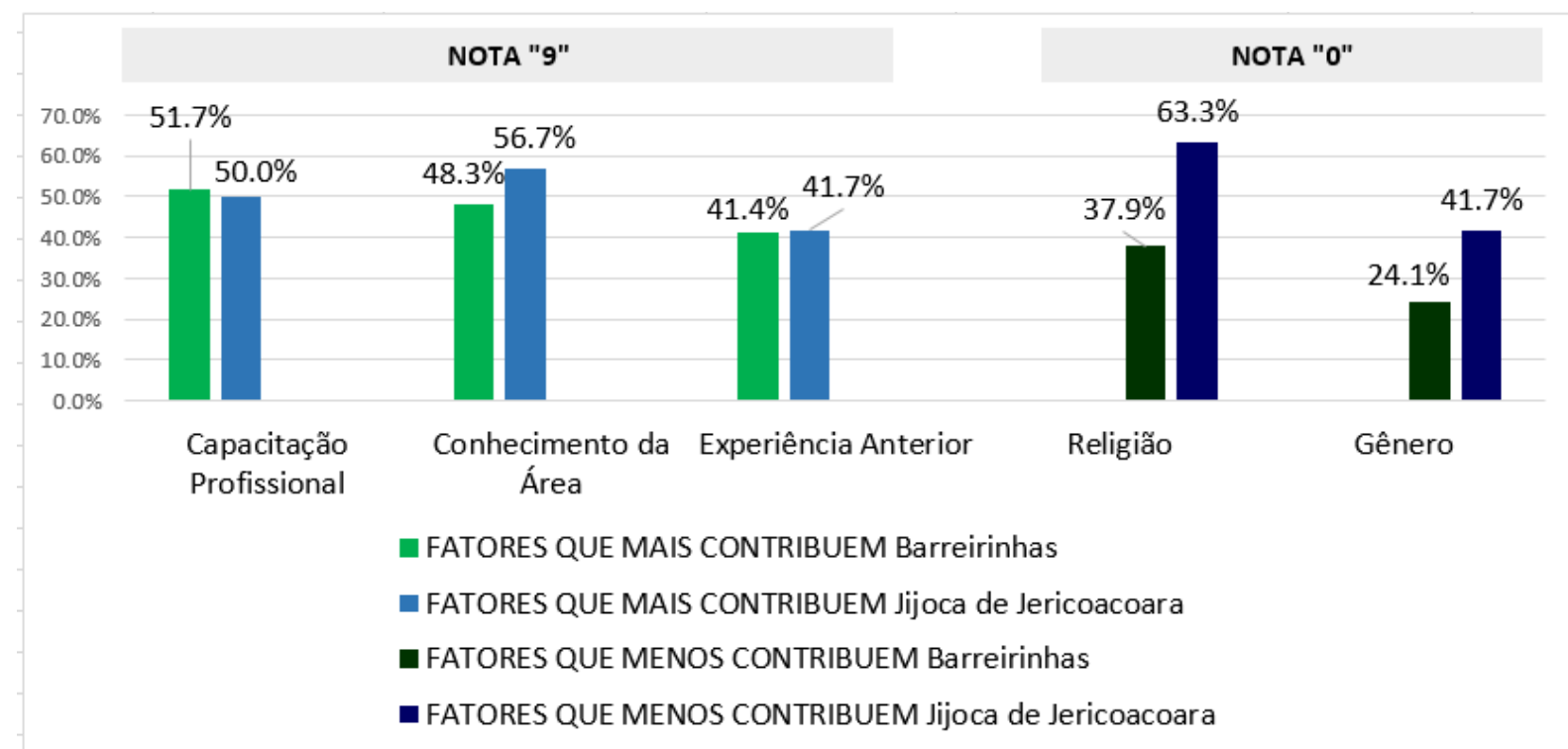

Gráfico 18: Fatores de maior e menor contribuição na visão do empresariado (DIRETA) Fonte: pesquisa do autor.

É importante que se analise, ainda, faixas de avaliação agrupadas. Numa faixa de avaliação cujas notas foram "4" ou inferiores, identifica-se a mesma característica - anteriormente destacada - em Barreirinhas e Jijoca: a "religião" (61,9\% e 80,0\%) e o "gênero" (53,4\% e 50,1\%) permanecem como os fatores ressaltados pela maioria dos entrevistados como sendo os de menor contribuição para a inclusão direta.

Numa faixa de avaliação cujas notas foram " 5 " ou superiores, o contexto se modifica nos dois destinos. Em Barreirinhas, os fatores com maior frequência de respostas nesta faixa passam a ser a "escolaridade" (96,6\%) e o "conhecimento da área/região" (96,6\%), seguidos por uma porcentagem bem próxima do fator "capacitação profissional" (96,4\%).

Em Jericoacoara, por sua vez, os fatores mais citados nesta faixa de avaliação são "conhecimento da área/região" (95,1\%), e "proximidade do local de trabalho" (95,0\%).

\section{(C) Fatores específicos por função: avaliados pelos empresários}

Os representantes do empresariado puderam destacar, ainda, os fatores que podem contribuir para a efetivação nas 16 funções específicas abrangidas pelo estudo. Uma a uma foram avaliadas pelos mesmos, e as informações encontram-se distribuídas pelas Tabela 33,

Tabela 34, Tabela 35, Tabela 36, Tabela 37 e Tabela 38. 
A primeira função avaliada foi a de responsável pelo beneficiamento de produtos, identificada em 26 estabelecimentos de Barreirinhas, e em 25 de Jijoca. Os fatores mais frequentes, destacados em ambos destinos, foram a "capacitação profissional" (46,3\% em Barreirinhas e 30,3\% em Jijoca) e a "experiência anterior" (26,8\% em Barreirinhas e 21,2\% em Jijoca). Ver Tabela 33.

Tabela 33: Fatores avaliados por função na visão do empresariado (A)

\begin{tabular}{|c|c|c|c|c|c|c|c|c|c|c|c|c|c|}
\hline & \multicolumn{4}{|c|}{ Resp. beneficiamento } & \multicolumn{4}{|c|}{ Resp. Entregas } & \multicolumn{4}{|c|}{ Guias Turísticos } \\
\hline & & \multicolumn{2}{|c|}{ Barreirinhas } & \multicolumn{2}{|c|}{ Jijoca } & \multicolumn{2}{|c|}{ Barreirinhas } & \multicolumn{2}{|c|}{ Jijoca } & \multicolumn{2}{|c|}{ Barreirinhas } & \multicolumn{2}{|c|}{ Jijoca } \\
\hline & & Freq & Percent & Freq & Percent & Freq & Percent & Freq & Percent & Freq & Percent & Freq & Percent \\
\hline & Gênero & 2 & 4.9 & - & - & - & - & 7 & 29.2 & 4 & 3.6 & - & - \\
\hline & Idade & - & - & - & - & 3 & 14.3 & - & - & 8 & 7.3 & - & - \\
\hline & Religião & - & - & - & - & - & - & - & - & 1 & .9 & - & - \\
\hline & $\begin{array}{l}\text { Rede de relações sociais } \\
\text { (indicado por conhecidos) }\end{array}$ & - & - & 2 & 6.1 & 2 & 9.5 & 2 & 8.3 & 2 & 1.8 & 3 & 3.6 \\
\hline & Conhecimento da área/região & - & - & 1 & 3.0 & - & - & - & - & 26 & 23.6 & 23 & 27.4 \\
\hline & $\begin{array}{l}\text { Local de Nascimento } \\
\text { (ser nativo) }\end{array}$ & 1 & 2.4 & 1 & 3.0 & 1 & 4.8 & 1 & 4.2 & 17 & 15.5 & 4 & 4.8 \\
\hline & Nível de escolaridade & 1 & 2.4 & 1 & 3.0 & 2 & 9.5 & - & - & 12 & 10.9 & 12 & 14.3 \\
\hline & Experiência anterior & 11 & 26.8 & 7 & 21.2 & 6 & 28.6 & 6 & 25.0 & 7 & 6.4 & 2 & 2.4 \\
\hline & Capacitação profissional & 19 & 46.3 & 10 & 30.3 & 1 & 4.8 & 2 & 8.3 & 18 & 16.4 & 8 & 9.5 \\
\hline 으 & Proximidade do trabalho & 2 & 4.9 & 5 & 15.2 & - & - & 1 & 4.2 & 3 & 2.7 & 2 & 2.4 \\
\hline$\stackrel{\pi}{>}$ & Participação em cooperativas & - & - & - & - & - & - & - & - & 7 & 6.4 & 19 & 22.6 \\
\hline & Ter higiene/boa aparência & 1 & 2.4 & - & - & - & - & - & - & - & - & 2 & 2.4 \\
\hline & $\begin{array}{l}\text { Ser atento/ter conhecimento } \\
\text { sobre os produtos }\end{array}$ & - & - & - & - & 2 & 9.5 & 1 & 4.2 & - & - & - & - \\
\hline & $\begin{array}{l}\text { Ter boa vontade / ser } \\
\text { prestativo/proativo }\end{array}$ & 1 & 2.4 & - & - & - & - & - & - & - & - & - & - \\
\hline & $\begin{array}{l}\text { Ter responsabilidade/ } \\
\text { seriedade/profissionalismo }\end{array}$ & - & - & - & - & 3 & 14.3 & 1 & 4.2 & - & - & 1 & 1.2 \\
\hline & $\begin{array}{l}\text { Saber tratar bem o } \\
\text { turista/respeitar o turista }\end{array}$ & & & & & - & & . & & 2 & 1.8 & 2 & 2.4 \\
\hline & Ser ético & - & - & - & - & - & - & - & - & - & - & 2 & 2.4 \\
\hline & Não respondeu/não sabe & 3 & 7.3 & 6 & 18.2 & 1 & 4.8 & 3 & 12.5 & 3 & 2.7 & 4 & 4.8 \\
\hline & Total & 41 & 100.0 & 33 & 100.0 & 21 & 100.0 & 24 & 100.0 & 110 & 100.0 & 84 & 100.0 \\
\hline
\end{tabular}

Fonte: pesquisa do autor.

A segunda função avaliada foi a de responsável pela entrega de produtos, apresentada em 21 estabelecimentos de cada destino. Foram destacados como principais fatores, em Barreirinhas, a "experiência anterior" (28,6\%), a "responsabilidade/seriedade/profissionalismo" 
$(14,3 \%)$ e a "idade" (14,3\%). Em Jijoca o fator "experiência anterior" também teve destaque (25,0\%), porém, inferior ao destaque do fator "gênero" (29,2\%). Dados na Tabela 33.

Para a função de guia turístico - demandada por 38 estabelecimentos entrevistados em Barreirinhas, e por 43 em Jijoca -, o fator "conhecimento da área/região" foi o que apresentou maior frequência de respostas em ambos destinos. Foram 23,6\% em Barreirinhas e 27,4\% em Jijoca de Jericoacoara.

A "capacitação profissional" (16,4\%) e o "local de nascimento (ser nativo)" (15,5\%) foram também ressaltados, no município maranhense, como outros fatores com grande contribuição para a função de guia turístico. A "participação em cooperativas" $(22,6 \%)$, da mesma forma, ganhou destaque no município cearense. Ver Tabela 33.

No caso da função de responsável pelo transporte turístico, demandado por 35 estabelecimentos de Barreirinhas e por 40 de Jericoacoara, os fatores mais citados nos dois destinos foram similares. "Conhecimento da área/região" e "participação em cooperativas" foram os dois mais ressaltados, porém, em ordem invertida.

O primeiro fator foi, em Barreirinhas, o mais citado entre os entrevistados dessa região $(20,2 \%)$, enquanto que em Jijoca foi o segundo mais citado, com $17,9 \%$. Já o segundo ganhou o maior destaque em Jericoacoara $(26,9 \%)$ e o segundo maior destaque em Barreirinhas (18,3\%). Dados na Tabela 34.

A quinta função avaliada, presente em 13 estabelecimentos entrevistados de Barreirinhas, e em oito de Jericoacoara, foi a de responsável por eventos. Novamente, os fatores mais frequentes se repetiram nos dois destinos, e com ordem inversa.

Os fatores "capacitação profissional" e "experiência anterior" foram os mais citados em Barreirinhas, com 56,3\% e 31,3\%, respectivamente. Os mesmos fatores ganharam destaque em Jericoacoara, contudo, com $12,5 \%$ e $75,0 \%$, respectivamente. Vale mencionar que o "conhecimento da área/região" também ganhou destaque com Jijoca, com 12,5\%. Ver Tabela 34.

A função de instrutor de esportes de aventura, demandada por 13 estabelecimentos em Barreirinhas e por 32 em Jericoacoara apresentou similitudes nas avaliações pelos dois destinos. O fator "capacitação profissional" ganhou o maior destaque no município maranhense (52,9\%) e, também, no cearense $(31,4 \%)$. 
Com menores porcentagens estiveram os fatores "conhecimento da área/região" $(17,6 \%)$, em Barreirinhas, e "experiência anterior" (23,5\%), em Jericoacoara. Dados completos na Tabela 34.

Tabela 34: Fatores avaliados por função na visão do empresariado (B)

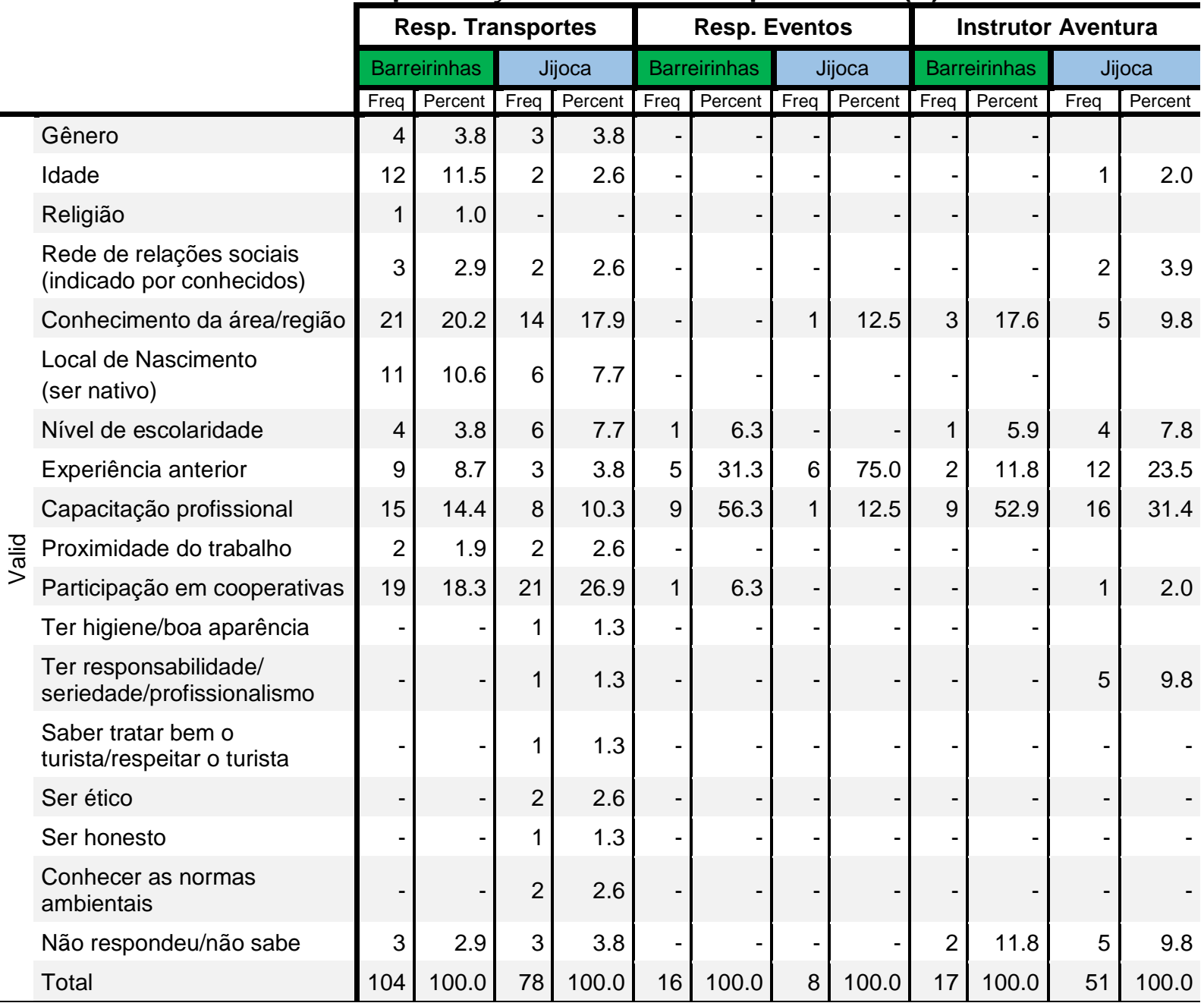

Fonte: pesquisa do autor.

Em seguida, a função avaliada foi a de camareira, realizada em 34 estabelecimentos maranhenses, e 36 cearenses. O "gênero" foi o fator com maior número de respostas em Barreirinhas (27,0\%) e a "capacitação profissional" o segundo mais citado (14,6\%).

Estes mesmos fatores ganharam destaque em Jijoca, todavia, em ordem inversa, com $14,5 \%$ e $17,3 \%$, respectivamente. Ainda assim, a "capacitação profissional" recebeu o mesmo 
número de respostas do fator "experiência anterior" (17,3\%), sendo, então, os dois fatores mais frequentes para essa função, em Jericoacoara. Ver Tabela 35.

Tabela 35: Fatores avaliados por função na visão do empresariado (C)

\begin{tabular}{|c|c|c|c|c|c|c|c|c|c|c|c|c|}
\hline & \multicolumn{4}{|c|}{ Camareira } & \multicolumn{4}{|c|}{ Garçom/Garçonete } & \multicolumn{4}{|c|}{ Chef/Cozinheira(o) } \\
\hline & \multicolumn{2}{|c|}{ Barreirinhas } & \multicolumn{2}{|c|}{ Jijoca } & \multicolumn{2}{|c|}{ Barreirinhas } & \multicolumn{2}{|c|}{ Jijoca } & \multicolumn{2}{|c|}{ Barreirinhas } & \multicolumn{2}{|c|}{ Jijoca } \\
\hline & Freq & Percent & Freq & Percent & Freq & Percent & Freq & Percent & Freq & Percent & Freq & Percent \\
\hline Gênero & 24 & 27.0 & 16 & 14.5 & 6 & 8.8 & 1 & 1.1 & 9 & 15.5 & 2 & 2.7 \\
\hline Idade & 8 & 9.0 & 8 & 7.3 & 3 & 4.4 & 4 & 4.5 & - & - & 1 & 1.3 \\
\hline Religião & 2 & 2.2 & - & - & - & - & - & - & - & - & - & - \\
\hline $\begin{array}{l}\text { Rede de relações sociais } \\
\text { (indicado por conhecidos) }\end{array}$ & 5 & 5.6 & 3 & 2.7 & 5 & 7.4 & 2 & 2.3 & 1 & 1.7 & 3 & 4.0 \\
\hline Conhecimento da área/região & 7 & 7.9 & 11 & 10.0 & 5 & 7.4 & 15 & 17.0 & 3 & 5.2 & 4 & 5.3 \\
\hline $\begin{array}{l}\text { Local de Nascimento } \\
\text { (ser nativo) }\end{array}$ & 3 & 3.4 & 3 & 2.7 & 3 & 4.4 & 1 & 1.1 & 1 & 1.7 & 1 & 1.3 \\
\hline Nível de escolaridade & 7 & 7.9 & 9 & 8.2 & 14 & 20.6 & 13 & 14.8 & 1 & 1.7 & 3 & 4.0 \\
\hline Experiência anterior & 9 & 10.1 & 19 & 17.3 & 18 & 26.5 & 17 & 19.3 & 16 & 27.6 & 22 & 29.3 \\
\hline Capacitação profissional & 13 & 14.6 & 19 & 17.3 & 9 & 13.2 & 14 & 15.9 & 16 & 27.6 & 15 & 20.0 \\
\hline Proximidade do trabalho & 3 & 3.4 & 10 & 9.1 & 1 & 1.5 & 9 & 10.2 & 2 & 3.4 & 7 & 9.3 \\
\hline Participação em cooperativas & 4 & 4.5 & - & - & 2 & 2.9 & - & - & 1 & 1.7 & & \\
\hline Ter higiene/boa aparência & - & - & 4 & 3.6 & - & - & 4 & 4.5 & 2 & 3.4 & 6 & 8.0 \\
\hline $\begin{array}{l}\text { Ser atento/ter conhecimento } \\
\text { sobre os produtos }\end{array}$ & - & - & 1 & .9 & - & - & - & - & - & - & 1 & 1.3 \\
\hline $\begin{array}{l}\text { Ter boa vontade / ser } \\
\text { prestativo/proativo }\end{array}$ & - & - & 2 & 1.8 & 2 & 2.9 & 1 & 1.1 & - & - & - & - \\
\hline $\begin{array}{l}\text { Ter responsabilidade/ } \\
\text { seriedade/profissionalismo }\end{array}$ & 1 & 1.1 & 1 & .9 & - & - & 2 & 2.3 & - & - & 1 & 1.3 \\
\hline $\begin{array}{l}\text { Saber tratar bem o } \\
\text { turista/respeitar o turista }\end{array}$ & & & - & & - & - & 3 & 3.4 & - & - & - & - \\
\hline Ser honesto & 1 & 1.1 & 2 & 1.8 & - & - & - & - & - & - & 1 & 1.3 \\
\hline $\begin{array}{l}\text { Conhecer as normas } \\
\text { ambientais }\end{array}$ & - & & - & - & - & - & - & - & - & - & - & - \\
\hline $\begin{array}{l}\text { Ter fluência em outros } \\
\text { idiomas (inglês/espanhol) }\end{array}$ & - & - & - & - & - & - & 1 & 1.1 & - & - & - & - \\
\hline $\begin{array}{l}\text { Ter bom relacionamento com } \\
\text { a equipe de trabalho }\end{array}$ & & & & & - & & - & & 1 & 1.7 & 2 & 2.7 \\
\hline Não respondeu/não sabe & 2 & 2.2 & 2 & 1.8 & - & - & 1 & 1.1 & 5 & 8.6 & 6 & 8.0 \\
\hline Total & 89 & 100.0 & 110 & 100.0 & 68 & 100.0 & 88 & 100.0 & 58 & 100.0 & 75 & 100.0 \\
\hline
\end{tabular}

Fonte: pesquisa do autor.

A avaliação da oitava função estudada - garçom/garçonete - disponível em 26 estabelecimentos entrevistados de Barreirinhas e em 37 de Jijoca, demonstrou que a "experiência anterior" é o fator com maior contribuição em ambos destinos. 
As suas porcentagens foram, em Barreirinhas e em Jericoacoara, de 26,5\% e de 19,3\%, respectivamente. $\mathrm{O}$ "grau de escolaridade" para essa função também ganhou destaque nos mesmos destinos, com $20,6 \%$ e $14,8 \%$, respectivamente. No caso de Jijoca, a "capacitação profissional" teve ainda maior porcentagem de respostas do que a escolaridade: 15,9\%. Dados na Tabela 35.

A avaliação seguinte foi da função chef de cozinha/cozinheiro(a), pelos 32 estabelecimentos de Barreirinhas e pelos 45 de Jericoacoara, que possuem essa função em seu quadro. Os fatores ressaltados foram os mesmos, nos dois destinos: "experiência anterior" (27,6\% e 29,3\%) e "capacitação profissional" (27,6\% e 20,0\%), em Barreirinhas e Jijoca, respectivamente. Ver Tabela 35.

A função de gerente, décima a ser avaliada, por 46 empreendimentos maranhenses entrevistados, e por 55 cearenses, não apresentou homogeneidade nas respostas. Os fatores mais citados em Barreirinhas foram "capacitação profissional" (23,6\%) e "nível de escolaridade" (23,0\%). Enquanto que em Jijoca foram "conhecimento da área/região" $(20,0 \%)$ e "experiência anterior" (17,4\%). Cabe ressaltar que o fator "nível de escolaridade" foi o terceiro mais citado em Jericoacoara, com 16,1\%. Dados na Tabela 36.

O cargo de secretário(a)/telefonista esteva presente em 23 empreendimentos de Barreirinhas e em 11 de Jericoacoara. A maior frequência de respostas pelos entrevistados de Barreirinhas foi para o fator "conhecimento da área/região" (25,4\%). Em contrapartida, em Jijoca, o fator mais citado foi o "nível de escolaridade" (22,6\%). Ver Tabela 36.

O fator "capacitação profissional" aparece em segundo plano em ambos municípios: 18,6\% em Barreirinhas e 16,1\% em Jericoacoara. Nesse último, a capacitação divide a segunda maior frequência de respostas com os fatores "conhecimento da área/região" e "experiência anterior", ambos com 16,1\% de respostas cada. Dados na Tabela 36.

No que tange o cargo de auxiliar administrativo financeiro, demandado por 24 e 25 estabelecimentos de Barreirinhas e de Jijoca, respectivamente, o fator "capacitação profissional" aparece como o segundo mais citado em ambos destinos (27,8\% e 17,5\%).

Os fatores com maior frequência de respostas foram, em Barreirinhas, o "nível de escolaridade" (29,6\%) e, em Jijoca, a "experiência anterior" (22,8\%). É importante mencionar que o nível de escolaridade também foi destacado em Jericoacoara, com uma frequência de apenas uma resposta a menos que o segundo fator mais citado (15,8\%). Ver Tabela 36. 
Tabela 36: Fatores avaliados por função na visão do empresariado (D)

\begin{tabular}{|c|c|c|c|c|c|c|c|c|c|c|c|c|c|}
\hline & \multicolumn{4}{|c|}{ Gerente } & \multicolumn{4}{|c|}{ Secretária/Telefonista } & \multicolumn{4}{|c|}{ Aux. Adm-Financeiro } \\
\hline & & \multicolumn{2}{|c|}{ Barreirinhas } & \multicolumn{2}{|c|}{ Jijoca } & \multicolumn{2}{|c|}{ Barreirinhas } & \multicolumn{2}{|c|}{ Jijoca } & \multicolumn{2}{|c|}{ Barreirinhas } & \multicolumn{2}{|c|}{ Jijoca } \\
\hline & & Freq & Percent & Freq & Percent & Freq & Percent & Freq & Percent & Freq & Percent & Freq & Percent \\
\hline & Gênero & 1 & .7 & 3 & 1.9 & 1 & 1.7 & 1 & 3.2 & - & - & 3 & 5.3 \\
\hline & Idade & 9 & 6.1 & 4 & 2.6 & 5 & 8.5 & 1 & 3.2 & 2 & 3.7 & 3 & 5.3 \\
\hline & Religião & 3 & 2.0 & 1 & .6 & 3 & 5.1 & - & - & - & - & - & - \\
\hline & $\begin{array}{l}\text { Rede de relações sociais } \\
\text { (indicado por conhecidos) }\end{array}$ & 5 & 3.4 & 9 & 5.8 & 2 & 3.4 & 1 & 3.2 & - & - & 3 & 5.3 \\
\hline & Conhecimento da área/região & 28 & 18.9 & 31 & 20.0 & 15 & 25.4 & 5 & 16.1 & 8 & 14.8 & 5 & 8.8 \\
\hline & $\begin{array}{l}\text { Local de Nascimento } \\
\text { (ser nativo) }\end{array}$ & 2 & 1.4 & 1 & .6 & - & - & 2 & 6.5 & - & - & 1 & 1.8 \\
\hline & Nível de escolaridade & 34 & 23.0 & 25 & 16.1 & 10 & 16.9 & 7 & 22.6 & 16 & 29.6 & 9 & 15.8 \\
\hline & Experiência anterior & 20 & 13.5 & 27 & 17.4 & 5 & 8.5 & 5 & 16.1 & 9 & 16.7 & 13 & 22.8 \\
\hline & Capacitação profissional & 35 & 23.6 & 22 & 14.2 & 11 & 18.6 & 5 & 16.1 & 15 & 27.8 & 10 & 17.5 \\
\hline & Proximidade do trabalho & 5 & 3.4 & 9 & 5.8 & 3 & 5.1 & 1 & 3.2 & - & - & 2 & 3.5 \\
\hline$\frac{\overline{\underline{0}}}{\bar{T}}$ & Participação em cooperativas & - & - & 4 & 2.6 & - & - & 1 & 3.2 & - & - & 1 & 1.8 \\
\hline & Ter higiene/boa aparência & - & - & 1 & .6 & - & - & 1 & 3.2 & - & - & - & - \\
\hline & Ser honesto & - & - & 1 & .6 & - & - & - & - & - & - & - & - \\
\hline & $\begin{array}{l}\text { Ter bom relacionamento com } \\
\text { a equipe de trabalho }\end{array}$ & 3 & 2.0 & 2 & 1.3 & - & - & - & - & - & - & - & - \\
\hline & Ser versátil & 1 & .7 & - & - & - & - & - & - & - & - & - & - \\
\hline & $\begin{array}{l}\text { Saber liderar um grupo de } \\
\text { trabalho }\end{array}$ & - & - & 2 & 1.3 & - & - & - & - & - & - & - & - \\
\hline & $\begin{array}{l}\text { Saber lidar com situações } \\
\text { difíceis }\end{array}$ & - & - & 1 & .6 & - & - & - & - & - & - & - & - \\
\hline & $\begin{array}{l}\text { Deve ter um bom histórico no } \\
\text { estabelecimento }\end{array}$ & - & 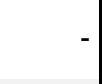 & 1 & .6 & - & - & - & - & - & - & - & - \\
\hline & Não respondeu/não sabe & 2 & 1.4 & 11 & 7.1 & 4 & 6.8 & 1 & 3.2 & 4 & 7.4 & 7 & 12.3 \\
\hline & Total & 148 & 100.0 & 155 & 100.0 & 59 & 100.0 & 31 & 100.0 & 54 & 100.0 & 57 & 100.0 \\
\hline
\end{tabular}

Fonte: pesquisa do autor.

A décima terceira função avaliada foi a de recepcionista, presente em 34 e 47 estabelecimentos de Barreirinhas e de Jijoca de Jericoacoara, respectivamente. A partir das respostas pôde-se notar que os fatores "nível de escolaridade" e "conhecimento da área/região" foram citados como os de maior contribuição para a efetivação de um candidato à recepcionista.

Foram $20,7 \%$ e $25,0 \%$ das respostas para o primeiro fator, e $19,6 \%$ e $14,4 \%$ das respostas para o segundo fator, em Barreirinhas e Jijoca, respectivamente. Ressalta-se que, em Jericoacoara, o fator "capacitação profissional" recebeu a mesma porcentagem $(14,4 \%)$ de respostas que o conhecimento da área/região, refletindo também sua notória contribuição. Dados na Tabela 37. 
Tabela 37: Fatores avaliados por função na visão do empresariado (E)

\begin{tabular}{|c|c|c|c|c|c|c|c|c|c|c|c|c|c|}
\hline & \multicolumn{4}{|c|}{ Recepcionista } & \multicolumn{4}{|c|}{ Serviços Gerais } & \multicolumn{4}{|c|}{ Segurança/Vigia } \\
\hline & & \multicolumn{2}{|c|}{ Barreirinhas } & \multicolumn{2}{|c|}{ Jijoca } & \multicolumn{2}{|c|}{ Barreirinhas } & \multicolumn{2}{|c|}{ Jijoca } & \multicolumn{2}{|c|}{ Barreirinhas } & \multicolumn{2}{|c|}{ Jijoca } \\
\hline & & Freq & Percent & Freq & Percent & Freq & Percent & Freq & Percent & Freq & Percent & Freq & Percent \\
\hline & Gênero & 1 & 1.1 & 2 & 1.9 & 10 & 10.6 & 13 & 10.3 & 8 & 16.3 & 17 & 14.7 \\
\hline & Idade & 10 & 10.9 & 4 & 3.8 & 11 & 11.7 & 4 & 3.2 & 6 & 12.2 & 14 & 12.1 \\
\hline & Religião & 2 & 2.2 & - & - & - & - & - & - & 2 & 4.1 & - & - \\
\hline & $\begin{array}{l}\text { Rede de relações sociais } \\
\text { (indicado por conhecidos) }\end{array}$ & 3 & 3.3 & 2 & 1.9 & 7 & 7.4 & 9 & 7.1 & 6 & 12.2 & 11 & 9.5 \\
\hline & Conhecimento da área/região & 18 & 19.6 & 15 & 14.4 & 4 & 4.3 & 7 & 5.6 & 4 & 8.2 & 8 & 6.9 \\
\hline & $\begin{array}{l}\text { Local de Nascimento } \\
\text { (ser nativo) }\end{array}$ & 2 & 2.2 & 2 & 1.9 & 7 & 7.4 & 6 & 4.8 & 1 & 2.0 & 7 & 6.0 \\
\hline & Nível de escolaridade & 19 & 20.7 & 26 & 25.0 & 6 & 6.4 & 7 & 5.6 & 1 & 2.0 & 6 & 5.2 \\
\hline & Experiência anterior & 12 & 13.0 & 13 & 12.5 & 14 & 14.9 & 21 & 16.7 & 3 & 6.1 & 17 & 14.7 \\
\hline & Capacitação profissional & 15 & 16.3 & 15 & 14.4 & 15 & 16.0 & 27 & 21.4 & 9 & 18.4 & 14 & 12.1 \\
\hline & Proximidade do trabalho & 3 & 3.3 & 7 & 6.7 & 6 & 6.4 & 19 & 15.1 & 3 & 6.1 & 12 & 10.3 \\
\hline & Participação em cooperativas & - & - & 1 & 1.0 & 4 & 4.3 & 2 & 1.6 & - & - & 3 & 2.6 \\
\hline & Ter higiene/boa aparência & - & - & 4 & 3.8 & - & - & 3 & 2.4 & - & - & - & - \\
\hline & $\begin{array}{l}\text { Ter boa vontade / ser } \\
\text { prestativo/proativo }\end{array}$ & - & - & 1 & 1.0 & 3 & 3.2 & 4 & 3.2 & - & - & - & - \\
\hline & $\begin{array}{l}\text { Ter responsabilidade/ } \\
\text { seriedade/profissionalismo }\end{array}$ & - & - & - & - & 1 & 1.1 & - & - & - & - & 2 & 1.7 \\
\hline & $\begin{array}{l}\text { Saber tratar bem o } \\
\text { turista/respeitar o turista }\end{array}$ & - & - & 3 & 2.9 & - & . & 1 & .8 & - & & - & - \\
\hline & Ser honesto & - & - & - & - & 1 & 1.1 & - & - & 1 & 2.0 & - & - \\
\hline & $\begin{array}{l}\text { Ter fluência em outros } \\
\text { idiomas (inglês/espanhol) }\end{array}$ & & & 2 & 1.9 & - & - & - & - & - & & - & - \\
\hline & $\begin{array}{l}\text { Ter bom relacionamento com } \\
\text { a equipe de trabalho }\end{array}$ & - & - & 1 & 1.0 & - & - & - & - & - & - & 1 & .9 \\
\hline & $\begin{array}{l}\text { Saber lidar com situações } \\
\text { difíceis }\end{array}$ & - & - & 1 & 1.0 & - & - & - & - & - & - & - & - \\
\hline & Não respondeu/não sabe & 7 & 7.6 & 5 & 4.8 & 5 & 5.3 & 3 & 2.4 & 5 & 10.2 & 4 & 3.4 \\
\hline & Total & 92 & 100.0 & 104 & 100.0 & 94 & 100.0 & 126 & 100.0 & 49 & 100.0 & 116 & 100.0 \\
\hline
\end{tabular}

Fonte: pesquisa do autor.

O cargo de serviços gerais estava presente em, respectivamente, 50 e 55 empreendimentos de Barreirinhas e de Jericoacoara. Os fatores com maior frequência foram os mesmos, nos dois destinos: "capacitação profissional" (16,0\% e 21,4\%) e "experiência anterior" (14,9\% e 16,7\%). Ver Tabela 37.

A avaliação da função de segurança/vigia por 26 e 43 estabelecimentos de Barreirinhas e de Jijoca, respectivamente, mostrou que dois fatores ganham destaque em ambos destinos: "gênero" (16,3\% e 14,7\%) e "capacitação profissional" (18,4\% e 12,1\%). Além destes, foram 
citados com notória frequência, em Jijoca, os fatores "experiência anterior" (14,7\%) e "idade" (12,1\%). Dados na Tabela 37.

Por fim, o último fator avaliado foi o de auxiliar de cozinha, por 27 e 35 empreendimentos entrevistados de Barreirinhas e de Jericoacoara, respectivamente. Os fatores ressaltados com maior frequência foram os mesmos nos dois destinos, porém, com ordem inversa.

Em Barreirinhas o fator "capacitação profissional" $(23,0 \%)$ foi o mais citado, seguido pelo fator "experiência anterior" (19,7\%). Em Jijoca apresentou-se o inverso, com 25,4\% para "experiência anterior" e 20,9\% para "capacitação profissional". Dados na Tabela 38.

Tabela 38: Fatores avaliados por função na visão do empresariado (F)

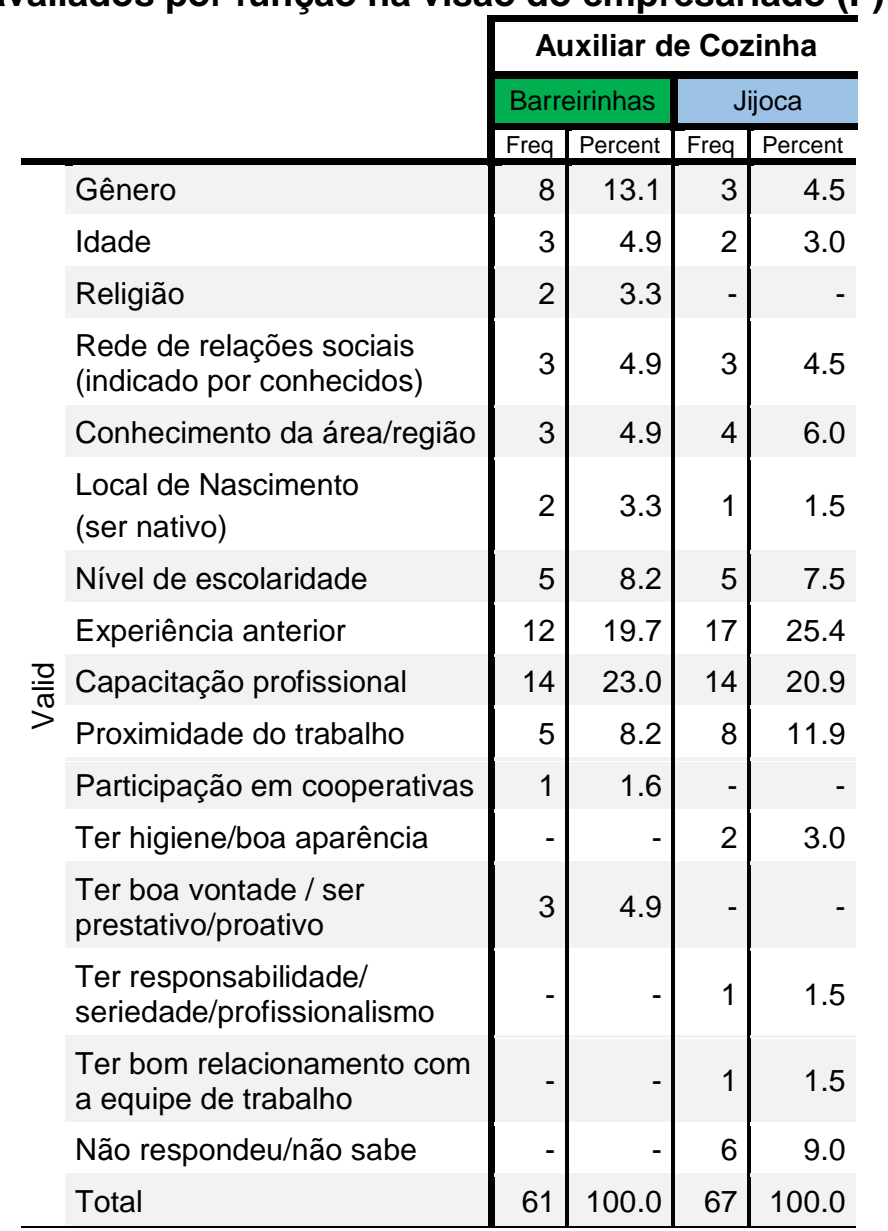

Fonte: pesquisa do autor. 


\subsection{Fatores que Prejudicam a Inclusão Direta}

No caso da não admissão ao emprego, o fator com maior frequência de respostas ${ }^{63}$ entre os entrevistados da população de Barreirinhas foi a "pouca capacitação técnica para o serviço" (34,7\% - 17 indivíduos), seguido do fator "baixa escolaridade" (22,4\% - 11 indivíduos). Ver

\section{Gráfico 19.}

Já em Jijoca de Jericoacoara, o número pouco expressivo de entrevistados que buscaram e não conseguiram sua admissão ao emprego - apenas seis pessoas - acabou por apresentar seis fatores distintos (16,7\% - um indivíduo, cada): "pouca capacitação técnica para o serviço"; "baixa escolaridade"; "idade inadequada"; "ausência de indicação por conhecidos"; "morar longe do local de trabalho"; e "falta de experiência anterior com o mesmo trabalho". Dados apresentados no Gráfico 19.

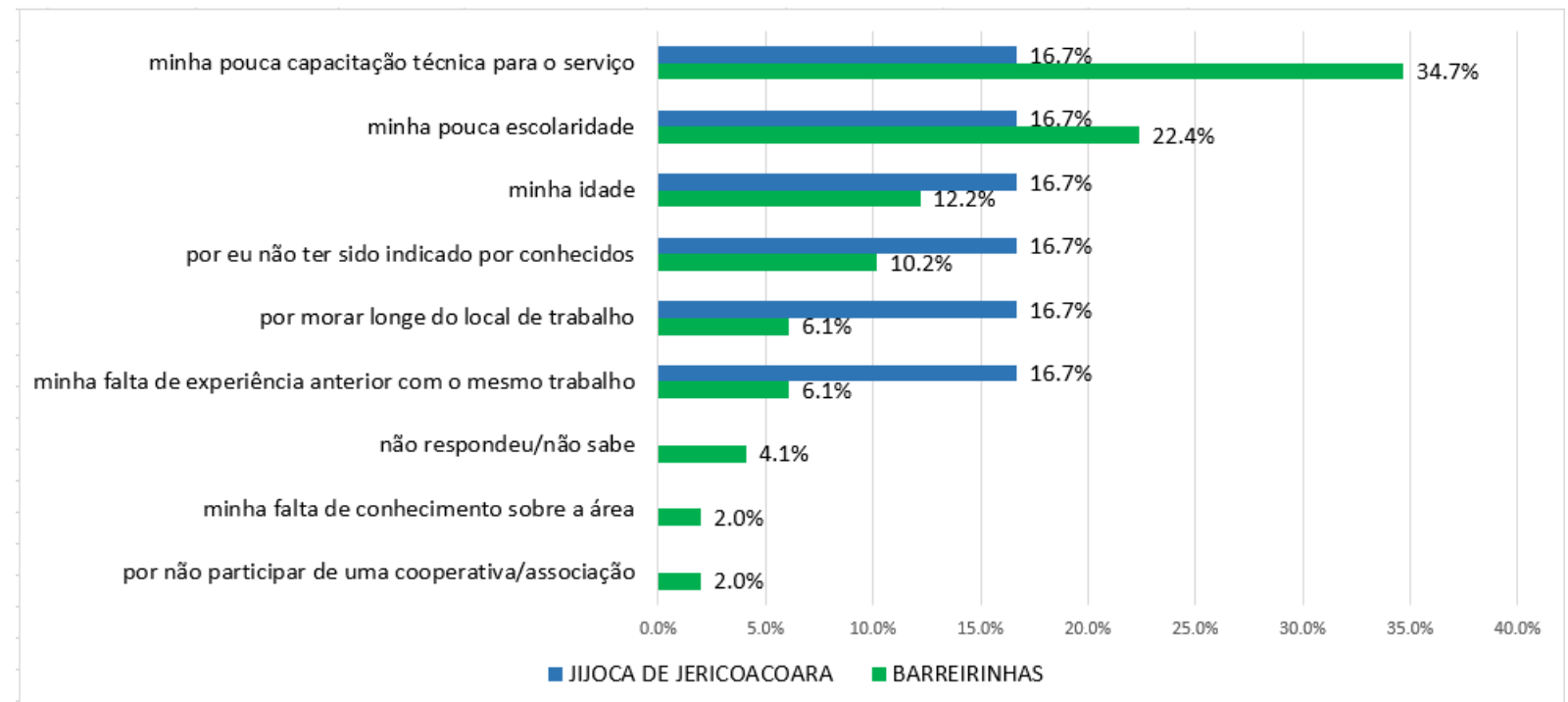

\section{Gráfico 19: Fatores que prejudicaram a inclusão direta}

Fonte: pesquisa do autor. 63 A questão sobre os fatores que prejudicaram a inclusão direta no setor de Turismo admitia mais de uma resposta
por parte dos entrevistados. O número total de respostas em Barreirinhas, pela população, foi de 49 (ultrapassando
os 41 indivíduos que não conseguiram), e em Jijoca foi de seis (equivalente aos seis indivíduos que não conseguiram. 


\subsection{Características dos Empreendimentos e dos Empreendedores}

\subsubsection{Funções dos entrevistados no estabelecimento}

Os formulários aplicados com os empresários do trade turístico dos dois destinos estudados abrangeram, com maior frequência, os principais responsáveis pelos estabelecimentos e, consequentemente, os que melhor conheciam a dinâmica de contratações de funcionários e de aquisições de produtos utilizados: proprietários e gerentes.

Dos entrevistados de Barreirinhas, 27 indivíduos (46,6\%) eram gerentes e 25 indivíduos $(43,1 \%)$ eram os próprios proprietários dos estabelecimentos. No caso e Jijoca, a proporção de gerentes foi maior, com $51,7 \%$ (31 indivíduos) e, consequentemente, menor de proprietários, com 41,7\% (25 indivíduos). As informações estão destacadas no Gráfico 20, a seguir.

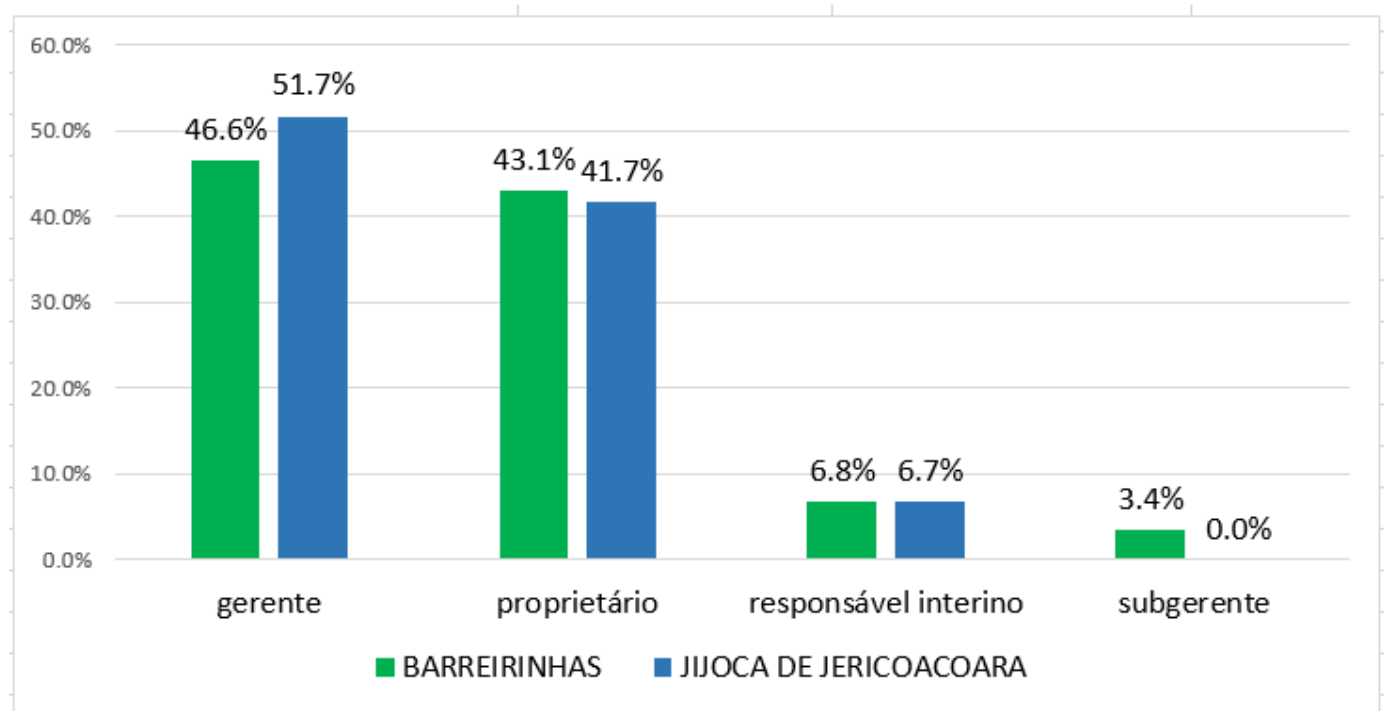

Gráfico 20: Funções dos entrevistados do trade turístico

Fonte: pesquisa do autor.

\subsubsection{Perfis dos estabelecimentos abrangidos}

A maioria dos estabelecimentos atingidos pela pesquisa foram, em ambos destinos, meios de hospedagem (dentre hotéis, pousadas, hostels e resorts) e empresas de alimentação (tais como restaurantes, bares, lanchonetes e pizzarias). 
Dentre outros perfis de estabelecimentos abrangidos, o foco recaiu sobre esses dois modelos não só por prevalecerem diante dos demais perfis, mas, principalmente, por serem, ao mesmo tempo, potenciais empregadores de mão de obra e notórios consumidores de produtos.

Diante disso, do total de estabelecimentos participantes da pesquisa em Barreirinhas, $41,4 \%$ (29 estabelecimentos) eram meios de hospedagem, e 24,3\% (17 estabelecimentos) eram empresas de alimentação. Em Jijoca, por sua vez, 54,5\% (36 estabelecimentos) era meios de hospedagem, e 33,3\% (22 estabelecimentos) eram empresas de alimentação. Dados no Gráfico 21.

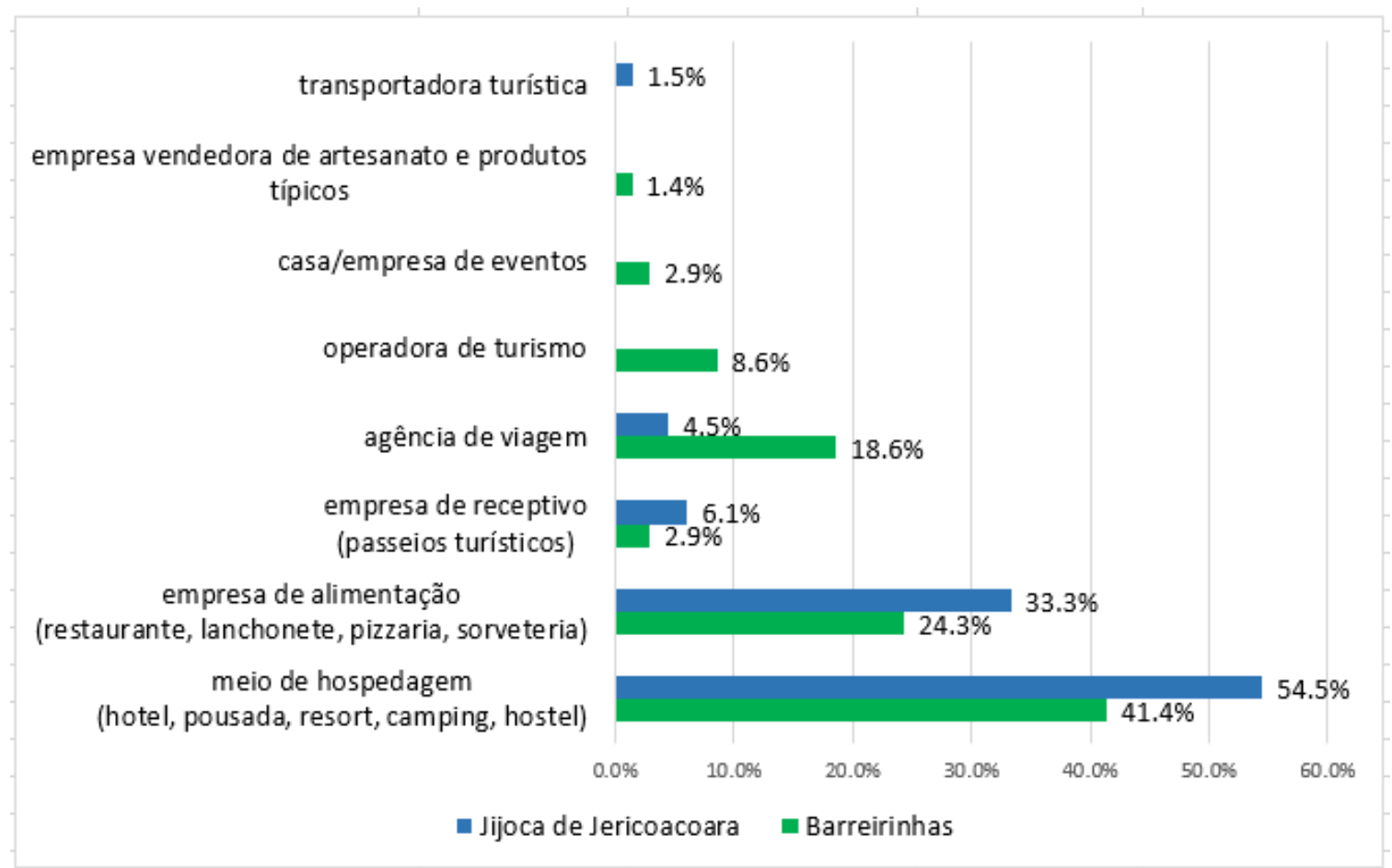

\section{Gráfico 21: Perfil dos estabelecimentos}

Fonte: pesquisa do autor.

Foram entrevistados representantes de empreendimentos turísticos de pequeno, médio e grande porte, das duas regiões. Encontrou-se estabelecimentos com apenas um funcionário ativo, até outros estabelecimentos com 90 funcionários efetivos.

Nos dois destinos a maior frequência de estabelecimentos entrevistados continha, em seu quadro de funcionários, entre três e seis pessoas efetivas (ver Gráfico 22). Em Barreirinhas, $48,3 \%$ (28 estabelecimentos) tinham esse perfil, e em Jijoca $25,0 \%$ (15 estabelecimentos). 


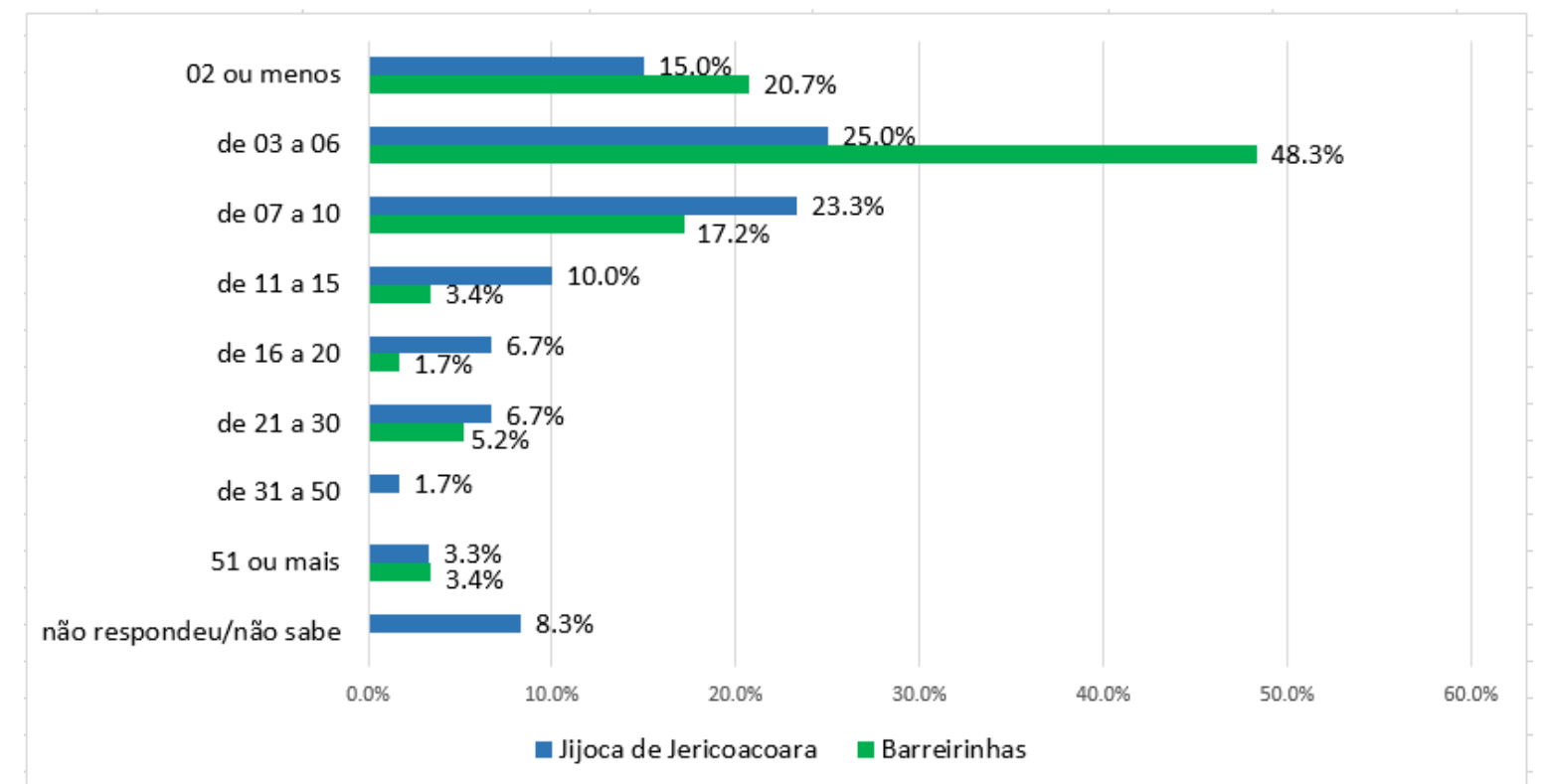

Gráfico 22: Número de funcionários do estabelecimento

Fonte: pesquisa do autor.

\subsubsection{Origem dos funcionários}

Para a análise da origem dos funcionários dos estabelecimentos participantes da pesquisa, as informações foram distribuídas em seis segmentos: moradores nativos (locais); moradores não nativos (de fora); empresas locais; empresas de fora; cooperativas locais; e cooperativas de fora.

Pôde-se perceber, em ambos destinos, a notória participação da população nativa (local) nas diversas funções ${ }^{64}$ desenvolvidas nos estabelecimentos turísticos estudados. Em Barreirinhas, dos 465 cargos (100\%) nos 58 estabelecimentos entrevistados, 393 (84,5\%) são desempenhados por nativos (pessoa física). Apenas 15 cargos $(3,2 \%)$ são ocupados por indivíduos nascidos em outras regiões que, atualmente, moram no município. Outros 25 cargos (5.3\%) por cooperativas, e 32 cargos (6,9\%) por empresas, ambos locais. Ver Tabela 39.

${ }^{64}$ Ao todo foram 16 funções analisadas, consideradas - a partir de informações levantadas junto às secretarias de turismo municipais - as mais comuns e frequentes nos destinos. 
Tabela 39: Origem dos funcionários por função (Barreirinhas)

\begin{tabular}{|c|c|c|c|c|c|c|c|c|c|c|c|c|c|}
\hline \multicolumn{14}{|c|}{ BARREIRINHAS } \\
\hline & & \multicolumn{4}{|c|}{ Morador } & \multicolumn{4}{|c|}{ Empresa } & \multicolumn{4}{|c|}{ Cooperativa } \\
\hline & & \multicolumn{2}{|c|}{ Local } & \multicolumn{2}{|c|}{ De fora } & \multicolumn{2}{|c|}{ Local } & \multicolumn{2}{|c|}{ De fora } & \multicolumn{2}{|c|}{ Local } & \multicolumn{2}{|c|}{ De fora } \\
\hline & & Freq & $\%$ & Freq & $\%$ & Freq & $\%$ & Freq & $\%$ & Freq & $\%$ & Freq & $\%$ \\
\hline & $\begin{array}{l}\text { Responsável pelo } \\
\text { beneficiamento (de } \\
\text { produtos) }\end{array}$ & 26 & 100.0 & - & - & - & - & - & - & - & - & - & - \\
\hline & Entregador (de produtos) & 21 & 100.0 & - & - & - & - & - & - & - & - & - & - \\
\hline & Guia turístico & 20 & 52.6 & - & - & 8 & 21.1 & - & - & 10 & 26.3 & - & - \\
\hline & Transporte para passeios & 10 & 28.6 & - & - & 13 & 37.1 & - & - & 12 & 34.3 & - & - \\
\hline & Organizador de eventos & 9 & 69.2 & - & - & 2 & 15.4 & - & - & 2 & 15.4 & - & - \\
\hline & $\begin{array}{l}\text { Instrutor de esportes de } \\
\text { aventura }\end{array}$ & 4 & 30.8 & - & - & 9 & 69.2 & - & - & - & - & - & - \\
\hline & Camareira & 34 & 100.0 & - & - & - & - & - & - & - & - & - & \\
\hline$\frac{\overline{\underline{0}}}{\bar{\sigma}}$ & Garçom/Garçonete & 26 & 100.0 & - & - & - & - & - & - & - & - & - & - \\
\hline$>$ & Chef de cozinha/cozinheira & 29 & 90.6 & 3 & 9.4 & - & - & - & - & - & - & - & - \\
\hline & Gerente & 37 & 80.4 & 9 & 19.6 & - & - & - & - & - & - & - & - \\
\hline & Secretária(o)/Telefonista & 23 & 100.0 & - & - & - & - & - & - & - & - & - & - \\
\hline & $\begin{array}{l}\text { Auxiliar administrativo- } \\
\text { financeiro }\end{array}$ & 21 & 87.5 & 3 & 12.5 & - & - & - & - & - & - & - & \\
\hline & Recepcionista & 34 & 100.0 & - & - & - & - & - & - & - & - & - & \\
\hline & Serviços gerais & 49 & 98.0 & - & - & - & - & - & - & 1 & 2.0 & - & - \\
\hline & Segurança/vigia & 23 & 88.5 & - & - & 3 & 11.5 & - & - & - & - & - & - \\
\hline & Auxiliar de cozinha & 27 & 100.0 & - & - & - & - & - & - & - & - & - & - \\
\hline & Total & 393 & - & 15 & - & 32 & - & - & - & 25 & - & - & - \\
\hline
\end{tabular}

Fonte: pesquisa do autor.

Os formulários mostraram que as funções desempenhadas com $100 \%$ da mão de obra local, em Barreirinhas, são: auxiliar de cozinha; recepcionista; secretário(a)/telefonista; garçom/garçonete; camareira; entregador; e responsável pelo beneficiamento. A função de "serviços gerais" poderia ser incluída dado que atingiu quase que sua totalidade $(98,0 \%)$.

Em contrapartida, as funções com porcentagens de indivíduos de fora são: chef de cozinha/cozinheiro(a) (9,4\%); gerente (19,6\%); e auxiliar administrativo-financeiro (12,5\%).

Em Jijoca de Jericoacoara, por sua vez, a porcentagem de nativos (pessoa física) nas atividades é menor que em Barreirinhas. Dos 558 cargos (100\%) nos 60 estabelecimentos entrevistados, 404 (72,4\%) são desempenhados por moradores nascidos na localidade. Outros 78 cargos (13,9\%) são ocupados por indivíduos não nativos, porcentagem bem superior, se comparado ao destino maranhense. Constatou-se, ainda, 48 cargos $(8,6 \%)$ por cooperativas locais, 26 cargos $(4,6 \%)$ por empresas locais, e 02 cargos $(0,35 \%)$ por empresas de fora. Dados completos na Tabela 40. 
Diferentemente de Barreirinhas, não houve nenhuma função a qual 100\% da mão de obra fosse nativa. De toda forma, algumas funções atingiram porcentagens superiores à $94 \%$, caracterizadas como funções próprias dos nativos. Inclusive, algumas delas, apresentadas em Barreirinhas. São elas: camareira $(97,2 \%)$; auxiliar de cozinha $(97,1 \%)$; serviços gerais $(94,5 \%)$; e segurança/vigia $(97,7 \%)$.

No caso das funções com maior porcentagem de indivíduos de fora, a realidade é distinta de Barreirinhas. Ainda que a similaridade da função de "gerente" seja presente, a porcentagem e Jijoca é bem superior (49,1\%). As demais funções são distintas do destino maranhense: organizador de eventos (25,0\%); garçom/garçonete (21,6\%); e recepcionista $(19,1 \%)$. Ver Tabela 40.

Tabela 40: Origem dos funcionários por função (Jijoca de Jericoacoara)

\begin{tabular}{|c|c|c|c|c|c|c|c|c|c|c|c|c|c|}
\hline \multicolumn{14}{|c|}{ JIJOCA DE JERICOACOARA } \\
\hline & & \multicolumn{4}{|c|}{ Morador } & \multicolumn{4}{|c|}{ Empresa } & \multicolumn{4}{|c|}{ Cooperativa } \\
\hline & & \multicolumn{2}{|c|}{ Local } & \multicolumn{2}{|c|}{ De fora } & \multicolumn{2}{|c|}{ Local } & \multicolumn{2}{|c|}{ De fora } & \multicolumn{2}{|c|}{ Local } & \multicolumn{2}{|c|}{ De fora } \\
\hline & & Freq & $\%$ & Freq & $\%$ & Freq & $\%$ & Freq & $\%$ & Freq & $\%$ & Freq & $\%$ \\
\hline \multirow{17}{*}{$\frac{\text { 음 }}{>}$} & $\begin{array}{l}\text { Responsável pelo } \\
\text { beneficiamento (de } \\
\text { produtos) }\end{array}$ & 22 & 88.0 & 3 & 12.0 & - & - & - & 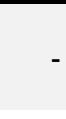 & & - & - & - \\
\hline & Entregador (de produtos) & 17 & 81.0 & 3 & 14.3 & 1 & 4.8 & - & - & - & - & - & - \\
\hline & Guia turístico & 15 & 34.9 & 2 & 4.7 & 3 & 7.0 & - & - & 23 & 53.5 & - & - \\
\hline & Transporte para passeios & 8 & 20.0 & 2 & 5.0 & 3 & 7.5 & 2 & 5.0 & 25 & 62.5 & - & - \\
\hline & Organizador de eventos & 4 & 50.0 & 2 & 25.0 & 2 & 25.0 & - & - & - & - & - & - \\
\hline & $\begin{array}{l}\text { Instrutor de esportes de } \\
\text { aventura }\end{array}$ & 11 & 34.4 & 4 & 12.5 & 17 & 53.1 & - & - & - & - & - & - \\
\hline & Camareira & 35 & 97.2 & 1 & 2.8 & - & - & - & - & - & - & - & - \\
\hline & Garçom/Garçonete & 29 & 78.4 & 8 & 21.6 & - & - & - & - & - & - & - & - \\
\hline & Chef de cozinha/cozinheira & 39 & 86.7 & 6 & 13.3 & - & - & - & - & - & - & - & - \\
\hline & Gerente & 28 & 50.9 & 27 & 49.1 & - & - & - & - & - & - & - & - \\
\hline & Secretária(o)/Telefonista & 9 & 81.8 & 2 & 18.2 & - & - & - & - & - & - & - & - \\
\hline & $\begin{array}{l}\text { Auxiliar administrativo- } \\
\text { financeiro }\end{array}$ & 21 & 84.0 & 4 & 16.0 & - & - & - & - & - & - & - & - \\
\hline & Recepcionista & 38 & 80.9 & 9 & 19.1 & - & - & - & - & - & - & - & - \\
\hline & Serviços gerais & 52 & 94.5 & 3 & 5.5 & - & - & - & - & - & - & - & - \\
\hline & Segurança/vigia & 42 & 97.7 & 1 & 2.3 & - & - & - & - & - & - & - & - \\
\hline & Auxiliar de cozinha & 34 & 97.1 & 1 & 2.9 & - & - & - & - & - & - & - & - \\
\hline & Total & 404 & - & 78 & - & 26 & - & 02 & - & 48 & - & - & - \\
\hline
\end{tabular}

Fonte: pesquisa do autor.

\subsubsection{Formas de divulgação de oportunidades de emprego}

Muitas foram as diferentes formas de divulgação de vagas de emprego citadas pelos entrevistados. Ainda assim, Barreirinhas e Jijoca compartilham, com maior frequência, da mesma 
forma de divulgação: "divulgação interna para que os funcionários indiquem conhecidos". Tal forma de divulgação foi citada por $26,2 \%$ (17 respostas) dos entrevistados de Barreirinhas, e por $28,7 \%$ (25 respostas) dos entrevistados de Jijoca de Jericoacoara.

Em seguida, as formas de divulgação de cada destino se distinguem. Os empresários de Barreirinhas mencionaram que o "banco de currículos" também é uma forma bastante utilizada (23,1\% - 15 respostas) para preencher as vagas, dada a constante procura na recepção dos próprios estabelecimentos, por parte de interessados.

Já os empresários de Jijoca relataram que o "boca a boca" (19,5\% - 17 respostas) iniciado, por vezes, com pequenos cartazes informativos (Figura 51) - também é uma forma eficaz de divulgação de oportunidades de emprego pelo município. Estas e as demais formas de divulgação encontram-se descritas na Tabela 41.

Tabela 41: Formas de divulgação de oportunidades de emprego

\begin{tabular}{|c|c|c|c|c|}
\hline & \multicolumn{2}{|c|}{ BARREIRINHAS } & \multicolumn{2}{|c|}{$\begin{array}{l}\text { JIJOCA DE } \\
\text { JERICOACOARA }\end{array}$} \\
\hline & Freq & Percent & Freq & Percent \\
\hline divulgam internamente para que os funcionários indiquem conhecidos & 17 & 26.2 & 25 & 28.7 \\
\hline $\begin{array}{l}\text { divulgam pela cidade (rádio, carro de som, estabelecimentos comerciais, } \\
\text { etc.) }\end{array}$ & 7 & 10.8 & 5 & 5.7 \\
\hline divulgam pela internet (facebook, twitter, site) & 3 & 4.6 & 9 & 10.3 \\
\hline banco de currículos/procura constante por interessados & 15 & 23.1 & 10 & 11.5 \\
\hline convidamos conhecidos/conversamos com conhecidos & 10 & 15.4 & 8 & 9.2 \\
\hline boca a boca & 8 & 12.3 & 17 & 19.5 \\
\hline 으 procuram o sindicato de hotelaria & 3 & 4.6 & - & - \\
\hline$>$ procuram o Sebrae/Senac & 2 & 3.1 & - & - \\
\hline divulgam para agências de emprego especializadas (CATHO) & - & - & 5 & 5.7 \\
\hline intranet dos gerentes de Jericoacoara & - & - & 1 & 1.1 \\
\hline conversam com outras agências de turismo & - & - & 1 & 1.1 \\
\hline jornais de Fortaleza & - & - & 2 & 2.3 \\
\hline divulgam pela região de Jericoacoara/entre os estabelecimentos & - & - & 3 & 3.4 \\
\hline não respondeu/não sabe & - & - & 1 & 1.1 \\
\hline Total & 65 & 100.0 & 87 & 100.0 \\
\hline
\end{tabular}

Fonte: pesquisa do autor. 

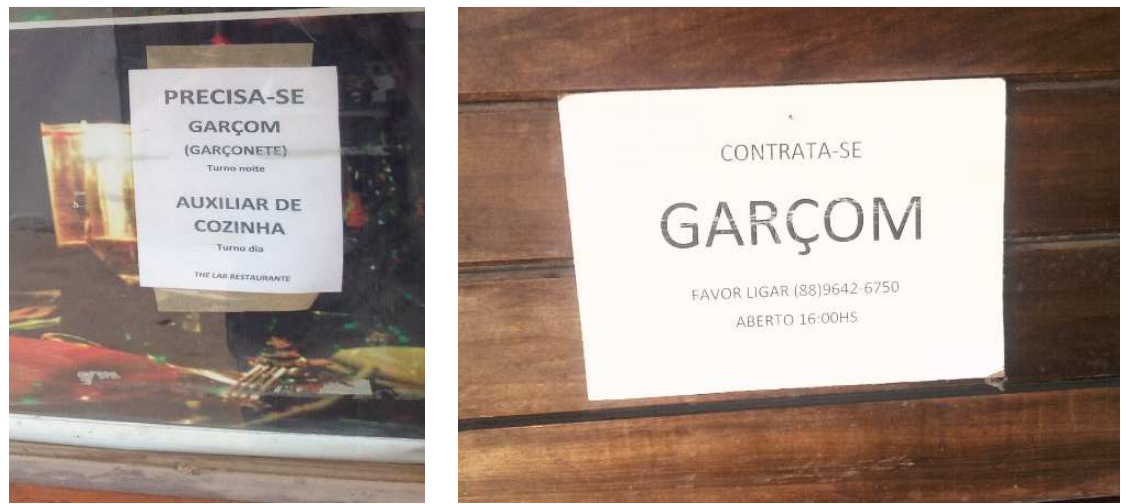

Figura 51: Cartazes informativos de vaga de emprego

Fonte: pesquisa do autor.

\subsubsection{Origem dos produtos consumidos}

Foi ressaltado pelos empresários dos dois destinos pesquisados que, a maior parte dos produtos consumidos pelos estabelecimentos que representam, com exceção das peças de artesanato, é de origem externa ao município.

Para aqueles empreendimentos que trabalham com o oferecimento de pescados aos turistas, a aquisição desse produto fora do município foi ressaltada por 37,5\% (09 respostas) deles em Barreirinhas, e por 55,6\% (15 respostas) em Jijoca. Dados nos Gráfico 23 e Gráfico 24.

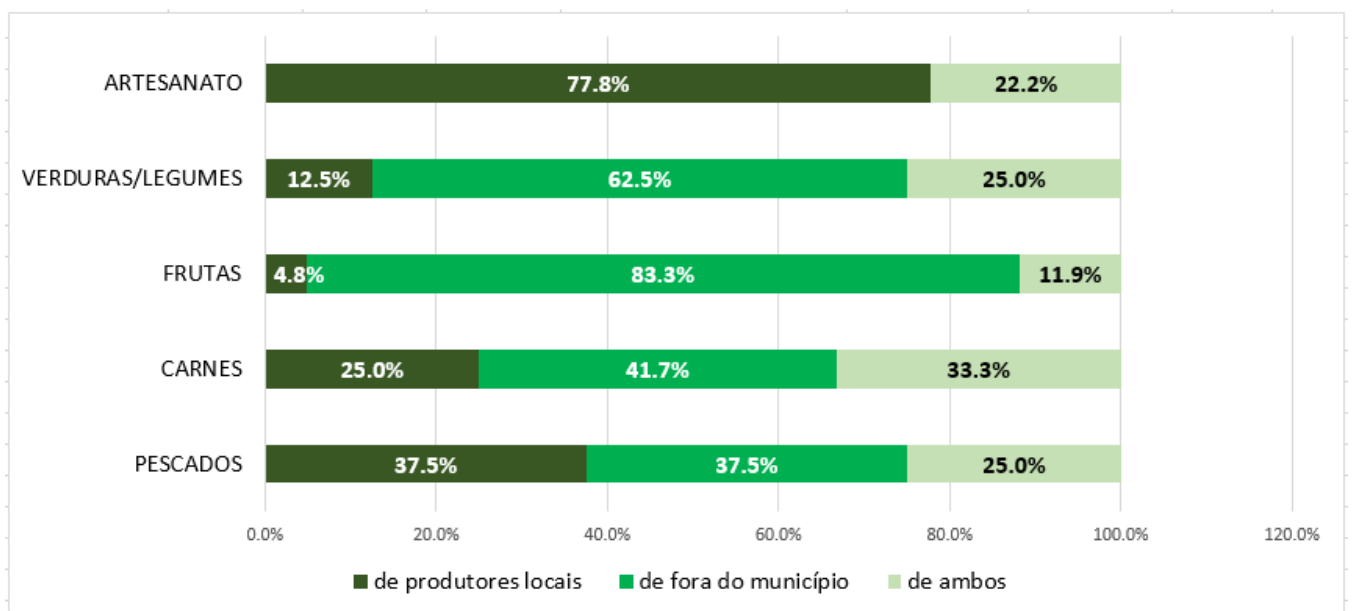

Gráfico 23: Origem dos produtos consumidos (Barreirinhas)

Fonte: pesquisa do autor. 


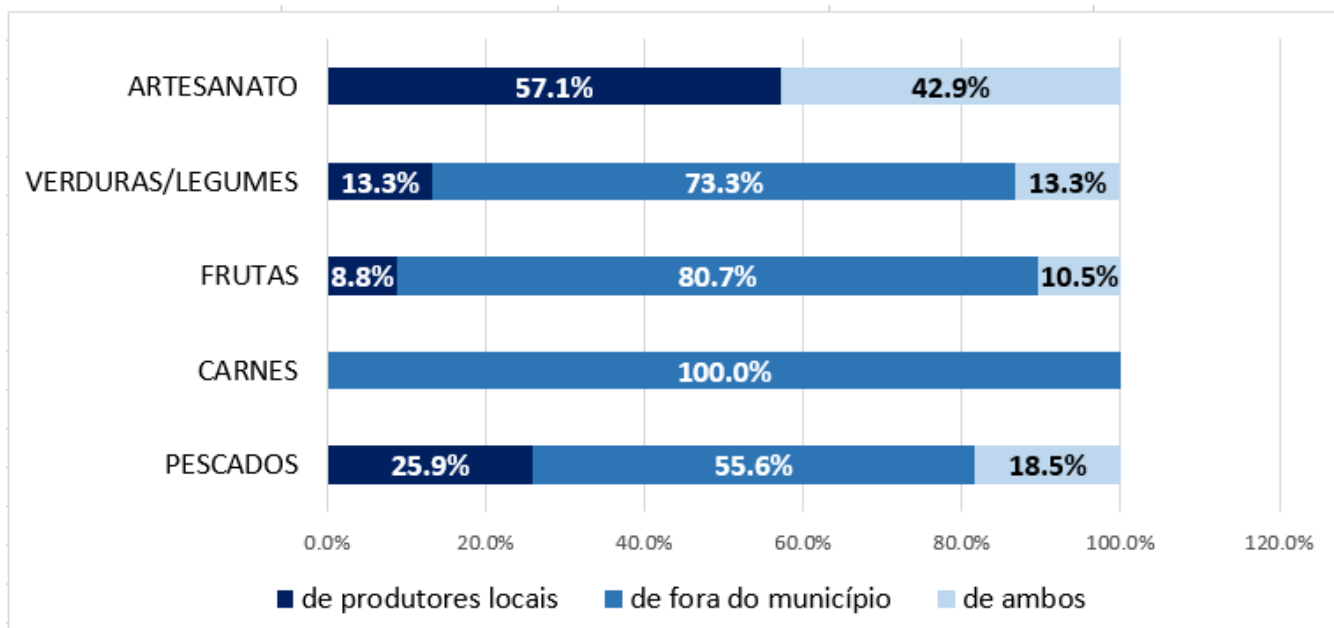

Gráfico 24: Origem dos produtos consumidos (Jijoca de Jericoacoara)

Fonte: pesquisa do autor.

Aquisições de carnes de fora chegaram a ser citados por 41,7\% (10 respostas) dos entrevistados maranhenses, e por 100\% (28 respostas) dos entrevistados cearenses.

As frutas, tão abundantes nos dois municípios, também são importadas de outras regiões - por vezes, disponibilizadas por pequenos mercados locais (Figura 52) - como destacado por 83,3\% (35 respostas) dos estabelecimentos de Barreirinhas, e por 80,7\% (46 respostas) dos estabelecimentos de Jericoacoara. Ver Gráfico 23 e Gráfico 24.
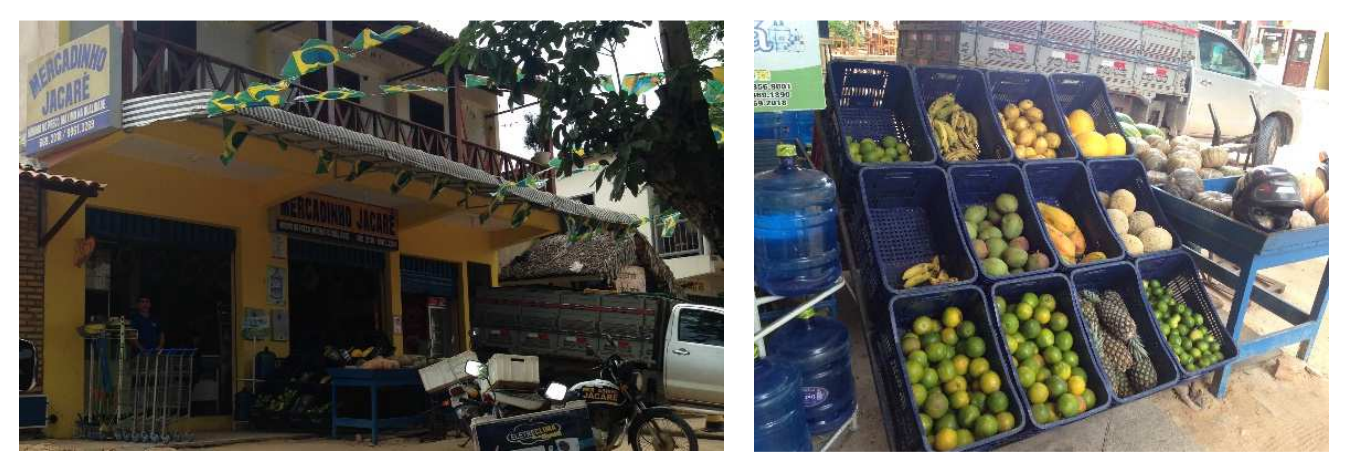

Figura 52: Frutas importadas de outras regiões vendidas nos mercados de Jericoacoara Fonte: pesquisa do autor.

As verduras e os legumes não fogem à regra. O seu consumo, pela maior parte dos entrevistados, vem de fora. Tal fato foi ressaltado por 62,5\% (15 respostas) dos empreendimentos maranhenses, e por $73,3 \%$ (22 respostas) dos cearenses.

Em contrapartida, o artesanato, em ambas localidades - oferecido num número reduzido dos estabelecimentos entrevistados - é minimamente importado de outras regiões. Em 
Barreirinhas $77,8 \%$ (07 respostas) dos empreendimentos consomem dos próprios produtores locais. E em Jijoca, a porcentagem do consumo interno chega a 57,1\% (04 respostas). Informações completas nos Gráfico 23 e Gráfico 24.

\subsection{Fatores que Contribuem para a Inclusão Indireta}

\section{(A) Fatores diversos: apresentados pelos empresários}

A aplicação dos formulários permitiu identificar as visões do empresariado com respeito aos fatores que, segundo eles, contribuem para a aquisição (ou não aquisição) de um produto, e para a utilização (ou não utilização) de um serviço local.

Assim como nas questões sobre fatores de contratação, os empresários responderam, inicialmente, a uma pergunta aberta, na qual eles puderam ressaltar fatores que, para eles, influem na decisão da compra ou da utilização de um serviço.

As respostas foram homogêneas. Tanto os empresários de Barreirinhas, quanto os de Jericoacoara, ressaltaram, com maior frequência de respostas, a "qualidade/frescor do produto" (56,5\% - 35 respostas, e 39,8\% - 43 respostas, respectivamente) e o "preço" (14,5\% - 09 respostas, e 27,8\% - 30 respostas, respectivamente). Dados descritos na Tabela 42.

Tabela 42: Fatores que contribuem para a compra de produtos/utilização de serviços

\begin{tabular}{|c|c|c|c|c|}
\hline & \multicolumn{2}{|c|}{ BARREIRINHAS } & \multicolumn{2}{|c|}{$\begin{array}{c}\text { JIJOCA DE } \\
\text { JERICOACOARA }\end{array}$} \\
\hline & Freq & Percent & Freq & Percent \\
\hline qualidade/frescor & 35 & 56.5 & 43 & 39.8 \\
\hline preço & 9 & 14.5 & 30 & 27.8 \\
\hline aparência do produto (eu prefiro ir ao local e escolher o produto) & 6 & 9.7 & 5 & 4.6 \\
\hline higiene do estabelecimento (fornecedor) & 2 & 3.2 & 2 & 1.9 \\
\hline necessidade & 1 & 1.6 & 4 & 3.7 \\
\hline prazo de validade & 2 & 3.2 & 1 & .9 \\
\hline armazenamento adequado/local de estocagem & 2 & 3.2 & 2 & 1.9 \\
\hline variedade & 1 & 1.6 & 3 & 2.8 \\
\hline$\tau^{\text {nota fiscal }}$ & - & - & 2 & 1.9 \\
\hline$\frac{\bar{\pi}}{\pi}$ se são frutas da época & - & - & 3 & 2.8 \\
\hline origem do produto & - & - & 1 & .9 \\
\hline certificação (SIF/SIE/SIM) & - & - & 1 & .9 \\
\hline regularidade de fornecimento/regularidade na qualidade & - & - & 4 & 3.7 \\
\hline cuidado com o produto & - & - & 1 & .9 \\
\hline se são frutas da região & - & - & 1 & .9 \\
\hline disponibilidade de entrega & - & - & 4 & 3.7 \\
\hline marca do produto & - & - & 1 & .9 \\
\hline não respondeu/não sabe & 4 & 6.5 & - & - \\
\hline Total & 62 & 100.0 & 108 & 100.0 \\
\hline
\end{tabular}

Fonte: pesquisa do autor. 


\section{(B) Fatores específicos: avaliados pelos empresários}

Da mesma forma que foi aplicada para o estudo dos fatores de contratação de indivíduos, os empresários avaliaram os nove fatores de inclusão indireta, analisados neste trabalho, novamente conferindo notas entre "0" e "9" para cada um deles. O método de avaliação também seguiu pelo mesmo critério: avaliar a relevância do fator, de forma individual, sendo: "0" equivalente à nenhuma relevância para a inclusão; e "9" equivalente à relevância extrema para a inclusão.

Algumas similitudes foram encontradas nos destinos estudados. Dentre os fatores que tiveram a maior frequência de notas "9", em Barreirinhas, aquele com maior destaque foi o de "regularidade de fornecimento de produtos e serviços (sazonalidade)" (64,4\% - 29 respostas), segundo mais citado em Jijoca (78,9\% - 45 respostas).

Com a mesma frequência de respostas que o fator anterior, aparece, em Jericoacoara, o fator "atendimento da quantidade demandada" (78,9\% - 45 respostas). Tal fator foi ressaltado, também em Barreirinhas, com a segunda maior frequência (48,9\% - 22 respostas), ao lado do fator "selos de inspeção sanitária (SIF/SIE/SIM)".

De toda forma, o fator com maior destaque em Jijoca de Jericoacoara foi o de "disponibilidade de entrega" (80,7\%). Tais informações encontram-se, completas, no Apêndice 8, e no Gráfico 25, a seguir.

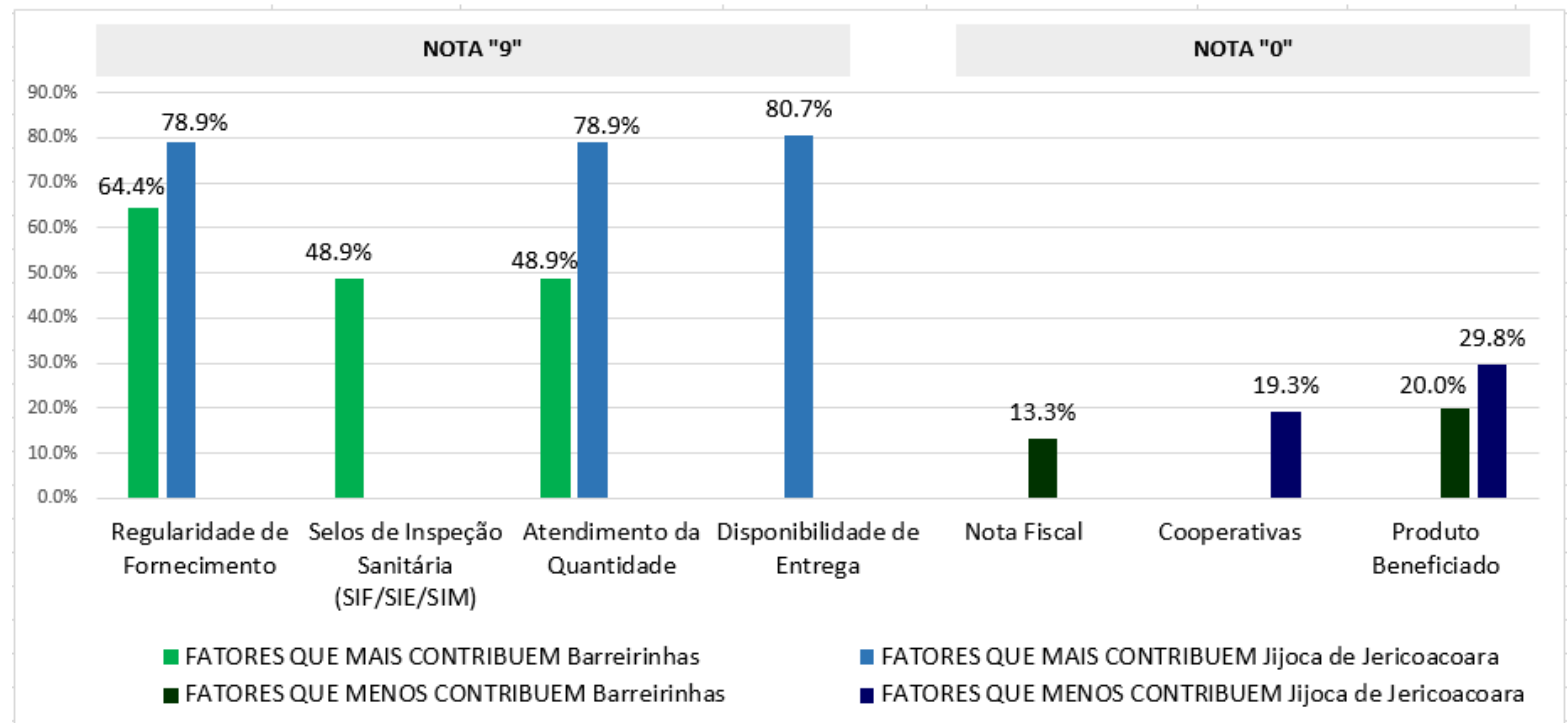

Gráfico 25: Fatores de maior e menor contribuição na visão do empresariado (INDIRETA) Fonte: pesquisa do autor. 
Já entre os fatores com maiores frequências de notas " 0 ", aparecem, como mais citados em Barreirinhas e em Jijoca, o fator "produto beneficiado" (20,0\% - 09 respostas, e 29,8\% - 17 respostas, respectivamente).

Em segundo plano ficaram os fatores "apresentação de nota fiscal" (13,3\% - 06 respostas), no município maranhense, e "participação em cooperativas" (19,3\% - 11 respostas), no município cearense.

Se analisadas as avaliações totais, com notas "4" ou menores, percebe-se que o fator "produto beneficiado" continuará sendo aquele com maior frequência nos dois destinos (35,5\% e $49,1 \%$, em Barreirinhas e Jijoca, respectivamente), ou seja, com menor contribuição para a inclusão indireta. Logo atrás estão, novamente, em Barreirinhas, o fator "nota fiscal" (24,4\%) e, em Jericoacoara, o fator "participação em cooperativas" (43,9\%).

Por sua vez, analisadas as avaliações com notas " 5 " ou maiores, pode-se notar que a "regularidade de fornecimento de produtos e serviços (sazonalidade)" permanece, em Barreirinhas, como o fator de maior contribuição para a inclusão indireta, atingindo esta faixa de avaliação em $95,5 \%$ das respostas. A "disponibilidade de entrega", da mesma forma, permanece em Jijoca como o fator de maior contribuição, atingindo esta faixa de avaliação em $100 \%$ das respostas.

Contudo, nessa mesma faixa de avaliação, os fatores secundários ganham novas perspectivas. No município maranhense, a "capacitação técnica e gerencial dos fornecedores" aparece como o segundo fator mais frequente $(93,2 \%)$ e o "atendimento da quantidade demandada" como o terceiro $(91,1 \%)$.

Em Jijoca identifica-se, como segundo mais citado, o fator "atendimento da quantidade demandada" (99,9\%), seguido, em terceiro, pela "regularidade de fornecimento de produtos e serviços (sazonalidade)" (96,6\%).

\section{(C) Fatores diversos: apresentados pelos grupos organizados locais}

Da mesma forma foram apresentados os fatores gerais que, na visão dos grupos organizados de pequenos produtores e de prestadores de serviços turísticos locais, prejudicam ou impedem a inserção dos mesmos, de forma competitiva, no mercado turístico. Ver Tabela 43. 
Os dois problemas, com maior frequência de respostas, foram análogos nos dois municípios estudados: "a concorrência com prestadores irregulares de serviços" e a "ausência de incentivo (financeiro) e de participação das autoridades públicas (federal, estadual e municipal)".

No primeiro caso pôde-se perceber os graves problemas enfrentados por guias, toyoteiros, taxistas e mototaxistas, na prestação de serviços de suporte ao turismo, de forma regular e formalizada. A ampla concorrência, refletida pelo aumento excessivo de serviços irregulares pelos, localmente conhecidos como, "piratas", acaba por se apresentar como um grande obstáculo para se manterem no mercado. Em Barreirinhas foram 16,1\% de respondentes que ressaltaram esse fator, e em Jijoca de Jericoacoara, foram 19,2\%.

Na mesma proporção esteve a ausência de incentivos (principalmente de ordem financeira) e de maior participação das autoridades públicas, em seus âmbitos federal, estadual e municipal, nas discussões sobre os problemas enfrentados cotidianamente pelos grupos.

Em Barreirinhas também se destacou (12,9\% de respondentes) o presente desrespeito entre os diversos atores locais, que atuam no setor de turismo. De acordo com os entrevistados, não há uma clara e harmônica divisão de atuações e atividades pelos atores locais. Todos querem, a todo custo, se apresentar ao mercado, competindo nas mais diversas atividades de suporte. São pousadas que criam agências de receptivo, agências que oferecem serviços próprios e exclusivos de transportes e de condução de visitantes (fazendo com que cooperativas percam espaço), restaurantes que dispõem de quartos para acomodação, etc. 
Tabela 43: Fatores que prejudicam a venda de produtos/prestação de serviços

\begin{tabular}{|c|c|c|c|c|}
\hline & \multicolumn{2}{|c|}{ BARREIRINHAS } & \multicolumn{2}{|c|}{$\begin{array}{l}\text { JIJOCA DE } \\
\text { JERICOACOARA }\end{array}$} \\
\hline & Freq & Percent & Freq & Percent \\
\hline $\begin{array}{l}\text { concorrência com prestadores irregulares de serviços } \\
\text { (guias/toyoteiros/taxistas/mototaxistas "piratas") do próprio município e } \\
\text { de fora/ problemas com os "guias de rua", que encaminham turistas } \\
\text { direto para as agências de viagens }\end{array}$ & 5 & 16.1 & 5 & 19.2 \\
\hline $\begin{array}{l}\text { falta de capacitação e qualificação profissional/dificuldade com outros } \\
\text { idiomas/falta apoio técnico especializado }\end{array}$ & 2 & 6.5 & 3 & 11.5 \\
\hline $\begin{array}{l}\text { ausência de incentivo (financeiro) e de participação das autoridades } \\
\text { públicas (federal, estadual e municipal) }\end{array}$ & 5 & 16.1 & 5 & 19.2 \\
\hline desvalorização do nosso trabalho/desvalorizacão da nossa cultura & 1 & 3.2 & 1 & 3.8 \\
\hline ausência de fiscalização efetiva & 3 & 9.7 & 2 & 7.7 \\
\hline $\begin{array}{l}\text { dificuldade para aprovação de crédito em bancos/dificuldade para } \\
\text { conseguir financiamentos }\end{array}$ & 1 & 3.2 & 1 & 3.8 \\
\hline $\begin{array}{l}\text { falta de capital de giro/recurso financeiro/alto custo para renovar a } \\
\text { frota/desgaste massivo (veículos/voadeiras)/manutenção, combustível, } \\
\text { balsa, pintura, óleo }\end{array}$ & 3 & 9.7 & 2 & 7.7 \\
\hline $\begin{array}{l}\text { contínuo atraso nos pagamento/inadimplência das agências de turismo } \\
\text { com o pagamento na data combinada }\end{array}$ & 1 & 3.2 & 1 & 3.8 \\
\hline $\begin{array}{l}\text { T⿱乛龰 problemas com "porcentagens" pagas pelos "piratas" aos funcionários da } \\
\text { T recepção dos hotéis e pousadas }\end{array}$ & 1 & 3.2 & & \\
\hline problemas quanto à legislação (não tem SIF/SIE) & 1 & 3.2 & - & - \\
\hline $\begin{array}{l}\text { falta de suporte logístico (transporte até as comunidades), de materiais, } \\
\text { de equipamentos/insuficiência de maquinário de cozinha }\end{array}$ & 1 & 3.2 & 2 & 7.7 \\
\hline cobrança do Voucher Único & 1 & 3.2 & - & - \\
\hline insegurança quanto à grande quantidade de acidentes & 1 & 3.2 & - & - \\
\hline $\begin{array}{l}\text { desrespeito entre os diferentes atores/todos querem fazer tudo/falta de } \\
\text { contato direto com o turista }\end{array}$ & 4 & 12.9 & & \\
\hline competir com outros destinos nacionais & - & - & 1 & 3.8 \\
\hline ausência de canais de divulgação dos produtos/serviços & - & - & 1 & 3.8 \\
\hline profissão não reconhecida pelo MTE & - & - & 1 & 3.8 \\
\hline $\begin{array}{l}\text { dificuldades com as exigências do MTur (só podem ser cadastrados no } \\
\text { Cadastur veículos de } 07 \text { lugares) }\end{array}$ & 1 & 3.8 & - & \\
\hline $\begin{array}{l}\text { falta de conscientização dos próprios associados em participar mais } \\
\text { ativamente }\end{array}$ & & & 1 & 3.8 \\
\hline não temos dificuldades & 1 & 3.2 & & \\
\hline Total & 31 & 100.0 & 26 & 100.0 \\
\hline
\end{tabular}

Fonte: pesquisa do autor.

Outros dois fatores também tiveram recorrência nos municípios: "ausência de fiscalização efetiva" (9,7\% em Barreirinhas, e 7,7\% em Jericoacoara) e "falta de capital de giro" (9,7\% em Barreirinhas, e 7,7\% em Jericoacoara). O primeiro vai de encontro à ampla presença de prestadores de serviços irregulares nas regiões, como destacado anteriormente.

Já o segundo possui ligação direta com a falta de incentivo financeiro pelas autoridades públicas. Grupos organizados locais se veem desprovidos de condições financeiras que permitam a renovação das frotas de automóveis e de embarcações utilizadas para realização de 
serviços de suporte turístico. O desgaste massivo e os altos valores de manutenção de toyotas, bugues e voadeiras, somados aos diversos gastos com combustível, balsa, pintura e óleo, tornam a atividade insustentável.

Em Jijoca foi mencionada, ainda, com recorrência (11,5\% dos respondentes), a falta de capacitação e de qualificação profissional dos prestadores de serviços, que demandam por apoio técnico especializado e, frequentemente, se deparam com problemas para oferecer serviços de qualidade ao visitante, principalmente no que diz respeito ao idioma estrangeiro.

\section{(D) Fatores específicos: avaliados pelos grupos organizados locais}

Dentre os fatores com maior frequência de respostas com avaliações por nota 9, os fatores "regularidade de fornecimento (sazonalidade)" e "capacitação técnica e gerencial” foram comuns nos dois municípios. Ver Apêndice 9.

No caso da adequação da produção à sazonalidade do turismo pode-se perceber, a partir da ótica dos grupos organizados entrevistados, que a necessidade de se manter a regularidade de fornecimento permanece como um grande obstáculo (assim como destacado pelos empresários). Esse fator foi avaliado com nota 9 por 66,7\% (06 respondentes) dos grupos entrevistados de Barreirinhas, e por 88,9\% (08 respondentes) dos grupos de Jericoacoara (ver Gráfico 26).

A capacitação técnica e gerencial, da mesma forma, teve destaque em Barreirinhas $(55,6 \%$ - 05 respondentes) e em Jericoacoara (88.9\% - 08 respondentes) (ver Gráfico 26). Nota-se que a falta de capacitação profissional compromete a gestão adequada da produção, desde a organização do sistema produtivo, passando pelo beneficiamento, pelo gerenciamento dos gastos, dos estoques e das receitas, até a padronização dos produtos e o escoamento para o mercado. Torna-se um fator limitante nos processos de inserção e de competitividade no mercado turístico.

Em Barreirinhas, a "insuficiência produtiva" para atendimento da quantidade de produtos e serviços demandados foi o obstáculo destacado com a terceira maior frequência de respostas (44,4\% - 04 respondentes) avaliadas por nota 9, pelos grupos organizados entrevistados. Dados no Gráfico 26.

Já em Jericoacoara a participação efetiva em grupos organizados de prestação de serviços turísticos, como cooperativas e associações, foi avaliada pela nota 9 por $77,8 \%$ (07 
respondentes) dos grupos. De acordo com os entrevistados, tal participação contribui substancialmente com a inserção competitiva de interessados no mercado turístico de Jericoacoara. Dados no Gráfico 26.

Analisando-se as avaliações por faixa de notas entre "5" e "9" (Apêndice 9), pode-se reconhecer, novamente, o destaque para os fatores "regularidade de fornecimento (sazonalidade)" e "capacitação técnica e gerencial", em ambos municípios. Todos os respondentes (100\% - 09 respondentes em cada localidade) avaliaram tais fatores com notas nessa faixa.

No caso do fator "insuficiência produtiva (quantidade)", ao analisar-se tal fator pela mesma faixa de avaliação, percebe-se que o mesmo ganha notoriedade por todos os respondentes de Jericoacoara (100\% - 09 respondentes) e, em Barreirinhas, sua importância anteriormente destacada com nota 9 por $44,4 \%$, aumenta para $88,9 \%$ (08 respondentes).

Ainda na análise por faixa de notas entre " 5 " e "9", outros dois fatores ganham destaque em Jericoacoara, atestando 100\% (09 respondentes) das avaliações pelos grupos entrevistados: "prazo para pagamento" e "participação em cooperativas e associações".

Numa perspectiva oposta, nenhum dos nove fatores analisados recebeu avaliações negativas recorrentes (com notas "0" ou inferiores a "4"), por parte dos grupos organizados das duas localidades, que indicassem baixa contribuição para a inclusão socioeconômica indireta. Isso demonstra que, na ótica dos grupos, todos os fatores específicos avaliados influem, diretamente, sobre a inclusão socioeconômica indireta.

Apenas dois fatores receberam avaliações com nota "0" ou inferiores a "4", contudo, por um número inexpressivo de respondentes: a "emissão de notas fiscais", avaliada nessa perspectiva por 22,2\% (02 respondentes) dos grupos entrevistados de Barreirinhas, e por 11,1\% (01 respondente) dos grupos de Jericoacoara; a "participação em cooperativas e associações", tendo sido avaliado com nota "0" por 22,2\% (02 respondentes) dos entrevistados de Barreirinhas. Dados no Gráfico 26. 


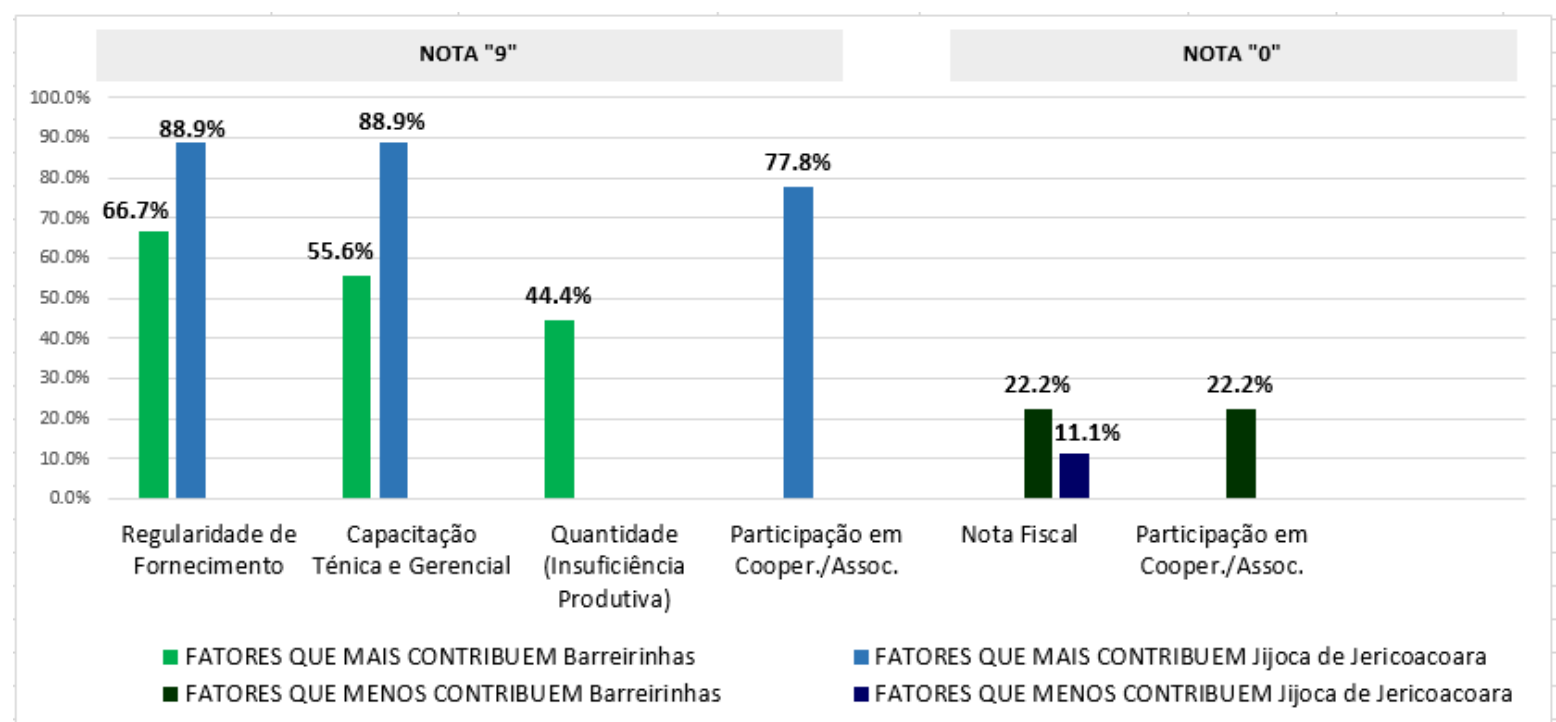

Gráfico 26: Fatores de maior e menor contribuição na visão dos grupos (INDIRETA) Fonte: pesquisa do autor.

Por fim, deve-se destacar os três fatores específicos que foram considerados apenas pelos grupos de pequenos produtores rurais - agricultores familiares, pescadores artesanais e artesãos -, dado que possuem especificidades referentes unicamente aos aspectos produtivos. São eles: "estrutura de beneficiamento"; "disponibilidade de entrega (escoamento da proução)"; e "selos de inspeção (SIF, SIE e SIM)".

Nos dois municípios, tais fatores receberam avaliações na faixa entre "5" e "9" por 100\% dos respondentes. Se analisadas apenas as notas "9", os respondentes de Barreirinhas terão uma maior preocupação com a apresentação ao mercado de produtos já beneficiados ("estrutura de beneficiamento") e contendo "selos de inspeção sanitária" (100\% dos respondentes). Em Jericoacoara, por sua vez, a disponibilidade de entrega ("escoamento da produção") é ainda mais importante, avaliado com a nota "9" por $100 \%$ dos respondentes.

\section{ANÁLISE ESTATÍSTICA PELA MODELAGEM DA REGRESSÃO LOGÍSTICA}

Para a realização da análise estatística, pela modelagem da regressão logística, foram aplicadas técnicas estatísticas adequadas (descritas a seguir), as quais permitiram avaliar a relação entre os diversos fatores elencados e a inclusão socioeconômica direta no SPLT, nos destinos turísticos estudados. 


\subsection{Conceito de Teste de Hipótese}

Para a obtenção dos resultados proporcionados pela análise estatística foram feitos, inicialmente, alguns testes de hipóteses. De acordo com Bussab e Morettin (1987) um teste de hipótese se dá da seguinte maneira: existe uma variável "X" associada à dada população, e temse uma hipótese sobre determinado parâmetro $\theta$ dessa população.

Afirmamos que o verdadeiro valor de $\theta$ é $\theta_{0}$. Colhe-se uma amostra aleatória de elementos dessa população, e com ela deseja-se comprovar ou não tal hipótese. Inicia-se a análise explicitando claramente qual a hipótese que estamos colocando à prova, e a chamamos de hipótese nula, e escrevemos:

$$
\mathrm{H}_{0}: \theta=\theta_{0}
$$

Em seguida, convém explicitar também a hipótese que será considerada aceitável caso $\mathrm{H}_{0}$ seja rejeitada. A essa hipótese chamamos de hipótese alternativa, e a sua caracterização estatística irá depender do grau de conhecimento que se tem do problema estudado. A hipótese mais geral seria:

$$
\mathrm{H}_{1}: \theta \neq \theta_{0}
$$

Poderíamos, ainda, ter alternativas da forma " $\mathrm{H}_{1}: \theta<\theta_{0}$ ou $\mathrm{H}_{1}: \theta>\theta_{0}$ ", dependendo das restrições que o problema traz.

O objetivo do teste de hipóteses é dizer, usando uma estatística $\hat{\theta}$, se a hipótese $\mathrm{H}_{0}$ é ou não aceitável. Operacionalmente, essa decisão é tomada por meio da consideração de uma região crítica $(R C)$. Caso o valor da estatística pertença a essa região, rejeitamos $\mathrm{H}_{0}$. Caso contrário, não rejeitamos $\mathrm{H}_{1}$. Essa região é construída de modo que $\mathrm{P}\left(\widehat{\theta} \in \mathrm{RC} \mid \mathrm{H}_{0}\right.$ é verdadeira $)$ seja igual a $\alpha$, fixado a priori.

O valor $\alpha$ recebe o nome de nível de significância. Esse valor é a probabilidade de se rejeitar a hipótese $\mathrm{H}_{0}$, dado que ela é verdadeira.

Outra maneira de se operacionalizar um teste de hipótese é por meio do $p$-valor do teste. O $p$-valor consiste na probabilidade de se obter uma estatística de teste igual, ou mais extrema, daquela observada em uma amostra, assumindo a hipótese nula como sendo verdadeira. Se o $p$-valor for inferior ao nível de significância $\alpha$, rejeita-se a hipótese $\mathrm{H}_{0}$. Se $\circ p$-valor for maior do que o nível de significância, a hipótese $\mathrm{H}_{0}$ não é rejeitada. 
O critério de decisão utilizado para a realização de todos os testes foi a comparação do $p$ valor de cada teste com o seu respectivo nível de significância.

\subsection{Teste Qui-Quadrado}

Para mensurar o nível de associação entre os fatores de inclusão socioeconômica e a resposta definida para o estudo (incluído ou não incluído, por meio do emprego formal) foi utilizado o teste Qui-Quadrado de Independência de Variáveis. Esse teste é voltado para avaliar a dispersão dos dados, sem utilizar parâmetros populacionais, sendo assim um teste nãoparamétrico.

Para esse teste, foram formuladas as seguintes hipóteses:

- $H_{0:}$ As variáveis em análise são independentes;

- $H_{1}$ : As variáveis em análise não são independentes.

Considerando um nível de significância (a) de $5 \%$, ou seja, estabelecendo em $5 \%$ a probabilidade de se rejeitar a hipótese nula $\left(\mathrm{H}_{0}\right)$ sendo ela verdadeira, rejeita-se a hipótese de independência entre as variáveis se o $p$-valor for inferior a 0,05.

Por exemplo, um p-valor igual a 0,10 indicaria uma probabilidade de $10 \%$ de se encontrar evidências de independência entre as variáveis analisadas, caso a pesquisa fosse realizada novamente, dado que essas questões são, verdadeiramente, independentes. Neste caso, não se rejeitaria a hipótese de independência, pois $p$-valor $>\alpha$.

\subsection{Regressão Logística}

Kutner et al. (2005) apresentam que o objetivo da Regressão Logística (RL) é modelar uma variável resposta como função de uma ou mais variáveis explicativas, que influenciam o seu acontecimento. Nesse tipo de regressão, a variável resposta é disposta em categorias e é expressa por meio de uma probabilidade de sucesso.

Entretanto, mesmo quando a variável resposta não é disposta em categorias, pode-se dicotomizá-la de modo que a probabilidade de sucesso possa ser modelada a partir da RL. Quando a variável resposta é organizada em duas categorias, a RL é classificada em binária.

A Regressão Logística Simples tem como objetivo explicar a relação de uma variável resposta qualitativa com uma variável independente, chamada também de covariável. O modelo 
de Regressão Logística Multivariado é uma extensão do modelo simples, já que utiliza duas ou mais covariáveis.

Considerando a variável resposta $\left(Y_{i}\right)$ binária, ou seja, assume os valores (sim ou não, certo ou errado, sucesso ou fracasso) "0" ou "1" na ausência ou presença da característica de interesse, respectivamente, e sua distribuição de probabilidade é representada por um modelo Bernoulli, com parâmetro $\Pi_{i}$, ou seja, tem-se:

$$
P=\left(Y_{i}=y\right)=\pi(1-\pi)^{1-y}
$$

No caso da Regressão Logística Múltipla, extensão do modelo Simples e objeto desta tese de doutoramento, o modelo é composto por duas ou mais variáveis independentes $\left(X_{1}, X_{2}, \ldots, X_{n}\right)$ e, por seus respectivos coeficientes de regressão $\beta_{1}, \ldots, \beta_{p}$. Portanto, tem-se:

$$
\boldsymbol{\beta}^{\mathbf{t}} \mathbf{X}=\beta_{0}+\beta_{1} X_{i, 1}+\ldots+\beta_{\mathrm{p}} X_{i, p}
$$

Desse modo, o modelo se estende para o modelo Logístico Múltiplo, representado por:

$$
E\left(Y_{i} / X_{i}\right)=\frac{\exp \left(\beta^{t} X\right)}{1+\exp \left(\beta^{t} X\right)}
$$

Para o modelo Múltiplo, a variável resposta $Y_{i}$ é obtida por $\boldsymbol{Y}_{\boldsymbol{i}}=E\left(\boldsymbol{Y}_{\boldsymbol{i}} / \boldsymbol{X}_{\boldsymbol{i}}\right)+\boldsymbol{\varepsilon}_{\boldsymbol{i}}$, onde o termo $\boldsymbol{\varepsilon}_{i}$ é o resíduo (ou erro aleatório) do modelo e representa a diferença entre o valor observado de $Y_{i}$ dado $X_{i}$, sendo $Y_{i}$ a variável resposta binária, assumindo apenas os valores 0 ou 1 . Os parâmetros $\beta_{0}, \beta_{1}, \ldots, \beta_{p}$ são estimados através do método de máxima verossimilhança.

\subsubsection{Razão de Chances (odds ratio - OR)}

A razão de chances, ou odds ratio, é uma das principais estatísticas utilizadas em estudos de dados binários. É definida como a razão entre a chance de um evento ocorrer em um grupo, e a chance de ocorrer em outro grupo, onde a chance é a probabilidade de ocorrência deste evento dividida pela probabilidade da não ocorrência do mesmo evento (AGRESTI,2003). Essas duas medidas são dadas por:

$$
\text { chance }_{i}=\frac{P\left(Y_{i}=1 / X_{i}\right)}{P\left(Y_{i}=0 / X_{i}\right)}=\frac{\pi\left(X_{i}\right)}{1-\pi\left(X_{i}\right)}, \quad \text { e } \quad R C=\frac{\frac{\pi\left(X_{i}=1\right)}{1-\pi\left(X_{i}=1\right)}}{\frac{\pi\left(X_{i}=0\right)}{1-\pi\left(X_{i}=0\right)}}
$$




\subsubsection{Método de Seleção do Modelo}

O método de seleção Stepwise é um procedimento de seleção de variáveis explicativas para o modelo em estudo. Qualquer procedimento para seleção ou exclusão de variáveis de um modelo é baseado em um algoritmo, que checa a importância das variáveis, incluindo ou excluindo-as do modelo, se baseando em uma regra de decisão.

O critério mais comum para checar essa importância na construção de modelos é o Critério de informação de Akaike (AIC), que é uma medida geral de qualidade de ajustamento de modelos. Um modelo para a variável resposta $Y_{i}$ é considerado melhor que o outro se tiver um AIC mais baixo.

\subsubsection{Teste de Qualidade do Ajuste}

$\mathrm{Na}$ aplicação de técnicas de regressão, as suposições do modelo ajustado precisam ser validadas para que os resultados sejam confiáveis. Chamamos de Análise dos Resíduos um conjunto de técnicas utilizadas para investigar a adequabilidade de um modelo de regressão com base nos resíduos.

Na Regressão Logística podemos avaliar a qualidade do ajuste do modelo fazendo um gráfico do modelo ajustado, mas existem medidas, como a Deviance e a estatística qui-quadrada de Pearson, que ajudam a verificar a qualidade do modelo.

\subsubsection{Pearson}

Os resíduos de Pearson medem quão bem a observação é prevista pelo modelo. Observações que não se ajustam bem ao modelo apresentam alto valor para esse resíduo e, consequentemente, indícios de que modelo considerado não é satisfatório. Os resíduos de Pearson se aproximam assintoticamente para uma distribuição qui-quadrado.

\subsubsection{Deviance}

Assim como os resíduos de Pearson, a Deviance também pode ser utilizada como uma estatística indicativa sobre a qualidade do ajuste do modelo. Observações que não se ajustam bem ao modelo apresentam alto valor para a deviance. Sob a suposição de que o modelo ajustado é correto, a deviance possui assintoticamente distribuição qui-quadrado. 


\subsection{Resultados}

Para análise dos dados obtidos nas cidades de Barreirinhas e de Jijoca de Jericoacoara foi aplicada a Regressão Logística, com o intuito de modelar a probabilidade dos moradores locais conseguirem empregos no SPLT. Para a modelagem, a variável resposta "Conseguiu ou não conseguiu emprego" $\left(Y_{i}\right)$ foi codificada em 1, se a pessoa conseguiu emprego, e em 0 , se a pessoa não conseguiu emprego.

Os fatores explicativos considerados na modelagem foram: gênero, idade, religião, rede de relações sociais (ter sido indicado por conhecidos), conhecimento da área/região, local de nascimento, grau de escolaridade, experiência anterior, capacitação profissional, proximidade física (do local onde a atividade turística se desenvolve), e participação em cooperativas e/ou associações.

Inicialmente foi avaliado o nível de associação de cada um dos fatores com a variável resposta, por meio do teste qui-quadrado. Na sequência, foi analisado o modelo logístico completo, ou seja, considerando-se todos os fatores explicativos, como forma de avaliar o efeito de cada um desses fatores sobre a probabilidade do indivíduo conseguir o emprego.

Após essa análise inicial, foi aplicado o método de seleção Stepwise para selecionar o melhor modelo preditivo dentre todos os possíveis, segundo o AIC. Por fim, os resultados obtidos pelo modelo ideal foram analisados.

\subsubsection{Resultados Estatísticos de Barreirinhas}

Para análise dos dados do município de Barreirinhas foram considerados 83 respondentes do total de 87 individuos que buscaram por oportunidades de emprego no SPLT. Quatro respondentes foram desconsiderados, por apresentarem Não resposta em algum dos fatores explicativos).

O Apêndice 10 apresenta a análise de associação de cada um dos 11 fatores com a variável resposta. Nota-se que para um nível de significância de $5 \%$, apenas o fator "proximidade física" apresentou associação significativa com o fato de a pessoa conseguir ou não emprego. Também se destacam os fatores "escolaridade", "rede de relações sociais", "conhecimento da área/região" e "capacitação profissional" como possíveis fatores a serem considerados no modelo explicativo. 
A Tabela 44 apresenta a avaliação dos efeitos dos fatores de inclusão obtidos no ajuste do modelo logístico completo, ou seja, aquele que considera todas as variáveis explicativas. Novamente para um nível de significância de 5\%, apenas o fator "proximidade física" apresentou efeito significativo sobre a probabilidade de a pessoa obter emprego. Dentre os outros fatores, pode-se destacar também o fator "capacitação profissional", que teve um pvalor bem próximo do nível de significância.

Os resultados dos testes de qui-quadrado e do modelo completo indicam a necessidade do ajuste de um modelo mais simples, já que a maioria dos fatores de inclusão não apresenta relação significativa com a variável resposta.

Tabela 44: Avaliação dos efeitos dos fatores no modelo logístico completo (Barreirinhas)

\begin{tabular}{lccc}
\hline \hline \multicolumn{1}{c}{ Fator } & Qui-quadrado & g.l. & p-valor \\
\hline \hline Gênero & 0,0155 & 1 & 0,901 \\
Idade & 2,1212 & 4 & 0,713 \\
Proximidade Física & 11,9391 & 1 & 0,001 \\
Escolaridade & 9,0724 & 5 & 0,106 \\
Religião & 1,0747 & 2 & 0,584 \\
Local de Nascimento & 0,0018 & 1 & 0,966 \\
Participação em Cooperativa/Associação & 0,4395 & 1 & 0,507 \\
Ter sido indicado por conhecidos & 0,577 & 1 & 0,448 \\
Conhecimento da área/região & 0,0006 & 1 & 0,980 \\
Experiência anterior & 0,3362 & 1 & 0,562 \\
Capacitação Profissional & 3,2719 & 1 & 0,070 \\
\hline \hline
\end{tabular}

Fonte: pesquisa do autor.

Aplicando o método de seleção Stepwise, o modelo logístico que obteve o menor AIC foi aquele que apresentou como variáveis explicativas os fatores "proximidade física" e "capacitação profissional". Desse modo, o melhor modelo explicativo selecionado é dado por:

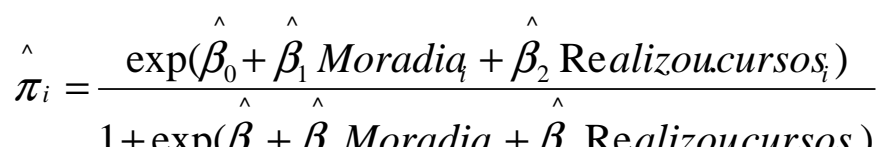

A Tabela 45 mostra as estimativas resultantes do ajuste do modelo. Nela, observa-se que o coeficiente positivo $\left(\beta_{1}=2,1939\right)$ para o fator "proximidade física" sugere que pessoas que moram mais distante do local onde a atividade turística se desenvolve apresentam maior probabilidade de conseguir o emprego do que as pessoas que moram em locais mais próximos. 
Avaliando a razão de chances, conclui-se que pessoas que moram em locais mais distantes tem aproximadamente nove vezes mais chance de conseguir o emprego do que pessoas que moram em locais mais próximos.

O coeficiente negativo $\left(\beta_{2}=-1,1404\right)$ para o fator "capacitação profissional" sugere que pessoas que não participaram de cursos para trabalhar com atividades no setor turístico apresentam menor probabilidade de conseguir o emprego do que pessoas que participaram de cursos.

Avaliando a razão de chances, conclui-se que a chance de conseguir o emprego para uma pessoa que não participou de cursos de capacitação profissional é aproximadamente $32 \%$ da chance de uma pessoa que participou de cursos, ou de maneira análoga, uma pessoa que participou de cursos tem aproximadamente três vezes mais chance de conseguir o emprego do que uma pessoa que não participou de cursos.

Tabela 45: Estimativas resultantes do modelo ajustado (Barreirinhas)

\begin{tabular}{c|c|c|c|c|c|c|c}
\hline \hline Preditor & Estimativa & $\begin{array}{c}\text { Erro } \\
\text { Padrão }\end{array}$ & $\mathbf{t}$ & $\mathbf{p}$-valor & $\mathbf{R C}$ & $\begin{array}{c}\text { IC(95\%) } \\
\text { - LI }\end{array}$ & $\begin{array}{c}\text { IC(95\%) - } \\
\text { LS }\end{array}$ \\
\hline \hline Intercepto & $-0,1121$ & 0,6255 & $-0,179$ & 0,858 & & & \\
Proximidade Física & 2,1939 & 0,5316 & 4,127 & $<0,001$ & 8,970128 & 3,31 & 27,12 \\
Capacitação Profis. & $-1,1404$ & 0,6988 & $-1,632$ & 0,103 & 0,319691 & 0,07 & 1,19 \\
\hline \hline
\end{tabular}

Fonte: pesquisa do autor.

A Tabela 46 mostra os testes de qualidade de ajustamento pelos métodos de Pearson e Deviance, que verificam a hipótese $\mathbf{H}_{0}$ : o ajuste dos dados é bom versus $\mathbf{H}_{1}$ : 0 ajuste dos dados não é bom. Considerando um nível de significância de 5\%, não há evidencias suficientes para rejeitar a hipótese nula de bom ajuste dos dados por parte do modelo considerado, portanto não há indicações de que o modelo seja inadequado e, consequentemente, os resultados obtidos são válidos.

Tabela 46: Testes de qualidade de ajustamento (Barreirinhas)

\begin{tabular}{lccr}
\hline \hline Método & Qui-quadrado & g.l. & p-valor \\
\hline \hline Pearson & 83,6118 & 80 & 0,36 \\
Deviance & 93,091 & 80 & 0,15 \\
\hline \hline
\end{tabular}

Fonte: pesquisa do autor.

A Tabela 47 apresenta as probabilidades de se conseguir emprego obtidas pelo modelo ajustado. Observa-se que pessoas que moram em locais distantes e que participam de cursos 
de capacitação profissional para trabalhar com atividades no setor turístico apresentam a maior probabilidade de conseguir o emprego, aproximadamente $89 \%$. A menor probabilidade de conseguir emprego foi apresentada por pessoas que moram em locais próximos e que não participam de cursos para trabalhar com atividades no setor turístico, aproximadamente $23 \%$.

Tabela 47: Probabilidades ajustadas a partir do modelo de RL selecionado

\begin{tabular}{ccc}
\hline \hline $\begin{array}{c}\text { Proximidade } \\
\text { Física }\end{array}$ & $\begin{array}{c}\text { Realizou cursos } \\
\text { (Capacitação Profissional) }\end{array}$ & Percentual \\
\hline \hline Distante & Sim & $88,91 \%$ \\
Distante & Não & $71,94 \%$ \\
Próximo & Sim & $47,20 \%$ \\
Próximo & Não & $22,22 \%$ \\
\hline \hline
\end{tabular}

Fonte: pesquisa do autor.

\subsubsection{Resultados Estatísticos de Jijoca de Jericoacoara}

Para análise dos dados do município de Jericoacoara foram considerados 68 respondentes dos 71 indivíduos que buscaram por oportunidades de emprego no SPLT. Três respondentes foram desconsiderados por apresentarem Não resposta em algum dos fatores explicativos.

O ajuste do modelo logístico para essa cidade foi afetado pelo pequeno número de respondentes que não conseguiram emprego, fato que acarretou frequências nulas quando realizado o cruzamento de determinados fatores de inclusão com a variável resposta, como por exemplo, o fator "experiência anterior". Algumas medidas corretivas foram adotadas e, por isso, a análise sobre o modelo ajustado se restringiu à avaliação dos efeitos dos fatores explicativos selecionados, dado que o poder preditivo do modelo é afetado e, consequentemente, não se aconselha realizar predições sobre ele.

O Apêndice 11 apresenta a análise de associação de cada um dos 11 fatores com a variável resposta. Nota-se que para um nível de significância de $5 \%$, apenas o fator "conhecimento da área/região" apresentou associação significativa com o fato de a pessoa conseguir ou não emprego. Também se destacam os fatores "experiência anterior" e "capacitação profissional" como possíveis fatores a serem considerados no modelo explicativo.

A Tabela 48 apresenta a avaliação dos efeitos dos fatores de inclusão obtidos no ajuste do modelo logístico completo, ou seja, aquele que considera todas as variáveis explicativas. Para um nível de significância de $5 \%$, os fatores "escolaridade", "conhecimento da área/região" e 
"capacitação profissional", apresentaram efeitos significativos sobre a probabilidade de a pessoa obter emprego, com destaque para o último, que foi o fator que obteve o menor $p$-valor.

Dentre os outros fatores, pode-se destacar também a "experiência anterior", que teve um p-valor bem próximo do nível de significância. Os resultados dos testes de qui-quadrado e do modelo completo indicam a necessidade do ajuste de um modelo mais simples, já que a maioria dos fatores de inclusão não apresenta relação significativa com a variável resposta.

Tabela 48: Avaliação dos efeitos no modelo logístico completo (Jericoacoara)

\begin{tabular}{|c|c|c|c|}
\hline Fator & Qui-quadrado & g.l. & p-valor \\
\hline Gênero & 0,0313 & 1 & 0,860 \\
\hline Idade & 5,6047 & 4 & 0,231 \\
\hline Moradia & 0,3791 & 1 & 0,538 \\
\hline Escolaridade & 11,171 & 5 & 0,048 \\
\hline Religião & 0,3123 & 1 & 0,576 \\
\hline Nascimento & 0,3104 & 1 & 0,577 \\
\hline Participação em Cooperativa/Associação & 0 & 1 & 1,000 \\
\hline Ter sido indicado por conhecidos & 0 & 1 & 1,000 \\
\hline Por eu conhecer bem a area/região & 9,4887 & 1 & 0,002 \\
\hline Experiência anterior & 3,771 & 1 & 0,052 \\
\hline Capacitação Profissional & 12,9333 & 1 & $<0,001$ \\
\hline
\end{tabular}

Fonte: pesquisa do autor.

Aplicando o método de seleção Stepwise, o modelo logístico que obteve o menor AIC foi aquele que apresentou como variáveis explicativas os fatores "conhecimento da área/região", "experiência anterior" e "capacitação profissional". Desse modo, o melhor modelo explicativo é dado por:

$$
\hat{\pi}_{i}=\frac{\exp \left(\hat{\beta}_{0}+\hat{\beta}_{1} \text { Por.eu.conhecerebem.a.área }{ }_{i}+\hat{\beta}_{2} \text { Experiência.anterior }_{i}+\hat{\beta}_{3}{\text { Re } \left.\text { alizou.cursos }_{i}\right)}_{1+\exp \left(\hat{\beta}_{0}+\hat{\beta}_{1} \text { Por.eu.conhecerebem.a.área }{ }_{i}+\hat{\beta}_{2} \text { Experiência.anterior }_{i}+\hat{\beta}_{3}\right. \text { Re alizou.cursos }}\right)}{1}
$$

A Tabela 49 mostra as estimativas resultantes do ajuste do modelo. Nela, observa-se que o coeficiente positivo $\left(\beta_{1}=2,474\right)$ para o fator "conhecimento da área/região" sugere que pessoas que conhecem bem a área/região apresentam maior probabilidade de conseguir o emprego do que as pessoas que não conhecem bem. 
Avaliando a razão de chances, conclui-se que pessoas que conhecem bem a área têm, aproximadamente, 12 vezes mais chance de conseguir o emprego do que pessoas que não conhecem bem a área.

O coeficiente positivo $\left(\beta_{2}=1,704\right)$ para o fator "experiência anterior" sugere que pessoas que possuem experiência anterior em funções da cadeia do turismo apresentam maior probabilidade de conseguir o emprego do que as pessoas que não possuem experiência anterior.

Avaliando a razão de chances, conclui-se que pessoas que possuem experiência anterior têm aproximadamente 5,5 vezes mais chance de conseguir o emprego do que pessoas que não possuem essa experiência.

O coeficiente negativo $\left(\beta_{2}=-1,891\right)$ para o fator "capacitação profissional" sugere que pessoas que não participaram de cursos para trabalhar com atividades no setor turístico apresentam menor probabilidade de conseguir o emprego do que pessoas que participaram de cursos.

Avaliando a razão de chances, conclui-se que a chance de conseguir o emprego para uma pessoa que não participou de cursos é aproximadamente $15 \%$ da chance de uma pessoa que participou de cursos, ou de maneira análoga, uma pessoa que participou de cursos tem aproximadamente sete vezes mais chance de conseguir o emprego do que uma pessoa que não participou de cursos.

Tabela 49: Estimativas resultantes do modelo ajustado (Jericoacoara)

\begin{tabular}{cccccccc}
\hline Preditor & Estimativa & $\begin{array}{c}\text { Erro } \\
\text { Padrão }\end{array}$ & t & p-valor & RC & $\begin{array}{c}\text { IC(95\%) } \\
\text { - LI }\end{array}$ & $\begin{array}{c}\text { IC(95\%) } \\
\text { - LS }\end{array}$ \\
\hline \hline Intercepto & 2,304 & 0,949 & 2,427 & 0,0179 & & & \\
Conhecimento da região & 2,474 & 1,029 & 2,592 & 0,0117 & 11,869 & - & - \\
Experiência anterior & 1,704 & 1,049 & 1,624 & 0,1089 & 5,495 & - & - \\
Capacitação Profissional & $-1,891$ & 1,052 & $-1,797$ & 0,0767 & 0,15 & - & - \\
\hline \hline
\end{tabular}

Fonte: pesquisa do autor.

A Tabela 50 mostra os testes de qualidade de ajustamento pelos métodos de Pearson e Deviance, que verificam a hipótese $\mathbf{H}_{0}$ : o ajuste dos dados é bom versus $\mathbf{H}_{1}$ : o ajuste dos dados não é bom. Considerando um nível de significância de 5\%, não há evidências suficientes para rejeitar a hipótese nula de bom ajuste dos dados por parte do modelo considerado, portanto não há indicações de que o modelo seja inadequado e consequentemente os resultados obtidos são válidos. 
Tabela 50: Testes de qualidade de ajustamento (Jericoacoara)

\begin{tabular}{lrrr}
\hline \hline Método & Qui-quadrado & g.l. & p-valor \\
\hline \hline Pearson & 33 & 64 & 0,995 \\
Deviance & 25,26 & 64 & 1,00 \\
\hline \hline
\end{tabular}

Fonte: pesquisa do autor.

\section{INTERPRETAÇÃO DOS FATORES}

\subsection{Interpretação dos fatores de inclusão socioeconômica direta}

Os dados levantados, tabulados e analisados, mostraram que grande parte das populações, de Barreirinhas e de Jijoca de Jericoacoara, não têm buscado por oportunidades de emprego no setor turístico.

Muitos deixam de buscar por não possuírem um bom nível de instrução formal (escolaridade), pensando que esse fator seria um impeditivo primário para obtenção do emprego. Outros, por não quererem abandonar suas atividades tradicionais, ou por, simplesmente, não gostarem desse tipo de atividade.

Em contrapartida, para aqueles que têm buscado, o fazem por, justamente, gostarem desse tipo de atividade, reconhecendo nesse setor a possibilidade de melhores salários, e permitindo-os deixar de trabalhar em suas atividades tradicionais. Há ainda indivíduos que, mesmo não tendo a predileção pelo Turismo, buscam por oportunidades por não identificarem qualquer outra opção de trabalho nas regiões, ou mesmo pela grande necessidade financeira.

Deve-se lembrar que a indicação por conhecidos foi outro motivo muito destacado que, segundo os entrevistados, estimula o interesse pela procura por oportunidades no setor. Mas não só estimula a busca, como também contribui para a inclusão direta.

Os fatores de maior contribuição para a inclusão direta, independente da função, segundo a análise descritiva dos dados, estão organizados no Quadro 12. Tratam-se daqueles com maior frequência de respostas pelos entrevistados da pesquisa.

No destino maranhense destacaram-se os fatores: (a) "capacitação profissional" e "conhecimento da área/região" (ambos citados com grande frequência pela população local, pelos incluídos e pelos empresários); (b) "indicação por conhecidos" (pela população local e pelos incluídos); e (c) "experiência anterior" (pelos incluídos e pelos empresários). 
Houve, ainda, recorrência de respostas, entre os empresários de Barreirinhas, para outros dois fatores: (a) "boa vontade (sem experiência)", recebeu a terceira maior frequência de respostas na questão aberta do questionário; e (b) "nível de escolaridade", destacado pela alta frequência de avaliações na faixa entre " 5 " e "9" de importância.

\begin{tabular}{|c|c|c|c|c|c|c|}
\hline & \multicolumn{3}{|c|}{ BARREIRINHAS } & \multicolumn{3}{|c|}{ JIJOCA DE JERICOACOARA } \\
\hline & POPULAÇÃO & \multicolumn{2}{|c|}{ INCLUÍDOS } & POPULAÇÃO & \multicolumn{2}{|c|}{ INCLUÍDOS } \\
\hline $1^{\circ}$ & Conhecimento & \multicolumn{2}{|c|}{ Indicação } & Indicação & \multicolumn{2}{|c|}{ Indicação } \\
\hline $2^{\circ}$ & Indicação & \multicolumn{2}{|c|}{ Conhecimento } & Capacitação & \multicolumn{2}{|c|}{ Capacitação } \\
\hline $3^{\circ}$ & - & \multicolumn{2}{|c|}{ Capacitação } & Experiência & \multicolumn{2}{|c|}{ Experiência } \\
\hline \multirow[t]{3}{*}{$4^{\circ}$} & \multicolumn{3}{|c|}{ Experiência } & - & \multicolumn{2}{|r|}{-} \\
\hline & \multicolumn{6}{|c|}{ EMPRESÁRIOS } \\
\hline & ABERTAS & NOTA “9” & FAIXA “5" e "9" & ABERTAS & NOTA “9” & FAIXA "5" e "9" \\
\hline \multirow{2}{*}{$1^{\circ}$} & \multirow{2}{*}{ Capacitação } & \multirow{2}{*}{ Capacitação } & Escolaridade & \multirow{2}{*}{$\begin{array}{l}\text { Boa vontade } \\
\text { (s/ experiência) }\end{array}$} & \multirow{2}{*}{ Conhecimento } & \multirow{2}{*}{ Conhecimento } \\
\hline & & & Conhecimento & & & \\
\hline $2^{\circ}$ & Experiência & Conhecimento & Capacitação & $\begin{array}{c}\text { Boa aparência / } \\
\text { Higiene }\end{array}$ & Capacitação & Proximidade \\
\hline $3^{\circ}$ & $\begin{array}{c}\text { Boa vontade } \\
\text { (s/ experiência) }\end{array}$ & Experiência & - & Indicação & Experiência & - \\
\hline
\end{tabular}

Quadro 12: Fatores de maior contribuição para a inclusão socioeconômica direta (Análise Descritiva)

Fonte: pesquisa do autor.

No destino cearense destacaram-se os fatores: "capacitação profissional", "indicação por conhecidos", e "experiência anterior" (todos citados com grande frequência pela população local, pelos incluídos e pelos empresários).

Considerando-se apenas o grupo do empresariado, se reconhece outros quatro fatores com recorrência de respostas: (a) "boa vontade (sem experiência)", tendo sido o fator mais frequente nas respostas abertas; (b) "boa aparência/higiene pessoal", tendo sido o segundo mais recorrente entre as respostas abertas; (c) "conhecimento da área/região", destacado como o fator com maior importância, tanto pela maior frequência de notas 9 , como pela maior frequência de avaliações na faixa entre 5 e 9; (d) "proximidade física de onde a atividade turística se desenvolve", por ter sido o fator com segunda maior frequência de avaliação na faixa entre $5 \mathrm{e}$ 9. 
É digno de nota que os fatores de menor contribuição - ou seja, aqueles que receberam a maior frequência de avaliações com notas "0", ou na faixa de notas "4" ou inferior - foram, nos dois destinos, a "religião" e o "gênero".

Há, ainda, a avaliação dos fatores de inclusão direta por função específica (Quadro 13) apresentado pelo empresariado. Em ambos municípios dois fatores ganharam destaque, dentre os mais citados: "capacitação profissional" (importante em 12 funções, de cada destino) e "experiência anterior" (importante em 07 funções de Barreirinhas e em 13 funções de Jijoca).

\begin{tabular}{|c|c|c|c|c|c|c|c|c|}
\hline & \multicolumn{2}{|c|}{ Resp. Beneficiamento } & \multicolumn{2}{|c|}{ Resp. Entregas } & \multicolumn{2}{|c|}{ Guia Turístico } & \multicolumn{2}{|c|}{ Resp. Transporte } \\
\hline & Barreirinhas & Jijoca & Barreirinhas & Jijoca & Barreirinhas & Jijoca & Barreirinhas & Jijoca \\
\hline $1^{\circ}$ & Capacit & Capacit & Experiênc & Gênero & Conhecim & Conhecim & Conhecim & Part. Coop \\
\hline \multirow{2}{*}{$2^{\circ}$} & \multirow{2}{*}{ Experiênc } & \multirow{2}{*}{ Experiênc } & Respons. & \multirow{2}{*}{ Experiênc } & \multirow{2}{*}{ Capacit } & \multirow{2}{*}{ Part. Coop } & \multirow{2}{*}{ Part. Coop } & \multirow{2}{*}{ Conhecim } \\
\hline & & & Idade & & & & & \\
\hline \multirow[t]{3}{*}{$3^{\circ}$} & - & - & - & - & Naturalid & - & - & - \\
\hline & \multicolumn{2}{|c|}{ Resp. Eventos } & \multicolumn{2}{|c|}{ Instrutor Aventura } & \multicolumn{2}{|c|}{ Camareira } & \multicolumn{2}{|c|}{ Garçom } \\
\hline & Barreirinhas & Jijoca & Barreirinhas & Jijoca & Barreirinhas & Jijoca & Barreirinhas & Jijoca \\
\hline \multirow{2}{*}{$1^{\circ}$} & \multirow{2}{*}{ Capacit } & \multirow{2}{*}{ Experiênc } & \multirow{2}{*}{ Capacit } & \multirow{2}{*}{ Capacit } & \multirow{2}{*}{ Gênero } & Capacit & \multirow{2}{*}{ Experiênc } & \multirow{2}{*}{ Experiênc } \\
\hline & & & & & & Experiênc & & \\
\hline \multirow{2}{*}{$2^{\circ}$} & \multirow{2}{*}{ Experiênc } & Capacit & \multirow{2}{*}{ Conhecim } & \multirow{2}{*}{ Experiênc } & \multirow{2}{*}{ Capacit } & \multirow{2}{*}{ Gênero } & Ecolarid & Conprit \\
\hline & & Conhecim & & & & & Escolarid & capacıt \\
\hline $3^{\circ}$ & - & - & - & - & - & - & - & Escolarid \\
\hline & Chef/Co & inheiro & Ger & nte & Secretário & Telefonista & Aux. Adm & Financeiro \\
\hline & Barreirinhas & Jijoca & Barreirinhas & Jijoca & Barreirinhas & Jijoca & Barreirinhas & Jijoca \\
\hline 10 & Experiênc & & & & & & & \\
\hline $1^{\circ}$ & Capacit & Experienc & capacıt & Connecım & Connecım & Escolarid & Escolarid & Experienc \\
\hline & & & & & & Conhecim & & \\
\hline $2^{\circ}$ & - & Capacit & Escolarid & Experiênc & Capacit & Capacit & Capacit & Capacit \\
\hline & & & & & & Experiênc & & \\
\hline $3^{\circ}$ & - & - & - & Escolarid & - & - & - & Escolarid \\
\hline & Recepc & onista & Serviço & Gerais & Segura & ça/Vigia & Aux. de & Cozinha \\
\hline & Barreirinhas & Jijoca & Barreirinhas & Jijoca & Barreirinhas & Jijoca & Barreirinhas & Jijoca \\
\hline & & & & & & Experiênc & & \\
\hline $1^{\circ}$ & Escolarid & Escolarid & Capacit & Capacit & Capacit & Gênero & Capacit & Experiênc \\
\hline 2० & Conherim & Conhecim & Fyneriênc & Fyneriên & Gônero & Capacit & Fyner & Canacit \\
\hline 2 & connecim & Capacit & Experienc & Experienc & Genero & Idade & Experienc & capacı \\
\hline
\end{tabular}

Quadro 13: Fatores de maior contribuição, por função, para inclusão socioeconômica direta

Fonte: pesquisa do autor. 
Foram ressaltados pelas duas populações locais os fatores que prejudicam a inclusão direta. Em Barreirinhas, o fator com maior frequência de respostas foi a "pouca capacitação profissional", seguido do "baixo nível de escolaridade". Já em Jijoca, o baixo percentual de respostas (apenas seis indivíduos) resultou em seis diferentes fatores: "pouca capacitação profissional"; "baixo nível de escolaridade"; "idade inadequada"; "ausência de indicação por conhecidos"; "por morar muito distante do emprego"; e pela "falta de experiência anterior".

A análise estatística dos dados, por sua vez, demonstrou, pelo seu modelo ideal, similitudes quanto ao fator "capacitação profissional", nos dois municípios estudados. Tal fator apresentou efeitos significativos sobre a probabilidade de um indivíduo ser efetivado no emprego, na cadeia do turismo.

Em Barreirinhas, o indivíduo que realizou cursos de capacitação profissional tem três vezes mais chances que aquele que não realizou. Enquanto que em Jijoca de Jericoacoara a chance aumenta para sete vezes mais.

Especificamente sobre Jijoca de Jericoacoara, outros dois fatores do modelo ideal também são destacados pela análise descritiva, e também demonstraram efeitos significativos sobre a probabilidade de inserção no emprego: "conhecimento da área/região" e "experiência anterior".

No município cearense, identifica-se que o indivíduo que possua conhecimento da área/região tem 12 vezes mais chance que outro indivíduo que não possua o mesmo conhecimento. Também se nota que aquele indivíduo que apresente experiência anterior, na mesma função buscada para emprego, possui 5,5 vezes mais chances do que o indivíduo que não conte com alguma experiência anterior.

\subsection{Interpretação dos fatores de inclusão socioeconômica indireta}

Os dados levantados ressaltaram a ampla aquisição de produtos de fora dos municípios, pelos estabelecimentos do trade turístico. Pôde-se notar que, com exceção do artesanato, os demais produtos consumidos - pescados, carnes, frutas, verduras e legumes - não são de origem local.

O maior destaque está entre as frutas que, ainda que abundantes localmente, acabam sendo importadas de outras regiões por mais de $80 \%$ dos estabelecimentos entrevistados de cada um dos destinos. 
No caso dos serviços prestados como suporte à atividade turística, esses são oferecidos, em sua grande maioria, por moradores locais, que se dividem entre regulares (principalmente aqueles formalizados como cooperativas ou associações) e irregulares (popularmente conhecidos como "piratas").

Os fatores gerais ressaltados como os de maior contribuição para a inclusão indireta (dados no Quadro 14) podem ser divididos entre diversos, específicos e restritos. Os fatores diversos, apresentados pelos entrevistados quando indagados por questões abertas, foram:

- "Alta qualidade dos serviços e produtos, e frescor dos produtos alimentícios", destacado nas respostas abertas dos empresários dos dois municípios como o fator mais importante no momento da aquisição de um produto ou utilização de um serviço;

- "Preço", destacado nas respostas abertas do empresariado dos dois municípios como o segundo fator mais importante no momento da compra ou utilização de um serviço;

- "Concorrência com prestadores de serviços irregulares" foi um dos obstáculos recorrentes, destacados pelos grupos de Jericoacoara e de Barreirinhas, nas questões abertas;

- "Ausência de incentivos (financeiros) e de participação das autoridades públicas (federal, estadual e municipal)", assim como no item anterior, também ganhou destaque como um obstáculo, recorrente nas questões abertas, tanto em Barreirinhas quanto em Jericoacoara.

- "Desrespeito entre os diversos atores locais", ressaltado como o segundo fator mais recorrente nas questões abertas dos grupos de Barreirinhas.

- "Ausência de fiscalização efetiva", destacado como o terceiro fator mais recorrente nas questões abertas dos grupos de Barreirinhas e de Jijoca. 


\begin{tabular}{|c|c|c|c|c|c|c|}
\hline & \multicolumn{3}{|c|}{ BARREIRINHAS } & \multicolumn{3}{|c|}{ JIJOCA DE JERICOACOARA } \\
\hline & \multicolumn{6}{|c|}{ EMPRESÁRIOS } \\
\hline & ABERTAS & NOTA “9” & FAIXA "5" e "9" & ABERTAS & NOTA “9” & FAIXA "5" e "9" \\
\hline \multirow{2}{*}{$1^{\circ}$} & \multirow{2}{*}{$\begin{array}{l}\text { Qualidade } \\
\text { /Frescor }\end{array}$} & \multirow{2}{*}{$\begin{array}{l}\text { Regularidade } \\
\text { (sazonalidade) }\end{array}$} & \multirow{2}{*}{$\begin{array}{l}\text { Regularidade } \\
\text { (sazonalidade) }\end{array}$} & \multirow{2}{*}{$\begin{array}{l}\text { Qualidade } \\
\text { /Frescor }\end{array}$} & \multirow{2}{*}{$\begin{array}{l}\text { Disponibilidade } \\
\text { de entrega }\end{array}$} & $\begin{array}{c}\text { Disponibilidade de } \\
\text { entrega }\end{array}$ \\
\hline & & & & & & $\begin{array}{l}\text { Suficiência } \\
\text { produtiva }\end{array}$ \\
\hline \multirow{2}{*}{$2^{\circ}$} & \multirow{2}{*}{ Preço } & $\begin{array}{l}\text { Suficiência } \\
\text { produtiva }\end{array}$ & \multirow{2}{*}{$\begin{array}{l}\text { Capacitação } \\
\text { Téc. e Gerenc. }\end{array}$} & \multirow{2}{*}{ Preço } & $\begin{array}{l}\text { Regularidade } \\
\text { (sazonalidade) }\end{array}$ & \multirow{2}{*}{$\begin{array}{l}\text { Regularidade } \\
\text { (sazonalidade) }\end{array}$} \\
\hline & & $\begin{array}{c}\text { Selos } \\
(\mathrm{SIF} / \mathrm{SIE} / \mathrm{SIM})\end{array}$ & & & $\begin{array}{l}\text { Suficiência } \\
\text { produtiva }\end{array}$ & \\
\hline \multirow{2}{*}{$3^{\circ}$} & \multirow[b]{2}{*}{-} & \multirow{2}{*}{$\begin{array}{l}\text { Capacitação } \\
\text { Téc. e Gerenc. }\end{array}$} & \multirow{2}{*}{$\begin{array}{l}\text { Suficiência } \\
\text { produtiva }\end{array}$} & \multirow[b]{2}{*}{-} & \multirow{2}{*}{$\begin{array}{l}\text { Capacitação } \\
\text { Téc. e Gerenc. }\end{array}$} & $\begin{array}{c}\text { Capacitação Téc. } \\
\text { e Gerenc. }\end{array}$ \\
\hline & & & & & & $\begin{array}{c}\text { Selos } \\
\text { (SIF / SIE / SIM) }\end{array}$ \\
\hline \multirow[t]{2}{*}{$4^{\circ}$} & & $\begin{array}{l}\text { Disponibilidade } \\
\text { de entrega }\end{array}$ & $\begin{array}{c}\text { Selos } \\
(\text { SIF / SIE / SIM })\end{array}$ & & $\begin{array}{c}\text { Selos } \\
\text { (SIF / SIE / SIM) }\end{array}$ & Nota Fiscal \\
\hline & \multicolumn{6}{|c|}{ GRUPOS ORGANIZADOS } \\
\hline \multirow{8}{*}{$1^{\circ}$} & \multirow{3}{*}{$\begin{array}{l}\text { Concor. } \\
\text { serviços } \\
\text { irregular. }\end{array}$} & \multirow{3}{*}{$\begin{array}{l}\text { Regularidade } \\
\text { (sazonalidade) }\end{array}$} & $\begin{array}{l}\text { Regularidade } \\
\text { (sazonalidade) }\end{array}$ & \multirow{3}{*}{$\begin{array}{l}\text { Concor. } \\
\text { serviços } \\
\text { irregular. }\end{array}$} & \multirow{3}{*}{$\begin{array}{l}\text { Regularidade } \\
\text { (sazonalidade) }\end{array}$} & $\begin{array}{l}\text { Regularidade } \\
\text { (sazonalidade) }\end{array}$ \\
\hline & & & \multirow{2}{*}{$\begin{array}{l}\text { Capacitação } \\
\text { Téc. e Gerenc. }\end{array}$} & & & $\begin{array}{c}\text { Selos } \\
\text { (SIF / SIE / SIM) }\end{array}$ \\
\hline & & & & & & $\begin{array}{l}\text { Suficiência } \\
\text { produtiva }\end{array}$ \\
\hline & \multirow{5}{*}{$\begin{array}{l}\text { Ausência de } \\
\text { incentivo } \\
\text { financeiro }\end{array}$} & $\begin{array}{l}\text { Beneficiamento } \\
\text { de produtos }\end{array}$ & $\begin{array}{l}\text { Beneficiamento } \\
\text { de produtos }\end{array}$ & \multirow{5}{*}{$\begin{array}{l}\text { Ausência de } \\
\text { incentivo } \\
\text { financeiro }\end{array}$} & $\begin{array}{l}\text { Disponibilidade } \\
\text { de entrega }\end{array}$ & $\begin{array}{c}\text { Disponibilidade de } \\
\text { entrega }\end{array}$ \\
\hline & & \multirow{4}{*}{$\begin{array}{c}\text { Selos } \\
(\mathrm{SIF} / \mathrm{SIE} / \mathrm{SIM})\end{array}$} & $\begin{array}{c}\text { Selos } \\
\text { (SIF / SIE / SIM })\end{array}$ & & \multirow{4}{*}{$\begin{array}{l}\text { Capacitação } \\
\text { Téc. e Gerenc. }\end{array}$} & $\begin{array}{c}\text { Capacitação Téc. } \\
\text { e Gerenc. }\end{array}$ \\
\hline & & & \multirow{3}{*}{$\begin{array}{l}\text { Disponibilidade } \\
\text { de entrega }\end{array}$} & & & $\begin{array}{l}\text { Beneficiamento de } \\
\text { produtos }\end{array}$ \\
\hline & & & & & & Prazo \\
\hline & & & & & & $\begin{array}{l}\text { Participação em } \\
\text { coop/assoc }\end{array}$ \\
\hline $2^{\circ}$ & $\begin{array}{c}\text { Desresp. } \\
\text { entre atores } \\
\text { locais }\end{array}$ & $\begin{array}{l}\text { Capacitação } \\
\text { Téc. e Gerenc. }\end{array}$ & $\begin{array}{l}\text { Suficiência } \\
\text { produtiva }\end{array}$ & $\begin{array}{c}\text { Capacitação } \\
\text { Téc. e } \\
\text { Gerenc. }\end{array}$ & $\begin{array}{l}\text { Participação em } \\
\text { coop/assoc }\end{array}$ & Nota Fiscal \\
\hline $3^{\circ}$ & $\begin{array}{l}\text { Ausência de } \\
\text { fiscaliz. } \\
\text { efetiva }\end{array}$ & $\begin{array}{l}\text { Suficiência } \\
\text { produtiva }\end{array}$ & - & $\begin{array}{c}\text { Ausência de } \\
\text { fiscaliz. } \\
\text { efetiva }\end{array}$ & $\begin{array}{l}\text { Beneficiamento } \\
\text { de produtos }\end{array}$ & - \\
\hline
\end{tabular}

Quadro 14: Fatores de maior contribuição para a inclusão socioeconômica indireta

Fonte: pesquisa do autor. 
Dentre os específicos, definidos inicialmente para serem avaliados durante a realização da pesquisa, destacaram-se:

- "Regularidade de fornecimento (sazonalidade)". Aparece, no município maranhense, como o fator com maior frequência de avaliação por notas "9" entre os empresários e, também, como fator de melhor avaliação na faixa entre " 5 " e "9". Em Jericoacoara tal fator aparece em segundo lugar com avaliações por notas "9" dos empresários, e também em segundo lugar na faixa de entre " 5 " e "9". É destacado pelos grupos organizados entrevistados de Barreirinhas e de Jericoacoara dentre aqueles com maior frequência de notas "9" e na faixa entre " 5 " e "9";

- "Capacitação técnica e gerencial", ganhou destaque nos dois municípios, como o terceiro fator com maior frequência de avaliações por notas "9". Nas avaliações por notas na faixa entre "5" e "9", foi o segundo fator mais frequente em Barreirinhas, e o terceiro em Jericoacoara. Também se destacou entre os grupos dos dois destinos, dentre os fatores com maior frequência de notas na faixa entre " 5 " e "9" (em ambos). Ainda nas avaliações destacadas pelos grupos organizados, agora por notas " 9 ", ficou entre os fatores de maior frequência em Jericoacoara, e como fator de segunda maior frequência em Barreirinhas;

- "Atendimento contínuo da quantidade demandada (suficiência produtiva)", se destacou como o fator com segunda maior frequência de respostas com avaliação pela nota " 9 " (em ambos municípios) pelo empresariado. Na faixa entre " 5 " e "9" está entre os fatores de maior frequência em Jericoacoara, e em terceiro em Barreirinhas, também pela avaliação dos empresários. Nas avaliações pelos grupos, tal fator recebeu a terceira mais frequente avaliação por notas "9", em Barreirinhas. Por faixa entre "5" e "9", esteve entre os mais bem avaliados em Jericoacoara, e como a segunda maior frequência em Barreirinhas;

- "Participação efetiva em grupos organizados (cooperativas ou associações)", citado entre os fatores com a maior recorrência de avaliações por faixa com notas entre " 5 " e "9", e com a segunda maior frequência de avaliações por notas "9", ambos entre os grupos de Jericoacoara;

- "Prazo para pagamento", avaliado de forma recorrente na faixa de notas entre 5 e 9, por parte dos grupos de Jericoacoara;

- "Emissão de Nota Fiscal', destacou-se entre os empresários como o fator com a quarta maior frequência de avaliações pela faixa entre " 5 " e " 9 ", e entre os grupos organizados como o fator com a segunda maior frequência de avaliações na mesma faixa. 
Por fim, quanto aos fatores restritos, ou seja, aqueles avaliados apenas pelos grupos de pequenos produtores rurais, ganharam destaque:

- "Disponibilidade de entrega", principalmente em Jericoacoara, onde esse fator foi avaliado, tanto pelos empresários, quanto pelos grupos organizados, entre aqueles com maior frequência de notas " 9 ", e por notas na faixa entre " 5 " e "9". Em Barreirinhas o destaque desse fator esteve na faixa de avaliação entre " 5 " e " 9 ", encontrando-se entre os fatores mais citados, e, com menor expressão, como o fator com a quarta maior frequência por notas "9";

- "Certificação dos produtos alimentícios com selos de inspeção sanitária (SIF/SIE/SIM)", foi o fator de segunda maior frequência de respostas por notas "9" pelos empresários de Barreirinhas, e o de quarta maior frequência pelos de Jericoacoara. Por avaliações na faixa por notas entre "5" e "9", foi o quarto mais recorrente em Barreirinhas, e o terceiro em Jericoacoara. Entre os grupos organizados, a evidência foi maior. Foi um dos fatores mais destacados por notas na faixa entre "5" e "9" em ambas localidades, e, em Barreirinhas, esteve entre os mais frequentes por notas "9";

- "Estrutura de beneficiamento", ressaltado em ambos municípios com fator entre aqueles de maior destaque com notas na faixa entre " 5 " e "9", pelos entrevistados dos grupos. Por notas "9" foi também um dos de maior frequência em Barreirinhas, e o de terceira maior recorrência em Jericoacoara.

Em contrapartida, os fatores lembrados como de menor contribuição se limitam a dois: a apresentação de nota fiscal pelos fornecedores (irrelevante em Barreirinhas); e a participação em grupos organizados (irrelevante em Barreirinhas). 


\subsection{Classificação dos fatores conforme o grau de contribuição}

Por fim, são apresentadas as classificações finais dos fatores estudados, avaliando o grau de contribuição dos mesmos nos processos de inclusão socioeconômica de habitantes locais no sistema produtivo local de turismo.

A classificação final foi realizada com base nos resultados obtidos na pesquisa de campo, sistematizados e analisados nos tópicos anteriores. O critério para classificação dos fatores foi definido da seguinte maneira:

\section{(1) Forte probabilidade}

1.1. INCLUSÃO DIRETA: fatores que, tanto pela análise descritiva, quanto pela análise estatística, geraram indícios de contribuição nos processos de inclusão;

1.2. INCLUSÃO INDIRETA: fatores que, tanto pela relevância ressaltada pelos empresários, quanto pela relevância ressaltada pelos grupos organizados, geraram indícios de contribuição nos processos de inclusão.

(2) Duvidosos

2.1. INCLUSÃO DIRETA: fatores que, mesmo com baixa relevância de associação demonstrada pelo teste estatístico, apresentaram indícios de notoriedade de respostas na análise descritiva. Ou seja, fatores que pela abundância de respostas homogêneas nos diferentes grupos de análise, demonstraram alguma influência nos processos de inclusão;

2.2. INCLUSÃO INDIRETA: fatores que ganharam grande relevância por apenas uma parte dos entrevistados (empresários ou grupos organizados), demonstrando alguma influência nos processos de inclusão, e reforçando a necessidade de maior aprofundamento.

(3) \& Descartados

3.1. INCLUSÃO DIRETA: fatores que, pela realização da análise estatística ou pela análise descritiva, não ganharam significado e foram excluídos da lista de possíveis fatores de contribuição;

3.2. INCLUSÃO INDIRETA: fatores que receberam baixas avaliações pelos empresários e pelos grupos organizados, não demonstrando, assim, notórias contribuições, ou mesmo nenhuma influência, sobre os processos de inclusão. 
Nessa perspectiva serão classificados, a seguir, os onze fatores de inclusão socioeconômica direta, e os nove fatores de inclusão socioeconômica indireta, avaliados nesta pesquisa, seguindo as interpretações anteriormente realizadas.

\subsubsection{Classificação dos fatores de inclusão socioeconômica direta}

\section{GÊNERO}

Fator duvidoso. A análise estatística não indicou nenhuma forte associação entre o fator "gênero" e a inclusão socioeconômica direta no sistema turístico. Pela análise descritiva tal fator esteve presente entre os aqueles com maior frequência de notas " 0 " ou na faixa entre " 0 " e "4".

Todavia, para algumas funções específicas, o fator "gênero" aparece entre os de maior consideração pelos empresários, de Jericoacoara e de Barreirinhas, no momento da contratação. Destacam-se:

- Responsável por entregas: fator de maior destaque, em Jericoacoara;

- Camareira: fator de maior destaque em Barreirinhas, e de segundo maior destaque em Jericoacoara;

- Segurança/Vigia: fator de maior destaque em Jericoacoara, e de segundo maior destaque em Barreirinhas.

Nota-se, a partir daí, que há, aparentemente, uma clara divisão de algumas funções por gênero, como é o caso de camareiras (onde funcionários do sexo feminino se sobressaem), e de seguranças/vigias noturnos (prevalecendo funcionários do sexo masculino).

\section{IDADE}

Fator duvidoso. Não foi identificada nenhuma forte associação entre o fator "idade" e a inclusão socioeconômica direta no sistema turístico, por meio da análise estatística. Contudo, pela análise descritiva, o fator foi ressaltado com frequência pelos empresários, como de necessária consideração no momento da contratação em duas funções específicas, destacadas a seguir:

- Responsável por entregas: fator de segundo maior destaque, em Barreirinhas; 
- Segurança/Vigia: fator de segundo maior destaque em Jericoacoara;

Aparentemente, para o cargo de vigia noturno, privilegia-se candidatos mais velhos, que atestem maior maturidade e responsabilidade no desempenho da função. Enquanto que para o cargo de entregas, pela grande necessidade de aptidão física para, muitas vezes, carregar produtos do mercado até no estabelecimento, busca-se por candidatos mais jovens.

\section{RELIGIÃO}

Fator descartado. Nenhuma das análises (estatística ou descritiva) demonstrou forte associação entre o fator "religião" e a inclusão socioeconômica direta no sistema turístico. Tal fator, inclusive, foi classificado dentre os de avaliação com maior frequência por notas "0" ou na faixa entre " 0 " e " 4 ".

Ainda que sejam identificadas religiões as quais condenam a realização de trabalhos assalariados em determinados dias da semana, nas duas localidades, o fator não foi considerado como um impeditivo à inclusão, nem pelo empresariado, nem pelos incluídos ou pela população local.

\section{REDE DE RELACCÕES SOCIAIS (INDICACÃO POR CONHECIDOS)}

Fator com forte probabilidade. A análise estatística, por meio do Teste Qui-Quadrado de independência, apresentou uma associação significativa entre o fator "rede de relações sociais" e a inclusão socioeconômica direta no sistema turístico do destino maranhense, tendo sido considerado como fator potencial na construção do modelo explicativo.

Da mesma forma, pela análise descritiva, ganhou destaque pela frequência de respostas descritas a seguir:

- Fator de maior destaque pelos Incluídos entrevistados em Barreirinhas e em Jericoacoara;

- Fator de segundo maior destaque pela População local de Barreirinhas, e de maior destaque pela População local de Jericoacoara;

- Fator de terceiro maior destaque pelos Empresários, por questão aberta, em Jericoacoara. 
Os procedimentos de indicação de amigos e de familiares, por funcionários efetivos do próprio estabelecimento, são bastante comuns nos dois destinos. Essa busca por interessados próximos (tratados pelos empresários, como "de confiança") parece contribuir, notoriamente, com a inclusão socioeconômica no turismo.

\section{CONHECIMENTO DA ÁREA/REGIÃO}

Fator com forte probabilidade. Identificou-se significativas associações entre o fator "conhecimento da área/região" e a inclusão socioeconômica direta nos sistemas turísticos dos dois destinos estudados. No caso de Jericoacoara, pelo método de seleção de modelo Stepwise, o fator ficou entre os três mais significativos para formação do melhor modelo preditivo.

Pela análise descritiva o fator é ressaltado com notória frequência por todos os entrevistados, inclusive sendo destacado para funções específicas:

- Fator de maior destaque pela População local de Barreirinhas;

- Fator de segundo maior destaque, pelos Incluídos de Jericoacoara;

- Fator de maior destaque pelos Empresários de Jericoacoara, com avaliações por nota "9", e segundo maior destaque pela mesma avaliação por Empresários de Barreirinhas. Também foi o fator de maior destaque pelos Empresários com avaliações por faixa entre "5" e "9", nos dois destinos.

- Guia turístico: fator de maior destaque, em ambos municípios;

- Responsável pelo transporte turístico: fator de maior destaque em Barreirinhas, e de segundo maior destaque em Jericoacoara;

- Responsável por eventos: fator de segundo maior destaque em Jericoacoara;

- Instrutor de esportes de aventura: fator de segundo maior destaque em Barreirinhas;

- Gerente: fator de maior destaque em Jericoacoara;

- Secretário(a)/Telefonista: fator de maior destaque em Barreirinhas, e de segundo maior destaque em Jericoacoara;

- Recepcionista: fator de segundo maior destaque, em ambas localidades.

Pela análise da razão de chances pôde-se perceber, em Jericoacoara, que o bom conhecimento sobre o contexto turístico local favorece o candidato que o possui, com 12 vezes mais chances de conseguir o emprego, diante de outro candidato que não o possui. 


\section{LOCAL DE NASCIMENTO (NATURALIDADE)}

Fator descartado. A partir da análise estatística não foi identificada nenhuma forte associação entre o fator "local de nascimento" e a inclusão socioeconômica direta no sistema de turismo.

Pela análise descritiva o fator ganha recorrência apenas como o terceiro maior destaque na função de guia turístico, porém, com baixa frequência e apenas em um município (Barreirinhas), não demonstrando notória significância. Ao que tudo indica, a inclusão socioeconômica direta não está ligada ao fato do candidato ser ou não um nativo da região.

\section{GRAU DE ESCOLARIDADE}

Fator com forte probabilidade. Foram identificadas, pela análise estatística, associações significativas entre o fator "grau de escolaridade" e a inclusão socioeconômica direta nos dois sistemas turísticos estudados. Em Barreirinhas, pelo Teste Qui-Quadrado de independência, o fator foi considerado como potencial para a definição do modelo explicativo. Em Jericoacoara, por sua vez, o fator apresentou efeitos significativos sobre a probabilidade de se conseguir o emprego no turismo.

$\mathrm{Na}$ análise descritiva pôde-se reconhecer recorrências de respostas pelos empresários referentes à importância do fator "grau de escolaridade" em funções específicas:

- Fator de maior destaque pelos Empresários de Barreirinhas, com avaliações por faixa entre "5" e "9";

- Garçom/Garçonete: fator de segundo maior destaque em Barreirinhas, e de terceiro maior destaque em Jericoacoara;

- Gerente: fator de segundo maior destaque em Barreirinhas, e de terceiro maior destaque em Jericoacoara;

- Secretário(a)/Telefonista: fator de maior destaque em Jericoacoara;

- Auxiliar administrativo-financeiro: fator de maior destaque em Barreirinhas, e de terceiro maior destaque em Jericoacoara;

- Recepcionista: fator de maior destaque em ambos municípios. 
O nível de instrução formal parece ter uma forte influência na decisão pela efetivação de um candidato às vagas de emprego disponíveis, principalmente para funções específicas como a de recepcionista. A escolaridade passa a ser tratada como um aspecto primordial para funções como essa.

\section{EXPERIÊNCIA ANTERIOR}

Fator com forte probabilidade. As associações entre o fator "experiência anterior" e a inclusão socioeconômica direta no sistema turístico de Jericoacoara foram significativas, segundo a análise estatística. Tal fator foi considerado potencial para a construção do modelo explicativo, segundo o Teste Qui-Quadrado de independência, e apresentando efeitos significativos sobre a probabilidade de efetivação no emprego.

Da mesma forma, pela análise descritiva, houve notória recorrência nas respostas dos entrevistados das duas regiões:

- Fator de terceiro maior destaque pelos Incluídos de Jericoacoara, e quarto maior destaque pelos Incluídos de Barreirinhas;

- Fator de terceiro maior destaque pela População local de Jericoacoara;

- Fator de segundo maior destaque pelos Empresários de Barreirinhas, nas questões abertas;

- Fator de terceiro maior destaque pelos Empresários de ambos municípios, com avaliações por nota "9";

- Responsável pelo beneficiamento de produtos: fator de segundo maior destaque em Barreirinhas e em Jericoacoara;

- Responsável por entregas: fator de maior destaque em Barreirinhas, e de segundo maior destaque em Jericoacoara;

- Responsável por eventos: fator de maior destaque em Jericoacoara, e de segundo maior destaque em Barreirinhas;

- Instrutor de esportes de aventura: fator de segundo maior destaque em Jericoacoara;

- Camareira: fator de maior destaque em Jericoacoara;

- Garçom: fator de maior destaque nas duas localidades;

- Chef de cozinha/cozinheiro(a): fator de maior destaque nos dois municípios; 
- Gerente: fator de segundo maior destaque em Jericoacoara;

- Secretário(a)/Telefonista: fator de segundo maior destaque em Jericoacoara;

- Auxiliar administrativo-financeiro: fator de maior destaque em Jericoacoara;

- Serviços gerais: fator de segundo maior destaque nos dois destinos;

- Segurança/Vigia: fator de maior destaque em Jericoacoara;

- Auxiliar de cozinha: fator de maior destaque em Jericoacoara, e de segundo maior destaque em Barreirinhas.

Nota-se a grande influência da experiência anterior nos processos de inclusão socioeconômica, nas diversas funções disponíveis, nos cenários turísticos dos destinos estudados.

Há indícios de que a experiência prévia no desenvolvimento da mesma função buscada contribui com o estabelecimento por, pelo menos, duas maneiras: não demanda pelo acompanhamento próximo e constante do novo empregado, dado que o mesmo já possui as noções para desempenhar as tarefas básicas da função; auxilia novos empreendedores que não possuem experiência na gestão hoteleira e que, ainda assim, se lançam ao mercado sem conhecimento prático e vivencial.

Pela razão de chances, apresentada pela análise estatística dos dados de Jericoacoara, aquele candidato com experiência anterior possui 5,5 vezes mais chance de conseguir 0 emprego, do que aquele que não a possui.

\section{CAPACITACÃO PROFISSIONAL}

Fator com forte probabilidade. Identificou-se, a partir da análise estatística, associações significativas entre o fator "capacitação profissional" e a inclusão socioeconômica direta nos sistemas turísticos dos dois destinos. Em ambos destinos, o fator ganhou notoriedade pelos efeitos significativos sobre a probabilidade de empregabilidade, inclusive, sendo classificado dentre os fatores com maiores razões de chance de inclusão.

Pela análise descritiva, todos os grupos entrevistados ressaltaram, de forma recorrente, o fator "capacitação profissional" como de extrema importância nos processos de inclusão socioeconômica direta, considerado em, praticamente, todas as funções específicas: 
- Fator de segundo maior destaque pelos Incluídos de Jericoacoara, e terceiro maior destaque pelos Incluídos de Barreirinhas;

- Fator de segundo maior destaque pela População local de Jericoacoara;

- Fator de maior destaque pelos Empresários de Barreirinhas, nas questões abertas;

- Fator de maior destaque pelos Empresários de Barreirinhas, com avaliações por nota "9", e de segundo maior destaque pelos Empresários de Jericoacoara, pela mesma avaliação;

- Fator de segundo maior destaque pelos Empresários de Barreirinhas, com avaliações na faixa entre " 5 " e "9";

- Responsável pelo beneficiamento de produtos: fator de maior destaque em Barreirinhas e em Jericoacoara;

- Guia turístico: fator de segundo maior destaque em Barreirinhas;

- Responsável por eventos: fator de maior destaque em Barreirinhas, e de segundo maior destaque em Jericoacoara;

- Instrutor de esportes de aventura: fator de maior destaque em ambos municípios;

- Camareira: fator de maior destaque em Jericoacoara, e de segundo maior destaque em Barreirinhas;

- Garçom: fator de segundo maior destaque em Jericoacoara;

- Chef de cozinha/Cozinheiro(a): fator de maior destaque em Barreirinhas, e de segundo maior destaque em Jericoacoara;

- Gerente: fator de maior destaque em Barreirinhas;

- Secretário(a)/Telefonista: fator de segundo maior destaque em ambos destinos;

- Auxiliar Administrativo-Financeiro: fator de segundo maior destaque nos dois municípios;

- Recepcionista: fator de segundo maior destaque em Jericoacoara;

- Serviços gerais: fator de maior destaque em ambas localidades;

- Segurança/Vigia: fator de maior destaque em Barreirinhas, e de segundo maior destaque em Jericoacoara;

- Auxiliar de Cozinha: fator de maior destaque em Barreirinhas, e de segundo maior destaque em Jericoacoara. 
Os dados levantados demonstraram a significativa contribuição da capacitação profissional, por meio da realização de cursos técnicos especializados, nos processos de inserção da comunidade local na cadeia produtiva do turismo.

Aparentemente, o mercado turístico tem demandado por, ou mesmo dado preferência para, candidatos mais bem preparados tecnicamente, para atuação em funções específicas. Na razão de chances, em Barreirinhas, aqueles candidatos capacitados possuem três vezes mais chances que os demais, enquanto que em Jericoacoara essa razão amplia-se, ainda mais: sete vezes mais chances.

\section{(2) \\ PROXIMIDADE FÍSICA DO LOCAL ONDE A ATIVIDADE TURÍSTICA SE DESENVOLVE}

Fator duvidoso. A análise estatística dos dados de Jericoacoara não identificou nenhuma forte associação entre o fator "proximidade física" e a inclusão socioeconômica direta em seu sistema turístico. Por outro lado, em Barreirinhas, no modelo ajustado, tal fator entra com notoriedade. Inclusive, demostrando uma razão de chance nove vezes maior para aquele candidato que resida distante do centro de Barreirinhas.

Porém, há que se lembrar que grande parte dos trabalhadores que atuam em funções específicas no trade turístico do destino, reside fora da sede municipal. Dessa forma, a análise estatística pode ter refletido numa situação em que, aparentemente, o mercado inclui uma maior parcela de trabalhadores de fora, quando, na verdade, a maior procura por emprego se dá, justamente, por moradores de baixa renda que residem fora do centro da cidade.

Fato que justifica tal afirmação é a inconsistente frequência de respostas pelos entrevistados, limitando-se, apenas aos Empresários de Jericoacoara, que ressaltaram, em suas respostas abertas, tal fator como o de segundo maior destaque no momento de contratação. Todavia, não ganhou significância nas avaliações por nota "9", nem mesmo por faixa. Em Barreirinhas, nem mesmo ganhou notoriedade nas respostas.

De todo modo, mesmo não podendo ser classificado entre os fatores mais bem avaliados, vistos como determinantes no processo, a proximidade física da Vila - no caso de Jericoacoara -, contribui visivelmente para efetivação no emprego para algumas funções. Camareiras, 
recepcionistas e auxiliares de cozinha, por exemplo, iniciam suas atividades matutinas bem cedo, na preparação do café-da-manhã, na organização dos quartos e no atendimento aos hóspedes.

Dessa forma, precisam estar presentes nos estabelecimentos já no início da manhã. E pela dificuldade de acesso à Vila, mesmo pelos transportes que, por vezes, acabam apresentando problemas, a proximidade física acaba sendo um fator considerado pelo empresariado desse destino.

\section{PARTICIPACÃO EM COOPERATIVAS E/OU ASSOCIACÕES}

Fator duvidoso. Não foi apresentada, pela análise estatística, nenhuma forte associação entre o fator "participação em cooperativas e/ou associações" e a inclusão socioeconômica direta nos sistemas turísticos dos destinos estudados.

No entanto, pela análise descritiva, ressaltou-se a grande relevância desse fator para a contratação de serviços em duas funções específicas:

- Guia turístico: fator de segundo maior destaque em Jericoacoara;

- Responsáveis pelo transporte turístico: fator de maior destaque em Jericoacoara, e de segundo maior destaque em Barreirinhas.

Percebe-se, a partir daí, que formas de organização coletiva do trabalho - como cooperativas e associações - contribuem nos processos de inclusão socioeconômica, em especial para realização de atividades de condução dos turistas até os pontos de visitação.

Por serem necessários, dentre outras coisas, equipamentos de transporte e grande contingente de recursos humanos especializados nos serviços de condução de visitantes, os estabelecimentos acabam primando pela contratação da cooperativa (que possui melhor estrutura de atendimento e suporte a esses serviços específicos) do que de um único indivíduo.

\subsubsection{Classificação dos fatores de inclusão socioeconômica indireta}

\section{EMISSÃO DE NOTA FISCAL}

Fator duvidoso. Ainda que, pela análise descritiva dos dados referentes aos grupos organizados de Jericoacoara, a "emissão de nota fiscal" tenha sido refletida como o fator de 
segundo maior destaque pela avaliação por notas na faixa entre " 5 " e "9", por parte dos empresários, pela mesma avaliação, o fator atingiu apenas a quarta posição. Em Barreirinhas, nessa mesma perspectiva, a posição do fator é ainda menos relevante.

Se analisadas as frequências de avaliação por notas " 9 ", em nenhuma das localidades se reconhece altas frequências de respostas, nem por parte do empresariado, nem pelos grupos organizados.

Percebe-se, então, a necessidade de se considerar o fator nos processos de inclusão socioeconômica indireta, contudo, como um obstáculo que não impede a inserção, mas sim, que a prejudica ou limita.

\section{CONDICOÕES DE PAGAMENTO (PRAZO)}

Fator duvidoso. Assim como no caso da emissão de nota fiscal em Jericoacoara, o fator "condições de pagamento" também não parece se configurar em um obstáculo que impede a inclusão socioeconômica indireta, mas que a prejudica ou a limita.

O fator foi ressaltado pelos grupos organizados do município cearense dentre aqueles de maior avaliação por notas na faixa entre " 5 " e "9". Entretanto, não se destacou nem mesmo entre os quatro mais importantes blocos de fatores, na visão do empresariado. E como no fator anterior, não ganhou destaque no município maranhense.

\section{ADEQUACÃO DA PRODUCÃO À SAZONALIDADE DO TURISMO (REGULARIDADE}

\section{NO FORNECIMENTO)}

Fator com forte probabilidade. O apontamento recorrente do fator "regularidade no fornecimento", como de significativa importância nos processos de inclusão socioeconômica indireta, pôde ser vislumbrado tanto pela análise dos dados do empresariado, quanto na análise dos dados dos grupos organizados entrevistados.

Foi frequente a classificação do fator, por parte dos empresários de ambos municípios, dentre aqueles com maior relevância no momento da definição pela aquisição de produtos ou utilização de serviços de suporte turísticos. O comprometimento com a continuidade no 
oferecimento de tais produtos e serviços foi tratada como de extrema importância para a efetivação da inclusão.

Da mesma forma, tal fator foi ressaltado com notória frequência pelos grupos organizados, dentre aqueles de maior significância para se apresentar ao mercado turístico de forma competitiva, e para se manter inserido.

\section{CAPITAL DE GIRO, ESTRUTURA DE BENEFICIAMENTO E LOCAL DE ESTOCAGEM}

Fator duvidoso. A análise descritiva das respostas dos grupos organizados, das duas localidades, referentes às questões abertas, refletiu, como um dos principais fatores de influência sobre a inclusão indireta, a ausência de incentivo financeiro e de maior participação das autoridades públicas (federal, estadual e municipal) nas discussões sobre os problemas que os mesmos enfrentam na rotina de trabalho.

A falta de capital de giro, somada às necessidades de estruturas físicas, adequadas para o beneficiamento dos produtos, e de locais de estocagem e armazenamento, são lacunas apresentadas pelos grupos dos dois destinos para se atingir o mercado turístico de forma competitiva.

Todavia, para os empresários dessas regiões, tal fator, assim como os demais classificados como duvidosos, podem limitar ou prejudicar a venda, mas não vai impedi-la de ser realizada. Como exemplo, pôde-se identificar que muitos empreendedores, das duas localidades, preferem, normalmente, adquirir produtos in natura, não-beneficiados. Tal fato ajuda a esclarecer essa divergência entre o entendimento do fator na visão dos grupos organizados e dos empresários.

\section{PRODUÇ̃̃O PARA ATENDIMENTO DA DEMANDA (SUFICIÊNCIA PRODUTIVA)}

Fator com forte probabilidade. O fator "suficiência produtiva" foi recorrente com frequências notórias de avaliações por notas "9", e por faixas de notas entre "5" e "9", identificadas nas respostas não apenas dos empresários, como também dos grupos organizados, em ambos municípios.

A provisão da quantidade, de produtos e de serviços, demandada pelos empreendimentos turísticos do trade, é reconhecida pelos atores locais (demanda e oferta) como um aspecto 
extremamente significativo para estabelecimento de uma relação direta entre eles, podendo ser um fator determinante que pode impedir ou permitir a inclusão.

\section{DISPONIBILIDADE LOGÍSTICA PARA O ESCOAMENTO DA PRODUCÃO (ENTREGA)}

Fator com forte probabilidade. Principalmente no destino turístico cearense, onde os meios de hospedagens, restaurantes e demais empreendimentos do trade estão concentrados em um espaço de difícil acesso (Vila de Jericoacoara), a "disponibilidade de entrega" ganha significância extrema nos processos de inclusão indireta.

Ressaltado, nos dois municípios, entre os fatores de maior limitação/contribuição para a inclusão socioeconômica indireta (tanto pelos empresários quanto pelos grupos organizados), a indisponibilidade logística para o escoamento dos produtos - como pela utilização de algum meio de transporte adequado - é, ainda hoje, um obstáculo enfrentado por pequenos produtores rurais dessas regiões.

\section{CAPACITAC̄̃̃O PROFISSIONAL TÉCNICA E GERENCIAL}

Fator com forte probabilidade. A capacitação técnica e gerencial foi avaliada por empresários e por grupos organizados, dos dois destinos, como fator notoriamente significativo. Classificado entre os fatores com maiores frequências de avaliação por notas "9" e por faixas de notas entre "5" e "9", a capacitação profissional é apresentada como uma lacuna de necessidade básica para grupos que buscam se inserir no mercado turístico.

Problemas de gerenciamento da produção e dos estoques, das receitas e dos gastos, e a ausência de orientação técnica quanto às boas práticas de fabricação e de higiene pessoal, ou quanto ao bom atendimento ao turista e segurança na condução dos mesmos até os pontos de visitação, fazem desse fator um aspecto determinante para inclusão socioeconômica indireta.

ORGANIZACÃO COLETIVA DE TRABALHO (PARTICIPACÃO EFETIVA EM COOPERATIVAS OU ASSOCIACÕES)

Fator duvidoso. A recorrência de avaliações positivas para o fator "participação efetiva em cooperativas ou associações" pôde ser identificada, apenas, pela análise das respostas dos 
grupos organizados de Jericoacoara. Em Barreirinhas tal significância não foi refletida pelas respostas.

$\mathrm{Na}$ avaliação pelos empresários entrevistados, das duas localidades, as maiores frequências de respostas não ultrapassaram os $25 \%$ nas avaliações por notas "9", para esse fator. Também não foi classificado entre aqueles mais significativos, em nenhuma das opções de avaliação pelo empresariado.

De toda forma, pela avaliação do fator por faixa com notas entre "5" e "9", a frequência identificada na análise de respostas dos empresários atingiu, em Barreirinhas, 77,7\% e, em Jericoacoara, 56,2\%, demonstrando a importância de contribuição do fator (ainda que não impedindo a inclusão indireta).

\section{REGISTROS DE SERVIÇOS DE INSPECÃO SANITÁRIA (SIF / SIE / SIM)}

Fator com forte probabilidade. A apresentação de selos que atestem a qualidade sanitária e a conformidade, do produto oferecido, com a legislação brasileira, parece ser um fator significativo no momento de aquisição pelo trade.

Tal fator foi ressaltado pelos empresários dos dois municípios entre os de maior destaque nas avaliações por notas " 9 " e por faixa de notas entre " 5 " e "9" e, da mesma forma, entre os grupos organizados entrevistados.

Geram-se indícios de que as exigências para se atingir o padrão de qualidade demandado, acabam não apenas limitando os pequenos produtores de se apresentarem competitivamente ao grande mercado turístico, mas os impedindo de tal feito. O resultado é, justamente, análogo às informações obtidas nesta pesquisa: responsáveis dos estabelecimentos do trade, das duas localidades, que se deslocam até as capitais de seus respectivos estados, para a compra de produtos em grandes frigoríficos, supermercados e peixarias, que dispõem dessa certificação. 


\section{CONCLUSÃO E CONSIDERAÇÕES FINAIS}

São muitos os gargalos para se compreender os processos de desenvolvimento local. Pesquisas têm esta função: buscar identificar estes gargalos e analisá-los. Mas o intuito maior e final é o de desenhar caminhos que possam superar os desafios do desenvolvimento local, e neste, a conservação ambiental e a equidade social.

Em um processo no qual o turismo se apresenta como principal instrumento potencializador de desenvolvimento, a complexidade tomada para análise se amplia. São aspectos multidimensionais, lacunas transversais e percepções plurais, que fazem do turismo um emaranhado de interações as quais demandam um olhar sistêmico.

Esses e muitos outros desafios, como os de ordem operacional e analítica, foram enfrentados ao longo de todo o período de realização do presente estudo. Limitações nas vias de acesso a algumas comunidades rurais, dificuldades no estabelecimento de diálogo com alguns investidores externos, desconfiança na apresentação de informações, dentre outros impedimentos, demandaram por ajustes nas peças metodológicas.

Numa perspectiva oposta, alguns aspectos facilitadores também foram vivenciados. Como por exemplo, a dinamização na aplicação de formulários com incluídos de Jericoacoara, percebendo-se, apenas em campo, que o espaço da praça central da Vila era utilizado, por muitos, como local de repouso após o almoço.

Durante o percurso de realização do estudo, muitos esforços foram assumidos com vista a superação dos desafios para se atingir o objetivo maior: avaliar os fatores de inclusão socioeconômica (direta e indireta) de habitantes de destinos turísticos no sistema produtivo local de turismo, e produzir insumos que contribuam para a formulação de políticas públicas mais eficazes.

O primeiro esforço se deu na busca pela caracterização dos sistemas turísticos dos dois municípios em foco, avaliando suas dinâmicas e especificidades. Pôde-se perceber que, nos últimos 40 anos, o cenário antes caracterizado por aspectos bucólicos, pela vida pacata e simples de pequenos produtores rurais, sofreu transformações radicais.

O número limitado de aventureiros, que enfrentavam obstáculos logísticos de acesso aos meios paradisíacos (representados pelas variadas lagoas dos Lençóis Maranhenses e pelas praias encantadoras de Jericoacoara), deram espaço à demanda nacional e internacional de turistas e de investidores externos. 
Em um período de 20 anos, entre 1990 e 2010, as taxas de crescimento populacional médio anual superaram, nos dois municípios, as taxas estaduais e do Brasil. A margem de crescimento populacional em Barreirinhas, nos dez primeiros anos do período, foi três vezes maior que a margem de seu estado e da federação. Em Jericoacoara, chegou a ser oito vezes maior. Nos dez anos seguintes, as taxas de crescimento se mantiveram três vezes maiores, nas duas localidades.

Concomitantemente, dinamizaram-se os processos de ordem infraestrutural básica e turística, assentados em iniciativas governamentais, estaduais e federais, de desenvolvimento do setor. Ampliaram-se, consideravelmente, os empreendimentos de acolhimento e de suporte à atividade. Acelerou-se a estruturação do setor para atendimento da demanda que, exponencialmente, aumentava.

Os valores adicionados pelo setor de serviços ao total do produto interno bruto (PIB), de Barreirinhas e de Jijoca de Jericoacoara, em 2010, chegaram a $R \$ 105.595,00$ (60,2\% do total) e $\mathrm{R} \$ 58.825,00$ (74,4\% do total), respectivamente. Isso demonstrou o protagonismo do setor de serviços, o qual se insere a atividade turística, na formação econômica dos destinos, na viabilização de infraestrutura básica, e na geração de oportunidades de trabalho, emprego e renda.

A criação dos Parques Nacionais dos Lençóis Maranhenses, em 1981, e de Jericoacoara em 2002, contribuiu para o planejamento e ordenamento de atividades voltadas à conservação e utilização prudente dos recursos naturais singulares. Todavia, ainda hoje são identificadas ações predatórias que, visivelmente, somam-se aos diversos impactos negativos resultantes de um modelo de exploração turística descomprometida da sustentabilidade em suas múltiplas dimensões.

O crescimento desenfreado de práticas turísticas nas duas regiões desencadeou uma série de impactos negativos - comuns ao corpo científico, nacional e internacional, das áreas de turismo e sustentabilidade - tais como: degradação de áreas naturais pela proliferação descontrolada de equipamentos turísticos e urbanos; aumento no trânsito de veículos nas praias e na Vila de Jericoacoara, e próximos às lagoas dos Lençóis Maranhenses, deixando rastros de combustível derramado e poluição sonora; aumento nos processos de favelização; ausência de um sistema de saneamento básico adequado; desenraizamento das atividades produtivas tradicionais; excesso de resíduos de todo o tipo, principalmente sólidos, nas áreas dos parques e nos municípios, modificando a paisagem original; prostituição e tráfico de drogas; 
descaracterização das manifestações culturais (como o artesanato típico); baixa qualificação do capital humano utilizado no setor de turismo; e a baixa participação das comunidades locais nos benefícios econômicos advindos da atividade turística, acarretando em situações de exclusão social latente.

No contexto geral, a realidade atual dos destinos turísticos estudados perpassa por reais problemas socioeconômicos. São amplas taxas de incidência da pobreza, que ultrapassam os $50 \%$ das populações. Vulnerabilidade à pobreza por, aproximadamente, $80 \%$ das populações nos dois municípios. Baixos indicadores de emprego e renda (0.3916 em Barreirinhas, 0.3652 em Jericoacoara), o que resulta em avaliações de baixo desenvolvimento para esse componente.

Analisadas apenas as populações economicamente ativas (PEA) serão notados, nas duas localidades, rendimentos inferiores a um salário mínimo por mais de $70 \%$ desses grupos $(77,4 \%$ em Barreirinhas, e 71,5\% em Jericoacoara). O baixo rendimento dessa ampla maioria pode estar atrelado ao baixo nível de instrução formal apresentado também pela maioria da PEA. Aqueles indivíduos sem escolaridade, ou com ensino fundamental incompleto, atingiram $65,4 \%$ pessoas em Barreirinhas, e 50,7\% em Jijoca de Jericoacoara. Ressalta-se que as taxas de analfabetismo, dos indivíduos com 15 anos ou mais, chegam a 25,4\% em Barreirinhas, e 23,5\% em Jericoacoara.

Com relação às taxas de ocupação da população com idade ativa (PIA), nota-se que, em Barreirinhas, apenas $45,1 \%$ dos indivíduos encontram-se ocupados. Em Jijoca de Jericoacoara a margem é maior, tendo atingido $53,7 \%$. Ainda que baixas, as taxas municipais superaram as taxas dos seus respectivos estados.

Identificou-se que a ampla maioria do pessoal ocupado encontra-se na administração pública (64,0\% em Barreirinhas e 53,8\% em Jericoacoara), seguida pela ocupação no segmento de serviços, onde se encaixa o turismo, por $23,3 \%$ e $34,4 \%$, nas localidades maranhense e cearense, respectivamente.

Aqueles ocupados por meio de emprego atingem 42,1\% em Barreirinhas, e 55,8\% em Jijoca. Margens essas não muito distantes às dos indivíduos que se encontram trabalhando informalmente, ou na produção para o próprio consumo, somando, no município maranhense, $49,5 \%$, e no município cearense, $40,5 \%$. 
Os processos de formalização dos empregados, em ambas regiões, são falhos. A grande maioria permanece sem carteira assinada. Eles são 65,9\% em Barreirinhas e $60,3 \%$ em Jericoacoara.

Como um segundo esforço para se atingir o objetivo geral da pesquisa, buscou-se identificar quais, dentre os habitantes locais, estão incluídos ou não incluídos economicamente no SPLT, e a forma dessa inclusão. Também foi buscado um melhor entendimento sobre como as comunidades locais visualizam a situação atual, e como elas reagem às possíveis alternativas de inserção nos processos produtivos relativos ao turismo.

Numa primeira perspectiva, a partir dos dados coletados junto às duas populações locais (por amostra probabilística e arranjos metodológicos, previamente definidos), pôde-se perceber que apenas $22,8 \%$ dos entrevistados de Barreirinhas, e $17,5 \%$ dos entrevistados de Jericoacoara, já haviam buscado por oportunidades de emprego no setor de turismo. A grande maioria dos entrevistados dos municípios maranhense e cearense $(76,6 \%$ e $82,5 \%$, respectivamente), não buscou emprego no setor de turismo porque "não gostam desse tipo de atividade" (15,6\% e 9,5\%), "não querem abandonar suas atividades tradicionais" $(14,8 \%$ e $30,7 \%$ ), ou "não possuem estudo suficiente" (12,8\% e 20,9\%). Portanto, os principais motivos de não buscar emprego no setor de turismo, que atinge até $1 / 3$ dos habitantes, está relacionado à satisfação com o que fazem ou ao desinteresse com as atividades relacionadas ao turismo.

Por outro lado, para aqueles indivíduos de Barreirinhas e de Jericoacoara que buscaram por oportunidades de emprego no setor, o fizeram por afirmarem que "gostam desse tipo de atividade" (25,3\% e 15,5\%), "tinham necessidades financeiras" (23,9\% em Jeri), "não querem mais trabalhar em suas atividades tradicionais" (18,4\% em Barreirinhas), "os salários são altos" (18,4\% em Barreirinhas), ou "foram indicados/receberam um convite por conhecidos" (14,1\% em Jeri). O desinteresse com a atividade que desempenhavam ou as atratividades - melhores salários e melhores condições de trabalho - do turismo foram os motivos que levaram cerca de $1 / 3$ a buscarem emprego neste setor.

Pela ótica daqueles que já estão trabalhando no setor - incluídos de Barreirinhas e de Jericoacoara -, e que foram entrevistados durante a pesquisa, o emprego foi buscado por "gostarem desse tipo de atividade" (23,1\% e 17,0\%), "necessidade financeira" (14,1\% e 25,0\%), "não encontrarem outras opções de emprego/é onde tem emprego" (34,6\% em Barreirinhas), "terem sido indicados/recebido convite por conhecidos" (20,0\% em Jeri). A falta de opção, a 
necessidade financeira ou o prazer de trabalhar no turismo são os motivos apresentados por aqueles que trabalham no setor.

O que se nota a partir de tais resultados é que, aparentemente, as oportunidades de emprego no setor de turismo atraem, com maior intensidade, aqueles que possuem apreço pela atividade, que já pensam em abandonar suas atividades tradicionais, ou que foram convidados por conhecidos. Para os que não gostam da atividade, mas ainda assim buscam por oportunidades, o fazem por ser essa, talvez, a única opção de emprego nas regiões, podendo com ela suprir as necessidades financeiras que lhes são impostas.

As principais características dos incluídos de Barreirinhas e de Jericoacoara são, respectivamente: idade entre 16 e 34 anos; ensino médio completo ou ensino fundamental incompleto; residência na própria sede do município e em comunidades circunvizinhas ao local onde a atividade turística se desenvolve; renda familiar média mensal entre um e dois salários mínimos; nativos; aproximadamente a mesma porcentagem de indivíduos de gênero masculino e feminino; de religião católica; e que não participam de grupos organizados de trabalho. Chamam a atenção nestas respostas o equilíbrio de gênero e a abertura do leque de escolaridade.

Com respeito à inserção no mercado turístico, por meio da prestação de serviços de suporte à atividade (como guias, bugueiros, pilotos de embarcações náuticas, motoristas de carros tracionados, etc.), identifica-se, pela ótica dos envolvidos, nas duas regiões, um conflito constante entre prestadores de serviços formais e prestadores de serviços informais ("piratas"). A busca pela formalização e prestação de serviços adequados se dá por meio da participação em grupos organizados de trabalho, do pagamento de impostos, da capacitação profissional coletiva, do credenciamento exigido, da disponibilização de equipamentos em boas condições de utilização, e da padronização dos serviços. Em contrapartida, enfrentam uma situação de concorrência com prestadores de serviços irregulares, despreparados, descredenciados, sem capacitação, utilizando-se de equipamentos impróprios, e que ampliam-se de forma constante, principalmente em períodos de alta temporada.

Esse conflito tem sido tratado pelos prestadores regulares de serviços como um obstáculo para se manterem no mercado. Tal aspecto foi ressaltado com a maior frequência de respostas - por questões abertas - pelos grupos organizados entrevistados, tanto em Barreirinhas quanto em Jericoacoara. 
Outro aspecto de mesma relevância, também destacado em ambas localidades, foi a ausência de incentivo financeiro e maior participação das autoridades públicas (federal, estadual e municipal) nas discussões sobre os problemas que tais grupos enfrentam no dia-a-dia.

Segundo os entrevistados, o lucro que conseguem obter no desenvolvimento das atividades, não é suficiente para suprir os amplos gastos com a manutenção dos equipamentos (combustível, troca de peças, pintura para padronização) e o pagamento de impostos. O que parece é que a formalização, e a apresentação ao mercado prestando serviços adequados, é inviável financeiramente, pela falta de incentivo das representações políticas locais que, segundo eles, não fiscalizam com vigor os irregulares, e não proporcionam apoio concretos aos regulares.

O terceiro esforço para cumprir o objetivo geral se deu pela identificação e avaliação dos fatores que mais influenciam os processos de inclusão socioeconômica no turismo, e também pela busca de aspectos recorrentes e relevantes entre os destinos estudados.

Dentre os onze fatores avaliados para inclusão socioeconômica direta, cinco foram considerados de forte probabilidade (capacitação profissional; rede de relações sociais; experiência anterior; grau de escolaridade; e conhecimento da área/região), quatro foram considerados duvidosos (gênero; idade; proximidade física de onde a atividade turística se desenvolve; e participação em cooperativas e/ou associações), e dois foram descartados (religião; e local de nascimento).

Quanto aos nove fatores de inclusão indireta, também elencados e avaliados nesta tese, cinco deles foram considerados de forte probabilidade (regularidade no fornecimento; suficiência produtiva; disponibilidade logística; capacitação técnica e gerencial; e registros de inspeção sanitária), e quatro foram tratados como duvidosos (emissão de notas fiscais; condições de pagamento/prazo; capital de giro, estrutura de beneficiamento e local de estocagem; e participação efetiva em cooperativas e/ou associações). Nenhum fator de inclusão indireta foi descartado.

O quarto e último esforço voltado ao cumprimento do objetivo geral se caracterizou pela reflexão sobre os fatores que as políticas públicas de inclusão social, em regiões turísticas no entorno de unidades de conservação, deveriam considerar para obter resultados mais satisfatórios. Naturalmente, buscou-se reconhecer as contribuições do presente estudo para a formulação de políticas públicas mais efetivas, no sentido de assegurar um modelo de desenvolvimento local mais inclusivo e sustentável. 
O contraste entre a potencialidade cênica, refletida pelos Parques Nacionais dos Lençóis Maranhenses e de Jericoacoara, a abundância de áreas produtivas e mão de obra, e os baixos índices de desenvolvimento local, principalmente no que tange a geração de oportunidades de trabalho, emprego e renda, é um primeiro ponto de reflexão.

Há que se pensar num modelo de desenvolvimento local no qual sejam primadas ações voltadas ao desenvolvimento a partir de dentro, ou seja, pensando-se na autossuficiência do destino. Serão necessárias, para tanto, ações integradas que:

(a) Estimulem a capacitação e a qualificação profissional de indivíduos que busquem se inserir diretamente no setor (pelo emprego formal), pelo oferecimento de cursos de orientação técnica em funções específicas demandas em cada contexto turístico municipal;

(b) Levem em consideração a importância das redes de confiança, que se formam entre os atores, e da vivência inicial no desempenho de uma ou mais funções, como um primeiro passo para se adquirir experiência, para efetivação dos processos de inclusão socioeconômica direta;

(c) Primem pela ampliação dos níveis de instrução formal (escolaridade), por meio do acesso às oportunidades de escolarização de qualidade;

(d) Sensibilizem e estimulem a vivência turística pelo próprio morador, para a melhoria do conhecimento sobre o setor de turismo e sobre a região, e sobre as oportunidades e potencialidades que esse setor pode viabilizar aos nativos, como formas de melhoria da qualidade de vida da população local;

(e) Proporcionem incentivos, principalmente financeiros, para que grupos organizados de trabalho (que dão suporte à atividade turística) se mantenham ativos, com a padronização de alta qualidade na estrutura de oferecimento de serviços, atuando com a formalização que lhes é exigida;

(f) Valorizem as atividades tradicionais, como a pesca artesanal e a agricultura familiar, fomentando o fortalecimento da organização produtiva (por meio do apoio técnico, logístico e jurídico) e a aproximação comercial (numa perspectiva justa, ética e solidária), entre pequenos produtores rurais e o trade turístico;

(g) Fortaleçam e ampliem a capacidade produtiva e a organização logística de escoamento, para que seja mantida a regularidade de fornecimento e, gradativamente, atinja-se a suficiência na produção para atendimento da demanda, envolvendo um maior número de grupos produtivos ao sistema de turismo. 
Todas essas ações integradas devem buscar articulações de propostas e projetos dos diversos órgãos com atuação no território. Será necessário dispor de contribuições do(a):

- Ministério do Desenvolvimento Agrário (MDA), pelo Programa Nacional de Fortalecimento da Agricultura Familiar (Pronaf);

- Ministério da Agricultura, Pecuária e Abastecimento (MAPA), pelo Departamento de Inspeção de Produtos de Origem Animal (DIPOA);

- Ministério do Turismo (MTur), pelos Programas de Integração à Produção Associada ao Turismo, Estruturação do Turismo em Áreas Priorizadas, Fomento ao Turismo de Base Comunitária, Programa de Qualificação para o Desenvolvimento do Turismo, e pelo Programa Nacional de Acesso ao Ensino Técnico e Emprego na vertente do Turismo (Pronatec - Turismo);

- Ministério do Meio Ambiente (MMA) e Instituto Chico Mendes de Conservação da Biodiversidade (ICMBio);

- Ministério da Educação (MEC), por meio do Programa Nacional de Acesso ao Ensino Técnico e Emprego (Pronatec);

- Serviço Brasileiro de Apoio às Micro e Pequenas Empresas (SEBRAE), principalmente pelo suporte nas ações locais e acompanhamento direto;

- Secretarias Municipais de Turismo, de Barreirinhas e de Jijoca de Jericoacoara, e Prefeituras;

- Outros.

O fundamental no esforço de criar condições favoráveis de inclusão socioeconômica para as populações locais e, desta forma, melhorar a sua qualidade de vida, é a ação integrada entre entidades governamentais e o segundo setor, em três segmentos: (a) na melhoria da qualidade da educação e da qualificação da força de trabalho local; (b) no estímulo ao empreendedorismo; e, (c) na melhoria do processo produtivo e na comercialização dos produtos locais.

No primeiro caso o essencial é a atração de talentos (professores competentes) com boas condições de trabalho e melhor remuneração, e a formatação de programas de qualificação no local do trabalho, por meio de incentivos governamentais. No segundo é a disseminação de informação de acesso ao crédito, ao empreendedorismo individual e à feitura de planos de negócios, com apoio do SEBRAE. E, finalmente, no terceiro foco, o esforço é menos simples porque deve associar, necessariamente, assistência técnica, melhoria dos transportes, acesso a crédito, criação de veículos de comercialização, dentre outros. 
Nesse último caso, vale a sugestão de criação de dois espaços exclusivos, no formato de duas feiras de produtos comunitários, no centro de Barreirinhas e na Vila de Jericoacoara, como forma de estimular a comercialização direta entre pequenos produtores rurais e empresários do trade dos dois destinos. Tal ideia surgiu do diálogo do pesquisador com os diversos atores do trade envolvidos que, constantemente, ressaltavam que o distanciamento físico dos produtores e a necessidade frequente por produtos, não Ihe davam outra alternativa que não a compra de produtos importados de outras regiões, em pequenos mercados próximos.

A aproximação física pode contribuir, inicialmente, como uma alternativa de compra de produtos, que não pretenda atingir, de imediato, a suficiência demandada, mas que proporcione a facilidade de escoamento da produção. Pensa-se, como um primeiro estímulo, que sejam realizadas vendas em pequenas quantidades, em um único dia da semana, trabalhando com produtos frescos das comunidades rurais de entorno.

Para tanto, será necessário o apoio de gestores locais para suprir duas necessidades primárias: organização e disponibilização de um espaço para exposição semanal dos produtos; disponibilização de um veículo adequado para transportar os produtos das comunidades rurais até os espaços de comercialização.

Deve-se refletir que em nenhum destes focos existe impossibilidade real. Basta uma boa articulação entre agentes governamentais, empresas e atores do trade e a sociedade em geral. Portanto, conclui-se que o desenho das políticas públicas de inclusão social nos destinos turísticos estudados, assim como em outros destinos brasileiros que possuam similitudes, deverá se ater ao desenvolvimento endógeno e includente.

Deverá encorajar a melhoria da estrutura do sistema turístico em favor da equidade, estimulando a capacidade de mobilização de recursos e de iniciativas locais. Deverá adotar estratégias de mitigação da dependência externa de recursos, focando no aproveitamento racional e ecologicamente sustentável das potencialidades naturais em benefício das comunidades receptoras.

E, por fim, como conditio sine qua non, atenuar o quadro de pobreza instaurado, assegurando, simultaneamente, um nível razoável de coesão social, a superação das disparidades, a sustentabilidade social e ambiental, e a viabilidade econômica do setor. 


\section{REFERÊNCIAS}

AB'SABER, Aziz Nacib. Litoral do Brasil. São Paulo: Metalivros, 2001. 288 p.

AFRICAN PRO-POOR TOURISM DEVELOPMENT CENTRE (APTDC). What is pro-poor tourism (PPT)? Disponível em: <http://www.propoortourism-kenya.org/what_is_propoortourism.html>. Acesso em: 22 maio 2013.

AGÊNCIA ESPANHOLA DE COOPERAÇÃO INTERNACIONAL (AECI). Diagnóstico da Oferta Turística de Barreirinhas. Projeto de Desenvolvimento Sustentável do Turismo na Região dos Lençóis Maranhenses. Brasília-DF: 2007.

AGUIAR, Lileane Praia Portela de Aguiar. Inclusão em destinos turísticos: estudo comparado entre os destinos turísticos de Presidente Figueiredo (AM) e Barreirinhas (MA). 2013, 176p. Tese (Doutorado em Desenvolvimento Sustentável) - Centro de Desenvolvimento Sustentável, Universidade de Brasília, Brasília, 2013.

AGRESTI, A. Categorical Data Analysis. 2. ed., New York: Jonh Wiley and Sons, 2003.

ALBAGLI, Sarita; BRITTO, Jorge (Org.). Glossário de arranjos produtivos locais. Projeto Políticas de Promoção de Arranjos Produtivos Locais de MPMEs. Rio de Janeiro: UFRJ/RedeSist, 2003.

ALFORD, P. A framework for mapping and evaluating business process costs in the tourism industry supply chain. In: FREW, A. J. (Ed.), Information and communication technologies in tourism 2005. Vienna: Springer Verlag, 2005.

ALLEMAND, Silvain. Les paradoxes du développement durable. Paris: les chevaliers bleus, 2007.

ALMEIDA, Érica T. Vieira de. O Programa de Geração de Trabalho e Renda em Campos dos Goytacazes: limites e contradições. Vértices, v. 11, n. 1, p. 87-108, 2009.

ALMEIDA, Paulo H. Pequena empresa e desenvolvimento local: os limites da abordagem competitiva. In: FISCHER, Tânia (Org.). Gestão do desenvolvimento e poderes locais: marcos teóricos e avaliação. Salvador, BA: Casa da Qualidade, 2002. p. 245-260.

ARDAHAEY, F. T. Economic impacts of tourism industry. International Journal of Business and Management, 6(8), 206-215. 2011.

ASSOCIAÇÃO DOS MUNICÍPIOS DO ESTADO DO CEARÁ (Aprece). Conheça o município. Disponível em: <http://www.aprece.org.br/site/?prefeitura=101\&acao=conheca_omunicipio >. Acesso em: 10 jul 13.

BAGGIO, R., SCOTT, N., \& COOPER, C. (2008) "Network science and socio-economic systems: a review focused on a tourism destination". Dondena Working Paper No. 7, Carlo F. Dondena Centre for Research on Social Dynamics, Bocconi University. http://www.dondena.unibocconi.it/wp7. Acesso em: 04 de março de 2014.

BAGGIO, R., y COOPER, C. Knowledge transfer in a tourism destination: the effects of a network structure. Service Industries Journal, 30 (10):1757-1771, 2010.

BALANZÁ, Isabel Milio; NADAL, Mónica Cabo. 2003. Marketing e Comercialização de Produtos Turísticos. São Paulo: Pioneira Thomson Learning.

BANCO DO NORDESTE. O Setor Turismo. Fortaleza: Banco do Nordeste / ETENE, 2000.(Estudos Setoriais, 10).

BARBETTA, P.A. Estatística aplicada às Ciências Sociais. Florianópolis: UFSC, 1998.

BARBOSA, M. A. C.; ZAMBONI, R. A. Formação de um cluster em torno do turismo de natureza de Bonito (MS). Brasília, DF: Ipea, 2000. (Texto para discussão n.772).

BARRETO, R. R., OLIVEIRA E. S., SICSÚ, A. B. Arranjo produtivo local e desenvolvimento endógeno: uma apresentação do APL de turismo no litoral norte do estado de Alagoas". In: XXVII Encontro Nacional de Engenharia de Produção, Foz do Iguaçu pp. 1-10. 2007.

BAUDIN, M. Le développment durable: nouvelle idéologie du XXI siécle? Paris: L'Harmattan, 2009.

BELLEN, Hans Michael Van. Indicadores de sustentabilidade: uma análise comparativa. - 2. ed. - Rio de Janeiro: Editora FGV, 2006, p. 253.

BENI, M. C. Globalização do turismo: megatendências do setor e a realidade brasileira. 1. ed. São Paulo: Aleph, 2003. cap. 1 e 2. 
BERNARDES, A. T.; PINHEIRO, C. F. S.; MACHADO, R. F.; SILVA, G. P., FLECHA, A. C. Redes complexas: interações dos atores do setor do turismo na cidade de Ouro Preto". IV Seminário de Pesquisa em Turismo do Mercosul. Turismo: Responsabilidade Social e Ambiental. Caxias do Sul, Julho, pp. 1-15, 2006.

BOUGET, Denis. Observatoire europeen des politiques de lute contre les exclusions sociales. Nantes, Centre d'Economie des Besoins Sociaux, 1992.

BOULDING, Kenneth E. The Economics of the Coming Spaceship Earth. In H. Jarrett (ed.) 1966. Environmental Quality in a Growing Economy, pp.3-14. Baltimore, MD: Resources for the Future/Johns Hopkins University Press.

BRASIL (2012a). Congresso Virtual Internacional. Economia Verde e Inclusão Socioprodutiva: o papel da agricultura familiar. Reflexões para a Rio+20. Disponível em: $<$ http://www.iica.int/Esp/regiones/sur/brasil/Lists/Noticias/Attachments/505/doc_final_cong_virtual_baixa_corrigido.pdf >. Acesso em: 05 jan 2013.

BRASIL (2012b). Ministério do Desenvolvimento Social e Combate à Fome (MDS). Editais para Projetos de Inclusão Produtiva. Disponível em: <http://www.fomezero.gov.br/editais-de-inclusao-produtiva/>. Acesso em: 20 jul 2012.

BRASIL (2013a). Ministério da Agricultura, Pecuária e Abastecimento (MAPA). Produto Final. Disponível em: <http://www.agricultura.gov.br/animal/produto-final>. Acesso em: 15 maio 2013.

BRASIL (2013b). Ministério da Agricultura, Pecuária e Abastecimento (MAPA). Regulamento da Inspeção Industrial e Sanitária de Produtos de Origem Animal (RIISPOA). Disponível em: <http://www.agricultura.gov.br/arq_editor/file/Aniamal/Mercadolnterno/Requisitos/Regulamentolnspecaolndustrial.pdf >. Acesso em: 15 maio 2013.

BRASIL (2011a). Cadeia Produtiva do Turismo em Parques Nacionais e entorno: Resumo Executivo. 2011.

BRASIL (2000). Lei $\mathbf{N}^{\circ}$ 9.985, de 18 de julho de 2000 . Disponível em: <http://www.planalto.gov.br/ccivil_03/leis/l9985.htm>. Acesso em: 02 agosto 13.

BRASIL (2014a). Ministério da Fazenda. Brasil reduziu desemprego e desigualdade mesmo com crise externa. Disponível em: <http://www.fazenda.gov.br/divulgacao/noticias/2014-1/abril/brasil-reduziu-desemprego-edesigualdade-mesmo-com-crise-externa>. Acesso em: 06 maio 2014.

BRASIL (2011b). Ministério da Pesca e Aquicultura (MPA). Dinâmica econômica da aquicultura e pesca: Território Sul Catarinense. Florianópolis: CEADES, 2011.

BRASIL (2014d). Ministério do Turismo (MTur). Estimular o desenvolvimento sustentável da atividade turística. Disponível em:

http://www.turismo.gov.br/turismo/programas_acoes/Estimular_desenvolvimento_sustentavel_da_atividade_turistica/ >. Acesso em: 04 agosto 2014.

BRASIL (2007a). Ministério do Turismo (MTur). Plano Nacional de Turismo 2007-2010: Uma Viagem de Inclusão. Brasília: Ministério do Turismo, 2007.

BRASIL (2007b). Ministério do Turismo (MTur). Conteúdo Fundamental: Turismo e Sustentabilidade. Brasília, 2007.

BRASIL (2013c). Ministério do Turismo (MTur). Plano Nacional de Turismo 2013-2016: O turismo fazendo muito mais pelo Brasil. Disponível em: <http://www.turismo.gov.br/export/sites/default/turismo/o_ministerio/plano_nacional/downloads_plano_nacional/PNT_ -_2013_2016.pdf>. Acesso em: 01 jul 2013.

BRASIL (2014b). Ministério do Turismo (MTur). Programas de Integração à Produção Associada ao Turismo. Disponível em: <http://www.turismo.gov.br/turismo/programas_acoes/Programas_de_Integracao_Producao_Associada_Turismo/>. Acesso em: 04 agosto 2014. 2014a.

BRASIL (2014c). Ministério do Turismo (MTur). Pronatec Turismo. Disponível em: <http://www.turismo.gov.br/turismo/programas_acoes/Pronatec_turismo/>. Acesso em: 04 agosto 2014. 2014c.

BRASIL (2011c). Ministério do Turismo (MTur). Serviço Brasileiro de Apoio às Micro e Pequenas Empresas. Associação de Cultura Gerais. Manual para o desenvolvimento e a integração de atividades turísticas com foco na produção associada. Brasília: Ministério do Turismo, 2011.

BRASIL (2013d). Ministério do Turismo (MTur). 65 Destinos Indutores de Desenvolvimento Turístico Regional. Disponível 
<http://www.turismo.gov.br/turismo/o_ministerio/publicacoes/cadernos_publicacoes/00destinos_indutores.html>. Acesso em: 19 ago 2013 (a).

BRASIL (2013e). Ministério do Trabalho e Emprego (MTE). Cadastro Geral de Empregados e Desempregados: Informações para o Sistema Público de Emprego e Renda (ISPER) - Dados por Município. Disponível em: $<$ http://bi.mte.gov.br/bgcaged/caged_isper/index.php\#>. Acesso em 22 out 2013 (b).

BRASIL (2013k). Ministério do Trabalho e Emprego (MTE). Emprego e Renda: Histórico. Disponível em: <http://www.trabalho.gov.br/ctps/historico.htm>. Acesso em: 18 out 2013.

BRASIL (2013j). Ministério do Trabalho e Emprego (MTE). Relação Anual de Informações Sociais (RAIS): Informações para o Sistema Público de Emprego e Renda (ISPER) - Dados por Município. Disponível em: <http://bi.mte.gov.br/bgcaged/caged_isper/index.php>. Acesso em 22 out 2013.

BRASIL (2013f). Ministério do Desenvolvimento Social e Combate à Fome (MDS). Bolsa Família. Disponível em: <http://www.mds.gov.br/bolsafamilia>. Acesso em: 27 nov 2013.

BRASIL (2013g). Ministério do Desenvolvimento Social e Combate à Fome (MDS). Transferência de recursos por ação de governo. Disponível em: <http://www.portaltransparencia.gov.br/PortalTransparenciaPesquisaAcaoUF.asp?codigoAcao=8442\&codigoFuncao $=08 \&$ NomeAcao $=$ Transfer $\% E A n c i a+d e+R e n d a+$ Diretamente $+\%$ Es + Fam\%EDlias+em+Condi\%E7\%E3o+de+Pobrez a+e+Extrema+Pobreza+\%28Lei+n\%BA+10\%2E836\%2C+de+2004\%29\&Exercicio=2013>. Acesso em: 27 nov 2013.

BRASIL (2013h). Ministério do Desenvolvimento Social e Combate à Fome (MDS). Agricultura Familiar. Disponível em: $\quad<$ http://www.mds.gov.br/falemds/perguntas-frequentes/bolsa-familia/programascomplementares/beneficiario/agricultura-familiar>. Acesso em: 03 dez 13.

BRASIL. Ministério do Turismo (MTur). Destino referência em turismo de sol e praia: Jericoacoara - CE. Instituto Casa Brasil de Cultura. Goiânia, 2010.

BRASIL (2013i). Ministério do Turismo (MTur). Sistema de Inventariação da Oferta Turística. Disponível em: <http://www.inventario.turismo.gov.br/invtur/swfs/prototipoVisitante.html>. Acesso em: 15 fev 2013.

BRASIL (2012c). Ministério do Turismo (MTur). Turismo já representa 3,7\% do PIB. Out. Disponível em <http://www.turismo.gov.br/turismo/noticias/todas_noticias/20121010-2.html>. Acesso em: 10 nov. 2012.

BRASIL TURISMO. Destino Barreirinhas. Disponível em: <http://www.brasilturismo.com/ma/barreirinhas/lazer.php>. Acesso em: 22 jul 13.

BRICKER, Kelly S.; BLACK, Rosemary; COTTRELL, Stuart. Sustainable tourism and the millennium development goals: effecting positive change. Burlington: Jones \& Barlett Learning, 2013.

BRÜSEKE, Franz Josef. O problema do Desenvolvimento Sustentável. In CAVALCANTI, Clóvis (Org). Desenvolvimento e natureza: estudo para uma sociedade sustentável. São Paulo: Cortez; Recife, PE: Fundação Joaquim Nabuco, 1995.

BRUYNE, P.; HERMAN, J.; SCHOUTHEETE, M. Dinâmica da pesquisa em ciências sociais: os pólos da prática metodológica. 2. ed. Rio de Janeiro: Francisco Alves, 1977.

BUARQUE, Cristovam. O que é apartação. São Paulo, Brasiliense, 1993 (Coleção Primeiros Passos).

BUDEANU, Adriana. Introduction and overview of the journal of cleaner production: special issue on sustainable tourism. Elsevier: Journal of Cleaner Production 13, 2004.

BURSZTYN, Marcel. Meio ambiente e interdisciplinaridade: desafios ao mundo acadêmico. In: Revista Desenvolvimento e Meio Ambiente, n. 10. Curitiba: Editora UFPR, jul./dez. 2004, p. 67-76.

BURSZTYN, Maria Augusta A.; Marcel BURSZTYN. Desenvolvimento sustentável: fundamentos e implicações. Brasília: CDS, 2010.

BUSSAB, W. O.; MORETTIN, P. A. Estatística Básica. 4ª ed. Atual Editora, 1987.

BUTLER, Richard. Sustainable tourism - looking backwards in order to progress? In: HALL, Michael e LEW, Alan. (Org.). Sustainable tourism: a geographycal analysis. Essex, UK: Addison Wesley Longman Limited, 1998. p. 2534.

CAETÉS TURISMO. Trekking Lençóis Maranhenses Apressadinho. Disponível em: <http://caetesturismo.com.br/?p=2416>. Acesso em: 06 out 2014. 
CAPELLESSO, Adinor José; CAZELLA, Ademir Antonio. Os sistemas de financiamento na pesca artesanal: um estudo de caso no litoral Centro-Sul Catarinense. Revista de Economia e Sociologia Rural, v. 51, n. 2, p. 275-294, 2013.

CAPRA, Fritjof. The turning point: science, society and the rising culture. US: Bantam Books, 1982.

CARNER, Françoise. Encadenamientos generados por el sector turismo. México: CEPAL, 2001.

CARSON, Rachel. Silent Spring. US: Houghton Mifflin, 1962.

CASTELL, Robert. De l'indigence à l'exclusion, la désaffiliation. Precarité du travail et vulnerabilité relationnelle, p. 137-168. Donzelot et Roman - Face à l'exclusion: le modéle français, Paris, Esprit, 1991.

Chon, K. S. Hospitalidade: conceito e aplicações". Pioneira Thomson Learning, São Paulo, 2003.

CLARKE, Jackie. A framework of approaches to sustainable tourism. Journal of Sustainable Tourism. Vol. 5. N. 3. 1997.

CNI, SENAI, IEL. Cadeia produtiva do turismo: necessidades de tecnologia e de recursos humanos no horizonte 2010 - Investigação Delphi. [S.I.], 1998. 11 p. (mimeo)

COMISSÃO MUNDIAL SOBRE O MEIO AMBIENTE E DESENVOLVIMENTO (CMMAD). Nosso futuro comum. - 2. ed. - Rio de Janeiro: FGV, 1991, 430 p.

CONFEDERAÇÃO NACIONAL DAS INDÚSTRIAS (CNI). Cadeia produtiva do turismo. Necessidades de tecnologia e de recursos humanos no horizonte 2010 - Investigação Delphi. Rio de Janeiro: CNI, 1998. Mimeografado.

CONFEDERAÇÃO NACIONAL DAS INDÚSTRIAS (CNI/SENAI/IEL). Cadeia produtiva do turismo: necessidades de tecnologia e de recursos humanos no horizonte 2010 - investigação Delphi. [S.I.], maio, 1998. 11 p. (mimeo.).

CONFEDERAÇÃO NACIONAL DE MUNICÍPIOS (CNM). Informações Municipais - Barreirinhas - MA. Disponível em: <http://www.cnm.org.br/index.php?option=com_wrapper\&view=wrapper\&ltemid=382>. Acesso em: 09 jul 13.

CONFEDERAÇÃO NACIONAL DE MUNICÍPIOS (CNM). Informações Municipais - Jijoca de Jericoacoara - CE. Disponível em: <http://www.cnm.org.br/index.php?option=com_wrapper\&view=wrapper\&ltemid=382>. Acesso em: 09 jul 13.

COOPER, C. P. OZDIL, I. From mass to responsible tourism. The Turkish Experience. Tourism Management, 1992. p. 377-386.

COOPER, Chris. Turismo: princípios e práticas. 3. ed. Porto Alegre: Bookman, 2007.

CORIOLANO, Luzia Neide M. T. A exclusão e a inclusão social e o turismo. Pasos: Revista de Turismo y Patrimônio Cultural. Vol. 3. p. 295-304. 2005.

CORIOLANO, Luzia Neide M. T. Arranjos produtivos locais do turismo comunitário: atores e cenários em mudança. Fortaleza: EdUECE, 2009.

COSTA, Helena Araújo. Mosaico da Sustentabilidade em Destinos Turísticos: cooperação e conflito de micro e pequenas empresas no roteiro integrado Jericoacoara - Delta do Parnaíba - Lençóis Maranhenses. 2009, 296p. Tese (Doutorado em Desenvolvimento Sustentável) - Centro de Desenvolvimento Sustentável, Universidade de Brasília, Brasília, 2009.

COSTA, Helena Araújo; SOUTO-MAIOR, Alice. Sistemas produtivos locais em turismo: relacionamentos estratégicos e aglomeração territorial com vantagens competitivas. 2008. Disponível em: <http://bibliotecadigital.fgv.br/ojs/index.php/oit/article/viewFile/5608/4329>. Acesso em: 04 março 2014.

CROSS, R., BORGATTI, S., PARKER A. Making invisible work visible: using social network analysis to support strategic collaboration. California Management Review, 44 (2): 25-46, 2002.

D'ANTONA, Álvaro de Oliveira. O verão, o inverno e o inverno: sobre o modo de vida de comunidades residentes na região do Parque Nacional dos Lençóis Maranhenses. Dissertação de Mestrado. Universidade Estadual de Campinas. Campinas, SP: [s.n.], 1997.

D’ANTONA, Álvaro de Oliveira. O verão, o inverno e o inverso: Lençóis Maranhenses, imagens = Summer, winter and their reverse: Lençóis Maranhenses, landscapes. Brasília: Edições IBAMA, 2002. 
DA CUNHA, S. K., DA CUNHA, J. C. Competitividade e sustentabilidade de um cluster de turismo: Uma proposta de modelo sistêmico de medida do impacto do turismo no desenvolvimento local. Revista De Administração Contemporânea, 1-17,169-170. 2005.

DALE, C. The competitive networks of tourism e-mediaries: new strategies, new advantages". Journal of Vacation Marketing, 3 (9):109-118, 2002.

DB CITY.COM. Geografia Jijoca de Jericoacoara. Disponível em: <http://es.db-city.com/Brasil--Cear\%C3\%A1-Jijoca-de-Jericoacoara>. Acesso em: 10 jul 13.

DEMO, Pedro. 0 charme da exclusão social. 2. ed. rev. - Campinas: Autores Associados, 2002.

DIAS, Reinaldo. Turismo sustentável e meio ambiente. 1. Ed. São Paulo: Atlas, 2008.

DISTANCIA CIDADES.COM. Distância entre Barreirinhas e Jijoca de Jericoacoara. Disponível em: <http://br.distanciacidades.com/distancia-de-barreirinhas-a-jijoca-de-jericoacoara>. Acesso em: 10 jul 13.

DONDA, Clarissa. Rota das Emoções: do Piauí em direção ao Parque Nacional dos Lençóis Maranhenses. Disponível em: <http://www.dondeandoporai.com.br/rota-das-emocoes-saindo-do-piaui-em-direcao-aos-lencoismaranhenses/>. Acesso em: 26 ago 2013.

DONZELOT, Jacques. Le social du troisième type. p. 15-39. Donzelot et Roman - Face à l'exclusion: le modèle français, op. cit.

DRYZEH, J. The politics of the Earth: environmental discourse. Oxford: Oxford University Press, 1997.

EHRLICH, Paul R. The Population Bomb. US: Sierra Club/Ballantine Books: 1968. 201 p.

ESTEVE SECALL, Rafael. Los agrupamientos (clusters) turísticos como base analítica de la competitividad de los territorios de orientación turística. Málaga: Universidad de Málaga, 2002. Mimeografado.

FIELD, Andy. Descobrindo a ESTATíSTICA usando o SPSS. São Paulo: ARTMED EDITORA S.A., 2009.

FLOWERS, Julie; EASTERLING, Katherine. Growing South Carolina's Tourism Cluster. Business and Economic Review, Jun, 52, 3, ABI/INFORM Complete, 2006.

FRACASSI, A.; MARQUES, M. E.; WALTER, J. (Dir.). La pauvreté: um approche au pluriel. Paris, ESF. 1985.

FRANCE, L. (Ed. ). The Earthscan reader in sustainable tourism. UK: Earthscan Publications Ltd., 1998.

FRIEND, A. Economics, ecology and sustainable development: Are they compatible? Environmental Values 1 (2), 157-170.

FUNDAÇÃO DE APOIO À PESQUISA, AO ENSINO E À CULTURA (FAPEC). Proposta de elaboração de estudo da cadeia produtiva do turismo em Mato Grosso do Sul. Campo Grande, MS: 2006.

FUNDAÇÃO INSTITUTO DE PESQUISAS CONTÁBEIS, ATUARIAIS E FINANCEIRAS (FIPECAFI). Análise multivariada: para os cursos de administração, ciências contábeis e economia. 1 ed. 3. reimpr. São Paulo: Atlas, 2011.

FUNDAÇÃO INSTITUTO DE PESQUISAS ECONÔMICAS - FIPE (2006). Meios de Hospedagem: estrutura de consumo e impactos na economia. Disponível em: <http://www.dadosefatos.turismo.gov.br/export/sites/default/dadosefatos/outros_estudos/meios_hospedagem/downlo ads_meios_hospedagem_economia/Relatorio_Executivo_- Meios_de_Hospedagem_-

Estrutura_de_Consumo_e_Impactos_na_Economia.pdf $>$. Acesso em: 23 maio 2012.

FUNDAÇÃO SOUSÂDRADE DE APOIO E DESENVOLVIMENTO DA UNIVERSIDADE FEDERAL DO MARANHÃO. Plano de Manejo do Parque Nacional dos Lençóis Maranhenses: resumo executivo. São Luís, 2002.

FURTADO, Celso. O Mito do Desenvolvimento Econômico. Rio de Janeiro: Paz e Terra, 1974.

GARRIDO, Inez Maria D. A. Modelos multiorganizacionais no turismo: cadeias, clusters e redes. $2001.124 \mathrm{f}$. Dissertação (Mestrado Profissional em Administração) - Escola de Administração, Universidade Federal da Bahia, Salvador.

GARROD, Brian; FYALL, Enoque. Beyond the rhetoric of sustainable tourism? Tourism Management. Reino Unido: Elsevier Science, v. 19, n3, 1998.

GEORGESCU-ROEGEN, N. The entropy law and the economic process. Cambridge, Mass, Harvard University Press, 1971. 
GLAESSER, Dirk. Crisis Management in the Tourism Industry. Oxford [U.K.]: Butterworth-Heinemann, 2003.

GOLLUB, James; HOSIER, Amy; WOO, Grace. Using cluster-based economic strategy to minimize tourism leakages. San Francisco, California: ICF / GEDP, 2002.

GOODWIN, Harold; FONT, Xavier (ed). Progress in Responsible Tourism. Vol 2 (1), 2012. Disponível em: <http://www.goodfellowpublishers.com/free_files/file123ProgressVol2\%281\%29.pdf >. Acesso em: 09 abril 2014.

GOUVEIA, Merícia; DUARTE, Teresinha. O cluster turismo em Portugal. Lisboa: GEPE, 2001. Mimeografado.

GUTIÉRREZ, E.; BORDAS, E. La competitividad de los destinos turísticos en mercados lejanos. St. Gallen: AIEST, 1993.

HALL, C. M. Planejamento Turístico: políticas, processos e relacionamentos. São Paulo: Contexto, 2001.

HARDIN, Garrett. The tradegy of the commons. Science, New Series, Vol. 162, n.3859, 1968.

HARRIS, Rob; GRIFFIN, Tony; WILLIAMS, Peter (ed). Sustainable tourism: a global perspective. Elsevier: Oxford, 2002.

HEATH, E. and WALL, G. (1992) Marketing Tourism Destinations: A Strategic Planning Approach. Chichester: John Wiley and Sons.

HUNTER, Colin. Aspects of the sustainable tourism debate from a natural resources perspective. In HARRIS, R.; GRIFFIN, T.; WALL, G. (eds). Sustainable Tourism: a global perspective. Oxford: Butterworth-Heinemann, 2002, p.3-33.

IBGE. (2007). Notas metodológicas, em Pesquisa Mensal de Emprego. Série Relatórios Metodológicos 23. Disponível em: <http://www.ibge.gov.br/home/estatistica/>. Acesso em: 06 maio 2014.

INSTITUTO AMBIENTAL BRASIL SUSTENTÁVEL (IABS). Produto II: análise e compilação dos resultados das entrevistas aplicadas em Barreirinhas - MA.. Projeto Básico 003C/08 (Produção Associada ao Turismo: Lençóis Maranhenses/Barreirinhas - MA. Convênio IABS/AECID/MTur. Brasília, 2008b.

INSTITUTO AMBIENTAL BRASIL SUSTENTÁVEL (IABS). Produto IV: Relatório das Oficinas de Oferta e Demanda. Projeto Básico 003C/08 (Produção Associada ao Turismo: Lençóis Maranhenses/Barreirinhas - MA. Convênio IABS/AECID/MTur. Brasília, 2008a.

INSTITUTO BRASILEIRO DE GEOGRAFIA E ESTATÍSTICA (IBGE). Barreirinhas: Síntese das Informações. Disponível

em:

<http://www.ibge.gov.br/cidadesat/xtras/temas.php?codmun=210170\&idtema=16\&search=maranhao|barreirinhas|sint ese-das-informacoes>. Acesso em: 09 jul 13.

INSTITUTO BRASILEIRO DE GEOGRAFIA E ESTATÍSTICA (IBGE). Censo Agropecuário 2006. Disponível em: $<$ http://www.cidades.ibge.gov.br/xtras/temas.php?lang=\&codmun=210170\&idtema=3\&search=maranhao|barreirinhas Icenso-agropecuario-2006>. Acesso em 09 set 2013.

INSTITUTO BRASILEIRO DE GEOGRAFIA E ESTATíSTICA (IBGE). Censo Demográfico 2010. Disponível em: <http://www.ibge.com.br/home/estatistica/populacao/censo2010/default.shtm>. Acesso em: 09 set 2013.

INSTITUTO BRASILEIRO DE GEOGRAFIA E ESTATÍSTICA (IBGE). Cidades. Disponível em: <http://www.cidades.ibge.gov.br/xtras/perfil.php?lang=\&codmun=210170>.Acesso em 09 set 2013.

INSTITUTO BRASILEIRO DE GEOGRAFIA E ESTATÍSTICA (IBGE). Histórico: Barreirinhas Maranhão - MA. Disponível

<http://www.ibge.com.br/cidadesat/painel/painel.php?codmun=210170\&search=maranhao|barreirinhas\#historico>.

Acesso em: 22 jul 13.

INSTITUTO BRASILEIRO DE GEOGRAFIA E ESTATÍSTICA (IBGE). Jijoca de Jericoacoara: Síntese das Informações. Disponível em:

http://www.ibge.gov.br/cidadesat/xtras/temas.php?codmun=230725\&idtema=16\&search=ceara|jijoca-dejericoacoara|sintese-das-informacoes>. Acesso em: 09 jul 13.

INSTITUTO BRASILEIRO DE GEOGRAFIA E ESTATÍSTICA (IBGE). Notas Metodológicas. Disponível em: <http://www.ibge.gov.br/home/estatistica/indicadores/trabalhoerendimento/pme/pmemet2.shtm>. Acesso em 09 set 2013.

INSTITUTO BRASILEIRO DE GEOGRAFIA E ESTATíSTICA (IBGE). Pesquisa Nacional por Amostra de Domicílios. Disponível em: 
<http://www.ibge.com.br/home/estatistica/populacao/trabalhoerendimento/pnad2011/default.shtm>. Acesso em: 09 set 2013. INSTITUTO BRASILEIRO DE GEOGRAFIA E ESTATÍSTICA (IBGE). Pesquisa Mensal de Emprego - PME.
Disponível

<http://www.ibge.gov.br/home/estatistica/indicadores/trabalhoerendimento/pme_nova/pme_201403tm_01.shtm>.

Acesso em: 06 maio 2014

INSTITUTO BRASILEIRO DE GEOGRAFIA E ESTATÍSTICA. Censo Demográfico 2010: Resultados da Amostra Rendimento. Disponível em: <http://www.ibge.gov.br/cidadesat/xtras/temas.php?codmun=230725\&idtema=108\&search=Cear\%C3\%A1\%7CJijoca \%20de\%20Jericoacoara|Censo\%20Demogr\%C3\%A1fico\%202010:\%20Resultados\%20da\%20Amostra\%20\%20Rendimento>. Acesso em: 04 abr 2013.

INSTITUTO BRASILEIRO DE GEOGRAFIA E ESTATÍSTICA. Mapa de Pobreza e Desigualdade - Municípios $\begin{array}{lllll}\text { Brasileiros } & - & 2003 & \text { (Barreirinhas). }\end{array}$ <http://www.ibge.gov.br/cidadesat/xtras/temas.php?codmun=210170\&idtema=19\&search=Maranh\%C3\%A3o|Barreiri nhas|Mapa\%20de\%20Pobreza\%20e\%20Desigualdade\%20-\%20Munic\%C3\%ADpios\%20Brasileiros\%202003>. Acesso em: 04 abr 2013.

INSTITUTO BRASILEIRO DO MEIO AMBIENTE E DOS RECURSOS NATURAIS RENOVÁVEIS (IBAMA/MMA). (2002) Plano de Manejo do Parque Nacional dos Lençóis Maranhenses. Disponível em: <http://www.icmbio.gov.br/portal/biodiversidade/unidades-de-conservacao/biomas-brasileiros/marinho/unidades-deconservacao-marinho/2264-parna-dos-lencois-maranhenses.html>. Acesso em: 23 jul 13.

INSTITUTO CHICO MENDES DE CONSERVAÇÃO DA BIODIVERSIDADE (ICMBio) (2013). Parque Nacional de Jericoacoara. Disponível em: <http://www.icmbio.gov.br/portal/o-que-fazemos/visitacao/ucs-abertas-a-visitacao/190parque-nacional-de-jericoacoara.html>. Acesso em: 15 abril 013.

INSTITUTO CHICO MENDES DE CONSERVAÇÃO DA BIODIVERSIDADE (ICMBio). Parque Nacional dos Lençóis Maranhenses. Disponível em: <http://www.icmbio.gov.br/portal/o-que-fazemos/visitacao/ucs-abertas-a-visitacao/191parque-nacional-dos-lencois-maranhenses.html>. Acesso em: 10 jul 13.

INSTITUTO CHICO MENDES DE CONSERVAÇÃO DA BIODIVERSIDADE (ICMBio). (2011) Plano de Manejo do Parque Nacional de Jericoacoara. Disponível em: < http://www.icmbio.gov.br/portal/biodiversidade/unidades-deconservacao/biomas-brasileiros/marinho/unidades-de-conservacao-marinho/2261-parna-de-jericoacoara.html>. Acesso em: 23 jul 13.

INSTITUTO CHICO MENDES DE CONSERVAÇÃO DA BIODIVERSIDADE (ICMBio). (2003) Parna dos Lençóis Maranhenses: Planos de Manejo. Disponível em: <http://www.icmbio.gov.br/portal/biodiversidade/unidades-deconservacao/biomas-brasileiros/marinho/unidades-de-conservacao-marinho/2264-parna-dos-lencoismaranhenses.html>. Acesso em: 23 jul 13.

INSTITUTO DE PESQUISA E ESTRATÉGIA ECONÔMICA DO CEARÁ (IPECE). (2006). Perfil Básico Municipal: Jijoca de Jericoacoara. Disponível em: <http://www.ipece.ce.gov.br/publicacoes/perfil_basico/PBM_2006/Jijoca\%20de\%20Jericoacoara.pdf>. Acesso em: 29 jul 13.

INTERNATIONAL CENTRE FOR RESPONSIBLE TOURISM (ICRT). Responsible Tourism: taking responsibility for tourism. Disponível em: <http://www.icrtourism.org/responsible-tourism/>. Acesso em: 09 abril 2014.

IRVING, M. A. Áreas protegidas de fronteira e turismo sustentável na Amazônia: entre o surrealismo e a invenção. Revista de Desenvolvimento Econômico. Ano VIII. N. 13. Salvador: 2006

IRVING, M. A. et al. Revisitando significados em sustentabilidade no planejamento turístico. Caderno Virtual de Turismo. Vol. 5. N. 4. 2005.

IRVING, M. A. Turismo como instrumento de desenvolvimento local. In: d'Ávila, M.I. e Pedro, R. (Orgs.) Tecendo o Desenvolvimento. Rio de Janeiro, R.J: Mauad, 2003.

INSTITUTO SOCIEDADE, POPULAÇÃO E NATUREZA (ISPN). Caderno de Normas Fiscais, Sanitárias e Ambientais para regularização de agroindústrias comunitárias de produtos de uso sustentável da biodiversidade. Brasília - DF: ISPN, 2011.

JAGUARIBE, Hélio. Brasil: reforma ou caos. Rio de Janeiro, Paz e terra, 1989. 
JAMIESON, Walter; GOODWIN, Harold; EDMUNDS, Christopher. Contribution of tourism to poverty alleviation: pro-poor tourism and the challenge of measuring impacts. Disponível em: <http://haroldgoodwin.info/resources/povertyalleviation.pdf. >. Acesso em: 22 maio 2013.

JERI.COM. História: Parque Nacional. Disponível <http://www.jericoacoara.com/j1/pages/portugues/lugar/histF3ria.php>. Acesso em: 24 jul 13.

JERI-BRAZIL. Como chegar. Disponível em: <http://www.jeri-brazil.org/como-chegar-jericoacoara.html>. Acesso em: 18 jul 13.

JERI-BRAZIL. O lugar. Disponível em: <http://www.jeri-brazil.org/historia-jericoacoara.html>. Acesso em: 18 jul 13.

KILIPIRIS, Fotis; ZARDAVA, Stella. Developing sustainable tourism in a changing environment: issues for the tourism enterprises (travel agencies and hospitality enterprises). Elsevier: Social and Behavioral Sciences, 44, p.4452, 2012.

KON, Anita. Pleno emprego no Brasil: interpretando os conceitos e indicadores. Revista Economia \& Tecnologia (RET). Vol 8, n. 2, p. 5-22, 2012.

KOTLER, Philip. Marketing público. São Paulo: Makron Books, 1995.

KOTLER, Philip. Projeto e gerência de serviços. In: Administração de marketing. 10.ed. São Paulo: Prentice Hall, 2000. Cap. 14. p.447-474

KOTTEK, M., J.; GRIESER, C.; BECK, B. Rudolf.; RUBEL, F. World Map of the Köppen-Geiger climate classification updated. Meteorol. Z., 15, 259-263, 2006.

KRIPPENDORF, J. Sociologia do turismo: para uma nova compreensão do lazer e das viagens. São Paulo: Aleph, 2001.

KUHN, Thomas S. The structure of scientific revolutions. Chicago: The University of Chicago, Forth edition, 2012.

KUTNER, M. H.; NETER, J.; NACHTSHEIM, C.J.; LI, W. Applied Linear Statistical Models. 5. ed. Boston, Mass.: McGraw-Hill, c2005. 1398 p.

LABORATÓRIO INTERDISCIPLINAR DE MEIO AMBIENTE (LIMA/COPPE/UFRJ). Avaliação Ambiental Estratégica - Região Costa Norte: Diagnóstico. Ministério do Turismo (MTur): 2007. Disponível em: <http://www.lima.coppe.ufrj.br/files/aaeturismocostanorte/06_Planos_e_Programas_07.pdf>. Acesso em: 05 jan 2013.

LATOUCHE, Serge. Decrescimento: É preciso deseconomizar o imaginário. Disponível em: <http://www.ihu.unisinos.br/noticias/503647-decrescimento-e-preciso-deseconomizar-o-imaginario>. Acesso: 27 jan 2014.

LEIPER, N. Tourism management. Australia- NSW: Pearson SprintPrint, 2003.

LIMA, Maria do Céu de. Comunidades pesqueiras marítimas no Ceará: território, costumes e conflitos. Tese de Doutorado. São Paulo: FFLCH/USP, 2002.

LINS, H. N. Florianópolis: cluster turístico? Turismo em Análise, v.11, n.2, p.45-54, nov. 2000.

LOHMANN, G., PANOSSO NETTO, A. Teoria do Turismo: conceitos, modelos e sistemas. São Paulo: Aleph, 2008. LOHMANN, Guilherme; PANOSSO NETTO, Alexandre. Teoria do turismo: conceitos, modelos e sistemas. $1^{\text {a }}$ reimp. São Paulo: Aleph, 2011.

MACHADO, V. F. A produção do discurso do desenvolvimento sustentável: de Estocolmo a Rio-92. Tese (Doutorado em Desenvolvimento Sustentável) - Centro de Desenvolvimento Sustentável. 2005.

MAGALHÃES, M. N.; LIMA, A. C. P. de. Noções de Probabilidade e Estatística. $3^{\underline{a}}$ ed. Editora USP, 2001.

MALHOTRA, Naresh K. Pesquisa de marketing: uma orientação aplicada. Porto Alegre: Bookman, 2001.

MAMBERTI, M. M. S.; BRAGA, R. Arranjos Produtivos Turísticos e Desenvolvimento Local. In: Seminário Internacional "O Desenvolvimento Local na Integração: Estratégias, Instituições e Políticas. 1. Rio Claro. Anais Eletrônicos. Disponível em: <http://www.rc.unesp.br/igce/planejamento/publicacoes/TextosPDF/mamberti01.pdf>. Acesso em: 15 abr 2012. 2004.

MARANHÃO. Mapa dos Pólos. Disponível em: <http://www.turismo.ma.gov.br/pt/principal.htm\#>. Acesso em: 30 Abril 2010. 
MARANHÃO. Secretaria de Planejamento, Orçamento e Gestão. Plano Maior: diretrizes e ações do Plano Maior para o turismo no Maranhão. São Luís, 2000. Disponível em: <http://www.seplan.ma.gov.br/turismo/lencois.htm>. Acesso em: 13 Set. 2006.

MASSARI, Cristina. Cadeia produtiva do turismo: modelos para análise e reflexão. Rio de Janeiro: Senac Nacional, 2005.

MEADOWS, Donella H.; MEADOWS, Dennis L.; RANDERS, Jorden; BEHRENS III, William W. The Limits to Growth. Universe Books, 1972. 205 p.

MELER, Marcel; HAM, Marija. Green Marketing for Green Tourism. Tourism \& Hospitality Management, 2012 , pp. 130-139.

MERLIJN, A. G. The role of middlemen in small-scale fisheries: a case study of Sarawak, Malaysia. Development and Change, 1989; 20:683-700.

MEYER, D. (2011). Pro-poor tourism: Can tourism contribute to poverty reduction in less economically developed countries? In: S. Cole \& N. Morgan (Eds.), Tourism and inequality: Problems and prospects (pp. 164-182). Wallingford, England: $\mathrm{CAB}$ International.

MOESCH, Marutschka Martini. El origen del conocimiento: el lugar de la experiencia y de la razón en la génesis del conocimiento del turismo. Estudios y Perspectivas en Turismo, Vol. 22, pp.985-1001, 2013.

MOESCH, Marutschka Martini. Epistemologia social do turismo. Tese (doutorado). Escola de Comunicação e Artes / Universidade de São Paulo, São Paulo, 2004.

MOESCH, Marutschka Martini. O fazer-saber turístico: possobilidades e limites de superação. GASTAL, Susana. In: GASTAL, Susana (org.) Turismo: 9 propostas para um saber-fazer. Porto Alegre: EDIPUCRS, 2000.

MOESCH, Marutschka Martini. Para além das disciplinas: o desafio do próximo século. In: GASTAL, Susana (org.). Turismo investigação e crítica. São Paulo: Contexto, 2002.

MOLINA, F. Jericoacoara: de vila de pescadores a destino internacional. In: CRUZ, R. D. C. (org.). Geografias do turismo: de lugares a pseudolugares. São Paulo: Roca, 2007

MOLINA, Fábio Siveira. Turismo e produção do espaço - o caso de Jericoacoara, CE. Dissertação de Mestrado. Universidade de São Paulo (USP). São Paulo: 2007.

MOLINA, S. El pos turismo. México: Edição do Autor, 1998.

MONFORT MIR, Vicente M. Competitividad y factores críticos de éxito en la "hoteleira de litoral": experiencia de los destinos turísticos Benidorm y Peñíscola. Madrid, FITUR /IFEMA, 2000.

MOORE, Danielle P., DOHERTY, Allison G. Tourism and Hospitality Development and Management: United States Travel and Tourism Industry. Nova Science Publishers: New York, 2011. 152p.

MORAIS BRITO VIAGENS E TURISMO. (2010). Mapa da Rota das Emoções -Jericoacoara Lençóis Maranhenses Delta do Parnaíba. Disponível em: <http://rotadasemocoes.blogspot.com/2010/09/mapa-da-rota-das-emocoesjericoacoara.html>. Acesso em: 10 jul 13.

MÜLLER, Hansruedi. The thorny path to sustainable tourism development. Journal of Sustainable Tourism, 2:3, 131-136. England: Routledge, 1994.

NASCIMENTO, E. P. do; COSTA, H. A. Sustainability as a new political Field. Cahiers do IIRPC, n. especial, p.51-8, 2010.

NASCIMENTO, Elimar P. A exclusão social no Brasil: algumas hipóteses de trabalho e quatro sugestões práticas. In: Cadernos do CEAS, n. 152, Centro de Estudos e Ação Social, Salvador, 1994.

NASCIMENTO, Elimar P. Globalização e exclusão social: fenômenos de uma nova crise da modernidade? In: DOWBOR, Ladislau \& outros. Desafios da globalização. Petrópolis: Vozes, 1998.

NASCIMENTO, Elimar P. Projetos Nacionais e Exclusão Social. Planejamento e Políticas Públicas, 10, dezembro de 1993, p. 91-116

NASCIMENTO, Elimar Pinheiro do. Dos excluídos necessários aos excluídos desnecessários. In: BURSZTYN, Marcel (org.). No meio da rua - nômades, excluídos e viradores. Rio de Janeiro: Garamond, 2000.

NASCIMENTO, Elimar Pinheiro do. Trajetória da sustentabilidade: do ambiental ao social, do social ao econômico. Estudos Avançados, São Paulo, v. 26, n. 74, 2012. Disponível em: 
<http://www.scielo.br.ezproxy1.lib.asu.edu/scielo.php?script=sci_arttext\&pid=S0103-

40142012000100005\&lng=en\&nrm=iso>. Acesso em: 20 Jan. 2014.

NASCIMENTO, Elimar Pinheiro do. Transição Política: Antecedentes, Natureza e Cenários. Sociedade e Estado, p. 7-21, 1989.

NELISSEN, Nico et al. (edits.). Classics in Environmental Studies - an overview of classic texts in environmental studies. International Books, Utrecht, 1997.

NOBRE, Marcos; AMAZONAS, Maurício de Carvalho. Desenvolvimento Sustentável: a institucionalização de um conceito. Brasília: Editora IBAMA, 2002. 367 p.

NOVELLI, M; SCHMITZ, B; SPENCER, T. Networks, clusters and innovation in tourism: a UK experience. Tourism Management, v. 27, n 6, pages. 1141-1152, 2006.

O POVO ONLINE. Concluída pista do aeroporto de Jericoacoara. Disponível em: <http://www.opovo.com.br/app/ceara/jijocadejericoacoara/2013/04/12/notjijocadejericoacoara,3037912/concluidapista-do-aeroporto-de-jericoacoara.shtml>. Acesso em: 18 jul 13.

O POVO. Jericoacoara é $08^{\circ}$ destino turístico mais procurado do Brasil. Disponível em: <http://www.opovo.com.br/app/fortaleza/2013/05/22/noticiafortaleza,3060920/jericoacoara-e-o-8-destino-turisticomais-procurado-do-brasil.shtml>. Acesso em: 28 jun 2013.

O'RIORDAN, T. The politics of sustentability. In: TURNER, K. R. (Org.) Sustainable environmental economics and management: principles and practice. London: Bethaven, 1993.

ORGANIZAÇÃO INTERNACIONAL DO TRABALHO (OIT). Mandato: Emprego. Disponível em: <http://www.ilo.org/public/portugue/region/eurpro/lisbon/html/genebra_trab_digno_pt.htm>. Acesso em: 05 maio 2014.

ORGANIZAÇÃO INTERNACIONAL DO TRABALHO (OIT). (2014b). O que é Trabalho Decente. Disponível em: <http://www.oitbrasil.org.br/content/o-que-e-trabalho-decente>. Acesso em: 06 maio 2014.

ORGANIZAÇÃO MUNDIAL DE TURISMO (OMT). Cuenta satélite de turismo: recomendaciones sobre el marco conceptual. Nueva York: Naciones Unidas; Madrid: Organización Mundial del Turismo, 2001. 149 p. In: IBGE. Economia do Turismo: uma perspectiva macroeconômica 2003-2007. Estudos e Pesquisas: Informação Econômica (13). Rio de Janeiro: 2010.

ORGANIZAÇÃO MUNDIAL DO TURISMO - OMT. EMBRATUR. Desenvolvimento de turismo sustentável: manual para organizadores locais. Brasília: EMBRATUR, 1994.

PALLANT, Julie. SPSS: Survival Manual. New York: Ligare Book Printer, 2007.

PANORAMIO. Aeroporto de Barreirinhas - MA. Disponível em: <http://www.panoramio.com/photo/18658487>. Acesso em: 18 jul 13.

PANOSSO NETTO, Alexandre. Fenomenologia do turismo: uma proposta de construção epistemológica. Tese (doutorado). Escola de Comunicação e Artes / Universidade de São Paulo, São Paulo, 2005.

PASTORE, José. (2003). O Estado de S. Paulo - Acervo Estadão. Disponível em: <http://acervo.estadao.com.br/pagina/\#!/20031026-40185-nac-29-eco-b2-not/busca/Jos\%C3\%A9>. Acesso em: 7 maio 2014.

PEDROZA, Carmen. Middlemen's informal trading system and its linkages with iuu fishing activities in the port of progreso, Mexico. Tanzania: II FET, 2012.

PORTAL DE BARREIRINHAS. Barreirinhas: História. Disponível em: <http://www.portalbarreirinhas.com.br/home/barreirinhas.html>. Acesso em: 23 jul 13.

PORTER, Michael. Clusters and Competition. On Competition, Harvard Business School, 1998, p.172.

PREFEITURA MUNICIPAL DE JIJOCA DE JERICOACOARA. História de Jericoacoara. Disponível em: <http://www.jijocadejericoacoara.ce.gov.br/hist\%C3\%B3ria-de-jijoca-de-jericoacoara>. Acesso em: 22 jul 13.

PREFEITURA MUNICIPAL DE JIJOCA DE JERICOACOARA. Jericoacoara - Transporte é o maior desafio para turistas. Disponível em: <http://www.jijocadejericoacoara.ce.gov.br/secretarias/turismo-e-meioambiente/jericoacoara-transporte-\%C3\%A9-o-maior-desafio-para-turistas >. Acesso em: 27 ago 2013.

PROGRAMA DAS NAÇÕES UNIDAS PARA O DESENVOLVIMENTO (PNUD). Atlas do Desenvolvimento Humano no Brasil 2013. Disponível em: <http://www.atlasbrasil.org.br/2013/>. Acesso em: 20 jul 13. 
PROGRAMA DAS NAÇÕES UNIDAS PARA O DESENVOLVIMENTO (PNUD). Inovar para incluir: jovens e desenvolvimento humano: Informe sobre Desenvolvimento Humano para o Mercosul. $1^{\underline{a}}$ ed. - Buenos Aires: PNUD, 2009.

PRO-POOR TOURISM PARTNERSHIP. Pro poor tourism: improving livelihood opportunities for local people. Disponível em: <http://www.propoortourism.info/intro.html>. Acesso em: 24 abril 2014.

PROVINCIALI, Vera L. N. Cadeia produtiva do turismo: concepção. Aracaju, SE: 2002. Mimeografado.

PRZECLAWSKI, K. (1993) Tourism as the subject of interdisciplinary research. In D.G. Pearce and R.W. Butler (eds) Tourism research: Critiques and Challenges. London: Routledge and the International Academy for the Study of Tourism.

QUEIROZ, Valéria Márcia. Sociologia da sociologia da exclusão social. Sociedade e Cultura, v. 5, no 2,193-198, jun/dez. 2002.

RAMOS, Carlos Alberto. Notas sobre Políticas de Emprego. Ipea: Brasília, 1997.

REDCHIFT, M. Sustentable development: exploring the contradictions. London: Routledge; New York: Methuen, 1987.

RODRIGUES, A. B. (Org.). 1. ed. Turismo Rural. São Paulo: Contexto, 2001. p. 133-150.

RODRÍGUEZ DOMÍNGUEZ, Maria del Mar. Competitividade e análise estratéxica do sector turístico: unha primeira aproximación á potencial creación dun cluster institucional para a mellora competitiva da zona Rías Baixas. Santiago de Compostela: Xunta de Galicia, 2001.

ROGERS; JALAL; BOYD. An introduction to sustainable development. London, UK: Earthscan, 2008.

ROSSAVALON, Pierre. La nouvelle question sociale; repenser l'Etat-providence. Paris, Seuil, 1995.

SAARINEN, J. Traditions of sustainability in tourism studies. In Annals of Tourism Research, v. 33, n. 4, p. 11211140, 2006.

SACHS, Ignacy. Desenvolvimento: includente, sustentável, sustentado. Rio de Janeiro: Garamond, 2008.

SACHS, Ignacy. Inclusão social pelo trabalho decente: oportunidades, obstáculos e políticas públicas. Estudos Avançados, 18 (51), 2004.

SANTOS, A.A.; REZENDE, J.L.P.; BORGES, L.A.C.; BORÉM, R.A.T. Cadeia de serviços turísticos: possibilidade de inclusão social nos parques nacionais brasileiros. Revista Brasileira de Ecoturismo, São Paulo, v.4, n.1, 2011, pp.208-227.

SANTOS, Danilton Nobrega dos; FRANCO, Roberto Kennedy Gomes. (2012) A importância dos sítios arqueológicos da região do Delta do Parnaíba para o ensino de história. Disponível em: <http://editorarealize.com.br/revistas/fiped/trabalhos/57b983b5c5d7463448bf17bb3ddb6b6a_2061.pdf>. Acesso em: 22 jul 13.

SAWYER, Eric J; TASSO, João Paulo Faria; ASSAD, Luís Tadeu (Org). Turismo Sustentável: Projeto de Desenvolvimento do Turismo Sustentável nas regiões dos Lençóis Maranhenses, Delta do Parnaíba, Serra da Capivara e Jericoacoara. Brasília: Editora IABS, 2010.

SCHNEIDER, Sergio; SCHIMITT, Claudia Job. O uso de método comparative nas Ciências Sociais. Cadernos de Sociologia, Porto Alegre, v. 9, p. 49-87, 1998.

SEBRAE. Cadeia produtiva do turismo: cenários econômicos e estudos setoriais. Recife: Sebrae, 2008.

SEBRAE. Proposta de elaboração de estudo da cadeia produtiva do turismo em Mato Grosso do Sul: relatório final. Convênio n025/2005. Campo Grande: Fundação Cândido Rondon, 2006.

SECRETARIA DE TURISMO DE BARREIRINHAS (SETUR-BARREIRINHAS). Plano Estratégico de Desenvolvimento do Turismo em Barreirinhas. Barreirinhas: Prefeitura Municipal de Barreirinhas, 2011.

SECRETARIA DE TURISMO DE BARREIRINHAS. Diagnóstico da Oferta Turística de Barreirinhas. Projeto de Desenvolvimento Sustentável do Turismo na Região dos Lençóis Maranhenses. Agência Espanhola de Cooperação Internacional (AECl) / Ministério do Turismo (MTur), 2012.

SECRETARIA MUNICIPAL DA CRIANÇA E ASSISTÊNCIA SOCIAL (SEMCAS). Inclusão Produtiva. Disponível em: <http://www.saoluis.ma.gov.br/semcas/frmPagina.aspx?id_pagina_web=304>. Acesso em: 06 jun 2013. 
SEGNINI, Liliana Rolfsen Petrilli. Educação e trabalho: uma relação tão necessária quanto insuficiente. São Paulo em Perspectiva, v. 14, n. 2, p. 72-81, 2000.

SEN, A. K. Social Exclusion: Concept, Application and Scrutiny. Social Development Papers $N^{\circ} 1$, Manila, Asian Development Bank, 2000.

SEN, Amartya. Desenvolvimento como Liberdade. [s.1.]: Companhia das Letras, 2000. 409 p.

SEN, Amartya. Social Exclusion: concept, application, and scrutiny. (2000b) Disponível em: <http://housingforall.org/Social_exclusion.pdf>. Acesso em: 15 abr 2014.

SERGIPE (2014). SECRETARIA DE ESTADO DA INCLUSÃO, ASSISTÊNCIA E DO DESENVOLVIMENTO SOCIAL. Inclusão Produtiva. Disponível em: <http://www.se.gov.br/index/leitura/id/1263/Inclusao_Produtiva.htm>. Acesso em: 20 jul 2012.

SERVIÇO DE APOIO ÀS MICRO E PEQUENAS EMPRESAS (SEBRAE). Cadeia Produtiva do Turismo: cenários econômicos e estudos setoriais. Recife, 2008.

SERVIÇO DE APOIO ÀS MICRO E PEQUENAS EMPRESAS (SEBRAE). Mapa da área do Parque Nacional. Disponível em: <http://www.pi.sebrae.com.br/guiaturismo/maranhao/img/ecoaventura/mapa_mostrando_a_area_do_parque_nacional.jpg>. Acesso em: 06 out 20114.

SESSA, Alberto. Turismo e política de desenvolvimento. Porto Alegre: Uniontur, 1993.

SHARPLEY, R. Tourism and Sustainable Development: Exploring the Theoretical Divide. In Journal of Sustainable Tourism, v. 8, n. 1, p., 2000.

SHARPLEY, Richard. Tourism and Sustainable Development: Exploring the Theoretical Divide. Journal of Sustainable Tourism. Vol. 8. N. 1. 2000.

SILVA, David Leonardo Bouças da. Turismo em Unidades de Conservação: Contribuições para a prática de uma atividade turística sustentável no Parque Nacional dos Lençóis Maranhenses. Dissertação de Mestrado. Centro de Desenvolvimento Sustentável, Universidade de Brasília, Brasília, 2008. 206 p.

SILVA, Jorge Antonio Santos. Turismo, crescimento e desenvolvimento: uma análise urbano-regional baseada em cluster. Tese (Doutorado) Escola de Comunicações e Artes, USP, 2004 (b). 480p.

SIMÕES, Leonor Gonçalves; PEIXOTO, Norma Macruz. Geração de Emprego, Trabalho e Renda nos Municípios Paulistas. Fundação Prefeito Faria Lima - CEPAM (Centro de Estudos e Pesquisas de Administracão Municipal), II Consad, Brasília, 2009. Disponível em: <http://www.consad.org.br/sites/1500/1504/00001315.pdf>. Acesso em: 05 jan 2013.

SINCLAIR, M. Thea, and Mike Stabler. The Tourism Industry: An International Analysis. Wallingford, Oxon, UK: C.A.B. International, 1991.

SISTEMA FIRJAN. Índice Firjan de Desenvolvimento Municipal (IFDM). Disponível em: <http://www.firjan.org.br/ifdm/consulta-ao-indice/>. Acesso em: 15 abr 2013.

SISTEMA NACIONAL DE UNIDADES DE CONSERVAÇÃO DA NATUREZA (SNUC). O Sistema Nacional de Unidades de Conservação da Natureza. <http://www.mma.gov.br/estruturas/250/_publicacao/250_publicacao30082011035301.pdf>. Acesso em: 29 jul 13.

SOUZA, Myrtis Arrais. A cadeia turística. Fortaleza: Banco do Nordeste, ETENE, 1998. Mimeografado.

STEAR, L. Definitions I use in tourism studies (aka Tourology). In: STEAR, L. Tourism and the industry I subject guide \& seminar workbook. Sydney: School of Leisure Sport and Tourism, University of Technology, 2003a.

STEAR, L. Studying highly industrialized tourism systems. Sydney: School of Leisure Sport and Tourism, University of Technology, 2003b.

SWARBROOKE, J. Turismo sustentável, conceitos e impacto ambiental. v.1. São Paulo: Aleph, 2000. (Série Turismo).

TASSO, João Paulo Faria. Turismo na Encruzilhada: estudo sobre os fatores de inserção socioeconômica em destinos turísticos emergentes (Barreirinhas - MA). 2011, 188p. Dissertação (Mestrado em Desenvolvimento Sustentável) - Centro de Desenvolvimento Sustentável, Universidade de Brasília, Brasília, 2011.

TELLES, Vera da Silva. A cidadania inexistente: incivilidade e pobreza. (Tese - doutorado em Sociologia). São Paulo, Departamento de Sociologia da USP/FFLCH, 1992. 
TERRA. Rota das Emoções reúne três destinos no Brasil e ganha prêmio. Disponível em: $<$ http://vidaeestilo.terra.com.br/turismo/brasil/rota-das-emocoes-reune-tres-destinos-no-brasil-e-ganhapremio,d1081675d4237310VgnCLD100000bbcceb0aRCRD.html>. Acesso em: 28 jun 2013.

THE GUARDIAN. Travel: Runaway beach. Disponível <http://www.guardian.co.uk/travel/2007/feb/24/saturday.beach.brazil?page=all>. Acesso em: 24 jun 13.

THE WASHINGTON POST. Beauty and the beach. Disponível em: <http://pqasb.pqarchiver.com/washingtonpost/access/73804844.html?dids=73804844:73804844\&FMT=ABS\&FMTS= ABS:FT\&date=Mar+15\%2C+1987\&author $=$ Cal+Fussman\&pub=The+Washington+Post+\%28pre-

1997+Fulltext\%29\&edition=\&startpage=w.20\&desc=Beauty+and+the+Beach $>$. Acesso em: 24 jul 13.

TINARD, Yves. Turismo: economía y gestión. Barcelona: Bosch, 1996.

TOLEDO, G. L; ÁLVAREZ VALDÉS, J.; POLLERO, A. C. Empresas Turísticas em Ambiente Globalizado: marketing y competitividad, estúdio de casos de Clusters turísticos. REAd -Revista Eletrônica de Administração da UFRGS - ed. 33, v. 9, n. 3, mai-jun 2003.

TOURAINE, Alain. Face à l'exclusion. p. 165-173. J. Baudrillard e outros. Citoyenneté et urbanité. Paris, Esprit, 1991. UOL VIAGEM. (2009). Lençóis Maranhenses: como chegar. Disponível em: <http://viagem.uol.com.br/guia/cidade/lencoismaranhenses_comochegar.jhtm>. Acesso em: 11 jul 2013.

URRY, J. O olhar do turista. São Paulo: Studio Nobel, 1998.

VASCONCELLOS, M. J. E. de. Pensamento sistêmico: o novo paradigma da ciência. Campinas: Papirus, 2002.

VEIGA, J. E. da. O prelúdio do Desenvolvimento Sustentável. In: CAVC, Economia Brasileira: Perspectiva do Desenvolvimento, pp. 243-266, 2005.

VEIGA, J. E. da. Sustentabilidade: a legitimação de um novo valor. São Paulo: Senac, 2010.

VEIGA, José Eli da. Um passo adiante e dois para trás. In: Política Externa, vol.21, n 3, 2012.

VIEIRA, RICARDO STANZIOLA. Rio+20 - Conferência das Nações Unidas sobre Meio Ambiente e Desenvolvimento: contexto, principais temas e expectativas em relação ao novo "direito da sustentabilidade". Novos Estudos Jurídicos (NEJ Eletrônica), v. 17, n. 1, p. 48-69, jan - abr 2012 2012. ISSN 2175-0491.

VINH, Do Thi Thanh (2008). Role of the middlemen in the supply of the processing industry. Case study: the Central South Region in Vietnam. <http://ir.library.oregonstate.edu/xmlui/bitstream/handle/1957/37776/178.pdf?sequence=1>. Acesso em: 31 maio 2013.

WILLIAMS, Stephen. Tourism: critical concepts in the social sciences. Routledge: London, 2004.

WORLD RESOURCES INSTITUTE (WRI); United Nations Development Programme; United Nations Environment Programme; World Bank. World Resources 2005: The Wealth of the Poor-Managing Ecosystems to Fight Poverty. Washington, DC: WRI, 2005.

WORLD TOURISM ORGANIZATION (UNWTO). Tourism and Poverty Alleviation: Background and objectives. Disponível em: <http://step.unwto.org/en/content/background-and-objectives>. Acesso em: 23 de abril 2014.

WORLD TOURISM ORGANIZATION (UNWTO). Tourism Bill of Rights and Tourist Code. Disponível em: <http://www.atlaskasbah.com/download/omt_sofia1985.pdf>. Acesso em: 19 março 2014.

WORLD TRAVEL \& TOURISM COUNCIL. Travel \& Tourism Economic Impact 2012 Brazil. Disponível em <http://wttc.org/site_media/uploads/downloads/brazil2012.pdf>. Acesso em: 13 mar. 2013.

WORLD TRAVEL AND TOURISM COUNCIL (WTTC). Economic Impact of Travel \& Tourism 2014 Annual Update: Summary. $\quad$ Disponível em: <http://www.wttc.org/site media/uploads/downloads/Economic Impact Summary 2014 2ppA4 FINAL.pdf>. Acesso em: 18 mar 2014.

WORSTER, D. The shaky ground of sustainability. In W. Sachs (ed): Global Ecology: A New Arena of Political Conflict (pp. 132-145). London: Zed Books, 1993.

XIBERRAS, Martine. Les theories de l'exclusion sociale. Paris, Meridiens-Klincksieck, 1992.

YUZBASIOGLU, Nedim; OTAMIS, Pelin Arsezen; DEMIR, M. Ozer. Antalya Region Tourism Cluster: to measure the impact of tourism cluster on regional development. Middle Eastern Finance and Economics, 2011. 
ZACARELLI, S. B. Estratégia e Sucesso nas Empresas. 4. ed. São Paulo: Saraiva. 2004. cap. 13. p.187-208.

ZHANG, Xinyan; SONG, Haiyan; HUANG, George Q. Tourism supply chain management: A new research agenda. Tourism Management, Vol. 30, Issue 3, 2009. P. 345-358. 


\section{ANEXOS}

ANEXO 1: Lista de atividades e produtos característicos do Turismo

\begin{tabular}{|c|c|}
\hline $\begin{array}{l}\text { CCP } \\
\text { / Código }\end{array}$ & DESCRIÇÃO \\
\hline \multicolumn{2}{|c|}{ 1. Serviços de alojamento } \\
\hline \multicolumn{2}{|c|}{1.1 Hotéis e outros serviços de alojamento } \\
\hline 63110.0 & Serviços de alojamento em hotéis e motéis \\
\hline 63191.0 & Serviços de centros de férias e casas de veraneio \\
\hline 63192.0 & Serviços de arrendamento de alojamentos mobiliados \\
\hline 63193.0 & Serviços para acampamentos e trailers \\
\hline 63194.0 & Serviços de centros de entretenimento e férias para crianças \\
\hline 63195.0 & Serviços para acampamentos e trailers \\
\hline 63199.1 & Serviços de carro-leito e similares em outros meios de transporte; residência de estudantes \\
\hline \multicolumn{2}{|r|}{1.2 Serviços de segundas residências por conta própria ou gratuitas } \\
\hline 72211.1 & Serviços auxiliares de atividades de multipropriedade \\
\hline \multicolumn{2}{|c|}{ 2. Serviços de provisão de alimentação e bebidas } \\
\hline 63210.0 & Serviços de provisão de comida com serviços completos de restaurante \\
\hline 63220.0 & Serviços de provisão de comida em estabelecimentos de autosserviço \\
\hline 63290.0 & Outros serviços de provisão de comida \\
\hline 63300.0 & Serviços de provisão de bebidas para seu consumo local \\
\hline \multicolumn{2}{|c|}{ 3. Serviços de transporte de passageiros } \\
\hline \multicolumn{2}{|c|}{ 3.1 Serviços de transporte interurbano por ferrovias } \\
\hline 64111.1 & Serviços regulares de transporte de passageiros por ferrovias \\
\hline 64111.2 & Serviços não regulares de transporte de passageiros por ferrovias \\
\hline \multicolumn{2}{|c|}{ 3.2 Serviços de transporte por rodovias } \\
\hline 64213.0 & Serviços regulares interurbanos de transporte de viajantes por rodovia \\
\hline 64214.0 & Serviços regulares especiais interurbanos de transporte de viajantes por rodovia \\
\hline 64219.1 & Serviços regulares de teleféricos para esquiar \\
\hline 64219.2 & Serviços de teleféricos e funiculares \\
\hline 64221.0 & Serviços de táxi \\
\hline 64222.0 & Serviços de aluguel de automóveis com motorista \\
\hline 64223.0 & Serviços de aluguel de lotação e ônibus com motorista \\
\hline \multicolumn{2}{|c|}{ 3.3 Serviços de transporte marítimo } \\
\hline 65111.0 & Serviços de transporte de viajantes em transbordadores de cabotagem e transoceânicos \\
\hline 65119.1 & Outros serviços regulares de transporte de viajantes em embarcações de cabotagem e exterior \\
\hline 65119.2 & Serviços de transporte de viajantes em ferryboats por vias interiores de navegação \\
\hline 65119.3 & Serviços de cruzeiro \\
\hline 65130.1 & Serviços de aluguel de embarcações de cabotagem e exterior com tripulação para transporte de viajantes \\
\hline 65211.0 & Serviços de transporte de viajantes em ferryboats por vias interiores de navegação \\
\hline 65219.1 & Serviços regulares de transporte de viajantes por vias interiores de navegação \\
\hline 65219.2 & Serviços de excursões panorâmicas \\
\hline 65219.3 & Serviços de cruzeiros \\
\hline 65230.0 & Serviços de aluguel de embarcações com tripulação para transporte de viajantes por vias interiores de navegação \\
\hline \multicolumn{2}{|r|}{ 3.4 Serviços de transporte marítimo } \\
\hline 66110.0 & Serviços de transporte de passageiros por linhas aéreas de serviço regular \\
\hline 66120.1 & Serviços de transporte de passageiros por linhas aéreas de serviço não regular \\
\hline 66120.2 & Serviços de excursão panorâmica em aeroplano ou em helicóptero \\
\hline 66400.0 & Serviço de aluguel de aeronaves com tripulação \\
\hline \multicolumn{2}{|c|}{ 3.5 Serviços auxiliares ao transporte de passageiros } \\
\hline 67300.0 & Serviços de ajuda à navegação \\
\hline 67400.0 & Serviços auxiliares do transporte por ferrovias \\
\hline 67510.0 & Serviços de terminais de ônibus \\
\hline 67530.1 & Estacionamento de terminais de transporte de passageiros \\
\hline 67610.0 & Serviços de exploração de portos e vias de navegação (exceto carga e descarga) \\
\hline 67690.1 & Serviços auxiliares de transporte por via aquática relacionados com o combustível \\
\hline 67690.2 & Serviços de manutenção e conservação de embarcações privadas de passageiros \\
\hline 67710.1 & Serviços de exploração de aeroportos (exceto carga e descarga) \\
\hline 67790.0 & Outros serviços auxiliares de transporte aéreo ou espacial \\
\hline \multicolumn{2}{|c|}{ 3.6 Aluguel de bens para o transporte de passageiros } \\
\hline 73111.0 & Serviços de leasing ou aluguel de automóveis ou camionetas sem motorista \\
\hline 73114.1 & Serviços de leasing ou aluguel de caravanas/autocaravanas sem motorista \\
\hline 73115.1 & Serviços de leasing ou aluguel de embarcações de passageiros sem tripulação \\
\hline 73116.1 & Serviços de leasing ou aluguel de aeronaves de passageiros sem tripulação \\
\hline \multicolumn{2}{|r|}{ 3.7 Serviços de manutenção e reparação de bens e equipamentos para o transporte de passageiros } \\
\hline 87143.0 & Serviços de manutenção e reparação de reboques, semirreboques e outros veículos de motor não classificados em outro lugar \\
\hline 87149.1 & Serviços de manutenção e reparação de embarcações de recreio para uso próprio \\
\hline 87149.2 & Serviços de manutenção e reparação de aviões de recreio de uso próprio \\
\hline
\end{tabular}


4.1 Serviços de agências de viagens

67811.0 Serviços de agências de viagem

4.2 Serviços de operadoras

$67812.0 \quad$ Serviço de tour -operadores

4.3 Serviços de informação turística e de guias de turismo

$67813.0 \quad$ Serviços de informação turística

67820.0 Serviços de guias de turismo

5. Serviços culturais

5.1 Representações artísticas

$96230.0 \quad$ Serviços de exploração de salas de espetáculos

96310.0 Serviços relacionados com atores

5.2 Museus e outros serviços culturais

96411.0 Serviços relacionados com museus, exceto lugares e edifícios históricos

$96412.0 \quad$ Serviços de conservação de lugares e edifícios históricos

$96421.0 \quad$ Serviços relacionados com jardins botânicos e zoológicos

96422.0 Serviços relacionados com reservas naturais, incluindo serviços de conservação da fauna

6. Serviços recreativos e outros serviços de entretenimento

6.1 Esportes e serviços recreativos esportivos

$96510.0 \quad$ Serviços de promoção e organização de provas desportivas de competição e de entretenimento

96520.1 Serviços de campos de golfe

96520.2 Serviços de exploração de pistas de esqui

96520.3 Circuitos de corridas

96520.5 Serviços de praia e de parques recreativos

96590.1 Esportes de aventura e risco

6.2 Outros serviços relacionados ao lazer

96910.1 Serviços relacionados com parques temáticos

96910.2 Serviços relacionados com carnavais

96910.3 Serviços relacionados com férias e carnavais

96920.1 Serviços relacionados com cassinos

96920.2 Serviços relacionados com máquinas caça-níqueis

7. Servicos turísticos diversos

7.1 Serviços financeiros e de seguros

71100.1 Serviços de cartões de viagem

$71100.2 \quad$ Serviços de crédito para viagem

71311.1 Serviços de seguros de vida

71320.1 Serviços de seguros de acidente em viagens

71320.2 Serviços de seguros de saúde em viagens

71334.1 $\quad$ Serviços de seguros particulares dos viajantes em aeronaves

71334.2 Serviços de seguros particulares dos viajantes em embarcações

\begin{tabular}{l|l}
71339.1 & Serviços de seguros de viagens
\end{tabular}

$71552.0 \quad$ Serviços de câmbio de divisas

7.2 Outros serviços de aluguel de bens

73240.1 Serviços de leasing ou aluguel de equipamentos de transporte terrestre que não sejam motorizados

$\begin{array}{ll}73240.2 & \text { Serviços de leasing ou aluguel de equipamentos para esportes de inverno }\end{array}$

73240.3 Serviços de leasing ou aluguel de equipamentos de transporte aéreo que não sejam motorizados

73240.4 Serviços de leasing ou aluguel de equipamentos de praia ou para esportes aquáticos

$73240.5 \quad$ Serviços de leasing ou aluguel de equipamentos de camping

73240.6 Serviços de leasing ou aluguel de selas de montar

$73290.1 \quad$ Serviços de aluguel de câmara fotográficas

7.3 Outros serviços turísticos

85970.0 Serviços de organização de feiras e exposições

97230.4 Serviços de balneários

$91131.1 \quad$ Serviços de licenças de pesca

91131.2 Serviços de licenças de caça

91210.1 Serviços de emissão de passaportes

91210.2 Serviços de emissão de vistos

96620.2 Serviços de guia (montanha, caça e pesca)

97910.0 Serviços de acompanhamento ou escolta

FONTE: OMT, 2001 in IBGE, 2010. Tradução IBGE. 


\section{ANEXO 2: LISTA DE PRODUTOS ESPECÍFICOS DO TURISMO (RELATIVO AO CONSUMO DO VISITANTE)}

\begin{tabular}{|c|c|}
\hline $\begin{array}{l}\text { CCP } \\
\text { / Código }\end{array}$ & DESCRIÇÃO \\
\hline 63110.0 & Serviços de alojamento em hotéis e motéis \\
\hline 63191.0 & Serviços de centros de férias e casas de veraneio \\
\hline 63192.0 & Serviços de arrendamento de alojamentos mobiliados \\
\hline 63193.0 & Serviços de albergues juvenis \\
\hline 63194.0 & Serviços de centros de entretenimento e férias para crianças \\
\hline 63195.0 & Serviços para acampamentos e trailers \\
\hline 63199.1 & Serviços de carro-leito e similares em outros meios de transporte; residência de estudantes \\
\hline 63210.0 & Serviços de provisão de comida com serviços completos de restaurante \\
\hline 63220.0 & Serviços de provisão de comida em estabelecimentos de autosserviço \\
\hline 63290.0 & Outros serviços de provisão de comida \\
\hline 63300.0 & Serviços de provisão de bebidas para seu consumo local \\
\hline 64111.1 & Serviços regulares de transporte de passageiros por ferrovias \\
\hline 64111.2 & Serviços não regulares de transporte de passageiros por ferrovias \\
\hline 64112.0 & Serviços urbanos e suburbanos de transporte de passageiros por ferrovias \\
\hline 64211.0 & Serviços regulares urbanos e suburbanos de transporte de viajantes por rodovia \\
\hline 64212.0 & Serviços regulares especiais urbanos e suburbanos de transporte de viajantes por rodovias \\
\hline 64213.0 & Serviços regulares interurbanos de transporte de viajantes por rodovia \\
\hline 64214.0 & Serviços regulares especiais interurbanos de transporte de viajantes por rodovia \\
\hline 64219.1 & Serviços regulares de teleféricos para esquiar \\
\hline 64219.2 & Serviços de teleféricos e funiculares \\
\hline 64221.0 & Serviços de táxi \\
\hline 64222.0 & Serviços de aluguel de automóveis com motorista \\
\hline 64223.0 & Serviços de aluguel de lotação e ônibus com motorista \\
\hline 64224.0 & Serviços de transporte de viajantes por rodovia em veículos de tração humana ou animal \\
\hline 65111.0 & Serviços de transporte de viajantes em transbordadores de cabotagem e transoceânicos \\
\hline 65119.1 & Outros serviços regulares de transporte de viajantes em embarcações de cabotagem e exterior \\
\hline 65119.2 & Outros serviços não regulares de transporte de viajantes em embarcações de cabotagem e exterior \\
\hline 65119.3 & Serviços de cruzeiro \\
\hline 65119.4 & Serviços de passageiros em embarcações de carga \\
\hline 65130.1 & Serviços de aluguel de embarcações de cabotagem e exterior com tripulação para transporte de viajantes \\
\hline 65140.0 & Serviços de reboque e tração de embarcações de cabotagem e transoceânicas \\
\hline 65211.0 & Serviços de transporte de viajantes em ferryboats por vias interiores de navegação \\
\hline 65219.1 & Serviços regulares de transporte de viajantes por vias interiores de navegação \\
\hline 65219.2 & Serviços de excursões panorâmicas \\
\hline 65219.3 & Serviços de cruzeiros \\
\hline 65230.0 & Serviços de aluguel de embarcações com tripulação para transporte de viajantes por vias interiores de navegação \\
\hline 65240.0 & Serviços de reboque e tração em vias interiores de navegação \\
\hline 66110.0 & Serviços de transporte de passageiros por linhas aéreas de serviço regular \\
\hline 66120.1 & Serviços de transporte de passageiros por linhas aéreas de serviço não regular \\
\hline 66120.2 & Serviços de excursão panorâmica em aeroplano ou em helicóptero \\
\hline 66400.0 & Serviço de aluguel de aeronaves com tripulação \\
\hline 67300.0 & Serviços de ajuda à navegação \\
\hline 67400.0 & Serviços auxiliares do transporte por ferrovias \\
\hline 67510.0 & Serviços de terminais de ônibus \\
\hline 67520.1 & Serviços de exploração de rodovias \\
\hline 67520.2 & Serviços de exploração de pontes e túneis \\
\hline 67530.1 & Estacionamento de terminais de transporte de passageiros \\
\hline 67590.0 & Outros serviços auxiliares de transporte por rodovia \\
\hline 67610.0 & Serviços de exploração de portos e vias de navegação (exceto carga e descarga) \\
\hline 67630.0 & Serviços de salvamento e reboque de embarcações \\
\hline 67690.1 & Serviços auxiliares de transporte por via aquática relacionados com o combustível \\
\hline 67690.2 & Serviços de manutenção e conservação de embarcações privadas de passageiros \\
\hline 67710.1 & Serviços de exploração de aeroportos (exceto carga e descarga) \\
\hline 67790.0 & Outros serviços auxiliares de transporte aéreo ou espacial \\
\hline 67811.0 & Serviços de agências de viagem \\
\hline 67812.0 & Serviço de tour - operadores \\
\hline 67813.0 & Serviços de informação turística \\
\hline 67820.0 & Serviços de guias de turismo \\
\hline 71100.1 & Serviços de cartões de viagem \\
\hline 71100.2 & Serviços de crédito para viagem \\
\hline 71100.3 & Serviços de crédito para a aquisição de veículos \\
\hline 71311.1 & Serviços de seguros de vida \\
\hline 71320.1 & Serviços de seguros de acidente em viagens \\
\hline 71320.2 & Serviços de seguros de saúde em viagens \\
\hline 71331.1 & Serviços de seguros de veículos e motor privados \\
\hline 71334.1 & Serviços de seguros particulares dos viajantes em aeronaves \\
\hline
\end{tabular}




\begin{tabular}{|c|c|}
\hline 71334.2 & Serviços de seguros particulares dos viajantes em embarcações \\
\hline 71339.1 & Serviços de seguros de viagens \\
\hline 71552.0 & Serviços de câmbio de divisas \\
\hline 72211.1 & Serviços auxiliares de atividades de multipropriedade \\
\hline 73111.0 & Serviços de leasing ou aluguel de automóveis ou camionetas sem motorista \\
\hline 73114.1 & Serviços de leasing ou aluguel de caravanas/autocaravanas sem motorista \\
\hline 73115.1 & Serviços de leasing ou aluguel de embarcações de passageiros sem tripulação \\
\hline 73116.1 & Serviços de leasing ou aluguel de aeronaves de passageiros sem tripulação \\
\hline 73240.1 & Serviços de leasing ou aluguel de equipamentos de transporte terrestre que não sejam motorizados \\
\hline 73240.2 & Serviços de leasing ou aluguel de equipamentos para esportes de inverno \\
\hline 73240.3 & Serviços de leasing ou aluguel de equipamentos de transporte aéreo que não sejam motorizados \\
\hline 73240.4 & Serviços de leasing ou aluguel de equipamentos de praia ou para esportes aquáticos \\
\hline 73240.5 & Serviços de leasing ou aluguel de equipamentos de camping \\
\hline 73240.6 & Serviços de leasing ou aluguel de selas de montar \\
\hline 73290.1 & Serviços de aluguel de câmara fotográficas \\
\hline 83811.1 & Serviços de fotografias para passaportes/vistos \\
\hline 83820.0 & Serviços de revelação fotográfica \\
\hline 83910.0 & Serviços de tradução e interpretação \\
\hline 84510.0 & Serviços de bibliotecas \\
\hline 84520.0 & Serviços de arquivos \\
\hline 85970.0 & Serviços de organização de feiras e exposições \\
\hline 87141.0 & Serviços de manutenção e reparação de veículos a motor \\
\hline 87142.0 & Serviços de manutenção e reparação de motocicletas e veículos para neve \\
\hline 87143.0 & Serviços de manutenção e reparação de reboques, semirreboques e outros veículos de motor não classificados em outro lugar \\
\hline 87149.1 & Serviços de manutenção e reparação de embarcações de recreio para uso próprio \\
\hline 87149.2 & Serviços de manutenção e reparação de aviões de recreio de uso próprio \\
\hline 87290.1 & Serviços de manutenção e reparação de outros produtos não classificados em outro lugar \\
\hline 91131.1 & Serviços de licenças de pesca \\
\hline 91131.2 & Serviços de licenças de caça \\
\hline 91210.1 & Serviços de emissão de passaportes \\
\hline 91210.2 & Serviços de emissão de vistos \\
\hline 92900.1 & Serviços de ensino de idiomas \\
\hline 92900.2 & Serviços de licenças para academias de ensino \\
\hline 96151.0 & Serviços de projeção de filmes cinematográficos \\
\hline 96230.0 & Serviços de exploração de salas de espetáculos \\
\hline 96310.0 & Serviços relacionados com atores \\
\hline 96411.0 & Serviços relacionados com museus, exceto lugares e edifícios históricos \\
\hline 96412.0 & Serviços de conservação de lugares e edifícios históricos \\
\hline 96421.0 & Serviços relacionados com jardins botânicos e zoológicos \\
\hline 96422.0 & Serviços relacionados com reservas naturais, incluindo serviços de conservação da fauna \\
\hline 96510.0 & Serviços de promoção e organização de provas desportivas de competição e de entretenimento \\
\hline 96520.1 & Serviços de campos de golfe \\
\hline 96520.2 & Serviços de exploração de pistas de esqui \\
\hline 96520.3 & Circuitos de corridas \\
\hline 96520.4 & Serviços de escola de equitação \\
\hline 96520.5 & Serviços de praia e de parques recreativos \\
\hline 96590.1 & Esportes de aventura e risco \\
\hline 96620.1 & Serviços de escolas de esportes \\
\hline 96620.2 & Serviços de guia (montanha, caça e pesca) \\
\hline 96910.1 & Serviços relacionados com parques temáticos \\
\hline 96910.2 & Serviços relacionados com carnavais \\
\hline 96910.3 & Serviços relacionados com férias e carnavais \\
\hline 96920.1 & Serviços relacionados com cassinos \\
\hline 96920.2 & Serviços relacionados com máquinas caça-níqueis \\
\hline 97230.1 & Serviços relacionados com ginásios \\
\hline 97230.2 & Serviços de sauna e banhos turcos \\
\hline 97230.3 & Serviços de massagem \\
\hline 97230.4 & Serviços de balneários \\
\hline 97910.0 & Serviços de acompanhamento ou escolta \\
\hline 99000.0 & Serviços prestados por organizações e entidades extraterritoriais \\
\hline 62121.1 & Serviços de comércio varejista de frutas e verduras em estabelecimentos não especializados \\
\hline 62122.1 & Serviços de comércio varejista de produtos lácteos, ovos, azeites e gorduras comestíveis em estabelecimentos não especializados \\
\hline 62123.1 & Serviços de comércio varejista de carnes, aves e caça em estabelecimentos não especializados \\
\hline 62124.1 & Serviços de comércio varejista de pescados e mariscos em estabelecimentos não especializados \\
\hline 62125.1 & Serviços de comércio varejista de produtos de pastelaria e confeitaria em estabelecimentos não especializados \\
\hline 62126.1 & Serviços de comércio varejista de bebidas em estabelecimentos não especializados \\
\hline 62128.1 & Serviços de comércio varejista de produtos de tabaco em estabelecimentos não especializados \\
\hline 63132.1 & Serviços de comércio varejista de barracas de campanha e artigos de camping em estabelecimentos não especializados \\
\hline 62133.1 & Serviços de comércio varejista de roupas de vestir, artigos de peles e acessórios de vestir em estabelecimentos não especializados \\
\hline 62134.1 & Serviços de comércio varejista de calçado em estabelecimentos não especializados \\
\hline 62141.1 & $\begin{array}{l}\text { Serviços de comércio varejista de equipamentos de rádio e televisão, instrumentos musicais e discos, partituras musicais e fita de } \\
\text { música em estabelecimentos não especializados }\end{array}$ \\
\hline 62151.1 & Serviços de comércio varejista de livros, periódicos, revistas e papelaria em estabelecimentos não especializados \\
\hline 62152.1 & Serviços de comércio varejista de equipamentos fotográficos, de ótica e de precisão em estabelecimentos não especializados \\
\hline
\end{tabular}




\begin{tabular}{|c|c|}
\hline 62154.1 & Serviços de comércio varejista de artigos de relojoaria e joalheria em estabelecimentos não especializados \\
\hline 62155.1 & Serviços de comércio varejista de artigos desportivos, incluindo bicicletas em estabelecimentos não especializados \\
\hline 62156.1 & Serviços de comércio varejista de artigos de couro e acessórios de viagem em estabelecimentos não especializados \\
\hline 62159.1 & Serviços de comércio varejista de souvenirs em estabelecimentos não especializados \\
\hline 62175.1 & Serviços de comércio varejista de artigos de perfumaria, cosmética e toucador em estabelecimentos não especializados \\
\hline 62181.1 & $\begin{array}{l}\text { Serviços de comércio varejista de veículos de motor, motocicletas, veículos para neve e peças de reposição em estabelecimentos } \\
\text { não especializados }\end{array}$ \\
\hline 62191.1 & $\begin{array}{l}\text { Serviços de comércio varejista de combustíveis sólidos, líquidos e gasosos e produtos similares em estabelecimentos não } \\
\text { especializados }\end{array}$ \\
\hline 62221.1 & Serviços de comércio varejista de frutas e verduras em estabelecimentos especializados \\
\hline 62222.1 & Serviços de comércio varejista de produtos lácteos, ovos, azeites e gorduras comestíveis em estabelecimentos especializados \\
\hline 62223.1 & Serviços de comércio varejista de carnes, aves e caça em estabelecimentos especializados \\
\hline 62224.1 & Serviços de comércio varejista de pescados e mariscos em estabelecimentos especializados \\
\hline 62225.1 & Serviços de comércio varejista de produtos de pastelaria e confeitaria em estabelecimentos especializados \\
\hline 62226.1 & Serviços de comércio varejista de bebidas em estabelecimentos especializados \\
\hline 62228.1 & Serviços de comércio varejista de produtos de tabaco em estabelecimentos especializados \\
\hline 62232.1 & Serviços de comércio varejista de barracas de campanha e artigos de camping em estabelecimentos especializados \\
\hline 62233.1 & Serviços de comércio varejista de roupas de vestir, artigos de peles e acessórios de vestir em estabelecimentos especializados \\
\hline 62234.1 & Serviços de comércio varejista de calçado em estabelecimentos especializados \\
\hline 62242.1 & $\begin{array}{l}\text { Serviços de comércio varejista de equipamentos de rádio e televisão, instrumentos musicais e discos, partituras musicais e fita de } \\
\text { música em estabelecimentos especializados }\end{array}$ \\
\hline 62251.1 & Serviços de comércio varejista de livros, periódicos, revistas e papelaria em estabelecimentos especializados \\
\hline 62252.1 & Serviços de comércio varejista de equipamentos fotográficos, de ótica e de precisão em estabelecimentos especializados \\
\hline 62254.1 & Serviços de comércio varejista de artigos de relojoaria e joalheria em estabelecimentos especializados \\
\hline 62255.1 & Serviços de comércio varejista de artigos desportivos, incluindo bicicletas em estabelecimentos especializados \\
\hline 62256.1 & Serviços de comércio varejista de artigos de couro e acessórios de viagem em estabelecimentos especializados \\
\hline 62259.1 & Serviços de comércio varejista de souvenirs em estabelecimentos especializados \\
\hline 62275.1 & Serviços de comércio varejista de artigos de perfumaria, cosmética e toucador em estabelecimentos especializados \\
\hline 62281.1 & $\begin{array}{l}\text { Serviços de comércio varejista de veículos de motor, motocicletas, veículos para neve e peças de reposição em estabelecimentos } \\
\text { especializados }\end{array}$ \\
\hline 62282.1 & Serviços de comércio varejista de outros equipamentos de transporte, exceto bicicletas, em estabelecimentos especializados \\
\hline 62284.1 & Servicos de comércio varejista de computadores e pacotes informáticos, em estabelecimentos especializados \\
\hline 62291.1 & Serviços de comércio varejista de combustíveis sólidos, líquidos e gasosos e produtos similares em estabelecimentos especializados \\
\hline
\end{tabular}

FONTE: OMT, 2001 in IBGE, 2010. Tradução IBGE. 


\section{APÊNDICES}

\section{APÊNDICE 1: Modelo de questionário (survey)}

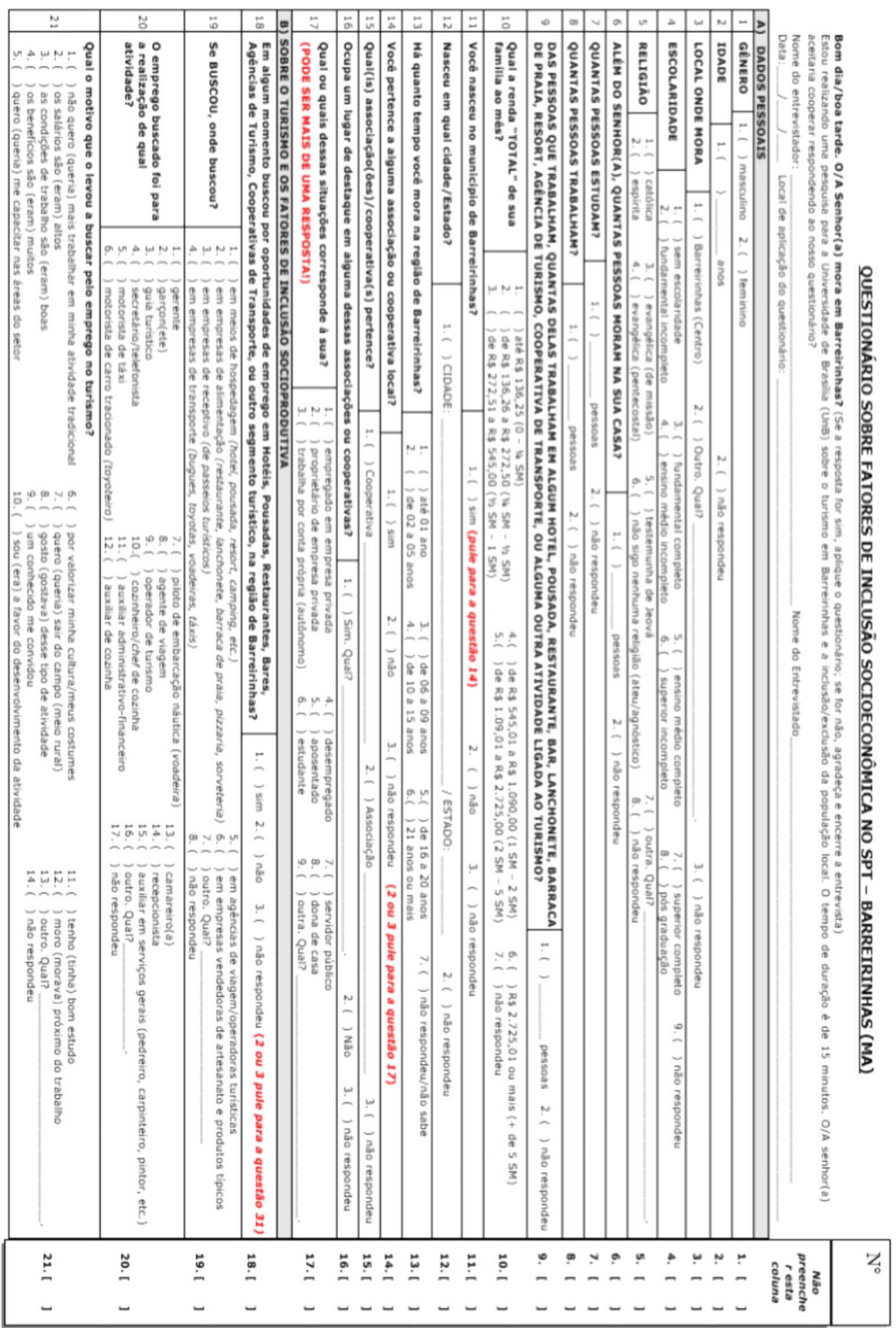




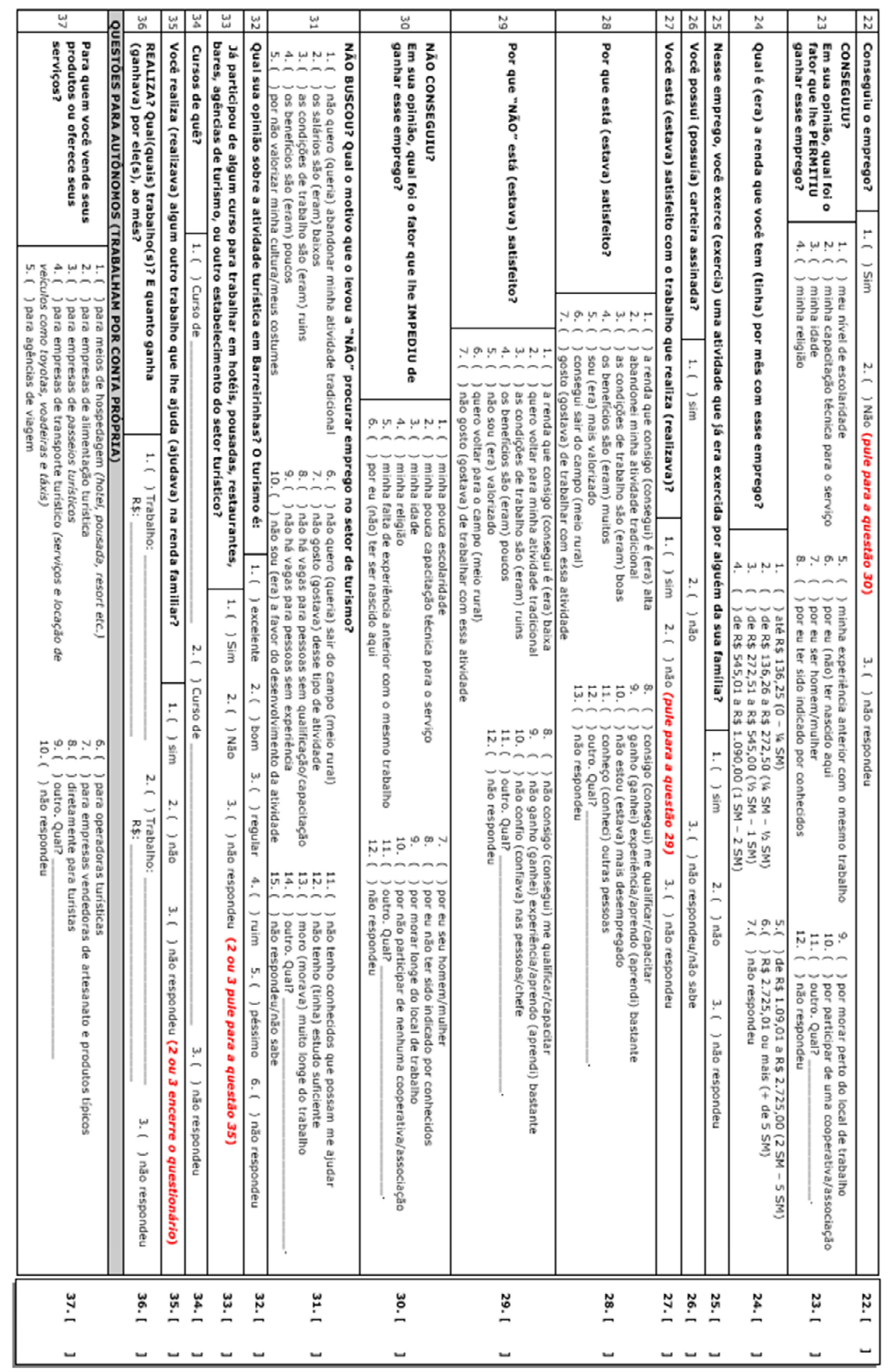




\section{APÊNDICE 2: Modelo de formulário - Empresários}

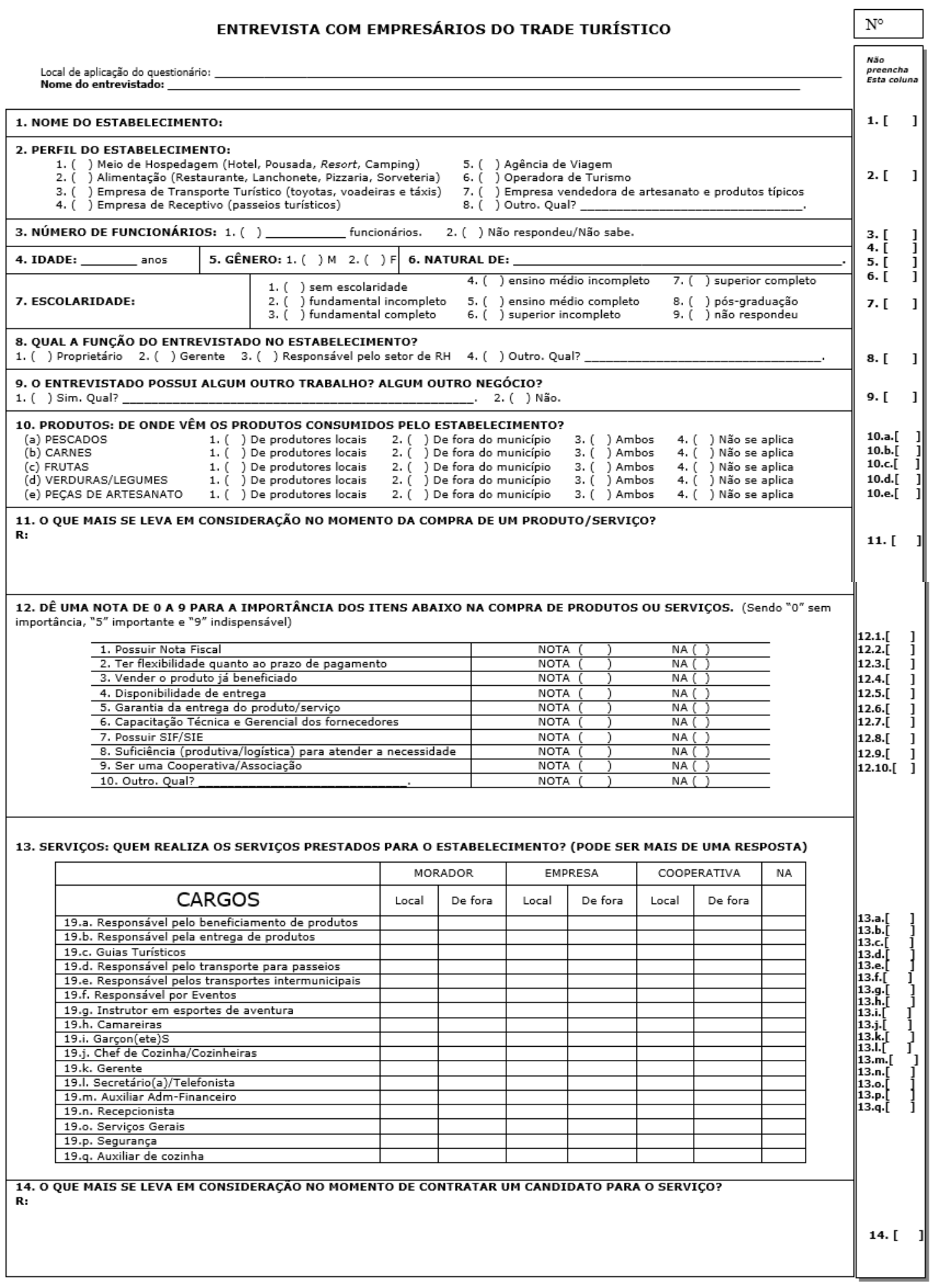




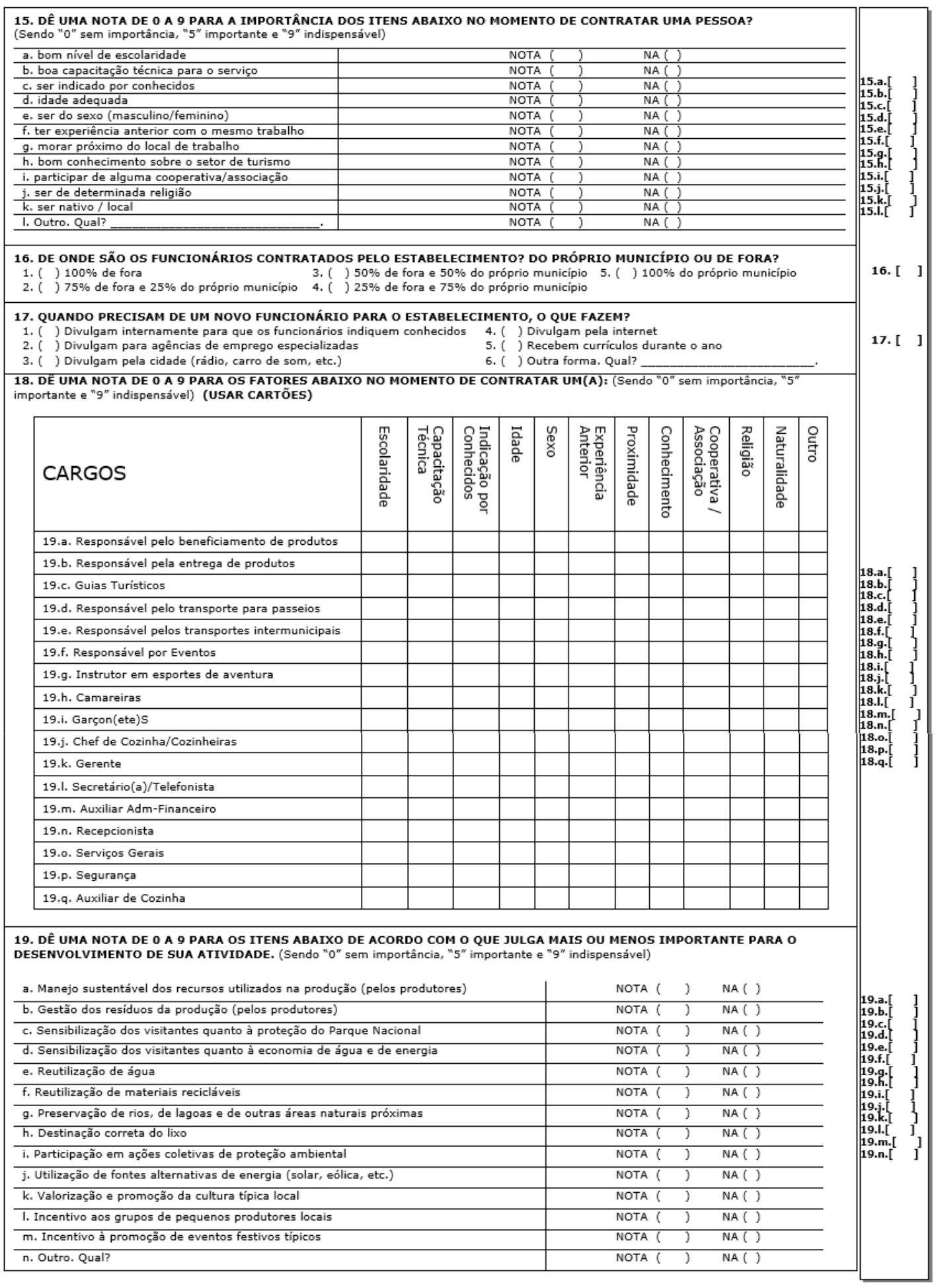


APÊNDICE 3: Modelo de formulário - Incluídos

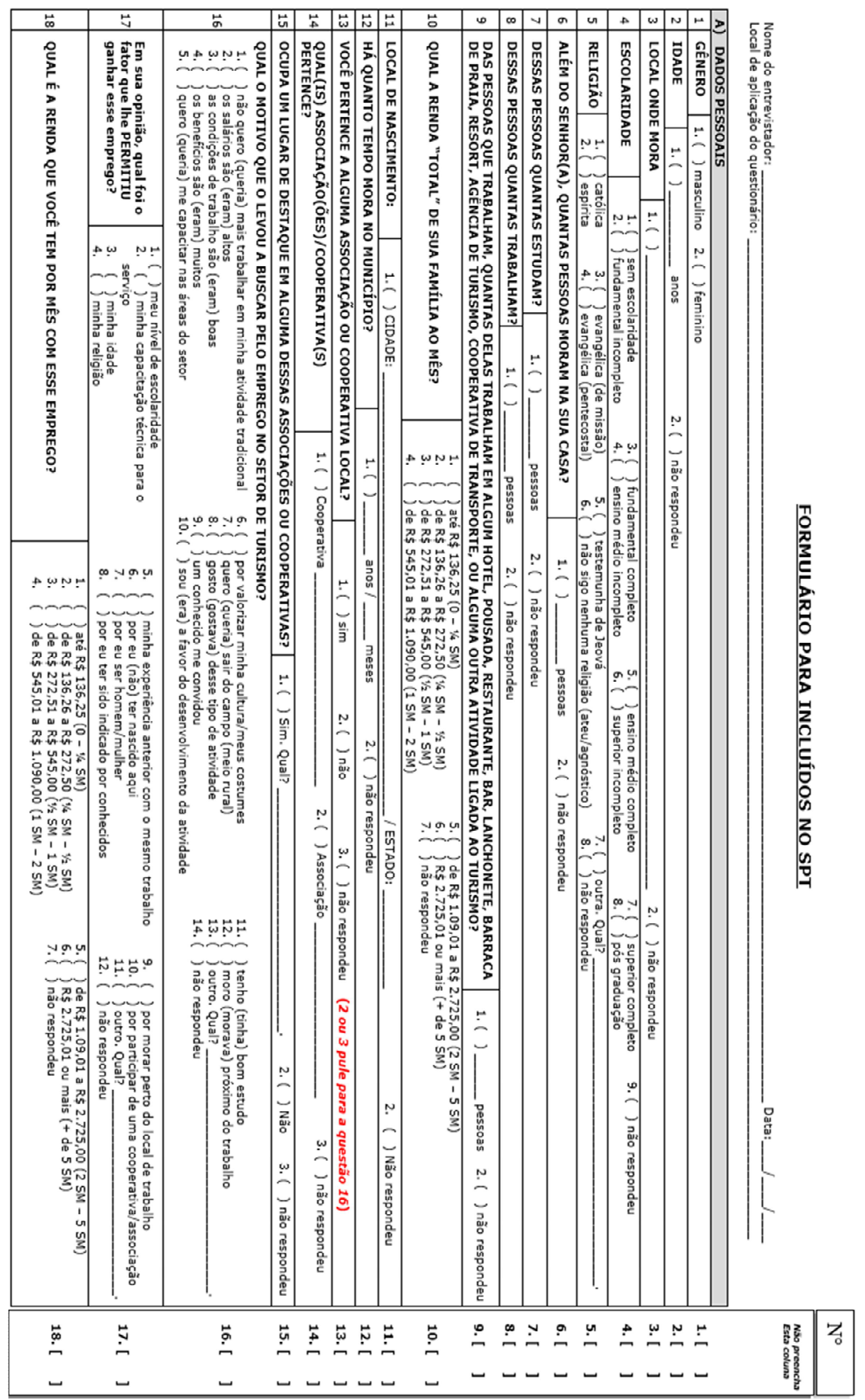




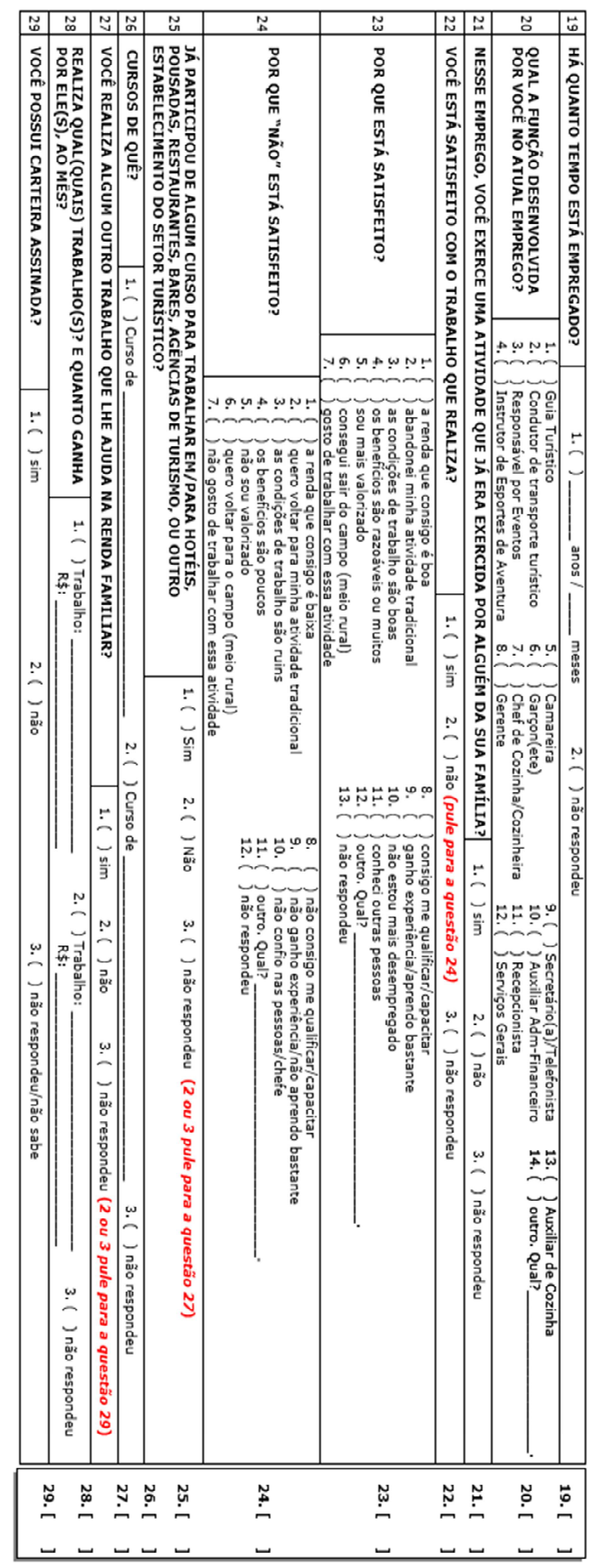




\section{APÊNDICE 4: Modelo de formulário - Grupos Organizados}

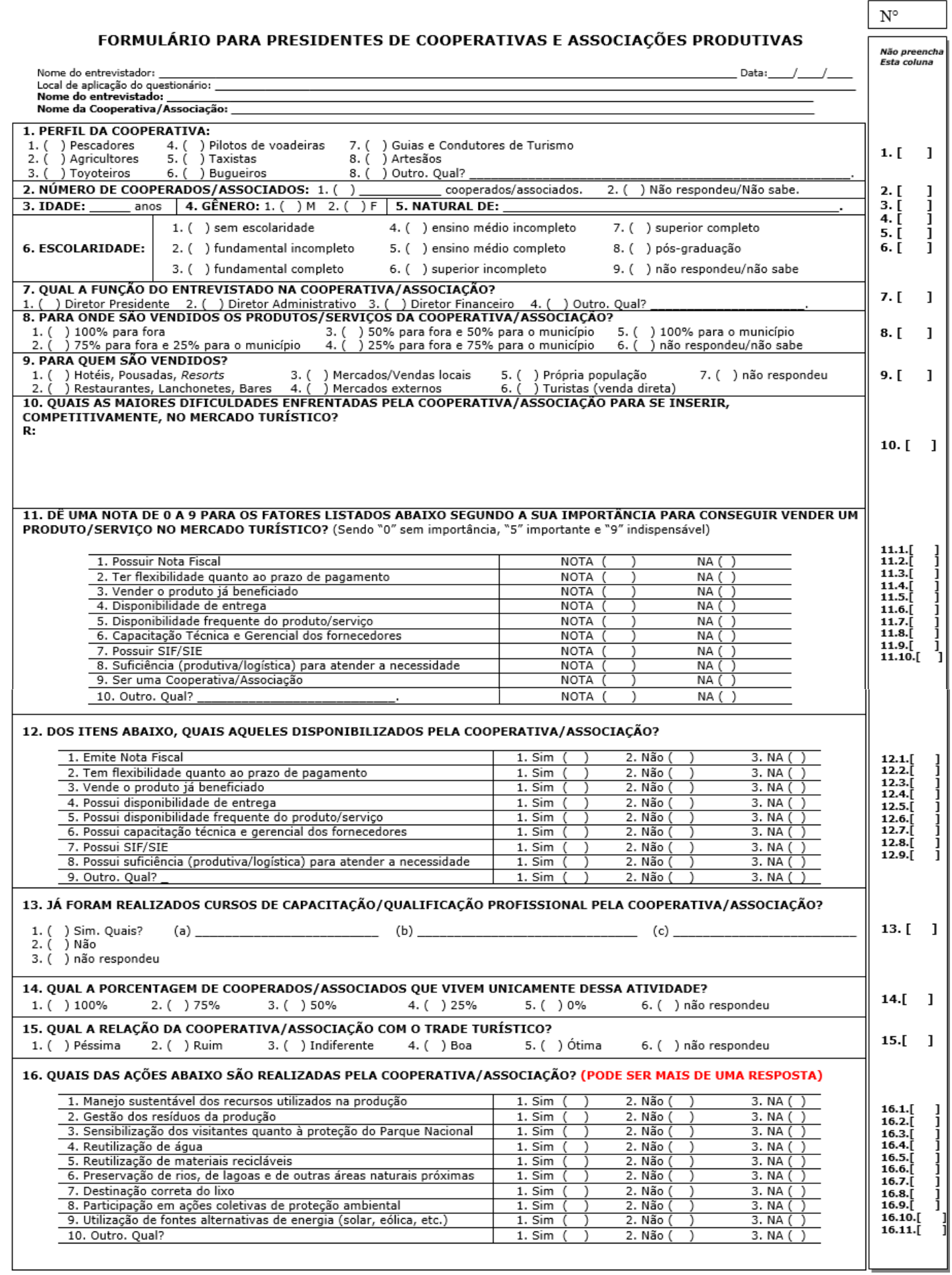




\section{APÊNDICE 5: Local onde os entrevistados nasceram}

Nasceu em qual cidade/estado? (População BARREIRINHAS)

\begin{tabular}{l|r|r|r|r}
\hline & Frequency & Percent & Valid Percent & Cumulative Percent \\
\hline Próprio município (Barreirinhas) & 335 & 87.9 & 87.9 & 87.9 \\
São Luís - MA & 12 & 3.1 & 3.1 & 91.1 \\
Tutóia - MA & 14 & 3.7 & 3.7 & 94.8 \\
Paulino Neves - MA & 6 & 1.6 & 1.6 & 96.3 \\
Porto Rico do Maranhão - MA & 1 & 0.3 & 0.3 & 96.6 \\
Castanhal - PA & 1 & 0.3 & 0.3 & 96.9 \\
Axixá - MA & 2 & 0.5 & 0.5 & 97.4 \\
윾 Urbano Santos - MA & 3 & 0.8 & 0.8 & 98.2 \\
Palmeira dos Veadeiros - MA & 1 & 0.3 & 0.3 & 98.4 \\
Chapadinha - MA & 1 & 0.3 & 0.3 & 98.7 \\
Belém - PA & 2 & 0.5 & 0.5 & 99.2 \\
Bacabau - MA & 1 & 0.3 & 0.3 & 99.5 \\
Primeira Cruz - MA & 1 & 0.3 & 0.3 & 99.7 \\
Maceió - AL & 1 & 0.3 & 0.3 & 100.0 \\
Total & 381 & 100.0 & 100.0 & \\
\hline
\end{tabular}

Fonte: pesquisa do autor.

Nasceu em qual cidade/estado? (População JERICOACOARA)

\begin{tabular}{|c|c|c|c|c|c|}
\hline & & Frequency & Percent & Valid Percent & Cumulative Percent \\
\hline & não se aplica & 260 & 65.8 & 65.8 & 65.8 \\
\hline & Cruz - CE & 25 & 6.3 & 6.3 & 72.2 \\
\hline & Bela Cruz - CE & 14 & 3.5 & 3.5 & 75.7 \\
\hline & Belo Horizonte - MG & 1 & .3 & .3 & 75.9 \\
\hline & Camocim - CE & 25 & 6.3 & 6.3 & 82.3 \\
\hline & Marco - CE & 10 & 2.5 & 2.5 & 84.8 \\
\hline & Capistrano - CE & 1 & .3 & .3 & 85.1 \\
\hline & Acaraú - CE & 33 & 8.4 & 8.4 & 93.4 \\
\hline & Granja - CE & 2 & .5 & .5 & 93.9 \\
\hline & Limoeiro do Norte - CE & 1 & .3 & .3 & 94.2 \\
\hline & Fortaleza - CE & 6 & 1.5 & 1.5 & 95.7 \\
\hline & Brasília - DF & 1 & .3 & .3 & 95.9 \\
\hline 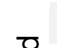 & Teixeira - PB & 1 & .3 & .3 & 96.2 \\
\hline$\frac{\sqrt{\frac{N}{N}}}{\sqrt{2}}$ & São Paulo - SP & 2 & .5 & .5 & 96.7 \\
\hline & Garanhuns - PE & 1 & .3 & .3 & 97.0 \\
\hline & Santana do Acaraú - CE & 1 & .3 & .3 & 97.2 \\
\hline & Massapê - CE & 1 & .3 & .3 & 97.5 \\
\hline & Meruoca - CE & 1 & .3 & .3 & 97.7 \\
\hline & Ipu - CE & 1 & .3 & .3 & 98.0 \\
\hline & Rosário - MA & 1 & .3 & .3 & 98.2 \\
\hline & Sobral - CE & 1 & .3 & .3 & 98.5 \\
\hline & Canindé - CE & 1 & .3 & .3 & 98.7 \\
\hline & Morrinhos & 1 & .3 & .3 & 99.0 \\
\hline & Umuarama - PR & 1 & .3 & .3 & 99.2 \\
\hline & Palmas - TO & 1 & .3 & .3 & 99.5 \\
\hline & São Luís - MA & 1 & .3 & .3 & 99.7 \\
\hline & Teresina - PI & 1 & .3 & .3 & 100.0 \\
\hline
\end{tabular}




\begin{tabular}{|c|c|c|c|c|}
\hline Total & 395 & 100.0 & 100.0 & \\
\hline \multicolumn{5}{|l|}{ Fonte: pesquisa do autor. } \\
\hline \multicolumn{5}{|c|}{ Onde o entrevistado nasceu (Empresários BARREIRINHAS) } \\
\hline & Frequency & Percent & Valid Percent & Cumulative Percent \\
\hline Pinheiro - MA & 1 & 1.7 & 1.7 & 1.7 \\
\hline Barreirinhas - MA & 30 & 51.7 & 51.7 & 53.4 \\
\hline São Paulo - SP & 4 & 6.9 & 6.9 & 60.3 \\
\hline Paulino Neves - MA & 1 & 1.7 & 1.7 & 62.1 \\
\hline São Luís - MA & 8 & 13.8 & 13.8 & 75.9 \\
\hline Bacabau - MA & 3 & 5.2 & 5.2 & 81.0 \\
\hline Gália - SP & 1 & 1.7 & 1.7 & 82.8 \\
\hline 으 Santo Amaro - MA & 2 & 3.4 & 3.4 & 86.2 \\
\hline$\stackrel{\overline{\widetilde{N}}}{>}$ Porto Alegre - RS & 1 & 1.7 & 1.7 & 87.9 \\
\hline Parnaíba - PI & 1 & 1.7 & 1.7 & 89.7 \\
\hline França & 1 & 1.7 & 1.7 & 91.4 \\
\hline Itália & 2 & 3.4 & 3.4 & 94.8 \\
\hline Chapada dos Guimarães - MT & 1 & 1.7 & 1.7 & 96.6 \\
\hline Porto Velho - RO & 1 & 1.7 & 1.7 & 98.3 \\
\hline João Pessoa - PB & 1 & 1.7 & 1.7 & 100.0 \\
\hline Total & 58 & 100.0 & 100.0 & \\
\hline
\end{tabular}

Fonte: pesquisa do autor.

Onde o entrevistado nasceu (Empresários JERICOACOARA)

\begin{tabular}{|c|c|c|c|c|c|}
\hline & & Frequency & Percent & Valid Percent & Cumulative Percent \\
\hline & Jijoca de Jericoacoara - CE & 12 & 20.0 & 20.0 & 20.0 \\
\hline & São Paulo - SP & 12 & 20.0 & 20.0 & 40.0 \\
\hline & Porto Alegre - RS & 3 & 5.0 & 5.0 & 45.0 \\
\hline & Itália & 8 & 13.3 & 13.3 & 58.3 \\
\hline & Porto Velho - RO & 1 & 1.7 & 1.7 & 60.0 \\
\hline & Argentina & 1 & 1.7 & 1.7 & 61.7 \\
\hline & Campinas - SP & 1 & 1.7 & 1.7 & 63.3 \\
\hline & Balneário Camburiú - SC & 1 & 1.7 & 1.7 & 65.0 \\
\hline & Fortaleza - CE & 5 & 8.3 & 8.3 & 73.3 \\
\hline 으 & Acaraú - CE & 2 & 3.3 & 3.3 & 76.7 \\
\hline $\bar{\pi}^{\pi}$ & Belo Horizonte - MG & 4 & 6.7 & 6.7 & 83.3 \\
\hline & Goiânia - GO & 1 & 1.7 & 1.7 & 85.0 \\
\hline & Camocim - CE & 3 & 5.0 & 5.0 & 90.0 \\
\hline & Campo Grande - MS & 1 & 1.7 & 1.7 & 91.7 \\
\hline & Brasília de Minas - MG & 1 & 1.7 & 1.7 & 93.3 \\
\hline & Formiga - MG & 1 & 1.7 & 1.7 & 95.0 \\
\hline & Belém - PA & 1 & 1.7 & 1.7 & 96.7 \\
\hline & Rio de Janeiro - RJ & 1 & 1.7 & 1.7 & 98.3 \\
\hline & Pereiras - SP & 1 & 1.7 & 1.7 & 100.0 \\
\hline & Total & 60 & 100.0 & 100.0 & \\
\hline
\end{tabular}

Fonte: pesquisa do autor. 
Você nasceu no município de Barreirinhas? (Incluídos de BARREIRINHAS)

\begin{tabular}{l|r|r|r|r}
\hline & Frequency & Percent & Valid Percent & Cumulative Percent \\
\hline Barreirinhas - MA & 64 & 86.5 & 86.5 & 86.5 \\
São Luís - MA & 3 & 4.1 & 4.1 & 90.5 \\
Londrina - PR & 1 & 1.4 & 1.4 & 91.9 \\
읋 Porto Rico do Maranhão & 1 & 1.4 & 1.4 & 93.2 \\
Belém - PA & 1 & 1.4 & 1.4 & 94.6 \\
não respondeu/não sabe & 4 & 5.4 & 5.4 & 100.0 \\
Total & 74 & 100.0 & 100.0 & \\
\hline
\end{tabular}

Fonte: pesquisa do autor.

Você nasceu no município de Jijoca de Jericoacoara? (Incluídos de JIJOCA DE JERICOACOARA)

\begin{tabular}{l|r|r|r|r}
\hline & Frequency & Percent & Valid Percent & Cumulative Percent \\
\hline Jijoca de Jericoacoara - CE & 56 & 58.9 & 58.9 & 58.9 \\
Uruoca - CE & 1 & 1.1 & 1.1 & 60.0 \\
Camocim - CE & 10 & 10.5 & 10.5 & 70.5 \\
São Paulo - SP & 1 & 1.1 & 1.1 & 71.6 \\
Cruz - CE & 11 & 11.6 & 11.6 & 83.2 \\
음 Acaraú - CE & 6 & 6.3 & 6.3 & 89.5 \\
Bela Cruz - CE & 4 & 4.2 & 4.2 & 93.7 \\
Belo Horizonte - MG & 1 & 1.1 & 1.1 & 94.7 \\
Marco - CE & 4 & 4.2 & 4.2 & 98.9 \\
Granja - CE & 1 & 1.1 & 1.1 & 100.0 \\
Total & 95 & 100.0 & 100.0 & \\
\hline
\end{tabular}

Fonte: pesquisa do autor.

Onde o entrevistado nasceu (Grupo organizado de BARREIRINHAS)

\begin{tabular}{l|r|r|r|r}
\hline & Frequency & Percent & Valid Percent & Cumulative Percent \\
\hline Barreirinhas - MA & 2 & 22.2 & 22.2 & 22.2 \\
São Luís - MA & 2 & 22.2 & 22.2 & 44.4 \\
Dores do Indaiá - MG & 1 & 11.1 & 11.1 & 55.6 \\
음 Rio de Janeiro - RJ & 1 & 11.1 & 11.1 & 66.7 \\
$\overline{\text { Tे }}$ Anapurus - MA & 1 & 11.1 & 11.1 & 77.8 \\
Presidente Prudente - SP & 1 & 11.1 & 11.1 & 88.9 \\
São Benedito do Rio Preto - MA & 1 & 11.1 & 11.1 & 100.0 \\
Total & 9 & 100.0 & 100.0 & \\
\hline
\end{tabular}

Fonte: pesquisa do autor.

Onde o entrevistado nasceu (Grupo organizado de JIJOCA DE JERICOACOARA)

\begin{tabular}{l|r|r|r|r}
\hline & Frequency & Percent & Valid Percent & Cumulative Percent \\
\hline Jijoca de Jericoacoara - CE & 4 & 44.4 & 44.4 & 44.4 \\
Fortaleza - CE & 1 & 11.1 & 11.1 & 55.6 \\
Acaraú - CE & 1 & 11.1 & 11.1 & 66.7 \\
윾 Triunfo - RS & 1 & 11.1 & 11.1 & 77.8 \\
Cruz - CE & 1 & 11.1 & 11.1 & 88.9 \\
Uruóca - CE & 1 & 11.1 & 11.1 & 100.0 \\
Total & 9 & 100.0 & 100.0 & \\
\hline
\end{tabular}

Fonte: pesquisa do autor. 


\section{APÊNDICE 6: Grupos organizados que os entrevistados participam}

Qual(is) associação(ões)/cooperativa(s) pertence? (População de BARREIRINHAS)

\begin{tabular}{l|r|r|r|r}
\hline & Frequency & Percent & Valid Percent & Cumulative Percent \\
\hline não respondeu/não sabe & 6 & 4.4 & 4.4 & 4.4 \\
Associação de terrenos & 1 & .7 & .7 & 5.1 \\
Associação Comunitária/de Moradores & 44 & 32.4 & 32.4 & 37.5 \\
Sindicato/Associação dos Trabalhadores & & & \\
Rurais/Lavradores/Associação dos Agricultores & 24 & 17.6 & 17.6 & 55.1 \\
Ruralistas de Tabocas (AGRUTAC) & & & \\
Associação de Moto-taxistas & 1 & .7 & .7 & 55.9 \\
Associação/Colônia de Pescadores & 25 & 18.4 & 18.4 & 74.3 \\
Associação dos Mecânicos & 1 & .7 & .7 & 75.0 \\
Associação das Funerárias & 11 & 8.1 & 8.1 & 83.1 \\
Associação/Cooperativa de Guias e Condutores de & 2 & 1.5 & 1.5 & 84.6 \\
Turismo & 12 & 8.8 & 8.8 & 93.4 \\
Progresso Gambá & 2 & 1.5 & 1.5 & 94.9 \\
Clube dos Idosos & 1 & .7 & .7 & 95.6 \\
CDH do Bar & 1 & .7 & .7 & 96.3 \\
Associaçao de Empresários de Turismo (AETRI) & 1 & .7 & .7 & 97.1 \\
Associação Barco-Escola & 1 & .7 & .7 & 97.8 \\
Sindicato das Arrumadeiras & 1 & .7 & .7 & 98.5 \\
Associação Brasileirinho FC & 1 & .7 & .7 & 99.3 \\
Associação Agrapecuária do São José & 1 & .7 & .7 & 100.0 \\
Associação Giramundo & 136 & 100.0 & 100.0 & \\
Total & & & \\
\hline Fon & & & \\
\hline
\end{tabular}

Fonte: pesquisa do autor.

Qual(is) associação(ões)/cooperativa(s) pertence? (População de JIJOCA DE JERICOACOARA)

\begin{tabular}{l|r|r|rc}
\hline & Frequency & Percent & Valid Percent & Cumulative Percent \\
\hline Associação São Raimundo (de terrenos) & 1 & 4.3 & 4.3 & 4.3 \\
Associação Pais e Mestres & 1 & 4.3 & 4.3 & 8.7 \\
Associação/Cooperativa de Turismo & 1 & 4.3 & 4.3 & 13.0 \\
Associação Comunitária/de Moradores & 10 & 43.5 & 43.5 & 56.5 \\
Associação/Cooperativa de Caminhoneteiros & 2 & 8.7 & 8.7 & 65.2 \\
Sindicato dos Trabalhadores Rurais & 1 & 4.3 & 4.3 & 69.6 \\
을 Associação de Áreas Apropriadas do Incra de & 3 & 13.0 & 13.0 & 82.6 \\
Mangue Seco & 1 & 4.3 & 4.3 & 87.0 \\
Associação dos Deficientes & 1 & 4.3 & 4.3 & 91.3 \\
Associação das Mulheres Produtoras do Córrego & 1 & 4.3 & 4.3 & 95.7 \\
da Forquilha II & 1 & 4.3 & 4.3 & 100.0 \\
Associação de Artesanato de Jeri & 23 & 100.0 & 100.0 & \\
Associação dos Cavalos & & \\
Total &
\end{tabular}

Fonte: pesquisa do autor. 
Qual(is) associação(ões)/cooperativa(s) pertence? (Incluídos de BARREIRINHAS)

\begin{tabular}{l|r|r|r|r}
\hline & Frequency & Percent & Valid Percent & Cumulative Percent \\
\hline Associação/Cooperativa de Guias e Condutores & 2 & 9.5 & 9.5 & 9.5 \\
de Turismo - Concoop & 3 & 14.3 & 14.3 & \\
Associação/Cooperativa/Sindicato dos & 3 & 14.3 & 14.3 & 23.8 \\
Hoteleiros & 5 & 23.8 & 23.8 & 38.1 \\
Associação/Cooperativa/Sindicato/Colônia de & 1 & 4.8 & 4.8 & 61.9 \\
Pescadores & 1 & 4.8 & 4.8 & 66.7 \\
$\frac{.0}{\bar{T}}$ Associação Comunitária/de Moradores & 2 & 9.5 & 9.5 & 71.4 \\
Associação/Cooperativa/Sindicato de Artesãos & 4 & 19.0 & 19.0 & 81.0 \\
Associação de mototaxistas & 21 & 100.0 & 100.0 & 100.0 \\
Associação/Sindicato dos Trabalhadores Rurais & & & \\
não respondeu/não sabe & & & \\
Total & & & \\
\hline
\end{tabular}

Fonte: pesquisa do autor.

Qual(is) associação(ões)/cooperativa(s) pertence? (Incluídos de JIJOCA DE JERICOACOARA)

\begin{tabular}{l|r|r|r|r}
\hline & Frequency & Percent & Valid Percent & Cumulative Percent \\
\hline Cooperativa dos 4X4 de Jericoacoara & 1 & 12.5 & 12.5 & 12.5 \\
Associação Comunitária/de Moradores & 3 & 37.5 & 37.5 & 50.0 \\
Cooperativa de Bugueiros de Jericoacoara & 1 & 12.5 & 12.5 & 62.5 \\
$\underline{\underline{\underline{O}}}$ Associação dos Cavalos & 1 & 12.5 & 12.5 & 75.0 \\
Associação/Cooperativa de Caminhoneteiros & 1 & 12.5 & 12.5 & 87.5 \\
Associação de áreas priorizadas do Incra de & 1 & 12.5 & 12.5 & 100.0 \\
Mangue Seco & 8 & 100.0 & 100.0 & \\
Total & &
\end{tabular}

Fonte: pesquisa do autor. 


\section{APÊNDICE 7: Avaliação dos fatores de inclusão direta (empresários)}

Avaliação dos fatores de inclusão direta pelo empresariado (A)

\begin{tabular}{|c|c|c|c|c|c|c|c|c|c|c|c|c|}
\hline & \multicolumn{2}{|c|}{ BARREIRINHAS } & \multicolumn{2}{|c|}{$\begin{array}{c}\text { JIJOCA DE } \\
\text { JERICOACOARA }\end{array}$} & \multicolumn{2}{|c|}{ BARREIRINHAS } & \multicolumn{2}{|c|}{$\begin{array}{c}\text { JIJOCA DE } \\
\text { JERICOACOARA }\end{array}$} & \multicolumn{2}{|c|}{ BARREIRINHAS } & \multicolumn{2}{|c|}{$\begin{array}{c}\text { JIJOCA DE } \\
\text { JERICOACOARA }\end{array}$} \\
\hline & \multicolumn{4}{|c|}{ ESCOLARIDADE } & \multicolumn{4}{|c|}{ CAPACITAÇÃO TÉCNICA } & \multicolumn{4}{|c|}{ INDICAÇÃO } \\
\hline & Frequency & Percent & Frequency & Percent & Frequency & Percent & Frequency & Percent & Frequency & Percent & Frequency & Percent \\
\hline Nota 0 & 1 & 1.7 & 6 & 10.0 & - & - & 6 & 10.0 & - & - & 5 & 8.3 \\
\hline Nota 1 & - & - & 1 & 1.7 & - & - & 1 & 1.7 & - & - & 1 & 1.7 \\
\hline Nota 2 & - & - & - & - & - & - & 0 & 0.0 & 1 & 1.7 & - & - \\
\hline Nota 3 & - & - & 1 & 1.7 & - & - & 3 & 5.0 & 2 & 3.4 & 1 & 1.7 \\
\hline Nota 4 & - & - & 1 & 1.7 & 1 & 1.7 & - & - & 4 & 6.9 & 1 & 1.7 \\
\hline 으 Nota 5 & 7 & 12.1 & 14 & 23.3 & 6 & 10.3 & 12 & 20.0 & 10 & 17.2 & 14 & 23.3 \\
\hline$>^{\pi}$ Nota 6 & 8 & 13.8 & 6 & 10.0 & 1 & 1.7 & 1 & 1.7 & 7 & 12.1 & 7 & 11.7 \\
\hline Nota 7 & 6 & 10.3 & 2 & 3.3 & 2 & 3.4 & 5 & 8.3 & 6 & 10.3 & 7 & 11.7 \\
\hline Nota 8 & 12 & 20.7 & 2 & 3.3 & 17 & 29.3 & 1 & 1.7 & 10 & 17.2 & 8 & 13.3 \\
\hline Nota 9 & 23 & 39.7 & 26 & 43.3 & 30 & 51.7 & 30 & 50.0 & 17 & 29.3 & 15 & 25.0 \\
\hline NR & 1 & 1.7 & 1 & 1.7 & 1 & 1.7 & 1 & 1.7 & 1 & 1.7 & 1 & 1.7 \\
\hline \multirow[t]{4}{*}{ Total } & 58 & 100.0 & 60 & 100.0 & 58 & 100.0 & 60 & 100.0 & 58 & 100.0 & 60 & 100.0 \\
\hline & \multicolumn{2}{|c|}{ BARREIRINHAS } & \multicolumn{2}{|c|}{$\begin{array}{c}\text { JIJOCA DE } \\
\text { JERICOACOARA }\end{array}$} & \multicolumn{2}{|c|}{ BARREIRINHAS } & \multicolumn{2}{|c|}{$\begin{array}{c}\text { JIJOCA DE } \\
\text { JERICOACOARA }\end{array}$} & \multicolumn{2}{|c|}{ BARREIRINHAS } & \multicolumn{2}{|c|}{$\begin{array}{l}\text { JIJOCA DE } \\
\text { JERICOACOARA }\end{array}$} \\
\hline & \multicolumn{4}{|c|}{ IDADE } & \multicolumn{4}{|c|}{ GÊNERO } & \multicolumn{4}{|c|}{ EXPERIÊNCIA ANTERIOR } \\
\hline & Frequency & Percent & Frequency & Percent & Frequency & Percent & Frequency & Percent & Frequency & Percent & Frequency & Percent \\
\hline Nota 0 & 3 & 5.2 & 6 & 10.0 & 14 & 24.1 & 25 & 41.7 & 2 & 3.4 & 4 & 6.7 \\
\hline Nota 1 & 1 & 1.7 & 1 & 1.7 & 2 & 3.4 & 1 & 1.7 & - & - & 1 & 1.7 \\
\hline Nota 2 & 2 & 3.4 & 5 & 8.3 & 4 & 6.9 & 3 & 5.0 & - & - & 2 & 3.3 \\
\hline Nota 3 & 1 & 1.7 & - & - & 3 & 5.2 & 1 & 1.7 & 1 & 1.7 & - & - \\
\hline Nota 4 & - & - & - & - & 8 & 13.8 & - & - & - & - & 2 & 3.3 \\
\hline 으 Nota 5 & 11 & 19.0 & 16 & 26.7 & 7 & 12.1 & 8 & 13.3 & 9 & 15.5 & 14 & 23.3 \\
\hline$\stackrel{\pi}{>}$ Nota 6 & 4 & 6.9 & 3 & 5.0 & - & - & 3 & 5.0 & 8 & 13.8 & - & - \\
\hline Nota 7 & 10 & 17.2 & 6 & 10.0 & 7 & 12.1 & 2 & 3.3 & 6 & 10.3 & 5 & 8.3 \\
\hline Nota 8 & 13 & 22.4 & 8 & 13.3 & 6 & 10.3 & 3 & 5.0 & 7 & 12.1 & 7 & 11.7 \\
\hline Nota 9 & 12 & 20.7 & 14 & 23.3 & 6 & 10.3 & 13 & 21.7 & 24 & 41.4 & 25 & 41.7 \\
\hline NR & 1 & 1.7 & 1 & 1.7 & 1 & 1.7 & 1 & 1.7 & 1 & 1.7 & - & - \\
\hline \multirow[t]{4}{*}{ Total } & 58 & 100.0 & 60 & 100.0 & 58 & 100.0 & 60 & 100.0 & 58 & 100.0 & 60 & 100.0 \\
\hline & BARREIR & NHAS & $\begin{array}{r}\text { JIJOCA } \\
\text { JERICOAC }\end{array}$ & $\begin{array}{l}\text { DE } \\
\text { SOARA }\end{array}$ & BARREIR & INHAS & $\begin{array}{r}\text { JIJOC } \\
\text { JERICOA }\end{array}$ & $\begin{array}{l}\text { DE } \\
\text { COARA }\end{array}$ & BARREIF & INHAS & $\begin{array}{r}\text { JIJOC } \\
\text { JERICOAC }\end{array}$ & $\begin{array}{l}\text { DE } \\
\text { COARA }\end{array}$ \\
\hline & \multicolumn{4}{|c|}{ PROXIMIDADE } & \multicolumn{4}{|c|}{ CONHECIMENTO } & PARTI & CIP. CO & OPERATI & VAS \\
\hline & Frequency & Percent & Frequency & Percent & Frequency & Percent & Frequency & Percent & Frequency & Percent & Frequency & Percent \\
\hline Nota 0 & 4 & 6.9 & - & - & \begin{tabular}{|l|}
- \\
\end{tabular} & - & - & - & 2 & 3.4 & 18 & 30.0 \\
\hline Nota 1 & 1 & 1.7 & 1 & 1.7 & - & - & - & - & - & - & 2 & 3.3 \\
\hline Nota 2 & 1 & 1.7 & - & - & 1 & 1.7 & 1 & 1.7 & 3 & 5.2 & 3 & 5.0 \\
\hline Nota 3 & 6 & 10.3 & - & - & - & - & - & - & 1 & 1.7 & 6 & 10.0 \\
\hline$\frac{\bar{v}}{\sqrt{\sigma}}$ Nota 4 & - & & 1 & 1.7 & - & - & 1 & 1.7 & 8 & 13.8 & - & \\
\hline$>$ Nota 5 & 10 & 17.2 & 11 & 18.3 & 3 & 5.2 & 13 & 21.7 & 4 & 6.9 & 11 & 18.3 \\
\hline Nota 6 & 5 & 8.6 & 4 & 6.7 & 1 & 1.7 & 1 & 1.7 & 1 & 1.7 & 1 & 1.7 \\
\hline Nota 7 & 14 & 24.1 & 5 & 8.3 & 8 & 13.8 & 8 & 13.3 & 12 & 20.7 & 8 & 13.3 \\
\hline Nota 8 & 4 & 6.9 & 6 & 10.0 & 16 & 27.6 & 1 & 1.7 & 7 & 12.1 & 5 & 8.3 \\
\hline
\end{tabular}




\begin{tabular}{l|r|r|r|r|r|r|r|r|r|r|r|r}
\hline Nota 9 & 12 & 20.7 & 31 & 51.7 & 28 & 48.3 & 34 & 56.7 & 19 & 32.8 & 5 & 8.3 \\
NR & 1 & 1.7 & 1 & 1.7 & 1 & 1.7 & 1 & 1.7 & 1 & 1.7 & 1 & 1.7 \\
Total & 58 & 100.0 & 60 & 100.0 & 58 & 100.0 & 60 & 100.0 & 58 & 100.0 & 60 & 100.0 \\
\hline
\end{tabular}

Fonte: pesquisa do autor.

Avaliação dos fatores de inclusão direta pelo empresariado (D)

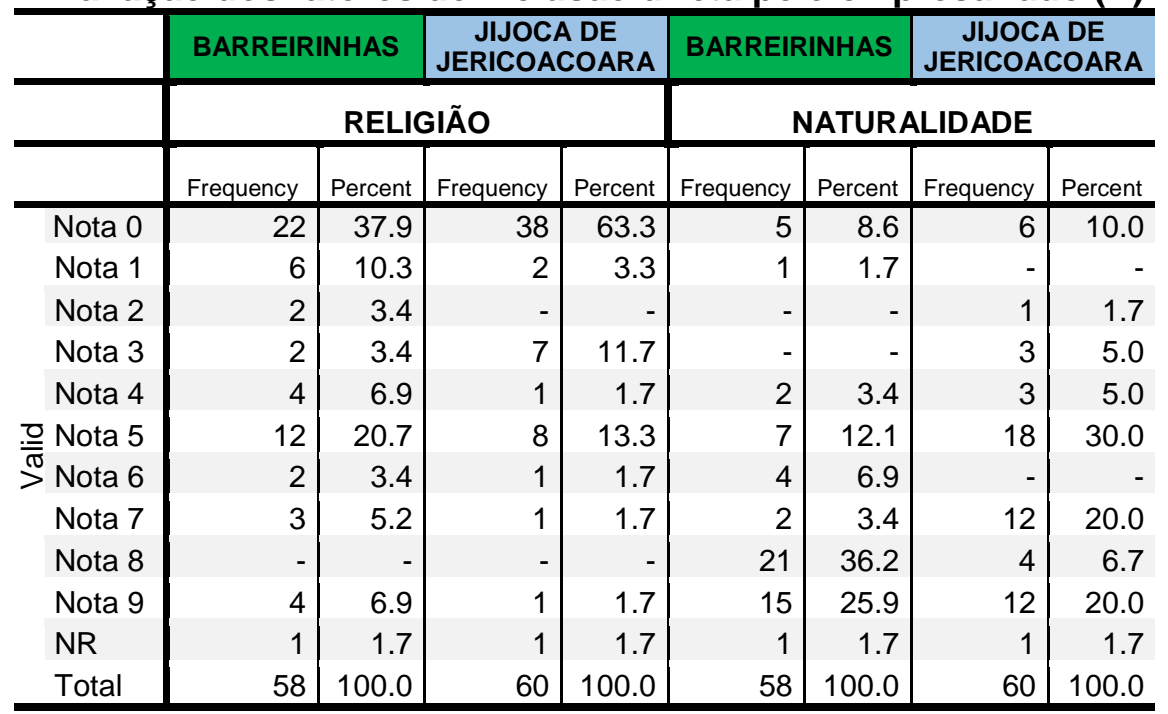

Fonte: pesquisa do autor. 


\section{APÊNDICE 8: Avaliação dos fatores de inclusão indireta (empresários)}

Avaliação dos fatores de inclusão indireta pelo empresariado

\begin{tabular}{|c|c|c|c|c|c|c|c|c|c|c|c|c|}
\hline & \multicolumn{2}{|c|}{ BARREIRINHAS } & \multicolumn{2}{|c|}{$\begin{array}{c}\text { JIJOCA DE } \\
\text { JERICOACOARA }\end{array}$} & \multicolumn{2}{|c|}{ BARREIRINHAS } & \multicolumn{2}{|c|}{$\begin{array}{c}\text { JIJOCA DE } \\
\text { JERICOACOARA }\end{array}$} & \multicolumn{2}{|c|}{ BARREIRINHAS } & \multicolumn{2}{|c|}{$\begin{array}{c}\text { JIJOCA DE } \\
\text { JERICOACOARA }\end{array}$} \\
\hline & \multicolumn{4}{|c|}{ NOTA FISCAL } & \multicolumn{4}{|c|}{ PRAZO DE PAGAMENTO } & \multicolumn{4}{|c|}{ PRODUTO BENEFICIADO } \\
\hline & Frequency & Percent & Frequency & Percent & Frequency & Percent & Frequency & Percent & Frequency & Percent & Frequency & Percent \\
\hline Nota 0 & 6 & 13.3 & 3 & 5.3 & 5 & 11.1 & 4 & 7.0 & 9 & 20.0 & 17 & 29.8 \\
\hline Nota 1 & 1 & 2.2 & 1 & 1.8 & - & - & - & - & 1 & 2.2 & 2 & 3.5 \\
\hline Nota 2 & 3 & 6.7 & 1 & 1.8 & 3 & 6.7 & 3 & 5.3 & 4 & 8.9 & 2 & 3.5 \\
\hline Nota 3 & 1 & 2.2 & 2 & 3.5 & 1 & 2.2 & 5 & 8.8 & 1 & 2.2 & 6 & 10.5 \\
\hline Nota 4 & - & - & 2 & 3.5 & - & - & - & - & 1 & 2.2 & 1 & 1.8 \\
\hline 으 Nota 5 & 1 & 2.2 & 18 & 31.6 & - & - & 14 & 24.6 & 7 & 15.6 & 8 & 14.0 \\
\hline$\stackrel{\pi}{>}$ Nota 6 & 2 & 4.4 & - & - & 3 & 6.7 & 2 & 3.5 & 1 & 2.2 & 1 & 1.8 \\
\hline Nota 7 & 3 & 6.7 & 4 & 7.0 & 6 & 13.3 & 4 & 7.0 & 4 & 8.9 & 5 & 8.8 \\
\hline Nota 8 & 12 & 26.7 & 9 & 15.8 & 12 & 26.7 & 3 & 5.3 & 4 & 8.9 & 1 & 1.8 \\
\hline Nota 9 & 15 & 33.3 & 17 & 29.8 & 13 & 28.9 & 22 & 38.6 & 11 & 24.4 & 14 & 24.6 \\
\hline NR & 1 & 2.2 & - & & 2 & 4.4 & - & & 2 & 4.4 & - & \\
\hline \multirow[t]{4}{*}{ Total } & 45 & 100.0 & 57 & 100.0 & 45 & 100.0 & 57 & 100.0 & 45 & 100.0 & 57 & 100.0 \\
\hline & \multicolumn{2}{|c|}{ BARREIRINHAS } & \multicolumn{2}{|c|}{$\begin{array}{c}\text { JIJOCA DE } \\
\text { JERICOACOARA }\end{array}$} & \multicolumn{2}{|c|}{ BARREIRINHAS } & \multicolumn{2}{|c|}{$\begin{array}{c}\text { JIJOCA DE } \\
\text { JERICOACOARA }\end{array}$} & \multicolumn{2}{|c|}{ BARREIRINHAS } & \multicolumn{2}{|c|}{$\begin{array}{c}\text { JIJOCA DE } \\
\text { JERICOACOARA }\end{array}$} \\
\hline & \multicolumn{4}{|c|}{ DISPONIBILIDADE ENTREGA } & \multicolumn{4}{|c|}{ REGULAR. FORNECIMENTO } & \multicolumn{4}{|c|}{ CAPACIT. TÉCNICA E GERENC } \\
\hline & Frequency & Percent & Frequency & Percent & Frequency & Percent & Frequency & Percent & Frequency & Percent & Frequency & Percent \\
\hline Nota 0 & 2 & 4.4 & - & - & - & - & - & - & - & - & 2 & 3.5 \\
\hline Nota 1 & 2 & 4.4 & - & - & - & - & - & - & - & - & - & 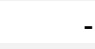 \\
\hline Nota 2 & 2 & 4.4 & - & - & - & - & - & - & - & - & 1 & 1.8 \\
\hline Nota 3 & - & - & - & - & - & - & 2 & 3.5 & - & - & - & - \\
\hline Nota 4 & 2 & 4.4 & - & - & - & - & - & - & 1 & 2.2 & 2 & 3.5 \\
\hline 으 Nota 5 & 1 & 2.2 & 3 & 5.3 & - & - & 1 & 1.8 & 3 & 6.7 & 3 & 5.3 \\
\hline$>^{\pi}$ Nota 6 & 2 & 4.4 & - & - & 1 & 2.2 & 1 & 1.8 & 2 & 4.4 & 4 & 7.0 \\
\hline Nota 7 & 3 & 6.7 & 2 & 3.5 & 3 & 6.7 & 1 & 1.8 & 2 & 4.4 & 7 & 12.3 \\
\hline Nota 8 & 10 & 22.2 & 6 & 10.5 & 10 & 22.2 & 7 & 12.3 & 15 & 33.3 & 5 & 8.8 \\
\hline Nota 9 & 19 & 42.2 & 46 & 80.7 & 29 & 64.4 & 45 & 78.9 & 20 & 44.4 & 33 & 57.9 \\
\hline NR & 2 & 4.4 & - & & 2 & 4.4 & - & - & 2 & 4.4 & - & \\
\hline \multirow[t]{4}{*}{ Total } & 45 & 100.0 & 57 & 100.0 & 45 & 100.0 & 57 & 100.0 & 45 & 100.0 & 57 & 100.0 \\
\hline & \multicolumn{2}{|c|}{ BARREIRINHAS } & \multicolumn{2}{|c|}{$\begin{array}{c}\text { JIJOCA DE } \\
\text { JERICOACOARA }\end{array}$} & BARREIR & INHAS & $\begin{array}{r}\text { JIJOC } \\
\text { JERICOA }\end{array}$ & $\begin{array}{l}\text { DE } \\
\text { COARA }\end{array}$ & BARREIR & INHAS & $\begin{array}{r}\text { JIJOCA } \\
\text { JERICOAC }\end{array}$ & $\begin{array}{l}\text { DE } \\
\text { COARA }\end{array}$ \\
\hline & & SIF - SI & E - SIM & & & QUAN7 & IIDADE & & & OOPEF & RATIVAS & \\
\hline & Frequency & Percent & Frequency & Percent & Frequency & Percent & Frequency & Percent & Frequency & Percent & Frequency & Percent \\
\hline Nota 0 & 1 & 2.2 & 2 & 3.5 & - & - & - & - & 1 & 2.2 & 11 & 19.3 \\
\hline Nota 1 & 1 & 2.2 & 1 & 1.8 & - & - & - & - & 1 & 2.2 & 2 & 3.5 \\
\hline Nota 2 & - & - & - & - & - & - & - & - & 3 & 6.7 & 7 & 12.3 \\
\hline هota 3 & 2 & 4.4 & 1 & 1.8 & - & - & - & - & 1 & 2.2 & 4 & 7.0 \\
\hline 旅 Nota 4 & - & & 1 & 1.8 & 2 & 4.4 & - & - & 2 & 4.4 & 1 & 1.8 \\
\hline Nota 5 & 4 & 8.9 & 10 & 17.5 & 5 & 11.1 & - & - & 9 & 20.0 & 9 & 15.8 \\
\hline Nota 6 & - & - & 1 & 1.8 & 3 & 6.7 & 2 & 3.5 & 1 & 2.2 & 3 & 5.3 \\
\hline Nota 7 & 8 & 17.8 & 4 & 7.0 & 6 & 13.3 & 4 & 7.0 & 8 & 17.8 & 4 & 7.0 \\
\hline Nota 8 & 5 & 11.1 & 5 & 8.8 & 5 & 11.1 & 6 & 10.5 & 6 & 13.3 & 3 & 5.3 \\
\hline
\end{tabular}




\begin{tabular}{l|r|r|r|r|r|r|r|r|r|r|r|r}
\hline Nota 9 & 22 & 48.9 & 32 & 56.1 & 22 & 48.9 & 45 & 78.9 & 11 & 24.4 & 13 & 22.8 \\
NR & 2 & 4.4 & - & - & 2 & 4.4 & - & - & 2 & 4.4 & - & - \\
Total & 45 & 100.0 & 57 & 100.0 & 45 & 100.0 & 57 & 100.0 & 45 & 100.0 & 57 & 100.0 \\
\hline
\end{tabular}

Fonte: pesquisa do autor. 


\section{APÊNDICE 9: Avaliação dos fatores de inclusão indireta (grupos)}

Avaliação dos fatores de inclusão indireta pelos grupos

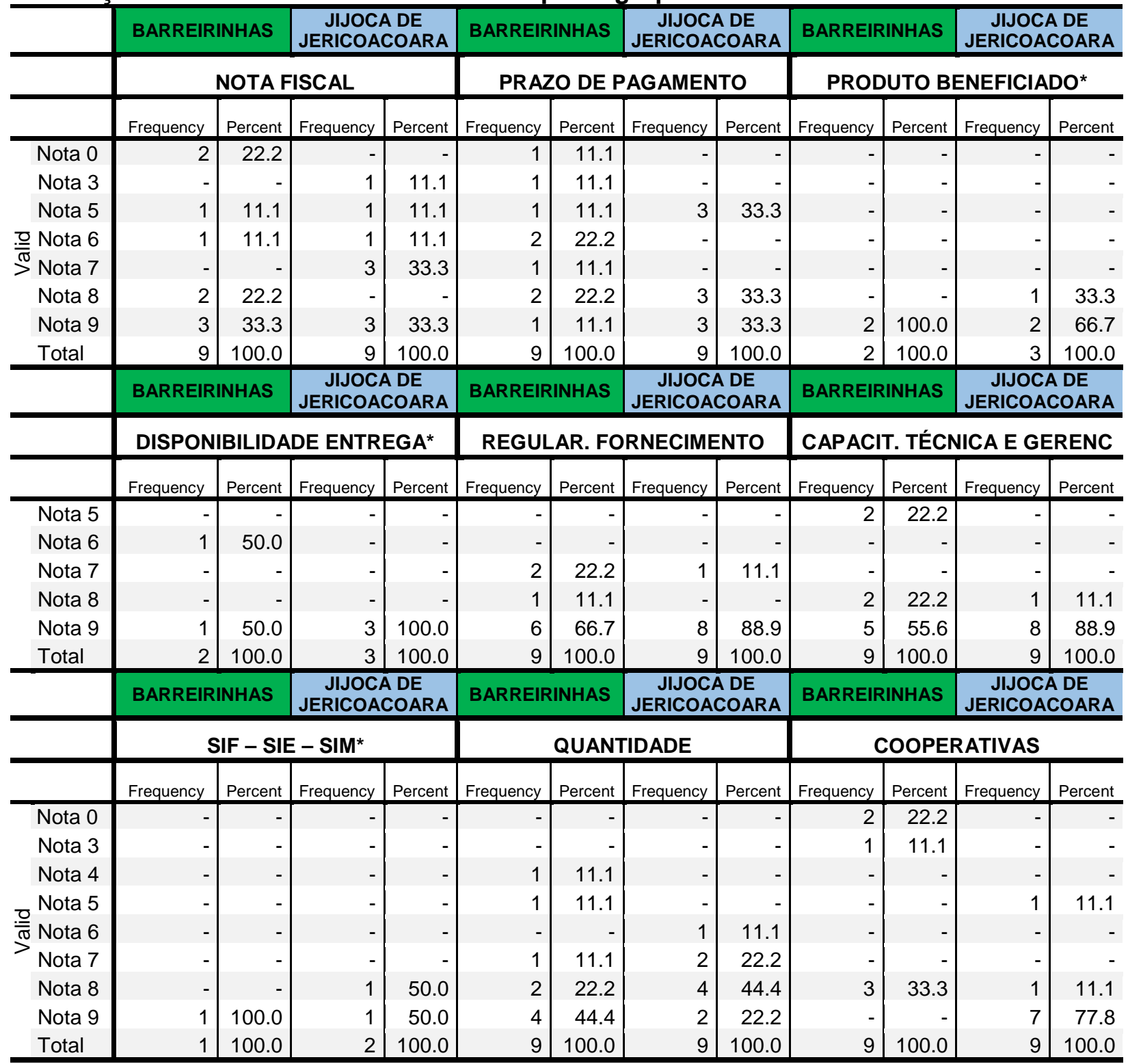

Fonte: pesquisa do autor. 


\section{APÊNDICE 10: Análise de associação dos fatores com a variável resposta (Barreirinhas)}

Teste qui-quadrado de independência para os fatores de inclusão na cidade de Barreirinhas

\begin{tabular}{|c|c|c|c|c|c|}
\hline \multirow{2}{*}{ Fatores } & \multicolumn{4}{|c|}{ Conseguiu o emprego? } & \multirow{2}{*}{ p-valor } \\
\hline & Sim & $\%$ & Não & $\%$ & \\
\hline \multicolumn{6}{|l|}{ Gênero } \\
\hline Masculino & 20 & 0,588 & 14 & 0,412 & \multirow{2}{*}{0,482} \\
\hline Feminino & 25 & 0,51 & 24 & 0,49 & \\
\hline \multicolumn{6}{|l|}{ Idade } \\
\hline 16 a 24 anos & 13 & 0,52 & 12 & 0,48 & \multirow{5}{*}{0,979} \\
\hline 25 a 34 anos & 16 & 0,552 & 13 & 0,448 & \\
\hline 35 a 44 anos & 7 & 0,5 & 7 & 0,5 & \\
\hline 45 a 54 anos & 7 & 0,583 & 5 & 0,417 & \\
\hline 55 anos ou mais & 2 & 0,667 & 1 & 0,333 & \\
\hline \multicolumn{6}{|l|}{ Proximidade Física } \\
\hline Próximo & 10 & 0,278 & 26 & 0,722 & \multirow{2}{*}{$<0,001$} \\
\hline Distante & 35 & 0,745 & 12 & 0,255 & \\
\hline \multicolumn{6}{|l|}{ Escolaridade } \\
\hline Sem escolaridade & 3 & 1 & 0 & 0 & \multirow{6}{*}{0,053} \\
\hline Fundamental incompleto & 23 & 0,561 & 18 & 0,439 & \\
\hline Fundamental completo & 4 & 0,8 & 1 & 0,2 & \\
\hline Ensino médio incompleto & 10 & 0,667 & 5 & 0,333 & \\
\hline Ensino médio completo & 4 & 0,25 & 12 & 0,75 & \\
\hline Superior completo & 1 & 0,333 & 2 & 0,667 & \\
\hline \multicolumn{6}{|l|}{ Religião } \\
\hline Católica & 34 & 0,54 & 29 & 0,46 & \multirow{3}{*}{0,995} \\
\hline Outros & 5 & 0,556 & 4 & 0,444 & \\
\hline Protestante & 6 & 0,545 & 5 & 0,455 & \\
\hline \multicolumn{6}{|l|}{ Local de Nascimento } \\
\hline Sim & 41 & 0,539 & 35 & 0,461 & \multirow{2}{*}{0,871} \\
\hline Não & 4 & 0,571 & 3 & 0,429 & \\
\hline \multicolumn{6}{|c|}{ Participação em Coop/Assoc } \\
\hline Sim & 18 & 0,581 & 13 & 0,419 & \multirow{2}{*}{0,586} \\
\hline Não & 27 & 0,519 & 25 & 0,481 & \\
\hline \multicolumn{6}{|l|}{ Indicado por conhecidos } \\
\hline $\operatorname{Sim}$ & 32 & 0,5 & 32 & 0,5 & \multirow{2}{*}{0,157} \\
\hline Não & 13 & 0,684 & 6 & 0,316 & \\
\hline \multicolumn{6}{|c|}{ Conhecimento da área/região } \\
\hline Sim & 30 & 0,6 & 20 & 0,4 & \multirow{2}{*}{0,193} \\
\hline Não & 15 & 0,455 & 18 & 0,545 & \\
\hline \multicolumn{6}{|l|}{ Experiência anterior } \\
\hline Sim & 14 & 0,609 & 9 & 0,391 & \multirow{2}{*}{0,451} \\
\hline Não & 31 & 0,517 & 29 & 0,483 & \\
\hline \multicolumn{6}{|l|}{ Realizou Cursos } \\
\hline Sim & 10 & 0,667 & 5 & 0,333 & \multirow{2}{*}{0,284} \\
\hline Não & 35 & 0,515 & 33 & 0,485 & \\
\hline
\end{tabular}

Fonte: pesquisa do autor. 


\section{APÊNDICE 11: Análise de associação dos fatores com a variável resposta (Jijoca de Jericoacoara)}

Teste qui-quadrado de independência para os fatores de inclusão na cidade de Jijoca de Jericoacoara

\begin{tabular}{|c|c|c|c|c|c|}
\hline \multirow{2}{*}{ Fatores } & \multicolumn{4}{|c|}{ Conseguiu o emprego? } & \multirow{2}{*}{ p-valor } \\
\hline & Sim & $\%$ & Não & $\%$ & \\
\hline \multicolumn{6}{|l|}{ Gênero } \\
\hline Masculino & 31 & 0,886 & 4 & 0,114 & \multirow{2}{*}{0,435} \\
\hline Feminino & 31 & 0,939 & 2 & 0,061 & \\
\hline \multicolumn{6}{|l|}{ Idade } \\
\hline 16 a 24 anos & 13 & 0,867 & 2 & 0,133 & \multirow{5}{*}{0,879} \\
\hline 25 a 34 anos & 23 & 0,92 & 2 & 0,08 & \\
\hline 35 a 44 anos & 17 & 0,944 & 1 & 0,056 & \\
\hline 45 a 54 anos & 6 & 0,857 & 1 & 0,143 & \\
\hline 55 anos ou mais & 3 & 1 & 0 & 0 & \\
\hline \multicolumn{6}{|l|}{ Proximidade Física } \\
\hline Próximo & 35 & 0,897 & 4 & 0,103 & \multirow{2}{*}{0,629} \\
\hline Distante & 27 & 0,931 & 2 & 0,069 & \\
\hline \multicolumn{6}{|l|}{ Escolaridade } \\
\hline Sem escolaridade & 7 & 0,875 & 1 & 0,125 & \multirow{6}{*}{0,665} \\
\hline Fundamental incompleto & 22 & 0,957 & 1 & 0,043 & \\
\hline Fundamental completo & 10 & 0,909 & 1 & 0,091 & \\
\hline Ensino médio incompleto & 6 & 1 & 0 & 0 & \\
\hline Ensino médio completo & 14 & 0,824 & 3 & 0,176 & \\
\hline Superior incompleto/completo & 3 & 1 & 0 & 0 & \\
\hline \multicolumn{6}{|l|}{ Religião } \\
\hline Católica & 55 & 0,917 & 5 & 0,083 & \multirow{2}{*}{0,696} \\
\hline Outros & 7 & 0,875 & 1 & 0,125 & \\
\hline \multicolumn{6}{|l|}{ Local de Nascimento } \\
\hline Sim & 43 & 0,935 & 3 & 0.065 & \multirow{2}{*}{0,333} \\
\hline Não & 19 & 0,864 & 3 & 0,136 & \\
\hline \multicolumn{6}{|l|}{ Participação em Cooper/Assoc } \\
\hline Sim & 4 & 0,8 & 1 & 0,2 & \multirow{2}{*}{0,359} \\
\hline Não & 58 & 0,921 & 5 & 0,079 & \\
\hline \multicolumn{6}{|l|}{ Indicado por conhecidos } \\
\hline Sim & 38 & 0,905 & 4 & 0,095 & \multirow{2}{*}{0,795} \\
\hline Não & 24 & 0,923 & 2 & 0,077 & \\
\hline \multicolumn{6}{|l|}{ Conhecimento da área/região } \\
\hline Sim & 37 & 0,974 & 1 & 0,026 & \multirow{2}{*}{0,042} \\
\hline Não & 25 & 0,833 & 5 & 0,167 & \\
\hline \multicolumn{6}{|l|}{ Experiência anterior } \\
\hline Sim & 22 & 1 & 0 & 0 & \multirow{2}{*}{0,076} \\
\hline Não & 40 & 0,87 & 6 & 0,13 & \\
\hline \multicolumn{6}{|l|}{ Realizou Cursos } \\
\hline Sim & 19 & 1 & 0 & 0 & \multirow{2}{*}{0,11} \\
\hline Não & 43 & 0,878 & 6 & 0,122 & \\
\hline
\end{tabular}

Fonte: pesquisa do autor. 